Please do not destroy or throw away this publication. If you have no further use for it write to the Geological Survey at Washington and ask for a frank to return it

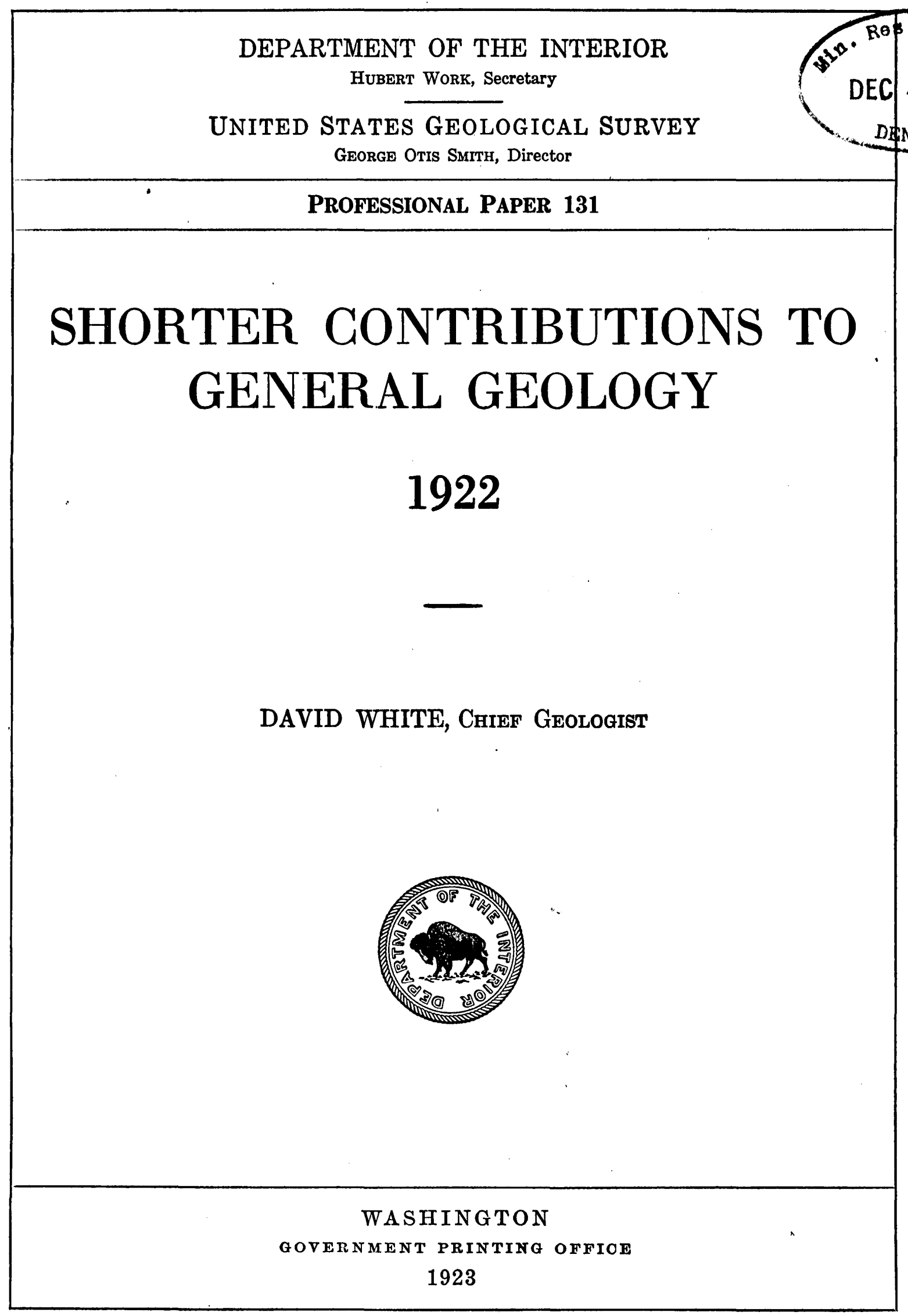


DEPARTMENT OF THE INTERIOR

HUBERT WORK, Secretary

United States Geological SuRvey

George OtIS Smith, Director

Professional Paper 131

\section{SHORTER CONTRIBUTIONS TO GENERAL GEOLOGY}

1922

DAVID WHITE, Chief Geologist

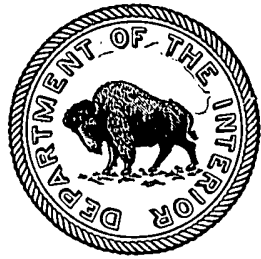

WASHINGTON

GOVERNMENT PRINTING OFFICE 1923
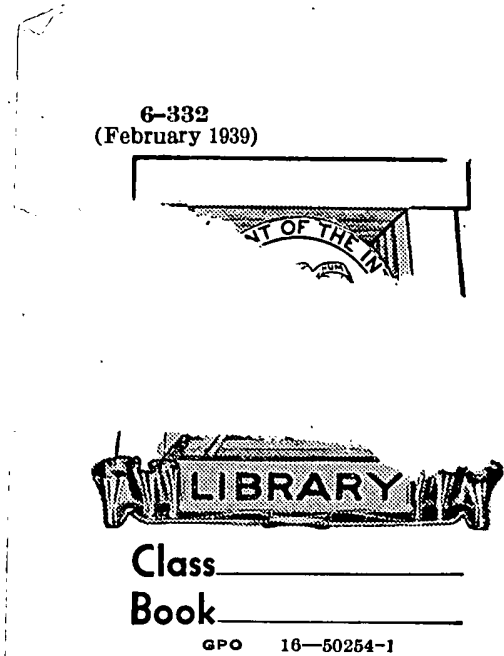

CHARLES W. HENDERSON MEMORIAL COLLECTION 
ADDITIONAL COPIES

OF THIS PUBLICATION MAY BE PROCURED FROM THE SUPERINTENDENT OF DOCUMENTS

GOVERNMENT PRINTING OFFICE

$$
\text { WASHINGTON, D. C. }
$$

\section{CENTS PER COPY}

PURCHASER AGREES NOT TO RESELL OR DISTRIBUTE THIS COPY FOR PROFIT.-PUB. RES. 57, APPROVED MAY 11, 1922 


\section{CONTENTS.}

[The letters in parentheses preceding the titles are those used to designate the papers for advance publication.]

(A) Additione to the flora of the Wilcox group, by E. W. Berry (published July 27,1922$) \ldots \ldots \ldots \ldots \ldots \ldots \ldots$.

(B) A section of the Paleozoic formations of the Grand Canyon at the Bass trail, by L. F. Noble (published Aug. $19,1922)$

(C) The shapes of beach pebbles, by C. K. Wentworth (published Dec. 20, 1922).

A geologic reconnaissance in the Gulf Coastal Plain of Texas, near the Rio Grande, by A. C. Trowbridge

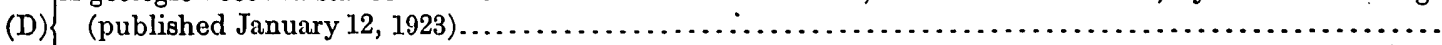

New species of Moll usca from the Eocene deposits of southwestern Texas, by Julia Gardner..................
(E) Preliminary report on fossil vertebrates of the San Pedro Valley, Ariz., with descriptions of new species of Rodentia and Lagomorpha, by J. W. Gidley (published Dec. 26, 1922).

(F) Revision of the flora of the Green River formation, with descriptions of new species, by F. H. Knowlton (published March 30, 1923)....

(G) Fossil plants from the Tertiary lake beds of south-central Colorado, by F. H. Knowlton (published March

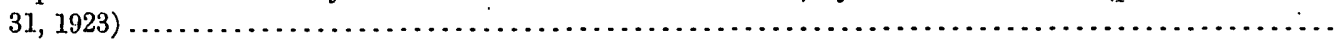

(H) The fauna of the so-called Dakota formation of northern central Colorado and its equivalent in south-

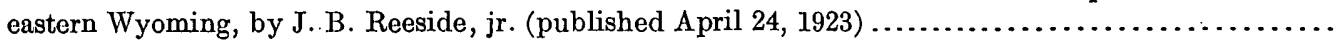

Index

Page.

I

23

75

85

10

119

133

183

199

209

\section{ILLUSTRATIONS.}

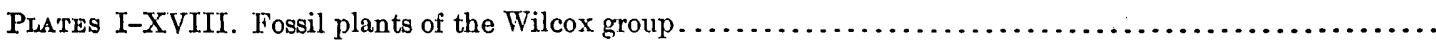

Page.

21 .

XIX. Columnar section of Paleozoic strata at Bass trail, Shinumo quadrangle, Ariz...............

XX. Columnar sections of Tonto group between Garnet Canyon and Cottonwood Creek, Shinumo, Bright Angel, and Vishnu quadrangles, Ariz.

XXI. A, Typical exposure of Tapeats sandstone on Colorado River opposite mouth of Elves Chasm, Shinumo quadrangle, Ariz.; $B$, Typical exposure of Bright Angel shale, Muav limestone, Temple Butte limestone, Redwall limestone, and Supai formation in north wall of Grand Canyon opposite Garnet Canyon, Shinumo quadrangle, Ariz...

XXII. $A, B$, Unconformity between Temple Butte limestone and Muav limestone in west wall of canyon of Slate Creek, Shinumo quadrangle, Ariz. . .

XXIII. $A$, Unconformity between Temple Butte limestone and Muav limestone in west wall of Turquoise Canyon, Shinumo quadrangle, Ariz.; $B$, Unconformity between Hermit shale and Supai formation at Red Top, on Hermit trail, Bright Angel quadrangle, Ariz. . ..........

XXIV. $A$, Unconformity between Hermit shale and Supai formation on trail between Red Top and Dripping Spring, Bright Angel quadrangle, Ariz.; $B$, Typical exposure of Hermit shale in Tapeats Amphitheater, northeast of Powell Plateau, Kaibab quadrangle, Ariz..........

XXV. $A$, Fossil tracks on slab of Coconino sandstone at Hermit trail, Bright Angel quadrangle, Ariz.; $B$, Cedar Mountain, Vishnu quadrangle, Ariz., from Desert View Camp.................

XXVI. $A$, Gravel in pocket beach south of Nantasket, Mass.; $B$, Gravel and jointed rock of promontory south of Nantasket, Mass.; $C$, Roller-shaped cobbles in two stages of formation, pocket

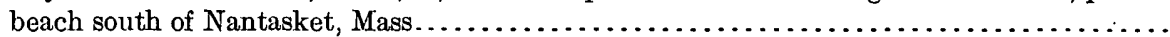

XXVII. $A$, Beach at Fort Hale, Conn.; $B$, Near view of cliff of joined trap and landward edge of

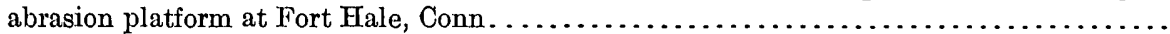

XXVIII. Geologic map of the Gulf Coastal Plain of Texas adjacent to the Rio Grande............ 104

XXIX-XXXIII. Mollusca from the Eocene of southwestern Texas. . . . . . . . . . . . . . . . . . . . 117

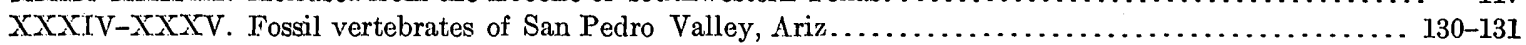

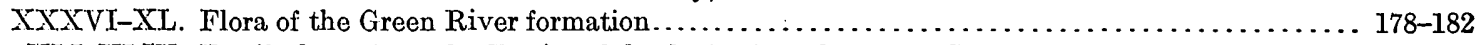

. XILI-XLIV. Fossil plants from the Tertiary lake beds of south-central Colorado................ 194-197

XLV-I. Fossils of the so-called Dakota formation of northern central Colorado and southeastern

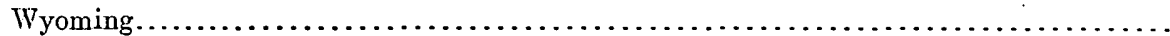


Figure 1. Map of Grand Canyon, Ariz., between Kanab Creek and Nunkoweap Valley....................

2. Outline of area about Bass trail, Shinumo quadrangle, Ariz., showing localities where different

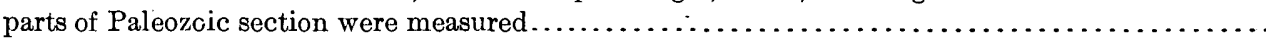

3. Diagrammatic sketches showing general character of unconformity between Temple Butte limestone and Muav limestone at eight localities between Garnet Canyon and Cottonwood Creek, Grand Canyon, Ariz.

4. Diagrammatic sketches showing character of unconformity between Hermit shale and Supai forma-

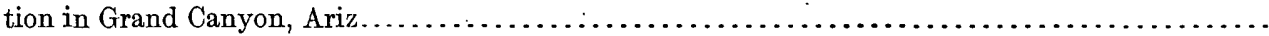

5. Graph showing flatness and roundness ratios of 61 pebbles of group A at Nantasket, Mass............

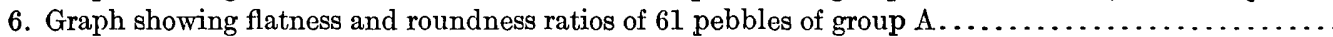

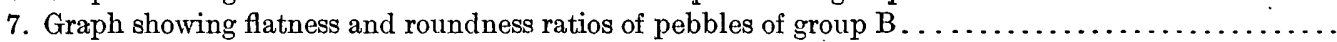

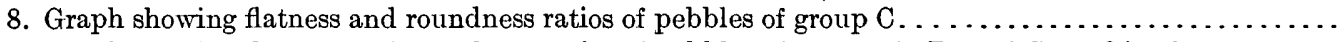

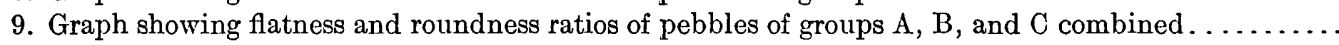

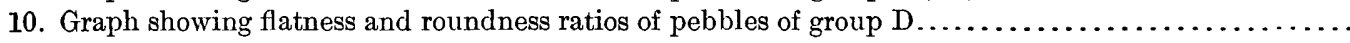

11. Diagrams showing average flatness and roundness of most angular and most rounded subgroups of pebbles of group $\mathrm{C}$ at Nantasket, Mass. . . . . . . . . . . . . . . . . . . . . . . . . . . . . . . . . . . .

12. Diagrams showing average flatness and roundness of most angular and most rounded subgroups of pebbles of group D at Fort Hale, Conn. 


\title{
SHORTER CONTRIBUTIONS TO GENERAL GEOLOGY, 1922.
}

\author{
ADDITIONS TO THE FLORA OF THE WILCOX GROUP.
}

By Edward Wilber Berry.

A rather full account of the extensive flora contained in the lower Eocene strata of the Mississippi embayment which are referred to the Wilcox group was published in $1916 .^{1}$ At that time it was not possible to obtain sections of the numerous specimens of petrified wood that had been collected from these beds. These woods have since been sectioned and studied, and it seems eminently desirable to place the results of this study on record, for although much of the material had suffered greatly from decay before silicification, some of it is fairly well preserved and shows, among other results, that conifers were individually much more plentiful during Wilcox time than would be inferred from the almost total absence of their foliage in the very large collections of remains of this class that have been studied.

Moreover, these coniferous woods show wellmarked seasonal rings, indicating periodicity in the climate, which can be explained as due either to severity of winters or to a seasonal rainfall and a regularly recurring dry season. As the facies of the flora appears to preclude the first alternative, the second would seem established, except that the general character of the flora is equally opposed to this alternative. As both the pines and the bald cypress in the existing flora at their southern limit in peninsular Florida show annual rings, it seems to me that a somewhat similar winter season must be predicated for the Wilcox. This does not mean annual snow or frost, although freezes may have occurred at intervals of years. Severity is a relative term, and I would not expect the Wilcox climate, even at the north end of the embayment, near the

\footnotetext{
1 Berry, E. W., U. S. Geol. Survoy Prof. Paper 91, 1916
}

present mouth of the Ohio, to have been any more severe during the winter than the present climate, for example, of Fort Pierce, in the southern Indian River region of peninsular Florida. This conclusion is practically the same as that arrived at in the previous analysis of the Wilcox flora.

Very little has heretofore been known of the Wilcox flora in the Texas area. In Professional Paper 91 Wilcox plants were recorded from only three localities in Texas, and two of these-Old Port Caddo Landing, in Harrison County; and Sabine River in Sabine Countyare in the extreme eastern part of the State. The third and westernmost locality from which Wilcox plants had been recorded is on Calaveras Creek in Wilson County. That the lack of fossils from the Wilcox in the region between San Antonio and the Rio Grande was due entirely to lack of exploration was shown by a short trip through this region during 1921. Although fossil plants are not so common there as farther east, because the upper Wilcox, which alone crops out, contains a large proportion of sandy beds, long ago recognized as the Carrizo sandstone, several collections were obtained. The age of the Carrizo sandstone has heretofore been somewhat uncertain. Referred originally to the Wilcox, it has been considered to be of Claiborne age by several Texas geologists. The plants found in the Carrizo sandstone, as well as those found both above and below it near the Rio Grande, definitely settle its upper Wilcox age. These will be discussed on a subsequent page.

In addition, a few collections have been sent to me from time to time from new localities, and I am particularly indebted to Mr. O. M. Ball for a large collection obtained near Mansfield, La. 
In Professional Faper 91 I recorded 342 species of plants from the Wilcox. In Professional Paper 108-E, published in 1917, species of Zamia and Nelumbo were added. The present contribution includes additional plants, but as a number of supposed species of Ficus are now reduced to synonymy, the total additions amount to 9 , making 353 as the number of species now recognized in the Wilcox flora.

The descriptions in the present paper include both lauraceous and sterculiaceous woods, also strikingly, well preserved and characteristic lauraceous fruits. Other novelties are a' liverwort (Marchantites,) the fern genus Dryopteris, palm nuts, the genus Monocarpellites (which helps to prove that the lignites of Brandon, Vt., are Eocene and not Miocene), an interesting fruit of the otherwise unrepresented family Icacinaceae, and a second which is referred with some hesitation to the family Anacardiaceae.

The upper Wilcox plant-bearing bed in the Grenada formation near Grenada, Grenada County, Miss., is at the southernmost point at which determinable fossil plants had been found in the Wilcox in the eastern Gulf area. Much interest therefore attaches to a small collection made recently in southern Alabama by $C$. W. Cooke and J. A. Gardner. The exact locality is at the wagon bridge on Claybank Creek 1 mile west of Clayhatchee, Dale County. This is about 300 miles southeast of Grenada and east of the typical localities of marine Wilcox beds. The matrix is a sandy brown clay, and the contained leaves are poor and fragmentary. Representatives of four different species are recognizable, although but one of these is determinable, and this represents a perfect leaflet of Mimosites variabilis Berry.

The following species are recorded from the Spinks pit, near Paris, Henry County, Tenn. The specimens occur in a gray plastic clay from which the entire leaves can be washed and mounted in balsam between glass, thus forming very exceptional specimens:

\footnotetext{
Monocarpellites perkinsi Berry.

Nectandra glenni Berry.

Oreodaphne salinensis Berry.

Sapindus mississippiensis Berry.
}

The following are additions to the flora from a locality 1 mile south of Grand Junction, Tenn.:
Sabalites grayanus Lesquereux.

Oreodaphne puryearensis Berry.

At the time of publication of Professional Paper 91 the collections obtained 4 miles southwest of Boydsville, Ark., were lost, and as they had only received a preliminary study the list of species from that locality was very incomplete. These collections have since received careful study, which has shown that Ficus denveriana should be omitted from this florule and that the following species should be added:

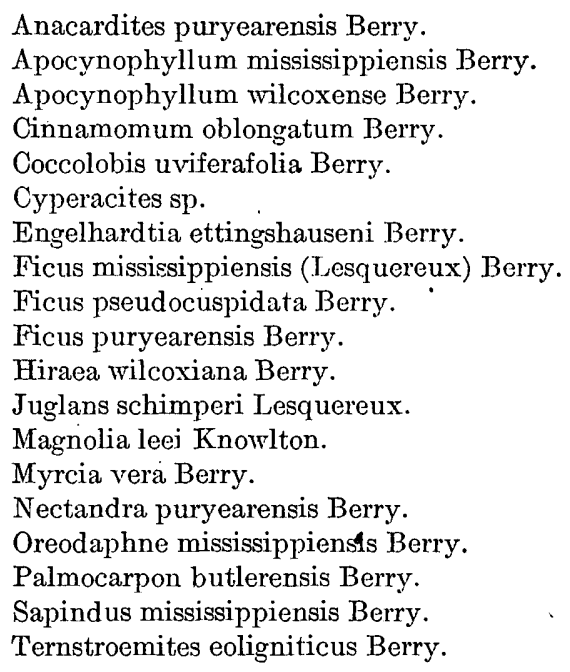

These all serve to emphasize the late Wilcox age of the Boydsville florule.

At a locality near Jacksonville, in Pulaski County, Ark., L. W. Stephenson collected the following species, which prove the outcrop to be of upper Wilcox age:

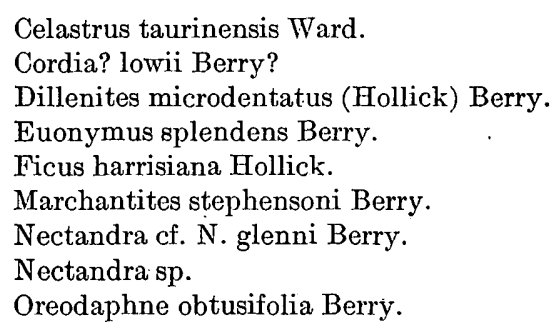

In material from a gray plastic clay at 304 to 319 feet below the surface in a well at Negreet, 9 miles southwest of Many, Sabine Parish, La., I recognized the two following Wilcox species:

Pteris pseudopinnaeformis Lesquereux. Simaruba eocenica Berry.

The following plants were collected by O. M. Ball at the Goss pit, half a mile east of Mansfield, De Soto Parish, La.: 
Apocynophyllum mississippiensis Berry. Artocarpoides balli Berry.

Bombacites formosus Berry.

Diospyros wilcoxiana Berry.

Dryopteris cladophleboides Knowlton.

Dryophyllum sp.

Euonymus splendens Berry.

Ficus artocarpoides Lesquereux.

Ficus mississippiensis (Lesquereux) Berry.

Inga laurinafolia Berry.

Juglans schimperi Lesquereux.

Laurus vera Berry.

Magnolia angustifolia Newberry.

Magnolia leei Knowlton.

Metopium wilcoxianum Perry.

Oreodaphne salinensis Berry.

Rhamnus eoligniticus Berry.

Rhamnus marginatus Lesquereux.

Rhamnus marginatus apiculatus Berry.

Rhamnites knowltoni Berry.

Sterculia wilcoxensis Berry.

Sterculiocarpus eocenicus Berry.

Terminalia hilgardiana (Lesquereux) Berry.

Terminalia lesleyana (Lesquereux) Berry.

The following were contained in a collection from a locality 10 miles south-southwest of Palestine, Anderson County, Tex., in Post Oak Prairie, 2 miles south of Needmore (collectors, O. B. Hopkins and O. C. Funderbunk):

Canavalia eocenica Berry?

Lygodium binervatum (Lesquereux) Berry.

Nectandra pseudocoriacea Berry?

The following were sent in by the last-named collectors from the Butler (or West Point) salt dome, in the eastern part of Freestone County, near Trinity River, 6 miles northeast of Oakville, Tex.:

Mespilodaphne coushatta Berry?

Palmocarpon butlerensis Berry.

Proteoides wilcoxensis Berry.

Sophora repandifolia Berry?

Calatoloides eocenicum Berry.

The following localities in central and southwestern Texas deserve some special comment, as no collections have heretofore been made from them and they show conclusively that the Carrizo sandstone is of upper Wilcox age, but that it is in the nature of a lens which becomes thinner toward the Rio Grande, where its upper part is replaced by more typical and more argillaceous Wilcox beds that also carry characteristic fossil plants.

Fossil plants were reported by Baker from the Elmendorf clay pit, south of San Antonio, in Bexar County. This pit was not being worked in 1921 and was partly full of water, about 25 feet of grayish laminated sandy clay with local more argillaceous and darker lenses. carrying leaves being all that was exposed. These leaves were poorly preserved, and the only. species recognized are Ficus mississippiensis (Lesquereux) Berry, Nectandra sp., and Sapindus linearifolius Berry. The manager of the Elmendorf plant informed me that the clay formerly mined came from the flooded part of the pit and was full of impressions of leaves.

The Wilcox is well exposed along Nueces River in Zavalla County. Fossil plants were collected from the right bank 1 mile below the Pulliam ranch house. The following species are represented:

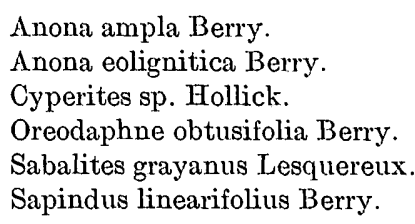

Sandy lenses contain many Sabalites, some of large size. One rachis of this species observed was $2 \frac{1}{2}$.inches in diameter at one end and 4 inches at the other. These species indicate a late Wilcox age and show the transgressive character of the beds, as the Midway appears to be absent on the Nueces, the Wilcox resting on the Cretaceous and not far above the conspicuous reef of Ostrea cortex just above the San Antonio, Uvalde \& Gulf Railroad bridge.

From Story's ranch to La Pryor crossing there is a long exposure of typical Wilcox beds, especially along the left bank of the Nueces for about 2 miles above the crossing. Fossil plants are abundant but so poorly preserved that no collections were made, although several Wilcox species were recognized.

From the crossing southward the Carrizo sandstone is exposed. At an outcrop in a deep arroyo along the left bank $1 \frac{1}{2}$ miles south of the crossing there is an exposure of about 30 feet of buff heavily bedded and prominently cross-bedded sand. At the base of this sand 3 to 4 feet of a small brownish clay lens is visible. This lens, which is stratigraphically above the ferruginous quartzite sand exposed at the crossing, is full of leaves. The following species, which indicate upper Wilcox age, were collected:

Banksia puryearensis Berry.

Eugenia grenadensis Berry. 
Gleditsiophyllum eocenicum Berry.

Mespilodaphne coushatta Berry.

Myrcia vera Berry.

Persea longipetiolatum (Hollick) Berry.

Sabalites grayanus Lesquereux.

The type exposure of the Carrizo sandstone is in the quarries about half a mile west of Carrizo Springs, in Dimmit County. This, as well as the numerous other exposures of Carrizo and other Wilcox deposits in southwestern Texas, will be described in detail in A. C. Trowbridge's report on this region.

From the Carrizo sandstone at the type locality the following species were collected:

Acrostichum sp.
Anona ampla Berry.
Anona wilcoxiana Berry.
Canavalia eocenica Berry?
Cassia tennesseensis Berry.
Cinnamomum vera Berry?
Dryophyllum tennesseensis Berry?
Ficus mississippiensis (Lesquereux) Berry.
Nectandra pseudocoriacea Berry.
Oreodaphne obtusifolia Berry.
Oreodaphne puryearensis Berry.
Palmocarpon butlerensis Berry.
Pterobalanus texanus Berry.
Sabalites grayanus Lesquereux.
Sophora wilcoxiana Berry.
Sterculia wilcoxensis Berry.

The foregoing list represents a typical upper Wilcox flora. Fragments of leaves are not at all uncommon in the hard sandstones of the Carrizo and were observed at a considerable number of additional outcrops, but the hardness of the material rendered collecting difficult, and the coarseness of the matrix, which obliterated the venation, made the determinations inconclusive. Nowhere, however, did these fragments suggest Claiborne forms, but all were believed to represent well-known upper Wilcox species.

Near the Rio Grande the Carrizo sandstone becomes thin and is overlain by beds showing more typical Wilcox lithology. A section on Concillas Creek a quarter of a mile above its mouth, in Webb County, exposes the following materials:

Sandstone.

Brownish laminated clay with leaves.

Local unconformity.

Ripple-marked sandstone.

Clay parting.

Sandstone with sticks and leaf fragments.

Gray clay.
From the brownish clay above the local unconformity, not far below the Wilcox-Mount Selman contact, the following plants were collected:
Anacardites grevilleafolia Berry.
Banksia puryearensis Berry.
Cassia marshallensis Berry.
Cyperites sp. Hollick.
Inga wickliffensis Berry?
Juglans schimperi Lesquereux.
Mimosites variabilis Berry.
Mimusops mississippiensis Berry.
Myrica wilcoxensis Berry.
Sabalites grayanus Lesquereux.
Sophora wilcoxiana Berry.

From the sandstone two excellent specimens of Canna eocenica Berry were collected. The whole section is clearly upper Wilcox in age.

From Elm Creek on the Schuddemagen ranch, in eastern Uvalde County, considerably above the Cretaceous-Midway contact described by Stephenson, ${ }^{2}$ a single specimen of Rhamnus coushatta Berry was collected. This is a typical upper Wilcox form and suggests that the Midway is unusually thin in this section, which is in conformity with its entire absence on the Nueces.

A systematic account of the new or noteworthy species of plants that have been added to the flora of the Wilcox group and are discussed in the present contribution is given below.

\section{Phylum BRYOPHYTA.}

Class HePATICAE.

Order MARCHANTIALES.

Genus MARCHANTITES Brongniart.

Marchantites stephensoni Berry, n. sp.

Plate IV, figure 1.

Plant body thallose, consisting of a linear, repeatedly dichotomously forked thallus thickened medianly and with somewhat irregularly placed oblique and transverse markings, believed to represent appressed rhizoids.

The material is scanty and of slight botanic importance. Except that the margins are straighter the present form is indistinguishable from Marchantia sezannensis Brongniart, ${ }^{3}$ from

2 Stephenson, L. W., U. S. Geol. Survey Prof. Paper 90, p. 177, 1915

3 Saporta, G. de, Prodrome d'une flore fossile des travertins anciens de Sézanne, p. 308, pl. 1, figs. 1-8, 1868. 
the Paleocene of France, which has the dis- and the pinnules are about 1 centimeter in tinction of having the receptacles preserved length by about 4 millimeters in width at their and therefore being conclusively identified. base. There is in the collection, however, a The present form is also much like Marchantia pealei Knowlton, ${ }^{4}$ of the Fort Union formation of Montana.

Thalloid liverworts are so rarely found in the geologic record that any of them are noteworthy. Similar remains are recorded from several Jurassic and Lower Cretaceous outcrops both in this country and abroad, and several Eocene and Oligocene species have been described.

The present species is named for the collector and comes from the upper Wilcox deposits near Jacksonville, Pulaski County, Ark.

Phylum PTERIDOPHYTA.

\section{ClasS LEPTOSPORANGIATAE.}

Order POLYPODIALES.

Family POLYPODIACEAE

Genus DRYOPTERIS Adamson.

Dryopteris cladophleboides Knowlton.

Plate IV, figures 5-7.

Dryopteris? cladophleboides Knowlton, U. S. Geol. Survey Prof. Paper 101, p. 284, pl. 54, fig. 1, 1918.

Frond pinnate or bipinnate. Pinnae long, linear-lanceolate, divided nearly or quite to the rachis into numerous orate-lanceolate, oblong, or conical obtuse or acutely pointed pinnules, with entire margins. Texture coriaceous. Rachis stout, channeled. Midrib of pinnules stout, diverging from the rachis at angles of about $65^{\circ}$ to $70^{\circ}$, curving slightly upward distad, its course throughout nearer to the proximal margin of the pinnule. The lateral veins are thin and closely spaced; they diverge at wide angles and number about 16 pairs. Those in the tip of the pinnule are simple; the majority are once forked; several basal pairs, particularly on the proximal side of the pinna, pass from a single lateral with two simple branches to a lateral with two dichotomous forks, as shown in the accompanying figure. There is some variation in the shape and degree of separation of the pinnules.

The specimens are five in number, and none aro especially complete. All are sterile. The pinnae were at least 10 centimeters in length,

4 Knowlton, F. H., U. S. Nat. Mus. Proc., vol. 35, pp. 157-159, pl. 25, 1908. tiny specimen showing about 5 millimeters of a similar rachis with the impression of four stout pinnules. These are : slightly smaller than the sterile pinnules but have the same form and confluent bases; the midribs are stout; the lateral veins are thin and fewer than in the sterile pinnules; about halfway between the midrib and the margin each lateral shows the impression of a small; approximately circular and prominent sorus, and these decrease in size distad; there are about six prominent ones in each half of the lamina. Several of the proximal laterals are seen to be forked beyond the sori, but the majority appear to be simple. Although these fertile pinnules are not in organic union with the sterile parts of the frond, their association in a thin stratum at the same outcrop and the further fact that no similar species are known in the whole Wilcox flora make it seem very probable that both belong to the same form, and this conclusion is corroborated by their form and attitude, similar rachis, similar midrib, and lateral veins.

The type material of this species, described by Knowlton, came from the Raton formation of southeastern Colorado. It was very incomplete, with the venation obscured. There seems to be no doubt, however, that the Wilcox occurrence represents the same, species, a type of fern hitherto unknown in the Wilcox flora, in which ferns are unusually scarce.

Both the sterile and fertile pinnules are similar to those of certain species of Alsophila and Cyathea, and they are practically identical with a number of existing species of Dryopteris, as for example Dryopteris concinnum Mettenius, D. molle Swartz, and D. pteroides Swartz. I can see no reason for questioning their reference to Dryopteris.

The genus Dryopteris is a large one in the modern flora, with more than 1,000 species variously segregated or aggregated by students of existing ferns in the genera Lastrea, Nephrodium, Phegopteris, Polybotrya, and Dryopteris. Christensen ${ }^{5}$ unites them all in a single genus divided into 10 subgenera, many of which are entitled to generic rank, as I have pointed out several times in describing Tertiary species of

${ }^{5}$ Christensen, C., On a natural classification of the species of Dryopteris: Saertryk af Biologiske Arbeijdner Tilegnede E. Warming, pp. 73-85, 1911. 
Goniopteris, of which there is a very characteristic form in the Claiborne. ${ }^{6}$ The dryopterids are widely distributed and mainly tropical, although Christensen's subgenus Eudryopteris, with about 100 species, is largely confined to the North Temperate Zone. .

Occurrence: Goss pit, half a mile east of Mansfield, De Soto Parish, La.; collected by O. M. Ball.

\section{Genus ACROSTICHUM Linnê.}

Acrostichum sp.

This characteristic fern genus is represented in the Wilcox by a single fragment, too small for determination or description but showing the areolation of this genus. It is a strand type well represented in the Claiborne, Jackson, and Catahoula of the embayment area, and its unaccountable absence among the strand types in the Wilcox was the occasion for comment in the former discussions of this flora. The present fragment adds this interesting type to the. Wilcox flora and raises the number of fern species known in this flora to eight.

Occurrence: Carrizo sandstone, half a mile west of Carrizo Springs, Dimmit County, Tex.

\section{Phylum CONIFEROPHYTA.}

Order PINALES.

Family TAXODIACEAE.

\section{Genus CUPRESSINOXYLON Goeppert.}

[Monographie der fossilen Coniferen, p. 196, 1850.]

Coniferous wood composed of tracheids and xylem parenchyma only. In the tracheid walls the pits are generally round, bordered, and isolated, in one row; if in two rows the pits stand in adjacent pairs and are not alternating or compressed. Sanio's rims often conspicuous: Normal resin canals entirely absent. Resin containing xylem parenchyma present, generally in large quantities, and scattered all through the wood." Medullary rays uniseriate; a few may be partly biseriate. The cells of the rays all alike, generally smooth-walled, and without abietinean pitting (which is present in a few species); pits in the radial walls of the rays generally circular or oval, simple, small, and in groups of one to six, seldom more, per tracheid field. ${ }^{7}$

Cupressinoxylon wilcoxense Berry, n. sp.

Plates I-III.

Trunks, many of them of large size, preresenting this species are extremely common in

6 Berry, E. W., Torrey Bot. Club Bull., vol. 44, pp. 331-335, pl. 22, 1917.

7 Stopes, M. C., The Cretaceous flora: British Mus. Cat., pt.2, p. 167, 1915. the upper Wilcox sands of Louisiana. They have in general suffered much from decay before silicification, but some specimens are exceedingly well preserved. They are remarkable chiefly for the great variation in the width of the zone of spring wood and the well-marked or almost complete absence of summer wood. Thus in the sections figured the zone of spring wood ranges from 5 or 6 radial rows of tracheids to 23 or 24 rows, while the summer wood consists of 3 or 4 rows. In other specimens, notably two (Nos. 206, 211) from the vicinity of Naborton, La., the spring wood consists of 45 to 70 radial rows of tracheids of uniform size separated by two rows of summer wood in which the size of the tracheids or the cell lumen is so slightly reduced that a seasonal change is scarcely marked. These woods all come from the same horizon, and their variation can not be explained by the well-known differences in the annual rings of upland and lowland forms of the same species of conifers, for it is known that the Wilcox land surface was low, the nearest uplands at that time being in the Rocky Mountain region. It is of course possible that the present species extended its range westward through Colorado and that some of these large trunks may have been brought down from the west by river floods, for at the present time Red River reaches nearly to the New Mexico boundary, and the headwaters of Arkansas River reach the foothills of the Sangre de Cristo Mountains and the Front Range in central and southern Colorado. In general the best-preserved material shows the narrower and more marked growth rings, but both types are found in all stages of decay, so that no reliable conclusions can be drawn.

Transverse section: Growth rings feebly developed or well marked, variable in width in individual specimens. Spring wood of relatively large, thin-walled, mostly isodiametric tracheids and xylem parenchyma, the two elements not distinguishable in this section, arranged in radial rows of 5 to 70 cells, averaging 10 or 12 . Cell outlines round with wide lumen; diameter variable for different radial rows but in general uniform for each row, ranging from 0.025 to 0.975 millimeter. Summer wood consisting of two to four rows of somewhat reduced tracheids with narrower lumen or in some specimens scarcely reduced 
or narrowed and consisting of only one or two rows of cells.

Radial section: Tracheids with one or two rows of mostly well-spaced circular-bordered pits. When in single rows the pits are somewhat larger, and when in double rows the pits are almost invariably in pairs, although occasionally they may alternate for a short distance, as in the specimen figured; usually wellspaced occasional rows are in contact, as shown in the figure. The rims of Sanio are often prominently shown in the sections of the tangential walls. The septate xylem parenchyma is conspicuous in this section, the partitions being at right angles to the walls and from three to four times the diameter or slightly farther apart, usually containing more or less resin. The diameter of the xylem parenchyma is about the same as that of the tracheids but may be slightly greater. It is not excessively abundant, as in some other species of Cupressinoxylon, nor is it generally completely filled with resin. No traumatic or other resin canals are observable. Ray cells uniform in character seem to be radially elongated, with a radial length of $1 \frac{1}{2}$ to 2 tracheid fields and a height about one-fourth their length. End walls smooth (without abietinean pitting), mostly transverse and rarely much oblique; one or more in each ray partly resiniferous; radial walls with two small oval pits per tracheid field; these pits are relatively large for this genus and appear to have their long axis uniformly inclined about $40^{\circ}$ from the vertical.

Tangential section: The distribution and relative abundance and variation in the rays are well shown in the figure of a large area under low magnification (20 diameters). The rays are uniformly uniseriate, of relatively large, thin-walled, roundish quadrangular cells, one or more of which may be resiniferous; they range in height from 2 to 17 cells and consist prevailingly of alternations of rays 2 to 4 cells high with those of rays 6 to 8 cells high. There are rarely four rows of tracheids between adjacent rays, the normal number being two. The xylem parenchyma, as in the radial sections, is generally bordered by rays. The tangential walls of the tracheids are marked with circular-bordered pits about one-half the size of the pits on the radial walls. These pits are usually in a single rov and well spaced, but they may be in juxtaposition for a short distance or in double rows, either in pairs or alternating for short distances, as shown in the enlarged figure. In this section the rotted and spirally fractured walls of the tracheids are very obvious, and care is necessary to distinguish them when in this condition from normal spirally thickened tracheids, which are not present in this genus. In this section the cross sections of the bordered pits of the radial walls of the tracheids often come out beautifully, and they can even be seen in the figure enlarged but 20 times.

This well-marked species is perfectly distinct from Cupressinoxylon calli, described by Knowlton ${ }^{8}$ from material collected in beds of possible Wilcox age in Arkansas. It also appears to be unlike the rather numerous described species of Cupressinoxylon from other horizons or areas. The incompleteness of large numbers of the descriptions of previously known forms renders detailed comparisons futile. The distinction between the present species and those forms of fossil wood referred to the genus Podocarpoxylon Gothan, as amended by Stopes ${ }^{9}$ to inclúde Gothan's Podocarpoxylon and Phyllocladoxylon, are not especially obvious and rest on the size, form, and number of the pits on the radial walls of the ray cells, which are larger, fewer, and more eccentric in Podocarpoxylon. More recently Seward ${ }^{10}$ has proposed the form genus Mesembrioxylon for these. These differences are all relative and hardly generic in character, as a series of species can be selected which connect the extremes.

In the present state of our knowledge of wood anatomy, even among the comparatively well known group of conifers, it is not feasible to attempt to point out the most closely allied existing representative of the present species.

The genera Glyptostrobus and Taxodium are represented by foliage and seeds in the Wilcox, and it may well be that this abundant wood type represents one or the other of these genera.

Occurrence: Caddo and De Soto parishes, La. Figured specimens, northwest corner sec.

8 Knnowlton, F. H., Arkansas State Geologist Ann. Rept. for 1889, vol. 2, p. 254, pl. 9, figs. 3-7, 1891.

${ }^{\circ}$ Stopes, M. C., The Cretaceous flora: British Mus. Cat., pt. 2, p. 210, 1915.

${ }^{10}$ Seward, A. C., Fossil plants, vol. 4, p. 173, 1919. 
36 , a quarter of a mile south of Slaughter Pen Bluff, Caddo Lake (201); Shreveport (210, 269). Other specimens, Slaughter Pen Bluff, Caddo Lake (203); 6 miles sou theast of Naborton (205, $206)$; $4 \frac{1}{2}$ miles southeast of Naborton (216); 4 miles southeast of Naborton (208); 3 miles southeast of Naborton $(209,211) ; 2 \frac{1}{4}$ miles southeast of Naborton (204); 1 mile southeast of Naborton (268); half a mile southeast of Naborton (213); 6 miles southeast of Mansfield (270); $1 \frac{1}{2}$ miles north of Mansfield (266).

\section{Phylum ANGIOSPERMOPHYTA.}

Class MONOCOTYLEDONAE.

Order ARECALES.

Family ARECACEAE.

Genus PALmocarpon Lesquereux.

Palmocarpon butlerensis Berry, n. sp.

Plate IV, figures 2-4.

Fruit apparently a small, thin-fleshed drupe, in form a prolate spheroid-the long diameter less than one-half greater than the short diameter. Varying considerably in size. Surface of the stone dark in color (possibly a secondary feature), conspicuously papillose. Hilum large. Minimum dimensions 4 by 5 millimeters; maximum 14 by 18 millimeters. Abundant but generally slightly deformed. Specific name in allusion to the name of the salt dome from which the material was collected.

This form is very similar to Palmocarpon truncatum, from Golden, Colo., described by Lesquereux in 1878 and supposed to have come from the Denver formation. There is the same variation in size in both, and although Lesquereux makes the flattening of the Golden specimens a specific character this is of doubtful validity, as he states that the specimens were generally crushed. I would have referred these Wilcox fruits to Palmocarpon truncatum except for the definite and repeated statement by Lesquereux that the Golden form was smooth, which the Wilcox form is not. In any event the two are closely, related. Lesquereux ${ }^{11}$ compared the Golden forms with the fruits of the existing Sabal mexicana Martius, and similarly the Wilcox fruits may be those of Sabal. Leaves of Sabalites grayanus Lesque"L Lesquereux, Leo, The Tertiary flora: U. S. Geol. Survey Terr. Rept., vol. 7, p. 120, pl. 11, figs. 6-9, 1878. reux are widespread in the Wilcox, but they are not conclusively known to be related to Sabal. Moreover, very many modern palms have racemes of small fruits very similar to the present fossils. To mention but a few familiar existing species with fruits very close to the fossil I may cite our dwarf saw palmetto, Serenoa serrulata (Michaux) Hooker; the royal palm, Roystonea regia (H. B. K.) Cook; the goose-neck palmetto, Sabal etonia Swingle; and the cabbage palmetto, Sabal palmetto (Walter) Roemer and Schultes.

Occurrence: Butler salt dome, 6 miles northeast of Oakville, Freestone County, Tex.; 4 miles southwest of Boydsville; Ark.; Carrizo sandstone half a mile west of Carrizo Springs. Dimmit County, Tex.

\section{Class DICOTYLEDONAE.}

Order URTICALES.

Family MORACEAE.

Genus ARTOCARPOIDES Saporta.

Artocarpoides balli Barry, n. sp.

Plate IV, figures 8-10; Plate V.

Leaves of variable size, ovate, with a broadly rounded base, which is sometimes slightly inequilateral, and a narrowed and apiculate tip. Margins entire, slightly undulate. Texture subcoriaceous. Petiole invariably missing. Midrib stout, very prominent on the lower surface of the leaf. Secondaries stout and prominent, 9 to 15 pairs, opposite to alternate, approximately equally spaced and subparallel, the basal one or two pairs at right angles to the midrib, becoming regularly more ascending toward the upper part of the leaf, relatively straight at first, becoming curved in the marginal region and eventually camptodrome close to the margins. Tertiaries well marked, closely spaced, percurrent. Areolation well marked, quadrangular.

The smallest leaves referred to this species are only 4 centimeters in length and 2 centimeters in maximum width; the largest is 24 centimeters in length and 10 centimeters in maximum width. There are six specimens of various sizes in the collection, and all preserve their specific features unchanged. The type is well marked and clearly different from previously described members of the Wilcox flora. A species from Puryear, Tenn., was 
described as Artocarpoides wilcoxensis. ${ }^{12}$ This was more elliptical in outline, widest medianly and pointed at both ends, with fewer, thinner secondaries, less closely set tertiaries, and more open areolation.

The genus Artocarpoides was founded by Saporta for certain forms from the Paleocene of Sezanne, France, that he compared with the oxisting entire-leafed species of Artocarpus, which they really greatly resemble. Schenk ${ }^{13}$ considered them to be related to the Juglandaceae, but I fail to see any basis for this comparison. Among the French forms a considerable resemblance to the present species is shown by Artocarpoides conocephaloidea Saporta, ${ }^{14}$ a relatively small form, and a very great resemblance by Protoficus sezannensis Saporta ${ }^{15}$ and $P$. insignis Saporta. ${ }^{16}$ Among existing forms of Moraceae considerable resemblance is also shown by the tropical American genus Brosimum Swartz, which ranges from the West Indies and Central America to Brazil, and the tropical American genus Coussapoa Aublet, which has about 15 existing species with a similar range and which is found fossil in the Tertiary of Venezuela, southern Mexico (Miocene and Pliocene), and Bolivia. For example, the present species resembles a tropical American leaf figured by Ettingshausen and called Artocarpus rigida Linné. Whether Ettingshausen confused the oriental Artocarpus rigida of Blume or whether his leaf was an Ameriean species of Coussapoa or some related genus I do not know, nor is it material, for in any case the resemblance between the fossil and certain recent Moraceae is emphasized.

It is possible that these Wilcox forms are more closely related to these last-named genera than they are to Artocarpus, but they are surely referable to the Moraceae.

The present species is named for the collector, Prof. O. M. Ball.

Occurrence: Goss pit, half a mile east of Mansfield, De Soto Parish, La.; collected by O. M. Ball.

12 Berry, E. W., U. S. Geol. Survey Prof. Paper 91, p. 194, pl. 109, fig. $5,1916$.

1a Schonk, August, Palaeophytologie, pp. 451, 477, 1890

14 Snporta, C. de, op. cit., p. 68, pl. 7, fig. 6, 1868 .

15 Idom, p. 67, pl. 6, fig. 1 .

${ }^{18}$ Idom, p. 68 , pl. 6, flgs. 2-4.
Genus FICUS LINNNÉ.

Ficus mississippiensis (Lesquereux) Berry.

Plates VI, VII, and VIII.

Cinnamomum mississippiensis Lesquereux, in Dana, Manual of geology, 1st ed., p. 513, fig. 794, 1866; Am. Philos. Soc. Trans., vol. 13, p. 418, pl. 19, fig. 2, 1869.

Knowlton, Am. Geologist, vol. 16, p. 308, 1895; U. S. Geol. Survey Prof. Paper 101, p. 320, pl. 89, fig. 2, 1917.

Berry, U. S. Geol. Survey Prof. Paper 91, p. 298, pl. 37, fig. 2, 1916.

Ficus planicostata Lesquereux, U. S. Geol. and Geog. Survey Terr. Ann. Rept. for 1872, p. 393, 1873; Tertiary flora, p. 201, pl. 31, figs. 1-8, 10-12, 1878.

?Newberry, U. S. Geol. Survey Mon. 35, p. 88, pl. 46, fig: $1,1898$.

Cockerell, Colorado Univ. Studies, vol. 7, p. 151, 1910.

Ficus clintoni Lesquereux, U. S. Geol. and Geog. Survey Terr. Ann. Rept. for 1872, p. 393, 1873.

Ficus planicostata goldiana Lesquereux, idem for 1873 , p. 399, 1874; Tertiary flora, p. 202, pl. 33, figs. 1-3, 1878.

Ficus pseudopopulus Lesquereux, U. S. Geol. and Geog. Survey Terr. Bull., vol. 1, p. 387, 1875; idem, Ann. Rept. for 1874, p. 313, 1876; Tertiary flora, p. 204, pl 34, figs. la, 2 .

Berry, U.S. Geol. Survey Prof. Paper 91, p. 200, pl. 37, figs. 3-5; pl. 113, fig. 3, 1916.

Knowlton, U. S. Geol. Survey Prof. Paper 101, p. 304, pl. 72, figs. 2-4; pl. 73, figs. 1, 2; pl. 112, fig. 3, 1918.

Ficus occidentalis (Lesquereux) Lesquereux, Tertiary flora, p. 200, pl. 32, fig. 4, 1878; Mus. Comp. Zool. Bull., vol. 16, p. 50, 1888.

Penhallow, Report on Tertiary plants of British Columbia, p. 55, 1908.

Berry, U. S. Geol. Survey Prof. Paper 91, pp. 121, 197, pl. 28, fig. 3, 1916.

Knowlton, U. S. Geol. Survey Prof. Paper 101, p. 331, pl. 72, fig. 1, 1918 .

Dombeyopsis occidentalis Lesquereux, U. S. Geol. and Geol. Survey Terr. Ann. Rept. for 1872, p. 380, 1873.

Ficus planicostata clintoni Knowlton, U. S. Geol. Survey Bull. 152, p. 103, 1898; U. S. Geol. Survey Prof. Paper 191, p. 303, pl. 76, fig. 3, 1918.

Ficus planicostata latifolia Lesquereux, U. S. Geol. and Geog. Survey Terr. Ann. Rept. for 1872 , p. 393, 1873; Tertiary flora, p. 202, pl. 31, fig. 9, 1878.

Berry, U. S. Geol. Survey Prof. Paper 91, p. 199, 1916.

Ficus latifolia Knowlton (not Kunth, 1846), U. S. Geol. Survey Bull. 152, p. 102, 1898; U. S. Geol. Survey Prof. Paper 101, p. 304, 1917.

Ficus cockerelli Knowlton, U. S. Geol. Survey Bull. 696, p. $273,1919$.

Ficus planicostata max̌ima Berry, U. S. Geol. Survey Prof. Paper 91, p. 199, pl. 34, fig. 3, 1916.

Ficus planicostata Lesquereux. Hollick, Louisiana Geol. Survey Special Rept., p. 282, pl. 36, 1888. 
Ficus neoplanicostata Knowlton, U. S. Geol. Survey Prof. Paper 101, p. 303; pl. 73, fig. 4; pl. 74, figs. 2, 3; pl. 76, fig. 4, 1918.

Berry, U. S. Geol. Survey Prof. Paper 91, p. 198, pl. 114, fig. 1, 1916.

Ficus richardsoni Knowlton, U. S. Geol. Survey Prof. Paper 101, p. 305, pl. 76, fig. 1, 1918.

It would seem that if the systematic work of paleobotany is to be made available for the general purposes of geology and botany the paleobotanist must take the time to coordinate and digest the results of the work on local floras. There are certain general principles that should guide workers in founding new species, and I am thoroughly in accord with the principle which holds that analysis should precede synthesis, and that in describing specimens from a new horizon or a remote geographic locality the presumption should prevail that they are distinct from previously described forms unless identity can be conclusively shown. Likewise there are certain forms in a different category, long known and hence not susceptible of this treatment-for example, Podozamites lanceolatus, Asplenium dicksonianum, or Sequoia reichenbachi-which are obviously composite and yet which do not offer any criteria for segregation other than those of a stratigraphic nature. These forms may well remain as they are until the progress of knowledge enables the paleobotanist to treat them in a scientific manner.

In a recent study of a large and well-preserved collection from the Wilcox near Mansfield, La., I have been profoundly impressed with the graded variability in the leaves of certain genera, particularly Ficus and Rhamnus. In my report on the flora of the Wilcox group, published in 1916, 18 different species of Ficus were recognized, and in Knowlton's recently published report on the flora of the Raton formation 17 species of Ficus are recognized. In both works the comparisons made appear legitimate, but in neither, apparently, had the broader question of interrelationship in the genus received adequate consideration. To revert to the representation of Ficus in the Wilcox flora: Of the 18 identified forms a reexamination appears to confirm the validity of 13 beyond question. The remaining five species, which were identified as. Ficus neoplanicostata, pseudopopulus, planicostata maxima, occidentalis, and denveriana, represent ovate types with three basilar or subbasilar primaries and percurrent tertiaries. As sparingly represented in the original collections each showed a certain individuality, but in the later collection, where they are abundant, they show every gradation in size and in the ratio of width to length.

I do not consider it possible to maintain specific boundaries in this series, although the extremes of size or of short-elliptical or long and narrow ovate-acuminate outline are strikingly different in aspect.

This polymorphism, or better termed variability, led to the assembling of all the published figures of the so-called species enumerated in the foregoing synonymy. It was found that these forms had been described at different times by different workers and that the criteria of separation were as follows:

1. Size

2. Relative proportions of width to length.

3. Shortening or lengthening of the apex.

4. Character of base ranging from various degrees of cuneate through truncate to slightly cordate.

5 . Number and spacing of the secondaries.

6. Position of the primaries, whether basilar, subbasilar, or suprabasilar.

In all the species the general facies and tertiary venation remain identical throughout. It might be argued that these represent generic features and that the foregoing criteria of separation are legitimate specific features. It may be noted, however, that most of the features enumerated above are interrelated and dependent upon the proportions of the leaves, and it may also be noted that leaves which are normally large at maturity reach that normal size by growth, so that mere smallness is not a specific character. Howerer, I will not quarrel with my colleagues who prefer to keep the species listed in the foregoing synonymy distinct-the relationships sketched below hold good, whatever categories are used. Some will doubtless incline to consider them varieties of a single botanic species, but I can only think of them as varieties in the praenuntial or formative state, with the intermediate steps not yet extinct, and it seems to me that all could probably have been found on a single lower Eocene tree. Were they ever found unassociated there might be some justification for maintaining their distinctness, but wherever adequate col- 
lections are available, whether it be from the Denver formation, the Raton formation, or the Wilcox group, all or nearly all the forms are found associated in the same stratum. Fifteen to twenty species of a single genus do not grow together in nature.

If these forms are considered to represent a single variable species, then the earliest name available is mississippiensis, given by Lesquereux to what he regarded as a species of Cinnamomum. It is true that this form was rather small in size, but the type is no longer in existence and the later material identified as this species is larger. For example, the form so named in the Raton flora is identical with the associated forms referred to Ficus pseudopopulus. The type of this last-mentioned species was also based on small forms, which do not, however, differ in any essential respect from the larger leaves later determined, and the maximum of size and elongation is furnished by the forms from the Wilcox figured in the present contribution. I have not included Ficus denveriana in the foregoing synonymy, as it prevailingly lacks the three primaries and is pinnate veined. However, certain specimens so called appear to belong here, as, for example, the specimen shown in figure 5 on Plate XXXIII of Lesquereux's "Tertiary flora." mississippiensis would be the transformation of the basal secondaries into lateral primaries. As triveined forms of Ficus are not uncommon in the Upper Cretaceous the ancestral stock of Ficus mississippiensis may go back to some such form as Ficus ovatifolia Berry, of the Coastal Plain Cretaceous, or Ficus praetrinervis Knowlton, of the Vermejo formation; and Ficus denveriana may be unrelated or else represent the transformation of lateral primaries into basal secondaries.

Discussion may be eliminated by presenting the supposed interrelationship diagrammatically in terms of the specific names of the above synonymy, as follows:

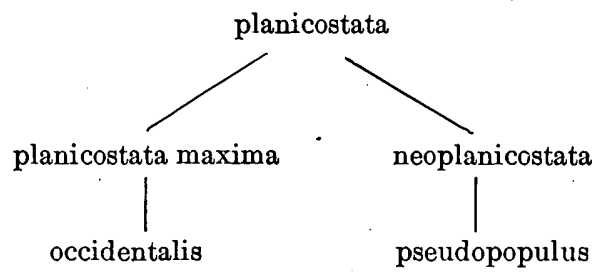

The maxima of these two lines of variation are shown in the accompanying figures, and no detailed description of them is regarded as necessary. A statement regarding the recorded geographic and geologic range of the species may not, however, be out of place. This may be presented in tabular form, as follows:

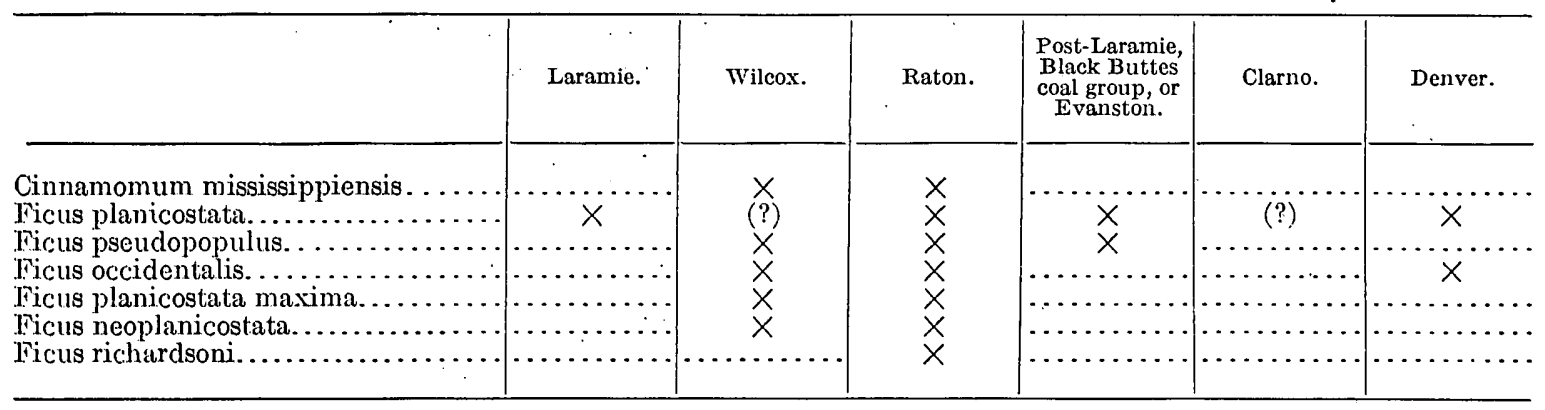

Ficus planicostata Lesquereux represents variants with a foreshortened apex, although the smaller leaves of this-so-called species as figured by Lesquereux are indistinguishable from the small leaves. of Ficus neoplanicostata figured by Knowlton.

If the central stock of this variable species is considered to have been an elliptical-ovate penniveined form similar to the typical Ficus denveriana Cockerell or to the young leaves referred to Ficus neoplanicostata, then the assumption of the specific character of Ficus
It may be noted that only one of these species, namely, $F$. planicostata, is recorded from a pre-Tertiary horizon, and that all are found associated in both the Wilcox and Raton floras, Ficus richardsoni Knowlton of the Raton not being an exception to this statement, for it is obviously identical with Ficus pseudopopulus. Occurrences in the Wilcox range throughor:t. the group and are as follows:

Ackerman formation: Raglans Branch, Lafayette County, Miss.; Colemans Mill, Choctaw County, Miss.; Hurleys, Benton County, Miss. 
Upper Wilcox: Shreveport, Caddo Parish, La.; Mansfield, Naborton and vicinity, De Soto Parish, La.; Old Port Caddo Landing, Harrison County, Tex.; Elmendorf clay pit, Elmendorf, Bexar County, Tex.; Carrizo sandstone half a mile west of Carrizo Springs, Dimmit County, Tex.

Lagrange formation (middle and upper Wilcox age): Puryear, Henry Co'ınty, Tenn.; Sandy, Hardeman County, Tenn.

\section{Order RANALES.}

Family MagnoliaceaE.

Genus MaGNolia Linnê.

Magnolia angustifolia Newberry.

Plate IX.

Magnolia angustifolia Newberry, U. S. Nat. Mus. Proc., vol. 5 , p. 513, 1882.

Berry, U. S. Geol. Survey Prof. Paper 91, p. 214, 1916.

Knowlton, U. S. Geol. Survey Prof. Paper 101, p. 309, pl. 79, fig. 1; pl. 80; pl. 81, fig. 1, 1917.

Magnolia attenuata Weber. Lesquereux, Tertiary flora, p. 250 , pl. 45 , fig. $6,1878$.

Terminalia radobojensis Heer (not Ungèr). Lesquereux, U. S. Geol. and Geog. Survey Terr. Ann. Rept. for 1871, Suppl., p. 15, 1872.

Magnolia lanceolata Lesquereux. Hollick, Louisiana Geol. Survey Special Rept. 5, p. 282, pl. ii, 1899.

This species, which is common in the Raton formation and in the upper part of the Wilcox group, is much more common west of the Mississippi than east of it. A specimen from Louisiana is figured in the present paper.

Occurrence: Goss pit, half a mile east of Mansfield, De Soto Parish, La.; collected by O. M. Ball.

\section{Magnolia leei Knowlton.}

Plate X.

Magnolia leei Knowlton MS. Berry, U. S. Geol. Survey Prof. Paper 91, p. 215, pl. 43, figs. 1, 2, 1916.

Knowlton, U. S. Geol. Survey Prof. Paper 101, p. 313, pl. 64, fig. 2; pl. 65, fig. 2 ; pl. 81, fig. 2, 1918.

This well-marked species, which is abundant in the Raton formation in Colorado and New Mexico, appears to range from the bottom to the top of the Wilcox group in the embayment region. It has not heretofore been found in that region west of the Mississippi but proves to be not uncommon in Louisiana.

Occurrence: Goss pit, half a mile east of Mansfield, De Soto Parish, La.; collected by O. M. Ball.
Family MENISPERMACEAE.

。Genus MENISPERMITES Lesquereux.

Menispermites cebathoides Berry, n. sp.

Plate XI, figure 1.

Leaves orbicular-ovate, about as wide as long, with a wide truncate base and a broadly and shortly pointed apex. Margins entire. Texture thin. Length about 10 centimeters; maximum width, below the middle, about 10 centimeters. Petiole missing, but from the character of the base it must have been of considerable length and expanded where it joined the lamina; the joint was at an angle with the plane of the lamina. There are 7 primaries from the widely expanded apex of the petiole at the extreme base of the leaf. These diverge at acute regularly spaced angles; all are curved, and the midrib is slightly, if at all, stouter than the lateral primaries. It is longer, however, and at about one-third of its distance to the apex it gives off, at acute angles, a pair of opposite secondaries, which sweep upward and are camptodrome in the tip of the leaf. The lateral primaries are all stout and prominent and decrease in length from above downward. The basal, shortest, and straightest pair form angles of about $70^{\circ}$ with the midrib; they give off on the outside three or four regularly spaced secondaries, which are camptodrome close to the margin; the tip joins the tip of the basal secondary of the primary next above by a simple camptodrome arch close to the margin. The second pair of primaries form angles of about $50^{\circ}$ with the midrib; they are longer and slightly stouter than the basal pair and slightly more curved, but less so than the third pair of primaries; they give off on the outside two to four regularly spaced stout secondaries, which are camptodrome close to the margin; their tip joins a simple camptodrome tertiary from the lowest secondary of the third primary by a simple camptodrome curve close to the margin. The third pair of primaries form angles of about $25^{\circ}$ with the midrib; they are more curved than the others and give off on the outside four or five regularly spaced secondaries, which are simply camptodrome close to the margins and the basal one of which may have the caliber and appearance of a dichotomous fork of the primary, as in the left side of the leaf figured; the tip of the third primary 
surves close to the margin to join a camptodrome tertiary from the outside of the main pair of secondaries from the midrib. The tertiaries, with the exception of the camptodrome ones already alluded to, are thin and largely immersed, exceedingly regular in their spacing, and prevailingly percurrent, although they occasionally fork and inosculate, as shown in the figured specimen. The ultimate areolation is fairly distinct in spots and must have been entirely so in life; it shows relatively large and prevailing subrectangular meshes.

This fine species is obviously new and forms a striking addition to the Wilcox flora, as its modern relatives are all climbing or twining herbs or shrubs prevailingly of wooded or stream-side habitats. It is similar in form to the Wilcox species Cercis wilcoxiana Berry but entirely different in its venation characters and obviously not related to that form. The previously known Wilcox species of Menispermites, M. wilcoxensis Berry, is a much more typically ovate form with a prolonged acuminate tip and but three instead of seven primaries. The tertiary venation and the camptodrome arches close to the margins are the same in both, and neither shows the tendency toward a lobation of the lamina, which is so pronounced a feature in so many of the existing species of this family.

The existing species are too imperfectly known and polymorphous to render detailed comparisons with this Eocene form of much value. The fossil is not unlike the leaves of our common Menispermum canadense Linné, which are nonlobate. It shows a similar resemblance to the leaves of our common Cebatha carolina (Linné) Britton, which are nonlobate, and similar statements might be made with regard to a large number of existing species of the family. Among fossil forms the most similar is Cocculus (Cebatha) latifolius, from the Pliocene of France, described by Saporta and Marion, ${ }^{17}$ but this similarity is of the same order as the comparisons with recent forms just mentioned.

The polymorphism of the existing species renders it desirable to refer this new form to the genus Menispermites, implying a fossil form of Menispermaceae of undeterminable generic affinity. It might very well be ancestral to the

17 Saporta, G. de, and Marion, A. F., Recherches sur les végétaux fossiles do Moximicux, p. 264, pl. 31, figs. 4-7; pl. 32, fig. 1, 1876. $91048^{\circ}-23-2$

genus Cocculus De Candolle, or Cebatha Forskal, as modern taxonomists prefer to call it, as Forskal's name was published in 1775 , or 43 years earlier than De Candolle's proposal.

The existing species of Menispermaceae number about 350 in about 60 genera. All are twining or climbing woody or herbaceous plants with alternate exstipulate leares and drupaceous fruits. A majority of the species are confined to moist tropical regions, but a considerable number are found in both temperate zones. None of the subfamilies are confined to a single continental region, and several of the genera are found on all the continents.

The existing species of Menispermum, but two or three in number, are confined to Atlantic North America and eastern Asia, which indicates a wider range during geologic time. The genus Cebatha (Cocculus) is a large one for this family, with about 30 species, its distribution including all the continents except Europe and extending to the Hawaiian Islands. Sereral fossil species that have been referred directly to it or to the form genus Cocculites go back as far as the Upper Cretaceous. A wellmarked species is present in the later Tertiary of the Mississippi embayment, and it would perhaps not be far from the truth if the present species were referred to this genus.

The family has 10 genera with about 75 species confined to the Western Hemisphere, mostly in tropical South America. Asia has 13 peculiar genera; Africa, including Madagascar, has 14; and Australia has 7, all monotypic and largely found in the peculiar environment of Western Australia. The largest number of existing species occur in tropical Asia, from which about 150 are known, or about 50 more than are known from America, which ranks second in the number of existing forms.

The fossils of the narrow triveined form of some species of Cocculus (Cebatha) are rather difficult to determine, for they show more or less resemblance to some leaves in the families Smilacaceae, Lauraceae, Urticaceae, Piperaceae, Melastomataceae, and others.

The wider leaves are more characteristic, and species of Menispermum are recorded from beds as early as the Oligocene of France. The form genus Menispermites has numerous Upper Cretaceous species, particularly of Cenomanian and Turonian age, and is recorded 
from Portugal, Bohemia, Greenland, Argentina, and various locailities in the United States and Canada. It is especially varied in the Dakota sandstone.

Forms referred to Cocculus De Candolle, Cocculites Heer, or Cebatha Forskal are recorded from the Upper Cretaceous of North America, Europe, and Asia and from the early Tertiary of Greenland, North America, and Europe. It seems probable that some of the forms referred to Unger's genus Daphnogene belong to this family. The genus Macclintockia. Heer, of the Upper Cretaceous and early Tertiary, particularly of the Arctic region, is often referred to this family, as by Schimper.

Occurrence: Goss pit, half a mile east of Mansfield, De Soto Parish, La.; collected by O. M. Ball.

\section{Order ROSALES.}

\section{Family CAESALPINIACEAE.}

Genus CASSIA Linne.

Cassia emarginata Berry.

Cassia emarginata Berry, U. S. Geol. Survey Prof. Paper 91 ; p. 233, pl. 45, fig. 17b; pl. 48, fig. 5, 1916.

Heer ${ }^{18}$ mentions a Cassia emarginata of Saporta, which would, if valid, necessitate changing the name of this Wilcox species. As near as I can discover, however, Cassia emarginata Saporta was a nomen nudum. It is not mentioned by either Schimper or Schenk, and Saporta appears to have renamed the form Caesalpinites latifolius when he actually described it. ${ }^{19}$

\section{Family MUMOSACEAE.}

\section{Genus MIMOSITES Bowerbank.}

\section{Mimosites variabilis Berry.}

Mimosites variabilis Berry, U. S. Geol. Survey Prof. Paper 91 , p. 227, pl. 45, figs. 6-11, 1916.

This common middle and upper Wilcox species has not heretofore been found south of Grenada, Miss. It is contained in recent collections from a locality 1 mile west of Clayhatchee, Dale County, Ala.

18 Recherches sur le climat et la végétation du pays tertiaire, p. 149, 1861.

${ }_{19}$ 'Saporta, G. de, Ettudes sur la végétation du sud-est de la France à l'époque tertiaire, vol. 1, p. 140, 1863.
Family PAPILIONACEAE.

Genus DALBERGIA Linné fils.

Dalbergia puryearensis Berry, new name.

Dalbergia eocenica Berry, U. S. Geol. Survey Prof. Paper 91, p. 245, pl. 53, figs. 1, 2, 1916.

The name assigned to this Wilcox Dalbergia in 1916 is antedated by Dalbergia eocenica Ettingshausen, ${ }^{20}$ based on Protamyris eocenica Unger, ${ }^{21}$ and I therefore propose that this species be called Dalbergia puryearensis, in allusion to the type localit $\bar{y}$.

Order SAPINDALES.

Family ICACDNACEAE

Genus CALATOLOIDES Berry, n. gen:

Calatoloides eocenicum Berry, n. sr

Plate XIV, figures 3-5.

The present species is based on casts of a nutlike fruit which appears to be very close to those of a recently described genus that is referred with some doubt to the family Icacinaceae and is based upon three new species of existing arborescent forms of the Central American region. In view of the incompleteness of the fossil material and the lack of certainty as to its identity with the recent fruits in all particulars, it has seemed best to propose a new genus for its reception. The name suggested for this new genus implies a relationship with the existing genus. The fossil fruit as restored from casts is a moderately prolate spheroid, 2.5 to 3 centimeters in length and about 2.25 centimeters in diameter, broadly rounded proximad and bluntly pointed distad. The ligneous shell is marked by somewhat irregular prominent branching and anastomosing longitudinal ridges, connected by low subordinate irregularly transverse ridges. If it was like the existing form it contained a single large seed.

I have had this Wilcox material in my possession for a number of years without any idea as to its botanic relationship. In collecting recent fruits in Panama in 1919 I obtained one which suggested the fossil. In seeking to determine the Panama specimen at the United

20 Ettingshausen, Constantin, Beiträge zur Kenntniss der fossilen Flora von Sotzka, p. 73, 1858 .

21 Unger, Franz, Die fossile Flora von Sotzka, p. 180, pl. 31, fig. 15, 1850 . 
States National Herbarium I found that it was identical with material from Costa Rica which Messrs. Standley and Safford considered to represent a new genus, very probably a member of the Icacinaceae. They have since recognized three species of this genustwo from Mexico and one from Costa Rica and Panama. These are trees of considerable size, with broadly lanceolate camptodrome-veined leaves. The fruits have a thin flesh in life and a single large spherical seed. The fossil form is similar in shape and ornamentation but is only about half the size of the recent fruits and may therefore be considered as standing in an ancestral relation to the modern genus, for which Standley and Safford have proposed the name Calatola.

The occurrence of a fossil representative of the family Icacinaceae in the lower Eocene of Texas is of very great interest. No member of the family, so far as I know, has ever before been found fossil. The family consists of about 39 genera and 150 existing species, of which only 8 genera, with less than 30 species, are found in America, where they are for the most part confined to the Tropics. None of these genera except Mappia, a native of the Antilles, occurs in any other geographic region, and this genus is supposed to be represented in Ceylon and farther India. As the forms from farther India constitute the subgenus Trichocrater and those from Ceylon the subgenus Eumappia, it seems doubtful if Mappia is really an exception to the peculiar character of the existing American members of this family. The family as a whole is distinctly oriental in the existing flora, with its center of dispersal in the south Asian region, for although there is only a single monotypic genus confined to southeastern Asia, this region pairs with Africa, the East Indies, or Australia in many occurrences: thus there are 8 genera with 23 species which are Malaysian, 6 genera with 34 species which are Asian and Malaysian, 3 genera with 19 species which are common to Africa and southern Asia, and 1 genus with 4 species common to Malaysia and Australia. Ten genera with 33 species are confined to Africa, and 3 genera with 6 species are confined to Australia.

The family contains 10 monotypic generaone of Guiana and all the remainder Old World forms, as follows: Africa 3, southeastern Asia 1,
East Indies 2, New Guinea 1, New Caledonia 2. All the existing American forms belong to the large subfamily Icacinoideae, which is also represented in all the other regions, so that its origin or interrelationships are unknown.

Occurrence: Butler (West Point) salt dome, in the eastern part of Freestone County, near Trinity River, 6 miles northeast of Oakville, Tex.; collected by O. B. Hopkins and O. C. Funderbunk.

\section{Order RHAMNALES.}

Family RHAMNACEAE.

Genus Rhamnus Linné.

Rhamnus cleburni Lesquereux.

Rhamnus cleburni Lesquereux, U. S. Geol. and Geog. Survey Terr. Ann. Rept. for 1872, p. 381, 1873; Tertiary flora, p. 280, pl. 53, figs. 1-3, 1878; U. S. Nat. Mus. Proc., vol. 11, p. 24, 1888.

Knowlton, U. S. Geol. Survey Bull. 204, p. 80, 1902.

Berry, U. S. Geol. Survey Prof. Paper 91, p. 283, 1916.

The present material, which is abundant, emphasizes the great similarity and possible identity between this form and Rhamnus coushatta. Berry, ${ }^{22}$ also the great variability in outline of these leaves, many of which are longer and relatively narrower than the type and show indications of grading into what I have called Rhamnus marginatus apiculatus. ${ }^{23}$

Occurrence: Goss pit, half a mile east of Mansfield, De Soto Parish, La.; collected by O. M. Ball.

\section{Rhamnus marginatus apiculatus Berry.}

Plate XI, figures 2, 3 .

Rhamnus marginatus apiculatus Berry, U. S. Geol. Survey Prof. Paper 91, p. 283, pl. 69, fig. 1, 1916.

At the time of the publication of the report on the Wilcox flora this variety was represented by a small number of specimens from the Ackerman formation of Mississippi. It is common in later collections from Louisiana and shows considerable variation in size and outline. All the specimens are somewhat narrower than the type; some have a very long acumen and others lack a prominent acumen. Two of these specimens are figured, the larger a leaf 21 centimeters in length and 4 centimeters in maximum width.

${ }_{22}$ Berry, E. W., U. S. Geol. Survey Prof. Paper 91, p. 284, pl. 68, fig. 1; ${ }^{93}$ Idem, p. 283, pl. 69, fig. 1. 
Occurrence: Goss pit, half a mile east of Mansfield, De Soto Parish, La.; collected by O. M. Ball.

Genus RHAMNITES Fortes.

Rhamnites knowltoni Berry, new, name. Plate XII, figure 7.

Cornus studeri Lesquereux, U. S. Geol. and Geog. Survey Terr. Ann. Rept. for 1871, p. 293, 1872 (not Heer, 1859); Tertiary flora, p. 244, pl. 42, figs. 4, 5, 1878.

Hollick, in Harris and Veatch, A preliminary report on the geology of Louisiana, p. 286, pl. 45, fig. 2, 1899.

Knowlton, U. S. Geol. Survey Bull. 163, p. 68, pl. 15, fig. 3,1900 .

Berry, U. S. Geol. Survey Prof. Paper 91, p. 331, pl. 68 , fig. 3, 1916 .

In the account of the Wilcox flora this species was said to be represented by fragments from a number of localities, the most complete specimen being the one figured from Coushatta, La. Subsequent collections show that this form is abundant in the Wilcox near Mansfield and confirm the previous statement that it differs from Heer's Swiss Miocene type and also is not properly referable to the genus Cornus. Although in some of the features it is similar to species that have been referred to Ficus, these features are not like any in existing forms of that genus, where the venation has certain characteristics that are easily recognized. They are, on the other hand, characteristic of certain members of the families Sapindaceae and Rhamnaceae, particularly the latter, and I have therefore transferred the American forms to the genus Rhamnites.

R. knowltoni may be described as follows:

Leaves large, broadly ovate, many of them slightly inequilateral, the tip somewhat narrowed and acuminate and the base rounded or very broadly pointed. Margins entire, in some specimens faintly undulate. Texture subcoriaceous. Midrib stout and prominent. Secondaries stout, six to nine pairs, diverge from the midrib at irregular intervals at angles of about $45^{\circ}$, camptodrome. Tertiaries thin, closely spaced, percurrent, typically rhamnaceous. Size variable, some leaves being as much as 19 centimeters in length and 9.5 centimeters in maximum width, which is in the lower half of the leaf. A large specimen from Mansfield is figured in the present paper. The single Louisiana specimen has a length of 16 centimeters and a maximum width, midway between the apex and the base, of 8.75 centimeters.
Occurrence: Goss pit, half a mile east of Mansfield, De Soto Parish, La.; collected by O. M. Ball.

\section{Order MaLVales.}

Family MALVACEAE?

Genus MONOCARPELLITES Perkins.

[Vermont State Geologist Rept. for 1903-4, p. 180.]

Monocarpellites perkinsi Berry, n. sp.

Plate XII, figures 1-6.

Ligneous single-celled carpels, with numerous seeds. General form spheroidal; whether oblate or prolate is uncertain, as the material has suffered much compression. Probably nearly spheroidal in life, with 10 to 12 thin longitudinal ribs. Apex mucronate-tipped. Hilum large depressed, about 2 millimeters in diameter.

This species is not uncommon at the locality cited, but it is impossible to determine the character of the interior. The conclusion that the ribs do not represent keels or sutures of a tardily dehiscent capsule rests upon their somewhat unequal spacing, the lack of any traces of sutures, and the fact that one specimen has undergone great compression in a vertical plane without developing any indications of a capsular nature. The conclusion that these carpels were many seeded also rests upon the manner in which compression has occurred and the resulting irregularities of surface, which differ from what would be shown if one or a few large seeds had been present.

The genus Monocarpellites, to which the present species is referred, is a form genus established by Perkins in 1904 and based upon abundant material from the Eocene lignite deposits at Brandon, Vt. Specimens of Monocarpellites are among the most abundant fossils at Brandon, and Perkins has described 11 different species based upon differential features that are more or less well marked but quite obviously not of specific grade. Although the Wilcox Monocarpellites resembles several of these so-called species from the Brandon lignite it can not be conclusively identified with any one of them, so that in the present unsatisfactory state of our knowledge of fossil fruits it must necessarily be considered to represent a new species.

In this connection attention should be called to the genus Hightea, which was described by 
Bowerbank ${ }^{24}$ from the abundant pyritized fruits found in the London clay of Sheppey (Ypresian). As elucidated by Bowerbank the genus Hightea possessed a one-celled valveless pericarp with large 4 to 6 angled placena and numerous down-bearing seeds, these fruits having every appearance of being five or more numerously valved capsules. Hightea is very abundant at Sheppey, and Bowerbank described no less than 10 so-called species, which are subject to the same limitations as Perkins's numerous species of Monocarpellites.

Although it is impossible to advance conclusive opinions without having studied a large suite of specimens, it seems probable that Hightea and Monocarpellites are congeneric, thus affording an important item for the correlation of these three widely separated deposits, valuable chiefly for the evidence it affords of the age of the Brandon lignite, as the parallelism between the London clay and the Wilcox is already well established.

Occurrence: Spink's clay pit, near Paris, Henry County, Tenn.

\section{Family STERCULIACEAE.}

Genus STERCULIa Linne.

Sterculia wilcoxensis Berry, n. sp.

Plate XIV, figures 1., 2; Plate.XV, figures 3, 4.

Sterculia puryearensis Berry, U. S. Geol. Survey Prof. Paper 91, pl. 72, fig. 3 (not other figures of this species), 1916.

Leaves (in discovered material) trilobate, divided from one-half to two-thirds of the distance to the base into a median conical to slightly ovate lobe and lateral, somewhat narrower conical lobes. All are acuminate, and all may be of equal length, or the median lobe may be somewhat longer. The intervening sinuses are open and rounded and of varying depth; their degree of openness depends on the attitude of the lateral lobes, for although the angle of divergence of the lateral primaries with the midrib is practically uniform, the lateral lobes and the primaries forming their midveins may be either incurved or recurved, as shown in the accompanying illustrations. The margins are entire and the texture coriaceous. Length ranging from 12 to 16 centimeters; maximum width, between the tips of the lateral lobes, ranging from 9.75 to 15.25 centimeters and

24 Jowerbank, J.S., A history of the fossil fruits and seeds of the London clay, p. 25, pls. $7-9,1840$. largely dependent on the attitude of the lobes. The petiole was evidently long and stout; it is preserved for 2 centimeters in one specimen. The midrib is stout and prominent, approximately straight or variously curved. The lateral primaries are approximately as stout and prominent as the midrib. They diverge from the midrib a considerable distance above the base, at angles between $35^{\circ}$ and $45^{\circ}$, and are variously curved. The secondaries are thin and not especially prominent; they are numerous, regularly spaced, and subparallel, diverge at wide angles, and are abruptly camptodrome. The tertiaries are obscure.

The present species is, on the whole, well marked. It is in many ways similar to the European Oligocene species Sterculia labrusca Unger ${ }^{25}$ and, like that and most other living and fossil species, may have varied to a fewer or greater number of lobes, although all the specimens known at present are trilobate. It may be properly considered ancestral to the Claiborne species Sterculia labruscoides Berry, a somewhat smaller form with more conical lobes and rounded base.

A fragment of this species from Puryear, Tenn., was figured in 1916 and referred to Sterculia puryearensis Berry. Recent collections from Louisiana show that this fragment represents the present species, which is quite distinct from the much larger and more ovate lobed and lobate Sterculia puryearensis. It adds a second and striking representative of this genus to the flora of the Wilcox group, in which it is also represented by the fruits referred to the genus Sterculiocarpus.

Occurrence: Puryear, Henry County, Tenn.; collected by E. W. Berry: Goss pit, half a mile east of Mansfield, De Soto Parish, Laa.; collected by O. M. Ball. Carrizo sandstone half a mile west of Carrizo Springs, Dimmit County, Tex.

\section{Genus STERCULIOCARPUS Berry.}

Sterculiocarpus eocenicus Berry.

Plate XV, figure 5; Plate XVI, figure 1.

Sterculiocarpus eocenicus. Berry, U. S. Geol. Survey Prof. Paper 91, p. 288, pl. 74, figs. 1-3, 1916.

The present specimen adds considerably to our knowledge of this form. It is relatively slightly longer and narrower than the type

25 Unger, Franz, Die fossile Flora von Sotzka, p. 45, pl. 28, figs. 1-11, 1850 . 
and shows that the capsules were tardily loculicidally dehiscent and contained many small elongated seeds on parietal placentae. It thus differs from the other known species, namely S. sezannelloides Berry, in which the placentae were axile and the dehiscence septicidal.

Occurrence: Goss pit, half a mile east of Mansfield, De Soto Parish, La.; collected by O. M. Ball.

\section{Genus HELICTOXYLON Felix.}

Helictoxylon wilcoxianum Berry, n. sp.

Plates XVII and XVIII.

Transverse section: Vessels large, oval, very numerous and closely spaced, generally single, sometimes in oblique pairs. Rays undulating, broad, several cells wide, charged with gum. Parenchyma filling most of the space between the rays and vessels. Prosenchyma well distributed as single or double strands in the parenchyma, with greatly thickened walls.

Radial section: Vessels reticulately marked or obscurely pored. Parenchyma much septate, without discernible pitting. Prosenchyma with pointed ends, sparingly septate, with ray of very minute pores on the radial walls. Rays high, the marginal cells square, the central long and narrow. Pitting obscured by gum.

Tangential section: Vessels often with oblique scalariform perforations; walls reticulately marked. Rays fusiform elliptical, 8 or 9 cells wide medianly, 25 to 35 cells high, the normal ray frequently continued in one or both directions by uniserial large rectangular cells. Parenchyma of short rectangular cells without discernible pitting. Prosenchyma sparingly septate, with a row of minute pores.

The wide rays, the abundance of xylem parenchyma, and the prosenchyma with simpie pits indicate that this wood represents some species of Sterculiaceae, and the size and abundance of the vessels suggest a liana. As it is not possible to make comparisons with recent material, nor desirable to propose a new generic term such as Sterculioxylon, the species is referred to the genus Helictoxylon, proposed by Felix ${ }^{26}$ for two species from the Oligocene of Antigua. Species are also known from the Tertiary of Java, Luzon, Galicia, and

${ }_{26}$ Folix, J., Fossile Hölzer Westindiens, p. 18, 1883.
Hungary. The Wilcox species appear to be entirely distinct from previously described forms.

Occurrence: Two miles east of Naborton, De Soto Parish, La.

\section{Order THYMELEALES.}

Family LAURACEAE.

Laurus verus Berry, n. sp.

Plate XVI, figures 2-7.

I am fortunate in having several specimens of this fruit preserved as a ferric oxide replacement in Wilcox sands. Several are detached from the persistent calyx with the hilum obscured, and their identity would be questionable were it not for the finding of specimens with the calyx attached which came loose from the calyx, showing the umbo. In form the fruit is a considerably prolate spheroid varying considerably in size, the minimum and maximum sizes observed being 11 millimeters in length by 7 millimeters in maximum diameter and 15 millimeters in length by 9.5 millimeters in maximum diameter. The distal end comes to a not very obvious point. The surface is smooth and polished. The calyx is small, thick, coriaceous, and gamosepalous, the sepals represented by six conical or rounded upright marginal teeth, 3.5 to 4.5 millimeters in diameter and 2.5 to 3 millimeters high. Peduncle stout and curved, 2.5 to 4 millimeters in length. These are well shown in the accompanying figures. The question of their proper generic reference may be left in abeyance for the present, as a considerable number of the genera of the Lauraceae have comparable fruits. The term Laurus is used in the present connection purely as a form genus implying their reference to this family. The only lauraceous leaves found in association with these fruits are those of Oreodaphne salinensis Berry, and even these are rare. It may be assumed that these fruits floated a considerable distance from their point of origin, as is frequently the case with modern lauraceous fruits. I am inclined to consider these fossils as representing the genus Cinnamomum, but this is entirely a matter of personal opinion.

A considerable number of fossil fruits belonging to this family have been described. Among them those from the Oligocene of Trotha and Bornstadt, in Saxony, described by Friedrich, ${ }^{27}$

${ }^{27}$ Friedrich, P., Beitrüge zur Kenntniss der Tertiärflora der Provinz Sachsen, pp. 12s, 234, pl. 15, fig. 9; pl. 31, fig. 10, 1883. 
are exceedingly like the Louisiana fruits. Without any pretense at citing records, attention may also be called to the Cinnamomum fruits recorded by Friedrich ${ }^{28}$ from the Oligocene and those recorded by Heer ${ }^{28}$ from the Miocene of Europe.

Occurrence: Goss pit, half a mile east of Mansfield, De Soto Parish, La.; collected by O. M. Ball.

\section{Genus LAURINOXYLON Felix.}

Laurinoxylon branneri Knowlton.

Laurinoxylon branneri Knowlton, Arkansas Geol. Survey Ann. Rept. for 1889, vol. 2, p. 256, pl. 9, figs. 8, 9; pl. 10, figs. 1, 2; pl. 11, fig. 4, 1891.

Penhallow, Roy. Soc. Canada Trans., $3 \mathrm{~d}$ ser., vol. 1 , p. 98, figs. 6-8, 1908.

Berry, U. S. Geol. Survey Prof. Paper 91., p. 314, pl. 16, figs. 6-10, 1916.

This species was described in previous reports, and doubtfully recorded from the Wilcox. It occurs in the Claiborne of Arkansas and Texas, according to the identifications of Knowlton and Penhallow.

A specimen from the Wilcox at Shreveport, La. (No. 207), appears to be identical with the type. It is rather indifferently preserved and adds nothing to our knowledge of the species.

Laurinoxylon wilcoxianum Berry, n. sp.

Plate XIII.

Transverse section:- Vessels single or in radial pairs or triplets, rarely more, occasionally in tangential pairs or excentric. Well distributed but sparse, no zonal arrangement or diminution in size throughout the year, oval in cross section, thin walled. Prosenchyma abundant, the walls scarcely thickened. Xylem parenchyma abundant, showing a tendency to an arrangement in tangential bands. Rays undulating, one to three cells wide, full of gum.

Radial section: Vessels full of tyloses, with pitted walls. Rays varying in height from 2 to 18 cells; marginal cells square, about twice the height and one-half the length of the central cells, their horizontal and end walls with numerous simple pits. Rays mostly full of gum. A constant feature is the large vertical series of ray cells running from one ray to another. Prosenchyma thin, fusiform; no markings or septation seen, although in speci-

28 Idom, p. 215 , pl. 16 , figs. $15,16$.

89 Heer, Oswald, Flora tertiaria Helvetiae, vol. 2, pl. 91, fig. 8, 1856 mens from the Claiborne group that appear to belong to this species the prosenchyma is irregularly septate. Parenchyma about twice as wide as the prosenchyma, abundantly septate; no pits seen in the Wilcox material but with numerous round pores in the Claiborne material.

Tangential section: Rays closely crowded, 2 to 3 cells wide, connected by uniserial stringers of large rectangular cells, all full of gum.

This species appears to be distinct from previously described forms. It is abundant in the Wilcox but is usually rather poorly preserved, having suffered much from decay before silicification. Much better preserved material of this species is present in the Yegua formation of Texas and will be fully described and figured in my account of the Claiborne and Jackson floras.. Sections have been cut from trunks from the following localities: Half a mile southwest (214) and 1 mile west (212) of Naborton, De Soto Parish, La.; near Dabney (242), Montgomery County, Miss. ; Piney Creek (238), 10 miles east of Bolivar, Hardeman County, Tenn. All from beds of upper Wilcox age except the last, which is probably middle Wilcox.

\section{Order MYRTALES.}

Family COMBRETACEAE.

Genus TERminalia Linné.

Terminalia leșleyana (Lesquereux) Berry.

Plate XVI, figure 8.

Terminalia radobojensis Heer. Lesquereux, U. S. Geol. and Geog. Survey Terr. Ann. Rept. for 1871, Suppl., p. 15, 1872.

Magnolia lesleyana Lesquereux, Am. Philos. Soc. Trans., vol. 13, p. 421, pl. 21, figs. 1, 2, 1869; Tertiary flora, p. 248 , pl. 44, figs. 1-3, 1878; U. S. Geol. and Geog. Survey Terr. Ann. Rept. for 1871, Suppl., p. 14, 1872.

Knowlton, U. S. Geol. Survey Prof. Paper 101, p. 313 , pl. 82, figs. 1, 2, 1917.

Terminalia lesleyana Berry, U. S. Geol. Survey Prof. Paper 91, p. 323, pl. 89, 1916.

A large specimen of this species from Louisiana is figured in the present paper. Since my account of the Wilcox flora was published Knowlton ${ }^{30}$ has given a very excellent account of the Raton flora. In that paper the present species is transferred back to Magnolia, although no reasons are given. I have compared the fossil with a large amount of re- 
cent material of both Magnolia and Terminalia and am satisfied that the fossil is much more like the latter than the former, which was Lesquereux's original identification before it became the fashion to refer all large leaves to Magnolia.

Occurrence: Goss pit, half a mile east of Mansfield, De Soto Parish, La.; collected by O. M. Ball.

Order GENTIANALES.

Family APOCYNACEAE.

Genus APOCYNOPHYLLUM Unger.

Apocynophyllum mississippiensis Berry.

Apocynophyllum mississippiensis Berry, U. S. Geol. Survey Prof. Paper 91, p. 342, pl. 108, fig. 6, 1916.

The present material contains numerous leaves of this species which average about 20 per cent larger than those previously collected, indicating a leaf about 18 centimeters in length by 4 centimeters in maximum width.

Occurrence: Gross pit, half a mile east of Mansfield, De Soto Parish, La.; collected by O. M. Ball.

\section{Apocynophyllum constrictum Berry.}

Apocynophyllum constrictum Berry, U. S. Geol. Survey Prof. Paper 91, p. 344, pl. 103, fig. 4, 1916.

This species was based on the single specimen figured, which was collected from the Wilcox of Benton, Ark. Additional material was collected recently from the clay ironstone near Somerville, Tenn: This is of importance in showing that the constricted form that suggested the name of this species was not anomalous but the normal form of this lower Eocene Apocynophyllum. It is also important in confirming the conclusion that all the known fossiliferous Wilcox in Arkansas, Louisiana, and Texas is of upper Wilcox age, and that the Wilcox sediments were progressively transgressive in the region west of the present Mississippi River.

Occurrence: Half a mile south of SomervilleWhiteville road, Fayette County, Tenn.; collected by Russell F. Ryan.
POSITION UNCERTANT.

Genus PtERobalanUs Berry, n. gen.

The genus has the characters of the type and only known species. The name is derived from the Greek for winged fruit.

Pterobalanus texanus Berry, n. sp.

Plate XV, figures 1, 2.

Fruit of uncertain nature, either a manyseeded indehiscent capsule or a drupe with a readily flattened stone; the impression as preserved shows no trace of a stone and rather points to its having been a many-seeded capsule. The fact that the wings are so well developed rather precludes the inference that the central papillose portion of the specimen represents the base from which the essential part of the fruit had been broken away.

The remains consist of a stout stalk or peduncle, about 2.25 centimeters in length, slightly enlarged and curved proximad, expanding distad to form the margin of a central circular thickened papillose disk, which is 2 millimeters in diameter. From this margin diverge in a semicircular fashion about twelve wings or enlarged bracts. These are believed not to be segments of a calyx, because of their collective lack of symmetry, none being developed on the proximal or inner side of the central disk.

These bracts are separate lanceolate in outline, entire margined, acutely pointed, and about 5 millimeters in length by 1.5 millimeters in maximum width in their expanded median region. Each appears to have two longitudinal veins.

The systematic position of this interesting winged fruit is unknown, nor do I recall anything similar in the existing flora or in described fossil floras. It is based on the single specimen figured and its counterpart.

Occurrence: Carrizo sandstone at quarries half a mile west of Carrizo Springs, Dimmit County, Tex. 


\section{PLATES I-XVIII.}

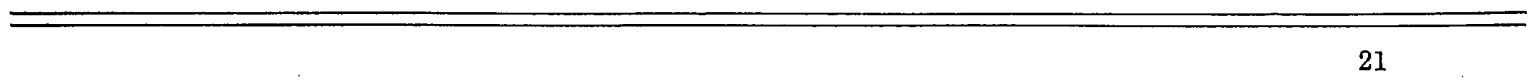




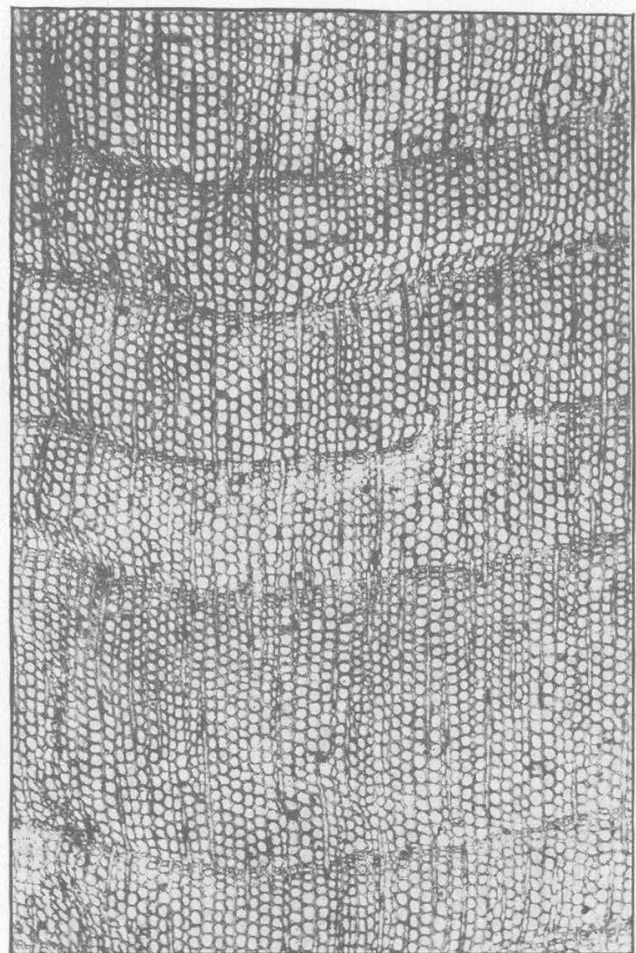

1

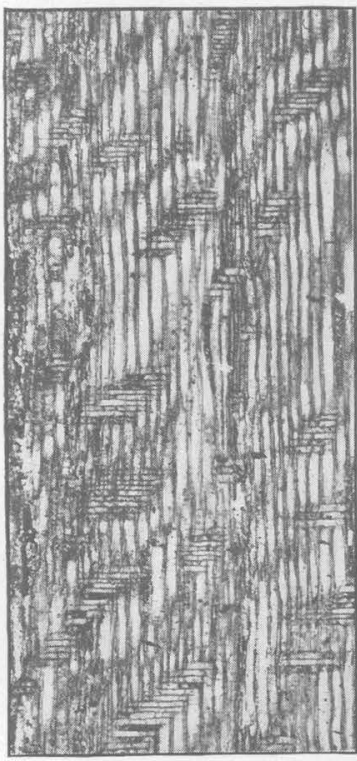

3

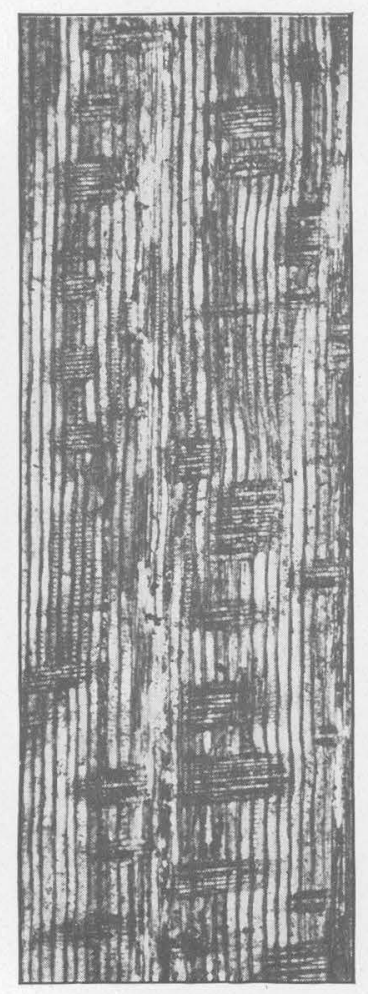

4

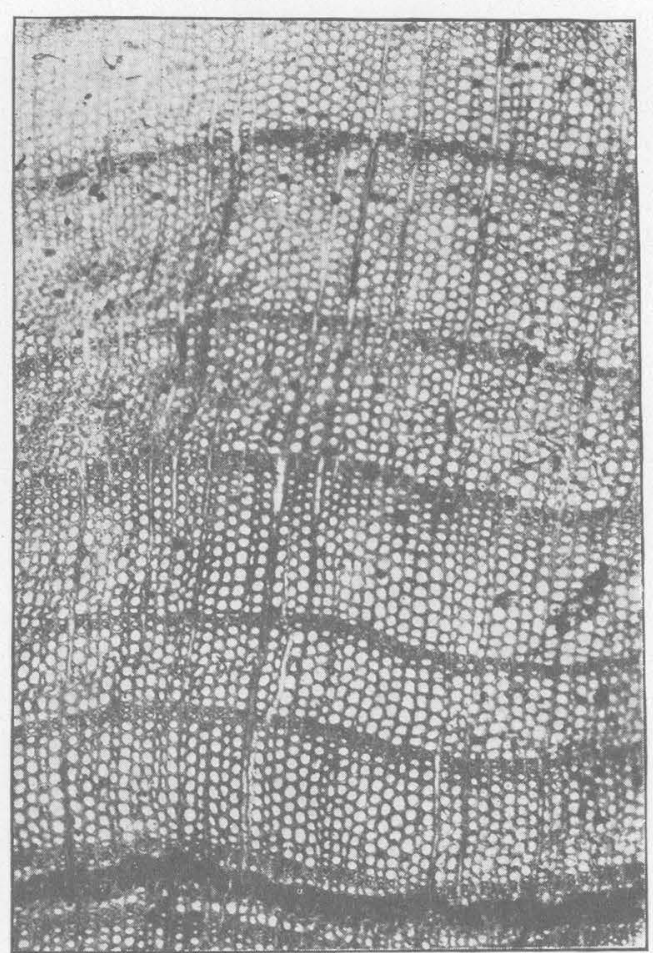

2

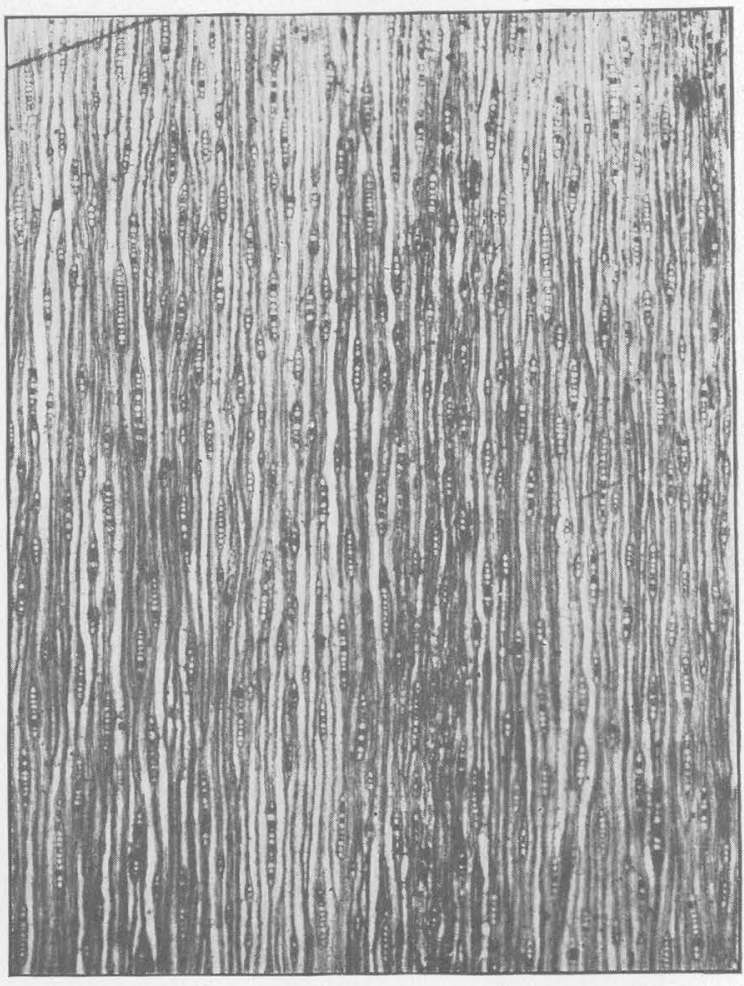

5

CUPRESSINOXYLON WILCOXENSE BERRY.

1, Transverse section showing growth rings from Shreveport, La.; 2, similar section from Caddo Lake, La.; 3 , radial seotion from Caddo Lake, La.; 4, similar section from Shreveport, La.; 5, tangential section from Caddo Lake, La. All enlarged 20 diameters. 


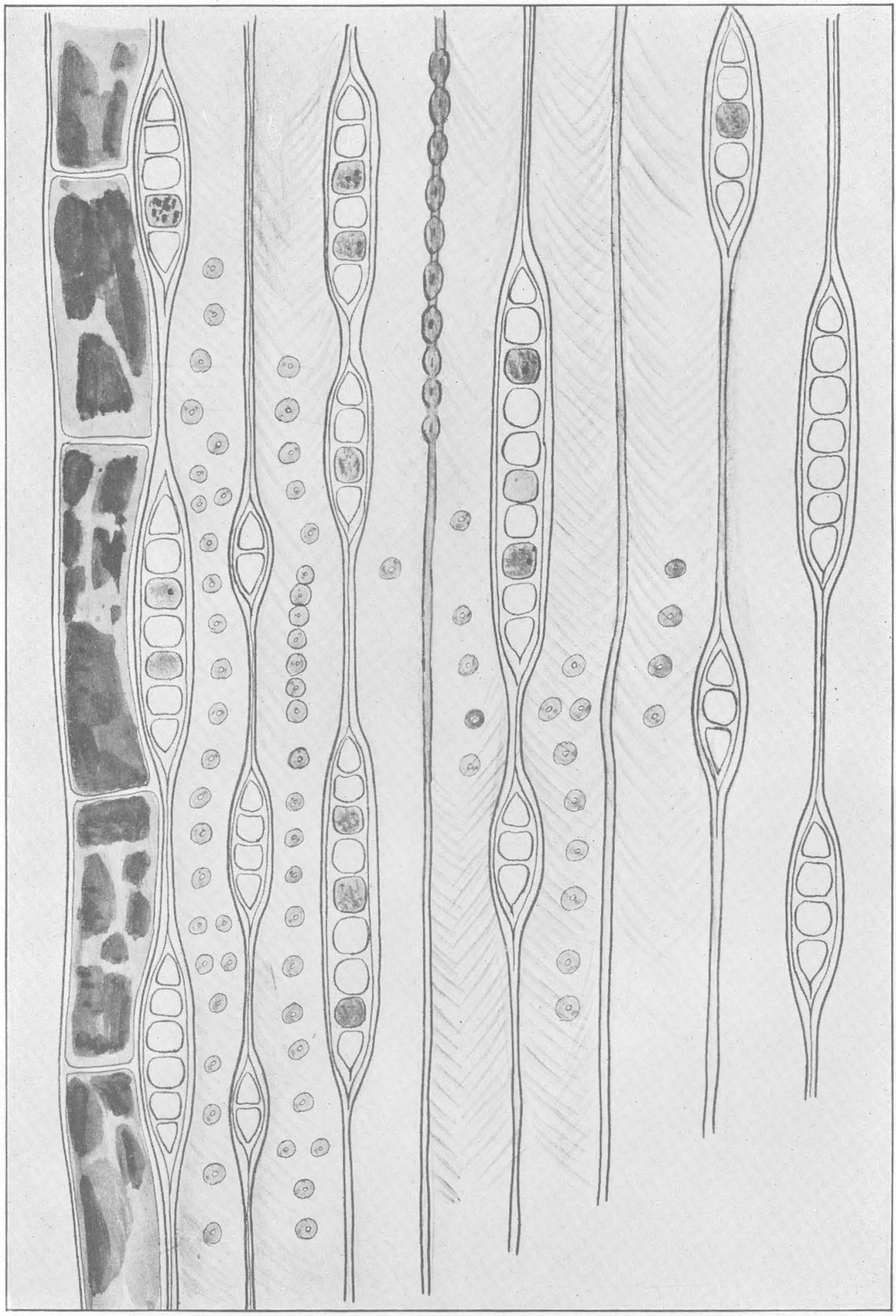

CUPRESSINOXYLON WILCOXENSE BERRY.

Tangential section from Shreveport, La., enlarged about 300 diameters. 


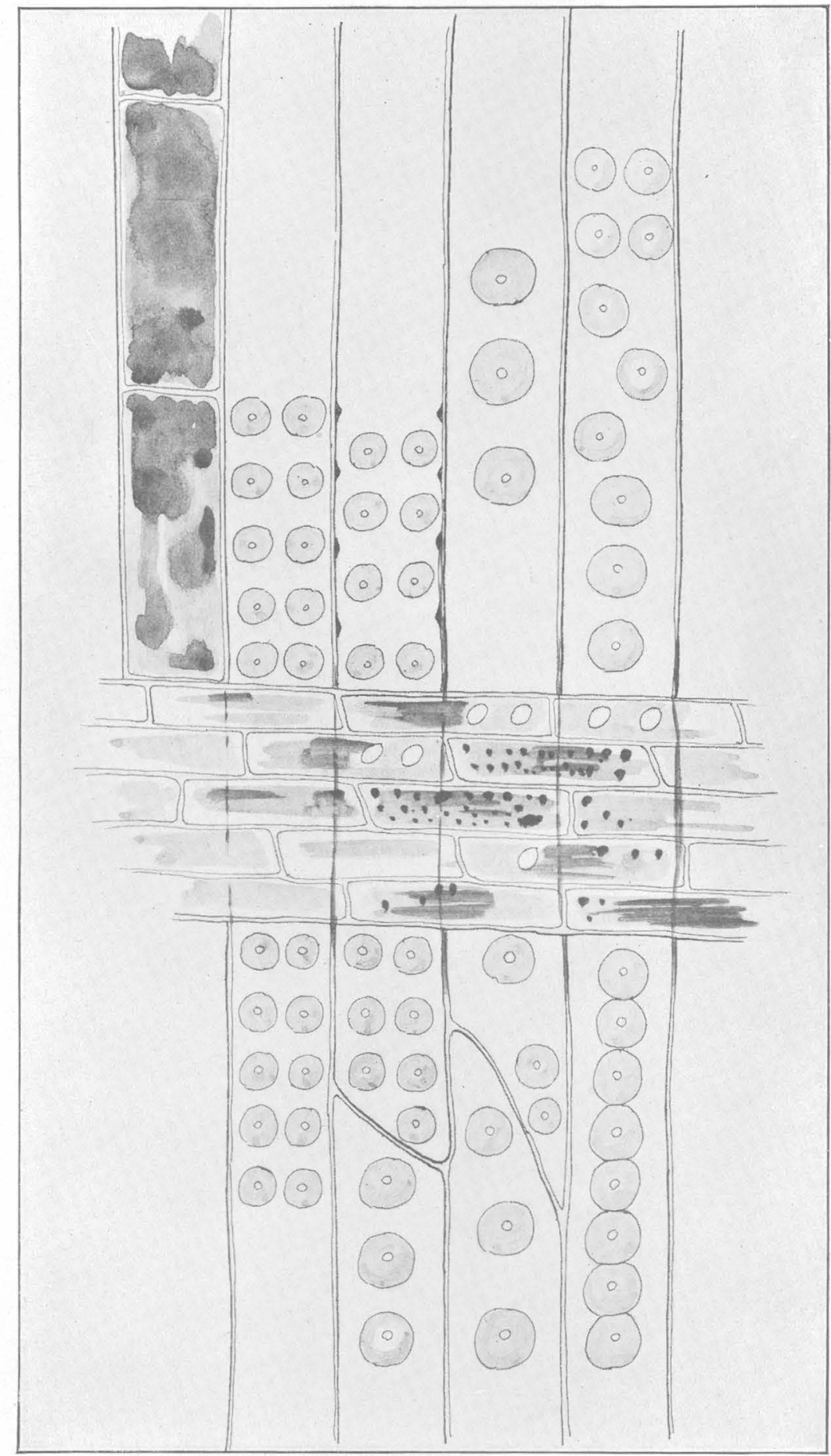

CUPRESSINOXYLON WILCOXENSE BERRY.

Radial section from Shreveport, La., enlarged about 300 diameters. 


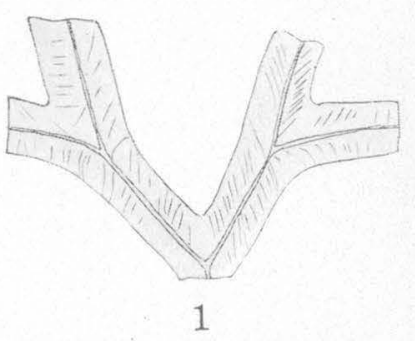

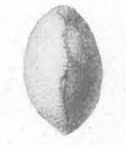

2

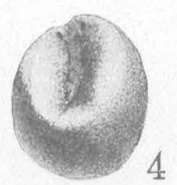

3
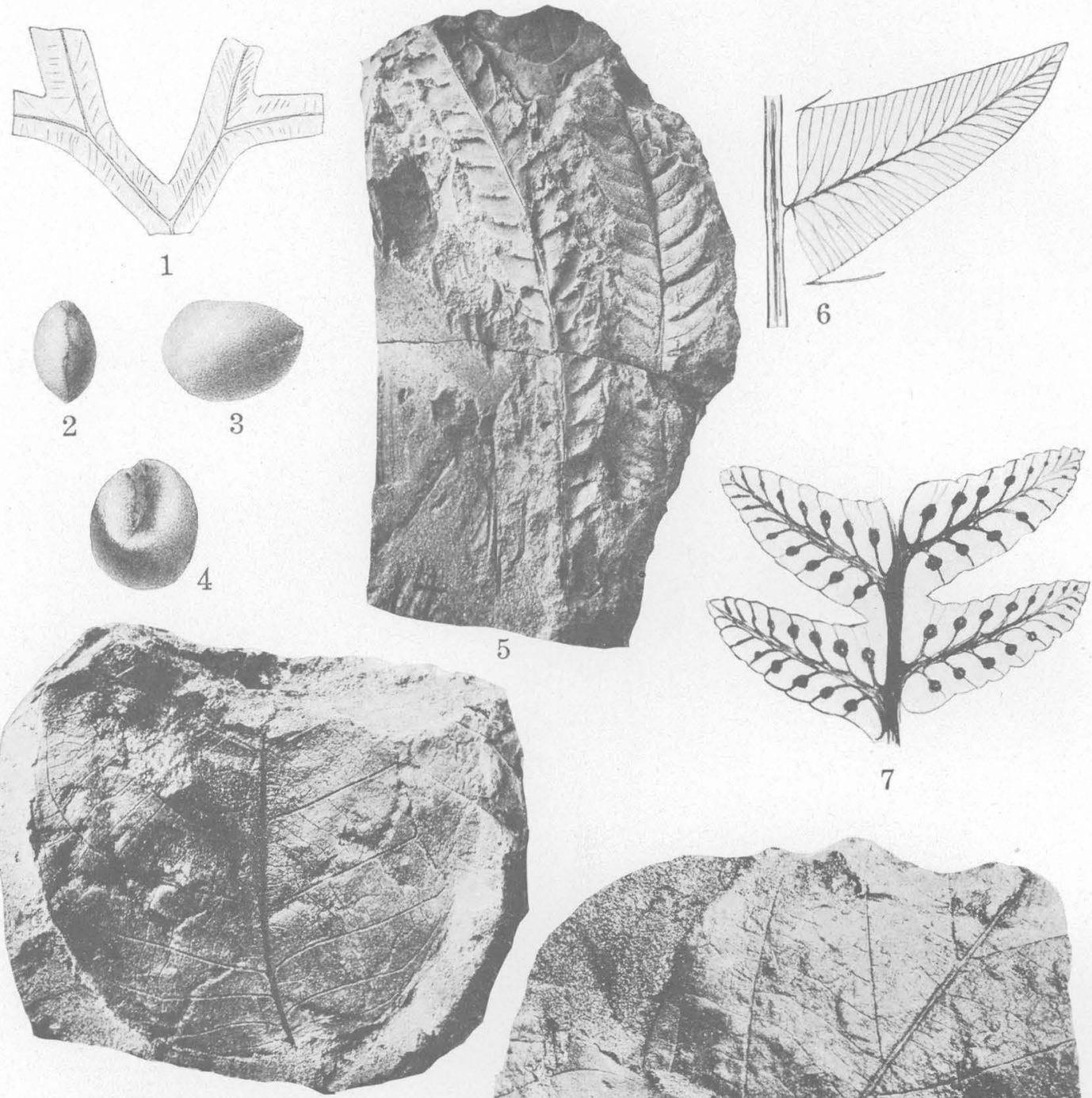

(8)

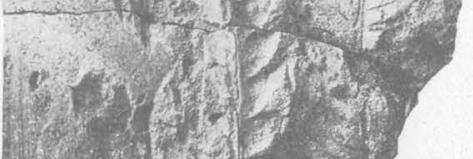

6

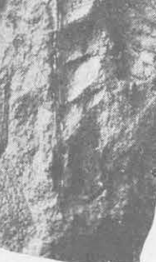

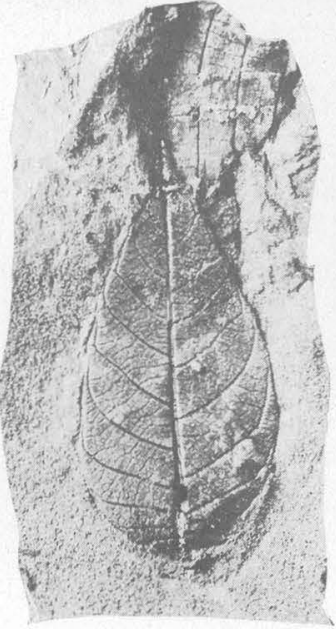

9

8

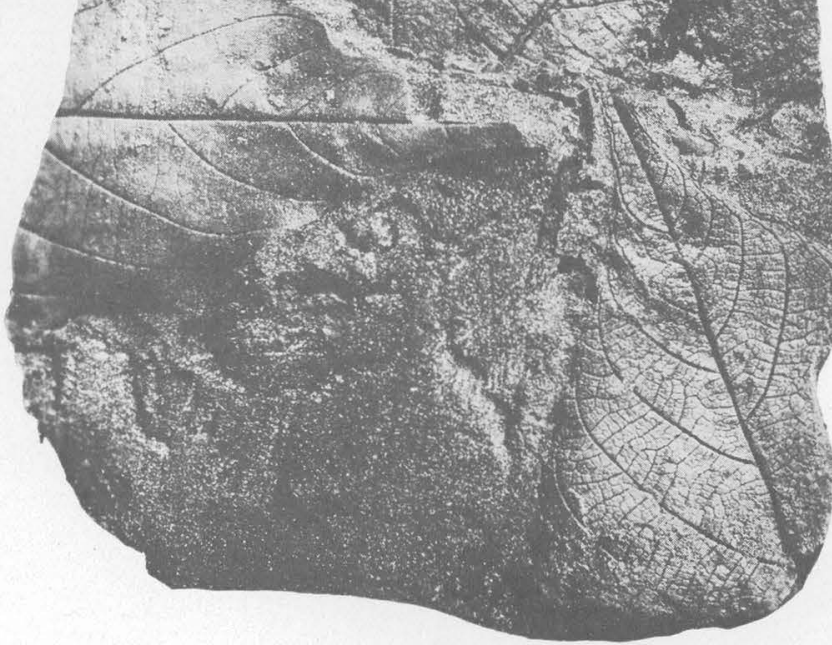

10

FOSSIL PLANTS OF THE WILCOX GROUP.

1. Marchantites stephensoni Berry, Jacksonville, Ark.; 2-4, Palmocarpon butlerensis Berry, near Oakville, Tex.; 5-7, Dryopteris cladophleboides Knowlton, Goss pit, near Mansfield, La. (6., pinnule to show venation, enlarged 5
diameters; 7, fertile pinnules, enlarged 5 diameters); 8-10, Artocarpoides balli Berry, Goss pit, near Mansfield, La. 


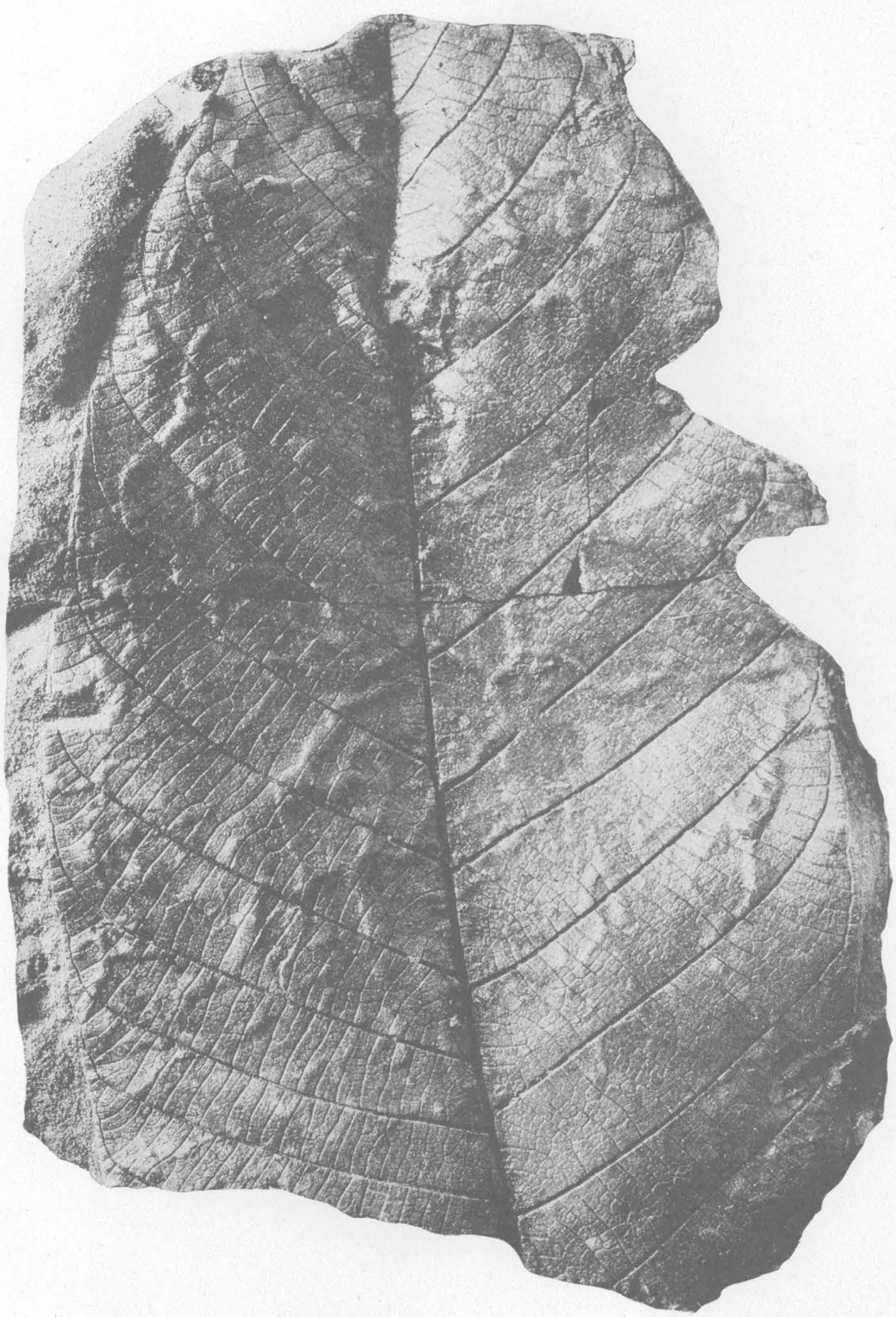

ARTOCARPOIDES BALLI BERRY.

A large leaf from Goss pit, near Mansfield, La. 

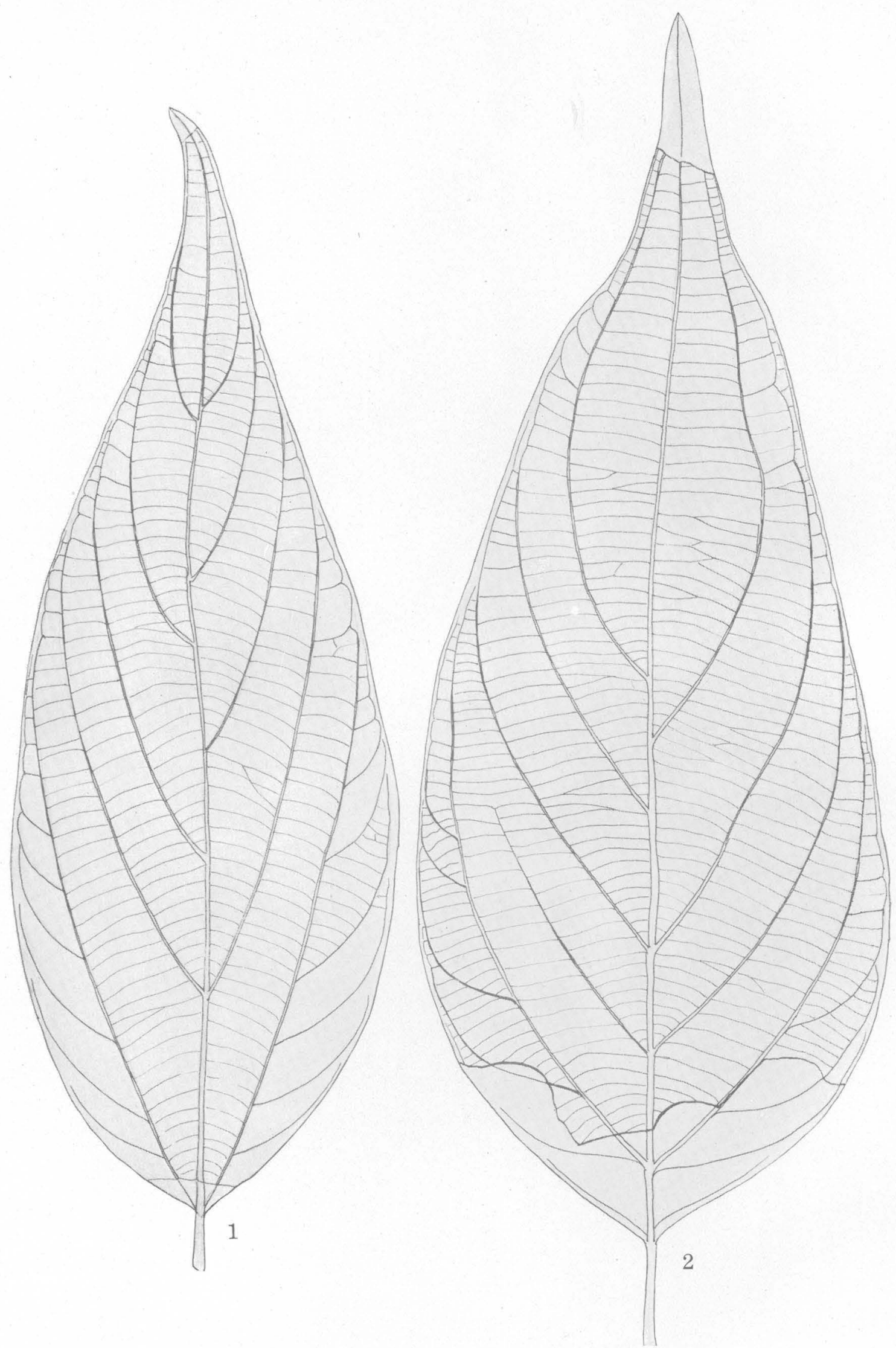

FICUS MISSISSIPPIENSIS (LESQUEREUX) BERRY.

Two of the large narrow forms from Goss pit, near Mansfield, La. 


\section{U. S. GEOLOGICAL SURVEY}

PROFESSIONAL PAPER 131 PLATE VII

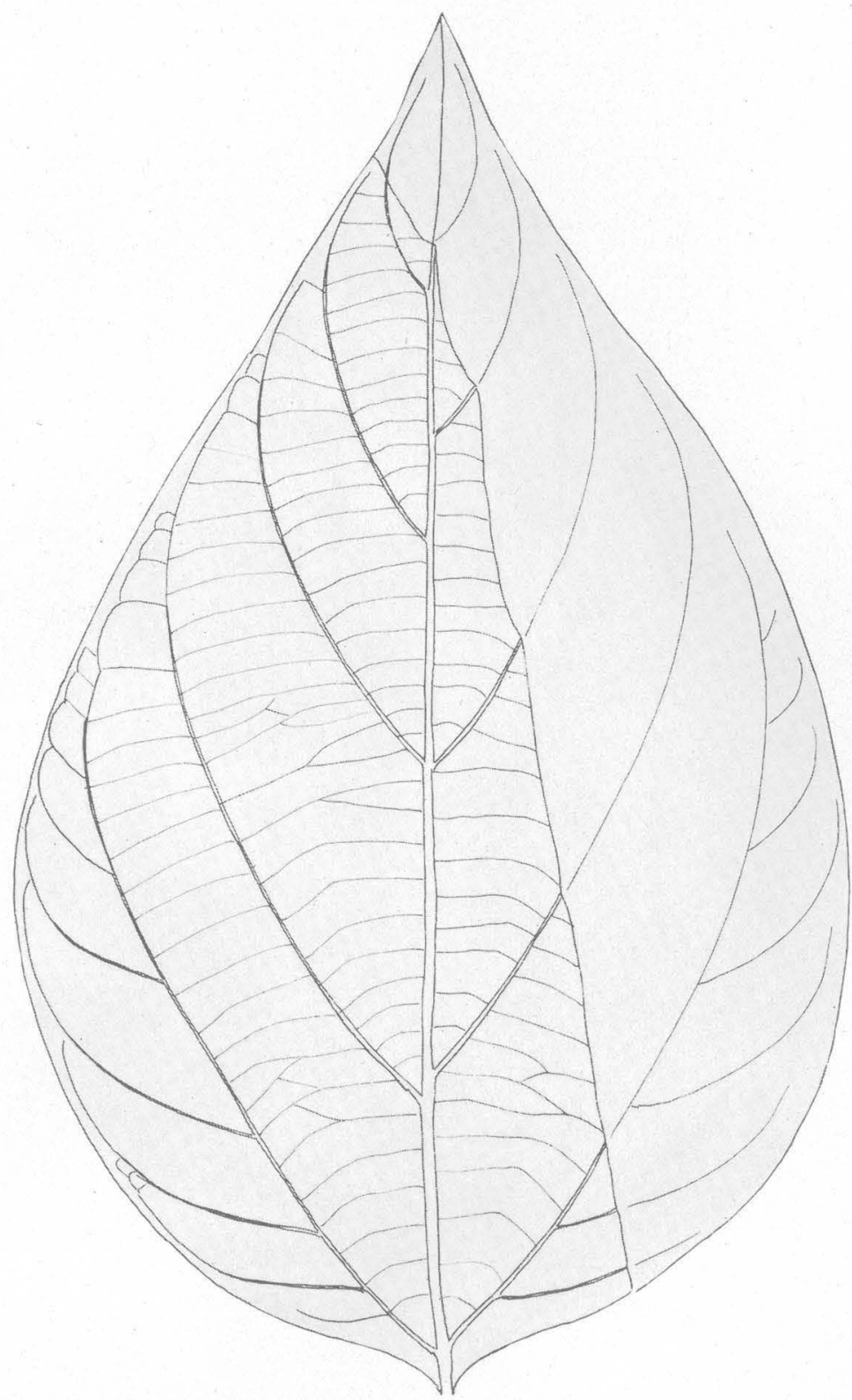

FICUS MISSISSIPPIENSIS (LESQUEREUX) BERRY.

Shorter and wider form from same locality as those figured on Plate VI. 


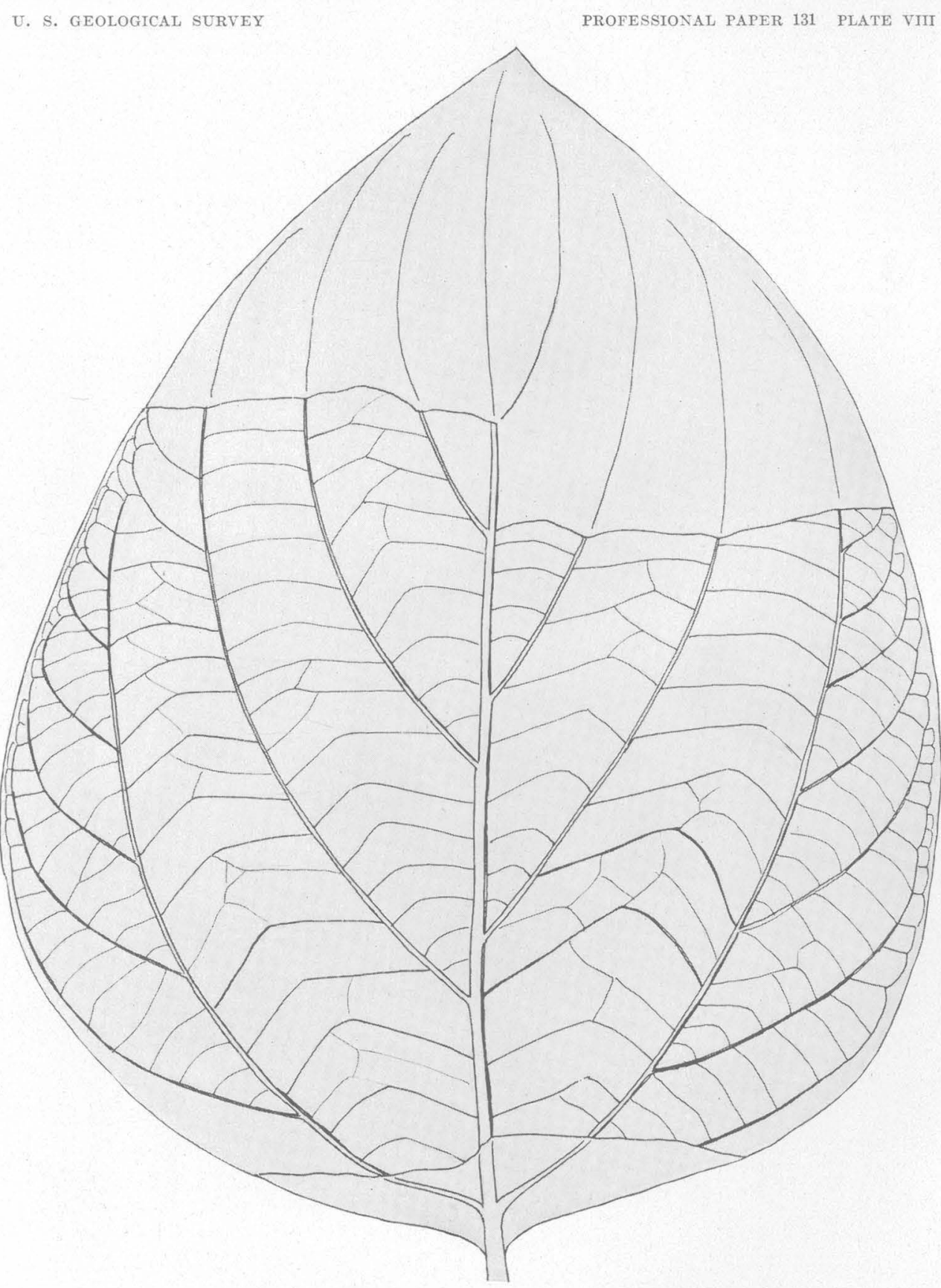

FICUS MISSISSIPPIENSIS (LESQUEREUX) BERRY.

Widest form from same locality as those figured on Plate VI. 


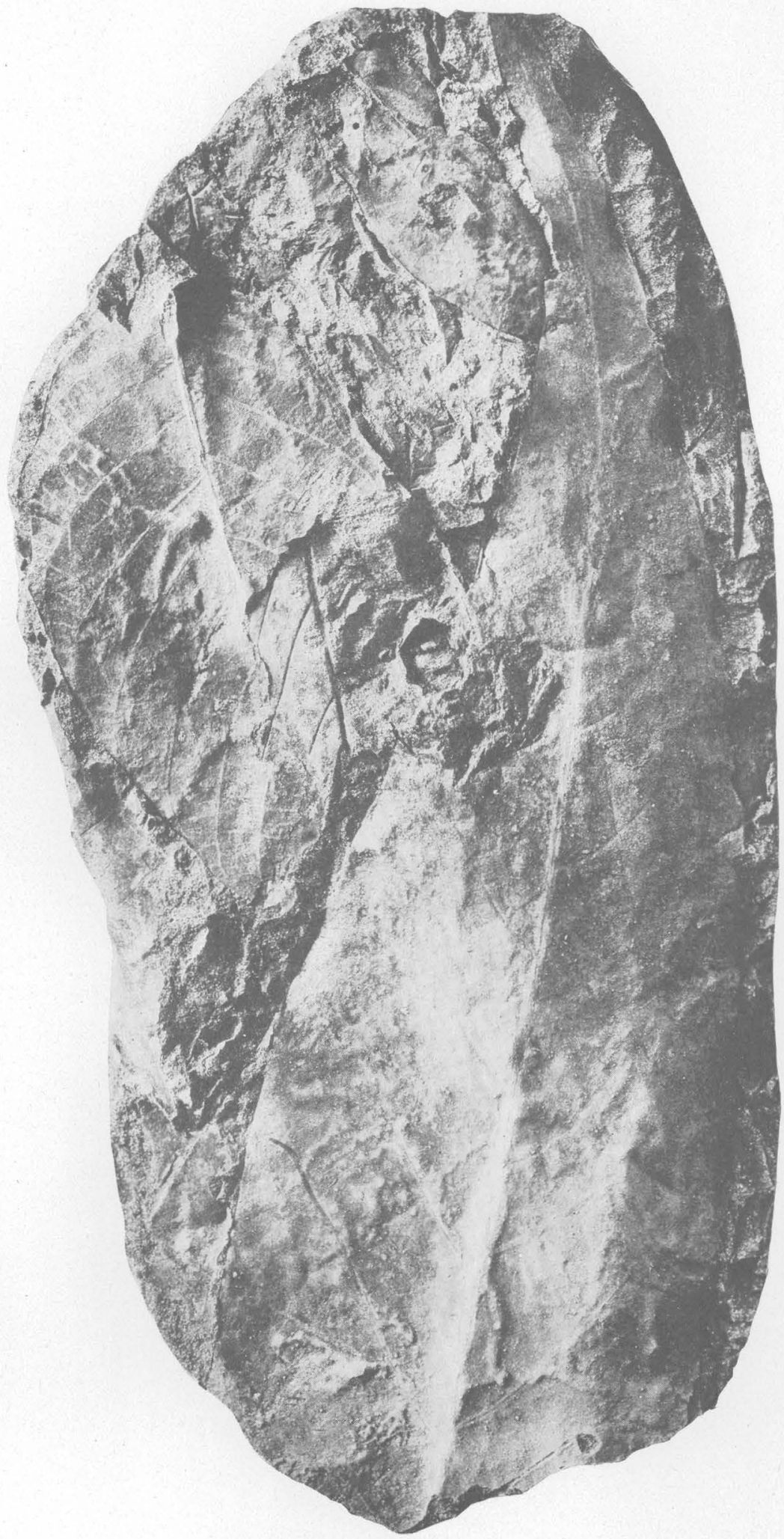

MAGNOLIA ANGUSTIFOLIA NEWBERRY.

From Goss pit, near Mansfield, La. 


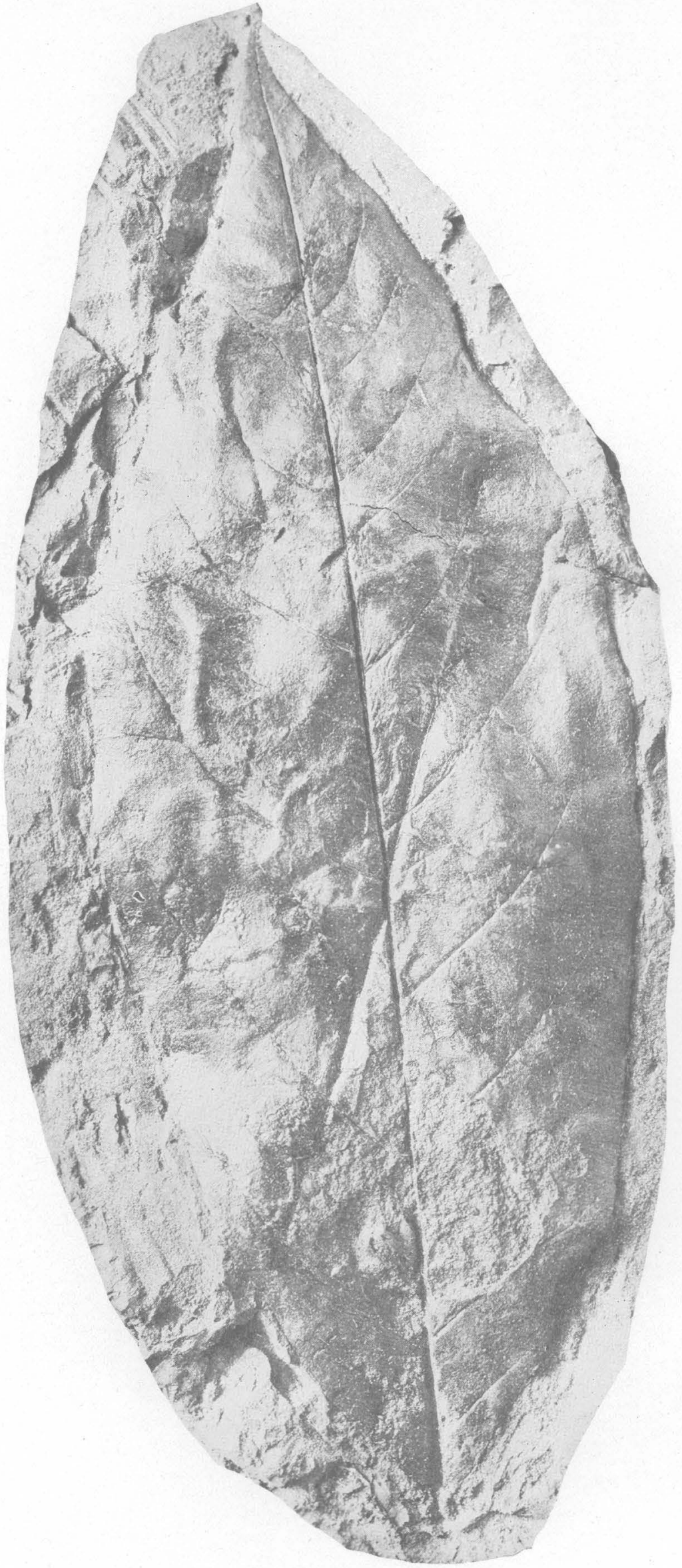

MAGNOLIA LEEI KNOWLTON.

From Goss pit, near Mansfield, La. 

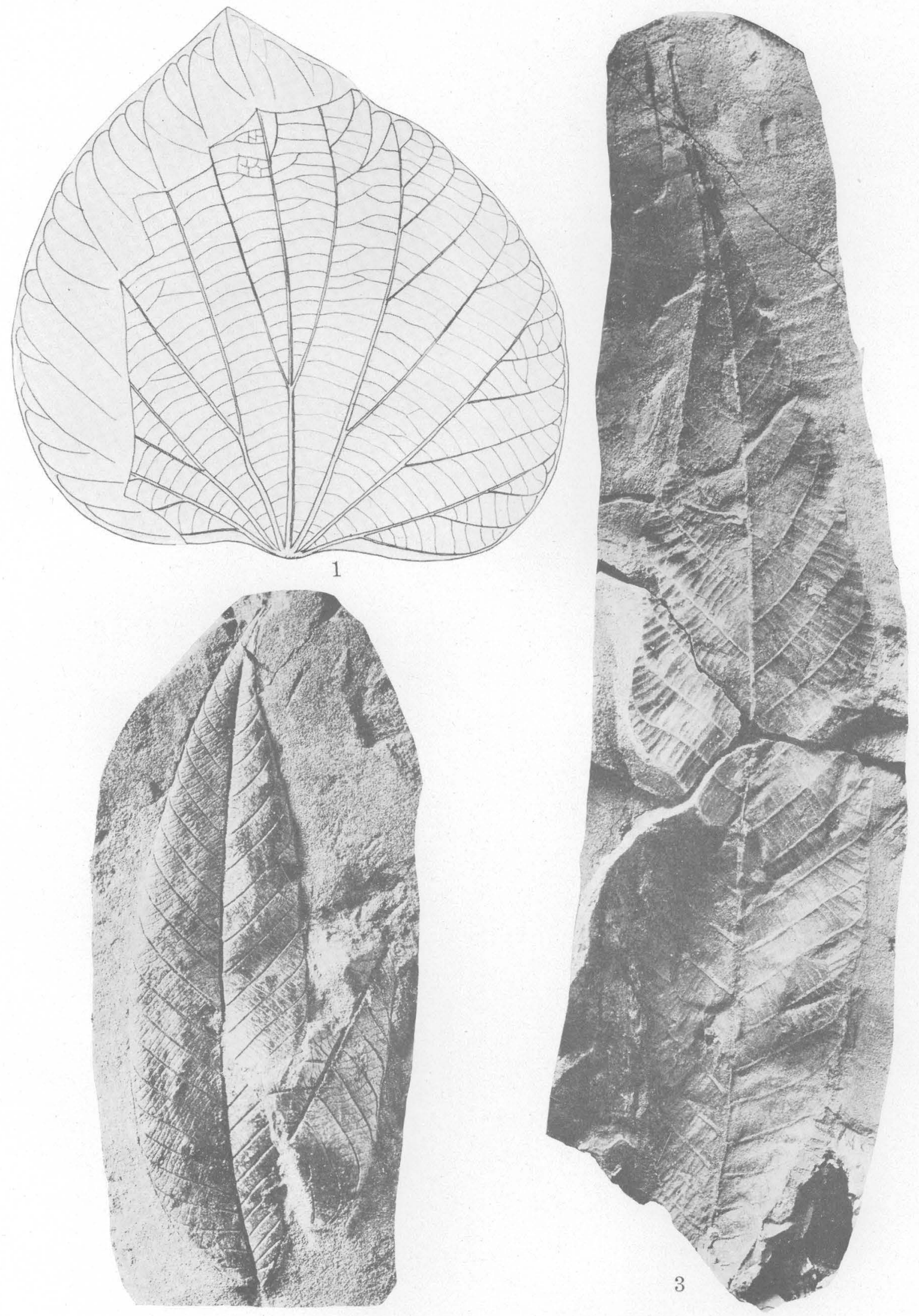

2

FOSSIL PLANTS OF THE WILCOX GROUP. 1, Menispermites cebathoides Berry; 2, 3, Rhamnus marginatus apiculatus Berry, small and large leaves. All from 
U. S. GEOLOGICAL SURVEY

PROFESSIONAL PAPER 131 PLATE XII
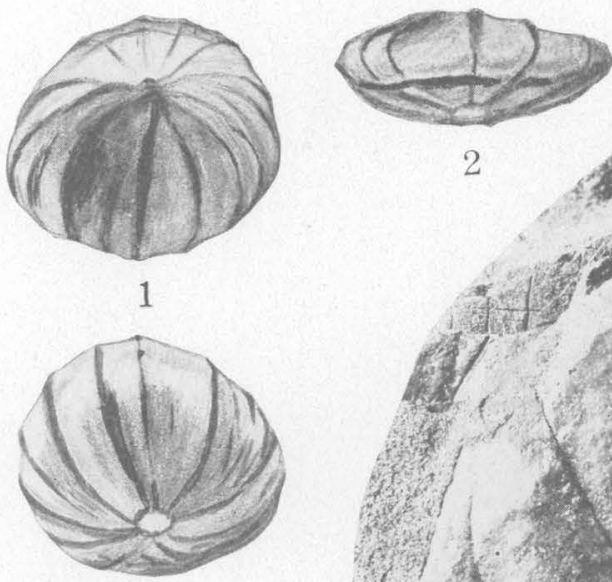

3

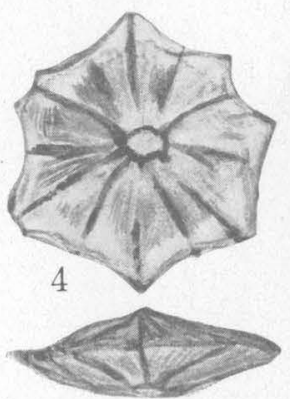

5

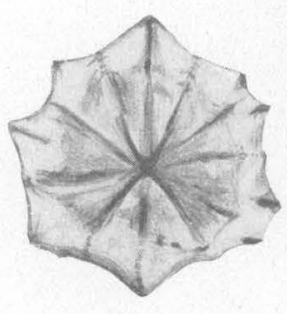

6

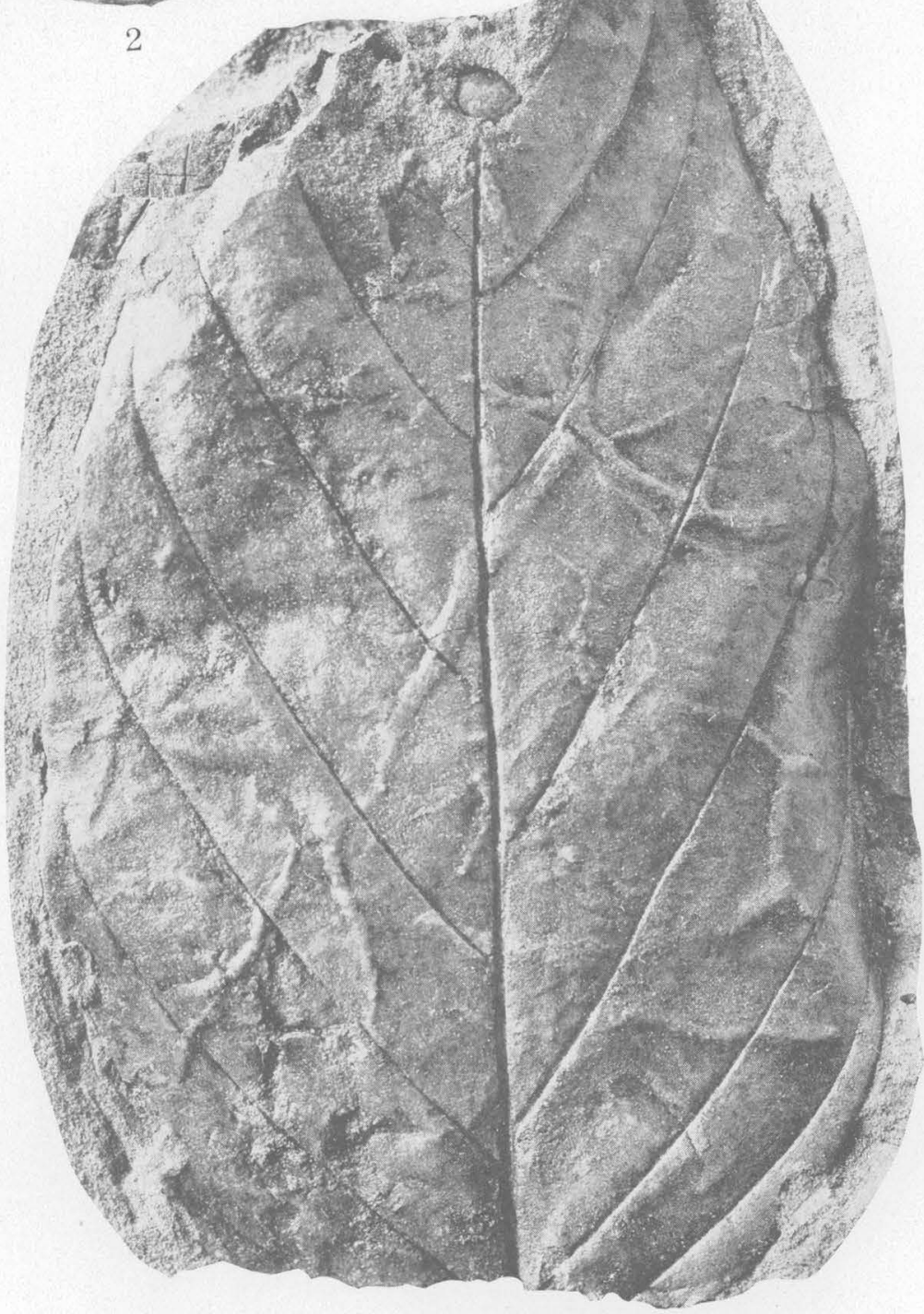

7

FOSSIL PLANTS OF THE WILCOX GROUP.

1-6, Monocarpellites perkinsi Berry, from vicinity of Paris, Tenn. (1-3, upper, lower, and side views of a partly compressed carpel; 4-6, lower, side, and upper views of a much compressed carpel); 7 , Rhamnites knowltoni 


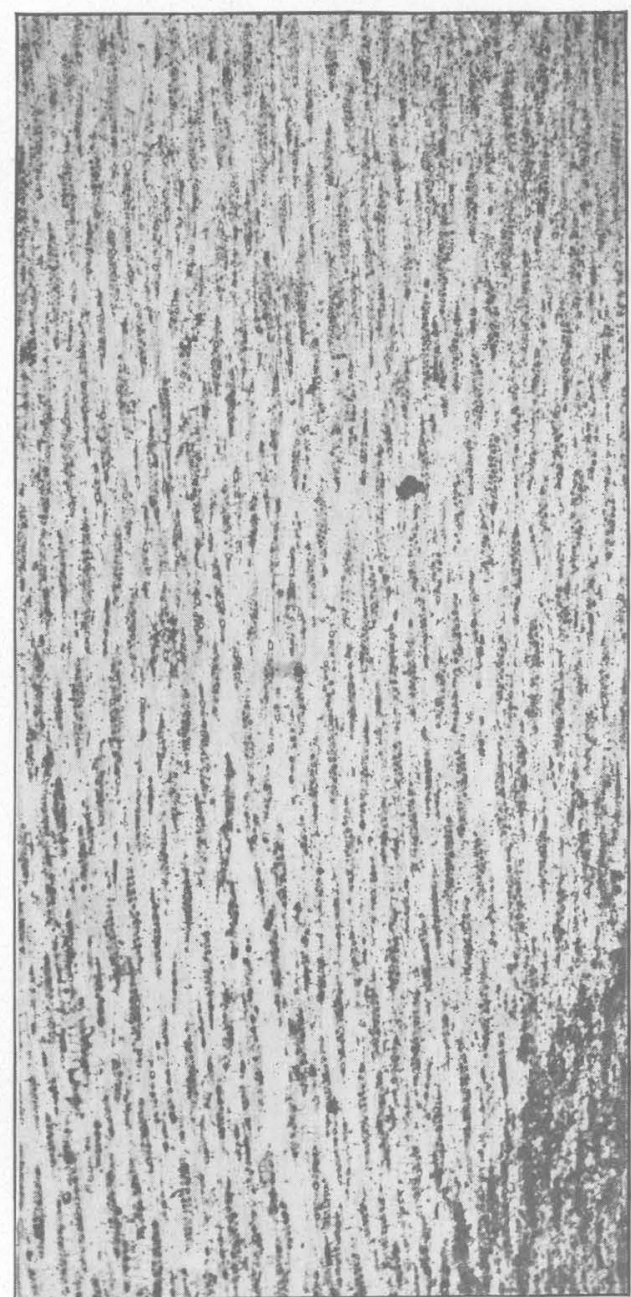

1

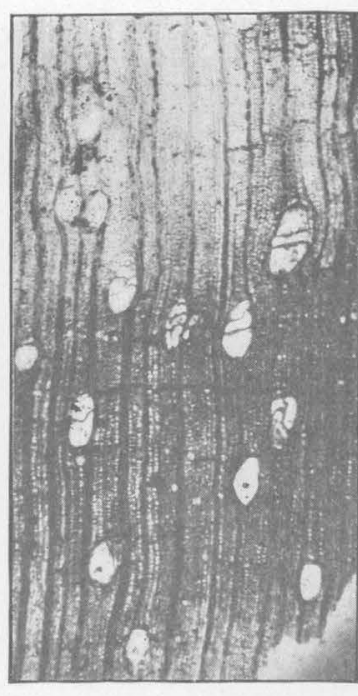

2

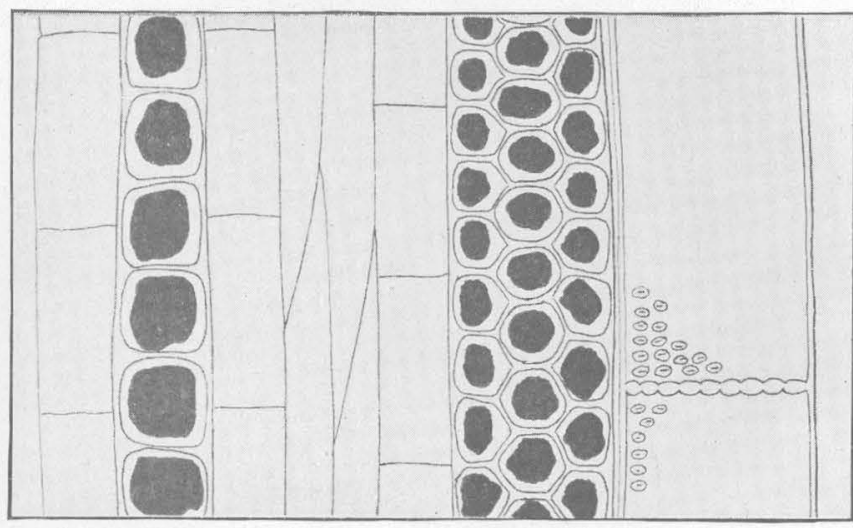

4

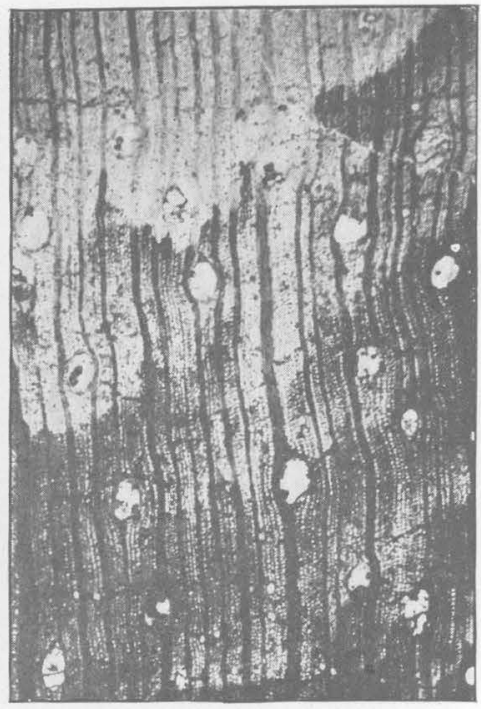

3

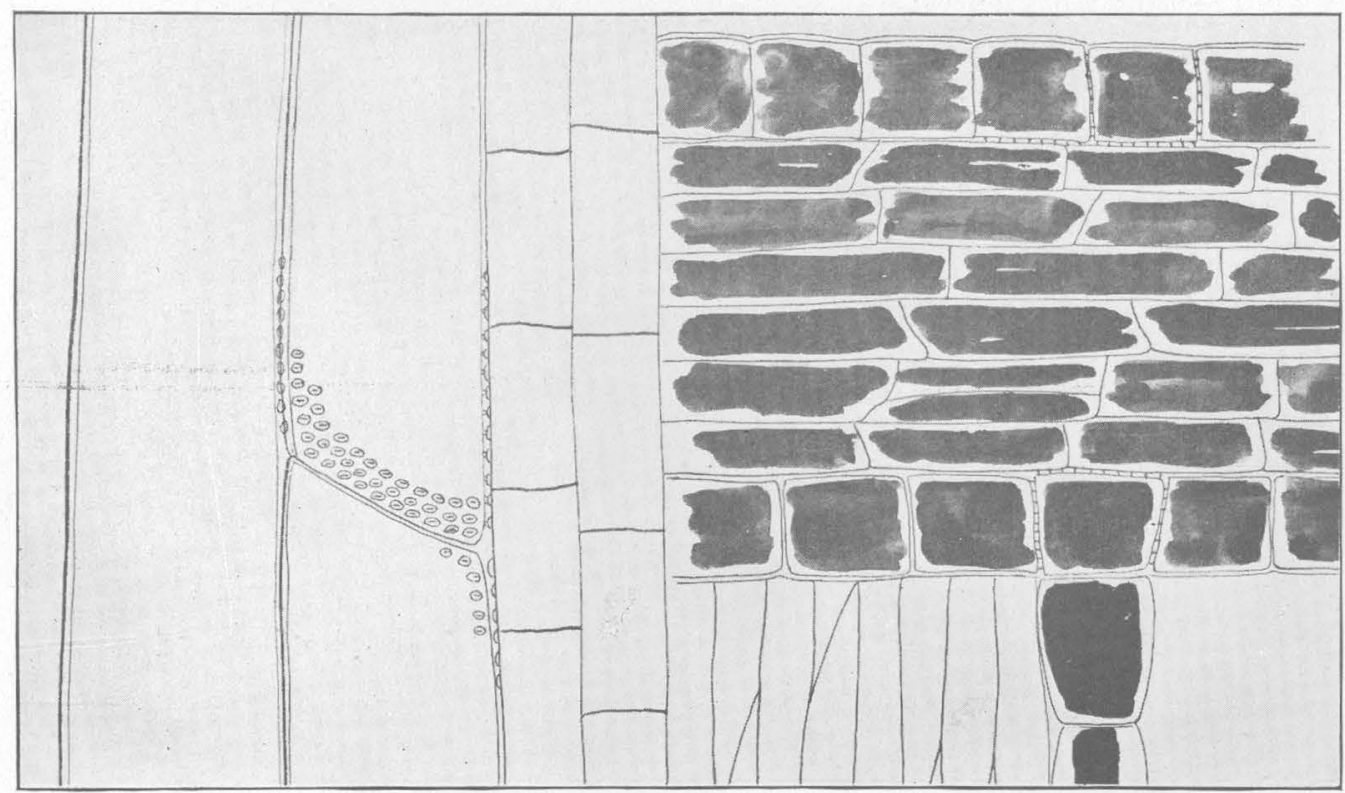

5

LAURINOXYLON WILCOXIANUM BERRY.

From vicinity of Dabney, Miss. 1, Tangential section enlarged 20 diameters; 2, 3, transverse sections, enlarged 20 diameters: 4 , tangential section, enlarged 300 diameters; 5 , radial section, enlarged 300 diameters. 


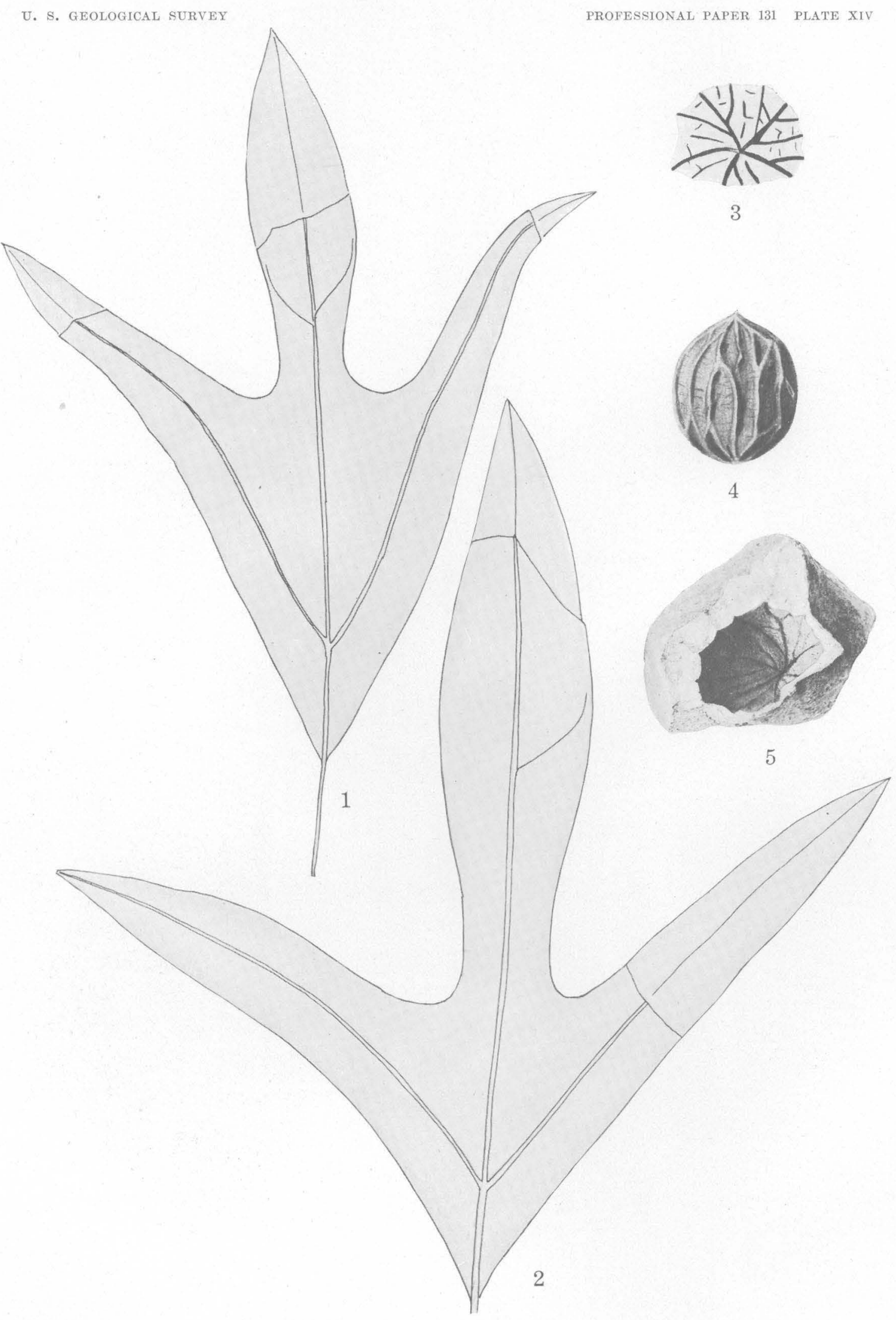

FOSSIL PLANTS OF THE WILCOX GROUP.

1, 2, Sterculia wilcoxensis Berry, from Goss pit, near Mansfield, La.; 3-5, Calatoloides eocenicum Berry, from Butler salt dome, Tex. 

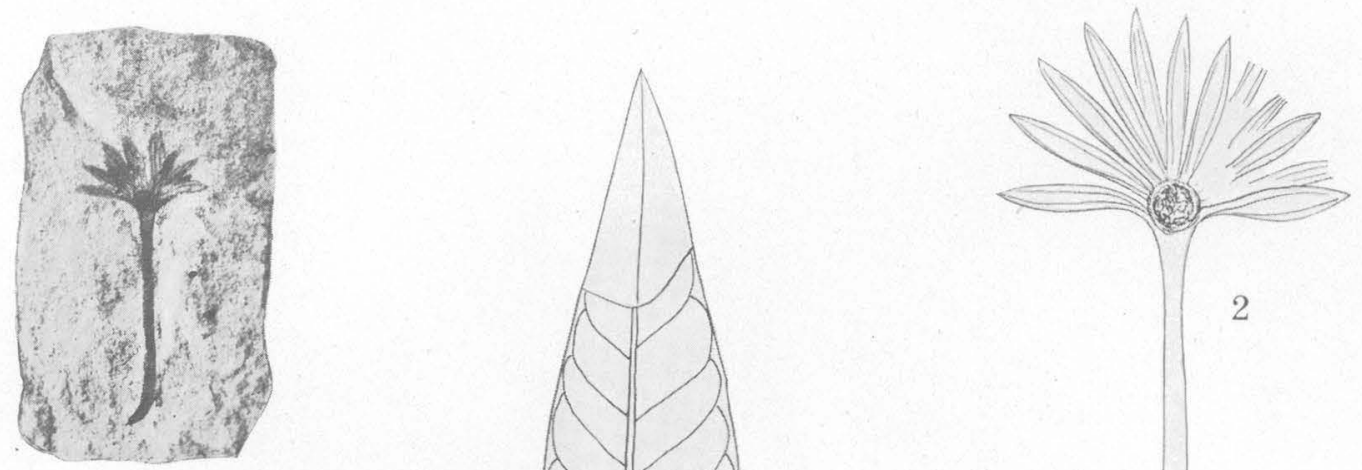

1
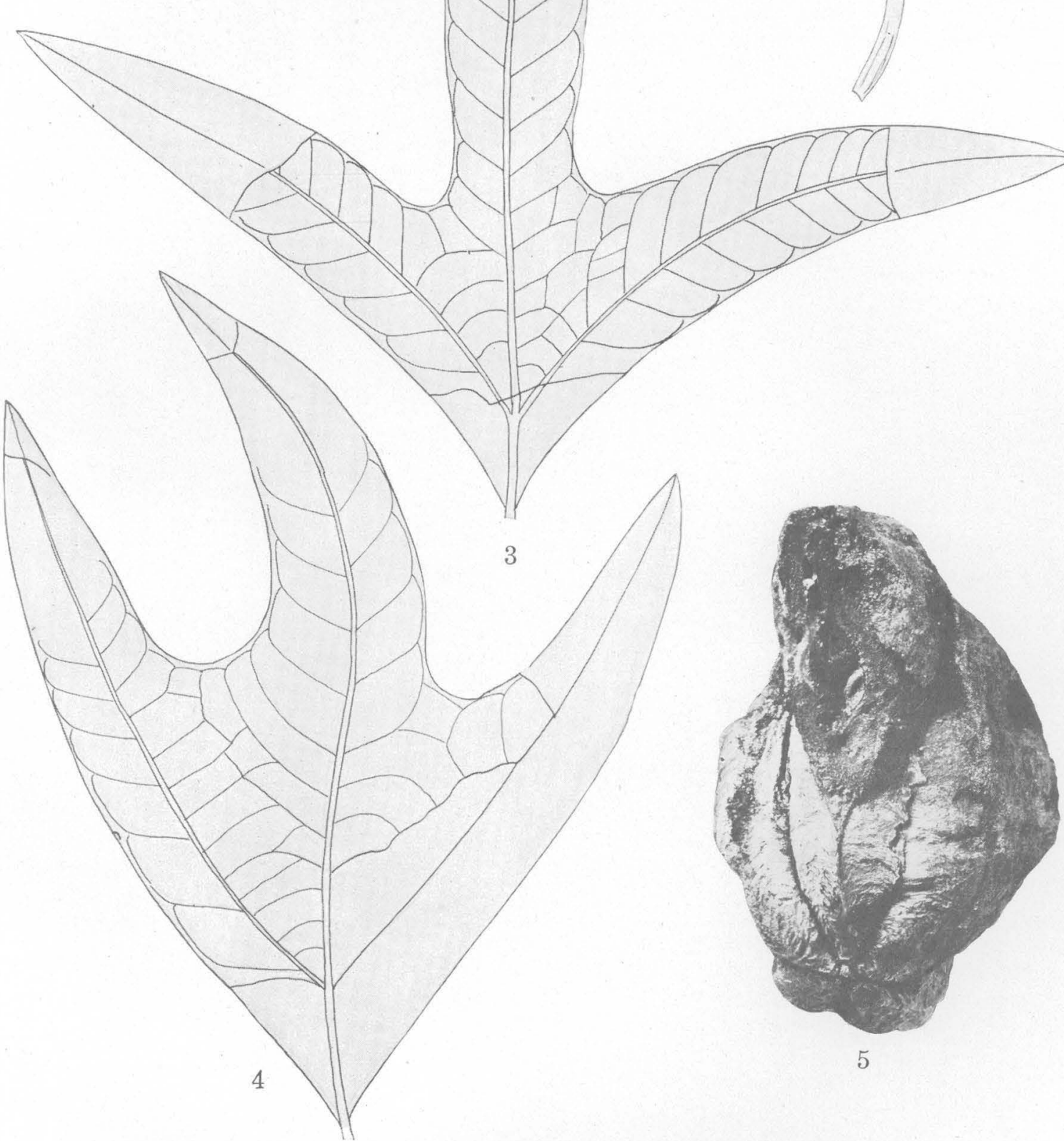

5

FOSSIL PLANTS OF THE WILCOX GROUP.

1-2, Pterobalanus texanus Berry; 3-4, Sterculia wilcoxensis Berry (3, Puryear, Tenn.; 4, Goss pit, near Mansfield, La.); 5, Sterculiocarpus eocenicus Berry (side view), from Goss pit, near Mansfield, La. 

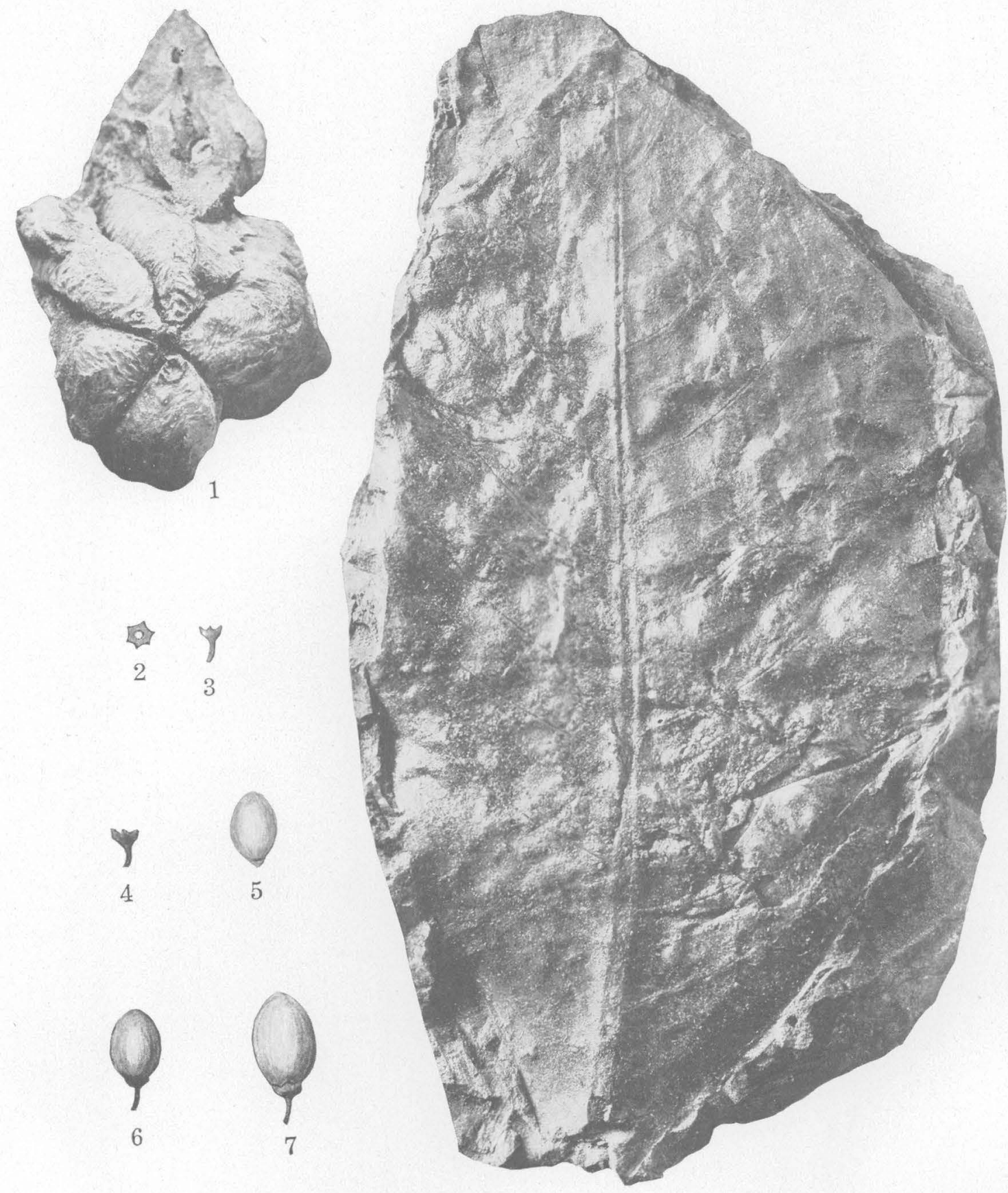

8

FOSSIL PLANTS OF THE WILCOX GROUP.

1, Sterculiocarpus eocenicus Berry (basal view); 2-7, Laurus verus Berry (2, persistent calyx from above; 3 , calyx and peduncle from side; 4, another calyx and peduncle from side; 5 , detached fruit; 6,7 , fruits with persistent calices and peduncles); 8, Terminalia lesleyana (Lesquereux) Berry. All from Goss pit, near Mansfield, La. 


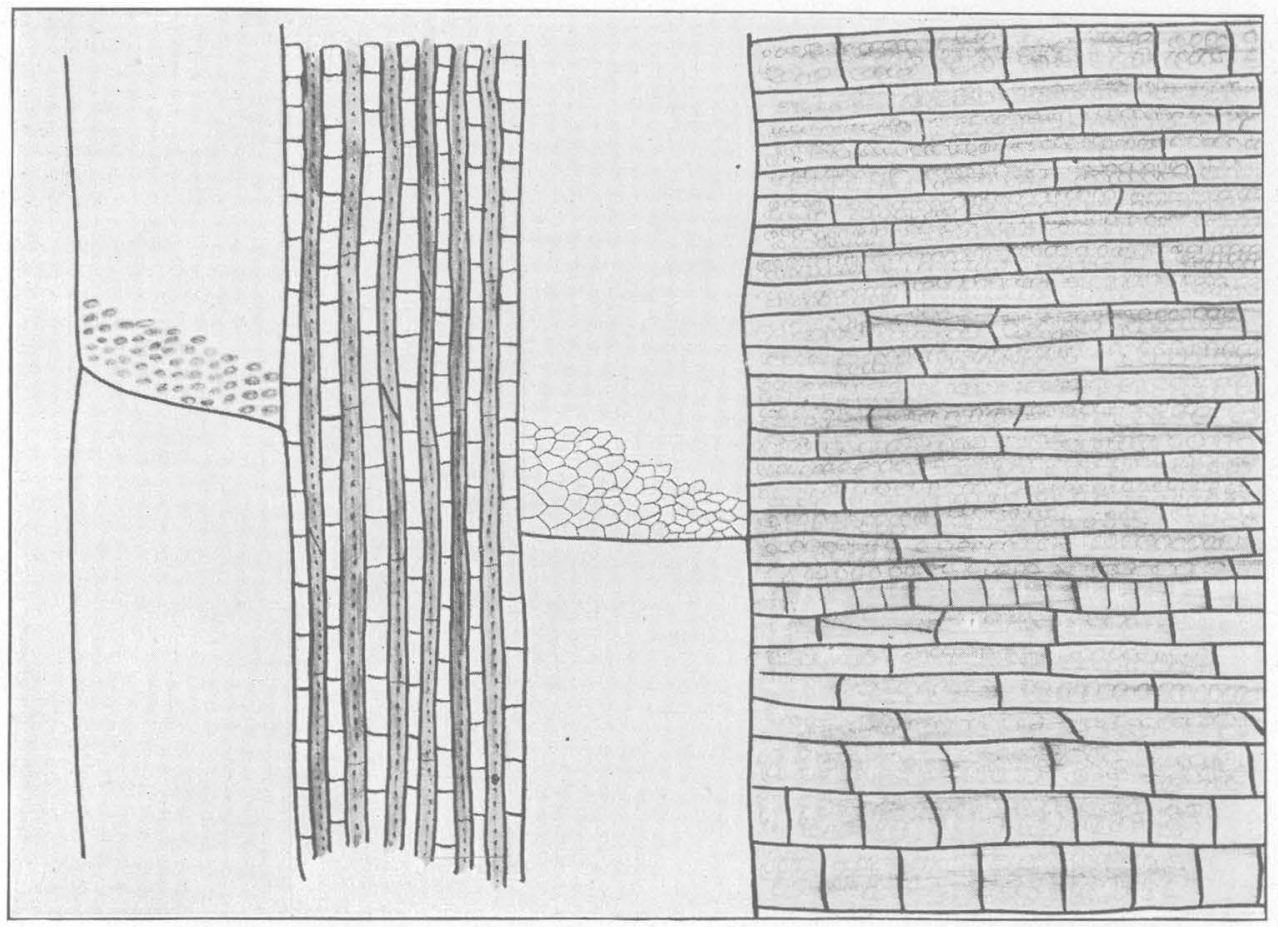

1

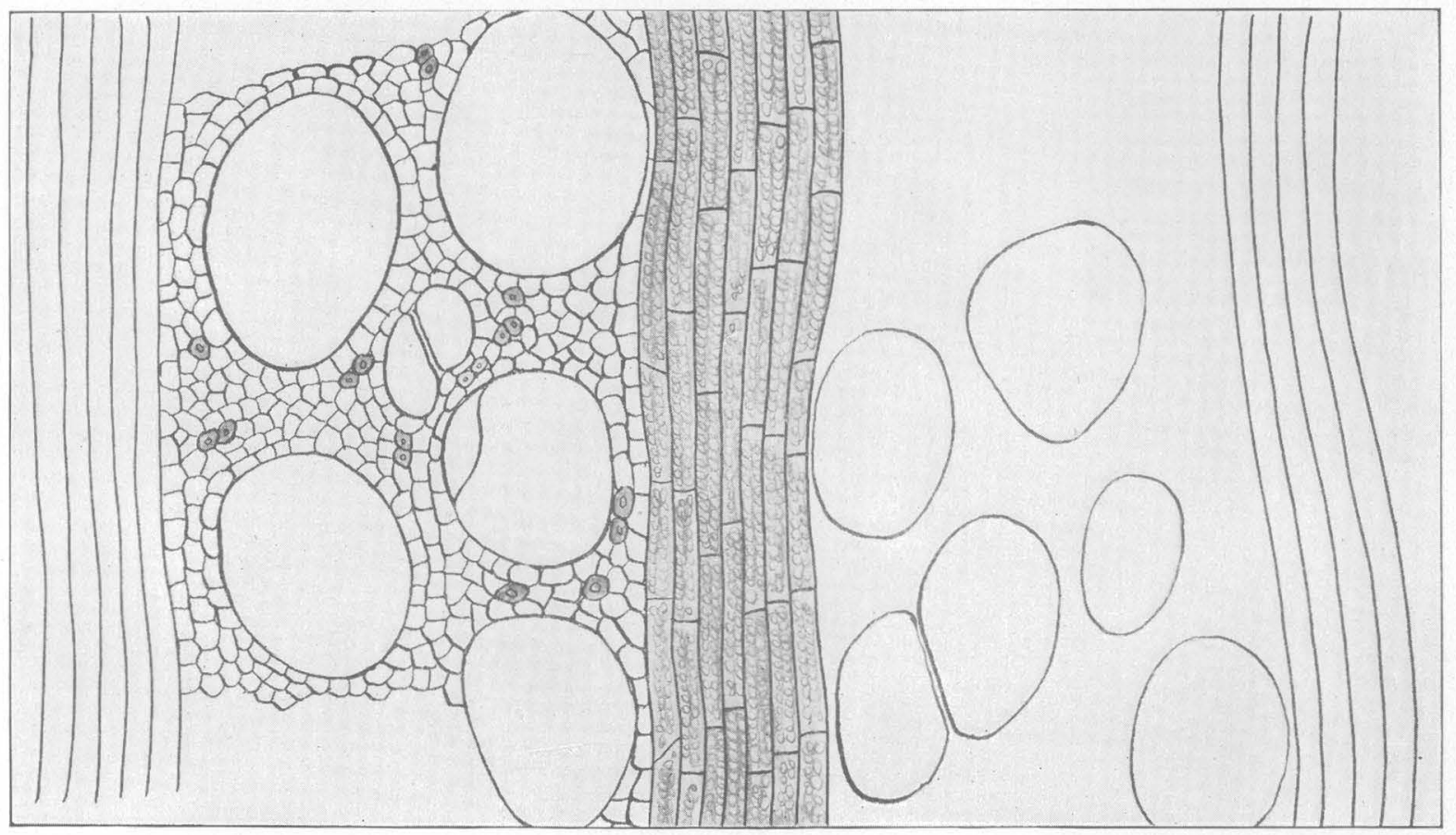

2

HELICTOXYLON WILCOXIANUM BERRY.

From vicinity of Naborton, La. 1, Radial section; 2, transverse section. Both enlarged about 300 diameters. 


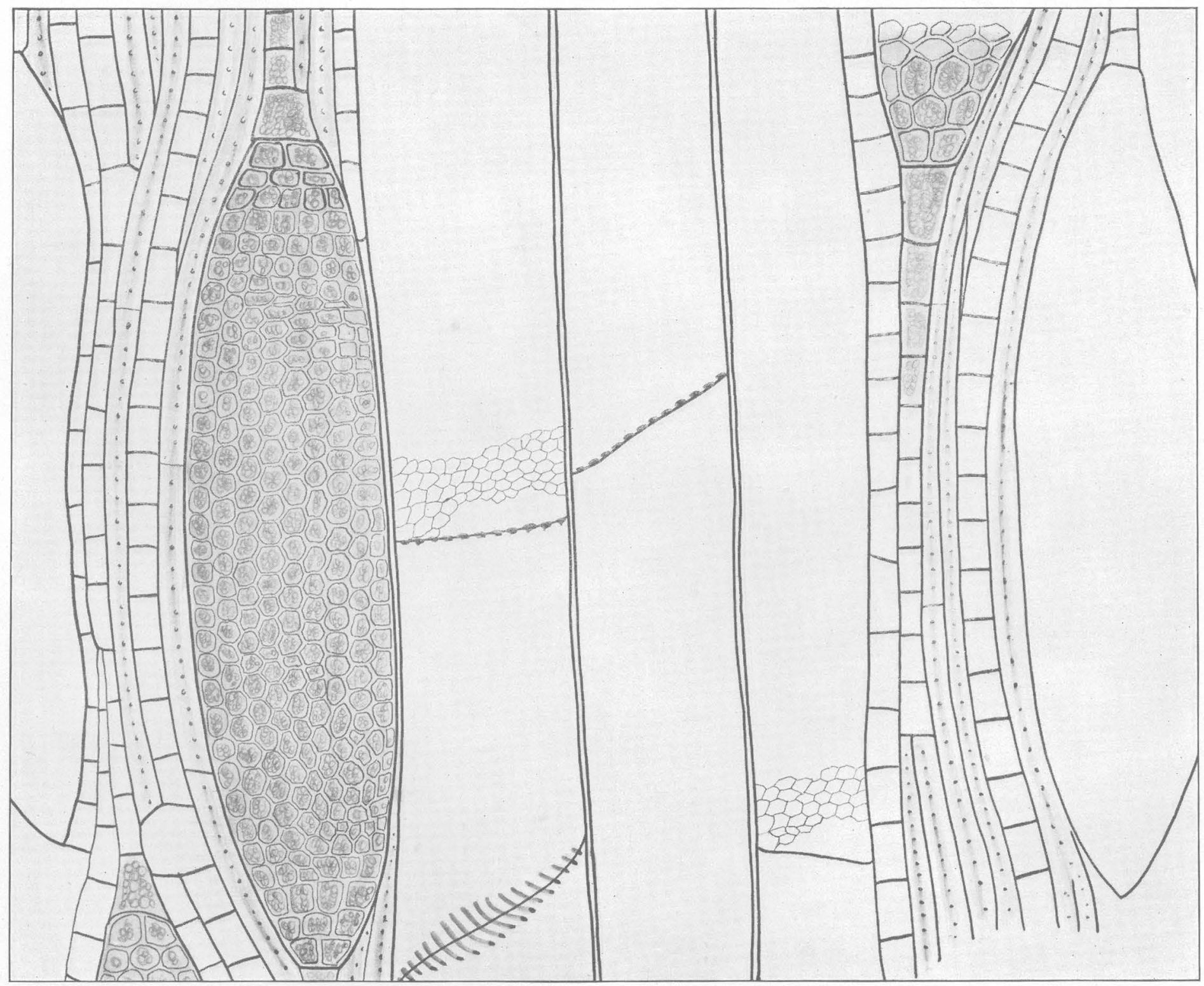

HELICTOXYLON WILCOXIANUM BERRY 


\title{
A SECTION OF THE PALEOZOIC FORMATIONS OF THE GRAND CANYON AT THE BASS TRAIL.
}

\author{
By L. F. NoBle.
}

\section{INTRODUCTION.}

The thick series of horizontal strata of Paleozoic age which makes the greater part of the wall of the Grand Canyon is probably broadly familiar to more people than the strata exposed in any other area in the western United States. Each detail of form or color in the wall is so definitely associated with a bed or set of beds in the series that these strata are the very elements of the canyon landscape. Consequently they have been described not only by geologists but by many writers who have been interested in the Grand Canyon chiefly as a scenic spectacle.

In few areas, however, where the general character and succession of the rock formations is so familiar are the details of the stratigraphy so imperfectly known. In the Kaibab division of the Grand Canyon, which lies within the borders of the Grand Canyon National Park and is the best known and most visited part of the canyon, sections of the Paleozoic formations have been measured at four different places(1) at Nunkoweap Valley, by Walcott; ${ }^{1}$ (2) at Congress Canyon (now known as Red Canyon), along the Hance trail, by Frech; ${ }^{2}$ (3) at Bright Angel (Cameron) trail, by Darton ${ }^{3}$ and by me; ${ }^{4}$ and (4) in the region about Shinumo Creek and Bass Canyon, by me. ${ }^{5}$

None of these sections shows in detail the lithology of all the Paleozoic formations at any

1 Walcott, C. D., U. S. Gool. Survey Tonth Ann. Rept., pt. 1, p. 584, 1890.

a Frech, F., Soction at Congress Canyon: Cong. géol. internat., 5e sess., Compto rondu, pp. 476-481, 1894 .

a Darton, N. H., A reconnaissance of parts of northwestern New Mexico and northern Arizona: U. S. Geol. Survey Bull. 435, p. 21, 1910; Guidebook of the wostern United States, Part C, The Santa Fe Route: U. S. Gool. Survoy .13ull. 613, pp. 124-130, 1915.

1 Noblo, I. F., 'Tho gcologic history of the Bright Angel quadrangle, Ariz.: U. S. Geol. Survey Bright Angel topographic map.

- Noble, L. F., Tho Shinumo quadrangle, Grand Canyon district, Ariz.: J. S. Gool. Survey Bull. 549 , pp. $60-73,1914$. one place, although some of them show the lithology of one or two formations in detail. Consequently none is adequate as a standard for close and accurate comparison and correlation of the formations from place to place in the canyon or for a detailed comparison with Paleozoic rocks exposed elsewhere in Arizona.

Realization of this lack of detailed stratigraphic information has led me to undertake a more thorough study of the Paleozoic rocks in the Grand Canyon than has been attempted previously. This work, begun in 1914 and continued in 1916 and 1920, has supplied material for a fuller description of the strata than was heretofore possible.

The present report includes a complete columnar section of the Paleozoic formations at the Bass trail, columnar sections of the Cambrian Tonto group at five other places in the Kaibab division, and a discussion of the age and correlation of the Paleozoic formations. Dr. Walcott has kindly furnished from his notes material for a fuller description of his section at Kanab Creek than has been published, and I have used this material freely in comparing and correlating the strata exposed at Bass Canyon, in the Kaibab division, with those exposed at Kanab Creek, in the Kanab division. I have also included in the report a section of the strata exposed in Cedar Mountain, a butte on the Coconino Plateau 2 miles east of the rim of the Grand Canyon near Tanner Canyon. This section carries the Grand Canyon geologic column up into the Mesozoic. The strata in Cedar Mountain, which is capped by the Shinarump "conglomerate, of Triassic age, are the only remnants near the canyon rim of formations 
that once covered the region but have been removed by erosion.

A map of the Grand Canyon between Nunkoweap Valley and Kanab Creek (fig. 1) shows the localities cited in this report and indicates the position of most of the displacements that cut the Paleozoic strata in this region. A key map (fig. 2) shows the localities where I measured the section at the Bass trail.

The section at the Bass trail presented in this report (Pl. XIX) supplants the Paleozoic section given in my report on the Shinumo quadrangle, ${ }^{\beta}$ because, except for the Bright Angel shale, the section given in the Shinumo report is a generalized reconnaissance section and is inaccurate in detail, the thicknesses assigned to formations having been either estimated or obtained by means of rough aneroid measurement. Several of the formations described in the Shinumo report are herein redefined.

6 Noble, L. F., op. cit., pp. $60-73$.

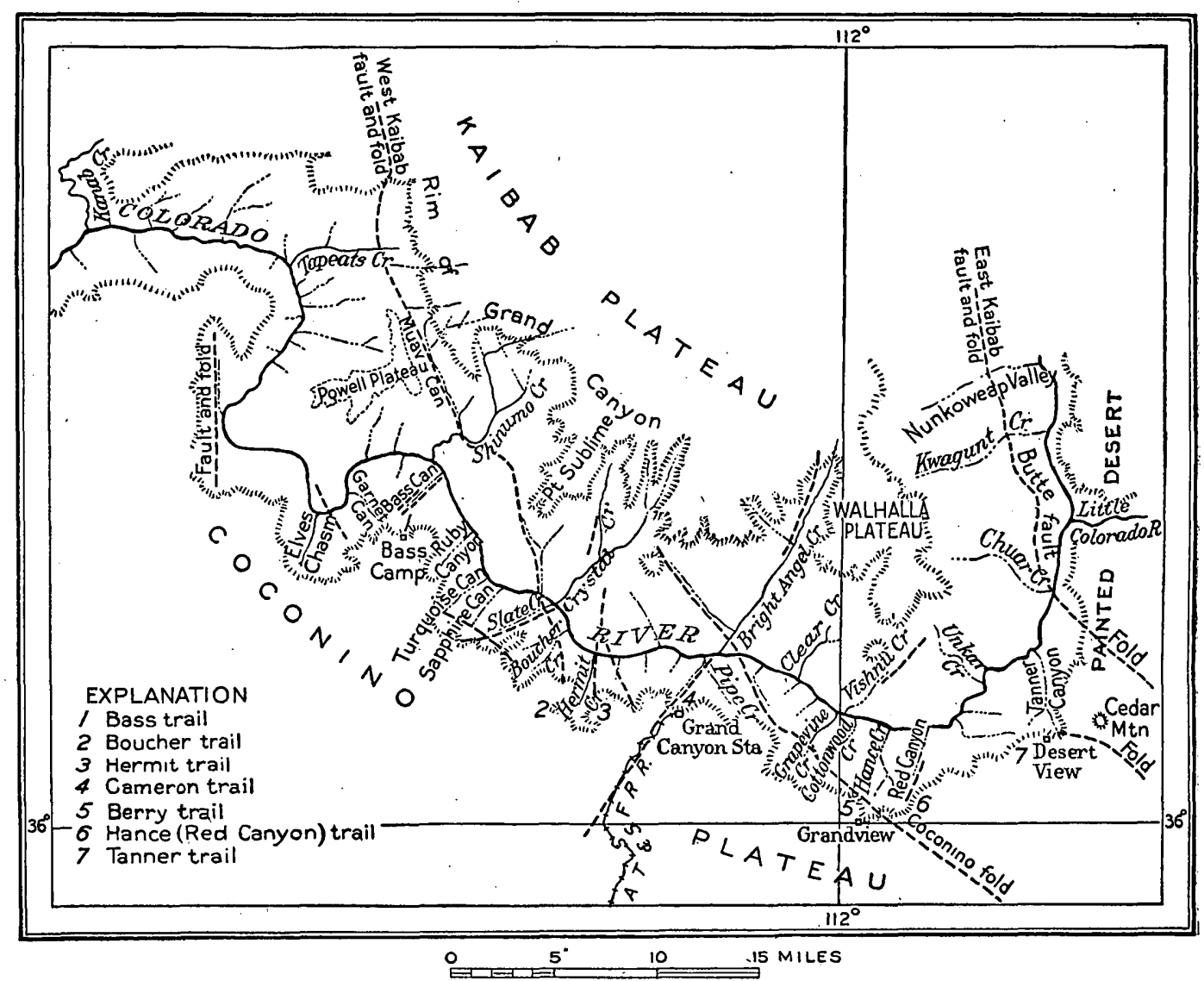

FigURe 1.-Map of Grand Canyon, Ariz., between Kanab Creek and Nunkoweap Valley. 


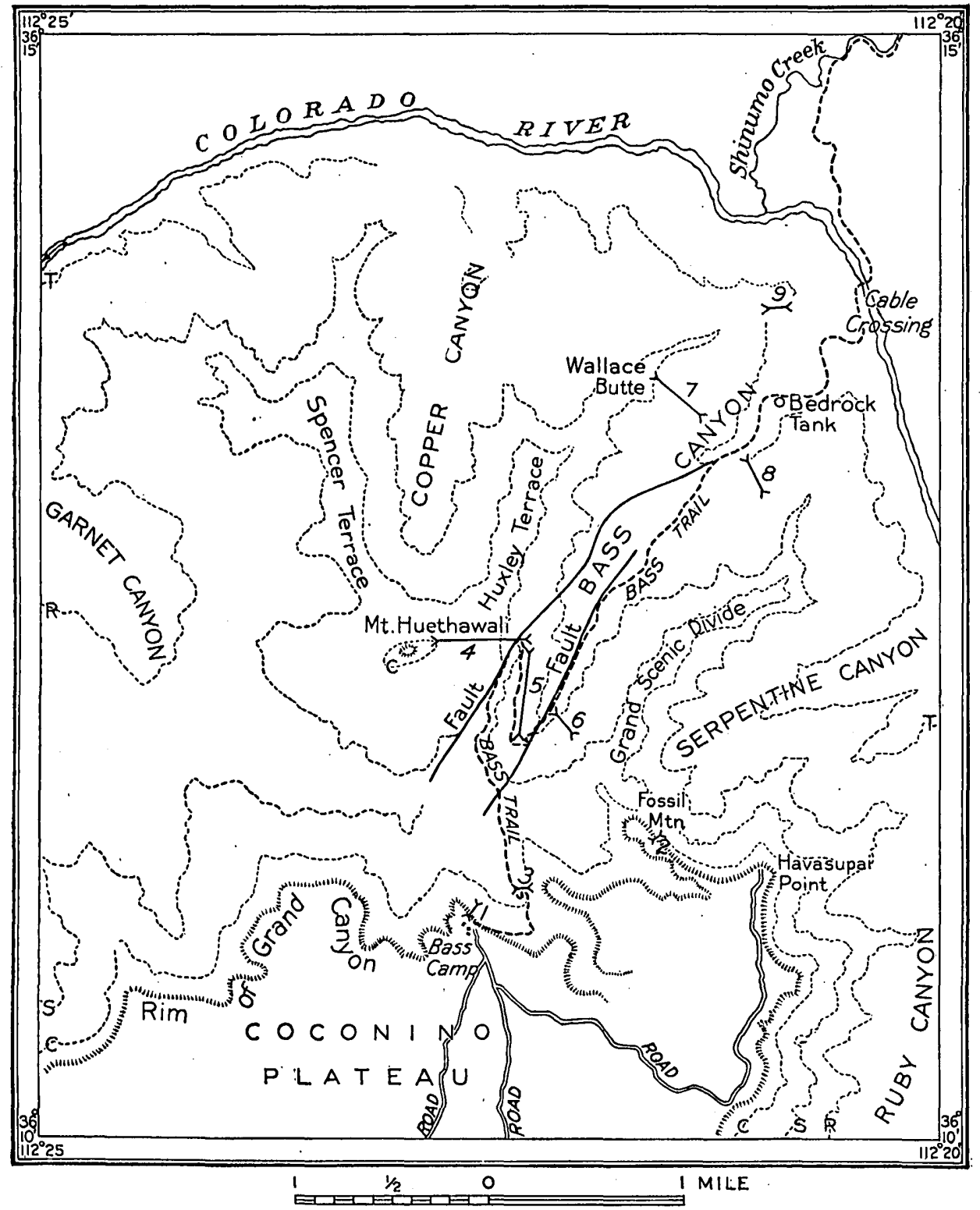

Fioure 2.-Outlino map of area about Bass trail, Shinumo quadrangle, Ariz., showing localities whero different parts of Paleozoic section were measured. Numbers correspond to those given in the detailed section. Dotted lines show cliffs as follows: $T$, Tapeats sandstone; $R$, Redwall limestone; S, Supai formation (uppermost cliff); C, Coconino sandstone. Hachures along rim of Grand Canyon and at Mount Huothawali show uppermost cliff formed by the Kaibab limestone. 


\section{SECTION AT BASS TRAIL.}

The section of Paleozoic rocks at the Bass trail is given below in two forms-a brief section showing the major subdivisions and a detailed section with comments on the beds.

Section of Paleozoic rocks at Bass trail.

1. General section.

CARBONIFEROUS SYSTEM.

Kaibab limestone (Permian):

A. Gray crystalline limestone, very fossiliferous and somewhat cherty, passing at base and top into alternating beds of very cherty limestone and buff calcareous sandstone; forms cliffs and steep slopes..

B. Buff and reddish fine-grained sandstone, poorly consolidated and irregularly bedded, containing beds of sandy breccia near top; forms slope.................

C. Buff sandstone and limestone in alternating beds, passing at top into massive siliceous limestone; upper portion forms a strong cliff; central portion forms cliffs and ledges; lower portion forms a slope......

Coconino sandstone (Permian):

Pale-buff, uniformly fine-grained sandstone characterized by crossbedding on a hige scale; presents the appearance of a single massive bed; forms the strongest and highest cliff in the upper wall of the canyon........

Hermit shale (Permian):

Deep brick-red sandy shale and fine-grained friable sandstone; characterized in upper portion by concretionary structure; beds form slope...........................

Unconformity.

Supai formation (redefined; Permian (?) and Pennsylvanian):

A. Alternating beds of red soft platy sandstone and buff hard cross-bedded sandstone, forming a ledgy slope broken by small cliffs; passing down into reddish or purplish to buff fine-grained cross-bedded sandstone in heavy massive beds, which form a strong cliff....................

B. Alternating beds of red friable shaly sandstone and massive cross-bedded calcareous sandstone including a few thin beds of limestone and a prominent bed of limestone conglomerate and forming a steep ledgy slope broken by small cliffs; passing down into reddish to buff fine-grained calcareous sandstone in heavy beds separated by thin layers of limestone or red shale and forming a strong cliff.......

C. Alternating beds of red. shale, bluish-gray or purplish-gray limestone, and reddish to buff calcareous cross-bedded sandstone; passing down into alternating beds of red sandy shale and bluish or purplishgray limestone containing red chert; form ledgy slope broken by small cliffs; outcrops of many beds concealed by talus..

Unconformity (?)

Redwall limestone (redefined and restricted; Mississippian):

A. Bluish-gray massive crystalline limestone in distinct beds, some of which are separated by thin partings of red shale; forms a succession of small cliffs and ledges above sheer cliff of subdivision B.....

B. Bluish-gray massive crystalline limestone in beds whose planes of separation are inconspicuous, so that when seen from a distance much of the limestone presents the appearance of a single massive stratum; forms sheerest and most sharply defined cliff in the canyon wall; thickness estimated.................... \pm 500

C. Brecciated limestone; forms slope under cliff of subdivision $B$

Unconformity (?)

Temple Butte limestone

Thin-bedded buff and pale-purplish sandy magnesian limestone; more or less blotched and mottled; harder, more massive beds alternate with softer, more conspicuously laminated beds; forms ledgy slope broken by small cliffs.

Unconformity

$$
\text { CAMBRIAN SYSTEM (TONTO GROUP). }
$$

Muav limestone:

A. Buff massive dolomite; forms strong cliff...

B. Buff fine-grained calcareous sandstone; massive at top, thinly laminated and in part micaceous and quartzose near base; forms cliff . ....................

C. Alternating thinly laminated beds of impure mottled limestone, intraformational conglomerate, platy fine-grained micaceous sandstone, and calcareous sandstone; form steep slope..................

D. Gray to buff hard thinly laminated mottled limestone; contains partings of greenish sandy shale for 10 feet at base; forms cliff.

Bright Angel shale:

A. Thin-bedded greenish and buff micaceous shale and sandstone with interbedded layers of impure mottled limestone and glauconitic snuff-brown dolomite at the base; beds form steep slope or weak cliff. .

B. Thin-bedded greenish and buff micaceous shale and sandstone with two beds of snuff-brown dolomite and sandstone in the middle portion which form two conspicuous brown cllffs in a long slope made by the shales and sandstones............ .}

0

.




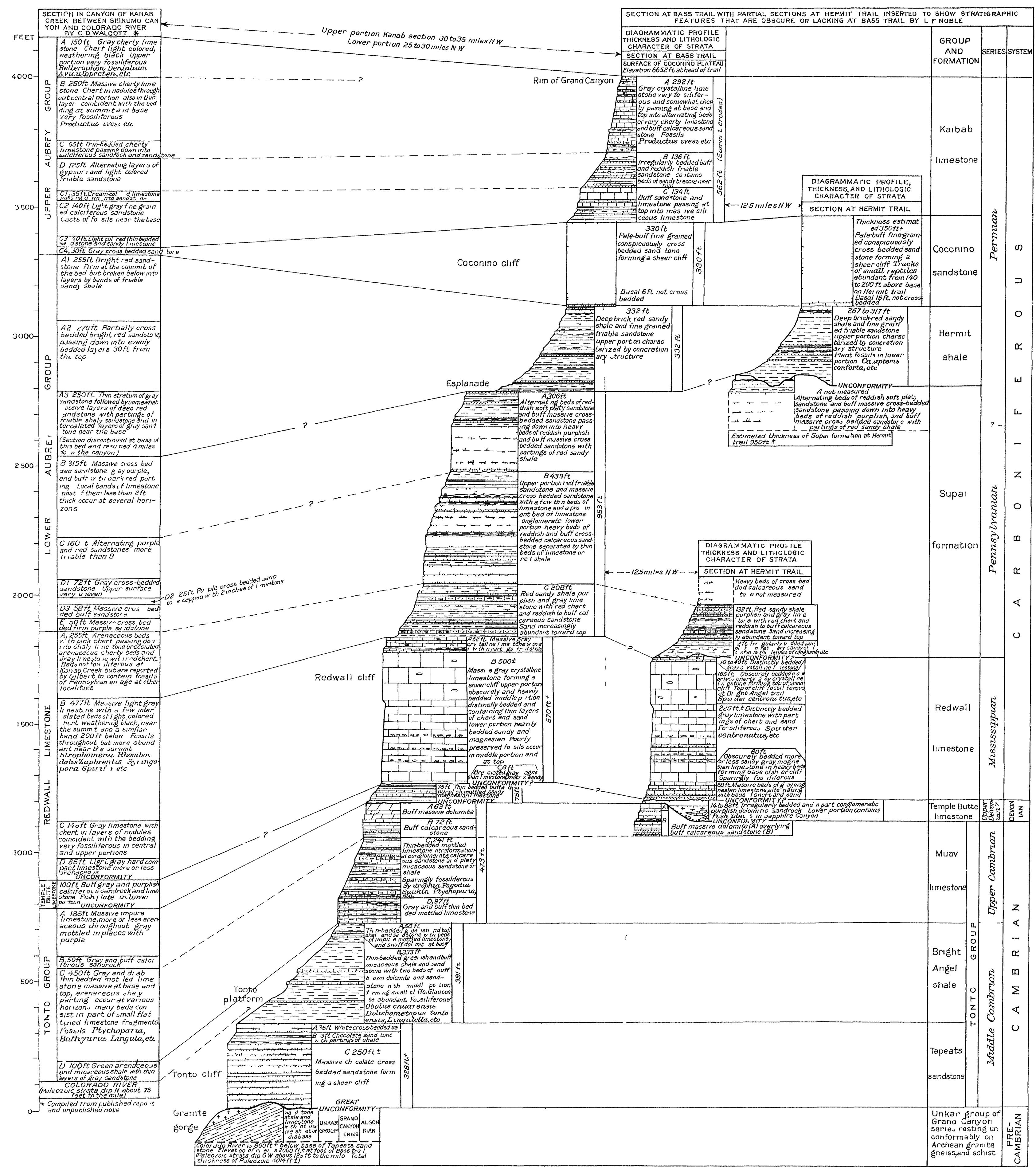

COLUMNAR SECIION OF THE PALEOZOIC STRATA OF THE GRAND UANYON AT BASS TRAIL 
Tapeats sandstone:

A. White cross-bedded sandstone; forms weak cliff.............................

B. Chocolate-colored sandstone with partings of shale; forms steep ledgy slope........

C. Massive chocolate-colored cross-bedded sandstone; forms sheer cliff along rim of Granite Gorge.....................

Total thickness of Paleozoic rocks...... $\frac{\overline{14,014}}{\overline{\frac{328}{4,014}}}$ 2. Detalled section.

Kaibab limestone:

A. 1. Limestone, buff, compact; effervesces strongly with dilute hydrochloric acid; caps a small cliff on the rim of the canyon at the head of Bass trail. Bass Camp, on the Coconino Plateau, at the head of the trail, is built upon this stratum. Higher beds, which form the surface of the plateau just east of the camp, are not included in this section..........................

2. Limestone (for analysis see p. 69), buff, siliceous; texture compact, chalky; contains small cavities lined with tiny crystals.......................

3. Sandstone, buff, fine grained, calcareous; effervesces with acid............

4. Alternating thin beds of variegated chert and fine-grained calcareous sandstone.

5. Limestone, gray, crystalline, very cherty, fossiliferous. The chert occurs in nodules and in bands; in places it constitutes half of the rock. Aside from the abundance of chert the limestone resembles No. 6....................

6. Limestone (for analysis see p. 69), gray, hard, crystalline, somewhat cherty, very fossiliferous; effervesces strongly with acid. Beds differ greatly in thickness; some are a few inches thick, others several feet. The chert occurs in scattered nodules and in bands but is not a conspicuous feature of the rock..........................

7. Alternating beds of fine-grained buff calcareous sandstone, buff limestone, and chert; form small conspicuous cliff .

8. Limestone, gray, hard, crystalline, somewhat cherty, fossiliferous; like No. 6 ..

9. Sandstone, lemon-buff, fine-grained, calcareous; bedding irregular, gnarly; forms a gentle slope covered in most places by talus...................

10. Limestone, thin-bedded, very cherty; effervesces with acid. The chert constitutes over half of the rock and occurs in parallel bands whose average thickness is 2 inches.....................

[NoTE.-The foregoing section of subdivision $A$ was measured under the rim of the canyon directly in front of Bass Camp, at locality 1 , figure 2.]
B. 1. Sandstone, buff, massive, fine-grained, calcareous; effervesces weakly with acid.

2. Breccia composed chiefly of angular fragments of evenly bedded buff finegrained sandstone embedded in a matrix of fine lemon-buff sand; contains a few fragments of siliceous limestone. The fragments range in diameter from less than an inch to over 4 feet. The contact of the breccia with the underlying sandstone is wavy and irregular, exhibiting in places inequalities of several feet...............

3. Sandstone, buff, fine-grained, friable. The component grains are quartz, as in other sandstones of the Kaibab, but are very loosely cemented, so that the rock crumbles to sand when struck with the hammer....................

4. Sandstone like No. 3, but bright red....

5. Buff sandstone like No. 3 ...............

6. Bright-red sandstone like No: $4 \ldots \ldots \ldots$.

7. Lemon-buff sandstone like No. 3 ........

8. Bright-red sandstone like No. 4; contains a 1-inch layer of pale-green sandstone in the central portion............

9. Sandstone, lemon-buff, fine-grained, friable; bedding irregular, gnarly; contact with underlying sandstone slightly wavy and irregular.

10. Sandstone, bright red, shaly; bedding gnarly; contact with underlying breccia wavy and irregular, exhibiting inequalities of 2 feet or more.

11. Breccia composed of angular fragments of fine-grained sandstone averaging 4 inches in diameter. Very little matrix between the fragments. The appearance of the rock suggests that it was crushed and shattered after it was deposited. The contact with the underlying sandstone is irregular, exhibiting inequalities of several feet. .

12. Reddish-buff, loosely consolidated finegrained sandstone in indistinct but fairly even beds, some of which display gnarly structure; forms débris-covered slope; exposures poor. The upper 3 feet of the sandstone is bright red and thinly laminated...................

13. Sandstone like No. 12 but more compact, forming a weak cliff; gnarled and twisted structure very pronounced; color lemon-buff to reddish buff.......

14. Sandstone like No. 12, very soft, forming a gentle slope that is covered nearly everywhere by talus; no good exposures obtainable. Colored white, lemon-buff, greenish, and bright red. In some places the color is in blotches or streaks; in others a single color characterizés each bed. 
. [NотE.-The foregoing section of subdivision $B$ was measured on the northeast side of Fossil Mountain, at locality 2 , figure 2 .]

C. 1. Limestone, buff, dense, siliceous; in heavy, massive beds; forms a strong cliff; contains much chert in bands and nodules and many small cavities lined with crystals of quartz or calcite. In appearance the rock suggests silicified chalk. Some beds effervesce weakly with acid .......................

2. Limestone like No. 1 butin thinner beds (1 foot or less) which are separated by thin partings of buff fine-grained shaly sandstone; forms a steep ledgy slope....

3. Limestone like No. 1 ; forms a cliff.......

4. Shaly sandstone, lemon-buff, soft, thinbedded, fine-grained; makes alcove under overhanging cliff of No. 3.......

5. Limestone, buff, in heavy beds with thin sandy partings, not notably siliceous; effervesces strongly with acid; forms cliff.

6. Shaly sandstone like No. 4 ; makes alcove under overhanging cliff of No. $5 . . . . .$. .

7. Limestone like No. 5 but in thinner beds (1 foot or less); forms slope............

8. Limestone, buff, dense, siliceous, in heavy beds; contains numerous crystallined cavities apparently formed by the solution of brachiopods; does not effervesce with acid..................

9. Limestone like No. 7, in beds separated by very thin partings of sand...........

10. Sandstone, buff, fine-grained.............

11. Limestone like No. 7, but in a single bed.

12. Sandstone, buff, fine-grained...........

13. Limestone, buff, siliceous, fossiliferous; does not effervesce with acid; contains numerous small cavities lined with calcite crystals......................

14. Alternating beds of lemon-buff finegrained sandstone and buff limestone; beds average 3 inches in thickness....

15. Limestone, buff, not notably siliceous; effervesces strongly with acid.........

16. Sandstone, lemon-buff, fine-grained....

17. Sandstone, red, fine-grained. The base of this layer truncates inclined laminae of the underlying Coconino sandstone, which $\operatorname{dip} 15^{\circ} \mathrm{S} . \ldots \ldots \ldots \ldots \ldots . . . . .$.

[Note.-The foregoing section of subdivision $\mathrm{C}$ was measured directly above the point where the Bass trail descends the Coconino sandstone, at locality 3 , figure 2.]

Coconino sandstone: Pale-buff fine-grained sandstone, cross-bedded on a huge scale; appears like single massive bed; forms highest cliff in upper wall of canyon. The base of the sandstone is marked by an abrupt change from buff sandstone to underlying red shale, and the contact is an even line. In places the

under surface of the sandstone shows impressions of sun cracks. For 25 feet above the base the cross-bedding is on a small scale, and horizontal layers alternate with cross-bedded layers; then the coarse cross-bedding begins and continues upward until the sandstone is truncated by the level base of the Kaibab....................

[NOTE.-The foregoing section of the Coconino sandstone was measured on the Bass trail at the point where the trail descends the sandstone, at locality 3 , figure 2. At Mount Huethawali, a mile northwest of this point, the basal layer of the Coconino is massive sandstone 5 feet thick which displays no cross-bedding.] Hermit shale:

1. Sandstone, red, soft, fine-grained, massive, with a thin layer of green shale at the top. Exhibits well-marked concretionary structure; the concretions are spheroidal forms which range from half an inch to 4 feet in diameter and consist of the general mass of the rock; in weathering, the rock splits off in concentric shells along the concretionary surfaces.

2. Sandstone, fine-grained, massive; resembles the Coconino sandstone in texture and composition but is not crossbedded; lower half buff; upper half red with buff blotches................

3. Concretionary sandstone like No. 1 , in massive layers. ..................

4. Shale, deep red, thinly laminated, sandy.

5. Beds of soft massive concretionary red sandstone like No. 1 alternating with thinner beds of deep-red shale like No. 4 ; sandstones and shales not conspicuously different in composition......

6. Shale, deep red, sandy ..............

7. Sandstone, pink, hard, very fine grained; contains cracks and cavities filled with crystals of calcite (dog-tooth spar); rock itself does not effervesce with acid; forms small prominent cliff...........

8. Shale, soft, brick-red, thinly laminated, sandy .........................

9. Sandstone, brick-red, friable, massive; forms weak cliff.................. All underlying beds of shale are like No. 8; all underlying beds of sandstone like No. 9. The beds designated shale and sandstone actually differ little in composition; both consist essentially of sandy mud colored red by a strong ferritic pigment. The beds designated sandstone are massive and relatively compact, as contrasted with the beds designated shale, which are thinly laminated and soft. Both types of rock are friable. 
10. Shale, containing beds of massive friable sandstone near the top..............

11. Sandstone in massive beds; contains a 1-foot layer of shale in the middle portion; forms weak cliffs...............

12 Shale..........................

13. Sandstone; forms weak cliff. ...........

14. Shale ...........................

15. Alternating lenticular beds of intraformational conglomerate and red finegrained sandstone averaging 1 foot in thickness; beds display indistinct sun cracks and rain prints; form weak cliff. The conglomerate consists chiefly of flattened pebbles of fine-grained sandstone or sandy shale less than $1 \mathrm{inch}$ in diameter embedded in a matrix of red sandy mud but contains some nodular or concretionary fragments of limestone

16. Shale..........................

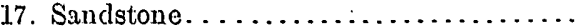

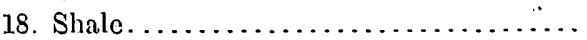

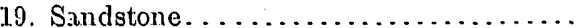

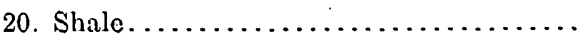

21. Sandstone; forms weak cliff. ..........

22. Shale ...........................

23. Sandstone; forms weak cliff ...........

24. Shale..........................

[Note.-The foregoing section was measured at the east end of Mount Huethawali, about a quarter of a mile northwest of the point where the Bass trail begins to descend into Bass Canyon, at locality 4 , figure 2 .]

Supai formation:

A. 1. Sandstone, white, fine-grained, crossbedded, hard, calcareous; effervesces with acid; contains many cracks lined with calcite; forms a small conspicuous cliff and determines a wide shelf at the general level of the Isplanade platform. At the point where the section was measured the floor of the Esplanade consists in part of this sandstone and in part of knolls of soft red Hermit shale which overlie the sandstone.

2. Sandstone, red, soft, friable, platy, finegrained; forms a long, gentle slope....

3. Sandstone, buff, fine-grained, massive, weathers white; effervesces with acid; unites with underlying bed in forming a cliff .

4. Sandstone, pinkish buff, cross-bedded..

5. Red soft platy sandstone like No. 2; forms slope.

6. Massive buff sandstone like No. 3 ; hard; forms strong cliff

7. Red soft platy sandstone; forms slope...

8. Pinkish-buff cross-bedded sandstone like. No. 4; forms cliff.................. $91.048^{\circ}-23-3$
A. 9. Soft platy beds of red sandstone alternating with harder, more massive beds; form long ledgy slope...............

10. Pinkish-buff cross-bedded sandstone; upper surface weathers white; forms cliff.

11. Red soft platy sandstone; forms wastecovered slope.

12. Pinkish-buff cross-bedded sandstone; forms cliff ......................

13. Red soft platy sandstone; forms wastecovered slope.

14. Fine-grained sandstone in heavy, massive beds, some of which are separated by thin partings of red soft platy sandstone; cross-bedded throughout; inclined laminae dip south; some heds near the base display an irregular, gnarly structure. The prevailing color of the upper 40 feet of the sandstone is pale brick-red; that of the lower 1.25 feet ranges from pale purplish to buff. The rock of most beds dôn not effervesce with acid. A bed of sandy limestone or very calcareous sandstone 2 feet thick occurs 35 feet above the base of the sandstone.

A. 15. Conglomerate, composed of subangular fragments of sandstone embedded in a matrix of fine sand of the same composition as the fragments; probably an intraformational conglomerate; displays a rude concretionary structure; fragments weather by splitting off in concentric shells. Many of these shells are embedded in the matrix. The conglomerate varies in thickness and in places is absent; appears to rest upon a slightly uneven surface........... $0-5$

[Note.-At the rim of Bass Canyon directly east of Mount Huethawali subdivision $A$ of the Supai is cut by a fault which breaks the strong cliff formed by bed 14. The Bass trail descends the cliff in a shattered zone a!ong the fault. The strata have been displaced about 130 feet by the fault, those on the east side being relatively lowered. In measuring subdivision $A$ at Bass trail it was necessary to divide the section at the fault. Beds 1 to 13 and the upper 40 feet of bed 14 were measured west of the fault, in the slope between the trail and the base of Mount Huethawali, at locality-4, figure 2. Bed 15 and the lower 125 feet of bed 14 were measured on the trail just east of the fault, at locality 5 , figure 2 . The thickness which I have assigned to bed 14 may be incorrect, because I could not locate equivalent layers in 
the bed on opposite sides of the fault, owing to the homogeneity of the sandstone. 7

B. 1. Magenta or reddish platy fine-grained shaly calcareous sandstone; effervesces with acid; forms slope.............

2. Hard massive sandy limestone or very calcareous sandstone; effervesces strongly with acid; unites with underlying bed in forming cliff...........

3. Gnarly sandstone blotched purplish and buff.

4. Red friable sandstone; forms slope......

5. Buff cross-bedded calcareous sandstone; forms cliff.

6. Red friable shaly sandstone; forms slope.

7. Alternating lenticular beds of conglomerate and fine-grained sandstone, both cross-bedded. Most of the conglomerate conspists of well-rounded waterworn pebbles 4 inches or less in diameter embedded in a matrix of red mud and sand; most of the pebbles are bluish-gray or purplish-gray nodular limestone, but some are fine-grained sandstone. Some beds exhibit the peculiar concretionary structure that characterizes bed 15 of subdivision $\mathrm{A}$ and consist of subangular fragments of sandstone ranging from less than 1 inch to more than 2 feet in diameter embedded in sand of the same composition as, the fragments. The beds of conglomerate and sandstone rest on an uneven surface that exhibits a relief of several feet.

8. Red friable shaly, sandstone; forms slope.

9. Pinkish-buff cross-bedded calcareous sandstone; unites with underlying bed in forming cliff . . ................

10. Pink hard massive sandy limestone or very calcareous sandstone; effervesces strongly with acid.

11. Red friable soft sandstone; exhibits concretionary structure; forms slope.....

12. Buff cross-bedded sandstone; forms cliff.

13. Beds of red shale and soft concretionary calcareous sandstone; form alcove under cliff of No. $12 \ldots \ldots \ldots \ldots . .$.

14. Light brick-red to pinkish-buff, rather soft cross-bedded calcareous sandstone with a few interbedded layers of red shaly sandstone; forms a steep ledgy slope broken by weak cliffs; some beds contain . elongated rudely cylindrical or conical forms which are lighter in color than the mass of the rock and in places weather out of the rock. These forms are of various sizes, but most of them are less than 1 inch in diameter. They are undoubtedly organic in origin and may be fucoids.............
B. 15. Red friable soft thinly laminated sandstone; forms slope..................

16. Massive sandy limestone or very calcareous sandstone; rests on a slightly uneven wavy surface that truncates inclined laminae of the underlying sandstone; caps cliff formed by the underlying sandstone to prevail; bed forms strong cliff.....

18. Alternating beds of red friable calcareous sandstone and maroon soft thinly laminated shale; form ledgy slope........

19. Light brick-red calcareous sandstone; effervesces strongly with acid; contains elongated cylindrical or conical forms similar to those in bed 14 and numerous obscure small branching forms which may represent either fucoids or worm burrows; makes a ledgy slope...

20. Nodular purplish-gray limestone; contains large numbers of the obscure forms noted in bed 19; caps cliff formed by underlying bed...........

21. Buff cross-bedded calcareous sandstone; like No. 17, but the cross-bedding is on a less coarse scale; forms strong cliff...

22. Beds of calcareous sandstone blotched red and buff separated by thin beds of maroon shale which exhibit suncracked surfaces; form alcove under cliff of No. 21. The Bass trail follows this alcove southward to a gulch in which it descends a long rock slide to the base of the Supai...............

23. Hard pinkish or purplish fine-grained limestone blotched greenish buff; crystalline in places; contains the obscure forms noted in bed 19 , also small masses, largely calcite, whose outlines suggest those of brachiopods; with underlying beds forms strong cliff...

24. Beds of pinkish fine-grained limestone; form cliff

25. Buff cross-bedded calcareous sandstone like No. 21; forms cliff..............

26. Red shale; forms small alcove...........

27. Buff cross-bedded calcareous sandstone like No. 21, divided into two beds by a thin parting of red shale in the center; forms strong cliff. The under 
surface of the lower sandstone bed exhibits casts of sun cracks at the contact with the underlying shale...........

B. 28. Maroon shale

29. Massive buff calcareous sandstone; base slightly uneven, wavy..............

C. 1. Bluish-gray nodular limestone mixed with red mud which imparts a blotched or mottled appearance to the rock....

2. Maroon shale; exhibits concretionary structure; in part brecciated; crac'ss between fragments infiltrated with red mud; contact with underlying bed

uneven, wavy .......................
3. Bluish-gray nodular limestone mixed with purplish mud, some of which appears to have been infiltrated along cracks; in part brecciated; contains the obscure forms, probably fucoids, noted in $\mathrm{B} 14,20$, and other beds...........

[Note.-Beds B 28 and 29 and C 1,2, and 3 form an alcove under the cliff at the base of subdivision B. The foregoing section, including all of subdivision $B$ and beds 1 to 3 of subdivision $\mathrm{C}$, was measured on or near the Bass trail on the west side of Bass Canyon, at locality 5, figure 2.]

4. Slope covered by talus, largely concealing underlying rock. Exposed beds consist of purplish platy calcareous sandstone or sandy limestone, blotched buff, separated by thin layers of red shale...........................

5. Pinkish-buff hard cross-bedded calcareous sandstone; forms cliff...............

6. Red platy sandy shale.................

7. Bluish-gray compact crystalline cherty limestone passing downward into hard cross-bedded calcareous sandstone; forms cliff.......................

8. Cross-bedded calcareous sandstone with a 2-inch layer of red shale at the base; forms steep slope.

9. Purplish sandy limestone; unites with underlying bed in forming a cliff; contact with underlying bed uneven, exhibiting inequalities of 2 feet in places.

1.0. Trard cross-bedded calcareous sandstone.

11.. Red soft shaly sandstone; in part crosshedded; forms a weak cliff...........

12. Red sandy shale; forms slope.........

13. Bluish-gray limestone with conspicuous bands of reddish or pink chert; in places the limestone is mixed with reddish or purplish mud, which imparts a mottled appearance to the rock......

14. Red sandy shale; forms slope.........

15. Purplish sandy limestone, in part crystalline; contains a few nodules of red chert; forms slope................

16. Red soft fine-grained shaly sandstone in platy beds; forms slope. . . . . . . . . . .
C. 17. Buff hard fine-grained calcareous sandstone; forms strong cliff. . . . . . . . . .

18. Buff fine-grained shaly sandstone; in part conglomerate composed of lumps of chert and buff sandy limestone averaging an inch in diameter; forms slope.........................

19. Red shale; forms slope..............

20. Bluish-gray limestone containing parallel bands of red chert..................

21. Purplish massive friable sandy shale speckled with small circular buff spots, passing down into bluish-gray nodular cherty limestone.................

narly nodular bed composed of lumps of purplish sandy shale mixed with purplish mud. ....................

23. Conspicuously banded bed composed of bluish-gray limestone and white or red chert; forms strong cliff; the alternating bands of chert and limestone average an inch in thickness; in places the limestone at the summit of the bed is mixed or infiltrated with red mud....

24. Gentle slope covered by talus which conceals the bed so completely that no outcrops can be found. The bed appears to be a reddish or purplish soft shale........................

[NotE.-The foregoing section was measured on the east side of Bass Canyon a quarter of a mile northeast of the point where the Bass trail descends a break in the Redwall cliff at the head of the canyon, at locality 6 , figure 2. This break is on the line of a fault along the axis of Bass Canyon. The strata are displaced about 75 feet by the fault, those on the west side of the canyon being relatively lowered.]

11 Redwall limestone:

A. 1. Bluish-gray massive limestone in heavy beds; contains a few scattered nodules of chert; forms strong cliff............

2. Red, purple, or greenish-buff shale; thinly laminated; forms slope..........

3. Beds of bluish-gray limestone separated in places by paper-thin partings of red shale; form steep ledgy slope........

4. Bluish-gray limestone and red shale in alternating beds which average 1 inch thick; form slope.

5. Crystalline limestone; white on freshly broken surfaces; effervesces strongly with acid; contains a few chert nodules and here and there a poorly preserved fossil (see pp. 56-57); forms strong cliff.

6. Bluish-gray crystalline limestone in beds less than 6 inches thick separated by paper-thin partings of reddish or buff 
sandy shale; wastes back in a slope, leaving a ledge at the summit of the sheer cliff of subdivision $B$.

[Nome.-The foregoing section was measured on the east side of Bass Canyon directly under the place where subdivision $\mathrm{C}$ of the Supai was measured, at locality 6 , figure 2 .]

B. Massive crystalline limestone forming a sheer high cliff; upper portion heavily and obscurely bedded; middle portion distinctly bedded and containing many thin interbedded layers of chert and sand; lower portion heavily bedded and magnesian. Most beds contain scattered nodules of chert. Many contain coarse crystals of calcite; some of the calcite lines cavities; some of it occurs in large masses in the rock; some of it forms beds several inches to a foot thick. Intercalated layers of sand are commonly less than a foot thick, are loosely cemented, and exhibit gnarly structure; most of them rest on irregular, wavy surfaces. In many places the limestone cliff is stained pink by ferritic pigment washed over it from overlying red shales; unstained surfaces of the limestone weather bluish gray; freshly broken surfaces are gray, buff, or white. Subdivision $\mathrm{B}$ is rudely divisible into three members, as follows:

1. Obscurely bedded limestone, most of which is in heavy beds; beds differ greatly in thickness, some being over 20 feet thick, others only a few inches; most of the limestone is finely crystalline, light gray or white on freshly broken surfaces, and very pure (for analysis see p. 55); effervesces strongly with acid. Contains a few thin beds of sand, some chert, and much calcite in coarse crystals. Surface of limestone at top of cliff exhibits very poorly preserved fossils. . Thickness estimated:.. \pm 200

2. Distinctly bedded limestone in rather uniform beds, most of which do not exceed 5 feet in thickness; limestone beds alternate with thin layers of chert or sand; effervesce strongly with acid; some beds are very fossiliferous, but fossils are poorly preserved. Owing to its laminated character this member is less resistant to erosion and recedes faster than the overlying heavy-bedded limestone, so that in many places it is overhung by the overlying member. This difference in erosion determines the formation of great niches or alcoves in the Redwall cliff. Thickness estimated...................... \pm 220

B. 3. Heavy-bedded magnesian limestone; chemical composition near that of dolomite (see analysis, p. 55); does not effervesce freely with acid; some beds are separated by thin layers of loosely consolidated sandstone; under Wallace Butte the limestone rests on a layer of loose gnarly sandstone 1 foot thick. Thickness estimated........ \pm 80

[NoTE.-The foregoing section of subdivision $B$ was examined along the Bass trail, at locality 6 , figure 2 . The thickness assigned to subdivision $B$ is the thickness of its cliff under Wallace Butte in Bass Canyon as measured on the topographic map of the Shinumo quadrangle.]

C. Brecciated limestone composed of subangular fragments of limestone 6 inches or less in diameter embedded in a matrix of yellowish or purplish sand; in places passes into gnarly calcareous sandstone or into limestone containing irregular masses of yellowish or purplish sand; forms steep slope or weak cliff under sheer cliff of subdivision B. In places the base of this curious bed is uneven; in places the summit is uneven. Average thickness.............

[Note.-The foregoing section of subdivision $\mathrm{C}$ was measured under Wallace Butte on the west side of Bass Canyon, at locality 7 , figure 2 .]

Temple Butte limestone:

1. Thinly laminated sandy magnesian limestone in rubbly beds mottled pale purplish or buff; effervesces feebly with acid; soft; forms slope. Some mottled beds resemble beds in the Muav limestone that have been bored by worms.......................

2. Limestone like No. 1 but harder and more massive; forms small cliff.

3. Thin beds of limestone like No. 1 alternating with thin beds of intraformational conglomerate composed largely of flattened pebbles of limestone; form slope..........................

4. Limestone like No. 2 ; forms cliff.........

5. Limestone like No. 1 ; forms slope.........

6. Limestone like No. 2 ; forms small cliff...

7. Limestone like No. 1 ; forms slope........

8. Limestone like No. 2 ; forms strong cliff..

9. Limestone like No. 2; forms cliff.

.


1.0. Massive bed of purplish crystalline magnesian limestone; forms cliff . .........

11. Limestone like No. 2 ; forms cliff; surface exhibits cross sections of poorly preserved cup corals (?) ................

12. Limestone like No. 1 ; forms slope.........

13. Limestone like No. 2 ; forms cliff.........

14. Limestone like No. 1 (for analysis see p. 52); very soft; forms gentle slope above strong cliff at top of underlying Muav limestone.

[NOTE.-The foregoing section was measured under Wallace Butte on the west side of Bass Canyon, at locality 7 , figure 2. At this locality the contact between bed 14 and the $1 ! n$ derlying Muav limestone exhibits no irregularity in a distance of 1,000 feet, and the bed appears to rest conformably upon the Muav limestone, but in Ruby Canyon, 2 miles southeast of Bass Canyon, the contact is very uneven, exhibits vertical inequalities of 40 feet or more in horizontal distances of a few hundred feet, and clearly represents a strong line of erosion.]

Muav limestone:

A. 1. Buft hard massive crystalline dolomite in heavy beds (for analysis see p. - -); does not effervesce with acid; forms cliff. At one place on the east side of Bass Canyon the thickness of the dolomite is 25 feet less than it is under Wallace Butte, on the west side of the canyon, where this section was measured. Apparently a depression in the surface of erosion at the top of the Muav exists at that point, but the feature is obscure because fans of talus mask the strata for some distance on both sides of the exposure..........................

2. Poorly exposed bed of soft rock, apparently greenish-buff shaly sandstone; determines a narrow ledge which breaks the cliff formed by Nos. 1 and 3

3. Buff hard massive crystalline dolomite in heavy beds; probably originally a very fine calcareous sand; exhibits indistinct cross-bedding; forms cliff.

13. Pale-buff to greenish-buff fine-grained calcareous sandstone blotched purplish in places; beds differ greatly in thickness, rauging from a fraction of an inch to 6 feet; some beds are massive; others thinly laminated; some exhibit indistinct cross-bedding; massive beds predominate in upper part of the sub- division, thinly laminated beds in lower part. The sand is prevailingly calcareous; many beds effervesce readily with acid, and specimens of these beds tested in the Survey laboratory show little magnesium; the rock in a few massive beds, however, resembles the overlying dolomite (A 3), effervesces feebly, and is magnesian. Some of the sand is finely micaceous, and some is finely quartzose. A number of the beds contain tiny greenish grains of glauconite. Some beds are worm-bored. Beds of intraformational conglomerate composed of flattened pebbles of calcareous sandstone occur at several horizons. A thin layer of reddish sandy shale associated with a bed of intraformational conglomerate, 40 feet above the base of the subdivision, exhibits well-preserved sun cracks. The laminated beds at the base of the subdivision consist chiefly of platy micaceous sandstone which does not effervesce with acid . .

C. 1. Thin layers of calcareous intraformational conglomerate, platy greenish micaceous sandstone, greenish micaceous shale, and buff cross-bedded calcareous sandstone in countless alternations. The intraformational conglomerate consists essentially of small flattened pebbles of gray and buff mottled limestone like that of subdivision D and buff calcareous sandstone; all parts of it effervesce with acid. The pebbles have rounded edges and are cemented together by fine-grained 'calcareous micaceous sandy mud or by calcium carbonate. Most of the rock contains worm burrows and fucoidal casts filled with buff sand. Beds range in thickness from less than half an inch to 6 inches and are lenticular; many wedge out in distances of 100 feet; some pass horizontally into cross-bedded sandstone; small Iocal unconformities are common. Some beds are blotched purplish. Many layers of the micaceous sandstone and shale are as thin as cardboard. Much of the calcareous sandstone consists almost entirely of calcium carbonate and might be classed as limestone, but the cross-bedding reveals its clastic origin. In most places bed 1 and the underlying beds 2 to 7 form cliffs .....

2. Gray and buff mottled limestone like subdivision $\mathrm{D}$, but in beds separated by partings of buff sand as thin as cardboard.........................

3. Intraformational conglomerate like that in

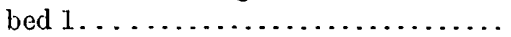

8 
C. 4. Mottled limestone in thin beds with sandy partings......................

5. Intraformational conglomerate ........

6. Mottled limestone in thin beds with sandy partings......................

7. Intraformational conglomerate........

8. Beds of intraformational conglomerate averaging 6 inches thick alternating with thin beds of gray and buff mottled limestone; form steep cliff...........

9. Hard massive bed of intraformational conglomerate; forms small cliff.

10. Beds like No. 8 but containing numerous very thin partings of fine micaceous and calcareous buff sandstone near base; form slope..................

11. Buff fine-grained crystalline limestone, weathering snuff-brown; effervesces strongly with acid; exhibits indistinct cross-bedding and is probably composed of fine calcareous sand; hard; forms small conspicuous brown cliff and is a very persistent bed in the western part of the Kaibab division, being traceable throughout the Shinumo quadrangle......................

12. Beds of gray and buff mottled limestone and intraformational conglomerate in countless alternations; contain many thin partings of fine-grained buff or greenish-buff micaceous and calcareous sand; worm borings and fucoidal casts abundant; beds form slope. In general the beds of mottled limestone contain more buff fine sandy material than those which constitute the underlying subdivision D, although some are comparatively pure. An analysis of a sample from a typical bed of the impure mottled limestone 35 feet below the top of No. 12 in Turquoise Canyon (seep. 43) shows that about a quarter of the rock consists of insoluble material, probably silica, whereas the remainder consists essentially of calcium carbonate with only a trace of magnesium. The beds of intraformational conglomerate effervesce as freely with acid as the mottled limestone; tests indicate that they are not magnesian and that they probably differ little in chemical composition from the impure mottled limestone.... ${ }^{\circ} 142$

D. Gray and buff hard thin-bedded mottled limestone; effervesces with acid; forms strong cliff. The color of the pure limestone is gray to bluish gray, but many beds contain a varying amount of buff fine calcareous, more or less micaceous sand or sandy mud which imparts a mottled appearance to the rock. The limestone contains numerous fucoidal or coralloid forms, most of which are composed of the buff sandy material, but some of which are com- posed of the limestone itself. Probably most of these forms are filled worm burrows. At the base of the subdivision thin layers of platy buff sandstone and greenish shale alternate with the mottled limestone for about 10 feet...

[Note.-The foregoing section of the Muav limestone was measured under Wallace Butte on the west side of Bass Canyon, at locality 7 , figure 2.]

Bright Angel shale:

A. Beds of greenish soft micaceous shale in paper-thin laminae alternating with beds of buff platy hard fine-grained micaceous quartzose sandstone which range in thickness from a quarter of an inch to an inch; worm borings abundant; beds form alcove under cliff of subdivision D of Muav limestone.....

2. Alternating thin beds of worm-worked buff calcareous sandstone and greenishbuff micaceous sandy shale; form steep slope..........................

3. Thin beds of buff sandstone, greenish shale, mottled limestone like subdivision D of the Muav, and snuff-brown dolomite in countless alternations; most beds less than 1 inch thick; worm borings abundant; many layers of sandstone ripple-marked; beds form weak cliff.

4. Snuff-brown hard crystalline glauconitic dolomite forming small cliff. The glauconite appears to constitute from a quarter to a half of the rock and occurs in tiny rounded grains scattered through a groundmass of crystalline dolomite. Although the rock is crystalline, weathered surfaces exhibit distinct cross-bedding, showing that the rock is of classic origin......

B. Thin beds of buff platy quartzitic sandstone and greenish micaceous shale in countless alternations; glauconite very abundant at top; a 4-inch bed of magenta sandstone containing groundup remains of linguloid brachiopods and much glauconite occurs 7 feet above the base; neither sandstone nor shale effervesces with acid;' beds form slope. The sandstone beds average a quarter of an inch in thickness and consist chiefly of tiny transparent grains of quartz but contain small flakes of muscovite and scattered grains of glauconite; most beds speckled with small reddish or brownish spots; ripple marks and worm burrows abundant. Much of the shale is in paper-thin laminae whose surfaces exhibit a satiny luster imparted by innumerable tiny flakes of muscovite; many outcrops are 
covered with a whitish saline efflorescence..

B. 2. Magenta to dark-green glauconitic sandrock passing at top into a 6 -inch bed of snuff-brown glauconitic crystalline dolomite; forms weak cliff. In places the sandrock and dolomite pass into intraformational conglomerate containing broken shells of linguloid brachiopods. The dark-green phase of the sandrock owes its color to glauconite; the magenta phase owes its color to ferritic cement, largely hematite, which makes the rock relatively heavy

3. Buff platy sandstone and greenish shale like No. 1 ; beds form slope............

4. Dark magenta cross-bedded sandstone containing much glauconite; forms small cliff......................

5. Buff platy sandstone and greenish shale like No. 1; glauconite very abundant; beds form slope.

6. Thin beds of snuff-brown to buff finegrained calcareous sandstone forming the upper of the two prominent brown cliffs in the middle of the Bright Angel shale; thin platy beds of finely crystalline buff dolomite containing shells of linguloid brachiopods occur in the upper 5 feet . ................

7. Buff platy sandstone and greenish shale like No. 1; beds form slope and ledge between the cliffs of Nos. 6 and 8; some thin beds consist almost wholly of glauconite......................

8. Heavy beds of snuff-brown massive crýstalline dolomite (for analysis see p. 40), 7 feet; passing down into beds of buff fine-grained cross-bedded glauconitic sandstone, 5 feet; the dolomite and sandstone form the lower of the two brown cliffs in the middle of the Bright Angel shale.................

9. Buff platy sandstone and greenish shale like No..1; a 4-inch bed of fossiliferous magenta glauconitic sandstone occurs 34 feet above the base; beds form gentle slope...................

10. Fossiliferous magenta glauconitic sandstone, 2 feet, passing up into buff platy quartzitic sandstone, 2 feet; beds form a weak cliff

11. Buff platy sandstone and greenish shale like No. 1 but containing more platy sandstone in proportion to the shale, so that the beds form a somewhat steeper slope. Beds of magenta sandstone containing hematite, glauconite, and ground-up shells of linguloid brachiopods occur at 16,23,32, 34, and 66 feet above the base; these beds range in thickness from 1 to 4 inches; part of the hematite occurs as cement
- between the sand grains; part of it coats the sand grains in tiny concentric layers, giving the rock an oolitic appearance; most of the sand grains are quartz or glauconite but some are pink feldspar; some of the ferritic beds resemble Clinton iron ore.............

[Note.-The foregoing section of the Bright Angel shale was measured on the east side of Bass Canyon about half a mile south of Bedrock Tank, at locality 8 , figure 2.]

Tapeats sandstone:

A. White to greenish-white cross-bedded sandstone in rather thick beds composed chiefly of clean quartz sand; contains a few lenses of soft greenish sandy shale; lenses of hard sandstone alternate with lenses of softer sandstone which etch out and form alcoves and shelves. The sandstone is speckled with small magenta or brownish spots which represent segregations of ferritic material...

B. Chocolate-colored sandstone in rather thin beds separated by layers of greenish or brownish shale; contains some crossbedded layers, but evenly bedded layers predominate...................

C. Hard chocolate-colored cross-bedded sandstone; commonly a pebbly grit composed chiefly of quartz sand; many beds are indurated to quartzite; small yellow rounded quartz pebbles, the largest the size of peas, are a characteristic constituent; thin lenses of shale are rather abundant in the upper half of the member; the lenses of the shale or softer sandstone etch out and form alcoves and shelves. In many places the lower half of the cliff is incrusted with salt (sodium chloride), and in some protected situations the salt forms stalactites. Lenticular beds of conglomerate from 1 to 15 feet thick occur throughout the sandstone but are more abundant in the basal portion. Some conglomerate beds consist of unassorted angular fragments of the underlying rocks; other consist chiefly of rounded pebbles of quartz. In some places where the sandstone rests against hills of pre-Cambrian rock, beds of coarse breccia occur in the sandstone at the base of the pre-Cambrian hills; one of these beds of breccia exposed in a cliff on the north side of Colorado River, half a mile southeast of the mouth of Bass Canyon, contains blocks of preCambrian quartzite 30 feet in diameter. The Tapeats sandstone rests on an eroded surface which in some places in 
the Shinumo quadrangle exhibits a.relief of nearly 600 feet; consequently the thickness of subdivision $\mathrm{C}$ at any point depends on the topography of the underlying surface. Near the mouth of Bass Canyon, where this section was measured, subdivision $\mathrm{C}$ is 328 feet thick, whereas a mile to the northeast, under Dox Castle, it is absent. The thickness of 250 feet which I have assigned to the subdivision represents approximately the average thickness in Bass Canyon. . . ................ \pm 250

[NoTE.-The foregoing section of the Tapeats sandstone was measured west of the mouth of Bass Canyon, at the point where a trail leading from Bedrock Tank to Copper Canyon ascends a break in the cliff formed by the sandstone, at locality 9 , figure 2.$]$

Total thickness of Paleozoic beds................... \pm 4014

THE PALEOZOIC ROCKS.

\section{CAMBRIAN SYSTEM.}

TONTO GROUP.

GENERAL FEATURES.

In the region about Bass Canyon the Tonto group is a series of conformable strata about 1,200 feet thick which lies at the base of the Paleozoic and is separated from underlying pre-Cambrian rocks and from overlying Devonian and Carboniferous rocks by unconformities of erosion. In lithology the group as a whole exhibits a passage upward from sandstone to limestone, roughly in three stages. The strata at the base of the group are sandstones; those in the middle portion are chiefly fine-grained sandstones and sandy shales; and those in the upper portion are more or less sandy calcareous rocks which pass at the top into magnesian limestone. These three lithologic stages afford a natural basis for dividing the group into formations. Accordingly, in a former report describing the region about Bass Canyon ${ }^{7}$ I proposed a threefold division of the Tonto group and used the names Tapeats sandstone, Bright Angel shale, and Muav limestone to designate the formations. The name Tapeats sandston? is applied to the sandstone at the base of the group, the name Bright Angel shale to the sandstone and shale of the middle portion, and the name Muav limestone to the

7 Noble, L. F., The Shinumo quadrangle, Grand Canyon district, Ariz.: U. S. Geol. Survey Bull. 549, p. 61, 1914. more or less calcareous strata that constitute the upper portion. Walcott had previously adopted a similar threefold division of the Tonto. He states, "I find among my notes made after the trip to the Grand Canyon in $1901 * * *$ that I had given names to the three divisions of the Tonto along the same lines that you have, so I can readily agree with your present subdivisions and nomenclature."

At Bass Canyon the three formations are distinct in lithology and in topographic expression, butfarther southeast, in the region between the Hermit and Grand View trails, where most visitors see the Grand Canyon, the boundary between the Muav limestone and the Bright Angel shale is indefinite, and the two formations do not appear at first sight to differ conspicuously, whereas the Tapeats sandstone and the Bright Angel shale preserve their distinctive characters and can be distinguished readily. Some uncertainty has therefore existed as to the limits of the Muav limestone in the more frequented part of the Grand Canyon, and the propriety of a threefold division of the Tonto has been questioned.

To determine whether the Muav limestone as defined at Bass Canyon is actually traceable into the region between the Hermit and Grand View trails, I have measured six sections of the Tonto group at different points in the south wall of the Grand Canyon. These sections, spaced from 3 to 8 miles apart, carry the lithology of the Tonto through a distance of about 28 miles southeastward-from Garnet Canyon, 3 miles west of Bass Canyon, to Cottonwood Creek, in the Grand View region-and, in connection with a section measured by Walcott at Nunkoweap Valley, 15 miles north of Cottonwood Creek, carry it practically through the Kaibab division of the Grand Canyon. These seven sections are shown on Plate XX. In addition to recording the Tonto lithology I have represented the unconformity at the summit of the Tonto by indicating diagrammatically the amount of relief which the eroded surface exhibits at each locality, and, where the beds that lie between the unconformity and the Redwall cliff were accessible, I have recorded their character and succession. Owing to lack of space in the drawing I have presented only a brief description of the lithology of each section. The Bass Canyon section is given in

8 Walcott, C. D., personal communication. 




COLUMNAR SECTIONS OF THE TONTO GROUP IN THE GRAND CANYON, FROM GARNET CANYON TO COTTONWOOD CREEK 
detail in the present report (see pp. 26-36), but an account of the detailed lithology of the other sections is beyond the scope of this paper and will be reserved for another report. In all six sections the Bright Angel shale and Muav limestone were measured by hand level and the Tapeats sandstone was measured by aneroid barometer except at Bass Canyon, where the level was used. The sections at Garnet Canyon, Bass Canyon, Slate Creek, and Hermit Creek are believed to be more accurate than those at Pipe and Cottonwood creeks because they were checked over in detail during a subsequent field trip, whereas the sections at Pipe and Cottonwood creeks were not reviewed.

These sections show that the Muav limestone as defined at Bass Canyon is represented by equivalent beds throughout the Kaibab division, and that the principal subdivisions of the Bass Canyon section preserve enough of their original character to be recognizable in the other localities, although large parts of the formation become sandy southeast of Bass Canyon, the proportion of sandstone to limestone increasing southeastward. The appearance of sandy material in the lower part of the Muav southeast of Bass Canyon makes it increasingly difficult to define exactly the boundary between the Bright Angel shale and the Muav limestone in that direction, as will be shown.

When I proposed the name Muav limestone I used the term "limestone" because in the type locality, near Bass Canyon, the formation as a whole contains more limestone than sandstone and shale. Inasmuch as the formation becomes increasingly sandy southeast of Bass Canyon it may be advisable eventually to change the name to Muav formation, but it seems best to retain the name Muav limestone for the present, until the formation has been studied over a wider area than that covered in this report.

TAPEATS SANDSTONE.

Character.-The Tapeats sandstone is essentially a medium to rather coarse sandstone, grading here and there into a pebbly grit and including beds of conglomerate and shale. The prevailing color is chocolate-brown, although many beds are buff or greenish buff and some beds are pale greenish white. The conglomerate forms lenticular beds that may occur at any horizon in the formation but are more abundant near the base, where as a rule the conglomerate is arkosic and consists of poorly assorted fragments of underlying rocks. Some of the conglomerate, however, is well assorted and consists of rounded pebbles of quartz. Most of the shale occurs above the middle of the formation in thin lenses between layers of sandstone. In general the component materials of the formation become finer and better assorted toward the top. The uppermost beds at Bass Canyon are clean white or greenishwhite cross-bedded sandstone.

Among the distinctive features of the formation are hardness, which causes it to weather into sheer cliffs, prevailing chocolate color, cross-bedding, and a rather coarse horizontal banding due to the fact that the beds form elongated horizontal lenses and differ in texture and hardness. Here and there beds of shale alternate with beds of sandstone, and at most places the sandstone itself, although prevailingly hard, exhibits wide differences in induration. A bed of sandstone which in one place is cemented into compact vitreous quartzite may be poorly consolidated a few hundred feet away. Vertically beds of hard quartzitic sandstone succeed beds of softer sandstone in countless alternations. Erosion etches the bands of softer material into long low alcoves overhung by shelves of harder rock. These shelves and alcoves appear on every outcrop of the Tapeats sandstone and are particularly conspicuous in its great cliff, which is furrowed by tier upon tier of them. (See Pl. XXI, A.) One who is traveling through the canyon along the Tonto platform, or "lower plateau," soon learns to appreciate the shelter which these "Tonto shelves" afford and usually selects them for his camp. Indeed, the selection is almost compulsory, for in most tributary canyons water comes to the surface in the dry watercourses only at the point where the stream channel crosses the summit of the Tapeats sandstone.

Another distinctive feature of the sandstone is the occurrence in many beds of numerous small yellow rounded quartz pebbles, the larg. est of which are the size of peas. Worm markings are common in the white sandstone at the 
top of the Tapeats and occur here and there in the underlying chocolate-colored beds. I have observed ripple marks at a few places in the formation and sun cracks at one place. Glauconite occurs sparingly in scattered grains in some beds.

In many places in the Kaibab division the Tapeats cliff is incrusted with salt. Commonly the deposits are less than an inch thick, but some of them may cover hundreds of square feet. A sample from one of these salt deposits in Garnet Canyon was tested in the laboratory of the Survey and is reported to consist essentially of sodium chloride. A spring that issues from the contact between the Tapeats sandstone and the underlying crystalline rocks at a point about half a mile west of Garnet Canyon yields a heavy brine. Other brine springs issue from this contact at several places in the Kaibab division. The water of the intermittent stream in Garnet Canyon is potable above the middle of the Tapeats sandstone, but below the middle of the sandstone it is too salty to drink. These occurrences indicate that the Tapeats sandstone contains' salt, although no beds of salt have been found within the sandstone. Perhaps a small amount of salt is widely distributed in the sandstone but has escaped observation because it is not concentrated in beds. Inasmuch as the Tapeats is a marine deposit the salt is probably an original constituent of the sandstone.

The Tapeats sandstone exhibits little variation from place to place in lithology or in general appearance and is readily identifiable in all parts of the Kaibab division.

Stratigraphic relations.-Both base and summit are well defined, the base by a great angular unconformity that truncates underlying pre-Cambrian rocks and the summit by a rather abrupt change from coarsely banded white cross-bedded sandstone at the top of the Tapeats to thinly laminated even-bedded sandstone and sandy shale at the base of the overlying. Bright Angel shale.

Subdivisions.-At Bass Canyon the formation is rudely divisible into three parts. (See Pl. XX.) Subdivision A, at the top of the formation, consists of white cross-bedded sandstone which includes a few layers of greenish shale. Subdivision $B$, beneath $A$, consists of evenly bedded chocolate-colored sandstone with partings of shale. Subdivision $\mathrm{C}$, at the base, consists of chocolatecolored cross-bedded sandstone and constitutes by far the greater part of the formation. As the Tapeats sandstone is traced southeastward from Bass Canyon, subdivision A decreases in thickness and becomes more and more like $\mathrm{C}$ in lithologic character until it is practically indistinguishable from $\mathrm{C}$, so that in the three easternmost sections shown on Plate $\mathrm{XX}$ the formation is divisible into only two parts and consists essentially of chocolatecolored cross-bedded sandstone capped by white cross-bedded sandstone. Where hills of pre-Cambrian rock project into the Tapeats sandstone, beds of coarse conglomerate may appear at any horizon in the sandstone where it rests against their steeper slopes, but these conglomerates are local in extent and do not persist many hundreds of feet.

Thickness.-The Tapeats sandstone varies irregularly in thickness from place to place, but the variations have no ultimate stratigraphic significance because the sandstone was deposited upon a surface which, although remarkably even when considered in relation to its vast horizontal extent, is uneven in detail, exhibiting at some places a relief of 600 feet. Thus at the point where the section at Bass Canyon was measured the sandstone attains a thickness of 328 feet, whereas the average thickness in Bass Canyon does not exceed 250 feet; and a mile away, on the north side of Colorado River, where a hill of hard pre-Cambrian strata rises several hundred feet above the general level of the pre-Cambrian surface, the sandstone was not deposited. The thickness assigned to the sandstone at Bass Canyon is exceptional. Perhaps 200 feet would be a fair estimate of the average maximum thickness in the Kaibab division.

Fossils.-No fossils have been found in the Tapeats sandstone except near the top. Schuchert ${ }^{\theta}$ has noted fragments of an obolid shell in the white cross-bedded sandstone at the top of the formation near Hermit Creek. Walcott ${ }^{10}$ reports the following fauna "in the Tapeats sandstone about 300 feet above its base at the head of Nunkoweap Valley":

S Schuchert, Charles, The Cambrian of the Grand Canyon of Arizona: Am. Jour. Sci., 4th ser., vol. 45, p. 365, 1918.

${ }_{10}$ Walcott, C. D., Cambrian geology and paleontology: Smithsonian Misc. Coll., vol. 64, No. 5, pp. 373, 374, 1916. 
Dolichometopus tontoensis.

Micromitra pealei.

Micromitra (Paterina) crenistria.

Micromitra (Paterina) superba.

Micromitra (Iphidella) pannula.

Obolus zetus.

Obolus (Westonia) chuarensis,

Obolus (Westonia) englyphus.

Lingulella lineolata.

Lingulella perattenuata.

Billingsella obscura.

Alokistocare althea.

According to Walcott the thickness of the Tapeats sandstone at Nunkoweap Valley is 300 feet (see Pl. XX), so that the beds from which he obtained this fauna must lie at the very top of the formation. The age of the fauna is stated to be Middle Cambrian. Practically all the forms listed occur also in the Bright Angel shale.

The age of the summit beds of the Tapeats sandstone is therefore Middle Cambrian. Inasmuch as the formation appears to have been deposited continuously, as is indicated by its homogeneous character, and to have accumulated rapidly, as is indicated by its relatively coarse cross-bedded structure, it is not likely that any part of it is older than Middle Cambrian.

BRIGHT ANGEL SHALE.

Character.-The chief constituent of the Bright Angel shale is fine-grained quartzose micaceous sand, which forms innumerable platy beds mostly less than a quarter of an inch thick. Many beds of sandstone are separated by partings of micaceous sandy shale, and at some horizons the sandstone and shale are associated with dolomitic limestone or with cross-bedded glauconitic sandstone.

The distinctive features of the formation are thin, platy lamination, a prevailingly dull greenish-buff color, the occurrence of glauconite in many beds, and the abundance of wormmarkings and fucoidal casts. Many beds are ripple-marked. Shells of obolid or linguloid brachiopods are abundant at many horizons, and most of the shells are broken and worn, showing marks of grinding and attrition. The ripple marks indicate that the strata were deposited in shallow water, and the broken shells indicate that the deposits were subjected to repeated pounding by waves.

The formation as a whole is the least resistant to erosion of all the formations in the can- yon wall. It makes a more or less continuous slope, which at most places has retreated far back from the summit of the Tapeats cliff, leaving the so-called "lower plateau," or Tonto platform. It owes its weakness to the alternations of shale and sandstone and to the thin platy lamination of the beds. Actually most of the platy sandstone is well indurated, and some of it is as compact as quartzite.

Glauconite is decidedly more abundant in the Bright Angel shale than in the other two formations of the Tonto group. It occurs rather sparingly in most beds in tiny grains scattered through the rock but is widely distributed in the formation, both vertically and horizontally. Apparently no beds consist entirely of glauconite, but an examination of the formation anywhere in the Kaibab division of the Grand Canyon will disclose a few beds sereral inches thick in which nearly half of the rock is glauconite and many beds in which the grains are sufficiently abundant to impart a greenish tinge to the rock. The mineral is not confined to the prevailing platy sandstone and shale but occurs in the dolomite, intraformational conglomerate, and cross-bedded sandstone described below. An interesting feature of its occurrence is its association with deposits that were obviously laid down in shallow water.

Interbedded with the platy sandstone and shale are two types of rock which, although they form only a subordinate part of the Bright Angel shale, are particularly characteristic of the formation.

One of these rocks is a compact crystalline limestone whose color is deep snuff-brown on weathered surfaces and pale tan on freshly broken surfaces. Beds of this limestone are very resistant to erosion and make cliffs. In the region about Bass Canyon two beds vertically 35 feet apart appear in the Bright Angel shale at a horizon about 125 feet above its base and make two conspicuous brown cliffs in the slope above the Tonto platform. Each cliff is about 12 feet high. The beds of snuffbrown limestone, which determine the cliffs, range in thickness from a few inches to 8 feet and are associated with beds of green, magenta, and brown cross-bedded sandstone. The cliffs are sharply defined and are wonderfully persistent. (See Pl. XXI, B.) Wherever possible the Tonto trail in this part of the canyon follows 
the narrow ledge at the top of one or the other of these clifis, because the ledges afford much smoother going than the dissected and débriscovered slopes of the Tonto platform below. Other beds of snuff-brown limestone appear in the Bright Angel shale between the twin cliffs just described and the base of the Muav limestone, but at Bass Canyon they are thin and do not make conspicuous cliffs. Most of them are associated with beds of greenish and magenta cross-bedded sandstone.

The snuff-brown limestone effervesces weakly with acid. Some beds contain no visible impurities, but others contain scattered grains of glauconite and tiny rounded grains of quartz and exhibit cross-bedding. Many beds contain broken shells of brachiopods. In places the limestone passes laterally into an intraformational conglomerate composed chiefly of rounded, flattened fragments of limestone but containing glauconite, quartz sand, and broken shells.

The following analysis of a specimen of the snuff-brown limestone forming the lower of the twin cliffs at Bass Canyon (see p. 35) probably represents approximately the composition of the purer limestone. The bed from which the specimen was taken contains no visible glauconite or quartz and appears to consist entirely of coarsely crystalline limestone.

Partial chemical analysis of snuff-colored limestone from Bright Angel shale.

[Alfred A. Chambers, analyst.]

Insoluble........................ . 2.66

$(\mathrm{Al}, \mathrm{Fe})_{2} \mathrm{O}_{3} \ldots \ldots \ldots \ldots \ldots \ldots \ldots \ldots . .6 .44$

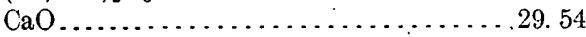

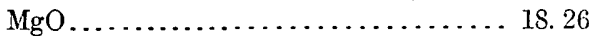

From this analysis it appears that the rock is an impure dolomite. The presence of quartz grains in beds closely associated with the one analyzed suggests that the insoluble impurities are largely quartz sand, and the fact that the rock weathers brown suggests that the other impurities are largely iron. Inasmuch as the snuff-colored limestones effervesce weakly with acid and differ from one another chiefly in the amount of impurities that they contain I have called them all dolomites in this report.

Another characteristic rock in the Bright Angel shale is dark-green or magenta crossbedded sandstone. Most of this sandstone forms rather massive beds, which range in thickness from a few inches to several feet. The component grains are rather coarse and in most beds are loosely cemented, so that the rock crumbles easily. Some beds, however, form weak cliffs. The chief constituent of the sandstone is quartz, but many beds contain glauconite and many contain a large amount of ferritic sandy mud and more or less hematite. Broken shells of brachiopods are abundant in some beds. These green and magenta sandstones are readily distinguishable from the prevailing platy sandstone by their deep colors, cross-bedding, absence of thin lamination, and relatively coarse texture. The colors of some beds are very striking, green shading into deep. bottle-green and magenta into deep purplish brown. In places these colors are mingled in blotches in the same bed, producing a curious mottled effect. The greenish beds owe their color largely to glauconite, and the magenta beds owe theirs to ferritic material. Some beds associated with snuff-colored dolomite weather brown.

At Bass Canyon the thickness of the Bright. Angel shale is 391 feet and I have divided it into two members-subdivision $A$, at the top, 58 feet thick, and subdivision B, below, 333 feet thick. Both subdivisions consist essentially of thin-bedded greenish and buff micaceous shale and sandstone, with which snuff-brown dolomite and greenish and magenta sandstone of the types just described are interbedded at irregular intervals. The character and succession of the beds are recorded in the columnar section (pp. 34-35). In general composition subdivision A differs from B only in that it contains, near the base, a few beds of mottled limestone similar to those which constitute subdivision D of the overlying Muav limestone. In a former report ${ }^{11} \mathrm{I}$ included subdivision $\mathrm{A}$ in the Muar limestone, placing the base of the Muav at the lowest point where mottled limestone appears in the Tonto group, but in the present report I have included subdivision A in the Bright Angel shale, which as here defined includes all strata between the white cross-bedded sandstone at the top of the Tapeats and the cliff-making gray and buff mottled limestone that constitutes subdivision D of the Muav. This definition is in accord with Walcott's observations at Kanab Creek. Wal11 Noble, L. F., op. cit., p. 65. 


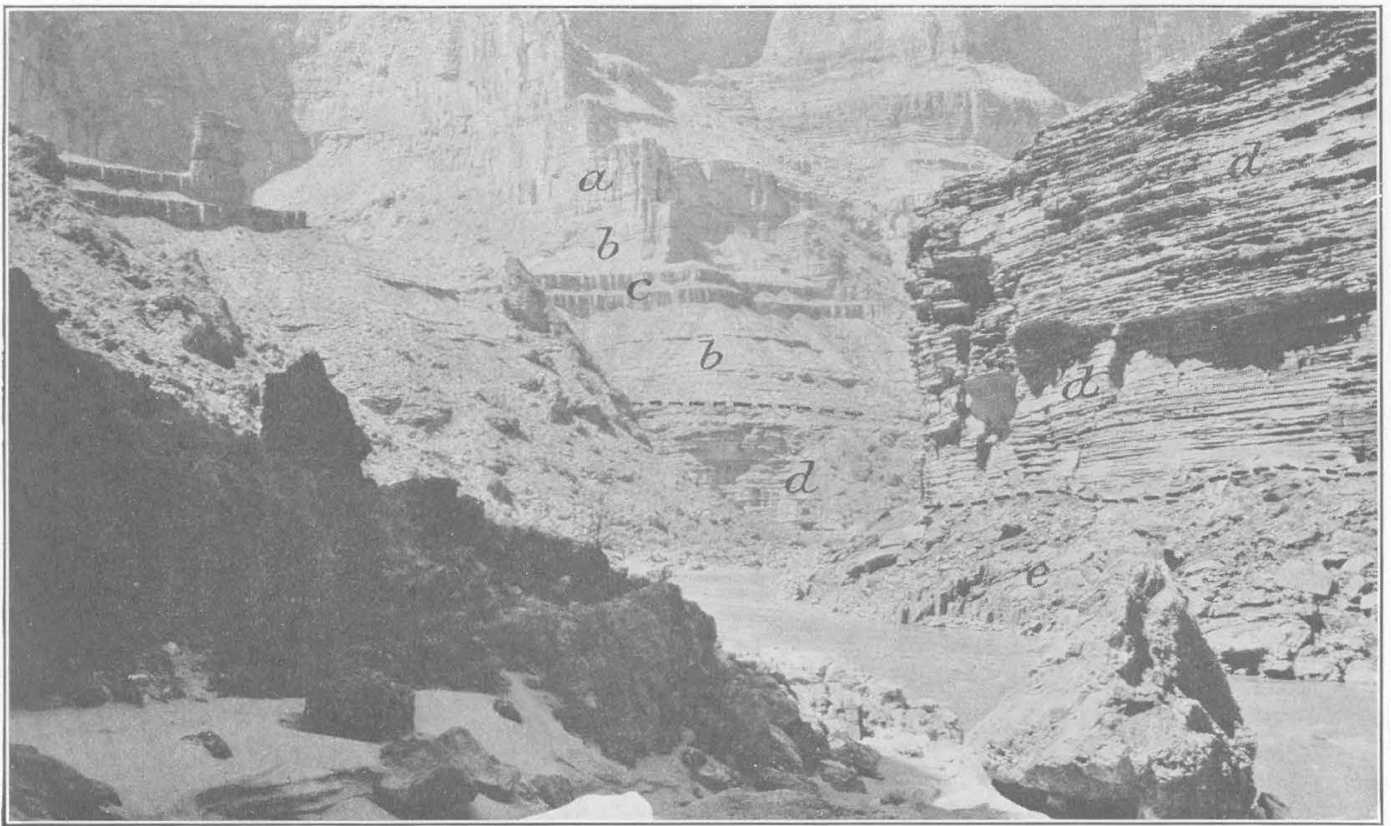

A. TYPICAL EXPOSURE OF TAPEATS SANDSTONE ON COLORADO RIVER OPPOSITE MOUTH OF ELVES CHASM, SHINUMO QUADRANGLE, ARIZ.

$a$, Muav limestone; $b$, Bright Angel shale; $c$, twin cliffs of snuff-colored dolomite of Bright Angel shale; $d$, Tapeats sandstone; $e$, Vishnu schist.

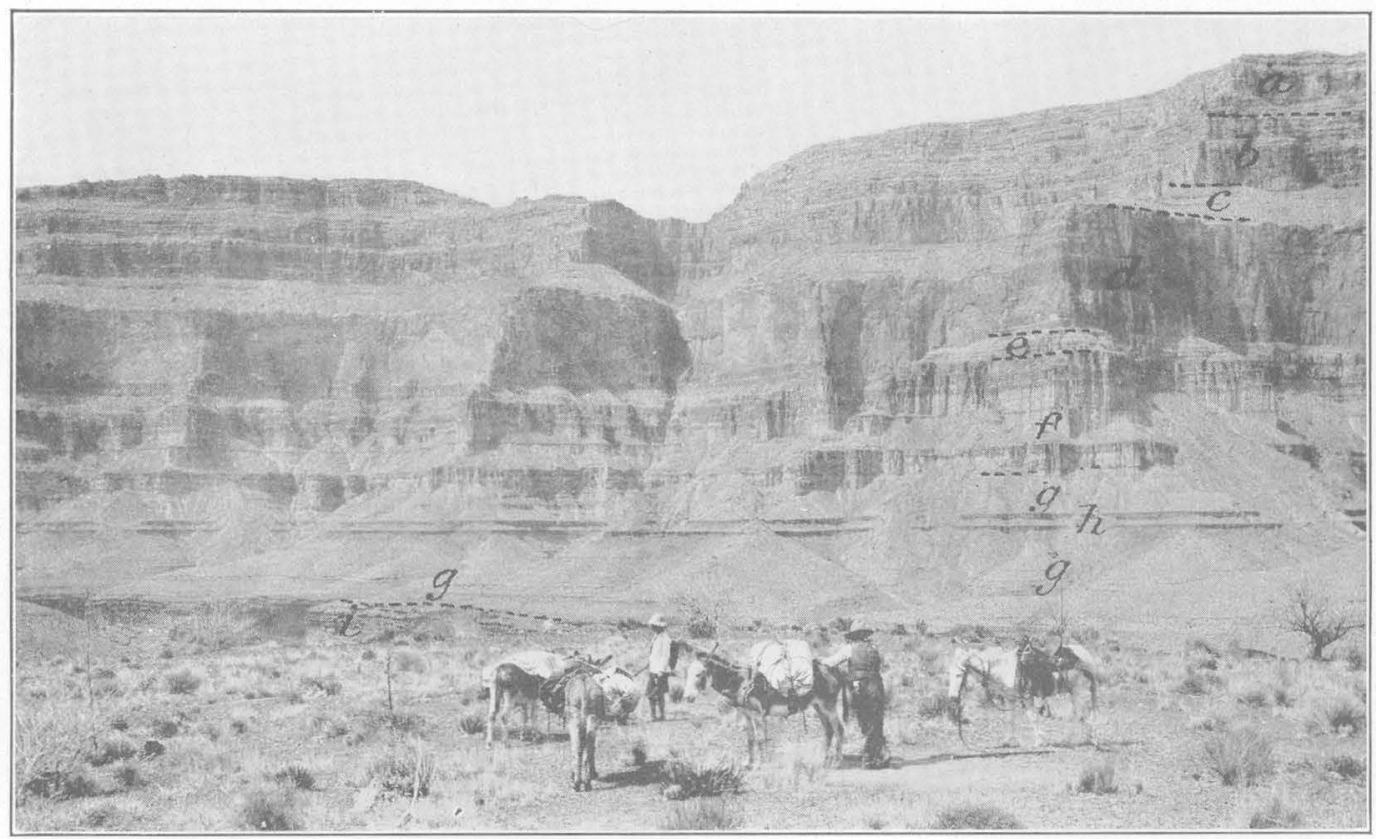

$B$, TYPICAL EXPOSURE OF BRIGHT ANGEL SHALE, MUAV LIMESTONE, TEMPLE BUTTE LIMESTONE, REDWALL LIMESTONE, AND SUPAI FORMATION IN NORTH WALL OF GRAND CANYON OPPOSITE GARNET CANYON, SHINUMO QUADRANGLE, ARIZ.

$a, b, c$, Supai formation, subdivisions A, B, C; $d$, Redwall limestone; $e$, Temple Butte limestone; $f$, Muav limestone; $g$, Bright Angel shale; $h$, twin cliffs of snuff-colored dolomite in Bright Angel shale; $i$, Tapeats sandstone. 
cott's section at Kanab Creek (see Pl. XX) shows 100 feet of greenish micaceous shale and sandstone (d) beneath beds of mottled limestone (c) that are evidently equivalent to subdivision $\mathrm{D}$ of the Muav limestone of my Bass Canyon section. He states ${ }^{12}$ that a mile or two east of Kanab Creek, where more of the greenish micaceous shale and sandstone (d) is exposed, the shale and sandstone pass downward into mottled gray limestone, calcareous and micaceous shale, and dark indurated sandstone. Probably this mottled gray limestone is equivalent to the mottled limestone that apperrs in thin beds at the base of subdivision A of the Bright Angel shale in my Bass Canyon section, so that subdivision d of Walcott's section at Kanab Creek is roughly equivalent to my subdivision $\mathrm{A}$ at Bass Canyon. Walcott states ${ }^{13}$ : "I find on my locality label 75 that the thin-bedded sandstone and shale (d) at Kanab Creek is placed in the Bright Angel shale and the overlying mottled limestone (c) in the Muav limestone."

The columnar sections of the Tonto group shown on Plate XX trace the lithology of the Bright Angel shale through the greater part of the Kaibab division. They show that although the formation exhibits little change in general composition from place to place the interbedded layers of green and magenta sandstone and snuff-colored dolomite increase in number and become thinner and more widely distributed through the prevailing platy sandstone and shale toward the southeast. This change is shown clearly in the profiles of the different sections. Thus, at Garnet and Bass canyons the formation contains only two prominent sets of beds of green and magenta sandstone and snuff-brown dolomite, so that only two cliffs break the long slope formed by the platy beds. But southeast of Bass Canyon, at Slate, Hermit, and Pipe creeks, two other sets of beds of sandstone and dolomite have appeared above the lower pair, so that the slope is broken by four cliffs instead of two. These four cliffs are strongly defined at Slate Creek, fairly well defined at Hermit Creek, and poorly defined at Pipe Creek because the beds become thinner toward the southeast. Southeast of Pipe Creek, at Cottonwood Creek, these beds are so widely distributed in the platy sandstone and

12 Walcott, C. D., unpublished notes.

13 Personal communication. shale and are all so thin that no bed or set of bèds makes a prominent cliff. Here the whole formation presents a continuous slope. Three miles east of Cottonwood Creek, at "Congress Canyon" (Red Canyon), that part of Frech's section of the Tonto group ${ }^{14}$ which represents the Bright Angel shale is similar in lithology to my section of the Bright Angel shale at Cottonwood Creek.

Southeast of Bass Canyon beds of green and magenta sandstone are more abundant in the Bright Angel shale than beds of snuff-colored dolomite. In the region between Slate and Pipe creeks these sandstones have attracted attention as a possible source of platinum and at one time were extensively prospected. No samples of the rock examined by the Survey have yielded platinum, but some of the rock when crushed and panned yields a small amount of magnetite. At Slate Creek some of these sandstones, near the base of the Bright Angel shale, contain considerable hematite and form thin beds that are conspicuous by their bright-red color. Between Bass Canyon and Garnet Canyon some ferritic beds at this horizon exhibit oolitic structure. (See p. 35.)

Probably the beds of snuff-brown dolomite and sandstone that make the twin cliffs at Bass and Garnet canyons are traceable far west of the area covered by the present report, because a section of the Bright Angel shale at the mouth of the Grand Canyon ${ }^{15}$ shows a double cliff of snuff-colored sandstone that is said to be continuous throughout the Shivwits division, Gilbert having traced it from the Grand Wash to Diamond Creek.

Southeastward from Bass Canyon the thin beds of mottled limestone at the base of subdivision A gradually give way to calcareous sandy shale and finally disappear southeast of Hermit Creek.

Few hills of pre-Cambrian rock rise far into the Bright Angel shale, but one hill on the north side of Colorado River about 3 miles east of Bass Canyon rises nearly to the top of subdivision B. So far as known, this is the highest hill of pre-Cambrian rock in the Grand Canyon.

Thickness.-The thickness of the Bright Angel shale decreases gradually from northwest

14 Frech, F., Cong. géol. internat., $5^{\mathrm{e}}$ sess., Compte rèndu, p. 479.

15 U. S. Geog. and Geol. Surveys W. 100th Mer. Rept., vol. 3, p: 199, 
to southeast. Thus the formation is 402 feet thick at Garnet Canyon, 391 feet at Bass Canyon, 392 feet at Slate Creek, 344 feet at Hermit Creek, 325 feet at Pipe Creek, and 334 feet. (estimated) at Cottonwood Creek. At Nunkoweap Valley, 15 miles north of Cottonwood Creek, it is 325 feet thick. The beds equivalent to subdivision $A$ of the Bass Canyon section decrease from 60 feet at Garnet Canyon to 42 feet at Pipe Creek, and the beds equivalent to subdivision B decrease from 342 feet at Garnet Canyon to 283 feet at Pipe Creek. At Cottonwood Creek the two subdivisions can not be separated with certainty.

Fossils.-Fossils are abundant at several horizons in subdivision B of the Bright Angel shale. The following species listed in my report on the geology of the Shinumo quadrangle ${ }^{16}$ were collected by Walcott or by me at several horizons in subdivision $B$ in the region about Bass Canyon and Shinumo Creek:

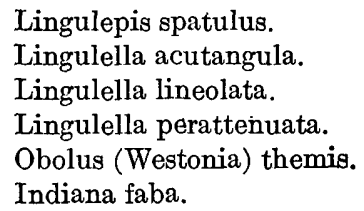

At 25 feet above the base of subdivision $B$ in Serpentine Canyon I have collected and Edwin Kirk has identified Micromitra (Paterina) superba and Lingulella lineolata, and at 165 feet above the base of subdivision B near Hermit Creek Obolus (Westonia) chuarensis and .Micromitra (Iphidella) pannula.

At 100 to 120 feet above the base of subdivision B near the Bright Angel (Cameron) trail Walcott ${ }^{17}$ has collected the following species:

Obolus (Westonia) chuarensis.

Eocystites? undet. sp.

Hyolithes.

Alokistocare althea.

Dolichometopus productus.

Dolichometopus tontoensis.

The age of this fauna is stated by Walcott to be Middle Cambrian.

In 1915 Schuchert studied the Bright Angel shale at Hermit Creek and collected fossils at several horizons. He states ${ }^{18}$ :

When the sandy muds were forming, seaweeds (Palaeophycus) were common, along with a great abundance of burrowing annelids. Trailings and fucoidal casts are

${ }_{16}$ Noble, L. F., op. cit., p. 64

17 Walcott, C. D., Cambrian geology and paleontology: Smithsonian Misc. Coll., vol. 64, No. 5, p. $374,1916$.

13 Schuchert. Charles, op. cit., p. 367. nearly always to be seen, and also the vertical burrowings of worms like Arenicolites. * * * In spite of the fact that almost no good fossils are to be had in the Bright Angel formation, yet the physical phenomena show that the epeiric sea of this time must have been rich in life. This is proved by the abundance of fucoidal casts, trailings, and annelid burrows. Further, in some of the sandstones obolid fragments teem, and at times their shells make up one-third of a stratum. When the obolid shells are prevalent, glauconite is also common, and the formation of this mineral is probably conditioned by the decomposition of the organic remains. On the other hand, there are entire beds of glauconite up to a few inches thick that are almost devoid of fossils. When glauconite is very abundant, there are also apt to be thin beds and even zones a few feet thick of low-grade iron ore.

Palaeophycus casts are very common and well preserved at 15 feet above the Tapeats sandstone, and 150 feet higher is a glauconitic sandstone replete with the brachiopods Micromitra (Iphidella) pannula (White) and Obolus (Westonia) chuarensis. Ten feet higher occur abundantly in thin-bedded sandstones Obolus zetus and rarely Obolus (Westonia) themis and Lingulella acutangula.

The most prominent horizon for fossils, consisting almost entirely of obolids, is the one just mentioned, which occurs from 150 to 170 feet above the base of the Bright Angel formation and is at the same time a general level for thin-bedded sandstones.

It is evident that the age of at least the lower 170 feet.of subdivision $B$ of the Bright Angel shale is Middle Cambrian, as shown by fossils. I have found no determinable fossils in the upper part of the subdivision but have noted in a bed near the top small fragments of obolid shells similar to those that occur in the lower 170 feet. I have found no fossils in subdivision $\mathrm{A}$ at Bass Canyon, nor in beds that occupy the equivalent horizon at localities where I measured the other Tonto sections. But inasmuch as subdivision A differs in general lithologic character from subdivision $B$ only in that it contains a few layers of mottled limestone, which gradually disappear east of Bass Canyon, and is evidently equivalent to a set of beds at Kanab Creek in which Walcott has found Middle Cambrian fossils and which he includes in the Bright Angel shale (see p. 41), I believe the entire Bright Angel shale as defined in this report is Middle Cambrian.

\section{MUAV IIMESTONE.}

Character.-At Bass Canyon the Muav limestone consists chiefly of impure limestone and calcareous sandstone but includes much platy sandstone and shale that do not differ from those which occur throughout the Bright Angel shale. Platy or shaly lamination is a prominent feature except at the top of the formation, but 
unlike the Bright Angel shale the Muav, as a whole, is fairly resistant to erosion and makes cliffs or steep slopes. The prevailing rock is a peculiar gray and buff mottled limestone, which occurs in countless beds averaging less than an inch thick. The lower two-thirds of the formation consists largely of this mottled limestone and partly of platy sandstone and shale; the upper third consists of calcareous sandstone overlain by massive magnesian limestone.

Subdivisions.-At Bass Canyon four subdivisions with persistent features can be differentiated, although the boundaries between them are not sharp. The massive magnesian limestone at the top of the Muar constitutes subdivision A, 63 feet thick, and forms a strong cliff. The underlying calcareous sandstone constitutes subdivision $B, 72$ feet. This sandstone, massive at the top but thin-bedded at the base, makes a set of weak cliffs that in most places unite with the cliff formed by the overlying limestone. Beneath subdivision B is 241 feet of thin-bedded mottled limestone containing many interbedded layers of platy sandstone and shale. These alternating beds constitute subdivision $\mathrm{C}$ and form a steep slope. Beneath them is a cliff-making bed of relatively pure mottled limestone 97 feet thick, which constitutes subdivision $\mathrm{D}$, at the base of the Muav.

In appearance the mottled limestone of the Muav is unlike any other rock in the Paleozoic section. Characteristically it is a hard thinbedded impure limestone, whose outcrops when seen from a distance resemble outcrops of shale. The beds range in thickness from less than an eighth of an inch to several inches but commonly do not exceed half an inch. The purer limestone is gray, but most of the rock contains a considerable amount of buff material which was originally a fine-grained micaceous sandy mud. Some of this material forms shaly partings between the beds of limestone, and some - of it is mixed with the limestone, so that in most beds the gray and buff colors are mingled. Many limestone beds are intraformational conglomerates composed of small flattened rounded. pebbles of mottled limestone embedded in a matrix which in some places consists of crystalline limestone and in others of buff calcareous material. Nearly every bed of limestone or conglomerate exhibits numerous coralloid or fucoidal markings. These markings, which Newberry and other early observers ascribed to branching corals but which Schuchert and Walcott have shown to be largely the work of worms, are one of the distinctive features of the mottled limestone. Schuchert ${ }^{10}$ states:

Where the calcareous materials become more dominant the beds are completely riddled with vertical and anastomosing worm burrows. These are usually filled with a very fine sand, and it is this feature that gives so much of the Muav its mottled appearance and that led Gilbert many years ago to call the formation in the western part of the Grand Canyon the "mottled limestone." Throughout the middle third of the Muav many of the shaly limestones are intraformational conglomerates with the pebbles small, flat, and more or less rounded on the edges. It is an interesting shallow-water, near-shore marine deposit. This is shown in the great abundance of annelid burrows, in the intraformational conglomerates, and in the variable nature of the calcareous deposits. * * * The writer has not seen a Paleozoic marine deposit more bored into and consumed by mud eaters than this one, and these burrows are most prevalent in the calcareous zones. Worm castings are often well preserved in the thin-bedded shale zones and occur as little confused heaps or in circular sausage-like strings, .

Most beds of the mottled limestone effervesce freely with acid. An analysis of a. typical specimen from a bed that exhibits the usual mixture of gray limestone and buff sandy material is given below.

Partial chemical analysis of mottled limestone from Muav limestone.

[Albert A. Chambers, analyst.]

Insoluble. . . . . . . . . . . . . . . . 23. 46

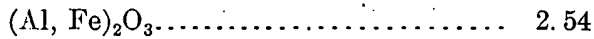

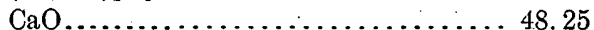

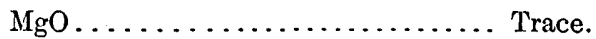

This analysis shows that the limestone is not magnesian and indicates that the sandy impurities constitute about a quarter of the rock.

Subdivision D, at the base of the Muav, consists almost wholly of the thin-bedded mottled limestone just described and contains very little limestone of the intraformationalconglomerate type. In the basal 10 feet of the subdivision thin layers of fine-grained platy sandstone are interbedded with the limestone. These alternating beds define the lower limit of the Muav limestone, and their separation from the underlying greenish shale and platy sandstone of the Bright Angel shale is distinct at Bass Canyon, although they represent a transition in lithology rather than an abrupt change. Owing to the hardness of the mottled limestone subdivision D forms a strong cliff, a feature

19 Schuchert, Charles, op. cit., pp. 368,369 
which at once distinguishes it from the overlying subdivision $\mathrm{C}$ and from the underlying Bright Angel shale, which forms slopes. Just beneath the cliff are the soft underlying greenish shale and sandstone, which persist over a considerable area east and west of Bass Canyon and etch out everywhere, leaving a small alcove overhung by the cliff. The alcove will guide the observer to the contact between the Bright Angel shale and the Muav limestone.

Subdivision $\mathrm{C}$ consists chiefly of thin-bedded mottled limestone but unlike subdivision D contains many thin interbedded layers of sandstone and shale. The character and succession of the strata, which are variable in composition and occur in countless alternations, are shown in the detailed section on pages 33-34. Some parts of the subdivision contain as much sandstone and shale as mottled limestone, but other parts contain considerably more mottled limestone than any other rock, and large parts consist almost entirely of mottled limestone. The mottled limestone in subdivision $\mathrm{C}$, unlike that in the underlying subdivision, is chiefly of the intraformational-conglomerate type. In general the beds contain more worm markings than those of subdivision D and vary more in thickness and composition. Some beds attain a thickness of a foot or more, and many are from 4 to 6 inches thick, although most are less than 1 inch. The thicker beds of intraformational conglomerate are lenticular, exhibiting considerable variation within horizontal distances of a few hundred feet. Glauconite occurs sparingly in some strata. Most of the interbedded sandstone and shale resemble those which prevail in the Bright Angel shale. The sandstone is fine grained, quartzose, and micaceous and occurs in thin platy layers; the shale is greenish, soft, micaceous, and sandy. Some of the sandstone, however, is calcareous and resembles that which occurs in the overlying subdivision B. A prominent bed of hard brownish-buff cross-bedded calcareous sandstone 8 feet thick appears at a horizon 142 feet above the base of subdivision C and makes a small conspicuous and persistent brown cliff that is traceable over many miles in the region about Bass Canyon. Other beds of calcareous sandstone are interbedded with intraformational conglomerate and platy quartzose sandstone at the top of the subdi- vision. Some of these upper beds exhibit purplish spots and mottlings similar to those which appear in the rocks of subdivision B, and some of the intraformational conglomerates are purplish.

Subdivision B consists chiefly of fine-grained calcareous sandstone but includes beds of platy quartzose sandstone, sandy micaceous shale, crystalline limestone, dolomite, and intraformational conglomerate. The prevailing color of the strata is pale buff, but pinkish, purplish, and greenish hues occur. Many beds contain pinkish or purplish blotches and mottlings. The upper portion of the subdivision is relatively thick bedded; many beds attaining a thickness of 2 feet or more. The lower portion contains some beds as much as 1 foot thick but in general is thin bedded. Toward the base the lamination becomes shaly and many layers are as thin as cardboard. Most of the subdivision forms a cliff or a steep ledgy slope broken by cliffs.

The typical calcareous sandstone is hard, compact, and fine grained, effervesces with acid, and is easily scratched with a knife. Weathered surfaces feel gritty and display indistinct cross-bedding, although freshly broken surfaces may exhibit no cross-bedded structure. Some beds are crystalline and consist entirely of calcareous material. Others contain more or less fine quartzose and micaceous sand. It is difficult to decide whether to classify some beds as limestone or as calcareous sandstone, but the cross-bedded structure indicates that the component material, whatever its composition, is of clastic origin.

The upper half of the subdivision is composed largely of the calcareous sandstone just described. Here and there a bed of pinkish or purplish crystalline limestone is interbedded with the calcareous sandstone. Beds of fine quartzose sandstone, sandy shale, and intraformational conglomerate appear at several horizons, and near the top of the subdivision there is a bed or two of dolomite similar to that in the overlying subdivision $A$. The lower half of the subdivision is composed partly of calcareous sandstone and partly of platy quartzose micaceous sandstone, sandy micaceous shale, and intraformational conglomerate. Worm markings are abundant, and some beds exhibit sun cracks and ripple marks. Scat- 
tered grains of glauconite occur in some beds. Most beds in the lower part of the subdivision do not effervesce with acid.

Although intraformational conglomerate may appear at any horizon in subdivision $B$ it does not form thick sets of beds and is not abundant in the subdivision as a whole. Most of it differs in composition from the conglomerate in the underlying subdivision in that, although composed chiefly of small flattened rounded pebbles, it is not essentially a limestone. Most of the pebbles are fine-grained sandstone, and the matrix is fine sand.

Subdivision A, at the top of the Muav, consists of hard buff limestone which forms massive beds from 2 to 10 feet thick. Thin partings of sandy shale separate some beds. The limestone is entirely crystalline and exhibits no bedded structure on freshly broken surfaces, but weathered surfaces show faint traces of cross-bedding. Most of the rock contains small cavities, some of which are filled with crystalline material. Some beds exhibit purplish blotches and mottlings. Most beds do not effervesce with acid, although some effervesce feebly. The following analysis shows the composition of a typical specimen of the limestone from a bed 15 feet above the base of the subdivision in Bass Canyon.

Partial chemical analysis of limestone from subdivision $A$, Muav limestone.

[Alfred A. Chambers, analyst.]

Insoluble.................... 1.52

$(\mathrm{Fe}, \mathrm{Al})_{2} \mathrm{O}_{3} \ldots \ldots \ldots \ldots \ldots \ldots \ldots \ldots . .80$

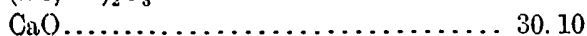

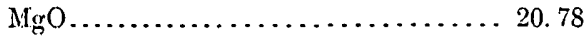

From this analysis it appears that the rock is a magnesian limestone that differs little in composition from typical dolomite. The small amount of insoluble material which the rock contains suggests that if, as the indistinct crossbedding indicates, the rock was composed originally of detrital sand, the sand was calcareous, not siliceous.

These massive dolomites of subdivision A are the most resistant strata in the Tonto group and in consequence of their hardness weather everywhere into strong cliffs. In appearance they are wholly unlike the thin-bedded strata of the Bright Angel shale and lower Muav, resembling rather beds at the base of the great cliff formed by the Redwall limestone. How- ever, they are separated from the Redwall cliff in Bass Canyon by 75 feet of thinly laminated beds that form a slope, so that the observer will experience no difficulty in distinguishing them from the Redwall strata. The upper limit of subdivision $A$ is an unconformity of erosion, which is described on pages 49-51.

Thickness and correlation.-The columnar sections in the Kaibab division of the Grand Canyon (see Pl. XX) in connection with Walcott's section at Kanab Creek (see Pl. XIX) trace the lithology of the Muav limestone through a distance of 50 miles southeastward. These sections show that the formation thins steadily from northwest to southeast. The thickness at Kanab Creek is 685 feet; at Garnet Canyon, 504 feet; at Bass Canyon, 473 feet; at Slate Creek, 429 feet; at Hermit Creek, 419 feet; at Pipe Creek, 383 feet; and at Cottonwood Creek (estimated), 238 feet. At Nunkoweap Valley the thickness is 425 feet, but this locality is 15 miles north of Cottonwood Creek. Thus the formation loses about two-thirds of its thickness in the 50 miles between Kanab Creek and Cottonwood Creek. The thinning is due primarily to decrease in deposition, not to erosion, although at some places-for example, at Cottonwood Creek-more beds have been removed below the erosional unconformity at the top of the Muav than at others.

The chief lithologic units into which the formation is divisible at Bass Canyon are rec-. ognizable in all the other sections, although it is difficult to trace from one locality to another the exact boundaries that limit the subdivisions, because the strata undergo gradual changes in composition from place to place and the subdivisions grade into one another vertically. Broadly the lower two-thirds of the formation everywhere is thin bedded and consists of mottled limestone and interbedded sandy material, whereas the upper third is comparatively thick bedded and consists of calcareous sandstone below and massive limestone above. Large parts of the formation, however, become increasingly sandy toward the southeast. At Kanab Creek the formation consists chiefly of limestone, whereas at Cottonwood Creek, 50 miles southeast of Kanab Creek, and at Nunkoweap Valley, 15 miles north of Cottonwood Creek, it consists chiefly of calcareo-arenaceous rocks. 
Most of the lithologic change occurs in subdivisions $\mathrm{C}$ and D. (See Pl. XX.) Thus at Bass Canyon subdivision $\mathrm{D}$, at the base of the Muav, is 97 feet thick and consists almost wholly of mottled limestone. Only 10 feet of limestone, at the base of the subdivision, contains interbedded layers of sandstone. At Slate Creek, southeast of Bass Canyon, the mottled limestone of subdivision $\mathrm{D}$ is 50 feet thick, and the basal 44 feet of the subdivision is made up of alternating beds that consist chiefly of sandstone and shale but include a few layers of mottled limestone. That these prevailingly sandy beds are actually a part of subdivision $\mathrm{D}$ as defined at Bass Canyon and are not equivalent to beds included in the Bright Angel shale at Bass Canyon is clear, because the conspicuous soft green shale that marks the upper limit of the Bright Angel shale at Bass Canyon (see p. 34) is traceable continuously from Bass Canyon to Slate Creek. At Hermit Creek the mottled limestone of subdivision $\mathrm{D}$ is 40 feet thick and the underlying sandy beds 42 feet; and at Pipe Creek, still farther southeast, the mottled limestone is 34 feet thick and the sandy beds 51 feet. At the last two localities the mottled limestone interbedded with the sandy beds is very impure, so that the beds do not differ conspicuously from the Bright Angel shale and are difficult to separate from it. At Cottonwood Creek, southeast of Pipe Creek, the mottled limestone at the top of subdivision $\mathrm{D}$ is only 25 feet thick and overlies beds of greenish sandstone which contain layers of impure mottled limestone in the upper 17 feet. Here I have placed the base of subdivision $\mathrm{D}$ at a point 37 feet below the 25-foot bed of mottled limestone. This horizon, as nearly as I could determine, is equivalent to that which marks the top of the Bright Angel shale at Bass Canyon, but the horizon is not actually traceable between Bass Canyon and Cottonwood Creek. Probably, however, my estimate of its position at Cottonwood Creek is correct within 25 feet.

West of Bass Canyon, at Garnet Canyon, the mottled limestone is 122 feet thick and occupies all of subdivision D. A few thin layers of sandy material are interbedded with the basal 6 feet of the limestone.

Thus subdivision $D$ decreases in thickness and undergoes a gradual change in composition southeastward through the Kaibab division.
It decreases from 122 feet at Garnet Canyon to 62 feet at Cottonwood Creek, 28 miles southeast of Garnet Canyon. At Garnet Canyon it consists almost entirely of mottled limestone; at Cottonwood Creek it contains only a third as much mottled limestone as sandstone and shale, the limestone measuring only 25 feet. The increase of sandy material in the lower part of the subdivision makes its separation from the Bright Angel shale increasingly difficult southeast of Bass Canyon. Subdivision C, like subdivision $D$, decreases in thickness southeastward. At the type locality, at Bass Canyon, it is 241 feet thick. Southeast of Bass Canyon equivalent beds are 225 feet thick at Slate Creek, 215 feet at Hermit Creek, 185 feet at Pipe Creek, and 176 feet at Cottonwood Creek. These correlations are necessarily approximate, because subdivision $\mathrm{C}$ is nowhere separated from the overlying and underlying subdivisions by sharp lithologic changes, but in general the limits of the beds correlated with subdivision $\mathrm{C}$ are believed to be correctly placed within 25 feet. At all localities. the subdivision is prevailingly calcareous but variable in composition, thin beds of mottled limestone, in traformational conglomerate, sandstone, and shale succeeding one another in countless alternation, yet it contains much more limestone in proportion to sandy material at Garnet Canyon than at Cottonwood Creek and thus, like subdivision $\mathrm{D}$, becomes increasingly sandy toward the southeast. Glauconite, which occurs sparingly in the subdivision at Garnet and Bass canyons, becomes increasingly abundant southeast of Bass Canyon.

Subdivisions $\mathrm{C}$ and $\mathrm{D}$ together constitute that part of the Muav limestone in which thin-bedded mottled limestone is the prevailing rock and occupy the lower two-thirds of the formation. I have separated them at Bass Canyon, (1) because at that locality subdivision D consists essentially of mottled limestone, whereas subdivision $\mathrm{C}$ includes many interbedded layers of sandstone and shale; (2) because practically no limestone in subdivision $\mathrm{D}$ is of the intraformational-conglomerate type, whereas most of the limestone in subdivision $\mathrm{C}$ is intraformational conglomerate; and (3) because the two subdivisions differ in topographic expression, D forming a cliff and C forming a slope. Walcott in his sections at 
Kanab Creek and Nunkoweap Valley (see Pls. XIX and XX) does not subdivide this part of the Muav in which mottled limestone is the prevailing rock.

The mottled limestone at Kanab Creek is described by Walcott ${ }^{20}$ as follows:

The limestone is hard and brittle, breaking into angular fragments. Arenaceous shaly partings occur at various horizons, and there is considerable arenaceous detrital matter mixed with the limestone. At the base a massive bed 70 feet in thickness occurs, which is followed by several hundred feet of thin-bedded limestones. Many layers are gray limestone full of small flattened fragments [intraformational conglomerate?]. Toward the summit the upper 85 feet is essentially a repetition of the 70 feet at the base. The entire mass has a thickness of 450 feet. The coralline mottling, as it has been called by authors, extends from base to summit. That a portion of the mottling is produced by the former presence of branching corals may be true, but that such is usually the case is questioned. A study of the various forms of ramifying annelid trails and borings in the shales beneath prepares us to look for the origin of the mottling in that direction. On the surface of the intercalated arenaceous shales and also of the shaly sandstone layers these trails are seen in abundance. They may be traced into the limestone from the surface. Where the matrix is arenaceous they are frequently calcareous, and in the calcareous layers they are often silicified. Usually of a purplish color, they may be gray or buff according to the material by which they have been replaced. *** I should assign to annelids by far the greater share in the origin of the mottling of the limestone.

The 450-foot mottled-limestone member just described constitutes subdivision $\mathrm{c}$ of Walcott's section at Kanab Creek and is undoubtedly roughly equivalent to subdivisions $\mathrm{C}$ and $\mathrm{D}$ of my Bass Canyon section. At Nunkoweap Valley it constitutes subdivision 3 of Walcott's section, is 340 feet thick, and is a series of mottled and variegated calcareoarenaceous rocks. Thus it decreases from 450 feet at Kanab Creek to 338 feet (the aggregate thickness of subdivisions $\mathrm{C}$ and $\mathrm{D}$ ) at Bass Canyon, 30 miles southeast of Kanab Creek. Between Bass Canyon and Nunkoweap Valley, 30 miles to the northeast, the thickness changes very little, but between Bass Canyon and Pipe Creek, 18 miles to the southeast, it decreases from 338 to 270 feet, and at Cottonwood Creek, southeast of Pipe Creek, it appears to be less than it is at Pipe Creek. Walcott's descriptions indicate that the member is much less sandy at Kanab Creek than at Nunkoweap Valley and somewhat less sandy at Kanab

\footnotetext{
${ }_{20}$ Walcott, C. D., unpublished notes.
}

Creek than at Bass Canyon. It is therefore evident that the member as a whole becomes increasingly sandy southeastward from Kanab Creek.

Subdivisions $\mathrm{A}$ and $\mathrm{B}$, which constitute the upper third of the Muav at Bass Canyon, are represented by equivalent strata in all the sections shown on Plates XIX and XX, except in the section at Cottonwood Creek, where they have been removed by erosion.

The relatively thick-bedded calcareous sandstone in the upper part of subdivision B of my Bass Canyon section is evidently equivalent to the gray and buff calciferous sandrock, 50 feet thick, which constitutes subdivision $B$ of Walcott's section at Kanab Creek, and to the yellowish sandstone, 25 feet thick, which constitutes subdivision 2 of his section at Nunkoweap Valley. Probably subdivision $\mathrm{B}$ as defined by me includes a wider range of strata than the corresponding subdivision as defined by Walcott, and if so the thin-bedded sandstones of variable composition in the lower part of my subdivision $B$ may be equivalent to beds of limestone at the top of Walcott's subdivision $\mathrm{C}$ at Kanab Creek and to beds of calcareo-arenaceous rocks at the top of his subdivision 3 at Nunkoweap Valley. Subdivision $B$ as defined at Bass Canyon does not appear to undergo any significant lithologic change in the area between Garnet Canyon and Pipe Creek. The thick-bedded calcareous sandstone in the upper portion maintains a thickness of about 35 feet; whereas the subdivision as a whole varies irregularly in thickness, being 78 feet thick at Garnet Canyon, 72 . feet at Bass Canyon, 95 feet at Slate Creek, 93 feet at Hermit Creek, and 87 feet at Pipe Creek. The fact that the boundary between subdivisions $\mathrm{B}$ and $\mathrm{C}$ is indefinite suggests that these variations may be only apparent, because in measuring some sections I may have included in subdivision $B$ beds that are actually equivalent to beds in the underlying subdivision $\mathrm{C}$ of the Bass Canyon section.

Subdivision $A$ as defined at Bass Canyon consists of massive buff crystalline limestone whose composition is approximately that of dolomite and which appears to be formed largely of calcareous or dolomitic sand. This subdivision is constant in lithologic character in all the sections between Garnet Canyon and Pipe Creek but exhibits many irregularities 
in thickness, owing to the fact that its upper surface is an unconformity of erosion. Its thickness is 70 feet at Garnet Canyon, 63 feet at Bass Canyon, 15 feet at Slate Creek, 29 feet at Hermit Creek, and 26 feet at Pipe Creek. In the region between Bass Canyon and Hermit Creek the beds of subdivision A have been entirely removed at many places and a large part of the underlying subdivision $B$ has been removed at some places. These variations in thickness show the character and relief of the surface produced by erosion after the beds of subdivision $A$ were deposited but afford no evidence concerning the original thickness of the beds.

Subdivision A is apparently equivalent to the massive mottled limestone, 60 feet thick, which constitutes subdivision 1 of Walcott's section at Nunkoweap Valley and to the massive arenaceous and more or less mottled limestone, 185 feet thick, which constitutes subdivision a of his section at Kanab Creek. At Kanab Creek, at Nunkoweap Valley, and in the area between Garnet Canyon and Pipe Creek these limestones lie at the top of the Muav. Everywhere, therefore, they occupy the same stratigraphic position with regard to the underlying beds of calcareous sandstone of subdivision B. Moreover, if it is assumed that the sand in Walcott's limestones is calcareous, they do not appear to differ conspicuously from the equivalent beds in the area between Garnet Canyon and Pipe Creek. Some of the beds in this intermediate area exhibit purplish blotches and mottlings, and all of them, like Walcott's beds, are massive. Inasmuch as the top of subdivision A is eroded at Kanab Creek and at Nunkoweap Valley as well as in the intermediate area it is impossible anywhere to determine the original thickness of the subdivision and consequently of the Muav limestone.

Frech's section ${ }^{21}$ at "Congress Canyon" (Red Canyon), 3 miles east of Cottonwood Creek, shows only 129 feet of strata at the summit of the Tonto group that can be confidently assigned to the Muav limestone. Probably he has included strata in the Redwall limestone which are actually equivalent to the Muav and Temple Butte limestones, because the thickness of 1,000 feet which he assigns to the Redwall at that locality is certainly too great by several hundred feet.

21 Frech, F., op. cit., p. 479.
Fossils.-Fossils are scarce in the Muav limestone. At Kanab Creek, from the lower bed of mottled limestone in subdivision $\mathrm{c}$ of his section, Walcott ${ }^{22}$ obtained the following species:

$$
\begin{aligned}
& \text { Hyolithes primordialis? } \\
& \text { Lingulepis prima? } \\
& \text { Acrotreta? sp. } \\
& \text { Orthisina sp. } \\
& \text { Ptychoparia sp. } \\
& \text { Bathyurus? sp. }
\end{aligned}
$$

This bed of mottled limestone is probably roughly equivalent to my subdivision $\mathrm{D}$ of the Muav at Bass Canyon. (See pp. 43-44.)

From the upper bed of mottled limestone in subdivision $c$ at Kanab Creek Walcott obtained the forms listed above and in addition a species of Lingula. This mottled limestone is probably equivalent to beds in the upper part of my subdivision $\mathrm{C}$ at Bass Canyon.

From beds in the upper part of the Muav limestone at Kanab Creek which are probably equivalent to my subdivision $A$ at Bass Canyon Walcott obtained a species of Trematis and an imperfect specimen of Discina.

At Nunkoweap Valley the beds at the top of the Muav which are equivalent to my subdivision A: at Bass Canyon are reported by Walcott to contain Lingulepis and Ptychoparia. (See columnar section at Nunkoweap Valley, Pl. XX.)

In the area covered by my sections between Garnet Canyon and Cottonwood Creek I have obtained fossils from the Muav limestone at only one locality. At Hermit ${ }^{\circ} \mathrm{Creek}$, from a bed of mottled limestone in subdivision C, 118 feet above the base of the subdivision, I collected

$$
\begin{aligned}
& \text { Finkelnburgia sp. } \\
& \text { Syntrophia sp. } \\
& \text { Anomocarella sp. } \\
& \text { Pagodia? sp. } \\
& \text { Ptychoparia? sp. }
\end{aligned}
$$

The locality is on the west slope of Cope Butte a few hundred feet north of the Hermit trail. The fossils were identified by Edwin Kirk, who states:

The fauna as shown in the collection might be either Middle or. Upper Cambrian. I think more extensive collections are needed definitely to prove its age. In this connection a faunal list given by Walcott ${ }^{23}$ might be of interest. This fauna is cited from the Tonto at Kanab Creek and is given as Upper Cambrian.

22 Walcott, C. D., unpublished notes.

23 Walcott, C. D., U. S. Geol. Survey Mon. 51, p.214, locality 75, 1912. 
At Hermit Creek, from a bed in subdivision C, 50 feet lower than that in which I found the fossils listed above, Schuchert ${ }^{24}$ obtained pygidia of Saukia and of Neolenus. In discussing the fossils collected at Hermit Creek he states, "These fossils, and more especially the trilobites, show that the Muav is of Upper Cambrian age."

Regarding the age of the Muav limestone Walcott ${ }^{25}$ states:

As far as can be determined from the present collections I should include the Muav limestone in the Upper Cambrian; the Bright Angel shale and Tapeats sandstone in the Middle Cambrian. However, it is very desirable that larger collections be made from the Muav limestone.

Therefore I have assigned the Muav limestone to the Upper Cambrian in the present report, although I realize that further collections of fossils are necessary before its age can be fixed definitely. A careful search for fossils at the top of the formation may yield interesting results, for if the Muav is in fact Upper Cambrian it is conceivable that strata younger than Cambrian and older than Upper Devonian may be preserved in some places beneath the surface of erosion at the top of the formation.

\section{ONCONFORMITY BETWEEN CAMBRIAN AND} DEVONIAN SYSTEMS.

Walcott has shown that both at Kanab Creek ${ }^{26}$ and in the region about Nunkoweap Valley, ${ }^{27} 50$ miles southeast of Kanab Creek, the upper limit of the Tonto group is an unconformity. The unconformity at Kanab Creek he describes as a strong line of erosion that in places exhibits vertical irregularities of 80 feet within horizontal distances of a few hundred feet. In studying the Tonto group between Garnet Canyon and Cottonwood Creek I have traced this unconformity through a distance of about 28 miles in the south wall of the Grand Canyon in the Kaibab division. (See Pl. XX.) Probably, therefore, it extends continuously from Kanab Creek to Nunkoweap Valley. Further study may show that it extends far west of Kanab Creek.

Inasmuch as the unconformity lies within horizontal strata it can not be detected by

${ }^{24}$ Schuchert, Charles, op. cit., p. 369.

25 Walcott, C. D., personal communication.

26 Walcott, C. D., The Permian and other Paleozoic groups of the

Kanab Valley, Ariz.: Am. Jour. Sci., 3d ser., vol. 20, pp. 221-225, 1880.

${ }^{27}$ Walcott, C. D., Pro-Carboniferous strata in the Grand Canyon of the Colorado, Ariz.: Am. Jour. Sci., 3d ser., vol. 26, p. 438, 1883. discordance of dip and is plainly recognizable only where the eroded surface exhibits strong relief. In places where the eroded surface is level or nearly level, as, for example, at Bass Canyon and at Cottonwood Creek, the unconformity is obscure. Even where the surface is moderately irregular, as in the region about the Hermit and Bright Angel trails, the visitor may at first experience considerable difficulty in recognizing the unconformity until he knows exactly where to look for it.

At present the Hermit and Bright Angel trails afford the visitor the easiest opportunity to examine the unconformity. If he will descend either of these trails to a point about a hundred feet below the base of the sheer cliff formed by the Redwall limestone, pick out the beds of massive cliff-making dolomite that constitute the topmost subdivision of the Muav limestone (see Pl. XX), and follow their upper surface, he will find broken-down areas in the top of the dolomite cliff, which at first sight may appear to be caused by masses of rock breaking off from the cliff but which close inspection will show to be hollows eroded in the dolomite and filled by overlying strata. As a rule the strata in the hollows exhibit pale purplish or pinkish tints, which contrast slightly with the prevailing buff or gray of the dolomite, although in many places: their color is obsçured by buff and gray stains: washed over them from overlying beds. Moreover, they are softer than the dolomite and are irregularly bedded, so that they weather more easily than the dolomite and form. slopes. Commonly, these slopes are wholly or partly covered with talus.

In the canyon of Garden Creek, through which the Bright Angel trail descends from the rim of the Grand Canyon at El Tovar, a hollow of the type just described is well exposed near the north end of the promontory that separates the canyon of Garden Creek from that of Pipe Creek. This hollow lies about half a mile east of Indian Garden and may be reached by leaving the trail near Indian Garden and climbing the long slope of Bright Angel shale and Muav limestone east of the Garden. Other hollows are exposed in the canyon of Garden Creek which the visitors will easily discover when he has learned where to look for them. The canyon of Pipe. 
Creek, east of Garden Creek, contains at least ten of them. Several are exposed in each of the canyons west of Garden Creek, between Garden Creek and Hermit Creek.
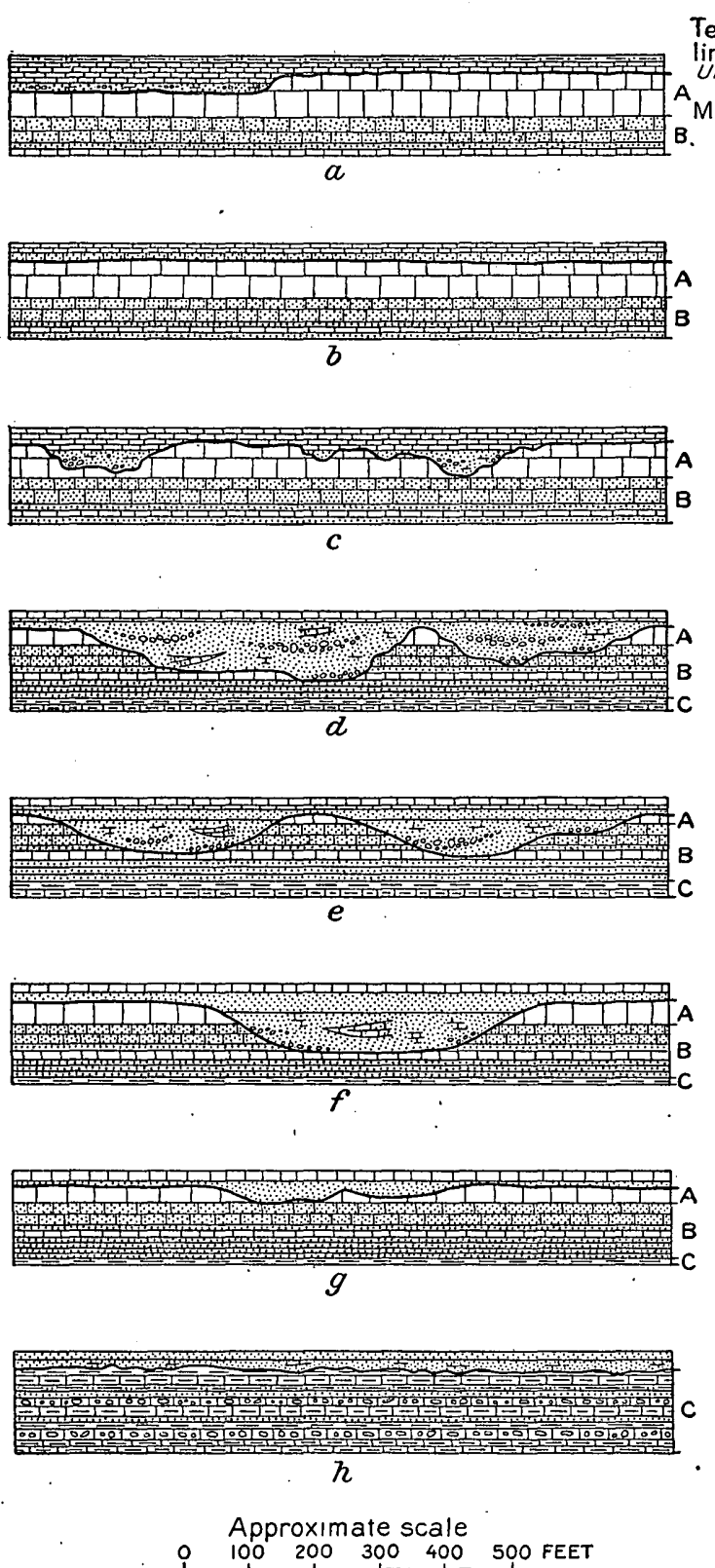

FIGURE 3.-Diagrammatic sketches showing general character of unconformity between Temple Butte limestone and Muav limestone at eight localities between Crarnet Canyon and Cottonwood Creek, Grand Canyon, Ariz. $a$, Garnet Canyon; $b$, Bass Canyon; $c$, Ruby Canyon; $d$, Turquise Canyon; $e$, Slate Creek; $f$, Hermit Creek; $g$, Pipe Creek; $h$, Cottonwood Creek.

In the canyon of Hermit Creek a hollow nearly 80 feet deep lies in the northern slope of Cope Butte just east of and above the Hermit trail. To reach this hollow the visitor should leave the trail at the lower end of the tangent called "Long Drag" and climb eastward several hundred feet up the steep ledgy slope formed by subdivisions $\mathrm{C}$ and $\mathrm{B}$ of the Muar limestone, following a contact between bare rock on his emple Butte left and talus on his right. The hollimestone low is difficult to find, because all but the north end of it is concealed by talus, and the observer may doubt its existence until he actually reaches it. The north end of the hollow affords good exposures of the gnarly, irregularly bedded pinkish or purplish calcareous sandrock that constitutes the typical deposit of known Devonian age in this part of the Grand Canyon (see p. 51), so that to one interested in the stratigraphy the hollow is. well worth a visit because of its accessibility. A similar hollow is exposed on the west side of the canyon of Hermit Creek about a mile west of the hollow just described. It lies near the north end of the promontory that separates the canyon of Hermit Creek from the next large canyon west of it:

By far the best exposures of the unconformity which I have seen in the Grand Canyon are in the region between Hermit Creek and Bass Canyon, in the long straight canyons that head behind Diana, Pollux, and Castor temples, namely, Slate Creek; Agate, Sapphire, and Turquoise canyons; also in Ruby Canyon, $2 \frac{1}{2}$ miles southeast of Bass Canyon. In all these canyons the surface of erosion is irregular in many places, so that the unconformity is plainly evident at first sight, even when viewed from a considerable distance. This interesting region, however, is not easily accessible to the tourist.

The accompanying sketches of the unconformity (fig. 3) show the topographic character of the eroded surface at eight different localities between Garnet Canyon and Cottonwood Creek. The photographs reproduced in Plates XXII and XXIII, $A$, show details of the unconformity. At Garnet Canyon the surface is comparatively even and exhibits no narrow hollows. Depressions are eroded in it, but they appear to be so broad and flat that the general aspect of the surface is mesa-like. At Bass Canyon, 3 miles from Garnet Canyon, the surface is practically level, and I have observed only one irregularity in it in a distance of several thousand feet. This irregularity is a steplike drop of about 25 feet from one mesa-like level to another. At Ruby Canyon, $2 \frac{1}{2}$ miles from Bass Canyon, the surface is very uneven. The 


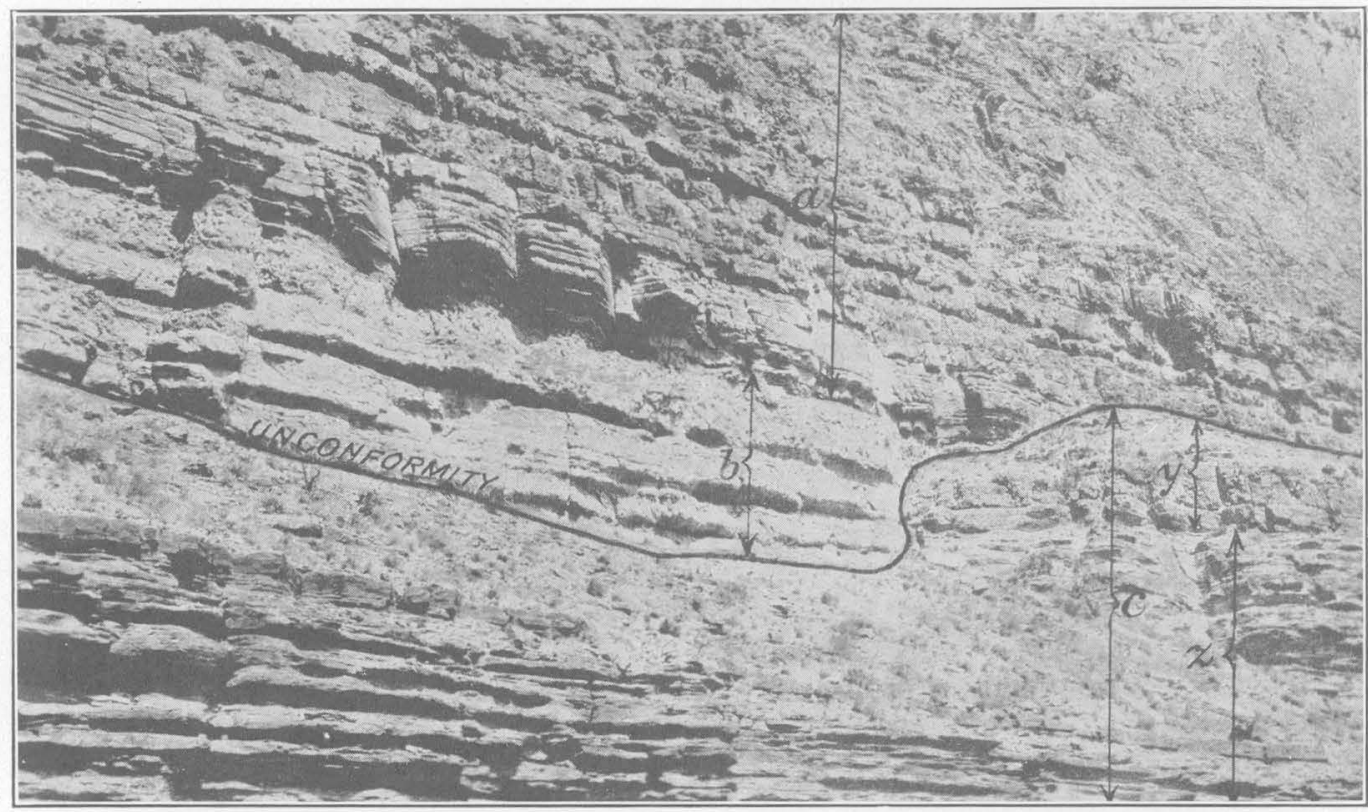

A.

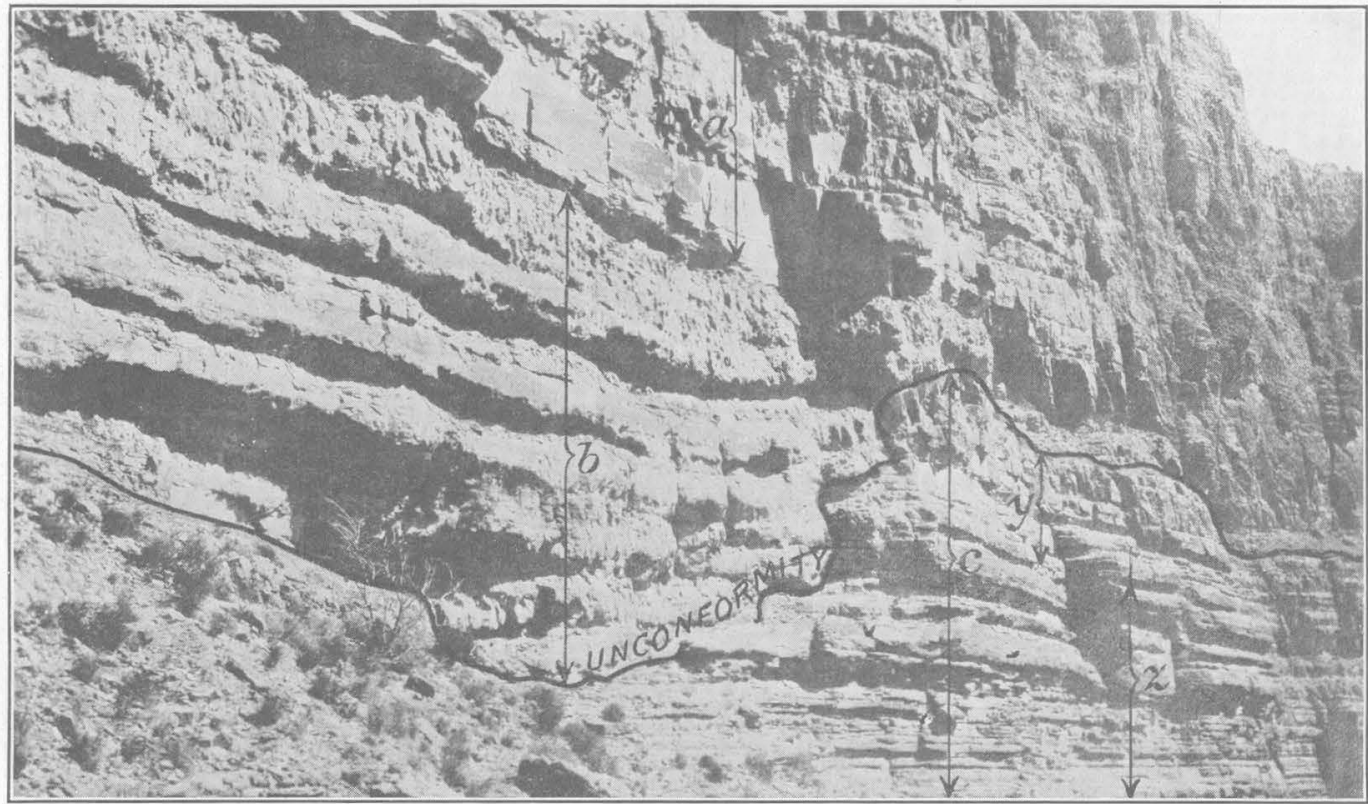

$B$.

UNCONFORMITY BETWEEN TEMPLE BUTTE LIMESTONE AND MUAV LIMESTONE IN WEST WALI OF CANYON OF SLATE CREEK, SHINUMO QUADRANGLE, ARIZ.

$a$, Pedwall limestone; $b$, Temple Butte limestone; $c$, Muav limestone; $y$, $z$, subdivisions A, B of Muav limestone. The human figure just at the right of the sharp bend in the unconformity in $A$, gives an idea of the scale of the photograph. 


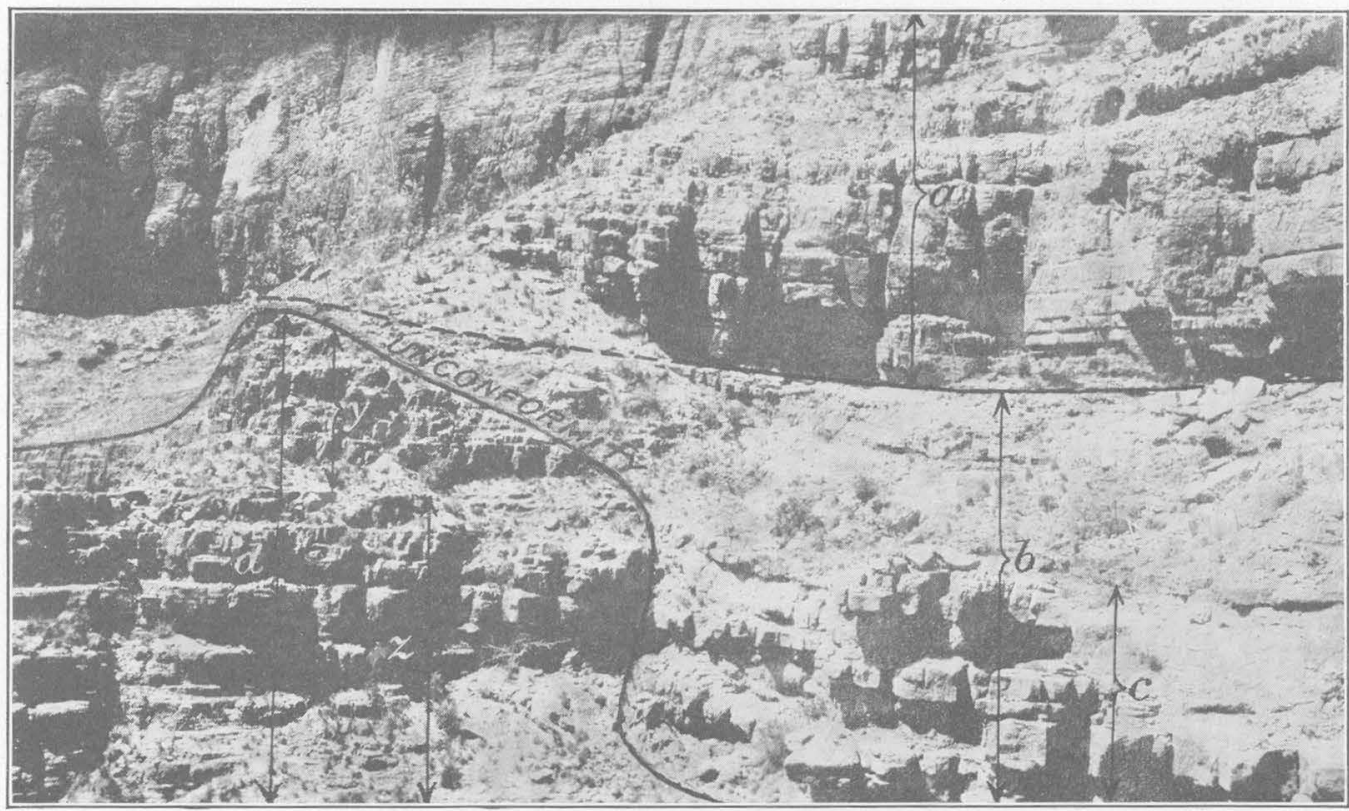

A. UNCONFORMITY BETWEEN TEMPLE BUTTE LIMESTONE AND MUAV LIMESTONE IN WEST WALL OF TURQUOISE CANYON, SHINUMO QUADRANGLE, ARIZ.

$a$, Redwall limestone; $b$, Temple Butte limestone; $c$, conglomerate; $d$, Muav limestone; $y, z$, subdivisions A, B of Muav limestone.

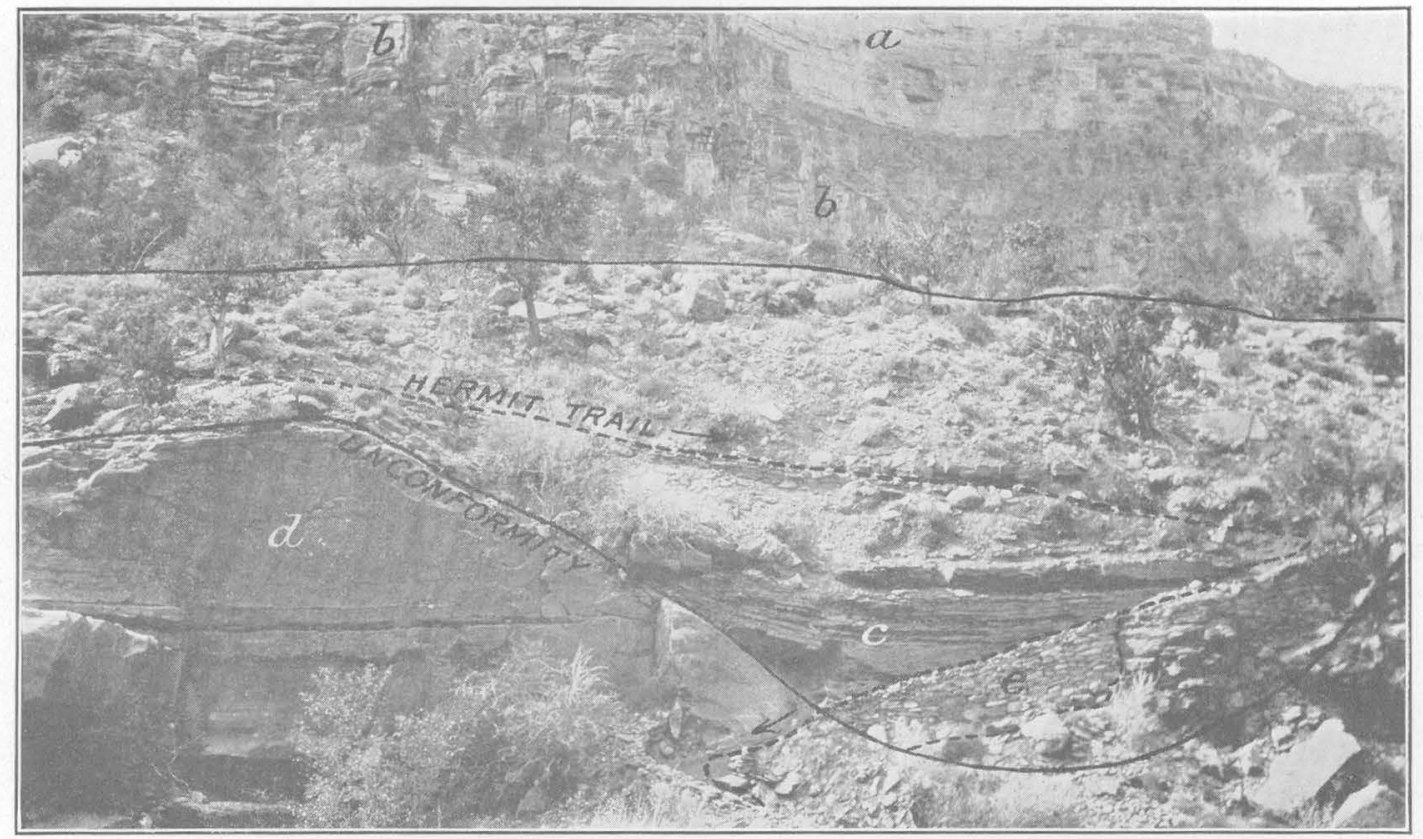

$B$. UNCONFORMITY BETWEEN HERMIT SHALE AND SUPAI FORMATION AT RED TOP, ON HERMIT TRAIL, BRIGHT ANGEL QUADRANGLE, ARIZ.

$a$, Kaibab limestone; $b$, Coconino sandstone; $c$, Hermit shale; $d$, Supai formation; $e$, artificial fill below trail. 
depressions in it are numerous, irregular in profile, and comparatively narrow. Some of these hollows are 40 feet deep. At Turquoise Canyon, $2 \frac{1}{2}$ miles from Ruby Canyon, the hollows nre less numerous but are broader and deeper than they are at Ruby Canyon. Some are 80 feet deep. In profile they are irregular, like those at Ruby Canyon. At Slate Creek, 3 miles from Turquoise Canyon, the hollows are broad and deep but are more symmetrical in profile than those at Ruby Canyon. At Hermit Creek, 5 miles from Slate Creek, they are symmetrical; brond; and deep but 'are much less numerous than at Slate Creek. At Pipe Creek; $5 \frac{1}{2}$ miles from Hermit Creek, they are shallower and narrower than at Hermit Creek but otherwise resemble those at Hermit Creek. Southeast of Pipe Creek they disappear, and at Cottonwood Creek, 7 miles from Pipe Creek, the unconformity is represented by a slightly wavy surface which does not appear to exhibit vertical irregularities of more than 3 or 4 feet in horizontal distances of hundreds of feet.

In the region between Ruby Canyon and Pipe Creek the hollows look like cross sections of ancient stream valleys. If they are, I believe it would be possible by studying and mapping the hollows between Slate Creek and Ruby Canyon to identify certain ancient valleys in opposite walls of a canyon, trace them through the narrow promontories separating the canyons, and thus by restoring in imagination their courses over a considerable area determine their direction and grade.

\section{DEVONIAN SYSTEM.}

TEMPLE BUTTE LIMESTONE.

Although the upper limit of the Tonto group is clearly defined by the unconformity just described, the correlation of the beds that lie between this unconformity and the sheer cliff of the Redwall limestone is a difficult problem. The beds differ from place to place in thickness, character, and succession and are not separated from the overlying Rediwall strata, of known Mississippian age, by a sharp stratigraphic break like the unconformity at the summit of the Tonto. Some beds are unquestionably of Devonian age, and others may be Mississippian, but owing to their variation in character and succession and to the absence of sharp stratigraphic breaks their separation can be established definitely only by the aid of fossils.
Many beds contain obscure traces of life, but determinable forms are scarce and the beds are difficult to reach in many places where it seems desirable to study them. It will be necessary to make a more thorough study of the beds than I have yet attempted, and particularly to make a systematic search for fossils in them, before their age and corrèlation can be established in detail. Meanwhile the correlations presented in this report (see $\mathrm{Pl}$. XX) should be regarded as tentative.

Fortunately one type of deposit that can be recognized wherever it is present by its peculiar lithologic character has yielded fossils at one locality which conclusively establish. its age as Devonian. This deposit is an irregularly bedded, gnarly pinkish or purplish calcareous sandrock which fills hollows in the surface marked by the unconformity. It is exposed most typically in the canyons between Ruby Canyon and Pipe Creek (see fig. 3 and Pl. XX) and is apparently represented by equivalent beds at Garnet Canyon and at Cottonwood Creek. It is not exposed at Bass Canyon. Apparently it is the oldest deposit laid down upon the post-Tonto surface in this part of the Grand Canyon.

The locality where I found fossils in the deposit is in Sapphire Canyon, at an elevation of about 3,700 feet, in the main stream course of the canyon. At this point the deposit fills a depression about 50 feet deep eroded in the Muav limestone. It consists essentially of irregularly bedded calcareous sandrock whose component grains are chiefly calcareous or dolomitic sand; the rock might thus be classed either as limestone or as sandstone. Some beds, however, are compact crystalline limestone or dolomite, and some are coarse conglomerate. A few beds consist of bright-red finegrained friable sandstone or sandy shale which resembles the Hermit shale higher in the canyon wall. (See p. 64.) In places this red sandstone shows concretionary structure, and some beds exhibit sun cracks. Practically all the calcareous sandrocks and associated beds are in lenticular layers which are highly irregular and are of no great horizontal extent, commonly wedging out within distances of less than 100 feet. Local unconformities are common between the beds. No two vertical sections of the deposit are alike, even in the same hollow. The prevailing color of the beds is 
- pinkish or purplish gray, but some beds display green or yellowish tints, and some are white or cream-colored. In many places the colors are mingled in blotches and streaks. Most of the rock is moderately fine grained, and nearly all of it exhibits cross-bedded structure. - In many parts of the deposit, but particularly at the top, the bedding is curiously gnarled and contorted. Probably this gnarly structure is an irregular form of cross-bedding.

The fossils occur in the lower part of the deposit, most of them within 3 feet of the base. They are abundant but are fragmentary and poorly preserved. A few fragments are scattered through higher beds. The following analysis of a representative sample of the rock in which the fossils occur shows that the rock is an impure dolomite.

Partial chemical analysis of limestone from Sapphire Canyon. [Alfred A. Chambers, analyst.]

Insoluble..................... 10.96

$(\mathrm{Al}, \mathrm{Fe})_{2} \mathrm{O}_{3} \ldots \ldots \ldots \ldots \ldots \ldots \ldots \ldots .2 .89$

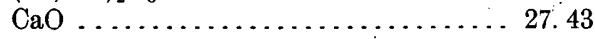

$\mathrm{MgO} \ldots \ldots \ldots \ldots \ldots \ldots \ldots \ldots \ldots \ldots \ldots \ldots \ldots, 17.88$

The fossils are scales and plates of fishes. The material which I collected was examined by J. W. Gidley, who writes:

I have gone over your collection critically and find only Bothriolepis represented in the lot. The material is too fragmentary to be determined specifically. However, the form represented appears to agree rather more closely with an Eastern species, B. nitidus, found in the Catskill formation, than it does with the common western form, $B$. canadensis. This, however, is not important for your purpose, except that it certainly indicates Upper Devonian.

So far as I know, Bothriolepis is characteristic of the Upper Devonian and is not known to occur below the Middle Devonian.

In addition I may state that in the character of the rock and broken condition of the fish remains your collection is very similar to the Catskill material.

The deposits of the type just described can therefore be assigned without question to the Devonian Temple Butte limestone, which, according to Walcott, ${ }^{28}$ "is unmistakably marked by thin purplish-colored layers of fine-grained sandstone that pass into calcareous sandrock and limestone in which cyathophylloid corals, casts of brachiopods and gastropods, and plates of placoganoid fishes usually occur." Fossils will probably be found in other localities than the one in Sapphire Canyon when systematic search is made for them.

28 Walcott, C. D., Pre-Carboniferous strata in the Grand Canyon of the Colorado, Ariz.: Am. Jour. Sci., 3d ser., vol. 26, p. 438, 1883.
The deposits just described are essentially similar wherever they are exposed, although they may differ somewhat in lithologic detail. At Turquoise Canyon, for example, they contain many lenses of conglomerate, whereas at many other localities they may contain little or none. At some places they may contain no bright-red sandstone or shale, and at some places little or no limestone or dolomite. Calcareous sandrock characterized by gnarly or contorted bedding, however, is always present. At Turquoise and Sapphire canyons and at the canyons of Slate and Hermit creeks the upper part of the deposits consists wholly of gnarly sandrock, which forms a massive; rather distinct bed from 20 to 25 feet thick. Commonly the upper part of this bed extends over the top of the higher Cambrian knolls to a depth of 5 to 15 feet.

At Bass Canyon the massive dolomite (subdivision A) at the top of the Muar limestone is overlain by 75 feet of thin-bedded purplish to white sandy limestone which is mottled in places by worm markings and contains a few beds of intraformational conglomerate similar to that in the Muar limestone. This thinbedded limestone contains no determinable fossils, although one bed contains obscure forms that are probably cup corals. A detailed section of the limestone is given on pages 32-33. The following analysis shows the composition of a sample of the limestone taken from bed 14, at the base of the section:

Partial chemical analysis of limestone from bed 14, Temple Butte limestone.

[Alfred A. Chambers, analyst.]

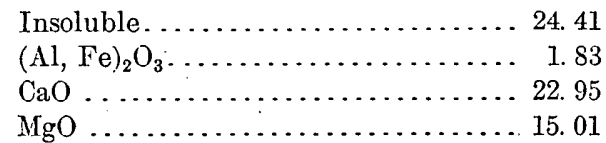

The rock is therefore an impure magnesian limestone or dolomite. The insoluble impurities are probably largely quartzose sand.

The beds of sandy limestone are overlain by a massive bed of brecciated limestone (see $p$. 32 ), which lies at the base of the Redwall cliff. Both upper and lower surfaces of this brecciated limestone are wavy, but I am not sure that they represent planes of erosion. At any rate the brecciated bed marks an abrupt change in lithology, and I have placed it at the base of the Mississippian Redwall. 
At most places in Bass Canyon the contact between the thin-bedded sandy limestone and the underlying massive dolomite of the Muav limestone is an even line, so that the two formations appear to be conformable. But at Garnet Canyon, 3 miles west of Bass Canyon, and at Ruby Canyon, 2 miles southeast of Bass Canyon, the thin-bedded sandy limestone is separated from the Muav by a plain line of erosion. (See fig. 3.) The contact is therefore an unconformity.

I have assigned the 75 feet of thin-bedded sandy limestone exposed at Bass Canyon to the Devonian Temple Butte limestone, because at Garnet Canyon (see Pl. XX) similar beds overlie a gnarly purplish conglomeratic sandrock that resembles the deposit in which fish remains occur in Sapphire Canyon and are overlain by other beds of gnarly conglomeratic sandrock and red shale, so that at Garnet Canyon the thin-bedded sandy limestone is actually included within beds that are lithologically identical with the known Temple Butte limestone.

\section{POSSIBLE UNCONFORMITY BETWEEN DEVONIAN} AND CARBONIFEROUS SYSTEMS.

Walcott ${ }^{20}$ has shown that at Kanab Creek the Redwall limestone is separated from underlying Devonian beds by a line of erosion, but I am unable confidently to trace this unconformity in the region between Garnet Canyon and Cottonwood Creek and at all places to separate Devonian beds from the Redwall limestone.

At Hermit Creek the sequence of beds between the Devonian Temple Butte limestone and the Redwall strata of known Mississippian age is as follows:

Section in western slope of Cope Butte, near Hermit trail.

[For profiles of section see Pls. XIX and XX.]

Massive gray magnesian limestone of known Mississippian age forming lower part of sheer Redwall cliff........................ $80 \pm$

1. Alternating beds of gray magnesian limestone, buff sandstone, and chert; partly concealed; form slope.......................... 15

2. Massive gray vesicular crystalline magnesian limestone; cavities contain coarse crystals of of calcite; forms cliff................... 11

3. Concealed beds; form slope................ 6

4. Limestone like bed 2 ; cliff................ 7

so Walcott, C. D., The Permian and other Paleozoic groups of the Kanab Valloy, A riz.: Am. Jour. Sci., 3d ser., vol. 20, pp. 221-225, 1880.
5. Band of chert layers; weathering black .......

Feet.

6. Limestone like bed 2 ; cliff............... 7

7. Buff sandstone with bands of chert.......... 5

8. Limestone like bed 2 ; cliff................ 7

9. Buff sandstone with bands of chert.......... 2

10. Limestone like bed 2 but sandy; slope........ 4

11. Sandy conglomerate composed largely of fragments of calcareous sandrock; cliff; base of bed uneven, wavy $\ldots \ldots \ldots \ldots \ldots \ldots \ldots . . . . .$.

Gnarly purplish and white calcareous sandrock of known Devonian age (Temple Butte limestone) lying in hollow eroded in Muav lime. stone; upper surface of sandrock uneven, wavy; in places exhibits inequalities of 3 feet............................ 14-76

The following analysis of a representative sample of the limestone forming bed 8 of the foregoing section probably shows approximately the composition of beds 2,4 , and 6 as well, because none of these beds differ in anpearance.

Partial chemical analysis of limestone from bed 8, Cope Butte. [Alfred A. Chambers, analyst.]

\begin{tabular}{|c|c|c|c|c|}
\hline \\
\hline & & & & \\
\hline & & & & 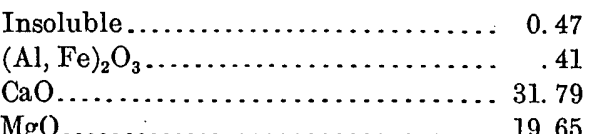 \\
\hline
\end{tabular}

The limestone is therefore a practically pure dolomite, and it is interesting to note that tho chemical composition of this rock is almost exactly that of the overlying limestone, which forms the lower part of the Redwall cliff (see analysis, p. 55) and from which, indeed, the limestone of bed 8 is almost indistinguishable in appearance, differing only in the thickness of the bedding.

Because the limestones in the series of beds 1 to 11 of the above section are lithologically identical with the beds at the base of the overlying Redwall limestone I have assigned the series to the Redwall limestone. The lithologic change from these beds to the gnarly sandrock underlying them is sharp, and it is possible that the wavy line at their base marks an erosional unconformity which separates the Devonian from the Mississippian. However, I do not wish unduly to emphasize the importance of the latter feature, because wavy surfaces occur at many horizons in the Redwall and Temple Butte limestones and are not necessarily of widespread stratigraphic significance.

Massive beds of gray vesicular magnesian limestone that alternate with layers of sand or 
chert and are similar to the series at Hermit Creek just described are exposed at Turquoise Canyon and in the canyons of Slate, Pipe, and Cottonwood creeks, where I have also assigned them to the Redwall limestone. (See Pl. XX.) Apparently the series thickens southeastward and attains a thickness of more than 100 feet in the region about Cottonwood Creek, but I have examined it in detail only at Hermit Creek. At Turquoise Canyon and Slate Creek it is underlain by 15 to 20 feet of thin-bedded sandy purplish and whitish magnesian limestones; those at Slate Creek I have assigned tentatively to the Temple Butte limestone (see Pl. XX), because they resemble the thinbedded Temple Butte limestone at Bass Canyon (see pp. 51-53), although it is possible that they belong at the base of the Redwall limestone, for they are separated from underlying gnarly sandrock of Deronian age by a slightly wavy surface. At Bass Canyon no beds at all resembling the massive vesicular limestones of Hermit Creek appear below the base of the Rediwall cliff. The lithologic change from typical Redwall beds to the thin-bedded purplish sandy limestone of the Devonian takes place at a brecciated bed at the very base of the cliff, and the plane of separation, as stated on page 53 , may or may not be an unconformity. At Garnet Canyon all beds above the known Devonian are inaccessible. An uneven surface is exposed there at the top of the highest beds that I could reach, but I do not know whether this surface is an unconformity separating Deronian and Mississippian or only a local unconformity in the Temple Butte limestone.

In brief, if an unconformity separates the Temple Butte limestone and the Redwall limestone in the region which I have examined, it is so obscure and exhibits so little irregularity that it can be detected only by obtaining determinable fossils in the strata within which it lies. Certainly no surface of erosion exists which is at all comparable in irregularity with that which separates the Tonto group from overlying beds.

\section{CARBONIFEROUS SYSTEM.}

MISSISSIPPIAN SERIES.

REDWALL LIMESTONE (RESTRICTED).

Definition.-In previous publications the Redwall limestone has been classified as of Pennsylvanian and Mississippian age. As orig- inally defined by Gilbert ${ }^{30}$ the formation was "named from the red appearance of its escarpments on either side of the Grand Canyon" and included in its top 200 to 510 feet of alternating sandstones and limestones of "Coal Measures" (Pennsylvanian) age. Later writers have also included these Pennsylvanian beds in the Redwall, although Darton ${ }^{31}$ in 1910 expressed the belief that they properly belonged to the overlying Supai formation. In the present report these beds of Pennsylvanian age are transferred to the Supai formation, to which, by reason of their lithology, age, and probable unconformable contact with the Mississippian rocks, they seem more properly to belong. The name Redwall limestone is therefore here restricted to the massive gray crystalline limestones of Mississippian age, and this restricted definition has been adopted by the United States Geological Survey.

Character.-The Redwall limestone as here restricted consists almost wholly of bluish-gray crystalline limestone whose distinctive features are massive appearance, hardness, and relatively great thickness. The massive appearance of the limestone is due partly to the thickness and homogeneity of the beds but chiefly to the fact that the planes of separation between many beds are inconspicuous, so that when viewed from a distance large parts of the formation present the appearance of a single stratum. The hardness and thickness of the limestone cause it to make the sheerest and most continuous cliff in the canyon wall.

At Bass Canyon the Redwall limestone is about 570 feet thick and is divisible into three parts which differ in topographic expression. Subdivision C, at the base of the formation, makes a slope that unites with the steep ledgy slope formed by the Temple Butte limestone (see p. 32) and is a bed of sandy breccia 8 feet thick whose fragments consist chiefly of gray limestone. It is overlain by bluish-gray massive crystalline limestone, obscurely bedded at the base and top, which makes a cliff approximately 500 feet high. This cliff-making limestone constitutes subdivision B. Subdivision A, at the top of the formation, consists of distinctly bedded bluish-gray crystalline limestone which includes a few thin partings of red

30 Gilbert, G. K., U. S. Geog. and Geol. Surveys W. 100th Mer. Rept, vol. 3 , pp. 161, 162, 177, 178, 185, fig. 82,1875 .

${ }^{31}$ Darton. N. H., A reconnaissance of parts of northwestern New Mexico and northern Arizona: U. S. Geol. Survey Bull. 435, p. 22, 1910. 
shale. This subdivision, 62 feet thick, makes a succession of small cliffs and narrow ledges above the sheer cliff formed by subdivision $B$. The character and succession of the Redwall beds are described in the sections given on pages $31-32$, and the profiles of the subdivisions are shown in the columnar section (Pl. XIX).

Subdivisions $A$ and $C$ can not be traced with certainty far from Bass Canyon, but subdivision $\mathrm{B}$, the main cliff-making portion of the Redwall, is constant in lithology and in appearance and is readily recognizable everywhere in the Kaibab division of the Grand Canyon. The upper and lower portions of the subdivision are obscurely and heavily bedded, whereas the middle portion is distinctly bedded and contains many thin layers of chert and sand. Most beds in the subdivision contain a few scattered nodules of chert, but chert is conspicuously abundant only in the middle, distinctly bedded portion. Many beds contain coarse crystals of calcite, some of which line cavities, some of which form large irregular masses in the rock, and some of which form layers a few inches to a foot thick. Interbedded layers of sandstone occur throughout the subdivision but are numerous only in the middle portion. As a rule the sand is loosely cemented and exhibits gnarly structure. Many beds rest on irregular, wavy surfaces. In many places the limestone cliff is stained pinkish or pale rose color by ferritic pigment washed over it from overlying red shales in the Supai formation. Unstained surfaces of the limestone commonly weather gray or bluish gray. Freshly broken surfaces are gray, buff, or white.

The following analyses show the composition of representative samples of limestone from subdivision $B$ at Bass Canyon. No. 1 represents the obscurely bedded limestone (No. 1, p. 32) that forms the upper part of the subdivision; No. 2, the heavily bedded limestone (No. 3, p. 32) that forms the lower part.

Partial chemical analyses of limestone from subdivision $B$, Redwall limestone.

[Alfred A. Chambers, anslyst.

\begin{tabular}{|c|c|c|}
\hline & 1 & 2 \\
\hline 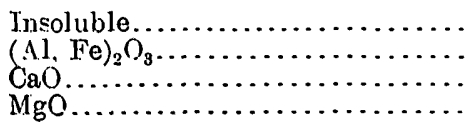 & $\begin{array}{r}0.48 \\
.10 \\
55.50 \\
.08\end{array}$ & $\begin{array}{r}0.82 \\
.40 \\
32.54 \\
19.52\end{array}$ \\
\hline
\end{tabular}

These analyses show that the limestone at the top of the subdivision is practically pure, whereas that at the base is magnesian and is essentially dolomite. The composition of the limestone forming the middle, laminated member of the subdivision was not determined by analysis, but inasmuch as this limestone resembles that in the overlying obscurely bedded member in appearance and effervesces freely with acid, it is probably not magnesian. The limestones in subdivision A resemble those in the upper part of subdivision B and effervesce freely with acid. It would appear, therefore, that the limestone in the whole upper portion of the Redwall is comparatively pure and only that in the basal member of subdivision $B$ is magnesian.

Southeastward from Bass Canyon subdivision $\mathrm{B}$ diminishes gradually but steadily in thickness. At Bass Canyon it is approximately 500 feet thick; at Hermit Creek, 13 miles southeast of Bàss Canyon, 475 feet; and at Red Canyon, 16 miles farther southeast, 375 feet. Red Canyon is 4 miles east of Cottonwood Creek. This decrease in the thickness of subdivision $B$ is readily apparent to most observers in the diminished height of the Redwall cliff when seen from Grandview or Desert View, as contrasted with the height of the cliff when seen from the head of the Hermit trail or from Bass Camp.

Subdivision A as defined at Bass Canyon is traceable southeastward at least as far as Hermit Creek (see columnar sections, Pl. XIX), but subdivision $\mathrm{C}$ is not traceable southeast of Ruby Canyon, 2 miles from Bass Canyon. At Slate Creek, 8 miles southeast of Bass Canyon, and in the region southeast of Slate Creek (see Pl. XX) subdivision B is underlain by a series of gray vesicular magnesian limestones and interbedded sandstones which make a steep ledgy slope beneath the cliff of subdivision B. A section of these alternating limestones and sandstones at Hermit Creek is given on page 53 . This series, which I have assigned to the Redwall limestone (see p. 53), apparently occupies a lower horizon in the Redwall than subdivision $\mathrm{C}$, which actually is probably a local bed at the base of subdivision $B$. The alternating limestones and sandstones thicken southeastward, for they are 68 feet thick at Hermit Creek and at least 130 feet (estimated) at Red Canyon. I have not measured them at Slate, Pipe, and Cottonwood creeks. 
Thickness.-The Redwall limestone decreases in thickness in the 29 miles between Bass Canyon and Red Canyon. It is 570 feet thick at Bass Canyon, 538 feet at Hermit Creek, and a little over 500 feet at Red Canyon. The decrease in thickness in the formation as a whole is not so great as the decrease in its cliff, because the series of alternating limestones and sandstones at the base of the formation increases in thickness southeastward as the overlying cliff-making limestone diminishes. At Kanab Creek, 30 miles northwest of Bass Canyon, the formation is a little over 700 feet thick. (See Pl. XIX.)

Fossils.-Fossils are scarce in the Redwall limestone at the Bass, Hermit, and Bright Angel trails. Commonly they are poorly preserved and are difficult to collect unless they are weathered out of the rock. In 1914 I made small collections at two localities. At Bass Canyon I obtained from the middle, distinctly bedded member (2) of subdivision B Fenestella sp. and Schuchertella chemungensis. This locality is at the Bass trail near the bottom of the narrow part of Bass Canyon in the Redwall.

In the canyon of Hermit Creek I obtained from the same middle member of subdivi$\operatorname{sion} \mathrm{B}$

Monilipora? sp.

Crinoid stems.

Fenestella, several sp.

Rhipidomella sp.

Camarotoechia sp.

Spirifer centronatus.

Syringothyris? sp.

The fossils were identified by G. H. Girty, who writes:

Although these fossils are poor and constitute a very small fauna, they indicate with but little uncertainty a Mississippian (Madison) age and thus confirm previous - determinations of the age of the lower and major part of the Redwall limestone. It is true that an undoubted Pennsylvanian fauna has been cited by Meek from the upper part of the Redwall limestone of this general region, but these fossils came from beds that are now being transferred to the Supai formation.

In 1920 I collected fossils from beds near. the top of the Redwall limestone at two localities.

One collection, which I labeled lot C, I obtained at the very top of the Redwall cliff in the canyon of Garden Creek directly under El Tovar. The locality is about an eighth of a mile east of the point where the Bright Angel (Cameron) trail descends the Redwall cliff and may be reached by leaving the trail at this point and walking eastward along the narrow bench at the summit of the cliff. The fossils weather from the upper surface of the limestone that underlies this bench, and the horizon appears to be equivalent. to the very top of subdivision $B$ of the Bass Canyon section.

The other collection, which I labeled lot A, I obtained from bed 5 of subdivision $\mathrm{A}$ in Bass Canyon. (See p. 31.) The locality is on the west side of Bass Canyon about a quarter of a mile north of the point where the Bass trail descends the break in the Redwall cliff at the head of the canyon. It may be reached by following the first bench above the top of the sheer cliff of subdivision $B$ that is wide enough for a man to walk upon. The fossiliferous horizon is about 14 feet above the top of the cliff.

Regarding these two collections Mr. Girty writes:

Lot $\mathrm{C}$ contains an abundant fauna, though one showing but little diversity and represented by very unsatisfactory specimens. I-recognize in it the following forms:

Diphyphyllum? sp. (probably the same form shown by better specimen in $\operatorname{lot} \mathrm{A}$ ).

- Camarotoechia? n. sp.

Spirifer centronatus.

Spirifer aff. S. incertus.

Composita? sp.

Bellerophon sp.

Euomphalus? sp.

Lot A contains Diphyphyllum (Lithostrotion?) sp., Camarotochia? (apparently the same form as in lot $\mathrm{C}$ ), and a fucoid.

These two lots contain essentially the same fauna and are of the same geologic age. As between Pennsylvanian and Mississippian, I should refer them with little question to the Mississippian. As between lower Mississippian and upper Mississippian - that is, as between Madison and Brazer-a definite conclusion can not be reached. So few occurrences of upper Mississippian rocks are known in this southwestern region that a general probability is established that these faunas belong to the lower horizon. The facies of the faunas corresponds so far as it goes with the lower Mississippian faunas, as we know them now, but the forms contained in these collections are so few, so poorly represented, and in some cases so ambiguous that one can not deny the existence of a possibility that the geologic age may be upper Mississippian. To state the matter briefly, as I see it, the evidence so far as it goes suggests lower Mississippian, but it does not go far enough definitely to establish the lower Mississippian age of the horizon. My personal convictions, I may add, are strong that the age is actually lower Mississippian. 
Schuchert, who has collected fossils in the Redwall at the Hermit trail, states: ${ }^{32}$

The base of the Redwall on the Hermit trail consists of three thick beds. The upper one is from 10 to 12 feet thick, and the lowest bed is 8 feet thick, of a vesicular gray dolomite with the cavities filled with calcite. The upper bed has Syringopora cf. surcularia. Between these two dolomite beds is a yellowish-white sandstone, 4 feet thick. ${ }^{33}$

The Redwall may be studied on the Hermit trail below the Cathedral Stairs, but the sequence can not be made out with certainty because all of it has slumped and slid down in a huge landslide. The parts are mixed, and even some of the Supai is included with blocks of the Redwall. One entire day was devoted to collecting fossils from it, but the results were very unsatisfactory. Toward the middle of the Redwall were seen sections of a few corals, of Menophyllum and Clisiophyllum, and a number of crinoidal columnals, besides Spirifer centronatus. Of the few fossils taken away there is a Syringopora like $S$. surcularia Girty, Menophyllum excavatum Girty, Fenestella and Polypora in several species, and a finely striate Spirifer.

These fossils are seen to belong to the same fauna as those identified by Girty from near Nelson, Ariz., and collected by W. T. Lee. The time indicated by them is that of the Madison limestone so widely distributed in the Rocky Mountain country, or of the older half of the Mississippian of the Mississippi Valley.

In 1879 Walcott collected fossils at Kanab Creek at many horizons in beds which he designated subdivisions $\mathrm{b}$ and $\mathrm{c}$ of the Redwall limestone. (See Pl. XIX.) These two subdivisions and the underlying subdivision $d$ of Walcott's section correspond closely in lithology with the Redwall of my Bass Canyon section and constitute the Redwall as it is here redefined. Subdivision a, at the top of Walcott's Redwall at Kanab Creek, corresponds in lithology to my subdivision $\mathrm{C}$ of the Supai formation at Bass Canyon and undoubtedly properly belongs in the Supai. (See p. 62.)

These collections from subdivisions $\mathrm{b}$ and $\mathrm{c}$ at Kanab Creek were never worked up in detail by Walcott and in the course of time have become badly mixed with collections made from other Carboniferous beds in the general region. However, Mr. Girty, who has examined the material, makes the following statement concerning as much of it as he is able to assign to the collections from $\mathrm{b}$ and $\mathrm{c}$ :

The faunas are much more extensive and conclusive than the one contained in your lots $\mathrm{A}$ and $\mathrm{C}$, and $\mathrm{I}$ refer them without hesitation to the lower Mississippian, to that widespread limestone formation which has commonly been

7. Schuchert, Charles, op. cit., pp. 360-361.

33 The threo dolomite beds described by Schuchert are probabiy beds 2,4 to 6 , and 8 of my section at Cope Butte given on page 53.-L. F. N. called the Madison limestone but which in New Mexico has received the name Lake Valley limestone. I do not myself feel in doubt, although the evidence is not entirely conclusive, that the entire Redwall limestone, so far as it is embraced within the horizons represented by your collections $\mathrm{A}$ and $\mathrm{C}$ and by Mr. Walcott's collections from Kanab Canyon, is of lower Mississippian age and belongs in a general alinement with the Madison limestone.

The type locality of the Redwall limestone selected by Darton ${ }^{34}$ is Redwall Canyon, in the Shinumo Amphitheater, only 4 miles north of Bass Canyon. The section at Bass Canyon, given in the present report, is so near Redwall Canyon that it may be assumed practically to represent the formation at the type locality. The evidence just presented indicates that at the type locality the entire Redwall as here restricted is of lower Mississippian age, although it is conceivable, but highly improbable, as Girty states, that the beds at the top of the formation in which I found fossils may be upper Mississippian.

No evidence has been found which indicates that any part of the Redwall as here recognized in the Kaibab division of the Grand Canyon is younger than Mississippian.

Ransome, ${ }^{35}$ who has examined the Redwall in the Jerome region, where he collected fossils in it that Girty identified as lower Mississippian, states: "No evidence was obtained at Jerome to indicate that any of the Redwall limestone is as young as the Pennsylvanian." In the Jerome region the beds assigned to the Redwall aggregate only 250 feet and probably belong to the lower part of the formation.

PROBABLE UNCONFORMTTY BETWEEN MISSISSIPPIAN AND PENNSYLVANIAN SERIES.

The top of the Redwall limestone is very difficult to reach, except at places near the trails that descend the canyon wall, and I have so far been able to examine it only at the Bass trail, at the trail which ascends the northern wall of the Grand Canyon through Muav Canyon, and at the Hermit, Bright Angel, and Hance (Red Canyon) trails. Viewed from a distance it appears to exhibit no irregularity at most places in the Kaibab division of the canyon.

At Bass Canyon the contact between the typical bluish-gray limestone of the Redwall

34 Darton, N. H., A reconnaissance of parts of northwestern New Mexico and northern Arizona: U. S. Geol. Survey Bull. 435, p. 21, 1910

35 Ransome, F. L.; Some Paleozoic sections in Arizona and their correlation: U. S. Geol. Survey Prof. Paper 9S, p. 162, 1916. 
and the red shale at the base of the overlying Supai appears to be remarkably even, and the only evidence of a stratigraphic break is the abrupt change from limestone to shale. However, actual exposures of the contact are not to be found, owing to the softness of the shale, which makes a slope at this horizon that is entirely concealed by talus.

At Muav Canyon the surface of the Redwall is uneven, but the beds are shattered along the axis of a faulted flexure, so that it is uncertain whether the unevenness is due to shattering or to erosion.

At the Hermit, Bright Angel (Cameron), and Hance trails the appearance of the top of the Redwall suggests that it was exposed to erosion before the overlying Supai beds were deposited, as I shall show.

Near the Hermit trail, just south of the point where the trail descends the Redwall, the upper surface of the Redwall limestone is decidedly uneven, and in places jagged knolls of the limestone project 25 feet or more above the general level of the surface. At this locality the basal deposit. of the Supai is a bright reddish or purplish sandy shale. Some parts of the shale exhibit no bedded structure whatever; other parts exhibit gnarly, irregular bedding and are more or less concretionary, whereas still other parts are evenly and thinly bedded. Thin lenses of conglomerate occur at some horizons in the shale. The pebbles in the conglomerate are. well $r$ unded and are coated with black "desert varnish." Most of them are composed of chert. derived, apparently, from the underlying limestone. The shale varies considerably in thickness from place to place. Above the tops of the higher limestone knolls the thickness may not exceed 45 feet, but between the knolls, where the deposit appears to fill depressions, the thickness may exceed 70 feet. The deposit becomes more evenly bedded toward the top, and the upper 21 feet consists of thinly laminated soft reddish shale. Above this shale are alternating beds of red sandy shale, purplish and gray limestone containing red chert, and reddish to buff calcareous sandstone. The thickness of these alternating beds is 132 feet. The section just described, 202 feet in total thickness, is shown diagrammatically on Plate XIX. The beds are undoubtedly equivalent to subdivision $\mathrm{C}$ of the Supai at the Bass trail. (See p. 61.)
The upper surface of the Redwall limestone is infiltrated with red mud, and the overlying irregularly bedded, more or less structureless red shale appears to represent just such a deposit of red clay as one would expect to find above a weathered limestone surface. It is possible that the roughness of the top of the Redwall is due to shattering of the beds in this locality, because the formation has slumped in a landslide at the point where the trail descends it. For this reason the evidence just presented should be regarded as inconclusive. Nevertheless the lithologic change from the massive limestone of the Redwall to the structureless red deposit above it is so sharp that it indicates a stratigraphic break at this horizon, and the variation in thickness of the red shale is also. suggestive. The bed is 72 feet thick at the Hermit trail, whereas the shale at the corresponding horizon in Bass Canyon is not over 14 feet thick. (See p. 31; also Pl. XIX.)

At the Bright Angel (Cameron) trail the summit of the Redwall is irregular, but here also the evidence is inconclusive, because the Redwall is shattered by a fault in the vicinity of the trail.

At Red Canyon the summit of the Redwall is well exposed near the 4,955-foot bench mark, where the Hance trail descends the Redwall on the east side of the canyon. This locality is some distance east of a fault that coincides with the axis of Red Canyon, so that the beds here have not been disturbed by the fault. Near the bench mark the surface of the Redwall is wavy, and the limestone is more or less infiltrated with red mud, but the best evidence of a stratigraphic break at the top of the limestone is found in the lithologic character of the overlying Supai beds. The Supai begins abruptly with a bed of conglomerate, which exhibits great variations in thickness. At one place it is 20 feet thick, at many places 5 to 10 feet thick, and at some places entirely absent. The conglomerate contains both angular and rounded pebbles of chert and limestone, derived, apparently, from the underlying Redwall. The pebbles range in diameter from a fraction of an inch to 6 inches but average about half an inch. The conglomerate is gravelly and contains very little matrix. Where present the matrix consists of red sandy clay. Where the conglomerate is thickest it appears to fill shallow depressions in the Red- 
wall. Above the conglomerate is 100 feet of red friable sandy shale that is more or less calcareous and in places exhibits concretionary structure, and above the shale are alternating beds of shale, limestone containing red chert, and calcareous sandstone, some of which is cross-bedded. The conglomerate, red shale, and overlying alternating beds just described are undoubtedly equivalent to subdivision $\mathrm{C}$ of the Supai as exposed at the Hermit and Bass trails.

Walcott, ${ }^{38}$ in describing the upper part of the Redwall at Kanab Creek, states:

Toward the close of the 700 feet of limestone and its intercalated cherty bands evidences of an approaching change occur. The horizontal bedding is broken by gradually increasing curves of depression and elevation of the previously level surface. The limestone becomes more and more interstratified with white chert, weathering black. Arenaceous layers of a detrital origin come in, with pink chert and chalcedony replacing the white chert of the beds beneath.

Massive layers of brecciated chert in a quartzitic matrix denote the increasing change of conditions, and soon the sandstone epoch of the Lower Aubrey group opens. The transition beds (a) have filled the hollows and leveled off the uneven surface of the limestone beneath, and, 255 feet above, the great sandstone group begins with a massive cross-bedded sandstone stratum (e), 50 feet in thickness.

The transition beds to which Walcott refers are the beds that constitute subdivision a of his Redwall at Kanab Creek (see Pl. XIX), which is now transferred to the Supai (see p. 62). Therefore the uneven surface which he describes actually lies at the top of the Redwall limestone as here restricted, and the horizon occupied by the uneven surface is equivalent to that at the Hermit, Bright Angel (Cameron), and Hance trails which $I$ have just described.

Schuchert, ${ }^{37}$ who has examined the RedwallSupai contact on the Hermit trail, writes:

The contact may be studied just beneath the signpost "Cathedral Stairs" that stands on Supai strata. It is of the disconformable type, and the Redwall is more or less eroded. Where the contact was studied this limestonedolomite series terminates in thin-bedded deposits, with the beds varying in thickness from 12 to 20 inches. The Supai begins at once with its characteristic sandy and rain-pitted shales and muddy sandstones. This disconformity has far greater significance than the physical phenomena as seen on the Hermit trail would seem to indicate,

so Wricott, C. D., unpublished notes.

${ }_{87}$ Schuchert, Charles, op. cit., p. 358. for the fossils of the Redwall are here all of early Mississippian age. Nothing of later Mississippian time is present, and the land interval preceding Supai deposition was certainly longer than all of Redwall time.

Ransome ${ }^{38^{\circ}}$ reports that 8 miles north of Jerome what he regards as the base of the Supai is a limestone conglomerate 2 to 3 feet thick in which the pebbles are generally less than 2 inches in diameter. $\mathrm{He}$ states that layers of a similar conglomérate also occur a little higher in the formation.

In brief, although the evidence just presented is inconclusive, it establishes a strong probability that the upper limit of the Redwall is an unconformity of erosion.

PENNSYLVANIAN AND PERMIAN (?) ROOKS.

SUPAI FORMATION (REDEFINED).

Definition.-As originally defined by Dar- · ton ${ }^{39}$ the name Supai formation was applied to about 800 feet of red sandstones and shales, the latter in part sandy, underlying the Coconino sandstone, overlying the Redwall limestone, and composing the lower part of the Aubrey group in northern Arizona. Darton's Redwall limestone, like Gilbert's and Walcott's Redwall, included rocks of Mississippian and Pennsylvanian age. In this report the Supai formation is redefined by cutting off at the top about 300 feet of deep brick-red sandy shale and fine-grained friable sandstone of Permian age, to which the new name Hermit shale is herein applied, and by adding at the bottom about 250 feet of red sandy shale, purplish and gray limestone with red chert, and reddish to buff calcareous sandstone of Pennsylvanian age that have heretofore been included in the Redwall limestone. This redefinition of the Supai formation has been adopted by the United States Geological Survey. As thus defined the Supai formation is of Pennsylvanian and Permian (?) age and rests with probable unconformity on the underlying Mississippian Redwall limestone. The accompanying table shows the different classifications of the Carboniferous rocks of the Grand Canyon.

38 Ransome, F. L., op. cit., p. 162.

${ }^{39}$ Darton, N. H., A reconnaissance of parts of northwestern New Mexico and northern Arizona: U. S. Geol. Survey Bull. 435, pp. 25-27, 1910. 
SHORTER CONTRIBUTIONS TO GENERAL GEOLOGY, 1922.

Classifications of the Carboniferous rocks of the Grand Canyon.

\begin{tabular}{|c|c|c|c|c|c|}
\hline \multicolumn{2}{|c|}{$\begin{array}{l}\text { G. K. Gilbert, 1875. } \\
\text { (U. S. Geog. and Geol. Surveys W. 100th Mer. } \\
\text { Rept., vol. 3, pp. 161-186, fig. 82.) }\end{array}$} & $\begin{array}{l}\text { C. D. Walcott, } 1880 . \\
\text { (Am. Jour. Sci., } \\
\text { 3d. ser., vol. 20, } \\
\text { pp. 221-225.) }\end{array}$ & $\begin{array}{l}\text { N.H. Darton, } 1910 . \\
\text { (U.S. Geol. Survey } \\
\text { Bull. } 435 .)\end{array}$ & $\begin{array}{l}\text { L. F. Noble, } 1922 . \\
\text { (This report.) }\end{array}$ & Age. \\
\hline \multirow{3}{*}{ Aubrey group. } & $\begin{array}{l}\text { Cherty limestone, } 200- \\
820 \text { feet. }\end{array}$ & Upper Aubrey. & $\begin{array}{l}\text { Kaibab lime- } \\
\text { stone. }\end{array}$ & Kaibab limestone. & \multirow{3}{*}{ Permian. } \\
\hline & $\begin{array}{l}\text { Cross-bedded and other } \\
\text { sandstones, } 300-1,000 \\
\text { feet. }\end{array}$ & \multirow{2}{*}{ Lower Aubrey. } & $\begin{array}{l}\text { Coconino sand- } \\
\text { stone. }\end{array}$ & Coconino sandstone. & \\
\hline & $\begin{array}{l}\text { Red and white shales } \\
\text { and sandstones, } 800 \\
\text { feet. }\end{array}$ & & $\begin{array}{l}\text { Supai forma- } \\
\text { tion. }\end{array}$ & $\begin{array}{l}\text { Hermit shale. } \\
\text {-Unconformity }\end{array}$ & \\
\hline \multirow{3}{*}{$\begin{array}{l}\text { Redwall lime- } \\
\text { stone group. }\end{array}$} & $\begin{array}{l}\text { Alternating sandstones } \\
\text { and compact lime- } \\
\text { stones, } 200-500 \text { feet. }\end{array}$ & \multirow{3}{*}{$\begin{array}{l}\text { Redwall lime- } \\
\text { stone. }\end{array}$} & \multirow{3}{*}{$\begin{array}{l}\text { Redwall lime- } \\
\text { stone. }\end{array}$} & \multirow{3}{*}{$\begin{array}{l}\text { Supai formation (re- } \\
\text { defined). } \\
\text {-Unconformity (?)- }\end{array}$} & $\begin{array}{l}\text { Permian (?) and } \\
\text { Pennsylva- } \\
\text { nian. }\end{array}$ \\
\hline & $\begin{array}{l}\text { Redwall limestone, } \\
\text { sheer escarpment, } 800 \\
\text { feet. }\end{array}$ & & & & \\
\hline & $\begin{array}{l}\text { Limestones in lesser es- } \\
\text { carpments and cal- } \\
\text { careous shales, } 800- \\
1,365 \text { feet. }\end{array}$ & & & & Mississippian. \\
\hline
\end{tabular}

Character of beds.-The Supai formation as here redefined consists chiefly of sandstone but includes many beds of sandy shale and a few beds of limestone. Much of the sandstone is in thick, massive beds that make strong cliffs. The shales and beds of laminated sandstone make slopes. As seen from a distance, the distinctive features of the formation are its prevailingly red color and its steplike profile, which consists of a succession of cliffs and slopes carved from the alternating hard and soft beds. Close inspection shows that the red color of the formation is derived from the shales. The outcrops of the sandstones are stained reddish by ferritic pigment washed over them from the interbedded shales, but the natural color of the sandstones, as shown on freshly. broken surfaces, is buff or pinkish buff.

The sandstones of the Supai are uniformly fine grained. Some of them are regularly bedded and exhibit thin, platy lamination, but most of them are conspicuously cross-bedded, and in the thicker layers the cross-bedded structure is on a coarse scale. In uniform fineness of grain and in coarseness of cross-bedding the more massive layers resemble the Coconino sandstone. Commonly, however, their grains are bound together by calcareous cement, whereas the binding material in the Coconino is siliceous. Curiously, the prevailing dip of the inclined laminae in the cross-bedded sandstones of the Supai is south, just as it is in the Coconino. Most of the shale in the Supai resembles that of the overlying Hermit shale and is essentially a red sandy mud. Some beds exhibit sun cracks and ripple marks, but these features are not conspicuous at the Bass trail. Two types of limestone occur in the Supai. One type, which is clearly of detrital origin, consists of grains of calcareous sand, exhibits faint cross-bedded structure on weathered surfaces, and in places passes into cross-bedded sandstone. Some beds of this type are crystalline, and others granular; most of them are pinkish buff. The other type of limestone is bluish or purplish gray, massive, and crystalline and contains nodules of red chert. Beds of this type occur only in the lower third of the Supai. Many of them resemble the limestone in the underlying Redwall.

Subdivisions.-At Bass Canyon I have divided the Supai into three members, which in lithol- 
ogy and in topographic expression are sufficiently constant to be recognizable throughout the Kaibab division of the Grand Canyon. These members I have designated subdivisions $A, B$, and $C$.

Near the top and just below the middle of the Supai the cross-bedded sandstones are exceptionally thick and massive and make strong, conspicuous cliffs. Between these two sets of cliffs and below them the strata make steep ledgy slopes. The strata that make the upper set of cliffs constitute subdivision A; those that make the lower set of cliffs and the ledgy slope above the cliffs constitute subdivision $\mathrm{B}$; and those that make the slope at the base of the Supai constitute subdivision C.

Subdivision A consists chiefly of sandstone but includes a few beds of sandy shale; subdivision $\mathrm{B}$ consists chiefly of sandstone but includes beds of sandy shale and a few beds of limestone; and subdivision $\mathrm{C}$ consists of sandstone, shale, and limestone in about equal proportions. Broadly, therefore, although the Supai consists chiefly of sandstone, it exhibits a passage upward from shale and limestone to sandstone.

Subdivisions A and B rest on slightly wavy surfaces at Bass Canyon. However, similar wavy surfaces occur at other horizons in the Supai (see sections of subdivisions B and C, pp.29-31), and some of these surfaces are more irregular than those at the base of subdivisions $A$ and $B$. Without further study it is impossible to determine whether any of them have widespread stratigraphic significance.

The order, character, and thickness of the strata that constitute the three subdivisions just outlined are described in the section of the Supai given on pages $29-31$, and the topographic profile of the beds is shown in the columnar section, Plate XIX.

Subdivision C, at the base of the Supai, 208 feet thick, begins at the bottom with alternating beds of red sandy shale and bluish-gray limestone carrying nodules of red chert, and the shales and limestones pass upward into alternating beds of red shale, bluish-gray limestone, and reddish to buff calcareous sandstone, a part of which is cross-bedded. The limestones and harder sandstones form small cliffs, and the shales and softer sandstones form slopes. Outcrops of many softer beds are concealed by talus. The contact between $91048^{\circ}-23-5$ this subdivision and the underlying Redwall limestone is described on pages 57-59, where I have presented evidence indicating that it is a plane of unconformity by erosion.

Subdivision $B$, the middle member of the Supai; 439 feet thick, begins at the base with heavy, cliff-making beds of buff cross-bedded sandstone, 200 feet in aggregate thickness, which are separated by thin layers of limestone or red shale. These massive sandstones pass upward into alternating beds of red friable shaly sandstone and cross-bedded calcareous sandstone that contain thin interbedded layers of limestone and, 66 feet below the top of the subdivision, a prominent bed of limestone conglomerate 28 feet thick. This conglomerate (see p. 30), which occurs in highly lenticular layers and consists chiefly of rounded pebbles of limestone embedded in a matrix of red sandy mud, appears to be continuously traceable not only through the Kaibab division of the canyon but far beyond. I have noted it on the Bright Angel (Cameron) and Tanner trails, respectively 18 and 32 miles southeast of Bass Canyon, and in the Aubrey Cliff, near Seligman, 70 miles southwest of Bass Canyon. At all these localities the conglomerate occupies approximately the same horizon in the Supai that it does at Bass Canyon. At the Bass trail and the Bright Angel trail it rests on an uneven surface which exhibits vertical irregularities of several feet within horizontal distances of 100 feet. It is conceivable that the conglomerate marks a stratigraphic break in the Supai that is more significant than the contact between subdivisions $\mathrm{A}$ and $\mathrm{B}$.

Near Pine, in the Jerome region, Ransome ${ }^{40}$ has noted a bed of limestone conglomerate in what he regards as the Supai at a horizon about 450 feet above the base of the formation. The conglomerate is 12 feet thick and overlies a seam of impure lignite.

Subdivision A, at the top of the Supai, 306 feet thick, begins at the base with massive beds of pinkish, purplish, or buff cross-bedded sandstone which form a set of cliffs nearly 200 feet in height. Above these sandstones are alternating beds of soft red platy sandstone and hard buff cross-bedded sandstone which form a series of cliffs and slopes.

At the top of subdivision $\mathrm{A}$ is a broad red platform known as the Esplanade, which begins

${ }^{40}$ Ransome, F. L., op. cit., p. 160. 
at Bass Canyon and extends far westward in the interior of the Grand Canyon. I have described this platform in a previous report ${ }^{41}$ and have shown that, like every other ledge in the canyon wall, it is a structural bench determined by the hardness of the beds that underlie it and the softness of the beds that overlie it, and that it does not necessarily, as Dutton supposed, ${ }^{42}$ represent a temporary baselevel of erosion produced by a pause in the uplift of the region during the cutting of the Grand Canyon. West of Bass Canyon the Esplanade is so broad that it is by far the most striking feature in the canyon landscape. East of Bass Canyon it shrinks to a narrow ledge and is inconspicuous as a topographic feature but is nevertheless traceable continuously through the Kaibab division. Inasmuch as this bench is cut on the summit beds - of the Supai it constitutes a landmark that enables the observer everywhere to distinguish the Supai formation from the overlying Hermit shale. In the region between Bass Canyon and the Hermit trail it marks a conspicuous unconformity between the Supai formation and the Hermit shale. (See pp. 63-64.)

Fossils.-No determinable fossils have been found in the Supai formation in the Kaibab division of the Grand Canyon. The available evidence concerning its age may be summed up as follows:

Subdivision a of Walcott's Redwall at Kanab Creek (see Pl. XIX), "arenaceous beds with pink chert passing down into. shaly limestone, brecciated arenaceous cherty beds, and gray limestone with red chert," not only corresponds closely with subdivision $\mathbf{C}$ of the Supai as I have defined the formation at Bass Canyon but is overlain at Kanab Creek by massive cross-bedded sandstone (subdivision e of Walcott's "Lower Aubrey group") that corresponds to the massive sandstone at the base of subdivision B of the Supai at Bass Canyon and is underlain at Kanab Creek by massive limestone which is obviously equivalent to the upper part of the Redwall as defined at Bass Canyon. Therefore there can be no reasonable doubt that subdivision a of Walcott's Redwall is subdivision $\mathrm{C}$ of the Supai as here

${ }^{41}$ Noble, L. F., U. S. Geol. Survey Bull. 549, pp. 21, 73-75, 1914.

42 Dutton, C. E., Tertiary history of the Grand Canyon district: U. S. Geol. Survey Mon. 2, p. 121, 1882. redefined. Subdivision a of Walcott's Redwall is division 5 of Gilbert's Paleozoic section at Kanab Creek, "purple and white arenaceous limestone with pink chert, in one bed passing in to cross-bedded sandstone." Walcott ${ }^{43}$ states that although at Kanab Creek he obtained no fossils from these beds nor from any part of the overlying sandstones, "the beds elsewhere have given evidence of their upper Carboniferous age by the presence of a fauna rich in many species." This fauna is the Pennsylvanian fauna described by Meek and listed by Gilbert, ${ }^{44}$ who says concerning it: "The fauna of the upper portion [of the Redwall] is rich in species and, while differing from that of the Aubrey limestone, is equally referable to the Coal Measures." By the "upper portion of the Redwall" Gilbert means not the upper portion of the Redwall as the formation is here restricted, but the beds that constitute division 5 of his section at Kanab Creek ${ }^{45}$ and division 4 of his section at the mouth of the Grand Canyon, ${ }^{45}$. which are equivalent to the lower part of the Supai as here defined. Recently Longwell ${ }^{46}$ has found Pennsylvanian fossils in the Grand Wash Cliffs north of the mouth of the Grand Canyon "near the top of beds which apparently correspond to Noble's basal Supai in the Grand Canyon."

The evidence just presented indicates that subdivision C, at least, of the Supai is of Pennsylvanian age. The Supai is overlain by the Hermit shale, which contains Permian fossils, and the two formations are separated by an unconformity of erosion, but inasmuch as no determinable fossils have been found in subdivisions A and B of the Supai there is no conclusive evidence that the unconformity separates Pennsylvanian and Permian beds. Therefore the Pennsylvanian-Permian contact may lie at. any horizen in the Supai between the' summit of the formation and the base of subdivision B. However, no stratigraphic break as great as the unconformity at the base of the Hermit shale appears to occur within the Supai itself, so I am inclined to regard the entire Supai as probably of Pennsylvanian age.

43 Walcott, C. D., unpublished notes.

${ }^{44}$ Gilbert, G. K., U. S. Geog. and Geol. Surveys W. 100th Mer. Rept., vol. 3, pt. 1, p. 178, 1875 .

${ }^{45}$ Idem, p. 162.

46 Longwell, C. R., Geology of the Muddy Mountains, Nev., with a section to the Grand Wash Cliffs in western Arizona: $\Lambda \mathrm{m}$. Jour. Sci., 4 th ser., vol. 50, p. $47,1921$. 
Robinson ${ }^{47}$ has reported Pennsylvanian fossils from the Redwall limestone at Elden Mountain, near Flagstaff. He states that at this locality "the limestone becomes thinner bedded than usual and gives way to red calcareous shale and sandstone. The limestone immediately overlying these beds contains many fragments of shale and includes at one point a patch of conglomerate." The fossils determined as Pennsylvanian came "from the uppermost strata" at this locality. In my opinion, Robinson's description of the beds indicates that they are equivalent to strata exposed in the basal part of the Supai in the Grand Canyon, and not to any part of the Redwall limestone as here restricted.

Lee ${ }^{48}$ has also reported a Pennsylvanian fauna from the top of the Redwall limestone in Truxton Canyon, near Yampai. The fossils are stated to have been obtained "near the top of the exposed section." Probably the limestone beds in which Lee found the Pennsylvanian fossils are also correlatives of limestones that lie in the basal part of the Supai at Bass Canyon.

\section{UNCONFORMITY BETWEEN SUPAT AND HERMTT FORMATIONS.}

In Hermit Basin, 12 miles southeast of Bass Canyon, a strong unconformity of erosion'separates the Supai formation as here redefined from the overlying red sandy shale here named the Hermit shale. The unconformity is beautifully exposed on the Hermit trail just under a signpost marked "Red Top." (See Pl. XXIII, B.) At this locality the top of subdivision A of the Supai consists of alternating beds of hard pinkish or buff cross-bedded sandstone and friable red platy sandstone. These beds make a succession of small cliffs and ledges just under the bench that forms the floor of Hermit Basin and locally represents the Esplanade platform. Just under the "Red Top" sign a sharp hollow 40 feet deep in these Supai beds is filled with the soft red sandy layers that constitute the Hermit shale. The soft Hermit. shale in the hollow determines a break in the small cliffs at the top of the Supai, and the trail takes advantage of this break to descend the

${ }^{47}$ Robinson, H. H., Tho San Franciscan volcanic field, Ariz.: U. S. Gool. Survey Prof. Paper 76, pp. 21-22, 1913.

${ }_{43} \mathrm{Lcc}$, W. T., Geologic reconnaisance of a part of western Arizona: U. S. Gcol. Survey Bull. 352, p. 15, $190 \Omega$. cliffs to a ledge on the summit of the massive sandstone that forms the main cliff of subdivision $A$. When the observer has examined the unconformity in the fine exposure under Red Top he will have no difficulty in following it with his eye all around the rim of the canyon of Hermit Creek, where it is in plain sight for several miles. The unconformity marks the change from the highest cliff-making stratain the Supai to the softer, shaly beds that overlie them. It is difficult to recognize the unconformity at first sight because the beds above and below it. are stained the same color, a deep brick-red. Many fine exposures of the unconformity may, however, be studied by following the trail that leads westward along the general level of the Esplanade from Red Top to Dripping Spring. The sketch in figure 4, $a$, and the photograph reproduced in Plate XXIV, $A$, show an exposure of the unconformity on this trail at a point about a quarter of a mile west of Red Top. As seen in the canyon of Hermit Creek the unconformity is comparable in irregularity to the unconformity at the top of the Tonto (see pp. 49-51), which, indeed, it strongly resembles, the eroded surface exhibiting in places irregularities of 50 feet or more.

I discovered the unconformity in 1916 at the end of a field trip when I came out of the canyon over the Hermit trail, and I furnished Prof. Schuchert with a sketch of it which he published in his paper on the Carboniferous formations of the Grand Canyon in 1918. ${ }^{49}$ However, until 1920 I had no opportunity to examine the horizon of the unconformity at other localities, to learn something of its extent, but in the fall of that year I was able to examine it at several points in the south wall of the Grand Canyon northwest and southeast of Hermit Creek. Northwest of Hermit Creek the unconformity is traceable at least 11 miles, being plainly recognizable from the rim of the Grand Canyon in the walls of Ruby Canyon, 2 miles southeast of Bass Canyon. Figure $4, b$, shows it just under Havasupai Point, the end of the promontory that forms the west wall of the Ruby Canyon. The sketch was drawn from the Grand Scenic Divide, a spur of the Esplanade a mile west. of Havasupai Point, and may be incorrect in detail, for I could not reach and examine the locality shown by the sketch. At Bass Canyon

49 Schuchert, Cha les, op. cit., p. 356. 
I could not detect the unconformity, but the beds at its horizon are poorly exposed at that locality.

At the Bright Angel (Cameron) trail, 5 miles southeast of Hermit Creek, the unconformity can be detected by very careful inspection, but the eroded surface exhibits so little relief that it would probably be unrecognizable to one who had not first examined it at the Hermit trail. At Tanner Canyon, 20 miles southeast of the Hermit trail, I could not detect it. In that region the Hermit shale is readily distinguishable from the underlying Supai formation both topographically and lithologically, but the contact with the Supai is so even that if it represents an unconformity of erosion the eroded surface is practically level.
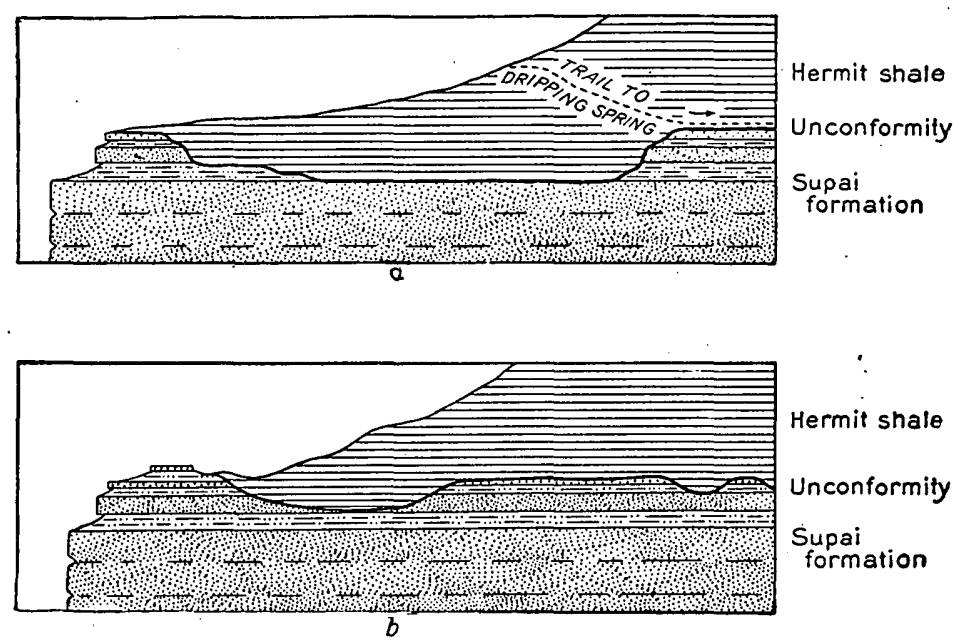

FIGURE 4.-Diagrammatic sketches showing character of unconformity between Hermi shale and Supai formation in Grand Canyon, Ariz. a, On trail between Red Top and Dripping Spring, Bright Angel quadrangle; $b$, under Havasupai Point,.Shinumoquadrangle.

In brief, although the Supai formation is separated from the overlying Hermit shale by an unconformity of erosion which is continuously traceable for at least 15 miles in the Kaibab division, study of a wider area than I have covered. will be necessary before it can be stated confidently that the unconformity is a widespread feature in the Grand Canyon district.

In the area which I have covered the un- conformity coincides with the general level of the Esplanade. If this association is significant, the unconformity may extend over a very wide area, for the Esplanade extends many miles west of the Kaibab division in the Grand Canyon.

\section{PERMIAN SERIES.}

HERMIT SHALE. .

Definition.-At Hermit Basin above the unconformity just described there is a series of deep brick-red sandy shales and fine-grained friable sandstones whose thickness is 317 feet measured from the base of the deepest depression and 267 feet measured from the summit of the highest knoll in the unconformity. (See Pl. XIX.) Formerly these strata were included in the Supai formation and were designated "shale of the Supai formation" or "Upper Supai shale," 50 but because they have been found to be separated from the underlying beds by an unconformity, because they contain determinable fossils of Permian age, and because they are constant in lithology and are distinct from the underlying beds in topographic expression everywhere in the Kaibab division, I have proposed that they be designated the Hermit shale, and the name has been adopted by the United States Geological Survey. The name is taken from Hermit Basin, where the beds are typically exposed. The formation is conformably overlain by the Coconino sandstone. Plate XXIV, $B$, shows an exposure of the Hermit shale in Tapeats Amphitheater, northwest of Powell Plateau.

Character and thickness.-At Bass Canyon the Hermit shale is 332 feet thick. The character and succession of the beds are given in the section on pages 28-29 and their profile is shown in the columnar section, Plate XIX. The beds differ little from one another in composition and consist essentially of sandy mud colored red by ferritic pigment. The beds that I have designated sandstone in the section are massive and relatively compact as contrasted with the beds that I have designated shale, which are thinly laminated, but the distinction between sandstone and shale is unimportant. All the strata are friable. Many beds exhibit sun cracks and rain prints, and some beds are ripple-marked. One bed (No. 15, p. 29) con- 


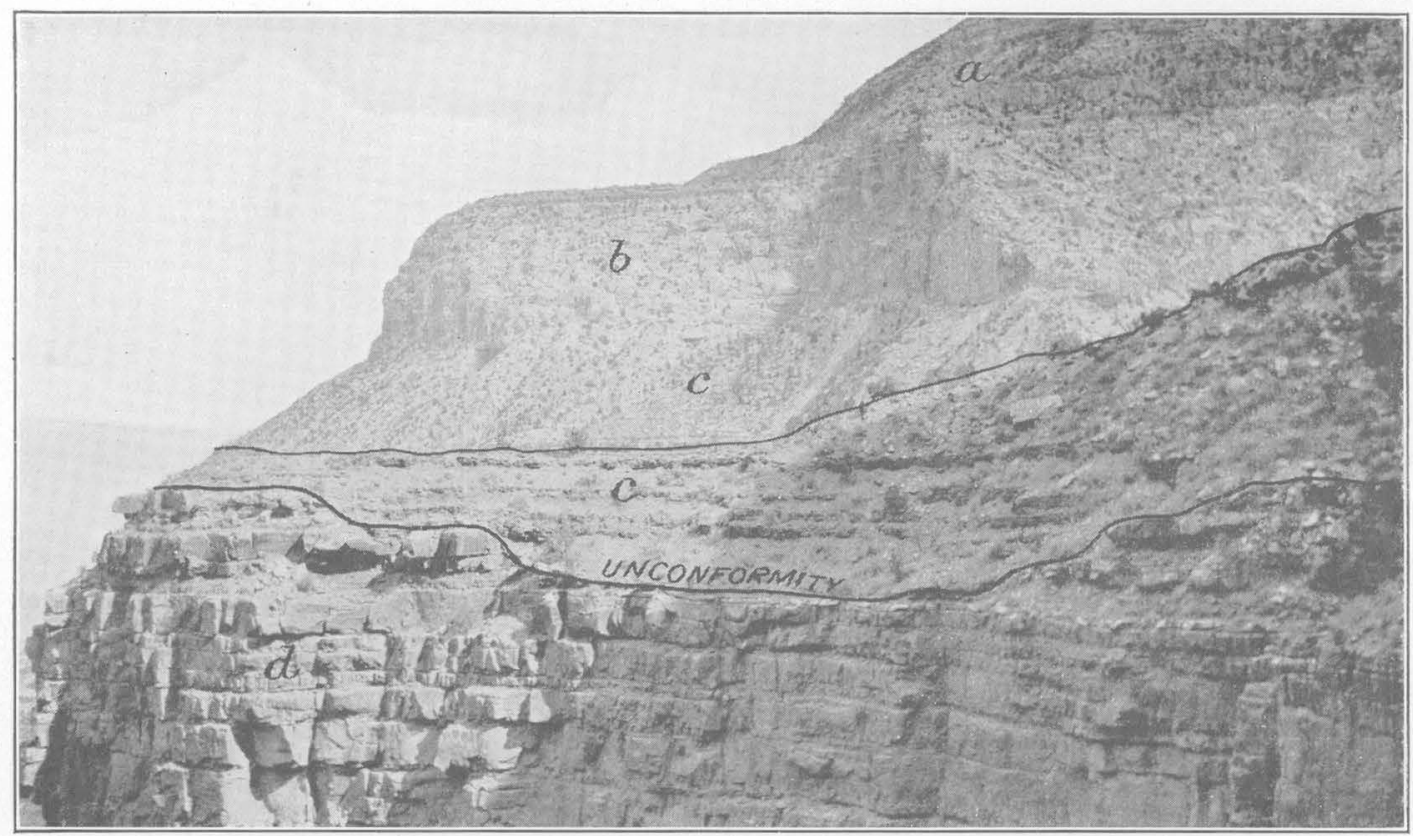

A. UNCONFORMITY BETWEEN HERMIT SHALE AND SUPAI FORMATION ON TRAIL BETWEEN RED TOP AND DRIPPING SPRING, BRIGHT ANGEL QUADRANGLE, ARIZ.

$a$, Kaibab limestone; $b$, Coconino sandstone; $c$, Hermit shale; $d$, Supai formation.

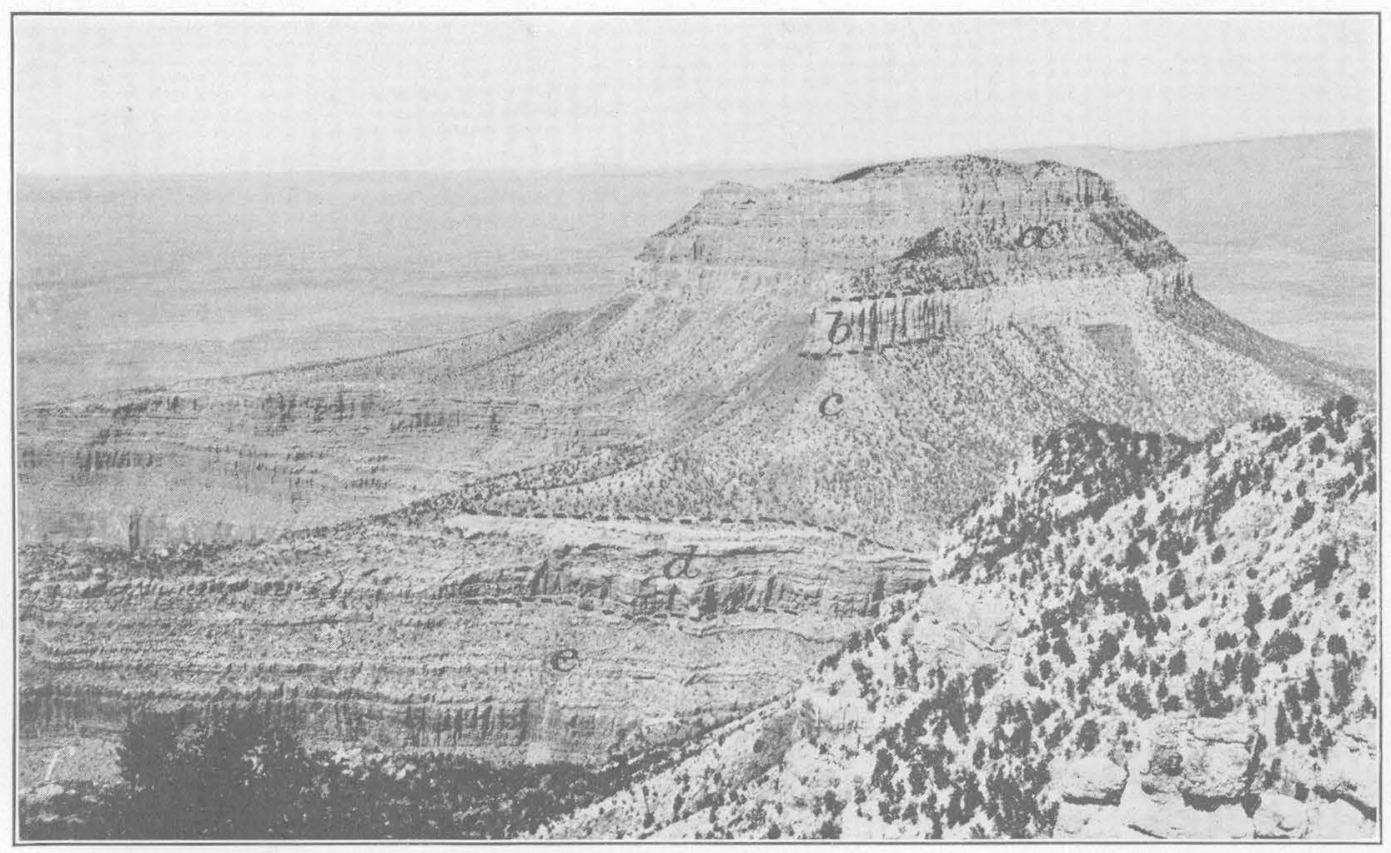

B. TYPICAL EXPOSURE OF HERMIT SHALE IN TAPEATS AMPHITHEATER, NORTHEAST OF POWELL PLATEAU, KAIBAB QUADRANGLE, ARIZ.

$a$, Kaibab limestone; $b$, Coconino sandstone; $c$, Hermit shale; $d, e, f$, subdivisions A, B, C of Supai formation. 


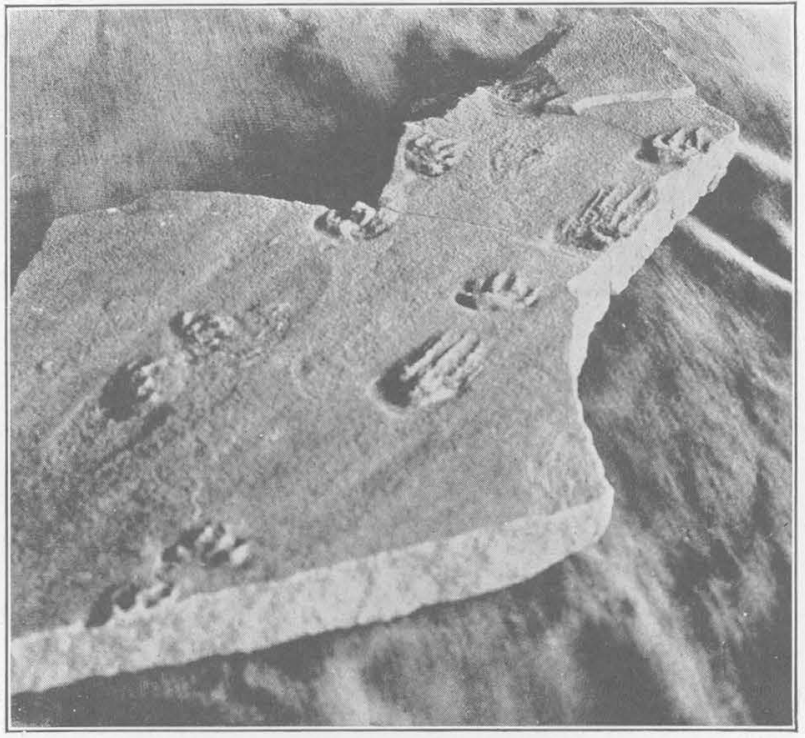

A. FOSSIL TRACKS ON SLAB OF COCONINO SANDSTONE AT HERMIT TRAIL, BRIGHT ANGEL QUADRANGLE, ARIZ.

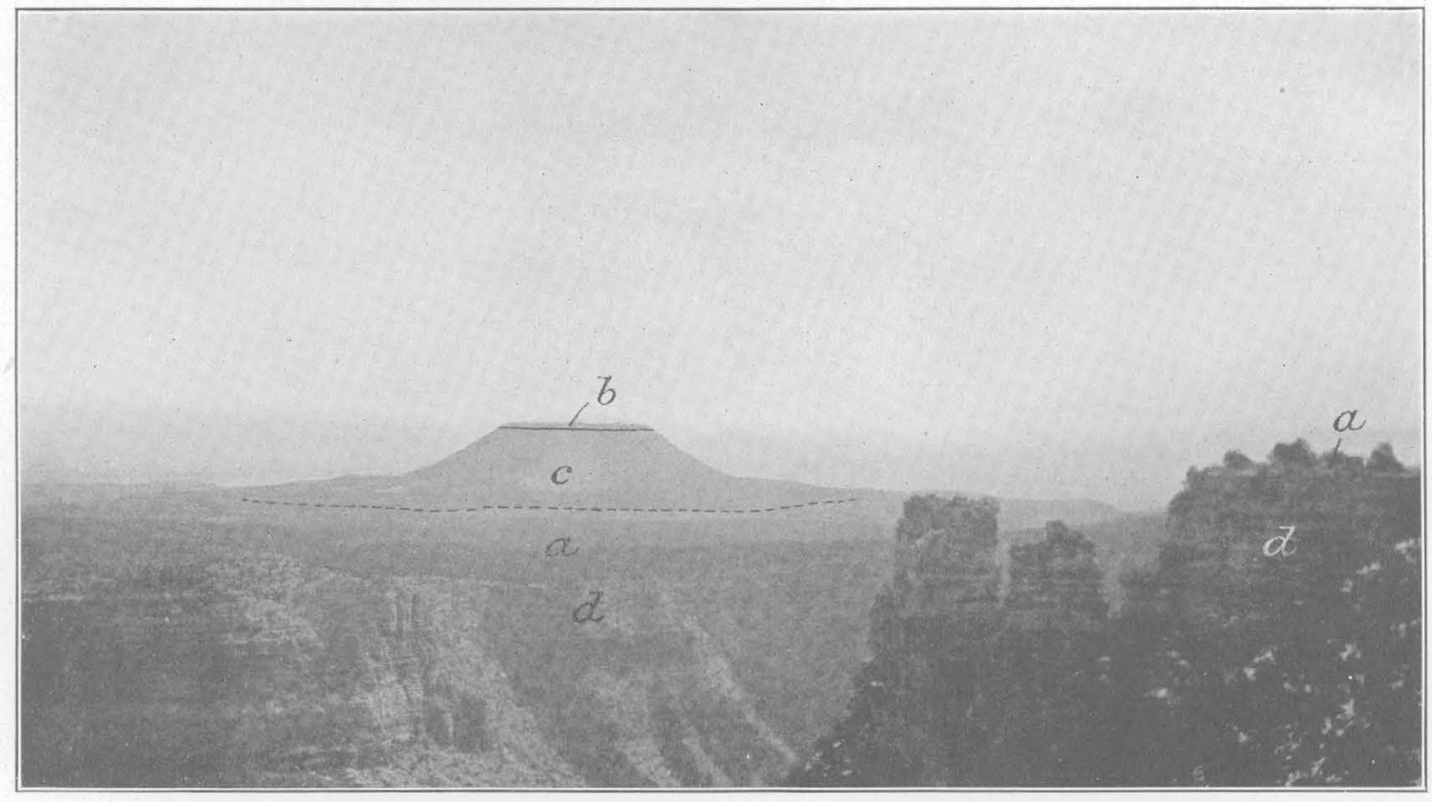

B. Cedar mountain, vishnu Quadrangle, ariz., From desert view Camp.

$a$, Surface of Coconino Plateau; $b$, Shinarump conglomerate, capping Cedar Mountain; $c$, Moenkopi formation; $d$, Kaibab limestone. 
sists of intraformational conglomerate. Near the top of the formation many beds exhibit concretionary structure. Lithologically the Hermit shale resembles many beds of sandy shale in the Supai, but unlike the Supai it contains no massive hard layers of crossbedded sandstone, and the more. sandy beds in the Hermit are prevailingly reddish, not buff, as they are in the Supai. Thin, platy lamination is the most prominent structural charactoristic of the Hermit shale. Everwhere the formation makes a slope which is in strong topographic contrast with the sheer cliff of the overlying Coconino sandstone and with the steplike cliffs and ledges of the underlying Supai.

Although the Hermit shale is constant in lithology throughout the Kaibab division of the Grand Canyon its thickness varies considerably. In the region about Tanner Canyon, in the eastern part of the Kaibab division, it is less than 100 feet thick (estimated) and may be less than 75 feet. At Bass Canyon it is. 332 feet thick, and west of Bass Canyon, at the west end of the Kaibab division, more than 500 feet. The widening of the Esplanade west of Bass Canyon is caused, as I have shown, ${ }^{51}$ by the increase in thickness of the soft Hermit shale, which wastes back from the floor of the platform, in conjunction with a corresponding shrinkage in the overlying hard Coconino sandstone, which defends the retreat of the wall above the platform. Apparently the Hermit shale continues to increase in thickness at least as far as Kanab Creek, for Walcott's subdivisions a1, a2, and a3 of the Aubrey group at Kanab Creek, which I believe represent the Hermit shale, are 775 feet in aggregate thickness. (See Pl. XIX.)

Beds in Gilbert's section at the mouth of the Grand Canyon, ${ }^{52}$ which he designates division 3 and which may represent the Hermit shale, are said to be 800 feet thick at that locality.

In the Aubrey cliff 4 miles north of Seligman beds identical in lithology with the typical Hermit shale underlie the Coconino sandstone and overlie a cliff-making portion of the Supai that corresponds in lithology and in stratigraphic position to subdivision $\mathrm{A}$ of the Supai as defined at Bass Canyon. The beds between the Supai and Coconino formations are 80 feet thick, are soft and thinly laminated,

of Noblo, L. F., op. cit., p. 70.

t2 Gillbert, G. K., op. cit., p. 162. and make a slope above a bench at the top of the Supai that corresponds to the Esplanade. Undoubtedly they are the Hermit shale. In this region the Coconino sandstone, although it is nearly 450 feet thick, does not make a cliff but weathers into a slope that is little steeper than that formed by the Hermit shale. The actual cliff-makers in the Aubrey cliff are the Supai formation and the Kaibab limestone.

Describing the beds in the Jerome region that were believed to represent the Supai, Ransome ${ }^{53}$ writes:

At this locality [mouth of Sycamore Creek, 8 miles north of Jerome] the lower 700 feet of the Supai consists chiefly of fine-grained cross-bedded sandstone in beds less than 6 feet thirk, with a smaller proportion of deep-red shale. The general color is not brilliant, and some of the sandstone beds incline to a tawny hue. The upper beds of this division of the formation are fairly massive and form an outer bench in the plateau escarpment at this locality. Overlying them and under the Coconino sandstone are apparently softer beds of much brighter red, with an estimated thickness of 200 to 300 feet. As seen through field glasses at a distance of 2 or 3 miles they show conspicuous cross-bedding and appear to grade upward with no sharp. break in to the Coconino sandstone.

Perhaps the soft beds noted by Ransome beneath the Coconino sandstone and the rock bench formed by the Supai are the Hermit shale.

Fossils.-Schuchert was the first geologist to find fossils in the Hermit shale. He states : ${ }^{54}$

Just below the sign "Red Top" in the lower turn of the Hermit trail [in Hermit Basin] and immediately above the thick upper sandstone [of the Supai] are seen thin. bedded red shaly sandstones alternating with deep-red zones of shale. The surfaces of the glistening and smooth platy sandstones are replete with fillings of the small prisms of interbedded sun-cracked shales, are often rainpitted, and further marked by the feet impressions of fresh-water amphibians described elsewhere in this number of the Journal by Prof. Lull ${ }^{55}$ as Megapezia? coloradensis and Exocampe? delicatula. Some of the tracks are distinct impressions of the feet, and others are mere strokes of the toes. In these same beds also occur plant remains in very fragmentary condition which were badly macerated and coated with a slime of red mud during their entombment. They are therefore difficult to determine, but after much effort Dr. David White tentatively identified them as Callipteris sp. cf. C. conferta, Walchia cf. W. gracilis, Gigantopteris, and cf. Sphenophyllum. * * * The plants listed above and found associated with the tracks led White in his letter to the writer dated June 27; 1916, to the following conclusions: "The condition of preservation of the tragments is so bad that caution is

6s Ransome, F. L., op. cit., p. 162.

${ }^{54}$ Schuchert, Charles, op. cit., pp. 353-354.

${ }^{55}$ Lull, R. S., Fossil footprints from the Grand Canyon of the Colorado: Jour. Am. Sci., vol. 45, pp. 337-346, May, 1918. 
necessary in basing conclusions of any kind on the material submitted. However, the presence of Gigantopteris, Walchia, and probably of Callipteris, if my tentative generic identification of the latter is correct, points to lower Permian age of the flora. * * * In any event, it appears probable that the flora, when it is better known, will be found to indicate a level not below the highest stage of the Pennsylvanian."

In 1916 I made a small collection of plant material from beds at the base of the Hermit shale resting in depressions in the unconformity near Red Top in Hermit Basin. The collection was examined by Mr. White, who made the following report:

The fossils are very obscure on account of the maceration of the plant substance, the washing of the surface with mud slimes, with more or less curling, and deformation produced apparently by shrinkage in the sun, so that the nervation is in general obliterated, even the midribs being imperfectly represented in some cases. Curling of the leaves obscures or even conceals their true forms.

One of the specimens probably belongs to the genus Pecopteris. Two other fragments may represent a species of Alethopteris. Another fragment has the outline of Callipteris. If the outline is not misleading as the result of shrinkage and curling of the borders of the leaf, the plant probably is a Callipteris, in which case the evidence of the fossils will conform to the tentative age determinations based upon the collection submitted by Prof. Schuchert, namely, that the beds are Permian in age, or possibly referable to the latest Pennsylvanian.

Pending the collection of additional material, some of which it is hoped will be found better preserved, the reference of the extremely obscure and imperfect fragments to the Permian must be considered as provisional. I anticipate, however, that more material will point more strongly to the Permian age of the upper part of the Supai formation. Should this prove to be the case, the unconformity at the base of the Permian in northern Arizona will remind geologists of the strong angular conformity beneath the Permian. "Red Beds" on the south flank of the Ouachita Mountains in southern Oklahoma and the presence of inconspicuous conglomerate in or near the base of the Permian in northern Oklahoma and southern Kansas.

In 1920 I returned to Hermit Basin and searched the Hermit shale in the hope of getting material that would prove to be specifically determinable, and at a point 50 feet above the base of the formation, a quarter of a mile west of Red Top on the trail to Dripping Spring, at the locality shown in the sketch and photograph (fig. 4, $a$, and Pl. XXIV, $A$ ), I obtained among other specimens a well-preserved part of a fernlike frond, concerning which $\mathrm{Mr}$. White writes: ${ }^{50}$

A close inspection shows it to belong to the genus Callipteris, which the world over is everywhere recognized as

60 White, David, personal letter the most characteristic and widespread exclusively Permian fern. I judge that the specimen is not even varietally distinguishable from Callipteris conferta. Accordingly this evidence practically confirms conclusively the opinions based on fragments previously collected by you and Prof. Schuchert and is of itself probably adequate to prove the Permian age of the Hermit shale. Taken in connection with the plant fragments previously transmitted by Prof. Schuchert and you, it can be only Permian.

In 1920 I noted imperfect fragments of plant impressions here and there in the Hermit shale near the Bass trail and near the Bright Angel trail. The fragments are not confined to any particular bed in the formation but occur at various horizons. They are not nearly so abundant as they are at Hermit Basin.

In the light of the evidence just presented the Hermit shale may be confidently assigned to the Permian.

COCONINO SANDSTONE.

Character.-The Coconino sandstone is a pale-buff fine-grained cross-bedded sandstone whose distinctive features are its massive appearance, the huge scale of the cross-bedding, and the uniform fineness of the component grains of sand. The massiveness of the sandstone, which is due to the coarseness of the cross-bedding, causes it to weather into the highest and most precipitous cliff in the upper wall of the canyon.

The formation is made up of lenticular beds, each of which is truncated by the bed above it in such a way that, as outlined in cross section or cliff faces, the beds commonly form irregular wedges whose sides are sweeping curves. Each wedge consists of innumerable thin inclined laminae. Horizontal bedding is absent except near the base of the formation, where it is inconspicuous. The wedges differ greatly in thickness. One wedge, near the Bass trail, is more than 75 feet thick; most are between 10 and 75 feet; some are less than 10 feet. In every wedge the laminae dip in a general southerly direction ranging from southeast to southwest, but the dip is not uniform in all parts of the wedge. The laminae form parillel curves that flatten downward. Commonly at the top of a wedge they are inclined at angles of $15^{\circ}$ to $25^{\circ}$, or exceptionally $30^{\circ}$, but near the base of a wedge they bend and become horizontal or nearly horizontal. The prevailing dip of the laminae is south wherever the Coconino sandstone is exposed in northern 
Arizona. This feature causes the formation to make a more continuous cliff in the southern wall of the Grand Canyon than it does in the northern wall, because where the outcropping edges of the sandstone face south, as they do in the northern wall, the sandstone breaks down here and there into slopes on the dip of the laminae. A break of this character permits the Hermit trail to descend the sandstone in Hermit Basin, and another permits the Bass trail to descend it near Bass Camp. At both places the Coconino cliff faces southwest in an alcove cut at right angles to the prevailing dip of the beds.

The sandstone is cut by many vertical joints. In weathering, it splits into blocks along these joints or into slabs along the inclined laminae rather than along contacts between the wedges. Although the prevailing color of the sandstone is pale buff, some wedges are rusty buff, pinkish, or pale red. The reddish color, where present, is strongest, as a rule, at the base of a wedge. The constituent grains of the Coconino sandstone are quartz, and they are bound together by siliceous cement; the rock does not efferresce with acid. Commonly the grains are uniformly small, translucent to transparent, and rudely globular or subangular rather than broken or angular, but fresh surfaces of the rock feel gritty and sparkle in the sunlight. Exceptionally the grains are rather coarse, are well rounded, and are dull on the surface, like ground glnss. These dull, rounded grains commonly form thin bands or streaks.

Ripple-marked or sun-cracked surfaces are very rarely seen in the Coconino sandstone. I have never seen ripple marks in it, but Schuchert ${ }^{57}$ has noted them at one place, near the Hermit trail. Near the Bass trail the under surface of the formation contains distinct impressions of sun cracks, but these impressions are derived from the upper surface of the underlying Hermit shale. The only sun cracks I have noted that are unmistakably within the Coconino itself are on a block in a talus slide near the Fermit trail.

At the Bass, Hermit, and Tanner trails the sandstone at the base of the Coconino is in horizontal layers for 5 to 25 feet above the Coconino-Hermit contact, and some of these layers do not exhibit cross-bedding. At the Tanner trail these horizontal beds of sandstone

ot Schuchert, Charles, op. cit., p. 349 . alternate with layers of red shale, so that the boundary between the Hermit shale and Coconino sandstone is not sharp. At the Bright Angel (Cameron) trail the cross-bedding begins abruptly at the base of the Coconino.

At the Hermit and Bright Angel trails the beds at the top of the Hermit shale are cut here and there by vertical fissures that do not extend upward into the Coconino sandstone. These fissures, some of which extend downward 15 to 20 feet into the Hermit shale and are 6 inches to a foot wide at the top, are filled with the buff sand that constitutes the overlying Coconino sandstone. Probably they are a widespread feature of the Coconino-Hermit contact, for a few of them are exposed under Fossil Mountain, near Havasupai Point, 11 miles from the Hermit trail. I have not seen them at Red Canyon or at Tanner Canyon, but the contact is poorly exposed at those localities.

The Coconino-Hermit contact is the most favorable horizon for springs in the upper part of the canyon wall, because the upper surface of the relatively impervious Hermit shale checks the downward movement of ground water percolating through the more pervious Coconino sandstone. Many small springs issue at this contact in the Kaibab division of the canyon. Dripping Spring, at Hermit Basin, and a spring at the Muav Saddle, near the head of Muav Canyon, are examples.

Thickness.-In the region between Kanab Creek and the east end of the Kaibab division the thickness of the Coconino sandstone increases steadily southeastward and is everywhere in inverse ratio to that of the underlying Hermit shale. For example, the Coconino is only 30 feet thick at Kanab Creek (see section by Walcott, Pl. XIX), where beds believed to represent the Hermit shale are 775 feet thick; 250 feet thick at the west end of the Kaibab division, where the Hermit shale is 550 feet; 330 feet at the Bass trail, where the Hermit shale is 332 feet; 350 feet at the Hermit trail, where the Hermit shale is 267 to 317 feet; 550 feet (estimated) at Red Canyon, where the Hermit shale is 130 feet (estimated); and 550 to 650 feet in the eastern end of the Kaibab division, between the Tanner trail and the Little Colorado, where the Hermit shale is 75 to 100 feet. The height of the Coconino cliff as seen from Desert View near the Tanner trail is 
thus almost double the height of the cliff as seen from the head of the Hermit trail or from Bass Camp.

Fossils.-The only traces of life that have been found in the Coconino sandstone are fossil footprints of small animals. The locality is on the Hermit trail between 140 and 200 feet above the base of the sandstone and is easily accessible. The tracks occur on the upper surfaces of inclined laminae of the sandstone that $\operatorname{dip} 15^{\circ}-25^{\circ} \mathrm{SW}$. , and they are found over a considerable area between the elevations stated. The beds that contain the tracks have a slightly darker color than most of the Coconino sandstone exposed on the trail, weathering a rusty buff. The tracks are hard to recognize at first, as they are small, like those of a squirrel or a small cat, and the impressions are faint, but the tracks are abundant, and the observer will see a great many of them after he has become familiar with their appearance. Most of them appear to have been made by animals walking up the slope of the inclined laminae. A large number will be found in place on the outcropping inclined surfaces of the sandstone, but many loose slabs of rock scattered about the trail contain good impressions. The photograph reproduced in Plate XXV, $A$, shows impressions on one of these slabs. Specimens of two kinds of tracks collected by Prof. Schuchert in 1915 and by me in 1916 have been described by Lull ${ }^{58}$ as Laoporus schucherti and Laoporus noblei. He regards the animals that made them as ancestral amphibia. He states:

The creatures which made the footprints were quadrupeds of moderate size, with broad, stumpy feet, apparently clawed, and having at least four toes in front and five behind. The hind foot, which is somewhat the larger, bore a proportionately greater share of the creature's weight, especially in the smaller species. The limbs were apparently short, with a wide trackway, implying a bulky body. No trace of a dragging trail is discernible on any of the specimens, and the body was evidently carried clear of the ground. Several known genera of Paleozoic footprints may be compared with the present species, but none agrees with sufficient closeness to warrant the inclusion of these forms. They therefore seem to pertain to a new genus, which will be called Laoporus and the affinities of which, from the criteria which they present, seem to lie with the genus.Limnopus Marsh, from the Kansas Coal Measures.

Probably the specimens described do not represent all kinds of tracks obtainable at this locality, for in examining the locality more

${ }_{58}$ Lull, R. . S., op. cit., pp. 338-341. carefully in $1920 \mathrm{I}$ noted tracks that differ from those already described.

In origin I believe the Coconino sandstone is essentially a dune deposit, because it resembles in many structural and lithologic features parts of younger formations exposed in the Navajo country, notably the DeChelly, Navajo, and Wingate sandstones, which, as Gregory ${ }^{59}$ has shown, are almost certainly dune deposits. Thin sections cut from specimens of the Coconino sandstone that I have collected for study may throw more light on the origin of the sand. This material, however, which also includes thin sections cut from beds in other Paleozoic formations of the Grand Canyon, has not yet been studied, and I will reserve a discussion of it for another report.

\section{KAIBAB LIMESTONE.}

Character.-The Kaibab limestone forms the surface of Coconino and Kaibab plateaus, which border the Grand Canyon, and makes the first cliffs that drop away at the rim of the canyon. It is composed of limestone and sandstone and at some horizons contains large amounts of chert. Fragments of chert weathered from the formation are abundant nearly everywhere on the surface of the plateaus. The beds of limestone are hard and make cliffs in the canyon wall; the sandstones are soft and make slopes. Relatively the Kaibab is not a heavily bedded formation, like the Redwall. Some limestone beds are over 6 feet thick, but many are from a few inches to 5 feet thick. The bedding planes are distinct throughout the formation. The prevailing colors of the limestones and of most of the sandstones are buff, cream, or gray, but some of the sandstones, notably in the middle part of the formation, are red or yellow. The limestones in the upper part of the formation are the most fossiliferous rocks in the Grand Canyon, some beds being composed almost entirely of the remains of sea animals, chiefly bryozoans, sponges, brachiopods, and gastropods. Fossil Mountain, a dissected promontory of the Coconino Plateau near Bass Camp, is carved from these fossiliferous beds and is so named because the fossils, weathered from the limestone, litter its southwest slope.

At Bass Canyon the Kaibab limestone is divisible into three members which in lithology and in topographic expression are distinct from

59 Gregory, H. E., Geology of the Navajo country: U. S. Geol. Survey Prof. Paper 93, pp. 31-34, 53-55, 57-59, 1917. 
one another everywhere in the Kaibaj division. Subdivision A, at the top of the formation, 292 feet thick, consists of gray crystalline limestone which passes at the base and top into alternating beds of fine-grained sandstone and very cherty limestone. Subdivision $B$, in the middle of the formation, 136 feet thick, consists of more or less irregularly bedded buff, yellow, and red fine-grained sandstone and contains beds of sandy breccia. Subdivision $\mathrm{C}$, at the base of the formation, 134 feet thick, consists of alternating beds of buft sandstone and limestone which pass up into a very massive bed of siliceous limestone. Subdivision A forms cliffs and steep slopes, $\mathrm{B}$ forms a slope, and $\mathrm{C}$ forms a succession of cliffs and slopes. The order, character, and succession of the beds that constitute these subdivisions are described in the section on pages $27-28$, and the profile of the subdivisions is shown in the columnar section, Plate XIX.

Two analyses of limestone in subdivision A follow. One analysis shows the composition of a sample taken from a bed (No. 2, p. 27) just under the rim of the canyon at the Bass trail. This limestone is associated with the sandy beds in the upper part of the subdivision. It is dense but not crystalline, feels dull or earthy when struck by the hammer, and in appearance suggests silicified chalk. Similar beds higher in the Kaibab limestone are exposed on the Coconino Plateau east of Bass Camp but are not included in my section.

This rock is an impure dolomite. The second analysis shows the composition of the limestone that forms the greater part of the subdivision. This limestone is hard, gray, more or less cherty, very fossiliferous, and entirely crystalline. The sample analyzed was taken from bed No. 6 at the Bass trail. (See p. 27.) The analysis shows that this limestone is not magnesian, although it is relatively impure. Probably the insoluble impurities are largely the silica that forms nodules of chert associated with the limestone, for the rock represented by the sample analyzed contains no detrital sand.

Partial chemical analyses of limestone from subdivision $A$, Kaibab limestone.

[AUfred A. Chambers, analyst.]

\begin{tabular}{|c|c|c|}
\hline & 1 & 2 \\
\hline 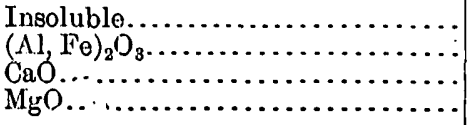 & $\begin{array}{r}6.98 \\
.56 \\
29.98 \\
18.68\end{array}$ & $\begin{array}{r}11.15 \\
.71 \\
48.68 \\
.00\end{array}$ \\
\hline
\end{tabular}

The sandstones of subdivision B consist entirely of quartzose sand which in composition, fineness, and uniformity of grain resembles the sand in the Coconino sandstone. Much of the sandstone is loosely consolidated and crumbles to sand when struck with the hammer. The cement appears to be siliceous, for the rock does not effervesce with acid. Some beds are evenly laminated; others exhibit curious gnarly structure like that in parts of the Devonian Temple Butte limestone (p. 51). Wavy, irregular surfaces separate many beds. A bed of brecciated sandstone occurs at the top of the subdivision at Bass Canyon, and a similar bed occurs near the middle. (See p. 27.) It is difficult to determine from the exposures at this locality whether the brecciated structure is detrital in origin, the fragments representing boulders in a conglomerate, or whether the structure was acquired after the beds were consolidated, the beds caving in and breaking because some soluble mineral, perhaps gypsum, was leached out of them. The sandstones of the subdivision contain no gypsum at the Bass trail, but equivalent beds at Kanab Creek described by Walcott (see Pl. XIX) contain gypsum, as also do equivalent beds at Cataract Creek described by Newberry. ${ }^{60}$ Cataract Creek is about 20 miles southwest of Bass Canyon.

The prevailing reddish and yellowish hues of the sandstones that constitute subdivision B contrast strikingly with the pale buffs and grays of the strata in the overlying and underlying subdivisions of the Kaibab and enable the observer readily to distinguish the subdivision.

In general appearance the limestone in the massive cliff-making bed at the top of subdivision $\mathrm{C}$ (see p. 28) resembles that in the bed at the top of subdivision A, whose composition is shown by the analysis on this page to be near that of dolomite. Probably the rock is a siliceous dolomitic limestone. The sandstones that alternate, with the limestones below this bed do not appear to differ conspicuously in composition from those in subdivision $B$, but all of them are evenly bedded, and some exhibit shaly lamination. The contact between subdivision $\mathrm{C}$ and the underlying Coconino sandstone is level and even, and the bottom bed of the subdivision,

60 Newberry, J. S., Report upon the Colorado River of the West explored in 1857-58 by Lieut. J. C. Ives, pt. 3, Geological report, 1861. 
a fine-grained reddish to yellowish sandstone, rests everywhere on the truncated edges of inclined laminae of the Coconino sandstone.

Thickness.-The Kaibab limestone is 562 feet thick at the Bass trail and about 25 feet thicker a short distance east of the trail, but inasmuch: as the summit of the formation is the eroded surface of the Coconino Plateau, the original thickness can not be determined. In fact, the only place where it can be determined in the Kaibab division is in the area between the rim of the Grand Canyon and Cedar Mountain, 35 miles southeast of Bass Canyon. At Cedar Mountain, 2 miles from the rim of the canyon, the Kaibab is overlain by younger beds that have not been removed by erosion, and the top of the Kaibab is exposed beneath these beds at the southern base of the mountain. As shown on page 72 certain beds at the top of the Kaibab at the base of the mountain can be identified with beds exposed at the top of the Kaibab at the rim of the canyon 2 miles away. Therefore the original thickness of the Kaibab can be obtained by measuring the formation in the canyon wall at this point and adding the thickness of Kaibab beds exposed under Cedar Mountain that have been removed at the rim of the canyon. These measurements have not been made.

Although the three subdivisions of the Kaibab limestone are everywhere readily distinguishable from one another they exhibit variations in thickness and lithology as they are traced southeastward through the Kaibab division from Bass.Canyon. At Red Canyon, on the Hance trail, 30 miles southeast of Bass Canyon, subdivision $\mathrm{C}$, at the base of the formation, is 75 feet thick, whereas at Bass Canyon it is 134 feet thick. The cliff-making bed of buff limestone at the top of the subdivision is about equally thick at both localities, but the alternating sandstones and limestones between, this bed and the $\mathrm{Co}$ conino sandstone have shrunk from 86 feet at Bass Canyon to 30 feet at Red Canyon.

Subdivision B is 143 feet thick at Red Canyon, practically of the same thickness as at Bass Canyon, and the component beds of sandstone differ very little at the two localities. The subdivision contains brecciated sandstone at Red Canyon, as it does at Bass Canyon, but at Red Canyon the brecciated sandstone occupies a horizon near the middle of the subdivision, whereas. at Bass Canyon it occurs at both the middle and the top. At Red Canyon the brecciated sandstone forms a bed 15 feet thick and consists of angular fragments of red and buff sandstone as much as 4 feet in diameter embedded in a matrix of gnarled and twisted sandstone. At this locality the brecciated sandstone appears to represent a conglomerate, not a bed shattered after deposition and consolidation. Undoubtedly these brecciated beds are a constant feature of subdivision $\mathrm{B}$, for I have seen them at all localities where I have examined the subdivision between Bass Canyon and Red Canyon. One of these beds is exposed on the Hermit trail.

Subdivision A is 355 feet thick at Red Canyon and 292 feet thick at Bass Canyon, but the summit is eroded at both places, so that the differences in thickness may not be significant. At Red Canyon, as at Bass Canyon, chert is less abundant in the middle of the subdivision than near the base and top and is most abundant near the top. The limestone in the subdivision at Red Canyon, however, is not nearly so pure as it is at Bass Canyon, is not prevailingly crystalline, and most beds are earthy, sandy, or siliceous, resembling the buffi magnesian limestone at the top of the Bass Canyon section rather than the gray crystalline limestone that constitutes the greater part of the subdivision at Bass Canyon. Thus subdivision $\mathrm{A}$ as a whole becomes sandier and more siliceous southeastward from Bass Canyon. The limestones are decidedly more sandy at the Hermit trail than they are at the Bass trail and more sandy at Red Canyon than they are at the Hermit trail.

Fossils.-Fossils are very abundant at many horizons in subdivision A. At Bass Canyon they are most abundant in the beds of gray crystalline limestone designated 5 and 6 in my section (p . 27). The following list of a collection in the possession of G. H. Girty obtained at Parusi-Wompats Spring, just north of the Shinumo region, includes most of the forms that occur near Bass Canyon: ${ }^{\text {11 }}$

Sponges.

Lophophyllum n. sp.

Crinoid stems.

Fistulipora sp.

${ }_{16}$ Noble, L. F., op. cit., p. 71. 
Meekopora sp.

Stenopora sp.

Septopora sp.

Polypora sp.

Lingulidiscina convexa?

Derbya sp.

Meekella pyramidalis.

Chonetes aff. C. hillianus.

Producus occidentalis.

Productus ivesii.

Productus aff. P. irginae.

Productus subhorridus var. rugatulus.

Productus sp.

Pugnax osagensis var:

Heterelasma n. sp.

Squamularia guadalupensis?

Spiriferina campestris?

Composita subtilita.

Aviculipecten, $2 \mathrm{sp}$.

Acanthopecten occidentalis.

Pseudomonotis aff. P. hawni.

Pseudomonotis? sp.

Anisopyge perannulata?

These and other fossils constitute the socalled Productus ivesii fauna. Girty regards this fauna as Permian and tentatively correlates the Kaibab limestone with the San Andres limestone in the Manzano group of New Mexico.

No fossils have been found in subdivision $B$, the sandstone member of the Kaibab, but a few occur in subdivision C.' So far as I know, no fossils have been collected and described from these two lower subdivisions of the Kaibab limestone in the Grand Canyon, and it is therefore conceivable that the lower part of the formation may contain a fauna differing somewhat from that in the upper part. However, Newberry's section at Cataract Creek ${ }^{22}$ mentions Productus ivesii in beds equivalent to those at the base of subdivision C. Inasmuch as the Hermit shale beneath the Kaibab contains Permian plant remains, no part of the Kaibab can be older than Permian.

BEDS OVERLYING THE KAIBAB LIMESTONE AT CEDAR MOUNTAIN.

No beds younger than the Kaibab limestone are exposed in the wall of the Grand Canyon in the Kaibab division, but Cedar Mountain, a flat-topped butte on the Coconino Plateau only 2 miles east of the rim of the canyon near Desert View Camp, is carved from younger beds. These beds at Cedar Mountain constitute two formations-the Shinarump conglom-

${ }^{62}$ Nowborry, J. S., op. cit. erate, 25 feet thick, which makes a cliff encircling the top of the mountain and determines its flat summit, and the Moenkopi formation, 481 feet thick, which makes the slopes of the mountain. The age of these two formations is Mesozoic, the Moenkopi being regarded as Lower Triassic and the Shinarump as probably Upper Triassic. The Moenkopi formation, which is relatively soft, owes its preservation to the hard Shinarump conglomerate that caps it. Cedar Mountain is accessible by a rather poor road or may be reached by walking 3 or 4 miles across country from Desert View Camp, which is connected with El Tovar by a good road. It is interesting not only because it affords evidence that the Moenkopi and Shinarump formations once covered the Grand Canyon region, but because the Shinarump conglomerate, which caps it, contains petrified wood. Plate $\mathrm{XXV}, B$, shows Cedar Mountain as seen from Desert View Camp.

Inasmuch as the formations in Cedar Mountain are exposed within 2 miles of the rim of the Grand Canyon they may be considered a part of the Grand Canyon stratigraphic section, and I have therefore included a section of them in, the present report. This section, which follows, is probably inaccurate in detail, because I obtained the thicknesses of the beds by rough aneroid measurement and because the exposures of many beds are poor owing to the apron of débris that cloaks the slopes of the mountain. However, the section serves to give a general idea of the character and succession of the beds.

Section of beds exposed on south side of Cedar. Mountain, Vishnu quadrangle.

Shinarump conglomerate (Upper? Triassic): Hard siliceous conglomerate or pebbly grit composed chiefly of pebbles of quartz or jasper embedded in a matrix of quartzose sand ; caps Cedar Mountain and forms strong cliff. Cross-bedded throughout; texture variable, some beds fine grained, others coarse grained. Rounded pebbles of white quartz a quarter of an inch to an inch in diameter predominate in the coarser beds; the jasper pebbles are of different colors and are banded and variegated; probably the jasper is petrified wood. Several logs of petrified wood are embedded in the conglomerate. The constituent pebbles of the conglomerate are unidentifiable with any rock in the underlying Moenkopi............
Feet, 
Unconformity (?). The contact between the Shinarump conglomerate and the underlying shale is concealed nearly everywhere by talus. The only exposure noted, a few feet in horizontal extent, shows conglomerate resting on reddish-brown sandy shale; lithologic change from shale to conglomerate very sharp.

Moenkopi formation (Lower Triassic):

1. Slope; practically all covered by débris. The few outcrops. consist of thinly laminated reddish-brown shale or shaly sandstone........................

2. Strong cliff; very massive reddish-brown fine-grained, strongly cross-bedded sandstone...........................

3. Slope; soft, thinly laminated tan to reddishbrown sandy shale. Outcrops covered with white saline efflorescence, indicating the presence of much saline material in the rock.........................

4. Weak cliff; rather massive buff sandstone exhibiting indistinct cross-bedding....

5. Slope; thinly laminated tan sandstone or sandy shale.......................

6. Cliff; light yellowish-buff to creamy-buff fine-grained rather massive cross-bedded sandstone.......................

7. Long, gentle slope almost entirely covered by talus. The few outcrops are mostly thinly laminated soft brownish or reddish shale. The upper part of this member, just under the overlying buff sandstone, is bright-vermilion shale; the basal portion is slabby fine-grained thin-bedded sandstone which exhibits lemon and tan tints and is markedly calcareous........

8. Tiny cliff; greenish-buff, thinly laminated crystalline limestone, somewhat sandy in places. . . . . . . . . . . . . . ......

9. Slope; platy, very thinly laminated greenish and brownish-buff calcareous shaly sandstone, passing up into brownish-buff and vermilion beds of the same character

10. Curious gnarly cherty bed. In places a conglomerate of angular chert fragments; in places a massive gnarly sandy chert. Thickness variable. .................

11. Massive yellowish-buff fine-grained sandstone. Thickness variable............

Unconformity (?). Theirregularity of the beds at this horizon and the presence in them of brecciated chert indicate a surface of erosion, but the outcrops are not of sufficient extent to afford conclusive evidence.
Feet.

Kaibab limestone (Permian):

1. Massive buff sandstone containing lenses of chert and many casts of fossils; casts of Productus? are the most abundant. Thickness of bed variable and its surface appears wavy ......................

2. Partly concealed bed, making slope. Apparently consists of alternating thin layers of chert and lemon-buff sand-

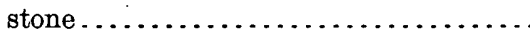

3. Cliff; massive gray to buff sandstone; calcareous; contains casts of Productus? ....
60

80

130

16

5

18

shi
Shinarump conglomerate exposed above it
and the top of the Kaibab limestone exposed below. Gregory's section of the Moenkopi is. 389 feet thick, whereas the section at Cedar Mountain above the Kaibab limestone measures 481 feet. The Cedar Mountain section differs. 150 from Gregory's section chiefly in that it contains massive beds of cross-bedded sandstone in the upper part, and it is conceivable that

1 this massive sandstone at Cedar Mountain represents the De Chelly sandstone of the Navajo country, which, as Gregory has shown,

15 is sporadic in occurrence and occupies a stratigraphic position between the Moenkopi formation and the Shinarump conglomerate. However, great and sudden variability in 0-4 lithology both vertically and horizontally is 0-2 a normal feature of the Moenkopi, as Gregory has pointed out. Moreover, cross-bedded sandits presence at Cedar Mountain is not neces sarily significant. Unconformities between the Shinarump and Moenkopi and between the Moenkopi and Kaibab can not be determined. by conclusive evidence at Cedar Mountain, 
because the exposures of the contacts between the formations are of small extent, but inasmuch as Gregory has shown conclusively that these unconformities exist in the general region and are widespread, it is.highly probable that the features I have described as occuring at the contacts between the formations at Cedar Mountain indicate their presence.

I obtained no fossils in the Moenkopi at Cedar Mountain, but fossils collected in it by
Longwell ${ }^{64}$ in Nevada and determined by Girty show that its age is Lower Triassic. Therefore the probable unconformity between the Moenkopi formation and the Kaibab limestone separates deposits of the Paleozoic and Mesozoic eras.

Gregory ${ }^{65}$ has tentatively assigned the Shinarump conglomerate to the Upper Triassic.

64 Longwell, C. R., op. cit., p. 50. 65 Gregory, H. E., op. cit., p. 41. 


\title{
THE SHAPES OF BEACH PEBBLES.
}

\author{
By Chester K. Wentworth.
}

\section{PURPOSE OF THE STUDY.}

There is much confusion in geologic literature as to the shapes of fluvial and beach pebbles and the differences between them, if differences exist. Though the contrary has been asserted, most geologists who have written on the subject appear to hold the view that beach pebbles are generally flatter than river pebbles, having discoid, lozenge-shaped, ellipsoid, or oval forms. ${ }^{1}$ It is asserted by some that these forms are produced by pushing of the rock fragments to and fro by the waves. ${ }^{2}$ Others have considered that the shapes of the original fragments and the inherent structure of the rock are dominant in determining the shapes of beach pebbles, ${ }^{3}$ and with this view the writer is in accord. That beach pebbles, even those composed of massive igneous rocks, are commonly of a flattened oval form seems certain, as has been stated elsewhere, ${ }^{4}$ but this fact is probably to be attributed to the development of such forms from original flat fragments or from rocks of schistose structure or to the segregation of such forms under the peculiar action of the waves, rather than to their production by a specialized wave abrasion.

Though many opinions on the subject have been expressed, no one, so far as known to the writer, has made any quantitative test of the development of such shapes on a beach. It was the writer's good fortune during the summer of 1921 to visit two localities on the Atlantic coast of New England where pebbles are

1 Suess, E., Der Boden der Stadt Wien, pp. 64, 65, 1882 (quoted from Grabau, A. W. Principles of s tratigraphy, p. 595; 1913).

Hoornos, R., Gerölle und Geschiebe: K. k. geol. Reichsanstalt Verh.

No. 12, pp. 42 et seq., 1911 (quoted from Grabau, A. W., op. cit., p. 595).

Cole, G. A. J., Rocis and their origins, p. 71, Cambridge Univ. Press, 1912.

Trowbrldge, A.C., Classification of common sediments: Jour. Geology, vol. 22, p. 435, 1914 .

Stephenson, L. W., The Coastal Plain of North Carolina: North Carolinn Geol. and Econ. Survey, vol. 3, pp. 274-275, 1912.

Geikio, A., Textbook of geology, vol. 1, p. 569, 1903.

${ }^{2}$ Suess, E., op. cit. Hoernes, R., op. cit. Cole, G. A. J., op. cit.

3 Grabau, A. W., Principles of stratigraphy, pp. 715-716, 1913.

Dunn, E. J., Pobbles, p. 7, Sydney, G. Robertson \& Co., 1911.

- Wentworth, C. K., Quantitative studies of the shapes of pebbles (unpublished thesis, Iowa State Univ.). being produced by wave abrasion of igneous rock in place. At these localities he measured more than 300 pebbles with the hope of obtaining evidence that would be conclusive, at least so far as these localities are concerned. The results obtained are presented on the following pages. It is the writer's hope that geologists acquainted with localities where similar measurements might be made or where conditions of wave abrasion are especially effective or peculiar will refer him to such places.

\section{BEACH CONDITIONS.}

The first locality visited was at the south extremity of Nantasket Beach, at the point shown on the topographic map of the Boston Bay quadrangle under the capital A of "Atlantic." Here, on the east side of the point, is a beach about 200 feet in length which is composed of material ranging from sand to blocks and boulders a foot or more in diameter. At each end the beach is terminated by low promontories of the local light-green to gray igneous rock, which is included in the Mattapan volcanic complex as mapped by Emerson. ${ }^{5}$ The greater part of the gravel of the beach is derived from the adjacent outcrops, which show, however, great variations in type within short distances, including some pyroclastic and sedimentary derivatives of the igneous rock. In addition to the local rock there is a considerable admixture of pebbles of granite, porphyry, breccia, felsite, and many other kinds of igneous rock from other parts of eastern Massachusetts which have been transported by glacial ice, by streams, and by shore currents. The general character of the beach gravel is shown in Plate XXVI. The conditions of abrasion at this point are those of a pocket beach. The tides rise and fall, shifting the zone of abrasion by several feet in height and about 75 to 100 feet horizontally. Storm waves break high over the north-south beach ridge and both adjacent rock promontories. Gravel is not transported to any extent from the beach, either

- Emerson, B. K., U. S. Geol. Survey Bull. 597, p. 200, 1917. 
alongshore or out to deep water, and remains indefinitely in the zone of effective abrasion. The coast at this place trends northwest, and the beach is exposed to the full force of waves from the northeast, but not so much to those from south of east.

The site of the second series of measurements was the rocky shore at the entrance to New Haven Harbor, near Fort Hale, Conn. Here, for a distance of several hundred feet, is a wavecut cliff and abrasion platform cut in the end of a north-south ridge of Triassic trap that reaches the shore. Along the cliff and strewn in both directions on the beach is considerable gravel composed of trap from the local exposure. This gravel extends only a few hundred feet in each direction, giving way to sand and finer materials. Mingled with the trap pebbles of the gravel are a few pebbles and larger pieces from the glacial till that overlies the bedrock at the top of the cliff and is exposed lower down along the adjacent parts of the shore. These are readily identified by inspection. The general character of the shore and gravel at this point is shown in Plate XXVII.

On this beach wave action is far less effective as an agent of abrasion than at Nantasket. Not only are the waves in this part of Long Island Sound less violent than those of the Atlantic Ocean at Nantasket, but the pebbles here are not confined in a pocket beach.

\section{METHODS OF MEASUREMENT.}

Three diameters mutually at right angles were measured for each pebble with a steel tape. The radius of curvature of the sharpest edge of each was measured with the convexity gage described elsewhere. ${ }^{6}$ All measurements were in millimeters. The data were recorded in several groups as follows:

Nantasket:

Pebbles.

A. Random selection, all materials........... 61

B. Miscellaneous rock types:

Quartzite..................... 20

Red porphyry.................. 20

Black porphyry ................. 10

Granite..................... 10

C. Local volcanic rock $\ldots \ldots \ldots$

Fort Hale:

D. Lócal trap.......................... 101

6 Wentworth, C. K., Quantitative studies of the shapes of pebbles (unpublished thesis, Iowa State Univ.), p. 61, 1921. See also Wentworth, C. K., The shapes of pebbles: U. S. Geol. Survey Bull. 730, pp. 91-114, 1922.

\section{LABORATORY DETERMINATIONS.}

The relative resistance of the local rocks at the two beaches was determined by an abrasion test in the tumbling mill. Four pebbles of each rock were ground at one end on a lap to a sharp $90^{\circ}$ edge. They were then subjected to abrasion in the mill for a total distance of about 80 miles. Measurements of the convexity of the prepared edge were made at intervals, and the resulting data were used in comparing the durability of the two types of rock.

\section{COMPUTATIONS.}

Computations were made as follows for each pebble:

Mean diameter, ${ }^{7}$ computed approximately by the formula $D=\sqrt[3]{D^{\prime} D^{\prime \prime} D^{\prime \prime \prime}}$ where $D^{\prime}, D^{\prime \prime}$, and $D^{\prime \prime \prime}$ are the length, breadth, and thickness as measured in the field.

Roundness ratio, $\frac{r_{1}}{R}=\frac{2 r_{1}}{D}$, where $r_{1}$ is the radius of curvature in millimeters of the sharpest edge and $R$ is the mean radius of the pebble.

Flatness ratio, $\frac{D^{\prime}+D^{\prime \prime}}{2 D^{\prime \prime \prime}}$ or the average of the length and breadth divided by the thickness. All these values were computed to two significant figures by the use of graphic charts. Further description of these ratios and methods of computation has been given elsewhere. ${ }^{8}$

\section{RESULTS.}

The results of the measurements are plotted on the graphs of figures 5 to 10 . The variations of the roundness ratios are so great that for practical considerations it seems better to average these ratios by subgroups. These averages were made as described below, and the subgroups are indicated by the large dots in figure 5 and by all the dots in figures 6 to 10 , where the number of pebbles represented by each dot is shown by the small accompanying figures. In the subgroups marked $\mathrm{X}$ under

7 The writer's use of the term "mean diameter" is open to the objection that in the use of the approximate formula given above the true value of the arithmetic mean of all diameters (the ideal concept of the term) is not derived. The writer does not consider the objection to be serious, for it applies in varying degree to all physical constants that are based on empirical data. It is customary to speak of the values derived for these constants as the theoretical constants themselves, and the common practice seems not to be unduly confusing. Therefore, in the following pages where the term "mean diameter" is used, the actual numerical values are understood to be approximations to the true arithmetical mean of all diameters.

8 Wentworth, C. K., The shapes of pebbles: U. S. Geol. Survey Bull. 730, pp. 91-114, 1922. 


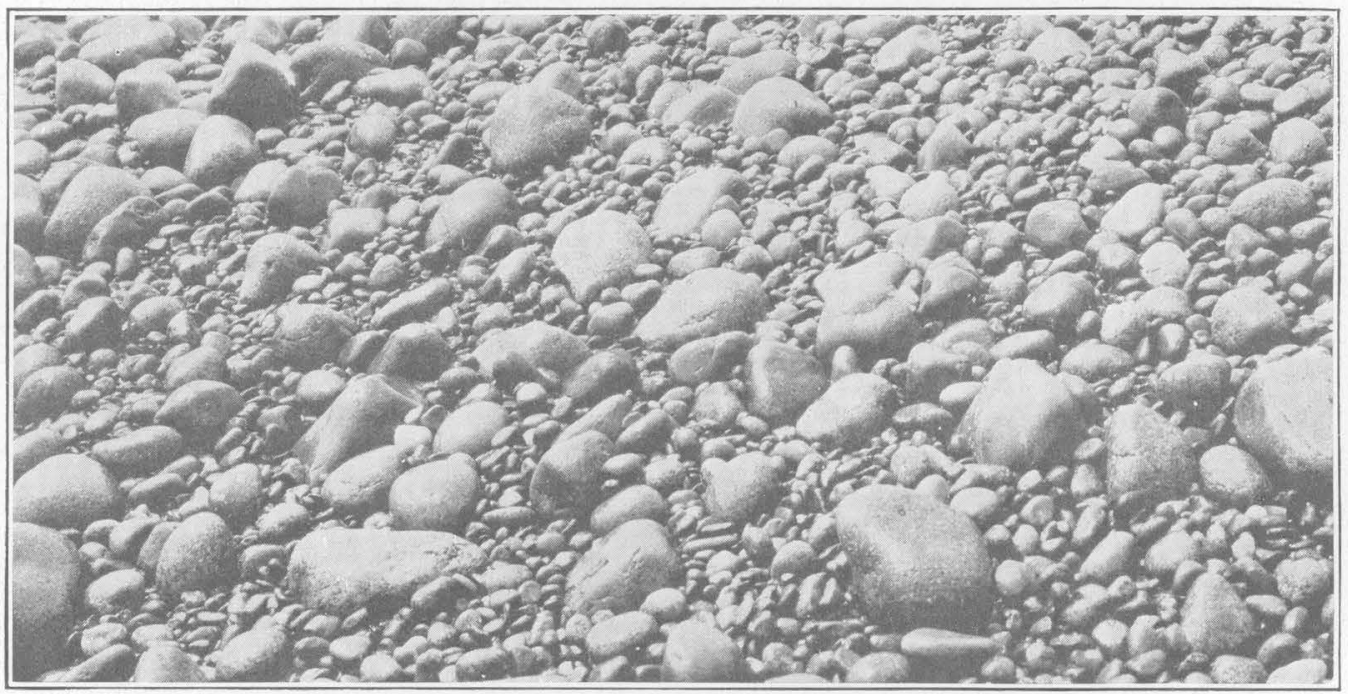

A. GRAVEL IN POCKET BEACH SOUTH OF NANTASKET, MASS.

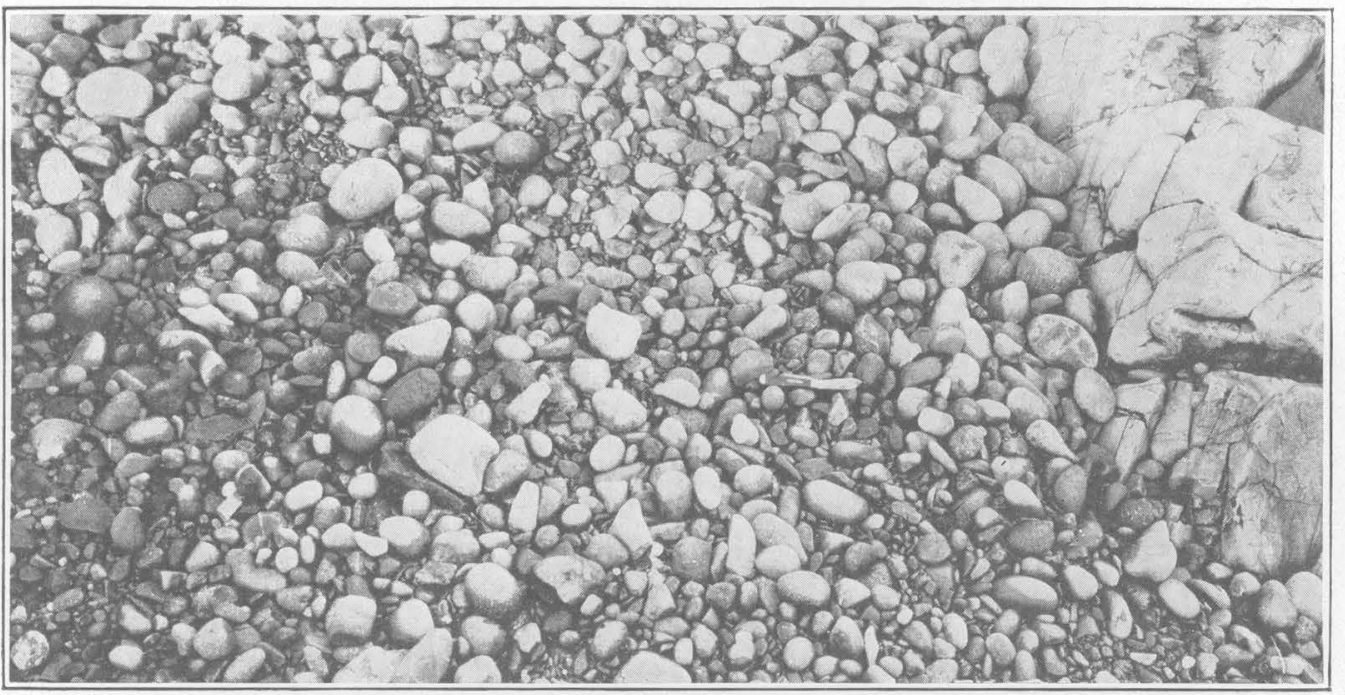

B. GRAVEL AND JOINTED ROCK OF PROMONTORY SOUTH OF NANTASKET, MASS.

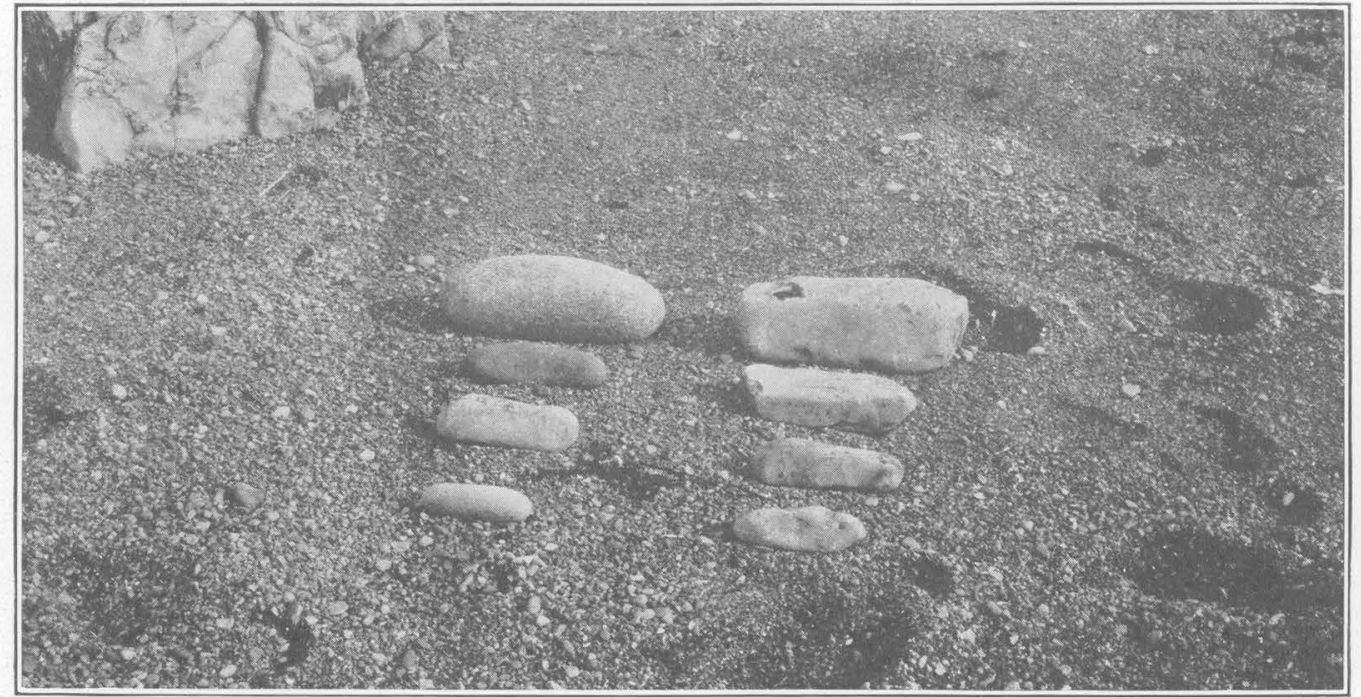

C. ROLLER-SHAPED COBBLES IN TWO STAGES OF FORMATION, POCKET BEACH SOUTH OF NANTASKET, MASS. 


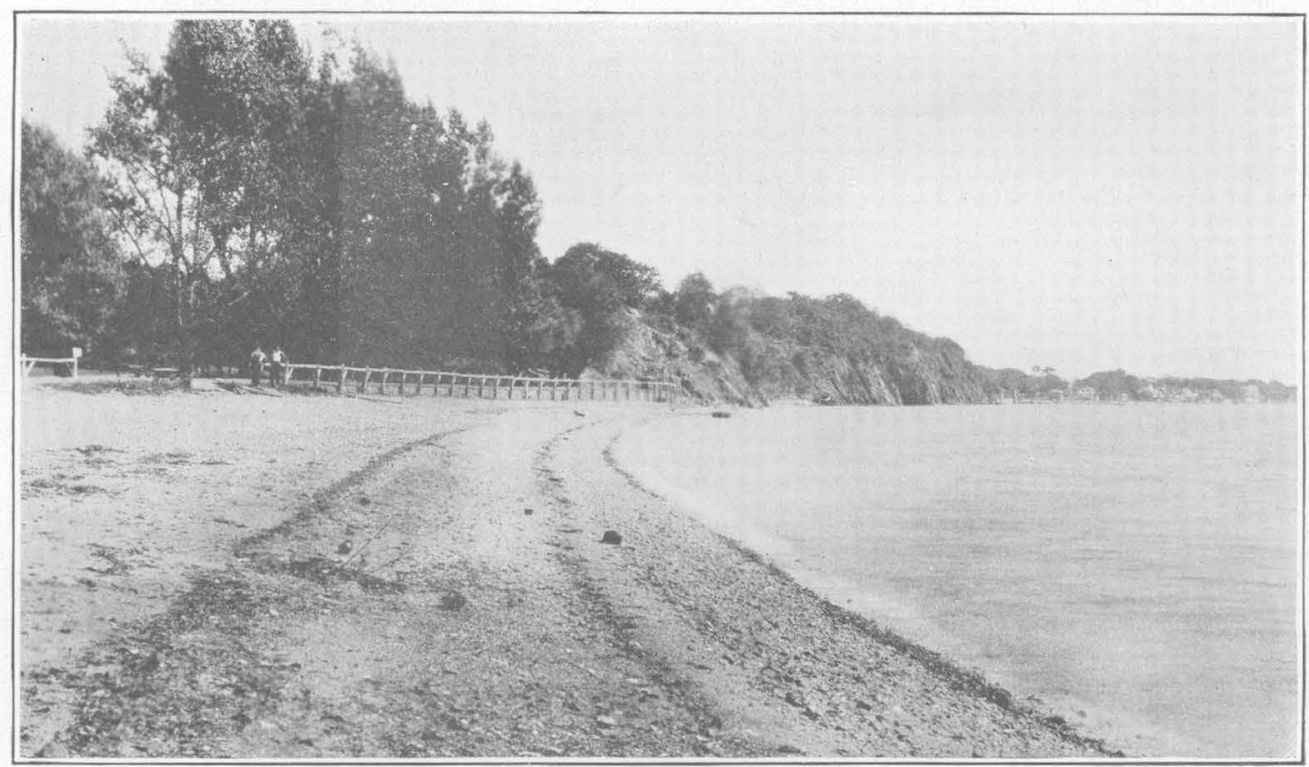

A. BEACH AT FORT HALE, CONN.

The cliff in the middle distance is the source of pebble material.

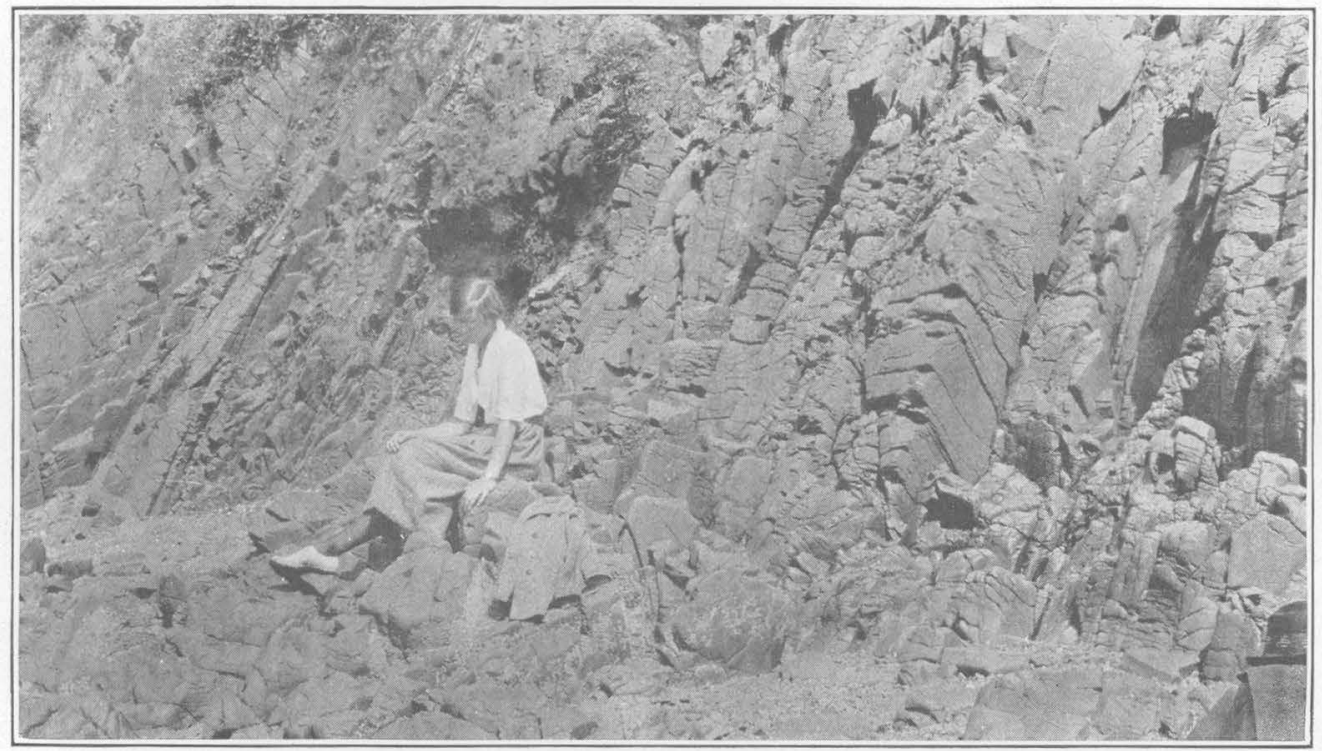

B. NEAR VIEW OF CLIFF OF JOINTED TRAP AND LANDWARD EDGE OF ABRASION PLATFORM AT FORT HALE, CONN. 


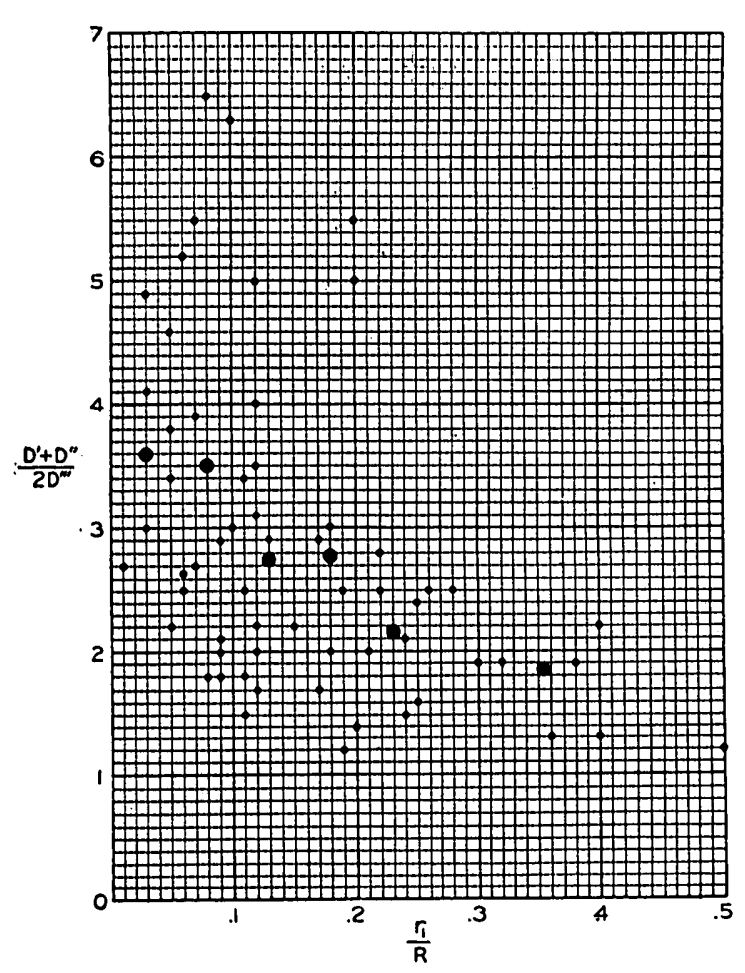

Froure 5.-Graph showing flatness ratios $\frac{D^{\prime}+D^{\prime \prime}}{2 D^{\prime \prime \prime}}$ (ordinate) and roundnoss ratios $\frac{r_{1}}{R}$ (abscissa) of 61 pebbles of group A at Nantasket, Mass. Large dots show avorage positions for subgroups of pebbles. (See ng. 0.)
"Method of computing averages" in the following table the values of $\frac{D^{\prime}+D^{\prime \prime}}{2 D^{\prime \prime \prime}}$ for all the pebbles of the subgroup were averaged arithmetically for the ordinate, and the mean of the limits of $\frac{r_{1}}{R}$ for the subgroup was used for abscissa. In the subgroups marked $\mathrm{Y}$ the values of $\frac{D^{\prime}+D^{\prime \prime}}{2 D^{\prime \prime \prime}}$ were averaged similarly for the ordinate and the values of $\frac{r_{1}}{R}$ for all the pebbles of the subgroup were averaged arithmetically for the abscissa. Method $\mathrm{X}$ was used for the subgroups in which values of $\frac{r_{1}}{R}$ were fairly uniformly and thickly distributed; method $\mathrm{Y}$ was used for subgroups in which a few erratic points needed to be averaged. The subgroup limits were chosen to avoid as far as possible very small subgroups or very great differences in the number of pebbles in adjacent subgroups. No data were rejected, and every measurement taken in the field is represented in the averages here presented.

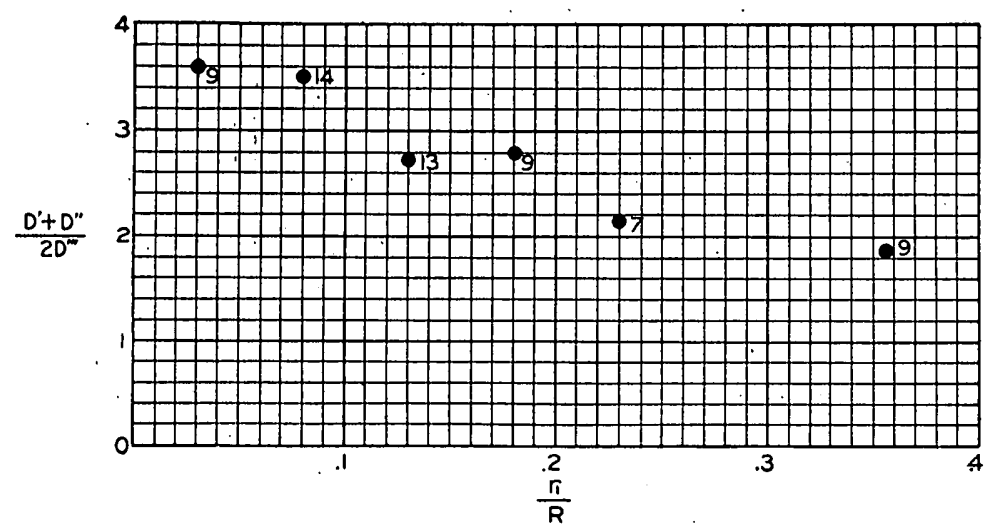

Fraure 6.-Graph showing flatness and roundness of 61 pebbles of group A. The flatness ratio $\frac{D^{\prime}+D^{\prime \prime}}{2 D^{\prime \prime \prime}}$ is plotted as the ordinate and the roundness ratio $\frac{r_{1}}{R}$ as the abscissa. For simplicity, the pebbles are arranged in subgroups, and each large dot shows the mean position of the number of pobbles indicated by the small figures. It is apparent that as the roundness increases the flatness decreases.

$91048^{\circ}-23-6$ 


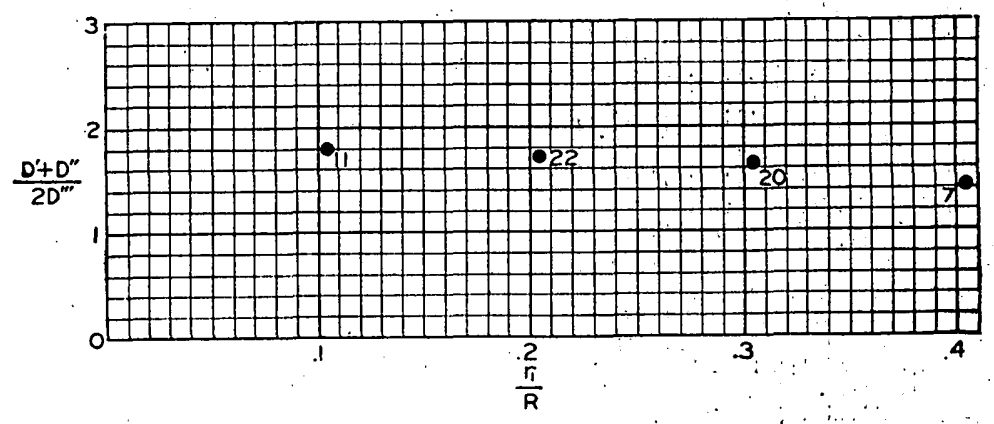

FTaURE 7.-Graph showing flatness and roundness ratios of pebbles of group B. For explanation, see figure 6 。

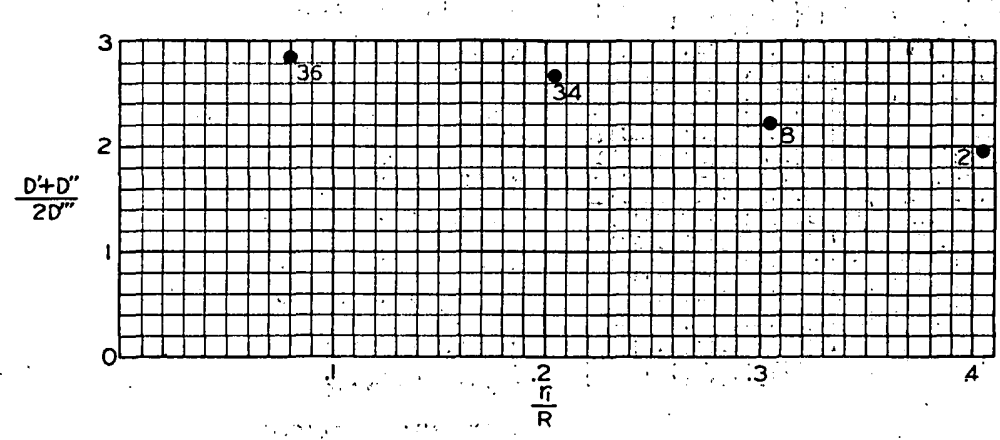

FTGURE 8.-Graph showing flatness and roundness ratios of pebbles of group C. For explanation, see figure 6.

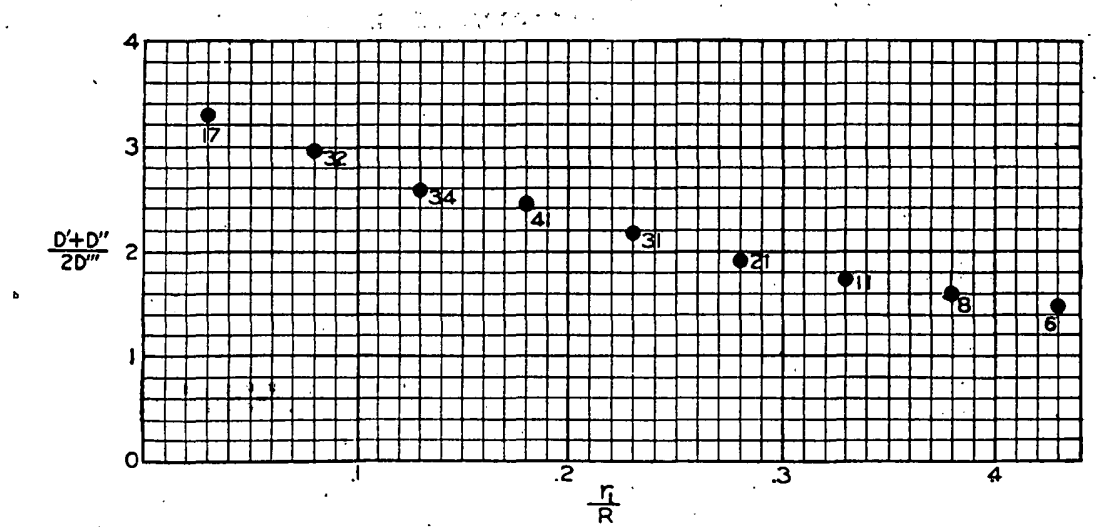

FTGURE 9.-Graph showing flatness and roundness ratios of pebbles of groups A, B, and C combined. For explanation, see figure $B_{\text {. }}$

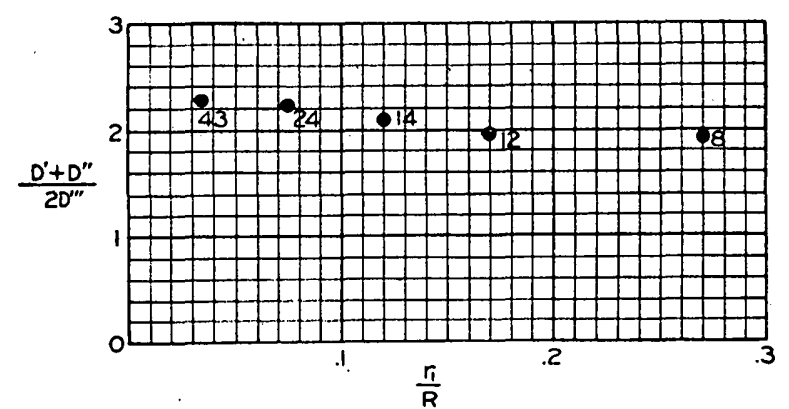

FrGuRE 10.-Graph showing flatness and roundness ratios of pebbles of group D. For explanation, see figure 6. 
THE SHAPES OF BEACH PEBBLES.

Method of computing averages for subgroups.

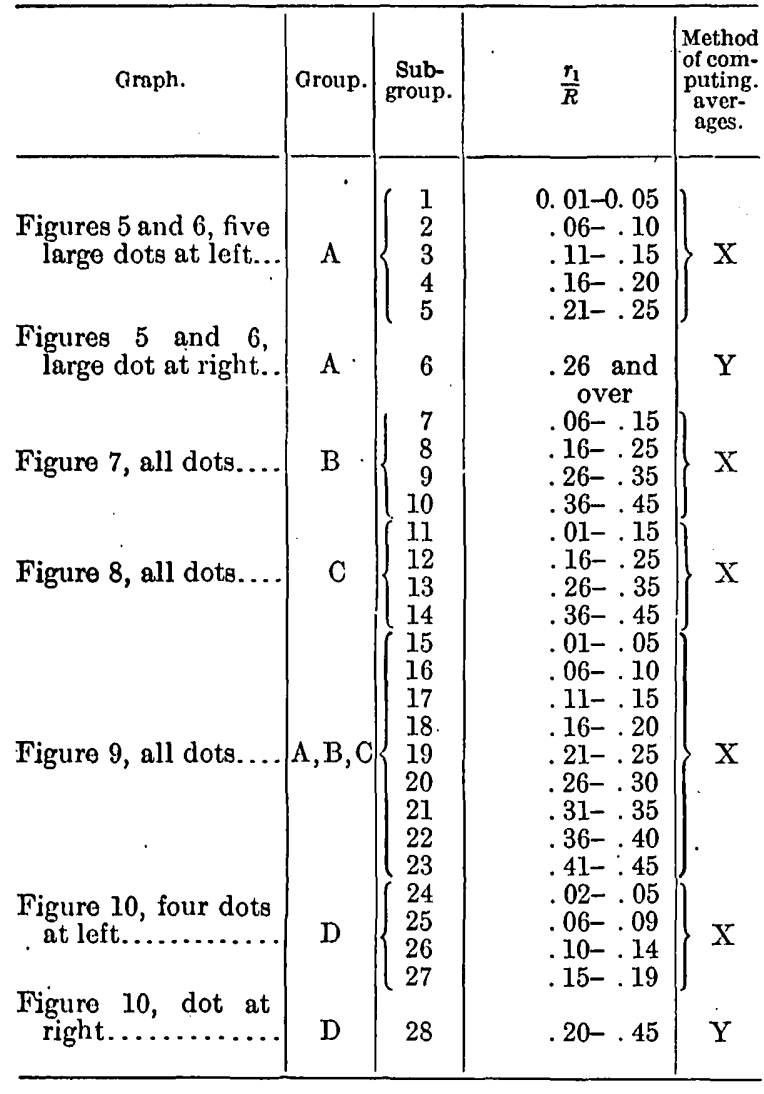

Roundness and flatness ratios of pebbles.

Group A, figures 5 and 6.

\begin{tabular}{|c|c|c|c|}
\hline Subgroup. & $\frac{r_{1}}{R}$ & $\frac{D^{\prime}+D^{\prime \prime}}{Q D^{\prime \prime \prime}}$ & Abscissa and ordinate. \\
\hline \multirow[t]{3}{*}{$1 \ldots \ldots$} & \multirow{4}{*}{$\begin{array}{l}.07 \\
.07 \\
.09 \\
.08 \\
.08 \\
.10 \\
.06 \\
.06 \\
.10 \\
.09 \\
.07 \\
.09 \\
.09 \\
.06\end{array}$} & $\begin{array}{l}2.7 \\
2.2 \\
3.6 \\
3.0 \\
4.1 \\
3.8 \\
4.6 \\
3.4 \\
4.9\end{array}$ & \multirow{4}{*}{$\begin{array}{l}\text { Method X, abscissa } 0.08 \\
\text { ordinate }(49.0 \div 14) 3.50\end{array}$} \\
\hline & & 32.3 & \\
\hline & & $\begin{array}{l}3.9 \\
2.7 \\
2.9 \\
6.5 \\
1.8 \\
6.3 \\
5.2 \\
2.5 \\
3.0 \\
2.1 \\
5.5 \\
2.0 \\
2.0 \\
2.6\end{array}$ & \\
\hline $2 \ldots \ldots \ldots$ & & 49.0 & \\
\hline
\end{tabular}

Roundness and flatness ratios of pebbles-Continued.

Group A, figures 5 and 6-Continued.

\begin{tabular}{|c|c|c|c|}
\hline Subgroup. & $\frac{r_{1}}{R}$ & $\frac{D^{\prime}+D^{\prime \prime}}{2 D^{\prime \prime \prime}}$ & Abscissa and ordinate. \\
\hline & $\left(\begin{array}{c}0.12 \\
.12 \\
.11 \\
.12 \\
.11 \\
.12 \\
.12 \\
.12\end{array}\right.$ & $\begin{array}{l}3.1 \\
1.7 \\
3.4 \\
5.0 \\
1.5 \\
4.0 \\
3.5 \\
2.2\end{array}$ & Method X, abscissa \\
\hline
\end{tabular}

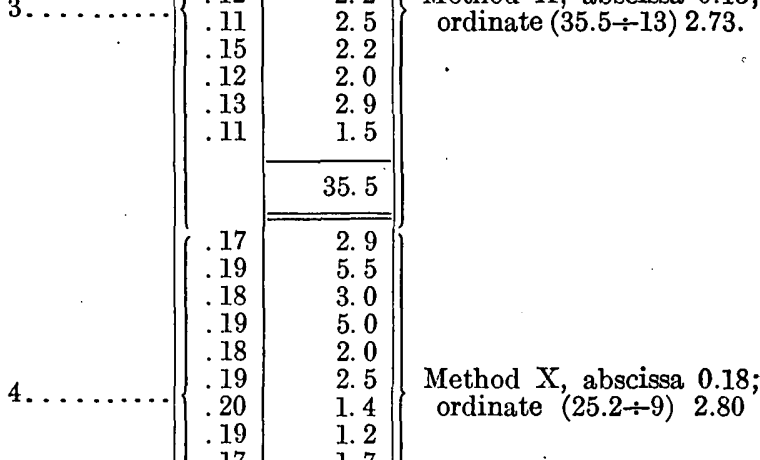

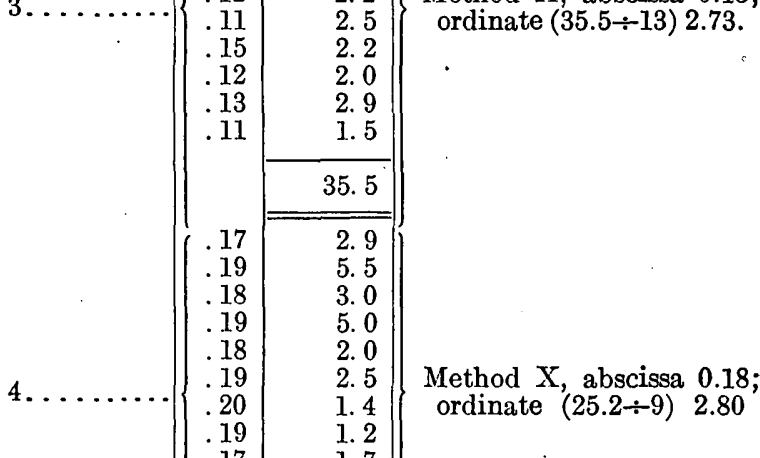

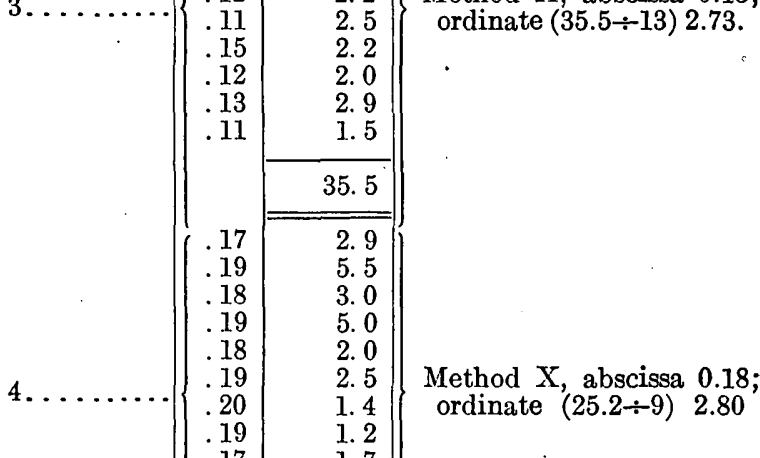

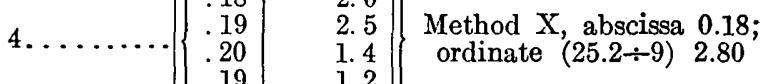

5

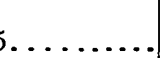

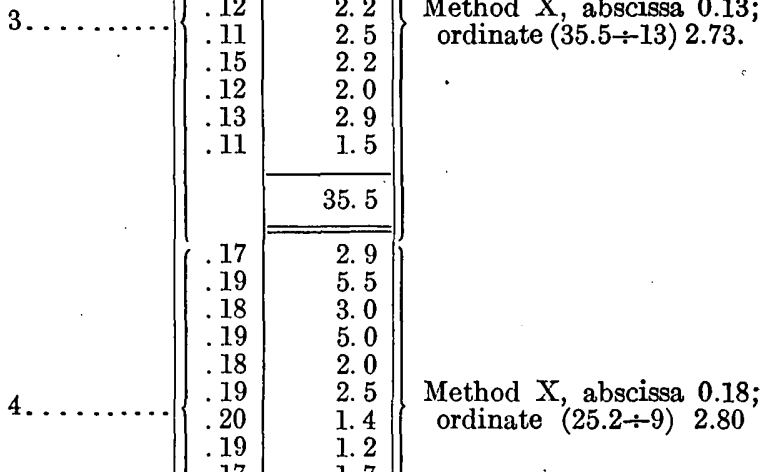

\begin{tabular}{r|r}
.17 & 1.7 \\
\hline 25.2
\end{tabular} $\left(\begin{array}{r|r} & 25.2 \\ .22 & 2.5 \\ .22 & 2.8 \\ .21 & 2.0 \\ .24 & 2.1 \\ .25 & 1.6 \\ .25 & 2.4 \\ 24 & 1.5\end{array}\right\} \begin{gathered}\text { Method X, abscissa } 0.23 ; \\ \text { ordinate }(14.9 \div 7) 2.13 .\end{gathered}$

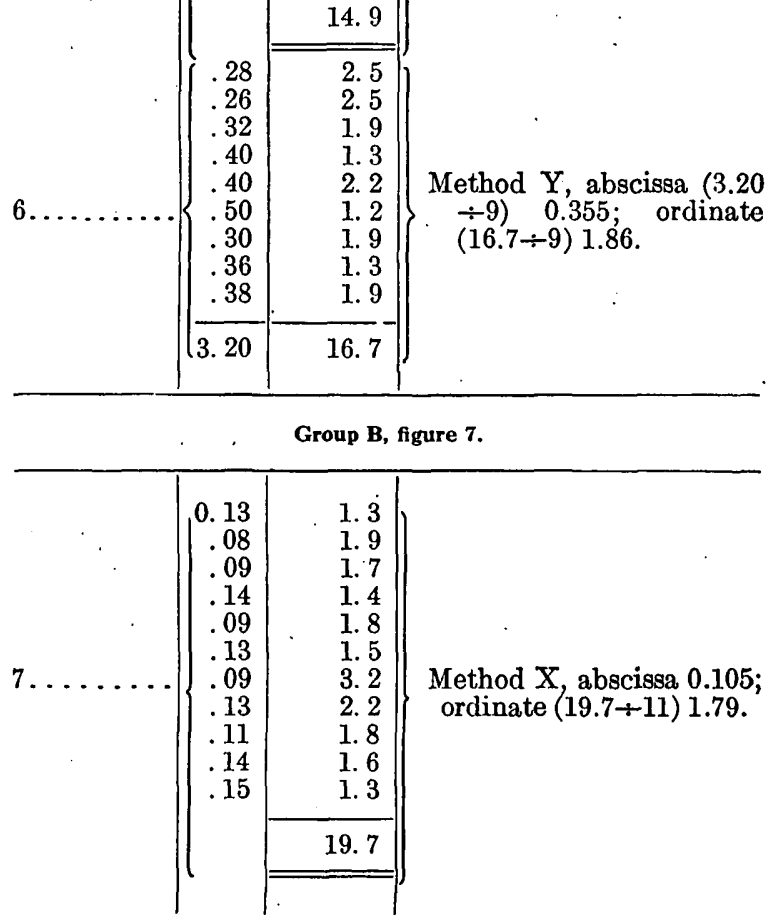

\begin{tabular}{r|r|}
.24 & 1.5 \\
\hline 14.9 \\
\hline
\end{tabular} 
Roundness and flatness ratios of pebbles-Continued.

Group B, figure 7-Continued.

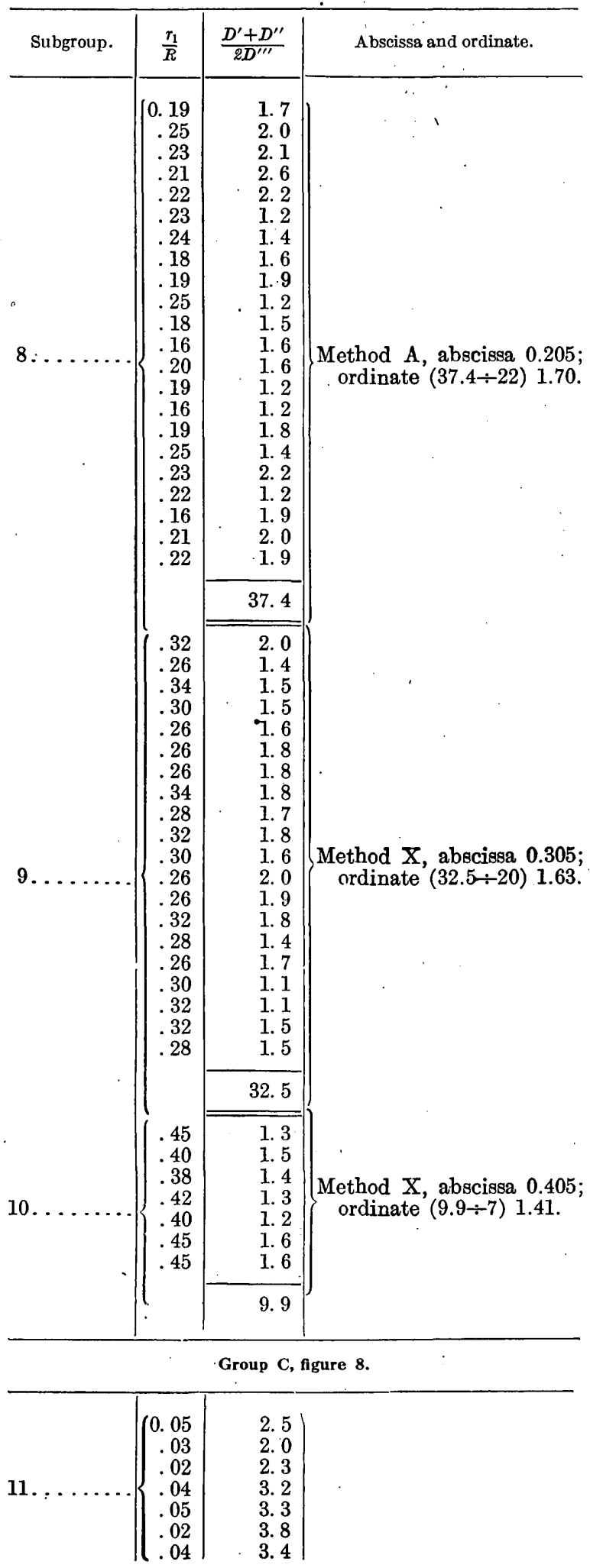

Roundness and flatness ratios of pebbles-Continued.

Group C, figure 8-Continued.

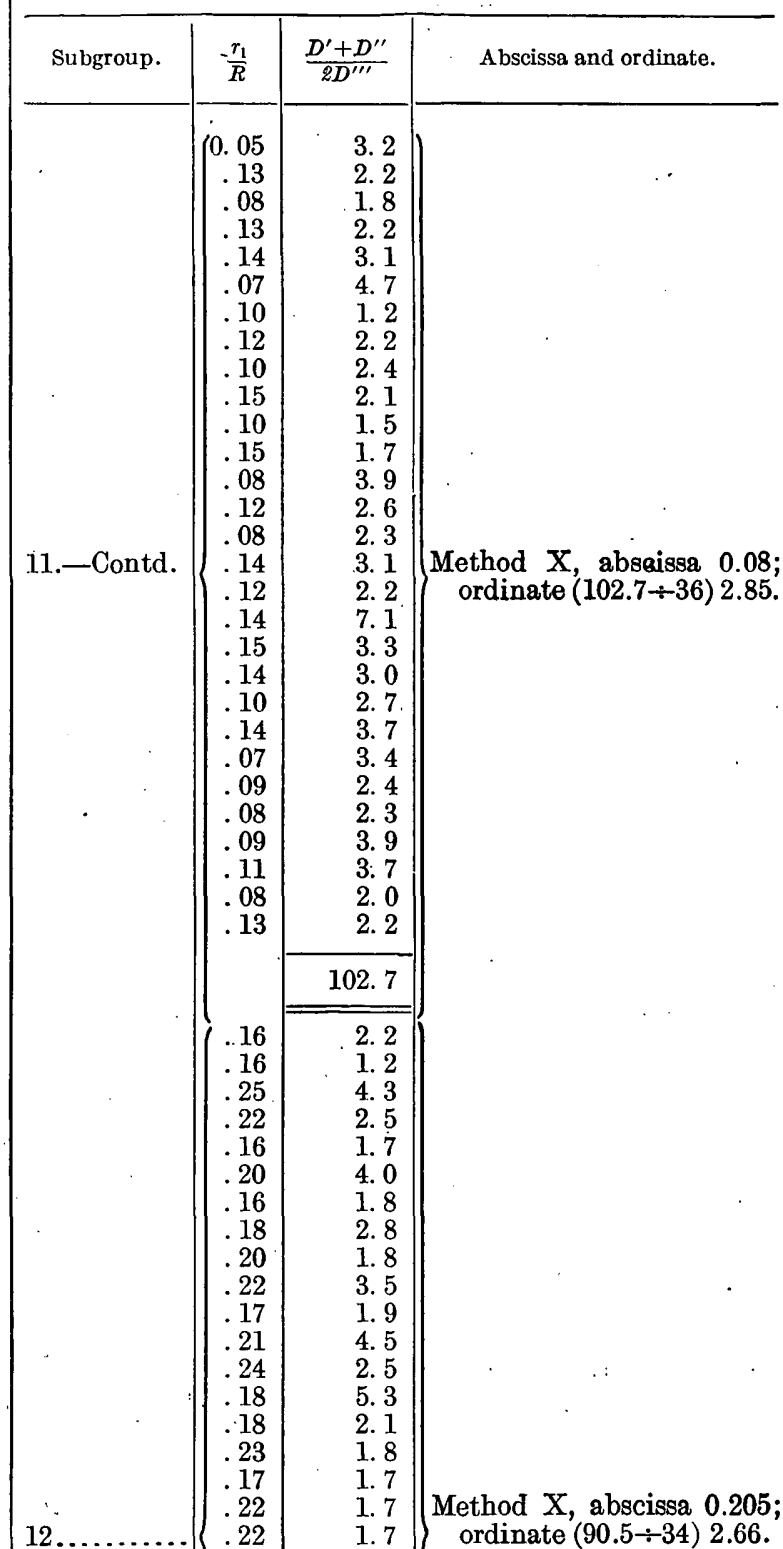$$
\left.\begin{array}{rr}
.22 & 1.7 \\
.16 & 1.9 \\
.18 & 2.3
\end{array}\right\} \begin{aligned}
& \text { ordinate }(90.5 \div 34) 2.66 \text {. } \\
& .22
\end{aligned}
$$$$
12
$$ 
THE SHAPES OF BEACH PEBBLES.

Roundness and flatness ratios of pebbles-Continued.

Group C, figure 8-Continued.

\begin{tabular}{|c|c|c|c|}
\hline Subgroup. & $\frac{r_{1}}{R}$ & $\frac{D^{\prime}+D^{\prime \prime}}{2 D^{\prime \prime \prime}}$ & Abscissa and ordinate. \\
\hline \multirow[t]{2}{*}{$13 .}$. & \multirow[t]{2}{*}{$\begin{array}{l}0.32 \\
.26 \\
.28 \\
.26 \\
.34 \\
.26 \\
.26 \\
.26\end{array}$} & $\begin{array}{l}1.5 \\
2.1 \\
3.3 \\
2.7 \\
1.8 \\
2.1 \\
1.9 \\
2.3\end{array}$ & \multirow[t]{2}{*}{$\begin{array}{l}\text { Method X, abscissa } 0.305 \\
\text { ordinate }(17.7 \div 8) 2.21\end{array}$} \\
\hline & & 1.7. 7 & \\
\hline 14. & \multirow[t]{2}{*}{$\begin{array}{l}.45 \\
.40\end{array}$} & $\begin{array}{l}1.9 \\
2.0\end{array}$ & \multirow{2}{*}{$\begin{array}{l}\text { Method } \mathrm{X} \text {, abscissa } 0.405 \\
\text { ordinate }(3.9 \div 2) 1.95\end{array}$} \\
\hline & & 3. 9 & \\
\hline
\end{tabular}

Groups A, B, and C combined, figure 9. a

\begin{tabular}{|c|c|c|c|}
\hline 15. & & 56.0 & Abscissa 0.03 ; ordinate \\
\hline 16. & & 95.1 & Abscissa 0.08 ; or dinate \\
\hline 17. & & 88.1 & $\begin{array}{l}\text { Abscissa } 0.13 ; \text { or d inate } \\
(88.1 \div 34) 2.59\end{array}$ \\
\hline 18. & & 100.4 & $\begin{array}{l}\text { Abscissa } 0.18 ; \text { or dinate } \\
\quad(100.4 \div 41) 2.45 \text {. }\end{array}$ \\
\hline 19. & & 67.6 & $\begin{array}{l}\text { Abscissa } 0.23 ; \text { or d inate } \\
\quad(67.6 \div 31) 2.18 \text {. }\end{array}$ \\
\hline 20. & & 40. 1 & $\begin{array}{l}\text { Abscissa } 0.28 ; \text { ord in ate } \\
\quad(40.1 \div 21) 1.91 \text {. }\end{array}$ \\
\hline & & 19.0 & $\begin{array}{l}\text { Abscissa } 0.33 ; \text { or dinate } \\
\quad(19.0 \div 11) 1.73 \text {. }\end{array}$ \\
\hline 22. & & 12.8 & Abscissa 0.38 ; ord in a te \\
\hline 23. & & 8. 9 & $\begin{array}{l}\text { Abscissa } 0.43 ; \text { ord in ate } \\
\quad(8.9 \div 6) 1.48 \text {. }\end{array}$ \\
\hline
\end{tabular}

Group D, figure 10.

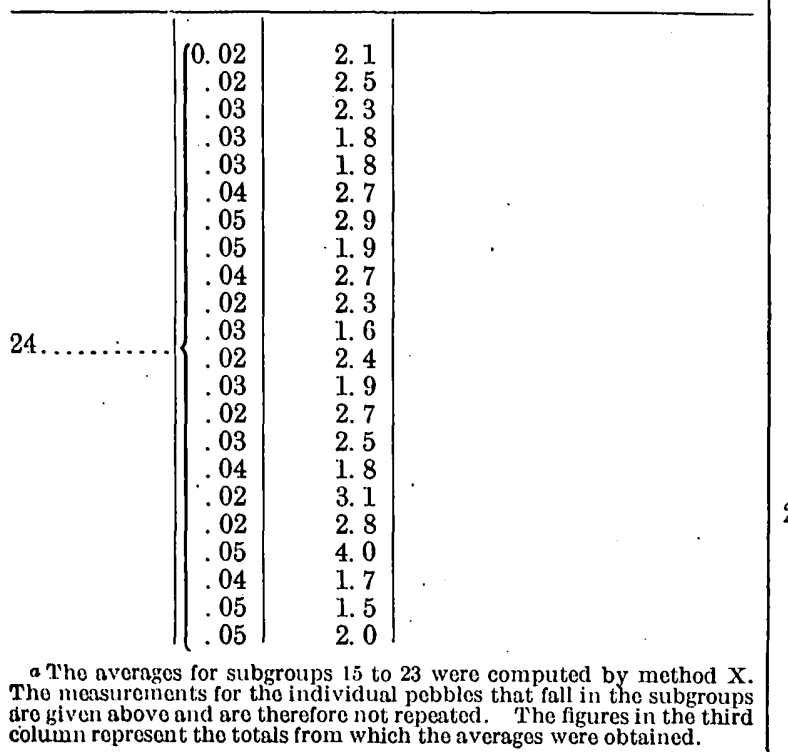

Roundness and flatness ratios of pebbles-Continued.

Group D; figure 10-Continued.

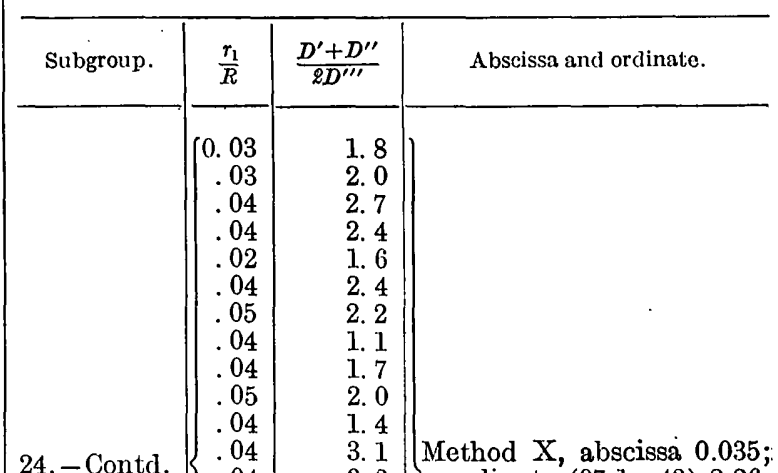

ordinate $(97.1 \div 43) 2.26$.

25

Method X, abscissa 0.075; ordinate $(53.6 \div 24) 2.23$.

26

$.02 \quad 2.0$

$.04 \quad 2.7$

1.7

.05
.05

$.03 \quad 2.0$

97.1

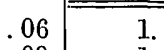

.09

.09

.07
.06

.06
.06
.09

.09
.06

.09

.07

.

.07
.07
.07

2. 2

1. 7

2. 9

1. 2

1. 8

1. 7

1. 8

1.5

1. 8

2.4
2.2

.08
.08

.09

2. 9

$\begin{array}{ll}.08 & 1.4 \\ .09 & 3.2\end{array}$

$\begin{array}{ll}.09 & 3.2 \\ .08\end{array}$

.08

1. 3

.07

4. 0

53. 6

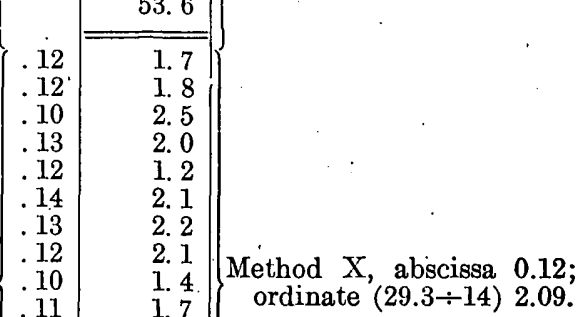

(1)

1. 7

3.0
2.7

. 3.2

29.3 
Roundness and flatness ratios of pebbles-Continued.

Group D, figure 10-Continued.

\begin{tabular}{|c|c|c|c|}
\hline Subgroup. & $\frac{r_{1}}{R}$ & $\frac{D^{\prime}+D^{\prime \prime}}{2 D^{\prime \prime \prime}}$ & Abscissa and ordinate. \\
\hline \multirow[t]{2}{*}{27.} & $\left\{\begin{array}{l}0.15 \\
.17 \\
.19 \\
.19 \\
.16 \\
.16 \\
.15 \\
.15 \\
.18 \\
.17 \\
.16 \\
.16\end{array}\right.$ & $\begin{array}{l}1.4 \\
2.9 \\
2.2 \\
1.2 \\
1.8 \\
1.7 \\
\text { 3. } 2 \\
1.2 \\
3.1 \\
1.1 \\
2.5 \\
1.4\end{array}$ & \multirow[t]{2}{*}{$\begin{aligned} \text { Method X, abscissa } & 0.17 \\
\text { ordinate }(23.7 \div-12) & 1.97\end{aligned}$} \\
\hline & & 23.7 & \\
\hline \multirow[t]{2}{*}{$28 .}$. & $\left\{\begin{array}{l}.23 \\
.30 \\
.20 \\
.45 \\
.34 \\
.20 \\
.24 \\
.21\end{array}\right.$ & $\begin{array}{l}1.7 \\
2.7 \\
2.2 \\
1.8 \\
2.0 \\
1.6 \\
1.9 \\
1.5\end{array}$ & \multirow[t]{2}{*}{$\begin{array}{l}\text { Method Y, abscissa }(2.17 \div \\
\text { 8) } 0.271 \text {; ordinate }(15.4 \div \\
\text { 8) } 1.92 \text {. }\end{array}$} \\
\hline & (2.17 & 15.4 & \\
\hline
\end{tabular}

It is evident that in each one of the five groups of pebbles the flatness and roundness of edges stand in inverse relation-that is, the more rounded the edges the less flat the pebbles. It is valid to assume that the pebbles with rounder edges have been longer affected by wave action than those with sharper edges. The former, which have been on the beach longer, are less flat than the latter, which have been a shorter time on the beach and are nearer to their original shape. It is conclusively proved that at these two beaches the pebbles become less flat as abrasion proceeds and that any predominance of flat, discoid forms is to be attributed to the flatness of the original fragments resulting from the current processes of disruption. Likewise the rather common rollershaped cobbles and pebbles are the result of the rounding and smoothing of original elongate fragments, as suggested by the series shown in Plate XXVI, $C$, and evidence that these shapes are the result of any special sort of abrasion or motion was not seen by the writer.

The data are insufficient to warrant drawing ideal curves correlating the diminution of flatness with the increase of roundness, but the definite trend described above is established for the two localities visited. In figures 11 and 12 are shown diagrammatically the average shapes of the extreme pebble subgroups at the two localities with regard to both the flatness and the roundness. In each of these figures the flatness and roundness shown in the upper and lower diagrams are those of the subgroups
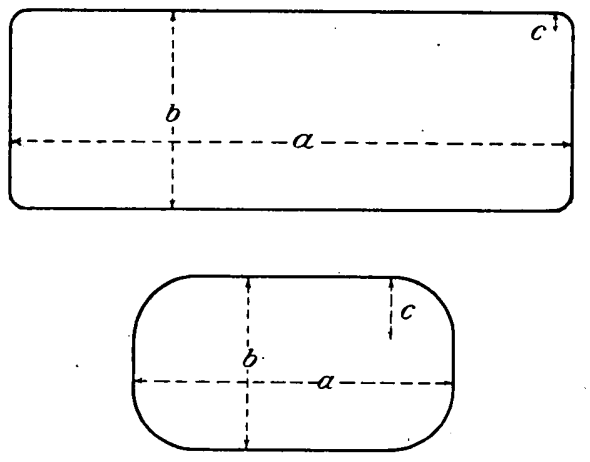

FIGURE 11.-Diagrams showing average flatness and roundness of most angular and most rounded subgroups of pebbles of group $C$ at Nantasket, Mass. Top diagram represents these values for the average of the 36 pebbles of the left-hand subgroup of figure 8 . Bottom diagram represents these values for the two pebbles of the right-hand subgroup of figure 8.

$$
\frac{a}{b}=\frac{D^{\prime}+D^{\prime \prime}}{2 D^{\prime \prime \prime}} \quad \frac{C}{\sqrt[3]{a^{2} b}}=\frac{r_{1}}{R}
$$

Sizes are arbitrary, but dimensions show true flatness and roundness ratios as indicated in the equation above.

represented by the dots at the extreme left and extreme right of figures 8 and 10, respectively. It will be noted that the Nantasket material yields flatter original fragments than that at Fort Hale: This is a result of factors related to the structure of the rocks and the processes

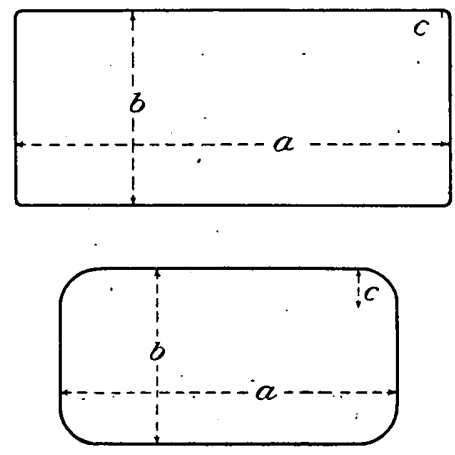

Figure 12.-Diagrams showing average flatness and roundness of most angular and most rounded subgroups of pebbles of group D at Fort Hale, Conn. Top diagram represents these values for the average of the 43 pebbles of the left-hand subgroup of figure 10. Bottom diagram represents these values for the 8 pebbles of the right-hand subgroup of figure 10. Notation same as in figure 11.

and conditions of disruption. The writer has not yet made a study of this important aspect of the problem.

Comparisons of the average roundness of the several groups follow. All the pebbles of 
group B and some of those of group A are at an unknown distance from their source, and little can be said about them except that they are rounder as a whole than those of groups $\mathrm{C}$ and $\mathrm{D}$ shown in figures 8 and 10 . Between those of groups $\mathrm{C}$ and $\mathrm{D}$ an interesting comparison can be made. The pebbles of group $\mathrm{C}$ are much rounder and indicate more travel or abrasion than those of group D. On comparing the average roundness of the two groups on the basis of his previous studies of the relation between abrasion and the roundness ratio $^{\circ}$ the writer finds that the pebbles of group C (Nantasket) indicate greater wear by abrasion than those of group D (Fort Hale) in the approximate ratio of 3.4 to 1 . It was found by abrasion tests, however, that the Nantasket rock requires much more abrasion to produce a given degree of rounding than the Fort Hale rock. The ratio is approximately 5. On multiplying this ratio by the ratio given above, we find that the average pebble at Nantasket represents about 17 times the amount

Wontworth, C.K., The shapes of pebbles: U. S. Geol. Survey Bull. 730, pp. 91-114, 1922. of abrasion that those at Fort Hale have received. The ratio is a result of two factorsthe violence of wave action and the effectiveness of retention of the same pebbles in the zone of wave action.

Although the writer has ventured to express the ratios in numerical form, he does not wish to convey any false impression as to their accuracy. He is aware, probably more clearly than the reader, of the extreme complexity of the problem, which involves a large number of unknown factors. The figures given are believed to be within 25 per cent of the truth, and it is hoped they may provoke more accurate and extensive investigation.

\section{ACKNOWLEDGMENTS.}

In conclusion, acknowledgment is due to Dr. J. B. Woodworth, of Harvard University, for his kindness in guiding the writer to the Nantasket Beach locality and for his advice and comment during two days of field work on the Massachusetts coast; and to Mr. J. S. Brown, of the United States Geological Survey, who suggested the Fort Hale locality. 



\section{A GEOLOGIC RECONNAISSANCE IN THE GULF COASTAL PLAIN OF TEXAS, NEAR THE RIO GRANDE.}

By A. C. Trowbridge.

\section{INTRODUCTION.}

During June, July, and August, 1919, part of June and all of July and August, 1920, and parts of July and August, 1921, the writer, assisted by A. G. Maddren in 1919 and by W. S. Glock and Lloyd North in 1920, and associated with L. W. Stephenson, E. W. Berry, E. B. Stiles, and Señor Enrique Díaz Lozano in 1921, carried on reconnaissance work along the Rio Grande in the southern extremity of Texas. As there seems to be immediate need for a map and a brief description of the formations on the Texas side of the Rio Grande, to serve as a key for important stratigraphic work in progress both in the United States and Mexico, it has been decided to prepare and publish now a preliminary report and map, which will show the general results of the work already done.

For aid in the preparation of this report the writer is indebted to Dr. T. W. Vaughan, under whose direction the field studies were made and the report was prepared; to Dr. Julia Gardner, who identified the molluscan faunas; to Prof. E. W. Berry, who aided in the collection of the floras and identified them; to Dr. J. A. Udden, who kindly supplied well logs from the files of the Bureau of Economic Geology and Technology of the University of Texas; to Mr. C. L. Baker, with whom the writer has carried on correspondence and from whom he hasreceived information and suggestions; to $\mathrm{Mr}$. G. C. Matson, who has already covered the field and whose field notes and maps were available for the writer's use; to Mr. E. T. Dumble, who freely gave his opinion on several difficult questions; and to Mr. Alexander Deussen, who by oral conference and by correspondence gave valuable assistance. Eighty-two published articles that bear more or less directly on the problems of the region were freely consulted.

\section{GEOGRAPHY OF THE REGION.}

The region here considered is bordered on the south and west by the Rio Grande which forms the International Boundary, a part of its eastern border is the Gulf of Mexico, and on the northwest and north it is limited by the line of contact between the Cretaceous and Tertiary systems as mapped by Stephenson. ${ }^{1}$ Roughly sketched, this line of contact extends from a point about 5 miles south of Uvalde, in Uvalde County, westward and southwestward through Pulliam, in the same county, and thence southwestward and southward through Maverick County to a point on the Rio Grande about 3 miles north of the Maverick-Webb county line and about 35 miles downstream from Eagle Pass. The eastern, northeastern; and northern boundary of the area considered is represented by a line drawn from a point about 5 miles south of Uvalde nearly southward to Carrizo Springs, in Dimmit County, thence southeastward to Hebbronville, in Jim Hogg County; thence eastward through Falfurrias, in Brooks County, and Sarita, in Willacy County, to the Gulf of Mexico. This line corresponds in part with the south and west boundary of a large area southwest of Brazos River that was surveyed by Deussen, whose report is now in press. ${ }^{2}$ The counties included in the Rio Grande region are extreme south-central Uvalde, western Zavalla, eastern Maverick, western Dimmit, and all or most of Webb, Zapata, Jim Hogg, Starr, Brooks, Hidalgo, Willacy, and Cameron. The total area considered is about 1:3,500 square miles, nearly one twentieth of the State of Texas.

1 Stephenson, L. W., The Cretaceous-Eocene contact in the Atlantic and Gulf Coastal Plain: U. S. Geol. Survey Prof. Paper 90, pl. 15, 1915. 2 Deussen, Alexander, Geology of the Coastal Plain region of Texas: U. S. Geol. Survey Prof. Paper 126. 
The region defined above lies wholly within the Rio Grande Plain of Hill and Vaughan. ${ }^{3}$ The Balcones faulted zone, which separates this plain from the Edwards Plateau, lies 20 to 75 miles north of the Cretaceous-Eocene line. At the landward edge of the territory the elevation above the Gulf averages about 800 feet, and from this elevation there is a gradual slope to sea level at the Gulf. Although no part of the region has high relief, the part along the Rio Grande from the WebbMaverick county line to Fort Sam Fordyce is notably rougher than that farther away from the river and that along the Gulf.

The rough belt near the river is commonly spoken of as "the breaks of the Rio Grande," and its roughness is due to the erosional work done by many intermittent tributaries. The width of the belt is not the same throughout but is determined in any area by the length of the tributary streams there. These streams average not more than 15 miles in length, but as most of them have only shallow valleys in their upper stretches the "breaks" they form are generally less than 15 miles wide. Although the relief at most places in this belt does not exceed 100 feet, there are localities where the tops of the highest hills stand more than 250 feet above the Rio Grande. In general both the relief and the roughness decrease with the decrease in average altitude downstream. 'It is in this belt that the best and the most numerous exposures of the rock formations are found.

The more nearly flat land east of the "breaks" is divided into two parts by a conspicuous cuesta known as the Bordas scarp. This scarp and the trench cut by the Rio Grande are the only notable topographic features of the region.

The Bordas scarp crosses the northeast border of the territory mapped at a point 7 miles northeast of Torrecillas, about 38 miles east of Laredo and 100 miles from the Gulf, and from this point it extends southwestward to Torrecillas, thence southward to Ojuelos, and thence in a somewhat irregular course, generally southward and a bit eastward, and is cut through by the Rio Grande at Rio Grande City. In general the scarp follows the course of the base of the Reynosa formation, whose resistant rocks

${ }^{3}$ Hill, R. T., and Vaughan, T. W.; Geology of the Edwards Plateau and Rio Grande Plain adjacent to Austin and San Antonio, Tex.: U. S. Geol. Survey Eighteenth Ann. Rept., pt. 2, pp. 193-322, 1898. produced it. As the land slopes steeply westward and almost imperceptibly eastward from its crest this scarp is conspicuous only if viewed from the west.

The area between the breaks of the Rio Grande and the Bordas scarp is not rough. Its gentle southward and eastward (Gulfward) slope is broken only by shallow valleys of the heads of tributaries of the Rio Grande, the many low hills due to the outcrops of the lenses of rock slightly more resistant to subaerial erosion (which is here of slight effect), and the scattered depressions scooped out by the wind and the corresponding slight elevations formed by material blown from the depressions. Few square miles in this plain have a relief of as much as 50 feet, and some of them, so far as the eye can see, are almost flat.

Except an area of sand dunes, which covers about 2,800 square miles, chiefly in Willacy, Brooks, Hidalgo, and Jim Hogg counties, and a narrow strip extending for 20 miles along the river between Rio Grande City and Sam Fordyce, the part of the region east of the Bordas scarp is notably flat. . The areas near the scarp, however, are slightly more undulatory than the areas near the coàst, where the surface generally stands less than 50 feet above sea level and where there is no visible relief except that produced by an occasional "clay butte" or a shallow stream channel or "resaca." This smoothness, however, is broken by the channel of the Rio Colorado, a distributary of the Rio Grande, which in places is 40 feet deep and has vertical walls.

In the sand belt the relief is measured by the heights of the dunes and the depths of the "blow-outs,." but even there it does not exceed 25 feet on an average and 60 feet at a maximum.

The lower. Rio Grande region, which is the southernmost part of the. United States except southern Florida and the Florida Keys, receives much heat through insolation, and its temperature is therefore high. 'The average annual temperature is about $72^{\circ} \mathrm{F}$., and the range is from $20^{\circ}$ in January to $110^{\circ}$ in July. The sensible heat of summer is greatly reduced by constant east winds of the monsoon type. The nights are comfortable, except a few during which cloudiness retards radiation and the wind dies down." The region is semiarid. There are long periods of drought, and when it does rain the water falls in great quantities, so that diry creek beds run full and roads become arroyos. 
The rainfall in 1910 was 12 inches, in 191516 inches, and in 191614 inches. The rainfall at Eagle Pass in 1.908 was 15.16 inches and in 1909 8.63 inches. At some places there was no rain at all for three years prior to the fall of 1918 .

The vegetation, which varies in luxuriance with the rainfall, consists of wild grasses, mesquite, guajillo, catclaw, prickly pear, and other forms of cactus, and many other plants, which together make up what is known as chaparral or brush. Large trees are found only along the main streams, where pecans grow, and on dunes in the sand belt, which bear live oaks. The open grassy prairie on the coastal flats is broken here and there by dense thickets of low live oak brush.

\section{STRATIGRAPHY.} GENERAL FEATURES.

The beds of rock dip at low angles Gulfward from the Cretaceous-Eocene line, and successively younger formations are therefore exposed at the surface in wide belts east and southeast of that line. The Rio Grande flows in general southeastward in a course that is oblique to the strike of the formations but that is at some places parallel with the strike and at others parallel with the dip. It flows from older to younger beds, but its gradient is so slightly less than the dip of the beds and so nearly parallel with the strike for considerable distances that the formations change only at intervals of many. miles along the river.

The formations are of Tertiary and Quaternary age. Eocene formations, which lie unconformably on Cretaceous formations along the irregular north boundary, continue at the surface enstward along the Texas-Mexican Railroad as far as.Torrecillas and southward and southeastward along the Rio Grande almost to Sam Fordyce. Oligocene and Miocene formations, which are exposed on the Gulf Coastal Plain farther north, do not outcrop in the lower Rio Grande region, the Oligocene probably because they do not exist here and the Miocene because they are covered by a great overlap of Pliocene rocks. Pliocene, Pleistocene, and Recent deposits are exposed at the surface over wide areas east of the Bordas scarp. (See Pl. XXVIII.)

\section{CRETACEOUS SYSTEM.}

Rocks of Cretaceous age crop out extensively in the Edwards Plateau, in the northern part of the Gulf Coastal Plain, and elsewhere in Texas, and form a great system, but these areas lie outside of the region here described. This system in Texas has long been well known, chiefly through the earlier work of R. T. Hill. ${ }^{4}$ More recently Udden ${ }^{5}$ and his assistants have published a summary of the geology of Texas, in which the Cretaceous rocks are classified, described, and interpreted, and L. W. Stephenson is now completing certain work north of the Cretaceous-Eocene line.

\section{THE CRETACEOUS-EOCENE IINE.}

As Stephenson ${ }^{6}$. has recently reported on the contact between the rocks of the Cretaceous and the Tertiary system in the lower Rio Grande region, the writer gave relatively little attention to this line of stratigraphic division. The line is shown on the map essentially as it was drawn by Stephenson, and the contact, at least between the Rio Grande and Nueces River, is essentially as he describes it. There is no marked lithologic break at the contact, though Stephenson found evidence of physical unconformity in Texas, as did Baker ${ }^{7}$ on the Mexican side of the border, but the systemic significance of such unconformities is difficult to recognize, especially in parts of the geologic column where locally unconformities are common. The faunal break, however, is great and its significance is unquestionable. Not a single species is common to the faunas below and above the break and many genera that occur in the Cretaceous are missing in the Eocene. As Vaughan ${ }^{8}$ pointed out in 1900 , it is clear that the unconformity at this horizon is really great, even though lithologically and stratigraphically it appears insignificant. In the Rio Grande region a long time must have elapsed between the end of the recorded Cretaceous and the beginning of the recorded Eocene.

TERTIARY SYSTEM.

EOCENE SERIES.

The history of Eocene classification in the West Gulf Coastal Plain has been long and complicated. Many synonymous and overlapping formation names have been used, and correlations have been made whịch have later been

4 Hill, R. T., The Texas section of the American Cretaceous: Am. Jour. Sci., 3d ser., vol. 34, pp. 287-309, 1887.

${ }^{\circ}$ Udden, J. A., Baker, C. L., and Böse, Emil, Review of the geology of Texas: Texas Univ. Bull. 44, 1916.

o Op. cit., pp. 169-181.

7 Baker, C. L., personal communication.

8 Vaughan, T. W., Reconnaissance in the Rio Grande coal felds' of Texas: U. S. Geol. Survey Bull. 164, pp. 35-36, 1900. 
found to be incorrect. The following classification seems to represent the present knowledge of the Eocene series in this region:

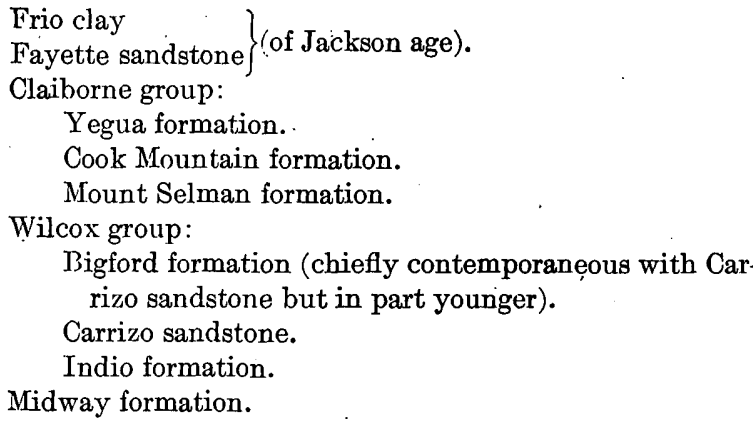

These formations are lithologically so very similar that their discrimination as units in mapping is extremely difficult, and the lines of contact shown on the map should therefore be considered only tentative, though there are slight differences in the rocks, which, taken together with their more significant faunas and floras make it possible to separate the formations with some confidence.

\section{MIDWAY FORMATION.}

Distribution.-The formation once known as the "Basal or Wills Point clays," now called the Midway formation, crops out only in a short and narrow belt in southern Maverick County. Its outcrop is not a continuous belt along the Cretaceous-Eocene line of contact, for it is overlapped in' southern Uvalde', western Zavalla, and northeastern Maverick counties by strata of Wilcox age. The outcrop is also obscured by patches of gravel belonging to the Reynosa formation, of probable Pliocene age.

Relations to adjacent formations. - The Midway formation lies disconformably on the Escondido formation of the Cretaceous system. There is also a great time break at this horizon and another at the top of the Midway, where it is overlapped by strata of Wilcox age. The unconformable contact between the Midway below and the Wilcox above is well exposed (1) at the north end of the westward-facing bluff of the Rio Grande in extreme southern Maverick County, 2 miles north of the Webb County line, and (2) on the west wall of the valley of Frio River at Bob Evans's apiary (Myrick's lower apiary of the Uvalde folio), in Uvalde County, 12 miles east of the Rio Grande region, as mapped in this report. In each of these sections the line between the Midway and Wilcox formations is the edge of an erosional surface and the basal Wilcox is conglomeratic, the pebbles being worn fragments, fossils, and concretions of 'iron carbonate derived from the underlying Midway. There is a great unconformity between the Midway and the Reynosa, the gravels of the Reynosa having been deposited on a surface which bevels the Midway and all other Eocene strata.

Character.-The Midway formation consists chiefly of shale, but includes interbedded lenses and layers of sandstone and limestone. At the base of the formation in some places there are thin and discontinuous beds of conglomerate containing abraded fragments of rock and fossils derived from the underlying Escondido formation. Heavy ledges of limestone overlie the conglomerate or form the basal bèds when there is no conglomerate. The limestone is gray, compact, and in some places crystalline, and it contains fossils. The beds are at few places more than $1 \frac{1}{2}$ feet thick and are interbedded with greenish-gray sand 1 to 2 feet thick. The shale is generally dark, and some beds are black, but the colors include green, brown, gray, bluish gray, and blue. Some of the beds are notably pure, but many are sandy or silty and gypsiferous. Individual beds do not exceed 40 feet in thickness. The beds of sandstone are gray, yellowish, brownish, or greenish, and are irregularly and thinly bedded. Many are micaceous and some are glauconitic. Most of them are rather soft, but some are firm. They vary in texture but are generally fine grained. Throughout the formation, but chiefly in the shale, there are numerous concretions, which range in diameter from 6 inches to 10 feet, are generally flat or biscuit-like, and consist chiefly of limestone. Many are septaria or "turtle stones." Some of the smaller ones 'are pyritized, some are clay ironstones, and some consist of iron carbonate.

A typical section of the formation on the Texas side of the Rio Grande, a mile below the Blessé ranch, on the Mexican side, is given below:

Section of the Midway formation in Texas near the Blessé ranch, Mexico.

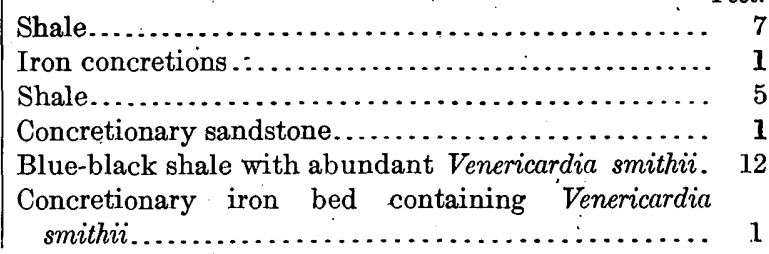


Dark-gray shale containing disc-shaped iron concretions and a few gastropods..................... 25 Thin and irregularly bedded sandstone, interbedded near the top with sandy shale.

Thickness.-As the dip of the Tertiary formations may not be entirely deformational but may have been in part original, the usual methods of determining thickness from the outcrops are of no great value. In any case, the Midway formation is probably nowhere exposed in its full thickness because of the Wilcox overlap. Only where it has been drilled through for oil or water and where its base and top can be determined from the log or from samples, of the core can its true thickness be estimated. Only one such boring is known in the Rio Grande region-the L. E. Hanchett oil-prospecting well, 10 miles west of Carrizo Springs. The $\log$ of this well shows that the formation is 194 feet thick. The average of all estimates of its thickness outside of the Rio Grande region but near it is 216 feet.

Fossils.-The fossils collected from the Midway formation of this and neighboring districts by the writer and others are listed below:

Aporrhais sp.

Callocardia ripleyana (Gabb).

Calyptrophorus velatus subsp. compressus Aldrich.

Cerithium penrosei Harris.

Cerithium? sp.

Crassatellites gabbi (Safford).

Cucullaea (macrodonta subsp.?) texana Gardner.

Cypraea sp.

Enclimatoceras vaughani Gardner.

Fusus ostrarupis Harris.

Leda milamensis Harris.

Lithophaga sp.

Mesalia pumila subsp. wilcoxiana Aldrich.

Mesalia sp.

Modiolus saffordi (Gabb)?

Natica sp.

Ostrea crenulimarginata Gabb.

Ostrea pulaskensis Harris.

Plejona limopsis (Conrad).

Plejona rugata (Conrad).

Pseudoliva ostrarupis Harris.

Teredo maverickensis Gardner.

Turris anacona (Harris).

Turritella alabamiensis Whitfield.

Turritella humerosa Conrad.

Turritella mortoni Conrad.

Turritella nerinexa Harris.

Venericardia bulla Dall.

Venericardia (alticostata subsp.?) hesperia Gardner.

Venericardia smithii Aldrich.

Venericardia (alticostata subsp.?) whitei Gardner.

Yoldia eborea (Conrad).
WILCOX GRŌ̃P.

SUBDIVISION.S.

A thick set of lithologically complex beds lies stratigraphically between the top of the Midway and the base of the Mount Selman formation. These beds have been variously known as the "Lignitic," the "Sabine," the "Sabine River," and the "Timber Belt," each of these names including all strata between the top of the "Basal clays" (Midway formation) and the base of the "Marine beds" (Claiborne group). Owen ${ }^{9}$ first segregated a notably sandy phase of the "Lignitic" and called it the Carrizo sandstone, from the town of Carrizo Springs, where it is characteristically developed and well exposed. After the upper sands were separated and named the underlying beds were correlated with the Wilcox of Mississippi and called by the same name. Vaughan ${ }^{10}$ considered the Carrizo formation a transgressive phase of the Wilcox. More recently Udden, Baker, and Böse ${ }^{11}$ have tentatively considered it the oldest formation of the Claiborne group. In a still later geologic publication of the University of Texas Liddle ${ }^{12}$ placed the Carrizo of Medina County in the Claiborne group without qualification. Deussen ${ }^{13}$ found that it lay unconformably on Wilcox beds and unconformably beneath the Mount Selman formation between Brazos and Nueces rivers, and Baker ${ }^{14}$ reported an unconformity between the Carrizo and underlying beds of Wilcox age on the Arroyo del Amole, on the Mexican side of the Rio Grande, across the river from the Chupadero ranch. As unconformities are common in the Wilcox and as neither the Wilcox nor the Carrizo contains fossils other than plants that had not been critically studied, the age of the Carrizo sandstone was an open question until 1921, when fossil plants were collected under the direction of $\mathrm{E}$. W. Berry from the lower beds of the Wilcox, from the Carrizo, and from beds above the Carrizo but below the Mount Selman. As a result of these studies of the flora and an investigation of the lithology of the lignitic beds, the Wilcox is here recognized as

Owen, J., Report of geologists for southern Texas: Texas Geol. and Min. Survey First Rept. Progress, for 1888, pp. 69-74, 1889.

10 Vaughan, T. W., Index to the stratigraphy of North America (by Bailey Willis and others): U.S. Geol. Survey Prof. Paper 71, p. 726, 1912. 11 Op. cit., pp. 83-84.

12 Liddle, R. A., The geology and mineral resources of Medina County: Texas Univ. Bull. 1860, pp. 87-93, 1918 [1921].

${ }^{13}$ Deussen, Alexander, Geology of the Coastal Plain region of Texas U. S. Geol. Survey Prof. Paper 126 (in press).

14 Baker, C. L., personal communication. 
a group, consisting of three formations, here named, in ascending order, the Indio formation, the Carrizo sandstone, and the Bigford formation.

INDIO FORMATION.

Name.-The strata overlying the marine Midway formation and underlying the Carrizo sandstone are here called the Indio formation: These strata have until now been known as the Wilcox formation, for they were believed to represent all the deposits of Wilcox age in this region. The new formation name is made necessary by the fact that the Wilcox as here developed becomes a group divisible into three formations, of which the Indio is the basal one. The Indio formation is named from the old Indio ranch, in Maverick and Dimmit counties, which includes most of the area of outcrop of the formation.

Character.-Although it is made up of an intricate mixture of sediments, the Indio formation consists chiefly of thin-bedded and laminated argillaceous sand and arenaceous shale but includes some layers of massive clay and lenses and layers of sandstone. The clay and shale are greenish or bluish gray and light chocolate-brown, and most of them are gypsiferous. The sandstone is gray, yellow, green, and brown, is not notably cross-bedded, and is of various textures. It includes also some beds of lignite and many calcareous and arenaceous concretions, most of them flat, biscuitshaped, or millstone-shaped bodies.

Until recently no marine sediments have been found in the Wilcox group except along Sabine River, but the discovery of marine Foraminifera between 125 and 148 feet from the surface and 500 feet above the base of the Indio formation in the L. E. Hanchett oil drillings Nos. 1 and 2, about 10 miles west of Carrizo Springs, in Dimmit County, ${ }^{15}$ shows that the Gulf advanced over the low-lying lands at least once for a short time during the Indio epoch. Beds of Ostrea tasex Gardner also are known west of the Hanchett wells and at and south of the Glass ranch headquarters, in Maverick County, and in the San Pedro sheep pasture, 19 miles southwest of Carrizo Springs, in Dimmit County. This form is similar to O: crenulimarginata, which is of Midway age, but is not identical with it. The oysters

15 Well $\log$ and description of samples.supplied independently by J.A Udden and C. L. Baker. and the Foraminifera appear to occur at the same horizon.

The formation is partly marine and partly nonmarine and was deposited on both sides of a shore line on the landward side of which the land was low and on the opposite side of which the sea was shallow. The shore line probably oscillated back and forth slowly during Indio time.

Distribution.-The Indio formation crops out in the Rio Grande region in a belt 10 to 14 miles wide in western Dimmit, southeastern Maverick, and northwestern Webb counties, where it is exposed in practically its full thickness. Here it adjoins the Midway on the west and the Carrizo on the east. Farther north, in Maverick County, the Indio overlaps the Midway and rests upon the Cretaceous. Still farther north, in western Dimmit and Zavalla counties and eastern and northeastern Maverick County, the Indio is in turn cut out by a great overlap of the Carrizo on the Cretaceous. In the extreme northeast corner of the region the Indio crops out again between the Cretaceous and the Carrizo where Nueces River has cut through the overlying and overlapping Carrizo sandstone.

Thickness.-The thickness of the Indio recorded in the Hanchett wells, in Dimmit County, is 648 feet, and as these wells are only about a mile west of the eastern boundary of the formation at a point where the belt of outcrop is widest, the maximum thickness of the Indio exposed probably does not exceed 700 feet. Other layers that are covered by the Carrizo overlap may or may not overlie those which crop out.

Fossits.-With the exception of Foraminifera, oysters, and a few fossil leaves, the Indio formation is faunally and florally barren in the Rio Grande region. The protozoans include Nodosaria, Textularia, and Globigerina. The mollusks are Ostrea tasex Gardner and Levifusus sp. cf. L. trabeatoides Harris.

Fossil plants were found (1) on the west wall of the valley of Nueces River a mile below Pulliam ranch, (2) on the east wall of the valley of Nueces River at the big bend $1 \frac{1}{4}$ miles above the Uvalde-La Pryor road crossing, (3) in the clay pit at the end of the unused aerial tram south of Elmendorf, Bexar.County, and (4) at the Schuddemagen ranch, 10 miles south of Sabinal, Uvalde County. Localities 3 and 4 . 
are outside the Rio Grande region. A list of | crystallized into a good grade of quartzite. identified species follows:

Anona ampla Berry.

Anona eolignitica Berry.

Cyperites sp. Hollick.

Ficus mississippiensis Berry.

Nectandra sp.

Oreodaphne obtusifolia Berry.

Rhamnus coushatta Berry.

Sabalites grayanus Lesquereux.

. Sapindus linearifolius Berry.

CARRIZO SANDSTONE.

Distribution.-The base of the Carrizo was located by Owen ${ }^{10}$ at a point 10 miles west of Carrizo Springs, and the formation, which is made up of sandy beds, extended eastward to the base of the "Marine beds," east of Asherton, occupying a belt about 20 miles wide. When it.is traced southward, however, the belt of sands becomes narrower until, at the Rio Grande, it is only 3 miles wide. The strata that cover it here are not prevailingly sandy. and are what is here called the Bigford formation. North of Carrizo Springs the Carrizo formation spreads northwestward to the Cretaceous rocks, overlapping both the Indio and the Midway. Northeast of Carrizo Springs, outside the region shown on the map, the belt of Carrizo sandstone becomes narrower, the Bigford formation here also probably wedging in between the Carrizo and the Mount Selman.

Relations to adjacent formations.-The Carrizo sandstone rests unconformably upon the Indio by overlap. In the area east of the outcrop of the contact, however, where the full thickness of the Indio is represented, the similarity of the flora indicates that the relations are conformable. The relation between the Carrizo and the Bigford formation is apparently conformable. Differences in flora suggest a break between the Carrizo and the Mount Selman, and there are indications of unconformity where the two come together in the railroad cut 3 miles west of Big Wells, an exposure 15 miles east of the Rio Grande region.

Character.-The Carrizo formation is decidedly more sandy than the other formations of the Wilcox group, the Indio formation below and the Bigford formation above, and the beds of sandstone in the Carrizo are more firmly cemented. Some of them are cemented and

10 Owen J., Report of geologists for southern Texas: Texas Geol. and Min. Survey First Rept. Progress, for 1888, pp. 70-74, 1889. Many of them are highly ferruginous, but some are gray or white, colors denoting little iron. The sand and the sandstone are characteristically cross-bedded. Owing to inequalities from place to place in the firmness of the cement erosion has in some places produced castellated forms, notably south of Chupadero ranch, in northwesternmost Webb County. The sandy beds vary greatly in texture. "In the quarries around Carrizo Springs and for some distance north of that place the rock is fine grained, but in many other localities it is medium and even coarse grained.

The Carrizo sandstone includes also thin beds and lenses of clay of various colors and beds of limestone, yellow on weathered surfaces and light chocolate-brown inside, forming concretions, rough beds, or lenses, botryoidal bodies, and irregular masses. Cone-in-cone structure is fairly common in the beds of fine texture in which calcareous and argillaceous material are mixed in about equal proportions.

Thickness.-The thickness of the Carrizo sandstone as estimated by Owen ${ }^{17}$ is 200 feet. Between a point 10 miles west of Carrizo Springs and a point 3 miles west of Big Wells, however, its thickness is probably more than 400 feet, there being at least 200 feet of strata exposed west of Carrizo Springs. At the Rio Grande, where the sandy belt is narrow, its thickness is estimated at 118 feet. At another point between the river and Carrizo Springs it appears to be about 392 feet. Where the Carrizo overlaps the Indio and Midway north of Carrizo Springs it is doubtless very thin. The average of all previous estimates is 250 feet. It evidently varies greatly in thickness, and the average is now put at 325 feet.

Fossils.-Invertebrate and vertebrate fossils have not been found in the Carrizo sandstone. Poorly preserved fragments of plants have often been noted, but the flora was not critically studied until 1921, when E. W. Berry accompanied the writer to the field and made collections. Identifiable leaves were found in a short arroyo in the east wall of Nueces River valley three quarters of a mile below the Uvalde-La Pryor road crossing and in the Bell quarries, southwest of Carrizo Springs, from which Carrizo sandstone was taken to build the courthouse and other buildings in Carrizo Springs.

17 Owen, J., idem, p. 72. 
The list given below shows, according to Berry, that the Carrizo is of Wilcox and not of Claiborne age, a fact which is in harmony with the lithology and stratigraphy of the sandstone and the associated beds.

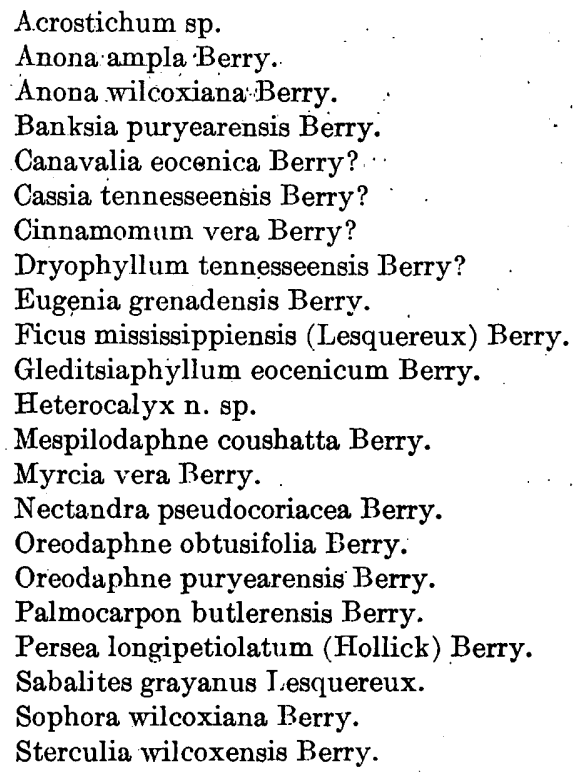

Name and distribution.--Most of those who have visited this region have believed that the Carrizo sandstone is continuous from the top of the Indio formation (the old Wilcox formation) to the base of the Mount Selman, and it appears to be continuous at the type section of the Carrizo near Carrizo Springs and in that latitude, but south of Carrizo Springs the sand and sandstone of the Carrizo give place along the strike to clay, thin-bedded sandstone, and lignite. To these beds, which consist so largely of clay that they can not be called Carrizo sandstone, the name Bigford is here given, from Bigford ranch, which is practically the only habitation in their belt of outcrop, where the beds are well exposed along the river within the ranch. The outcrop widens toward the south from 2 miles at the boundary of the Rio Grande region, southeast of Carrizo Springs, to about 12 miles at the Dimmit-Webb county line. The Rio Grande has exposed the beds in its north bluffs for 20 miles. Between Carrizo Springs and Big Wells, outside of the Rio Grande region, the formation is entirely absent. It may wedge in farther north, for similar beds appear to occur in well logs and in exposures along Nueces River southeast of Crystal City.
Character.-Lithologically the Bigford formation consists chiefly of clay of many colors and of subordinate quantities of gray, green, and brown sandstone, which is at most places not cross-bedded. It contains many beds of lignite, the heaviest 20 inches thick, and some lens-shaped concretionary masses. It contains no paper shales and sands, such as occur in the Indio, nor any thick, cross-bedded, and commonly quartzitic sands, such as occur in the Carrizo.

Relations to adjacent formations.-Although the Bigford formation is at least fairly distinct lithologically, it is not believed to represent, except in its uppermost part, a period of time entirely separate from the Carrizo epoch. The greater part of the formation probably grades along the strike into beds in the middle and upper parts of the Carrizo sandstone, and if so is contemporaneous with those beds. At some places, however, the uppermost part of the Bigford rests with apparent conformity on the Carrizo sandstone. The Bigford strata appear to represent a lagoon and tidal-flat phase of a stage of deposition during which the Carrizo sandstone was deposited at or landward from the shore line.

Thickness.-The Bigford formation ranges in thickness from about 80 to about 470 feet.

Fossils.-The only fossils found in the Bigford formation are some leaves of a few species of plants, which were collected at a place on Concillas Creek a quarter of a mile below the point where it is crossed by the road from Bigford ranch to Apache ranch, about half a mile from the Rio Grande, where two sets of beds of clay, sandstone, lignite, and lignitic clay are separated by an erosional unconformity. Leaves occur both below and above the unconformity but were collected only from the upper set of beds, in which they are best preserved. The forms identified are as follows:

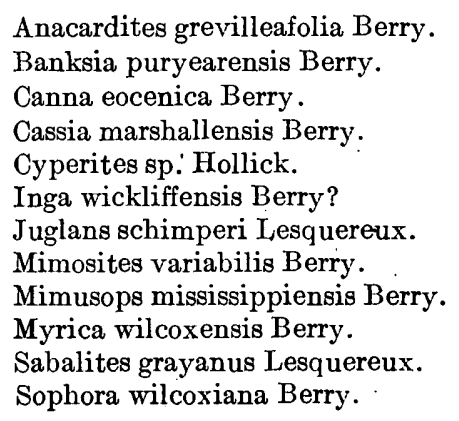


Berry reports that this is a Wilcox flora, one distinctly older than that in the base of the Mount Selman formation, which is of Claiborne age.

CLAIBORNE GROUP.

The "Marine beds" of earlier writers included the strata between the top of the "Lignitic" and the base of the Yegua. These beds are now separated into two formations, the almost unfossiliferous marine beds below constituting the Mount Selman formation and the highly fossiliferous marine strata above constituting the Cook Mountain formation. The overlying Yegua formation, which contains Claiborne fossils, is also included in the Claiborne group.

$$
\text { MOUNT SELMAN FORMATION. }
$$

Character.-The chief constituent of the Mount Selman formation is clay, and exposed sections of it are therefore rare except at places along drainage lines where thin ledges of sandstone and limestone hold up the clay in vertical faces. There are large flat areas where the formation is not exposed but where the shallow surficial drainage channels are so universally clayey that the underlying formation must be chiefly if not entirely clay or shale. The sections exposed probably exaggerate the proportion of sandstone in the formation, for they occur only where lenses of the more resistant materials are most abundant. The clay is gray, black, greenish gray, and bluish gray where fresh and yellow or buff where weathered. Some of the beds are sandy and some are limy, but most of them consist chiefly of stiff, compact clay, plastic and sticky when wet and hard but with a fracture like that of starch when dry. The beds of clay contain a large quantity of gypsum in lenses, beds, stringers, joint fillings, and irregular crystal aggregates. Most of it is the transparent platy variety, but some masses of bladed crystals are brown.

The sandstone occurs in layers and lenses, some of them 25 or 30 feet thick for short distances. The sand is coarse, medium, and fine, most of it is micaceous, and some is glauconitic. The beds are fairly well consolidated but are not quartzitic. The formation includes a few thin lenses of gray limestone.

Coal, both lignitic and bituminous, is a common constituent of the Mount Selman $91.048^{\circ}-23-7$ formation. It has been mined at Minero, Dolores, Cannel, and Santo Tomas, in Webb County. There are two main producing coal beds and several thinner beds, less pure, which are not worked. The coal beds here are about one-third of the distance from the top to the bottom of the formation, but beds occur nearer its base upstream from Palafox and almost at its top near the mouth of Arroyo Santa Isabella, and well logs show that coal beds occur throughout the whole thickness of the formation.

The Mount Selman formation contains throughout, from bottom to top, many calcareous concretions, chiefly in the clay and shale. Most of them are composed of compact, fine-grained, pure, almost lithographic limestone. On the outside they are pale yellowish gray or buff; on the inside they are light chocolate-brown or gray. Nearly all of them are septarian, and the fractures are filled with calcite. They are of diverse sizes and forms. The smallest are about the size of a pea and the largest are 6 feet in diameter; some are cylindrical, resembling pipe stems, some are biscuit-shaped, and some are nodular and extremely irregular: The average concretion is a foot in diameter and spheroidal in form.

Distribution.-The surficial distribution of the Mount Selman formation is shown on the map. The formation extends downstream along the Rio Grande from a point 6 miles above Palafox to the mouth of Sambarieto Creek, about 8 miles above Laredo, a distance of about 26 miles measured in a straight line. The course of the river is irregularly oblique to the strike, however, and this distance is not a measure of the width of the belt of outcrop, which is about 16 miles wide and of nearly uniform width. The western boundary of the formation, which is the Claiborne-Wilcox line of contact, is not sharply defined. In general it marks the line that separates beds of clay, sandstone, and lignite that contain no molluscan fossils and few concretions but that carry a Wilcox flora (the Bigford formation), from beds of gypsiferous, highly concretionary clay interbedded with beds of sandstone and limestone carrying unmistakable though few and fragmentary marine fossils. The Mount Selman-Cook Mountain line, on the east side of the belt, separates the Mount Selman material 
from the sandy, highly fossiliferous, redweathering Cook Mountain formation, which to stratigraphically overlies the Mount Selman.

The Mount Selman formation, though it contains marine rock, is evidently not entirely of marine origin. The coal and the sediments that carry land plants were doubtless deposited in isolated coastal basins and lagoons and perhaps to some extent on tidal flats.

Thickness.-The minimum measured thickness of the formation is 225 feet and the maximum is 707 . Deussen assigns to it an average thickness of 350 feet in the area next north of the Rio Grande region. The average within the Rio Grande region is 618 feet.

Fossils.-The Mount Selman formation is not highly fossiliferous, yet a few poorly preserved forms of both animals and plants have been recognized. The mollusks so far recognized are Cornulina armigera Conrad, Cytherea sp. cf. C. trigoniata var. winnensis Harris, Ostrea sp., Plejona petrosa (Conrad), Protocardia sp., and Venericardia planicosta Lamarck.

Only two collections of Mount Selman plants were made by the writer. They are fragmentary and obscure, but Berry has identified them provisionally as Apocynophyllum grevilleafolium Berry, Coccolobis claibornensis Berry, Ficus newtonensis Berry, Geonomites n. sp., and Myrcia n. sp.

\section{COOK MOUNTAIN FORMATION.}

Distribution and relations.-The Cook Mountain formation is the upper and highly fossiliferous part of what has been known as the "Marine beds." Its outcrops lie in a belt averaging 13 miles in width where it includes the full thickness of the formation, extending from the northeast border of the region at and west of Encinal, almost due south for about 40 miles to a point where the base of the formation is cut off by a bend in the Rio Grande 8 miles above Laredo. From this point for a distance of about 70 miles down the river the strike of the formation is almost parallel to the general course of the river. The river cuts the top of the formation-the Cook Mountain-Yegua line-15 miles upstream from Roma. Thus the formation is exposed in the "breaks of the Rio Grande" for a distance of 75 miles. The towns included within the belt of outcrop are Encinal, Laredo, San Ygnacio, Zapata, and a large number of places inhabited by Mexicans.
This change in the strike from west of south to east of south so as almost to correspond with the course of the Rio Grande from Laredo to Roma was not known to all previous workers. Dumble ${ }^{18}$ for instance, continuing the west of south by east of north strike, draws the Cook Mountain-Yegua contact line across the river 8 miles below Laredo, the Yegua-Fayette line about 4 miles above Zapata, and the FayetteFrio line on the Texas side a mile or two below Rio Grande City. The true structure was first pointed out by Vaughan, ${ }^{19}$ who had collected Claiborne fossils far down the Rio Grande and understood that they came from the "Marine beds." Thus much of what Dumble has considered Fayette was recognized by Vaughan as Cook Mountain. This fact explains Dumble's insistence that much if not all of the Fayette formation is of Claiborne age.

Character.-The Cook Mountain formation is primarily sandy, and the sand is more or less firmly cemented. Most of the rock is medium grained, but there are beds of fine-grained and coarse-grained sandstone. The beds are brown, red, yellow, green, and gray and are commonly ferruginous, micaceous, and glauconitic. Many of them are cross-bedded and ripple marked. Interbedded with the sandstone is some yellowish, bluish, and greenishgray or chocolate-colored clay and a few thin lenses of gray limestone. The sandstone and at some places the clay contains large, darkgray, hard-centered, crystalline limestone concretions, some of which are fossiliferous. The lower two-thirds of the formation weathers characteristically into red sandy soils; the upper third at most places weathers gray. All the soils derived from the Cook Mountain formation support vegetation, which is unusually luxuriant.

Thickness.-The estimates of the thickness of the Cook Mountain formation range from 187 to 668 feet, and average 422 feet.

Fossils.-The formation everywhere contains abundant fossils, by which it can be distinguished from the Mount Selman below and the Yegua above; indeed it can thus be distinguished from all other formations in the region, for its faunas are larger and more

18 Dumble, E. T., Geology of Southwestern Texas: Am. Inst. Min. Eng. Trans., vol. 33, p. 916, fig. 1, 1903.

19 Vaughan, T. W., Contributions to the geology and paleontology of the Canal Zone, Panama, and geologically related areas in Central America and the West Indies: U. S. Nat. Mus. Bull. 103, 1919. 
diversified than those of any other Tertiary formation in Texas. The faunas within the formation present four more or less distinct facies.

One of these faunas is found at the base of the formation. The complete specific list is as follows:

Anomia ephippoides Gabb.

Buccinanops sp. cf. B. ellipticum Whitfield.

Callocardia astartoides Gardner.

Callocardia sp. cf. C. bastropensis (Harris).

Callocardia sp.

Cerithium texanum Heilprin.

Cerithium webbi Harris.

Corbula (Cuneocorbula) conradi Dall.

Drillia? sp.

Egerella sp.

Epitonium sp.

Lacinia alveata Conrad?

Leda sp.

Levifusus trabeatoides Harris?

Levifusus sp.

Lucina sp.?

Natica dumblei Heilprin.

Olivula staminea Conrad.

Olivula sp.

Ostrea alabamiensis subsp. georgiana Conrad (small). Polynices arta (Gabb)

Pseudoliva vetusta Conrad.

Sinum declivum Conrad?

Solen sp.

Tuba antiquata Conrad.

Turritella sp.

Venericardia planicosta (Lamarck).

Yoldia sp. cf. Y. psammotea Dall.

A second fauna occurs in the lower part of the Cook Mountain formation but above the basal beds. A complete list of species follows:

Acteon pomilius Conrad.

Adeorbis? sp.

Anomia ephippoides Gabb.

Architectonica sp. aff. A. acuta Conrad.

Benoistia? sp.

Cadulus sp.

Callocardia astartoides Gardner.

Callocardia bastropensis (Harris).

Callocardia sp.

Cancellaria panones Harris.

Cancellaria sp.

Cardium (Cerastoderma) harrisi Vaughan?

Cardium (Cerastoderma) ouachitense Harris?

Cassis? sp.

Cerithium sp.

Cochlispira sp.

Corbula (Cuneocorbula) conradi Dall.

Crassatellites sp.

Crepidula sp.

Cylichna sp. cf. C. jacksonensis Meyer.

Drillia nodocarinata (Gabb)?

Drillia texacona Flarris.
Egerella sp.

Epitonium trapaquara (Harris).

Eucheilodon sp. cf. E. reticulatoides Harris.

Eucheilodon? sp.

Lacinia alveata Gabb.

Latirus moorei Gabb?

Leda bastropensis Harris.

Leda compsa Gabb.

Lima harrisiana Aldrich.

Lucina sp. cf. L. ozarkana Harris.

Mesalia claibornensis Harris.

Murex (Odontopolys) sp.

Natica dumblei Heilprin (large).

Natica semilunata Lea.

Nucula mauricensis Harris.

Olivula staminea Conrad.

Ostrea alabamiensis subsp. georgiana Conrad (small).

Ostrea sellaeformis Conrad?

Ostrea sp.

Pholadomya sp.

Plejona petrosa (Conrad).

Plejona precursor (Dall)?

Plejona sp. cf. P. haleiana (Whitfield).

Plejona sp.

Polynices arata (Gabb).

Protocardia sp. cf. P. gambrina Gabb.

Pseudamusium sp.

Pseudoliva sp. cf. P. vetusta Conrad.

Pteropsis lapidosa Conrad.

Pyrula (Fusoficula) sp. cf. P. texana Harris.

Sinum declivum (Conrad).

Solen sp.

Surcula gabbi Conrad.

Teinostoma? sp.

Tellina mooreana Gabb?

Tellina sp. A.

Terebra texagyra Harris.

Terebra houstonia Harris.

Tornatina sp.

Tortoliva texana Conrad?

Tuba antiquata Conrad?

Turbonilla? sp.

Turricula sp.?

Turris sp.

Turritella nasuta Gabb.

Venericardia mooreana (Conrad).

Volvula sp.

Yoldia sp. cf. Y. psammotea Dall.

Yoldia sp.

The middle part of the Cook Mountain formation carries a third fauna, the names of the species of which follow:

Ancillaria sp.

Architectonica sp.

Callocardia astartoides Gardner.

Callocardia bastropensis Harris.

Callocardia sp.

Cancellaria sp.

Cerithium texanum Heilprin.

Corbula (Cuneocorbula) conradi Dall.

Corbula sp.

Diplodonta sp. 
Distorsio septemdentata Gabb.

Drillia sp. cf. D. enstricina Harris.

Egerella sp.

Fusus sp.

Gaza? sp.

Lacinia alveata Conrad.

Latirus moorei Gabb?

Leda bastropensis Harris.

Levifusus sp.

Lucinia? sp.

Martesia sp.

Mesalia claibornensis (Conrad)?

Modiolus (Brachidontes) texanus (Gabb).

Natica dumblei Heilprin (large).

Natica dumblei Heilprin (small).

Natica semilunata Lea.

Olivula staminea Conrad?

Ostrea alabamiensis subsp. georgiana Conrad.

Ostrea sp.

Phos sagenus (Conrad)?

Pinna sp.

Plejona petrosa (Conrad).

Plejona sp.

Polynices arata (Gabb).

Psammobia? sp.

Pseudoliva ostrarupis subsp. pauper Harris.

Pseudoliva vetusta Conrad?

Pteropsis Japidosa Conrad subsp.?

Pteropsis sp.

Pyrula texana Harris?

Rimella sp. cf. R. texana Harris.

Siliqua sp.

Sinum declivum (Conrad)?

Sphaerella sp.

Surcula gabbi Conrad?

Teinostoma? sp.

Tellina sp. cf. T. mooreana Gabb.

Tellina sp. cf. T. tallecheta Harris.

Tellina sp. A?

Trinarcia declivis (Conrad).

Turris vaughani (Harris).

Turris sp.

Turritella nasuta Gabb.

Venericardia mooreana Gabb.

Venericardia sp.

Finally, a fourth Cook Mountain fauna is widely distributed at the top of the formation. This fauna marks the Cook Mountain-Yegua contact. The most prominent forms are a large variety of Natica dumblei, which is associated with Ostrea georgiana. Most of this fauna is contained in the limestone concretions, not all of which, however, carry fossils. Many of the shells have been rolled and abraded and perhaps concentrated before the concretions were formed. A list of the species making up this fauna follows:

Arca sp.

Callocardia astartoides Gardner.

Callocardia sp. cf. C. trigoniata Lea.
Calyptrophorus sp. cf. C. valatus Conrad.

Corbula (Cuneocorbula) conradi Dall.

Fusus? sp.

Natica dumblei Heilprin (large).

Ostrea sp.

Polynices arata (Gabb).

Polynices gibbosa (Lea).

Solen sp.

Tellina mooreana Gabb?

Tellina sp. $A$ ?

Tuba antiquata Lea?

Turritella sp.

Venericardia sp.

YEGUA FORMATION.

The Yegua, the youngest of the Claiborne formations, lies with some indications of unconformity upon the Cook Mountain and underlies the Fayette, of Jackson age.

Distribution.-The map shows the distribution of the formation at the surface in the lower Rio Grande region. The belt of outcrop varies in width from $4 \frac{1}{2}$ to 17 miles, the variation being probably due to an irregular overlap of the Fayette. The outcrop within the region is confined to Webb and Zapata counties and a small part of western Starr County.

Character.-About 90 per cent of the formation in this area appears to be dark gray, black, red, pink, purple, green; and brown. selenitic carbonaceous clays. The predominant color is dark gray, and the material weathers into darkgray clay soils. There are also many beds, lenses, and seams of soft gray and buff sands and sandstones, most of them thin. Dark, irregular limestone concretions occur sparingly in the clay.

Thickness.-The average thickness of the strata assigned to the Yegua outside the Rio Grande region is 817 feet, and the range is from 375 to 1,400 feet, but in this region the average thickness of the beds exposed, so far as it can be determined, is only about 406 feet.

Fossits.-Although Dumble ${ }^{22}$ reports Tellina mooreana Gabb, Turritella houstonia Harris, and Natica recurva Aldrich from beds in Mexico identified as Yegua, it seems likely that the beds from which they were collected should be included in the Cook Mountain of the Rio Grande region. Leaves are also reported to have been found in the formation at places outside the region, but none was found inside. The only fossil seen in the Yegua in the region covered by

20 Dumble, E. T., Tertiary deposits of northeastern Mexico: Californis Acad. Sci. Proc., 4 th ser., vol. 5, No. 6, p. 177, 1915. 
this report is Ostrea georgiana, and even this occurs more sparingly in the Yegua than in the Cook Mountain bolow or the Fayette above. In the Rio Grande region the deposits classified as Yegun are more closely allied faunally with the Jackson than with the Claiborne, but elsewhere the reverse is true: Possibly only the upper part of the Yegua occurs here, and this part may be really of Jackson age. Until this can be demonstrated, however, the Yegua will all be classed as of Claiborne age.

FAYETTE SANDSTONE.

Character.-The materials of the Fayette formation are fairly characteristic, although they are lithologically like those of the Cook Mountain formation, with which they are likely to be confused, but the fauna and flora are definite and on the whole the formation is not difficult to recognize in the field.

The Fryette contains more sand and sandstone than any other kind of rock, yet it is not so sandy in the Rio Grande region as it is farther north and east. The sandstone is exceedingly variable-in color almost white, gray, greenish gray, buff; in texture fine, medium, and coarse; in consolidation ranging from loose sand to quartzitic sandstone. The most characteristic fenture of the sandstone is that it is fossiliferous. It is commonly laminated and cross laminated in intricate patterns. Interbedded with the arenaceous beds there are many beds and lenses of sandy and limy greenish-gray, pink, and red shale and clay. Limestone is scarce but not entirely absent. Beds of white rolcanic ash are found in the formation at several places. Large, dark, crystalline limestone concretions are common. Silicified wood occurs abundantly, chiefly in the clays but in the sandstones as well. Most of the silica is opal, but chalcedony is found also. The silicified wood is characteristic of the formation in this region.

Thickness.-The thickness of the formation in this region averages not more than 360 feet, about 100 feet less than the average thickness elsewhere.

Fossils.-The formation contains a single identifiable fossil, a large variety of Ostrea georgiana Conrad. The rich Claiborne fauna attributed to the Fayette by Dumble is Cook Mountain, as explained on page 94 , but a number of species of fossil plants are found in the ash beds and some in the sandstones. The best collections were obtained at points $2 \frac{1}{2}$ and $4 \frac{1}{2}$ miles north of Miraflores ranch, in Zapata. County. Berry has identified the following forms:

Apocynophyllum 2 n. sp.

Bombacites n. sp.

Cinnamomum sp.

Coccolobis n. sp.

Conocarpus eocenicus Berry.

Diospyros n. sp.

Inga n. sp.

Mespilodaphne n. sp.

Myristica catahoulensis Berry (?).

Nectandra n. sp.

Papilionites $\mathrm{n}$. sp.

Pisonia n. sp.

Sabalites vicksburgensis Berry.

Sapindus dentoni Lesq.

Sapotacites n. sp.

Spohora claibornensis Berry (?).

Terminalia phaeocarpoides Berry.

Ternstroemites n. sp.

Berry regards these plants as of middle or upper Jackson age and states that they indicate a warm, probably subtropical climate, with local or seasonal aridity, probably without general deficiency in rainfall. Although some of the formation is marine, much of it, as the plants suggest, was doubtless deposited subaerially on coastal sandy and clayey plains. The character of much of the formation indicates deposition in shallow water that was subject to considerable agitation.

FRIO CLAY.

In the Frio formation there are 100 to 400 feet of gray, greenish and yellowish gray, red, pink, and blue pure and sandy clays and a very few seams of gray sandstone, 1 to 8 inches thick. Perhaps the pink color, doubtless due to weathering, predominates in the exposures, practically all of which are shallow. Nearly everywhere the clay is checked by joints in which secondary calcium carbonate occurs in thin plates, and it contains many small calcareous nodules and some small masses that appear to be rolled balls of calcareous mud. Some of the clay is gypsiferous. With the exception of an occasional oyster bed (Ostrea georgiana) and a very few fragments of silicified wood the formation contains no fossils. Some of the beds of volcanic ash, notably those at. Rio Grande City and at and in the neighborhood of La Loma de la Cruz east of Rio Grande City, at least one of which 
is 60 feet thick, are in the Frio formation rather than in the Fayette. These ash deposits, however, unlike those in the Fayette, carry no fossil plants; but it should be noted that not all the ash in the Fayette is leafbearing.

MIOCENE SERIES.

OAKVILLE SANDSTONE.

Deussen ${ }^{21}$ describes and maps in the area covered by him south and west of Brazos River to the border of the lower Rio Grande region a thin formation of white and light-gray quartzitic sandstone, which he calls the Oakville sandstone. This formation is also mentioned by Dumble, ${ }^{22}$ Udden, ${ }^{23}$ and others. As mapped by Deussen, it lies in a belt a mile wide along the west foot of the Bordas scarp, between the Frio and Reynosa formations, east of Torrecillas, in Webb County, at the north border of the Rio Grande region, but the writer found no certain evidence of the outcrop of this sandstone, although it is doubtless overlapped by the Reynosa, which forms the Bordas scarp. In the lower Rio Grande region the Frio clay seems to continue well up the west slope of the scarp and there to be in contact with the Reynosa formation. Where the Rio Grande has cut across the Bordas, exposing a section, the Reynosa lies directly upon the clay and ash of the Frio formation. Nor does the Oakville appear between these two formations, in the 15 miles of the exposure of their contact in a direction roughly parallel to the dip between Rio Grande City and Sam Fordyce. In roads, pastures, and fields between Randado and the Webb-Zapata shallow oil field and elsewhere along and near the Bordas, to the west, there is a deep white or gray sand which may have been derived from the Oakville. The same kind of sand, however, is commonly found east of the Bordas, where it is derived from the Reynosa formation. It even appears to be derived from the Reynosa west of the Bordas, where there are outliers of the Reynosa.

There are in the region, however, rather thick Miocene sediments, which are overlapped by younger formations. Driller's samples taken at depths ranging from 4,325 to 4,500

21 Deussen, Alexander, Geology of the Coastal Plain region of Texas: U. S. Geol. Survey Prof. Paper 126 (in press).

22 Dumble, E. T., Problem of the Texas Tertiary sands: Geol. Soc. America Bull., vol. 26, pp. 449 et seq., 1915.

${ }^{23}$ Udden, J. A., Baker, C. L., and Böse, Emil, Review of the geology of Texas: Texas Univ. Bull. 44, p. 97, 1916. feet in the Niels Esperson oil test, 15 miles east of Brownsville, have furnished many invertebrate fossils, of which Dr. Julia Gardner has identified 23 species, all of Miocene age. The exact position of these fossils in the Miocene can not be determined, but according to Dr. Gardner the single fauna represented should probably be assigned to a formation near the top of the lower Miocene or the base of the middle Miocene.

\section{PLIOCENE SERIES.}

LAPARA SAND AND LAGARTO CLAY.

The Pliocene Lapara and Lagarto formations, described by Deussen, ${ }^{24}$ Dumble, ${ }^{25}$ and Udden, Baker, and Böse, ${ }^{26}$ from areas farther north, do not outcrop in the Rio Grande region. If they were deposited there they have been covered by the overlapping Reynosa formation.

\section{TERTIARY (?) SYSTEM.}

PLIOCENE (?) SERLES.

REYNOSA FORMATION.

Name.-In 1890 Penrose ${ }^{27}$ described a deposit of limestone containing many pebbles and cobbles under the name "Reynosa limestone," from the town of Reynosa, Tamaulipas, Mexico. This limestone overlies what was then called the Fayette sand at Reynosa, directly across the Rio Grande from Hidalgo, Tex. Penrose found Recent shells embedded in the surface of exposures of this formation, and thinking it was Recent, included it in his "post-Tertiary formations." In 1891 Hill ${ }^{28}$ described remnants of a formation that consisted of coarse and fine gravel cemented by a calcareous matrix and that occupied terraces 400 to 1,000 feet above the Rio Grande to the north of this region. This he called the Uvalde' formation. Dumble ${ }^{29}$ applied the name Reynosa division to the series of deposits forming the plateau between Nueces and Rio Grande, which he called the Reynosa plateau.

24 Deussen, Alexander, Geology of the Coastal Plain region of Texas: U. S. Geol. Survey Prof. Paper 126 (in press).

25 Dumble, E. T., Geology of southwestern Texas: Am. Inst. Min. Eng. Trans., vol. 33, pp. 963-975, 1903.

${ }_{26}^{6}$ Udden, J. A., Baker, C. L., and Böse, Emil, op. cit., p. 90.

${ }_{27}$ Penrose, R. A. F., jr., Report of geology for eastern Texas: Texas Geol. Survey First Ann. Rept., pp. 57, 58, 63, 1890

${ }^{28}$ Hill, R. T., Notes on the geology of the Southwest: Am. Geologist, vol. 7, pp. 366-370, 1891.

${ }_{29}$ Dumble, E. T., The Cenozoic deposits of Texas: Jour. Geology, vol. 2 , p. 560,1894 . 
He stated that the "Reynosa limestone" of Penrose formed the top member of his Reynosa division, which rested on the Lagarto formation. These downstream deposits to which Dumble applied the name Reynosa are now known to be the same as the upstream remnants to which Fill applied the name Uvalde, and the necessity for discarding one of the names has become apparent. In view of the fact that Reynosa as applied to a part of this formation has priority over Uvalde, and that the downstream deposits perhaps afford a better type locality, the name Reynosa has been adopted - by the United States Geological Survey and "Uvalde" formation has been abandoned. The outcrop of the formation is continuous from Torrecillas and Rio Grande City eastward. In the area west of the Bordas scarp it occurs as remnantal patches, some of them doubtless reworked. These materials were included by McGee in his "Lafayette," a name no longer recognized as applicable to any geologic formation.

Distribution.-The map shows the distribution of the Reynosa formation in the lower Rio Grande region. Its resistant layers hold up the Frio clay; its base forms the Bordas scarp, from which it dips at a very low angle eastward, outcropping in a north-south belt 40 to 65 miles wide. In much of this area, however, its outcrops are obscured by the wind-blown sands of the sand belt. West of the Bordas it occurs only in patches that occupy the highest elevations.

Relations to adjacent formations.-The Reynosa lies unconformably on all older formations. The dip of the formation is much less than that of the older formations, and as the surface on which it lies is almost flat, it bevels the older formations. This structural unconformity, which is shown on the map, is well seen in the bluffs of the Rio Grande between Rio Grande City and Sam Fordyce. After the deposition of the Oakville, and doubtless after Lapara and Lagarto time, the strata of the region were slightly tilted and a flattish surface was developed across their beveled edges, and on this surface the Reynosa formation was deposited. In this area it is unconformably overlain by the Beaumont clay.

Character.-The Reynosa formation is an intricate mixture of gravel cemented by lime carbonate, uncemented gravel, limestone in which are embedded pebbles and cobbles, almost gravelless limestone, sand, sandstone, gravelly sand, and a relatively small amount of clay.

About 1 per cent of the pieces of gravel are over 4 inches in diameter, and the largest measure 8 inches. About a third of them are of sizes between $1 \frac{1}{2}$ inches and 4 inches; another third go through the $1 \frac{1}{2}$ inch screen but are caught on the $\frac{5}{8}$-inch; and nearly a third goes through the $\frac{5}{8}$-inch screen. The patches of gravel near the Rio Grande are a bit coarser than those farther away, and those inland and near the Balcones scarp seem to be somewhat coarser than those away from the river but nearer the Gulf. The gravel includes about 77 per cent of chert, limestone, and vein quartz, materials derivable and doubtless largely derived from the Edwards Plateau, and about 23 per cent of igneous rock, most of them derived from the western Cordillera. Some of the vein quartz may have been derived from points west of the plateau, but on the other hand some of the igneous rocks may have been derived from plugs near the Balcones scarp. Where the gravel overlies the Fayette and Frio formations it includes some silicified wood. Most of the pebbles and cobbles are well shaped by abrasion, many of them are highly polished, and some show bruises made by hard impact during transportation. The gravel deposits are roughly sorted into lenses and pockets of different textural grades.

The limestone is gray and sandy and weathers into rough, irregular surfaces, due to irregular concretions and impurities. In places it has surficially a tufaceous appearance. Its basin, rims, terraces, channels, and concentric banding are suggestive of deposition by springs. The patches south of Espejo ranch, in north-central Webb County, and at Carrizo Springs are clearly spring deposits, but these are not typical, for they contain little or no gravel.

The sand and the sandstone are gray or brown or red and almost universally weather into a dark-red sand. The grains are quartz coated with red iron oxide, but in places where this red coating has been worn off by the wind the sand is gray, or even white.

The few clays are generally sandy, but some are almost fat. Below Rio Grande City the Reynosa formation includes mud balls of Frio clay. 
The surficial material derived from the Reynosa is typically deep-red, pink, or gray sand, through which white or gray limestone projects at many places.

Thickness.-The thickness of the formation is not definitely known. The patchy deposits west of the Bordas do not exceed 30 feet in thickness except at a very few places, but at the east border of the main belt of outcrop the formation may be 500 feet thick or more, and around the borders of the Rio Grande region it is 200 to 600 feet thick.

Fossils.-No fossils have been found in the Reynosa formation except the remains of Recent land snails, crayfish, jackrabbits, and a few other animals, which have become embedded in the surface as the limestone has been dissolved and reprecipitated, and except the fossils originally deposited in the formations from which the gravel was derived.

Origin.-To attempt at this time a complete explanation of the conditions under which this complex formation was deposited and cemented would be premature. In the main it is of fluvial origin. At least the gravel and the interbedded sand and clay were laid down by streams. Hill and Vaughan ${ }^{30}$ gave an excellent description of the landward facies of the formation and interpreted it as residual material washed out from the Edwards Plateau in late Tertiary time and deposited on the downthrown side of the Balcones fault in fan-shaped areas. Perhaps, owing to peculiar climatic conditions, as suggested by Deussen, ${ }^{31}$ some of the limestone was deposited by ground water while the main mass of the formation was being laid down by streams. Some of the limestone also appears to have been deposited at the surface by springs that rose through the gravel.

\section{QUATERNARY SYSTEM.}

\section{PLEISTOCENE SERIES.}

LISSIE GRAVEI.

North of the Rio Grande region Deussen finds in valleys in the Reynosa formation a deposit of uncemented gravel without limestone, reaching in places a thickness of 900 feet. These are the "Equus beds" of earlier

${ }^{30}$ Hill, R. T., and Vaughan, T. W., Geology of the Edwards Plateau and Rio Grande Plain adjacent to Austin and San Antonio, Tex.: U.S. Geol. Survey Eighteenth Ann. Rept., pt. 2, pp. 244-247, 254-255, 1898. al Deussen, Alexander, orali nformation. writers, so called because they contain the remains of Pleistocene horses. This gravel was doubtless derived from the Reynosa, which was uplifted and eroded before the main body of Lissie gravel was deposited. No exposure of this material was seen in the Rio Grande region, but perhaps it may be hidden beneath the sand of the sand belt and the Recent delta deposits of the Rio Grande or overlapped by the Beaumont clay.

\section{BEAUMONT CLAY.}

Name and distribution.-Throughout the west Gulf Coast province there is a coastal belt of clay of varying width, from which deposits of silt, sand; and gravel project up along the main river valleys in the form of terraces. These terrace deposits are called the Leona formation.

The Beaumont formation has been called the "Coast clays" and the Port Hudson clay, but it is not known to be the same as the typical Port Hudson formation of Louisiana. It is correlated in time with the Columbia formation of the Atlantic coast. The term Beaumont, which was first employed by Kennedy, ${ }^{32}$ is used to designate the formation in this region. This formation is covered by Recent windblown sand for about 50 miles southward from the north border of the Rio Grande region, and still farther south by the younger clays and sands that form the present delta of the Rio Grande, but it is exposed at some places in the narrow strip north of the sand belt, within the sand belt where at places it has been uncovered by the migration of dunes, and south of the sand belt above high-water mark in the Rio Grande. Its areal distribution is shown on the map.

Character.-The Beaumont formation consists of blue and red calcareous clay, weathering yellow, a small number of thin lenses of sand, and a few scattered concretions of limestone. It includes also, as shown by well logs, a few beds of gravel which are not exposed at the surface and do not belong to the underlying Lissie and Reynosa formations. That part of the formation near the Rio Grande is coarser than that elsewhere. Much of this material was swept down the Rio Grande and reworked

${ }^{32}$ Hayes, C. W., and Kennedy, William, Oil fields of the Texas-Louisiana Gulf Coastal Plain: U. S. Geol. Survey Bull. 212, pp. 20, 27, pls. 1 and 2,1903 . 
more or less by Gulf currents before it was deposited. The surficial material of the formation in this belt is chiefly dark-gray clay loam overlain by a thin sheet of drifting sand.

Fossils.-No fossils were found in the coastal belt of this region, but oyster beds are reported from the formation at some places farther north.

LEONA FORMATION.

Distribution.-In the valleys of the Rio Grande and of Frio, Leona, and Nueces rivers there are a number of terraces, all of them lying at levels between the Reynosa upland piain and the present flood plains of the streams. Such terraces are also found for a few miles up the larger tributaries of the Rio Grande. Hill and Vaughan ${ }^{33}$ first described these deposits in the upper Nueces drainage basin as the Leona formation. They also mention ${ }^{34}$ the Rio Grande terraces and state that they are undoubtedly of the same age as the Leona formation. Certainly there are no greater differences, either in topographic position or in material, than would be expected in deposits of this sort and of the same age but in different drainage basins. Deussen ${ }^{35}$ on the other hand, believes that the Leona formation is older than the terraces of the Rio Grande. He correlates the Leona with the terraces in the basin of San Antonio River at San Antonio, and as the remains of vertebrates have been found in the terraces at San Antonio which identify them in age with the "Equus beds," he correlates the Leona formation with the Lissie. No vertebrate fossils have been found in the deposits on the Rio Grande, and these terraces appear both to Deussen and to the writer to be continuous with the Beaumont clay and of the same age. As no formation corresponding to Deussen's Lissie could be found in the lower Rio Grande district, as Udden, Baker, and Böse ${ }^{36}$ correlate the Lissie with the Reynosa and the "Equus beds" with the Beaumont, as identical invertebrate fossils occur abundantly in both the Rio Grande and the Nueces terraces, as in neither drainage basin have vertebrate fossils been found, and as both the Rio Grande terraces and the Leona formation occupy topographic positions from 20 to 60 feet above present stream beds and

${ }^{83}$ Op. cit., pp. 253-254, 275-276.

84 Op. cit., pp. 251-254.

8s Doussen, Alexander, oral information.

80 Op. cit., pp. 99 and 102. from 75 to 150 feet below the Reynosa plain, the terraces in the Rio Grande basin are included, for the present at least, in the Leona formation, and the Leona formation is correlated in time with the Beaumont clay.

Character.-The Rio Grande and Nueces terraces are composed mainly of light-gray and buff silt but include some sand and fine gravel. The terraces are flat topped and have steep riverward slopes. At most places there are two or three rather than a single terrace. At Palafox, for instance, there are three terraces above the present flood plain of the Rio Grande, one 21 feet, another 32 feet, and a third 63 feet above the level of the river when it was at a higher stage than the normal. These terraces converge downstream, to the south, becoming fewer in number until they merge into a single terrace. Hand-level traverses carried from the river to the top of the main terrace at several places gave the results shown below. The places are listed from north to south, and the apparent discrepancies are due to the fact that the several traverses were made at times when the water was at different stages.

Elevation of terraces along the Rio Grande above level of water in river.

Feet.

Mouth of San Lorenzo Creek. . . . . . . . . . . . 50

Bigford ranch......................... 45

Apache ranch........................ 43

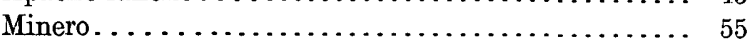

Laredo.................................. 60

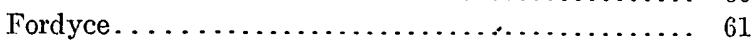

Ramereño............................. 61

Chapeño............................. 42

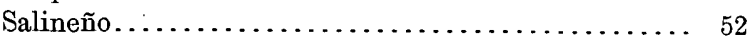

Santa Margarita............................ 52

Three miles below Roma.................. 34

Five miles above Rio Grande City............. 36

Rio Grande City . . . . . . . . . . . . . . . . . . . 26

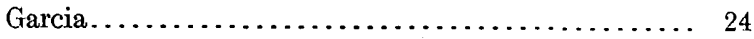

Fossils.-The Leona formation has yielded several fresh-water and air-breathing mollusks. The specific list includes:

Bulimulus dealbatus Schiedeanus.

Helicina tropica Pfeiffer.

Lampsilis purpuratus Lamarck?

Planorbis tricarinatus Say.

Polygyra texasiana Mori.

Unio tetralasmus var. camptodon.

Unio tetralasmus vas. manubius Gould.

These forms are Pleistocene or Recent. The heary dentition on the unios as compared with those now living in the Rio Grande and its 
tributaries suggests Pleistocene age rather than Recent. The fact that the streams have degraded their beds as much as 60 feet since the deposits in which the shells are inclosed were laid down also indicates a considerable lapse of time. The deposits are correlated with the Beaumont, which is classified as Pleistocene. The Leona formation is therefore regarded as of Pleistocene age.

\section{RECENT SERIES.}

FLUVIATILE DEPOSITS.

Delta deposits are still being formed at the mouth of the Rio Grande. Below Closner, where the normal flood plain merges into the delta, large areas are still subject to flood. What is known as the "Mission ridge," utilized for the railroad, the main automobile road, and the "valley" towns-Mission, McAllen, Pharr, San Juan, and Donna-stands above flood waters and is included within the Beaumont formation, but even here the land slopes away from and toward the river from the axis of the ridge. Other towns in the "valley," including Llano Grande, Mercedes, Härlingen, Raymondville, Lyford, Sebastian, and Brownsville, are likely to be flooded in years of high water, such as 1909,1919 , and 1922. These towns are on higher land, however, and are now largely protected by great irrigation canals and their borrow pits. Breaks occur in the river banks as far upstream as a point above Mission, and old river channels or "resacas" are found on the widening flood plain. These resacas extend down the valley as far as Donna, where they concentrate into the definite channel of the Rio Colorado, which thus becomes a distributary of the Rio Grande. The channel of the Rio Colorado is as much as 40 feet deep where it is deepest, near Harlingen, and 200 feet wide. It carries safely the flood waters of the Rio Grande except at times of the highest floods, when the water breaks through on both sides of Mercedes and flows into the basin of Lake Tiocano and thence northward toward Raymondville, eastward toward the Gulf (crossing the St. Louis, Brownsville \& Mexico Railway south of Lyford), and back again southeastward to the Rio Colorado near Harlingen. Much of this water never reaches the Gulf, for the surface is so flat and grassy and the Gulfward slope is so low that the water stands in shallow depressions and behind irri- gation canals, and there evaporates or seeps into the porous silts and sands. The area that is subject to flood is mapped as Recent fluviatile deposits. The Rio Grande flood plain above Closner is too narrow to be mapped separately from the Leona terraces and the Tertiary formations where the Leona is missing.

Only the surficial part of this deposit is nonmarine. The area having been reclaimed from the Gulf by the deposition of sediments brought down by the Rio Grande the lower beds are marine, for they contain marine Foraminifera, which are found where the beds are penetrated by wells. The material seen in surface exposures is a mixture of highly calcareous and somewhat selenitic gray, blue, red, and brown clay, checked by joints filled with calcium carbonate, gray micaceous sand, gray silt, and some pebbly sand, the whole impregnated with small white pellets of lime carbonate. The clay greatly predominates.

On the surface of the delta, particularly along the coast from Raymond ville to Brownsville, there are numerous mounds, 5 to 30 feet in height, made of clay and known as "clay buttes." Though several diverse suggestions as to the origin of these mounds have been offered, the suggestion made by Coffey, ${ }^{37}$ that they are "clay dunes," seems most reasonable. Most of them lie on the leeward side of shallow depressions, which are doubtless the source of the material of which they were formed. Many of these depressions contain salt lagunas.

Fresh-water and land shells, bones, logs, leaves, and other organic matter, all Recent in age, are found in the fluviatile deposits in considerable abundance.

\section{WIND-BLOWN SAND.}

Recent deposits that are most widely distributed are the sand dunes and wind-drifted sandy plains of a large area that extends continuously along the coast southward from Baffins Bay to a point east of Raymondville and westward for 75 miles in a belt that is 25 to 50 miles wide from north to south. This area includes practically all of Willacy and Brooks counties and the northern parts of Hidalgo and eastern Jim Hogg counties. Padre Island also consists chiefly of sand dunes blown up from the beach of the Gulfward side of the island. This is an area of migrating and stationary dunes, or "medanos," and of the

${ }^{37}$ Coffey, G. N., Clay dunes: Jour. Geology, vol. 17, pp. 754-755, 1909. 
shallow irregular depressions that are so common in all dune areas.

Near the coast, where the Beaumont clay underlies the sand, the depressions contain shallow lagunas, both salt and fresh. There are also considerable stretches of sandy prairie, and at many places where there is no surficial sand the Reynosa and Beaumont formations are exposed. The dunes are sparsely covered with live-oak trees and the prairies are dotted with patches of live-oak brush. There are also large areas of wild grasses and "sacahuista."

Most of the sand is gray or white, but some of it, especially where it overlies the Reynosa formation, is red or pink. It has been thought that all this sand was blown inland from the const, and perhaps most of it was, although there is no greater source of sand here than elsewhere along the coast, but some of it was derived from the Reynosa formation, on which the sand in the western part of the belt lies. Here "blowholes" expose the Reynosa reddishbrown sands, and the dunes consist of this sand. Even the gray sands mav be derived from the Reynosa, the colored iron coating having been abraded from the quartz grains during eolian transportation.

\section{COASTAL DEPOSITS.}

Padre Island is a long dune-covered barrier island, which is nowhere more than a mile wide. It incloses Laguna Madre, which is 4 to 10 miles wide. On the Gulf side of the island there are the usual littoral deposits. The beach is sandy and is strewn with innumerable sea shells. The water of the laguna is at most places so shallow that it can be easily waded; indeed, at some times and places it is only a mud flat incrusted with precipitated salts. At Point Isabel, however, gasoline launches ply between the mainland and the island, but long piers are necessary, and the boats drag the bottom for considerable distances out from either shore. In the laguna mud, silt, sand, shells and fragments of shells, and salt are all being laid down to form the usual lagoon deposit.

\section{IGNEOUS ROCKS.}

In southwestern Uvalde County, just outside the region and not shown on the map, there are several small exposures of igneous rocks in the form of plugs or necks. Most of them make hills, but some are exposed in stream valleys or on flat surfaces. The rocks are phonolites and basalts, which have been described by Cross. ${ }^{.8}$

\section{STRUCTURE.}

The general dip of the strata in the Rio Grande region is eastward. North of Laredo the dip is south of east, between Laredo and San Ygnacio it is nearly due east, and below San Ygnacio it is north of east.

The averages of the dips read for the formations are shown below.

Average dip, in feet per mile, of formations in the Rio Grande region.

Beaumont clay (Pleistocene)................... 25

Reynosa formation (Pliocene?)................ 17

Frio clay............................... 263

Fayette sandstone.......................... 201

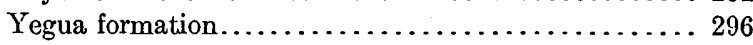

Cook Mountain formation.................... 435

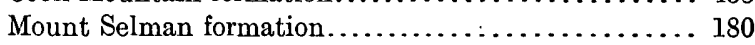

Wilcox group (Bigford formation, Carrizo sandstone,

and Indio formation $) \ldots \ldots \ldots \ldots \ldots \ldots \ldots \ldots \ldots \ldots \ldots+\ldots \ldots \ldots$

Midway formation.......................... 155

These arerages are probably too high, however, for the steeper. dips are those that are most commonly read. At most places the strata are so nearly horizontal that the dip is not observable. The true average dip of each formation is probably less than half that given above. According to the figures given the average dip of the Eocene formations is 273 feet per mile and the Reynosa and Beaumont together average 21 feet per mile. These figures should probably be reduced to 136 and 10 , respectively, or even to lower figures. The discrepancy between the Eocene and postEocene formations again emphasizes the structural unconformity at the base of the Reynosa.

The reconnaissance methods employed did not permit detailed structural investigations, but indications of abnormal structure were observed or were authentically reported to occur at a few places. According to Baker ${ }^{39}$ there is an anticline about 10 miles west of Carrizo Springs, another about 15 miles southeast of Eagle Pass, and probably still another, lying chiefly in Mexico, southwest of the old Indio ranch house. The writer saw indications of the first of these. The second is described by 'Udden. ${ }^{40}$ Along Nueces River

${ }^{39}$ Cross, Whitman, U. S. Geol. Survey Geol. Atlas, Uvalde folio (No. 64), pp. 3, 4, 1900.

${ }^{89}$ Baker, C. L., personal communication.

40 Udden, J. A., Report on a geological survey of the lands belonging to the New York \& Texas Land Co.: Augustana Library Pub. 6, pp. 8S-90, 1907. 
below Pulliam, there are anticlines and synclines and faults of small throw. The eastward dip is somewhat accentuated at the Webb-Zapata shallow oil field, in the southeast corner of Zapata County. There are relatively steep reversed dips in the vicinity of Roma. Probably an anticline here crosses the international boundary. A large anticline has been mapped by Crider ${ }^{41}$ east of Laredo. Normal faults of small displacement were observed on Chaparrosa Creek 11 miles west of La Pryor, and half a mile east of the Jones ranch, northwest of Crystal City.

The search for structural features in the Rio Grande region is full of difficulties and subject to inaccuracies, for formations vary in character from place to place, the beds occur in lenses and pockets, the formational contacts are ill defined, exposures are scarce, wells are few, and the logs of most of those which have been drilled are inadequate, and false bedding planes, which dip at all angles with reference to the true bedding, are abundant.

There is at least one salt dome in the region. It is about 5 miles southeast of Falfurrias and crosses the Beaumont-Reynosa contact. It is 5 miles long from east to west and 1 to $1 \frac{1}{2}$ miles wide from north to south. Quaquaversal dips are not plainly seen, but a surrounding laguna of salt brine, a large body of gypsum on the southwest side, and a topographic swell that is more than 40 feet high indicate that there is a salt dome at this place. La Lomita (little hill), $6 \frac{1}{2}$ miles south of Mission, on the Rio Grande, which stands conspicuously above its alluvial surroundings and exposes abnormal materials and abnormal dips may also be a salt dome, but the dips may not represent true bedding planes.

\section{ECONOMIC GEOLOGY.}

\section{OIL AND GAS.}

More than 45 separate projects are under way for the development of oil and gas in the region, but only three are producing. The locations of these projects are shown on the map (Pl. XXVIII).

In 1920 the Webb-Zapata Co. had drilled 45 wells in the southeast corner of Zapata County to an average depth of 160 feet and found some oil and a very little gas in the Fayette sandstone. The dip here is normal in direction, a few degrees south of east, and is 198 feet per

${ }^{11}$ Crider, A. F., personal communication. mile, somewhat more than the general dip in the neighborhood. As there are no reversed dips, the oil probably occurs in a lens of sand, which plays out and is sealed up westward, for the cap rock crops out $1 \frac{3}{4}$ miles west of the west border of the producing area. Eight of the wells were pumping in 1920, a gasoline engine on each. The average yield is between 3 and 4 barrels a day. As the field is more than 40 miles from the railroad at Hebbronville, and as the road is very sandy, all attempts to market the oil had failed up to the time of the writer's last visit. The oil was stored in steel tanks at the field. According to recent reports it is being marketed.

Another producing field is 25 miles south of Aguilares and 45 miles southeast of Laredo, in Zapata County. Gas only is produced. The field is developed and operated by the Border Gas Co., of Laredo. The gas is conducted through pipes to Laredo; where the company operates the city gas plant. The outcropping formation at the wells is Fayette. A little gas is obtained from a depth of 700 feet, but the main flow is obtained from a depth of 1,200 to 1,250 feet. The material penetrated in all the wells is almost entirely clay but includes thin seams of sandstone. The main gas sand lies in the basal part of the Yegua or the upper part of the Cook Mountain. The structure here also is homoclinal, the gas sand dipping eastward at the rate of 30 feet to the mile.

In the spring of 1921 oil was struck in a well of the Mirando Oil Co., in the extreme northeast corner of Zapata County. The well site is just west of the Reynosa-Frio contact, and. practically the full thickness of the Frio clay is represented under it. The oil sand was struck at 1,430 feet from the surface, in the Cook Mountain formation. The first well is variously reported as having given an initial production of 20 to 100 barrels a day. The new field has been rapidly developed. In the spring of 1922 it was credited with 13 producing wells, and the estimated possible production ranged from 1,000 to 2,300 barrels a day. ${ }^{2}$ In addition, more than a score of other wells were being drilled in other parts of Zapata and Webb counties.

This field has produced also considerable gas. The Caroline-Texas Co.'s test well near Bruni is reported as blowing $8,000,000$ to $10,000,000$

${ }^{42}$ MeGreal, P. L., Gulf coast oil operations: Oil and Gas Jour., vol. 20, No. 43, p. 18 , March $24,1922$. 


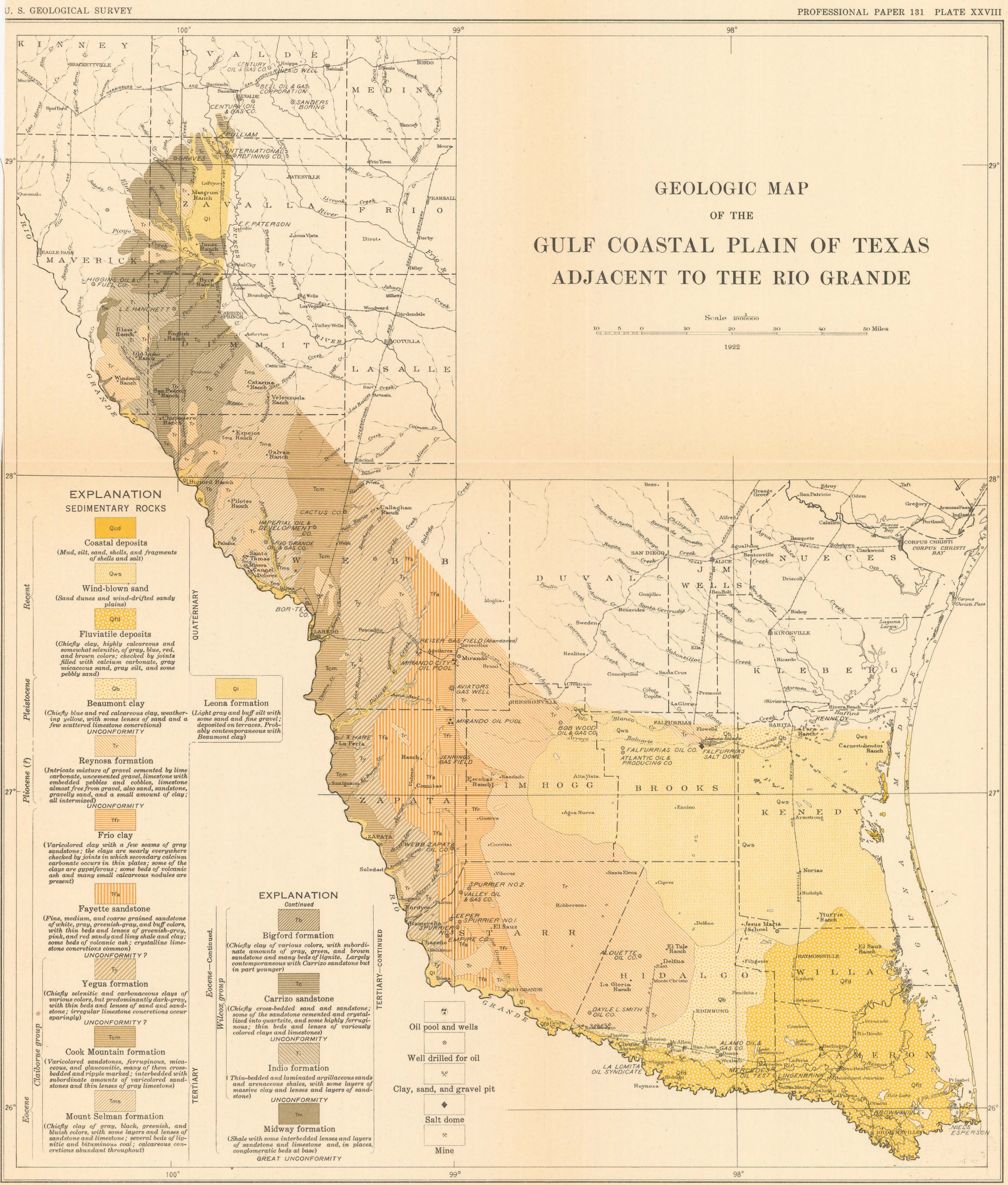


cubic feet and the Laurel Oil Co.'s well No. 1, drilling many of the wells have shown neither at Mirando, as blowing 40,000,000 cubic feet. intelligence nor diligence.

According to Lupton ${ }^{43}$ the Aviator well, which is about halfway between Mirando and the Mirando City pools, was brought in with an estimated production of $40,000,000$ cubic feet in June, 1922. Well No. 2 of the Schott Oil Co. is also a gasser.

As the first well was not completed when the writer was last in the field the structure in the Mirando district has not been worked out. Wrather, ${ }^{44}$ however, states that the producing sands in the Mirando and the Jennings fields are at approximately the same horizon.

The future of the Mirando field can not yet be confidently predicted, but the field will probably be thoroughly tested by the end of 1922 .

Gas has been found at several other places, notably at Reiser, $2 \frac{1}{2}$ miles west of Aguilares, in Webb County; in the Spurrier wells Nos. 1 and 3, in western Starr County; in the Higgins Oil \& Gas Co.'s wells, 15 miles southeast of Eigle Pass, in Maverick County; and in the well of the International Refining Co., 7 miles northeast of La Pryor, in Zavalla County. At Reiser, which is only a few miles northwest of the northern border of the Mirando field, the gas is obtained from the Yegua and Cook Mountain formations at depths ranging from 150 to 1,650 feet. The Spurrier wells also contain gas, though in small quantities, from the Yegua. The gas in the Higgins wells is obtained from Cretaceous beds. The well of the International Refining $C_{0}$. is reported to have struck a 50,000,000 cubic foot gas blow at a depth of 1,200 feet from the surface. The outcropping formation is the Indio, and presumably this gas also comes from Cretaceous beds. The first well at Pulliam, on the UvaldeZavalla county line, is reported to have produced about 5 barrels of oil a day.

So far as known the results of all other tests have been negative. However, outside of the Mirando field few of the deep test wells have been completed, and oil may have been struck in wells unknown to the writer. Several of the projects, notably those of the Higgins, International, and Empire companies and the Hanchett project, have been carried on in a serious and intelligent manner, but the operators

43 Lupton, C. T., oral communication to L. W. Stephenson.

14 Wrather, W. E., Tte Mirando Oil Co. well, Zapata County, Tex. Am. Assoc. Petroleum Geologists Bull., vol. 5, p. 625, 1921.

The search for oil and gas in paying quantities will be continued only with great difficulty and with large risk of money. The work of locating and mapping areas in which the structure is favorable is difficult, and even a well-developed and accurately mapped anticline may contain no oil-bearing sand. The possibility that the San Miguel formation (correlated with part of the Taylor marl and the Anacacho limestone) of the Upper Cretaceous, may be petroliferous is not unpromising. The Cook Mountain formation gives some indication of being a fairly persistent producing sand where the structure is favorable. Both oil and gas have been found in this formation in the Mirando field and in smaller quantities elsewhere. It appears to contain indigenous petroleum at Oil City, Nacogdoches County, and at Crowther, McMullen County. This formation should be tested wherever drilling is done. The expenses of development will be high, for a large part of the region is not easily accessible to railroads or seaports, and even after development there is still the problem of getting the product to market.

Probably the most promising structural features to look for and to test are salt domes. About 50 per cent of the known Texas salt domes have produced oil and some of them have produced it in large quantities. The salt dome southeast of Falfurrias was tested some years ago by the Texas Co., but with negative results. The hill south of Mission, known as La Lomita, which may be a salt dome, is now being tested by the La Lomita Oil Syndicate. Other salt domes will doubtless be discovered in the region, and petroleum may be found in them.

On the whole the prospects of the ultimate discovery of one or more highly productive oil or gas fields in this region are not discouraging, but the preliminary work should be done with great care and the money required will be expended at considerable risk.

COAL.

According to Ashley, ${ }^{45}$ the coal which has been extensively mined at Minero, Dolores, Cannel, and Santo Tomas, in Webb County,

45 Ashley, G. H., The Santo Tomas cannel coal: U. S. Geol. Survey Bull. 691, pp. 251-270, 1919. 
and which is in the Mount Selman formation, is probably the largest body of cannel coal of bituminous rank in the United States, if not in the world. Johnson \& Coleman are taking. out enough of this coal at their mine, 4 miles east of Palafox, to run their pumping plants on the river. Coal from the same formation, and probably of about the same quality, is found on Espada Creek, in Webb County, near the base of the Mount Selman formation. A 14-inch bed of coal is also reported to outcrop near the top of the Mount Selman formation on the Rio Grande at low water at and near the mouth of Arroyo Santa Isabella.

Beds of coal, probably of poorer quality, may be obtained from the Indio and Bigford formations at many places where these formations outcrop. Lignite is found at the surface and at shallow depths at places east and southeast of Dentonio and at the Mangrum and Rutledge ranches, west and south of La Pryor. It is also penetrated in wells at La Pryor. An 18 to 20 inch bed of hard, brittle, and bright coal outcrops $1 \frac{1}{2}$ miles above the mouth of San Lorenzo Creek, in Webb County, in the Bigford formation. There is also an exposure of coal at the mouth of the first creek south of the Apache ranch house.

At Pilotes ranch, about 10 miles north of Palafox, as many as 11 seams of coal and bone were struck in a test drilling at depths ranging from 74 to 236 feet. The surface formation here is the Mount Selman, but the carbonaceous beds are in the Bigford formation. Coal in this same formation outcrops on Concillos Creek near its mouth and on Nueces River $2 \frac{3}{4}$ miles east of the Asherton-Big Wells road, a few' miles outside the Rio Grande region.

Coal is reported by Judge A. F. Spohn, of Zapata, to occur just north of Zapata and in the valley of Dolores Creek near the WebbZapata county line. This locality is in the outcrop of the Cook Mountain formation. No coal was seen, however, in the many sections of the Cook Mountain formation examined.

\section{WATER RESOURCES.}

Deussen and Dole ${ }^{46}$ have investigated the underground water resources of La Salle and McMullen counties, and Deussen ${ }^{47}$ has reported

${ }^{6}$ Deussen, Alexander, and Dole, R. B., Ground waterin La Salle and McMullen counties, Tex.: U. S. Geol. Survey Water-Supply Paper 375, pp. 141-177, 1916. on the underground waters of the whole of the southern part of the Texas Coastal Plain. The counties mentioned are close to the lower Rio Grande region and the conditions that prevail in them extend into this region.

\section{BRICK-MAKING MATERIAL}

Few of the clays of the lower Rio Grande region are suitable for making good brick. There is an abandoned brick plant at Reiser. The pit is in uppermost Yegua or lowest Fayette, and the clay is fairly pure. Facing brick of good grade was made here. The plant was abandoned when the Border Gas Co. shut down its gas wells at Reiser, thus shutting off the gas used as fuel. At no other place in the region has facing brick been manufactured.

Along the lower Rio Grande and its main delta distributaries there are numerous pits from which material is taken by Mexicans for making crude adobe brick. The largest and most efficient plant of this kind is at Los Ebanos, about 2 miles southwest of Sam Fordyce. Beaumont terrace silts, or recent fluvial silts, are mixed with water in the pit and worked into plastic masses having the consistency of dough. This material is thrown into trays containing six brick-sized compartments, which are sprinkled with dry sand to prevent it from sticking. The clay-filled tray is then carried by hand to a sunny flat near the pit and inverted, the wet bricks being left for a time to dry. When they have dried out sufficiently they are stacked or "ricked" in open piles for further drying by sun and wind. Finally they are placed in rough kilns made of adobe bricks and baked, branches of mesquite being used as fuel. The brick is poor, but it stands fairly well the pressure of the common Mexican one-story house.

\section{GRAVEL.}

The gravel supplies of the region are plentiful, widely distributed, and of good quality. The Reynosa formation furnishes gravel of high grade for road ballast and concrete work practically wherever it is exposed, whether in the main outcrop of the formation or west of the Bordas scarp, where only patches of Rey-

47 Deussen, Alexander, Geology and underground waters of the southeastern part of the Texas Coastal Plain: U. S. Geol. Survey WaterSupply Paper 335, 1914; Geology of the Coastal Plain region of Texas: U.S. Geol. Survey Prof. Paper 126 (in press). 
nosa are found. As only 1 per cent of the gravel is over 4 inches in diameter, as threefourths' of the pebbles and cobbles are composed of chert or other siliceous material, as the pieces. are well rounded and smooth, and as the material is practically nowhere so firmly cemented as to require blasting in its excavation, this deposit makes excellent commercial gravel. There are half a dozen or more pits along the river between Sam Fordyce and Peñitas. In some the loosely cemented and unconsolidated gravel is taken out with steam shovels, and in others it is removed by hand. At some plants it is sorted by power-driven screens, and at others by hand screening: Most of the gravel is used in the valley, but some is shipped as far as Houston. At Green's, in Webb County, on the International \& Great Northern Railway, where there is an outlier of Reynosa, a large pit has long been under excavation. Most of the gravel is loaded by steam shovels into cars and used as ballast on the railroad. Some of it has been used to surface a section of the San Antonio-Laredo wagon and automobile road between Green's and Webb.

\section{SAND.}

Good sand is not so abundantly produced as gravel, although there is plenty of it. The sand lenses in the Reynosa would furnish some, but they do so only where the sand is mixed with the finest grades of gravel. The sand sorted out of the Reynosa by the wind and piled into dunes in the main sand belt and elsewhere is generally pure, fine-grained quartz sand, but it is not used commercially. An abundance of sand is derived from the coastal beaches and lagoons in the sand belt also, but neither is this produced. The only sand used commercially to-day is in the Beaumont delta-like deposits at Mission and $\mathrm{McAl}$ len, where 25-foot lenses of almost pure-white sand, underlie clay and silt. The sand obtained at Mission sells for $\$ 2.25$ a cubic yard at the pit.

\section{GYPSUM.}

The sediments of the region inclose a large amount of gypsum in thin beds, seams, plates, crystal aggregates, and larger bodies, but it is nowhere utilized.

\section{ROAD MATERIAL.}

The quartzites, sandstones, limestones, concretions, and conglomerates of the region would make good material for building roads, but as few roads have been built they have not yet been so utilized. Argillaceous and calcareous materials from the Reynosa formation have been used to harden an excellent road through the sand belt from Falfurrias to Edinburg, permitting automobile traffic into the valley from coastal points farther north.

Shallow pits are opened along the road every mile or two and the material is laid on a graded surface of sand. This road lacked about 10 miles of being completed in 1920 . The same material is being used in the same way on the sandy road to Rio Grande City from Hebbronville.

\section{CEMENT.}

It is possible that a proper combination of limestone, clay or shale, and gypsum might be found for the manufacture of Portland cement, coal, oil, or gas being used for fuel, but no commercial concern has yet found this combination. 


\title{
NEW SPECIES OF MOLLUSCA FROM THE EOCENE DEPOSITS OF SOUTHWESTERN TEXAS.
}

\author{
By Julia Gardner.
}

The new species and subspecies whose names are used in the preceding paper by A. C. Trowbridge are described below. One species that had already been described and that is here treated as a subspecies of Ostrea alabamiensis is considered in detail because of its abundance in the middle and upper Eocene deposits in the lower Rio Grande region.

The letters after some of the station numbers have the following significance: (a) abundant, (c) common, (p) present, (r) rare.

\section{PELECYPODA. \\ Family NUCULIDAE. \\ Genus NUCULA Lamarck: \\ Nucula sp. \\ Plate XXIX, figure 3.}

The rock in the area a little south of Laredo, in Webb County, is made up largely of a Nucula, which is probably distinct from any species described, though it is very close to $N$. magnifica Conrad. It is about 3 centimeters high and broad and is sculptured with prominent growth lines and a uniformly developed, subcutaneous radial threading. No hinges or perfect exteriors have been found, but the pearly fragments of the thick shell pack the matrix.

Occurrence: Cook Mountain formation. Station 7492 (p), 1 mile east of Laredo; station 8818 (a), 5 miles southeast of Laredo, Webb County.

\section{Genus OSTREA (Linnaeus) Lamarck. \\ Ostrea tasex Gardner, n. sp. \\ Plate XXXI.}

8Ostrea.multilirata Conrad, U. S. and Mex. Boundary Survey Rept., vol. 1 , pt. 2, p. 157, pl. 12, figs. 1 a-d, 1.857.

Shell of only moderate dimensions for the genus, subequivalve, ovate-trigonal in outline, generally somewhat produced anteriorly; surface layer decorticated; both the right and left valves radiately sculptured with 15 to 20 fine, approximately uniform, rippling riblets, similar to those developed upon the attached valve of $O$. crenulimarginata Gabb; ligament area mod$91048^{\circ}-23 \longrightarrow 8$ erately large, somewhat flattened in the right valve, the medial depression relatively wide, broadly but not deeply excavated; growth striae obvious; lateral margins very finely crenate, the crenae persistent in some individuals around the entire inner margin; basal margin often fluted in harmony with the external sculpture; adductor muscle scar crescentic, lying below the median horizontal, moderately large, not very deeply excavated; pedal scar obscure.

Dimensions: Right valve, altitude 80 millimeters, latitude 65 millimeters; left valve, altitude 98 millimeters, latitude 72 millimeters.

Type locality: Station 8925 , a quarter of a mile northeast of Glass ranch headquarters, Dimmit County, Tex.

Ostrea tasex is the analogue in southwestern Texas of Ostrea crenulimarginata of the Midway of Alabama. In the Alabama species, however, the right valve is smooth, but in those found along the Rio Grande the two valves are similarly sculptured. Toward the umbones the radials are sharply elevated, though they tone down into an even fluting toward the outer margin.

Ostrea tasex is probably identical with Ostrea multilirata Conrad, collected from the so-called Cretaceous of "Dry Creek, Mexico." Conrad's types are in the National Museum and are fairly well preserved. Nothing of the kind has been reported from the Cretaceous by later investigators who have collected extensively in the Rio Grande area. However, Ostrea cortex, collected at the same locality, is certainly a Cretaceous species, and until "Dry Creek" can be definitely located and the confusion in the stratigraphic relations cleared the Wilcox form may well be kept apart.

$$
\text { Stations in Indio formation. }
$$

8927 (c). 4 miles south of Rackdale, Milam County. 6278 (a). 11 miles south of Sabinal, Uvalde County.

3187 (r?). East side of the Rio Grande, in Maverick County, about $3 \frac{1}{2}$ miles above the mouth of San Ambrosia Creek.

9173 (c). 17 miles west of Carrizo Springs, Dimmit County. 
8925 (c). A quarter of a mile northeast of Glass ranch headquarters, Dimmit County.

1/67 (c). 3 miles north by west of San Pedro ranch, on the Maverick-Dimmit County line.

Ostrea alabamiensis subsp. georgiana Conrad.

Plate XXIX, figures 6, 7; Plate XXX.

Ostrea georgiana Conrad, Acad. Nat. Sci. Philadelphia Jour., 1st ser., vol. 7, p. 156, 1834.

Dana, Manual of geology, lst ed., p. 519, fig. 811, 1863.

Dall, Wagner Free Inst. Sci. Trans., vol. 3, pt. 4, p. $683,1895$.

Ostrea titan Conrad, Acad. Nat. Sci. Philadelphia Proc., 1st ser., vol. 6, p. 199, 1854; Pacific R. R. Rept., vol. 6, pt. 2, p. 72, pl. 4, fig. 17a; pl. 5, fig. 17a, 1857.

Ostrea contracta Conrad, U. S. and Mex. Boundary Survey Rept., vol. 1, pt. 2, p. 160, pl. 18, fig. 1 a-d, 1857.

Ostrea alabamiensis Conrad var. contracta Harris, Bull. Am. Paleontology, vol. 6, p. 9, pls. 3, 4, pl. 5, fig. 2, 1919.

Type localities: "Orangeburgh, S. C.; Shell Bluff and near Milledgeville, Ga."-Conrad, 1834.

Ostrea alabamiensis subsp. georgiana is the most conspicuous species in the later Eocene of Texas, and in many localities it is the only fossil collected. Its range of variation, like that of other oysters, is wide. Only a very small percentage of individuals retain the fine epidermal sculpture, the one constant feature, and one identical with that of $O$. alabamiensis. However, in the large mass of material available for study - several hundred individualscertain differences in the average individual developed at the different horizons can be detected. None of the huge, very much elongated and massive shells so common in the Fayette near Roma in Starr County have been found in the Cook Mountain formation farther north. The forms occurring at this lower horizon are of only moderate dimensions, usually relatively thin and broadening at the base, and, as a rule, conspicuously laminar. This decided laminosity is one of the more persistent features of the Cook Mountain O.georgiana. The Cook Mountain form grades in to $O$. alabamiensis though the hinge is usually heavier and more elongated. The very large, massive, narrow, and elongate individuals described by Conrad under $O$. contracta occur in considerable numbers in the Yegua, and in the Fayette this type has shut out almost entirely the smaller and thinner race of the Cook Mountain.

Stations in Cook Mountain formation. 6650 (c), 6657 (c), 6652 (c). Environs of Cotulla, La Salle County.
8816 (p). 100 feet south of windmill, Marguerita ranch, 6.4 miles west of Webb Station, Webb County. 8785 (p). 2.1 miles east of Webb, Webb County. 8841 (p). Half a mile west of triangulation station Dolores, 2 miles north of Dolores, Webb County. $8842(\mathrm{p})$. Three-fourths mile west of triangulation station Dolores, Webb County. 8830 (p): 10 miles northwest of Laredo, Webb County. 2113 (c). 5 miles northeast of Laredo, Webb County. 8765 (r). 2.3 miles northeast of Laredo, at crossing of San Antonio road with International \& Great Northern Railway, Webb County.

7492 (p). 1 mile east of Laredo, Webb County.

6058 (c) (old series). Laredo, Webb County.

8835 (a). 6 miles southeast of Laredo, Webb County.

6436 (r). La Perla ranch, below Laredo, Webb County. 8840 (c). North bank of Salado Creek, Zapata County. 9116 (c). Soledad, Zapata County.

9112 (c). 2 miles down the river from Zapata, Zapata County.

9109 (p). Rio Grande prospect, 4.8 miles southeast of Zapata, on Roma road, 2.5 miles northeast of main road, Zapata County

9110 (p). 4.8 miles southeast of Zapata, Zapata County. 9113 (c). $5 \frac{1}{2}$ miles southeast of Zapata, Zapata County. 9175 (p). 14.2 miles below Zapata, Zapata County. 6432 (r). Arroyo Dolores, Zapata County. 9106 (r). Zapata County.

\section{Stations in Yegua formation.}

8784 (a). 3.4 miles east of Cactus Station, Webb County. 8809 (c). 12 miles northeast of Laredo, Webb County. 8849 (p). 7 miles northeast of Laredo, Webb County. 8061 (c). 7 miles east of Laredo, Webb County. 8834 (a). 8 miles east of Laredo, Webb County. 9119 (p). $2 \frac{1}{2}$ miles southwest of Alejandreñas ranch, Zapata County.

7741 (r). 1 mile northwest of Pedernal ranch headquarters, Zapata County.

9182 (a). 3.2 miles northeast of Lopeño, Zapata County. 8843 (a). $23 \frac{1}{2}$ miles northwest of Rio Grande City, Zapata County.

9187 (p). $2 \frac{3}{4}$ miles south of Romireño, Zapata County. 9188 (p). 3 miles south of Romireño, Zapata County.

\section{Stations in Fayette sandstone.}

6147 (a). C. T. Tom ranch, $\frac{3}{4}$ mile south of Campbellton, Atascosa County.

6144 (a) 6 miles east of Campbellton, Atascosa County. 6146 (p). 3 miles southeast of Campbellton, Atascose County.

3601 (r). Winchester, Fayette County.

9094 (p). Reiser, Webb County.

9098 (c). 1.3 miles southwest of Webb-Zapata shallow oil field, Zapata County.

7740 (a). Charco Redondo ranch, Zapata County. 8060 (p). Charco Redondo ranch, Zapata County.

9179 (p). 3.6 miles northeast of Palo Blanco ranch, Zapata County.

9181 (a). 3 miles northeast of La Presa ranch house, Zapata County.

9096 (c). 3.6 miles south of Huisatche ranch, Jim Hogg County.

9192 (p). 19 miles north of Roma, Starr County. 
9191 (c). 15 miles north of Roma, Starr County. 9189 (r). 7 miles above Roma, Starr County. 9:193 (c). 1.7 miles northeast of Agua Dulce ranch, north of Roma, Starr County.

7493 (p). $12 \frac{1}{2}$ miles below Arroyo Tigre on road to Roma; Starr County.

$$
\text { Stations in Frio clay. }
$$

6666 (r). 9 miles north of Tilden, McMullen County. 6665 (a). One-fourth mile east of post No. 7, west of Tilden, McMullen County.

3093 (p). Fort Ringgold, Starr County.

\section{Family PARALLELODONTIDAE.} Genus CUCULLAEA Lamarck.

Cucullaea is one of the more conspicuous fossils in the Midway of Texas. Apparently there is but a single species, though the small and poorly preserved northern forms may prove to be distinct from those of the Rio Grande province. This species is certainly not identical with $C$. macrodonta, found farther east, though the differences may not be of specific rank. Its relation to $C$. saffordi Gabb, described from a lost type two-tenths of an inch in latitude, is even less definite.

Cucullaea (macrodonta subsp.?) texana Gardner, $n$. subsp.

Plate XXIX, figures 4, 5 .

Cucullaea macrodonta Harris (part), Bull. Am. Paleontology, vol. 1, No. 4, p. 165, 1896.

Cucullaea safordi Harris (part), Bull. Am. Paleontology, vol. 1, No. 4, p. 165, 1896.

Shell large, heavy, inflated, the single valves rudely quadrate. in outline, the double valves cordate in cross section through the umbones; umbones prominent, inflated, overhanging the cardinal area, the tips incurved and prosogyrate, slightly in advance of the median vertical; length of hinge approximately five-sixths that of the shell; anterior extremity angulated dorsally, rounding broadly into the ventral margin; base line approximately horizontal medially; posterior extremity obliquely truncate; posterior area flattened, delimited by a narrow but obtuse ridge with a shallow sulcus behind it; valves differentially sculptured, the right valve exhibiting about 30 low, broad radials separated by linear interspaces and persisting to the posterior keel, where they abruptly disappear; a very fine, close, and uniform radial cording developed upon the posterior area in some individuals, but commonly absent, as in the type, or evanescent toward the margin. Left valve exhibiting only about 24 radials distributed over the medial and anterior por- tions of the shell but absent upon the posterior third, narrower than those upon the right valve and separated by interspaces of a width almost equal to the radials; sculpture of posterior area similar in the two valves; incremental sculpture pronounced, particularly toward the base; hinge area of moderate width for the genus, obliquely grooved; hinge very imperfectly preserved; very narrow medially with short vertical teeth, abruptly widening near the extremities; distal teeth coarse, few in number, and rudely parallel to the hinge margin; characters of interior not known.

Dimensions: Altitude, 42.0 millimeters; length of hinge, 39.0 millimeters; maximum latitude, 47.5 millimeters; diameter, $40.0 \pm$ millimeters.

Type locality: White Bluff, Rio Grande, Maverick County, Tex. Type, U. S. National Museum:

The specimens from Kaufman County, in the northern part of the State, are smaller than those from points along the Rio Grande. They differ, too, in the more uniform development of a radial sculpture upon the posterior area.

Cucullaea (macrodonta subsp.?) texana varies widely in outline and to a lesser degree in detail of sculpture. The shell runs larger and heavier than the typical $C$. macrodonta Whitfield, and the sculpture of the left valve, though discrepant, is regular and differs from that of the right only in the narrower ribs, wider interspaces, and in its development over a more restricted portion of the shell. These differences, though slight, are fairly constant in the imperfect material in hand. Cucullaea saffordi Gabb was described from a shell 0.2 inch in latitude. This type, according to Harris, has been lost. Until the young have been correlated with adults at the type locality and the species adequately described from such material the characters of $C$. saffordi Gabb must be open to question. There is need for uncommon caution in Hardeman County, as the Upper Cretaceous and Eocene outcrops are very near to one another and were confused in some of the earlier collections.

\section{Stations in Midway formation.}

2440 (c). 4 miles east of Kemp, Kaufman County. 2439 (r). 1 mile east of Webberville, Travis County. ?6584 (r). D'Hanis-Yancey road, about $7 \frac{1}{2}$ miles east of south of D'Hanis, Medina County.

3180 (c). Bluff on Frio River, half a mile below Myrick's (Evans's) apiary, Uvalde County. 
583 (r). 18 miles southeast of Eagle Pass; Maverick County.

4398 (p). 18 miles southeast of Eagle Pass, Maverick County.

6583 (p). Biboro Creek, just below Biboro tank, about 18 miles southeast of Eagle Pass, Maverick County.

6575 (c). White Bluff on Rio Grande, land of Indio Cattle Co., about $4 \frac{1}{2}$ miles west of south of Jacal ranch house, in southeastern part of Maverick County.

\section{Family CARDITIDAE. \\ Genus VENERICARDIA Lamarck.}

Venericardia (alticostata subsp.?) whitei Gardner, n. subsp.

Plate XXXII, figure 3 .

Venericardia alticostata Harris (part), Bull. Am. Paleontology, vol. 1, No. 4, p. 171, pl. 5, fig. 3, 1896.

Not Venericardia perantiqua Conrad, Am. Jour. Conchology, vol. 1., p. 8, 1865 .

Shell small but thick and heavy, tranversely elongated in outline, rather compressed; umbones low, broadly rounded, for the most part strongly anterior in position; lunule minute; anterior extremity bowed in front of the lunule; posterior extremity obliquely produced and broadly rounded; base line feebly arcuate; surface coarsely sculptured radially; radials usually 19 to 21 in number, broad, crowded and heavily corrugated upon the anterior and medial portions of the shell; narrow and less closely spaced posteriorly; ligament characters not known; dentition apparently normal, very poorly preserved in all the material available for study; adductor scars very distinct; pallial line simple; inner margins very coarsely crenate.

Dimensions: Altitude, 25 millimeters; latitude, 31 millimeters; semidiameter, 13.5 millimeters.

Type locality: Station 3180, Bluff on Frio River half a mile below Myrick's apiary, Uvalde County.

The new subspecies differs from $V$. alticostata s. s. and from the subspecies hesperia in the simple radials. $V$. smithii is larger and relatively higher as a rule, with normally over 30 radials instead of less than 25 , as in whitei.

Venericardia perantiqua was described under the name Cardita subquadrata by Gabb from the Eocene of New Jersey. The casts are very imperfect, but they indicate a much compressed, trigonal to subquadrate form quite unlike anything reported from the Eocene of Texas or of the Gulf.

The form is named in honor of Dr. Charles A. White, one of the foremost of the earlier paleontologists and one of the first to collect from the Texas Tertiary formations.
Stations in Midway formation.

3180 (p). Bluff on Frio River half a mile below Myrick's (Evans's) apiary, Uvalde County.

6279 (r). 11 miles south of Sabinal, a few hundred yards south of the junction of Elm Creek with Sabinal Creek, Uvalde County.

4398 (r). 18 miles southeast of Eagle Pass, Maverick County.

Venericardia alticostata subsp. hesperia Gardner, n. subsp. Plate XXXII, figures 1, 2.

Venericardia alticostata Harris (part), Bull. Am. Paleontology, vol. 1, No. 4, p. 171, 1896.

Not Cardita alticostata Conrad, Am. Jour. Sci., 1st ser., vol. 23, p. 342, 1833.

Shell of moderate dimensions, thick, porcellanous, inflated-cordate in cross section; umbones prominent, well rounded, slightly anterior in position; lunule very small, deep; anterior extremity strongly and evenly bowed in front of the lunule; posterior dorsal margin gently sloping, the posterior lateral margin obliquely truncate; base line feebly arcuate, strongly upcurved anteriorly, abruptly rounded posteriorly; general character of surface sculpture similar to that of $V$. alticostata s. s.; radials not far from 20 in number, normally tripartite on the anterior and medial portions of the shell as in $V$. alticostata; crest of radials narrow and sharply serrate; lateral "terraces" well defined; inter-radial channels broadly. U. shaped; incremental sculpture very fine and sharp; heavy growth stages rarely developed; hinge and ligament characters poorly preserved; hinge plate thick, heavy; adductor scars impressed, the anterior excavated; pallial line simple; inner margins deeply crenate.

Dimensions: Altitude, 38 millimeters; latitude, 37 millimeters; diameter, 44 millimeters.

Type locality: Station 3180, Bluff on Frio River half a mile below Myrick's apiary, Uvalde County.

The subspecies hesperia is shorter and wider than $V$. alticostata and more inflated in the umbonal region. In sculptural characters, however, the two forms are similar.

Venericardia bulla Dall is smaller and relatively higher and has a higher and relatively heavier hinge plate and less numerous radials. In both $V$. smithii Aldrich and $V$. alticostata subsp. whitei the radials are simple.

\section{Stations in Midway formation.}

1/128 (p). 13 miles northwest of New Fountain, Medina County.

3180 (p): Bluff on Frio River half a mile below Myrick's (Evans's) apiary, Uvalde County. 
31.81 (p). Frio River just above waterhole opposite apiary, below Englemann's ranch, Uvalde County.

?6279 (r) (No. 274c). 11 miles south of Sabinal, a few hundred yards south of the junction of Elm Creek with Sabinal Creek, Uvalde County.

P4398 (r). 18 miles southeast of Eagle Pass, Maverick County.

6583 (p). Biboro Creek, just below Biboro tank, about 18 miles southeast of Eagle Pass, Maverick County.

$6575(p)$. White Bluff on Rio Grande, land of Indio Cattle Co., about $4 \frac{1}{2}$ miles west of south of Jacal ranch house, in the southeastern part of Maverick County.

Family VENERIDAE.

Genus CALLOCARDIA.

Callocardia astartoides Gardner, n. sp.

Plate XXXII, figures 4-7.

Shell small for the genus, thick shelled, trigonal, ovate in outline, astartiform, moderately compressed; umbones not conspicuous, the tips proximate and prosogyrate, slightly anterior; lunule rather wide, cordate, slightly depressed, and delineated by an incised line; escutcheon not defined; anterior extremity bowed slightly in front of the lunule; posterior end of shell obliquely truncate and feebly arcuate from the umbones to the basal margin; base line arcuate, more abruptly rounded posteriorly than anteriorly; external surface finely and evenly threaded concentrically; resting stages conspicuous, usually one strongly defined near the umbones and several not quite so prominent toward the base; a fine and regular radial lineation visible upon weathered surfaces; external ligament mounted upon a rather heavy nymph produced more than one-third of the length of the posterior dorsal margin; dentition robust; the laminar anterior cardinal of the right valve broken away; medial cardinal rather slender, cuneate; posterior cardinal produced; left anterior and medial cardinals united under the umbones to form an asymmetric $V$, the anterior cardinal slender, the medial cardinal relatively heavy and deltoid; posterior left cardinal broken away, doubtless very thin and laminar; a very short obtuse lateral tooth developed in the left valve, received in a corresponding socket in the right; adductor scars distinct, the anterior the more prominent; pallial sinus produced almost to the median vertical, obtusely trigonal; inner margins entire.

Dimensions: Right valve, altitude $16.0 \mathrm{mil}-$ limeters, latitude 16.5 millimeters, semidiameter 7.4 millimeters; left valve, altitude 17.0 millimeters, latitude 17.3 millimeters, semidiameter 8.6 millimeters.
Type locality: Station 8833, about 7 miles up the Rio Grande from Laredo, at Knob Bluffs, a quarter of a mile above pump of Santa Barbara farm, Webb County, Tex.

Callocardia astartoides is a remarkable species, uniting the dentition and sinal characters of the Veneridae with the external outline and surface sculpture of certain of the Astartidae. The occurrence of so primitive a type of a highly specialized group in the early Tertiary beds is of unusual interest.

Callocardia astartoides is the dominant species at the type locality and common at a number of other localities in the Cook Mountain formation.

\section{Stations in Cook Mountain formation.}

?8850 (c). 500 yards southwest of Espejo ranch, 8 miles south of Laredo, Webb County.

8833 (a). About 7 miles up the Rio Grande from Laredo, in Knob Bluffs, a quarter of a mile above pump of Santa Barbara farm, Webb County.

8768 (c). $1 \frac{1}{2}$ miles north of and a trifle east of the third gate, 7 miles southeast of Velenzuela ranch house, Webb County.

8770 (c). 39.9 miles north of Rio Grande City, Starr County, on river road to Zapata, just north of Lopeño post office, Zapata County.

\section{Family TELLINIDAE.}

Genus TELLINA (Linnaeus) Lamarck.

Tellina sp. A.

Plate XXXIr, figures 8, 9.

Shell large, not very thin, much compressed, transversely ovate-trigonal in outline, nearly equilateral; umbones flat, inconspicuous except by reason of their position at the apex of an angle of not far from $120^{\circ}$; anterior and posterior dorsal margins nearly similar, the posterior declining, perhaps, a little more steeply; lateral extremities quite sharply rounded; base line symmetrically arcuate; an inconspicuous rostral fold developed near the posterior dorsal margin, defined rather by the abrupt change, in the direction of the incrementals than by its elevation; surface sculpture incremental in character, least feeble posteriorly and toward the basal margin, becoming abruptly stronger behind the rostral fold and indicating by the undulation a second very obscure fold; characters of ligament and hinge not known; adductor scars commonly quite prominent; pallial sinus obscure but apparently very deep, produced almost to the anterior adductor, not confluent below. 
The species is decidedly larger than any other found in the Eocene of Texas. A latitude of 40 millimeters is not uncommon and one cast, presumably identical, reaches an altitude of 40 with a probable latitude of 60 millimeters or more. Unfortunately, only casts, some of them with a few fragments of shell adhering, are preserved.

\section{Stations in Cook Mountain formation.} 8771 (p). 4 miles southeast of Laredo, Webb County. 6404 (p). 1 mile west of Canada Verde ranch, Webb County.

6436 (c). La Perla ranch below Laredo, Webb County.

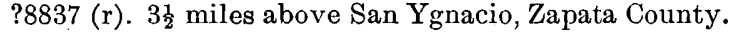
?8770 (p). Lopeño post office, Zapata County.

\section{Family PHOLADIDAE.}

Genus MARTESIA Leach.

Martesia? laredoënsis Gardner, n. sp.

Plate XXXII, figure 10.

Shell very thin, transversely elongated, tapering posteriorly, strongly inflated; anterior third of shell cut off by a deep but narrow groove, dropped from the umbones and extending obliquely backward; umbones low, conforming to the tubular cutline of the shell, prosogyrate; anterior extremity rounding smoothly into the upcurved base; posterior dorsal and ventral margins slowly converging, the narrow lateral extremity vertically truncate; shell usually decorticated but so thin that the sculpture is reflected on the cast; a concentric sculpture, incremental in character and more or less irregular, developed over the entire shell but stronger upon the anterior third; radials approximately equal in strength to the concentric rugae and, like them, somewhat irregular, developed only in front of the groove; characters of the hinge and of the interior not known.

Dimensions: Altitude, 9.0 millimeters; latitude, $20.0 \pm$ millimeters.

Type locality: Station 6434, a quarter of a mile south of Espejo ranch, south of Laredo, in Webb County, Tex.

Martesia texana Harris is similar to this species in outline and general dimensions, but the umbones of the Cherokee County species are not so near to the anterior extremity, the groove cuts off decidedly more than the anterior third, and there is an apparent absence of any radial sculpture. No trace of either $M$. texana or $M$. laredoënsis has been found except at the type localities.
Station in Cook Mountain formation.

6434. A quârter of a mile south of Espejo ranch, south of Laredo, Webb County.

\section{Family TEREDINIDAE.}

Genus TEREDO Linnaeus.

Teredo maverickensis Gardner, n. sp.

Tubes of moderate dimensions, somewhat irregular in growth habit though tending to follow the grain of the wood; closely and quite sharply rugose; characters of valves not known.

Dimensions: Diameter, 6.0 millimeters; thickness of shell, 0.6 millimeters.

Type locality: Station 1/277, Rio Grande, lower end of Marerick County, about 40 feet below Midway-Wilcox contact.

This teredo, which packs a large fragment of fossilized wood, is the first that has been reported from the Midway of the Gulf. It differs from the later Eocene teredos in the less regular growth habits and particularly in the very decided, close, sharp wrinkling of the surface. The value of these differences is increased by the difference in the habitat: It is interesting to find a record of the unfortunate appetite of this animal in the Midway of Texas.

Station in Midway formation.

1/277. Rio Grande, lower end of Maverick County, about 40 feet below Midway-Wilcox contact.

\section{GASTROPODA.}

Family CERITHIIDAE.

Genus CERITHIOM Bruguière.

Cerithium? sp. A.

Plate XXIX, figures 1, 2.

Internal casts of Cerithium-like forms occur in considerable numbers in southwestern Texas and serve as excellent horizon markers of the Midway. These casts indicate a rudely biconic shell with the maximum diameter in front of the median horizontal. The whorls of the conch were probably about 6 or 7 in number, rudely trapezoidal in outline and increasing quite rapidly in diameter. The body was smoothly rounded in the adults, though probably rather acutely angulated in the young. Some individuals show a suggestion of an irregular Cerithium-like ribbing. The aperture was ap-。 parently between one-third and one-half as long as the entire shell and was obliquely lenticular in outline. A specific name is reserved in the hope that the shell may come 
to light later. In the meantime these easily recognizable casts may be of service in indicating the Midway age of the formation in which they are carried.

Dimensions of imperfect figured specimen: Altitude, 42.0 millimeters; maximum diameter, 21.0 millimeters.

\section{Stations in Midway formation.}

31.80 (p). Bluff on Frio River, half a mile below Myrick's (Evans's) apiary, Uvalde County.

6576 (c). Land of Indio Cattle Co., 13 miles below White Bluff, about $4 \frac{1}{2}$ miles southwest of Jacal ranch house, Maverick County.

8799 (p). Texas side of the Rio Grande 1 mile below the Blessé ranch house, Maverick County.

CEPHALOPODA.

Family CLYDONAOTILIDAE Hyatt.

Genus ENCLIMATOCERAS Hyatt.

Enclimatoceras vaughani Gardner, n. sp. Plate XXXIII.

Shell large, rather compressed toward the apex, more broadly rounded ventrally toward the aperture, obliquely flattened laterally; whorls numerous, increasing but slowly in latitude; the altitude of the earlier whorls a little more than three times their average width from suture to suture, of the later whorls a little less; final whorl of a half grown specimen rudely reniform in outline, somewhat auriculate laterally, concave, the diameter of the whorl approximately double the altitude; umbilici quite strongly depressed, their periphories obscurely carinate; ventral saddle very broad and nearly horizontal; lateral lobes broad and very shallow; lateral saddles relatively narrow and moderately deep; siphuncle dorsad, migrating slowly toward the center with increasing age; surface not known.

Dimensions: Maximum diameter of shell, $168.0 \pm$ millimeters; diameter of shell at right angles to maximum diameter, $140.0 \pm$ millimeters; thickness 100.0 millimeters. Adolescent individual: Maximum diameter of shell, $93.0 \pm$ millimeters; diameter of shell at right angles to maximum diameter, $64.0 \pm$ millimeters; maximum thickness, 73.0 \pm millimeters. A larger but imperfect individual attains a maximum diameter of 220.0 millimeters.

Type locality: Station 3178, three-fourths mile northwest of Myrick's (Evans's) apiary, Frio River, Uvalde County.

Enclimatoceras vaughani is the Texas analogue of Enclimatoceras ulrichi (White), of the Midway of Alabama, a form very similar in seneral dimensions and outline. The adult $E$. vaughani are, as a rule, more compressed than the adult $E$. ulrichi, but the young of the two species show similar ranges of variation.

The umbilici also seem to be a little more depressed in the Texas species. The most obvious and constant difference, however, is in the outline of the lobes and saddles. The sutures in $E$. ulrichi are much more flexuous than those of E. vaughani. In E. vaughani the ventral saddle is nearly horizontal and the lateral lobes exceedingly shallow: In $E$. ulrichi the ventral saddle is perceptibly arcuate and the lateral lobes are strongly incurved. The lateral saddles are well developed in both species, though they are deeper in the Texas form.

I have the honor of dedicating this species to Dr. T. Wayland Vaughan.

\section{Stations in Midway formation.}

3178 (p). Three-fourths mile northwest of Myrick's (Evans's) apiary, north of Frio River, Uvalde County. 3179 (p). Half a mile northwest of Myrick's (Evans's) lower apiary, south side of Frio River, Uvalde County.

Frio River half a mile above Bob Evans's (formerly Myrick's) apiary, Uvalde County. 
PLATES XXIX-XXXIII.

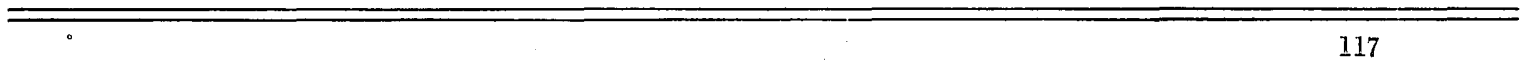




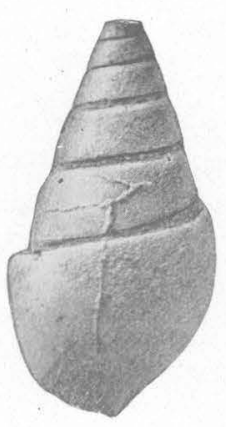

1

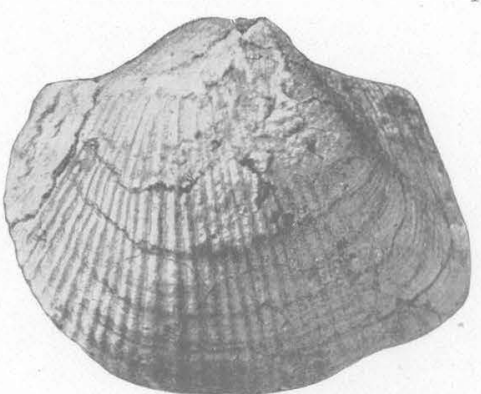

5

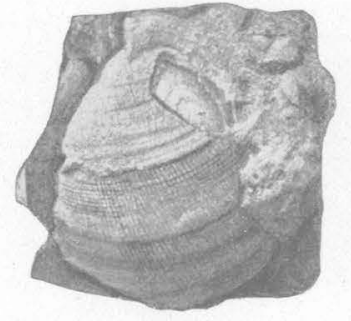

3
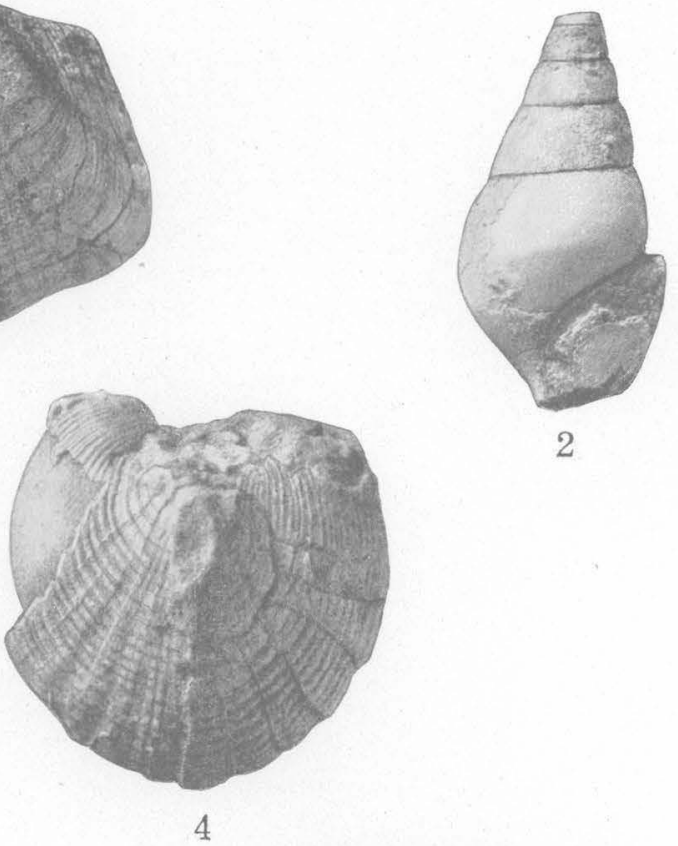

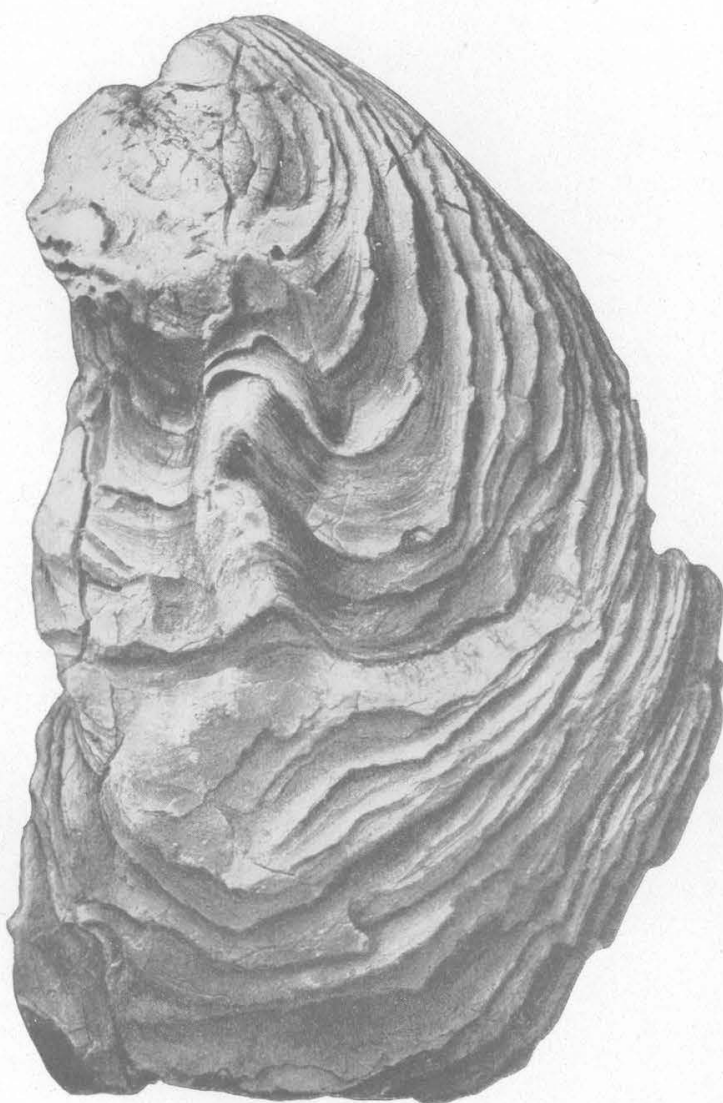

6

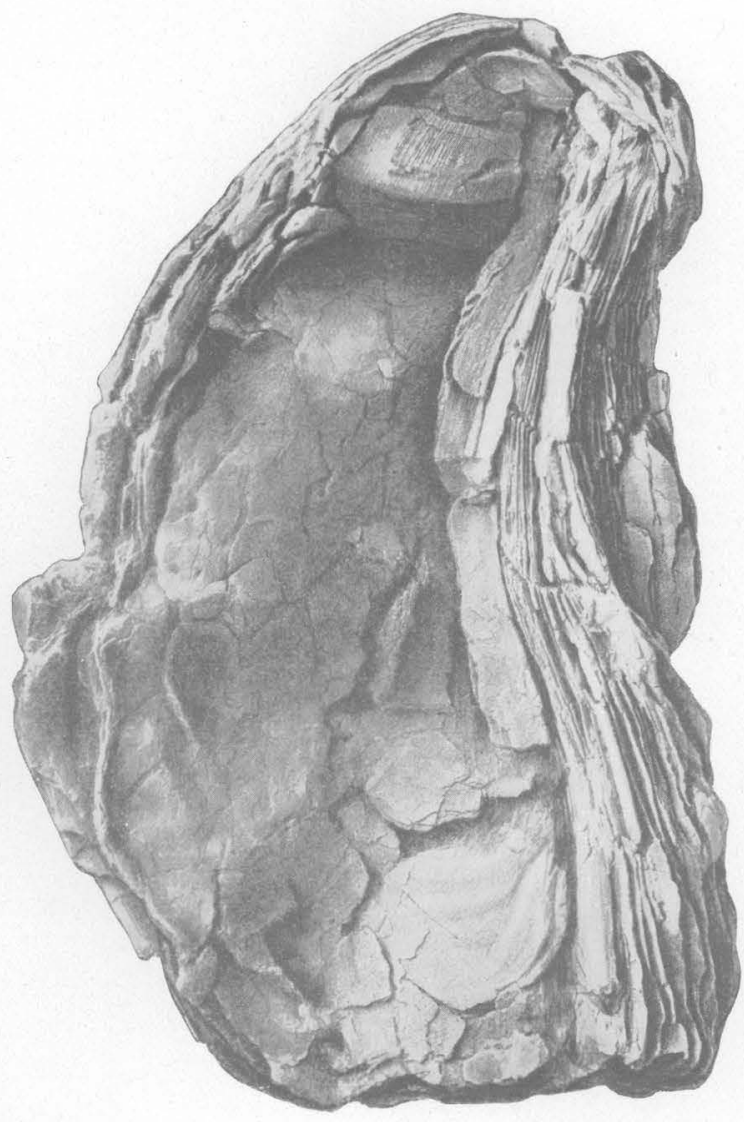

7

EOCENE MOLLUSCA FROM SOUTHWESTERN TEXAS.

1, 2. Cerithium? sp. A. 1, Dorsal view, $\times 1 ; 2$, apertural view, $\times 1$.

3. Nucula sp. Exterior of right valve, $\times 1$.

4, 5. Cucullaea (Macrodonta subsp. ?) texana Gardner, n. subsp. 4, Front view, $\times 1 ; 5$, exterior of left valve, $\times 1$.

6, 7. Ostrea alabamiensis subsp. georgiana Conrad, 6, Exterior of left valve, $\times 1$; 7 , interior of left valve, $\times 1$. 


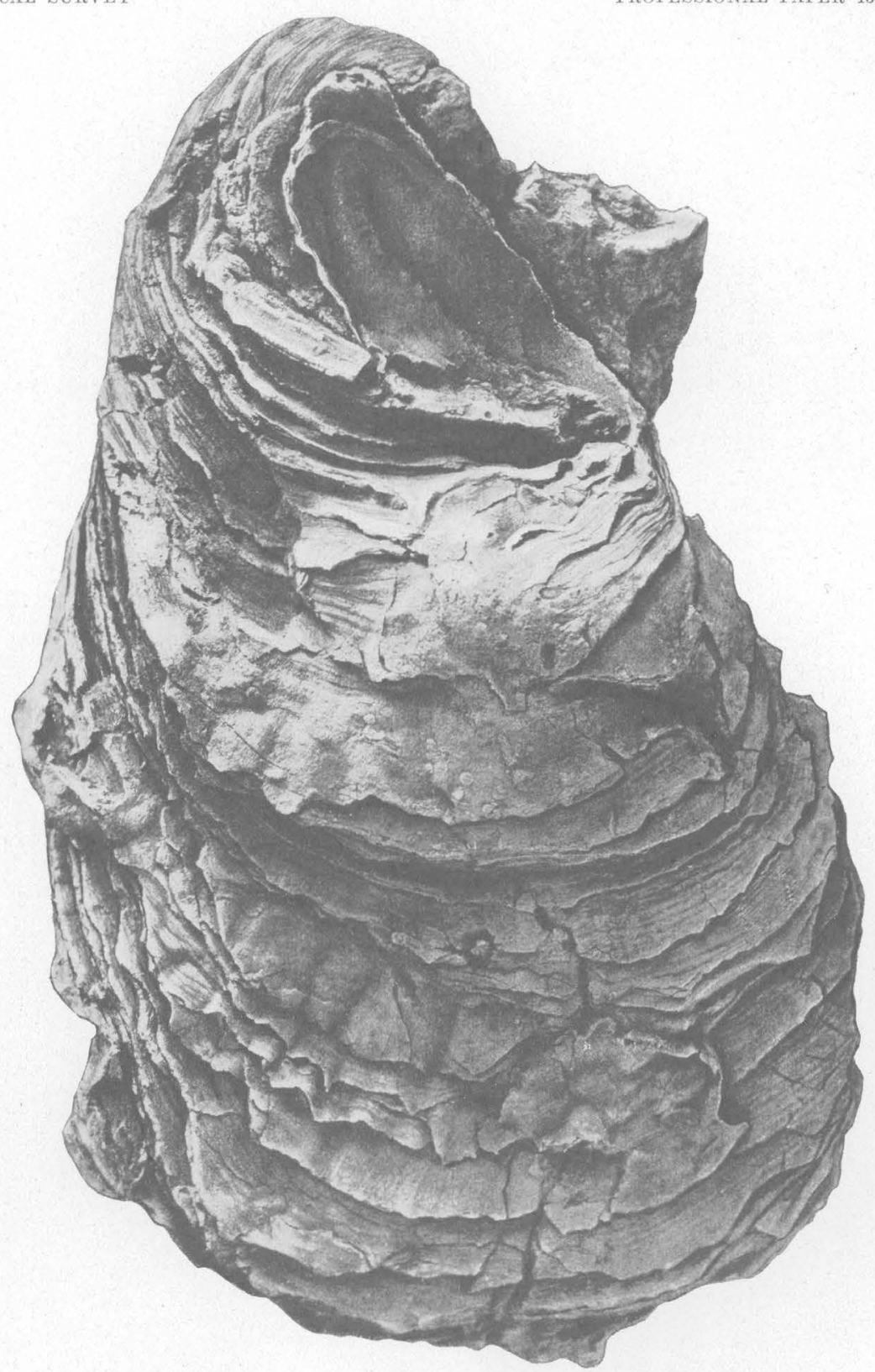

EOCENE MOLLUSCA FROM SOUTHWESTERN TEXAS.

Ostrea alabamiensis subsp. georgiana Conrad. Exterior of right valve, $\times 1$. 
U. S. GEOLOGICAL SURVEY

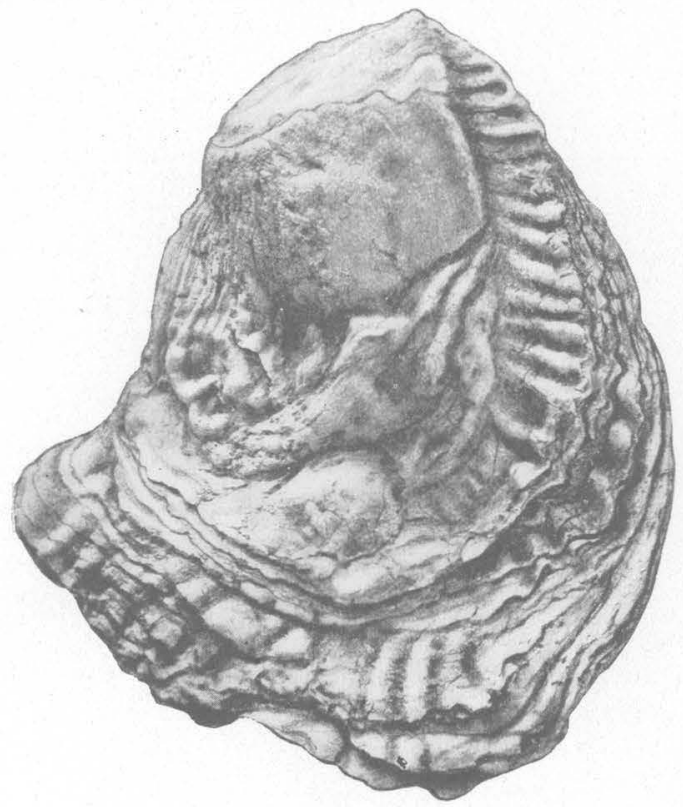

1
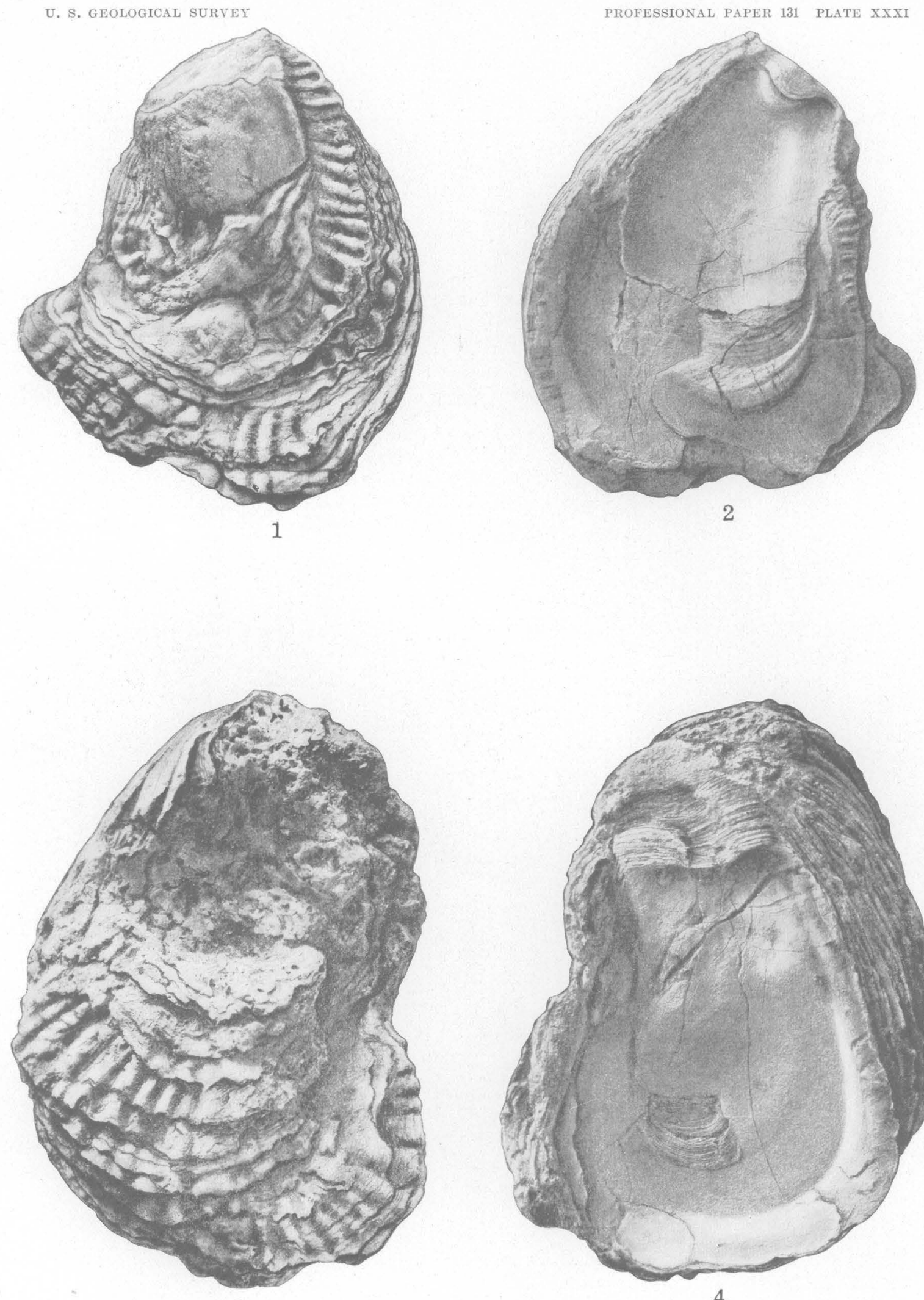

3

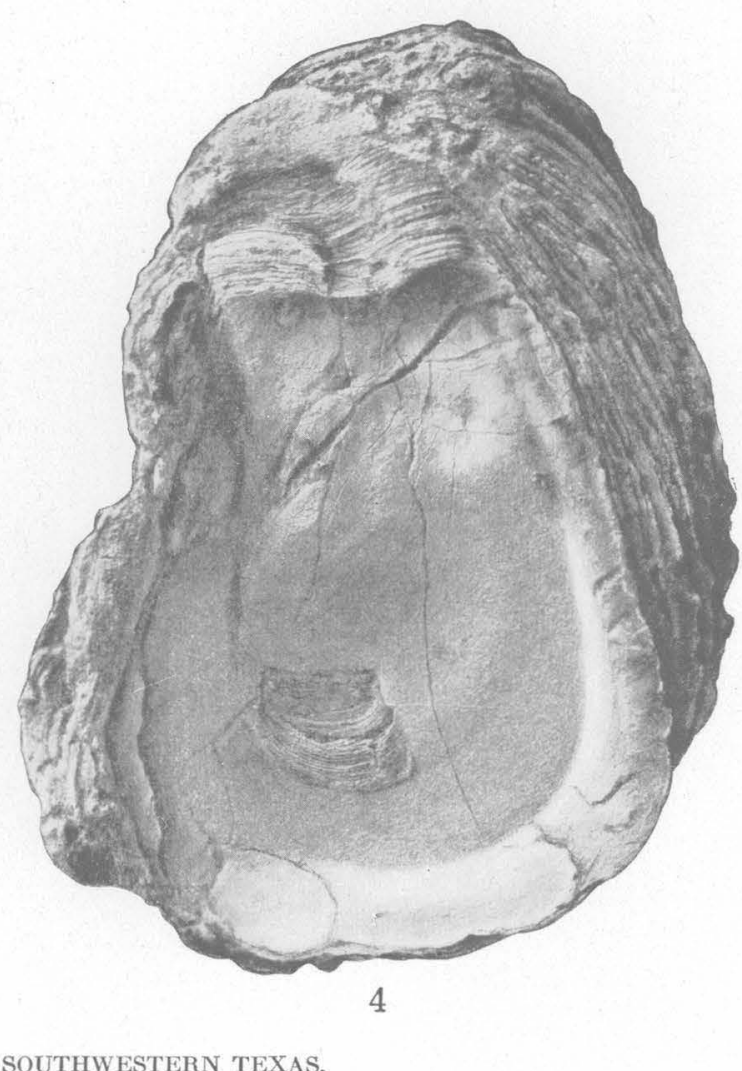

1-4. Ostrea tasex Gardner, n. sp. 1, Exterior of left valve, $\times 1$; 2 , interior of left valve, $\times 1$; 3 , exterior of right valve, $\times 1$; 4 , interior of right valve, $\times 1$. 

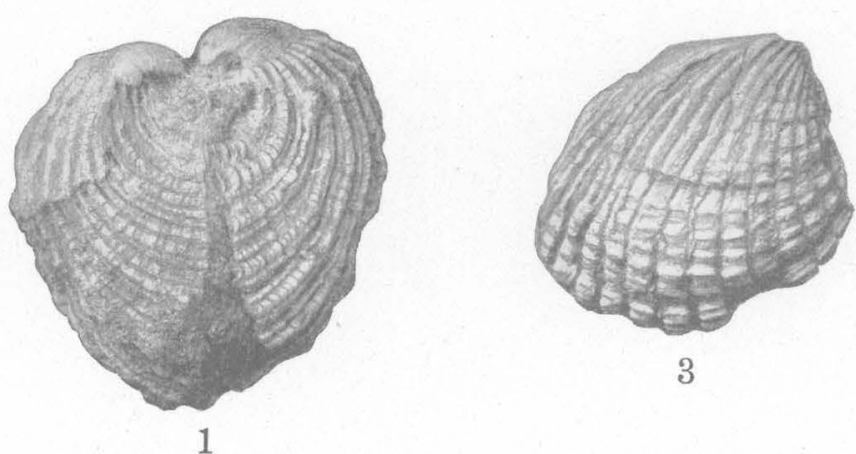

3

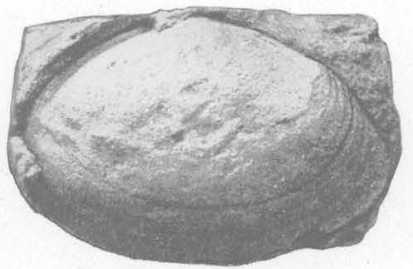

8

2

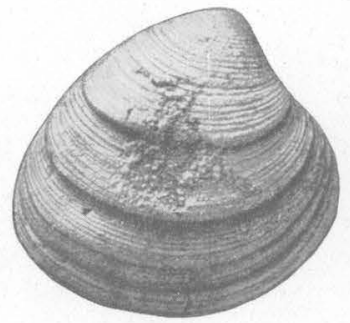

4

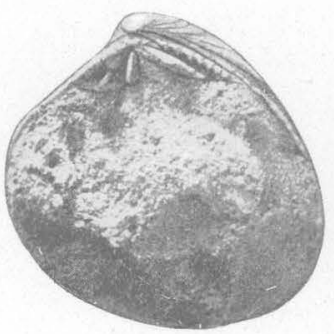

5

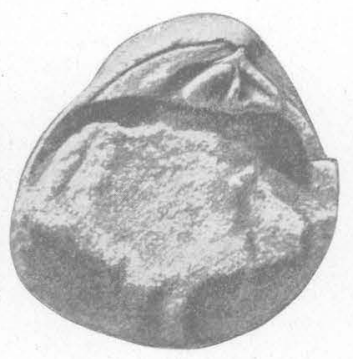

7

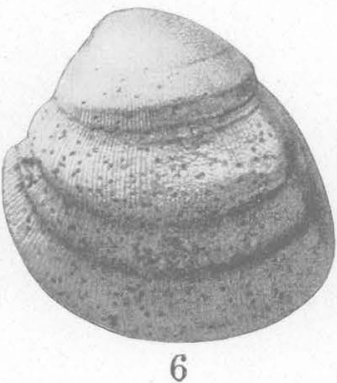

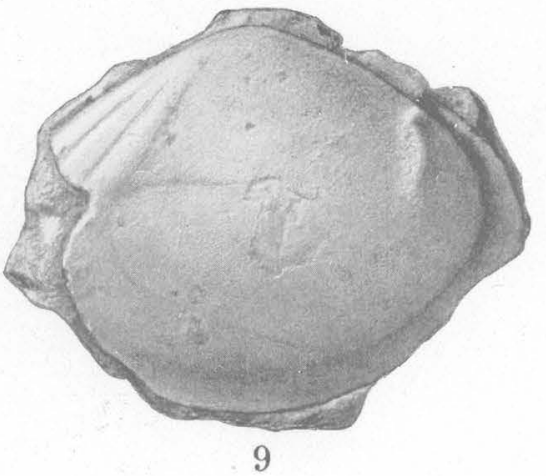

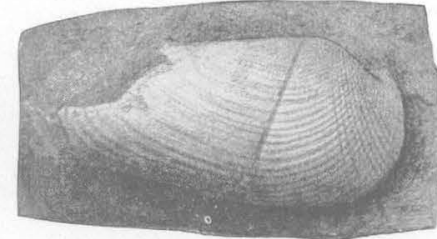

10

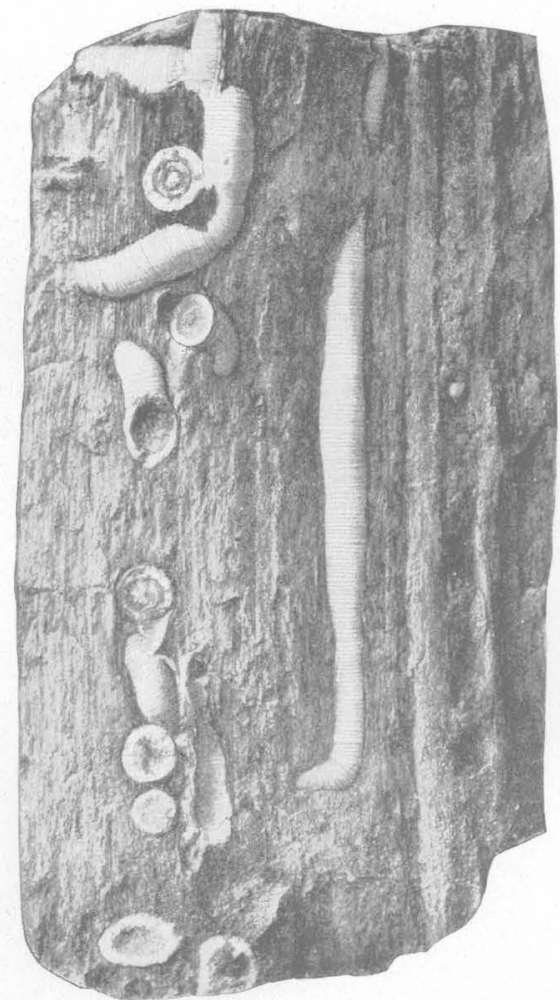

11

EOCENE MOLLUSCA FROM SOUTHWESTERN TEXAS.

1, 2. Venericardia alticostata subsp. hesperia Gardner, n. subsp. 1, Front view, $\times 1$; 2, exterior of right valve, $\times 1$.

3. Venericardia alticostata subsp. whitei Gardner, n. subsp. Exterior of right valve, $\times 1$.

4-7. Callocardia astartoides Gardner, n. sp. 4, Exterior of right valve, $\times 2 ; 5$, interior of right valve, $\times 2$; 6 , exteriorof left valve, $\times 2$; $\boldsymbol{\gamma}$, intericr of left valve, $\times 2$.

8, 9. Tellina sp. A. 8, Internal cast of left valve, $\times 1$; 9 , internal cast of left valve, $\times 1$.

10. Martesia laredoënsis Gardner, n. sp. External cast of right valve, $\times 2$.

11. Teredo maverickensis Gardner, n. sp. Longitudinal views and natural cross sections of tubes in fossil wood, $\times 1$, 


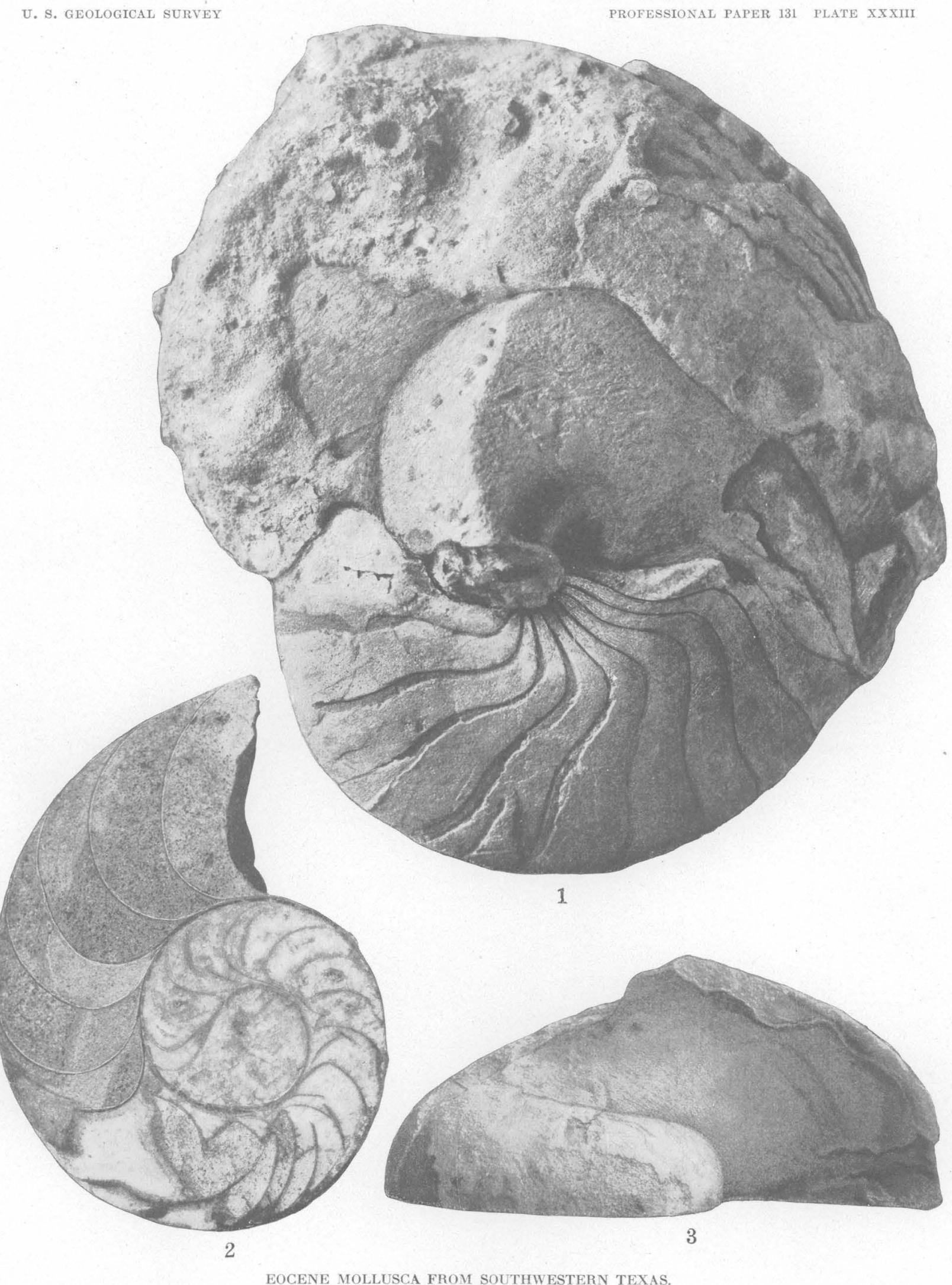

1-3. Enclimatoceras vaughani Gardner, n. sp. 1, Lateral view $\times 1 ; 2$, cross section of adolescent individual, $\times 1 ; 3$, apertural view of adolescent individual, $\times 1$. 


\title{
PRELIMINARY REPORT ON FOSSIL VERTEBRATES OF THE SAN PEDRO VALLEY, ARIZONA, WITH DESCRIPTIONS OF NEW SPECIES OF RODENTIA AND LAGOMORPHA.
}

\author{
By JaMes W. GidLey.
}

\section{INTRODUCTION.}

On the initiative of the United States Geological Survey and with the cooperation of the United States National Museum, I was privileged during February, March, and part of April, 1921, to collect fossil vertebrates in the San Pedro Valley, Ariz., where remains had previously been located by Kirk Bryan, of the Geological Survey. The results of this expedition are here published in part.

The special problem involved was the determination of the age of the sedimentary deposits, which up to that time had been termed Pleistocene. Two localities, apparently at slightly different horizons, yielded material representing a fauna sufficiently varied and distinctive to establish their age as Pliocene.

The locality first visited is a small area of badlands about 3 miles east of the Curtis ranch, which is on the State road about 14 miles northwest of Tombstone and an equal distance southeast of Benson by road. The second locality is west of the State road about 2 miles south of Benson. These two localities are about 12 miles apart and on opposite sides of the San Pedro Valley. The first locality yielded by far the greater bulk of material, but the species represented in the collection from the second are more numerous. Stratigraphically there seems to be no difference in the level of the beds of the two localities, and structurally they are very similar, yet, so far as I am able to determine, they contain no species in common. Because of this fact, as well as the general character and assemblage of the forms represented, I am led to consider them as of slightly different age, the beds at the Benson locality being apparently the older.

Most of the mammal material is fragmentary, but several good specimens were procured, including enough material for the restoration of the dermal armor and skeleton of a Glyptotherium and a possible skeletal restoration of a mastodon, both from the Curtis locality. The material from the Benson locality here described was all collected at one spot, a fossil bone quarry opened up and worked by Kirk Bryan and me. Immediately associated material from this quarry includes fragmentary specimens of Hipparion, Pliauchena?, Platygonus, and Pliohippus or Hippidium?, together with a new species of box turtle and eight new species of birds, not all of which are satisfactorily definable from the scanty material obtained.

The greater part of the specimens included in these collections have not yet been prepared, but those belonging to the orders Rodentia and Lagomorpha have been cleaned and studied, and the new species are here described. Those from the Curtis locality were all found during the excavation of one of the mastodon skeletons. Immediately associated with them were remains of a llama, a canid, a mustilid, a small land turtle, an edentate, and two species of small birds.

A tentative list of the orders, families, genera, and species, so far as they have been determined, represented in each locality is given on page 120. 
Preliminary list of fossil vertebrates from the San Pedro Valley, Ariz.

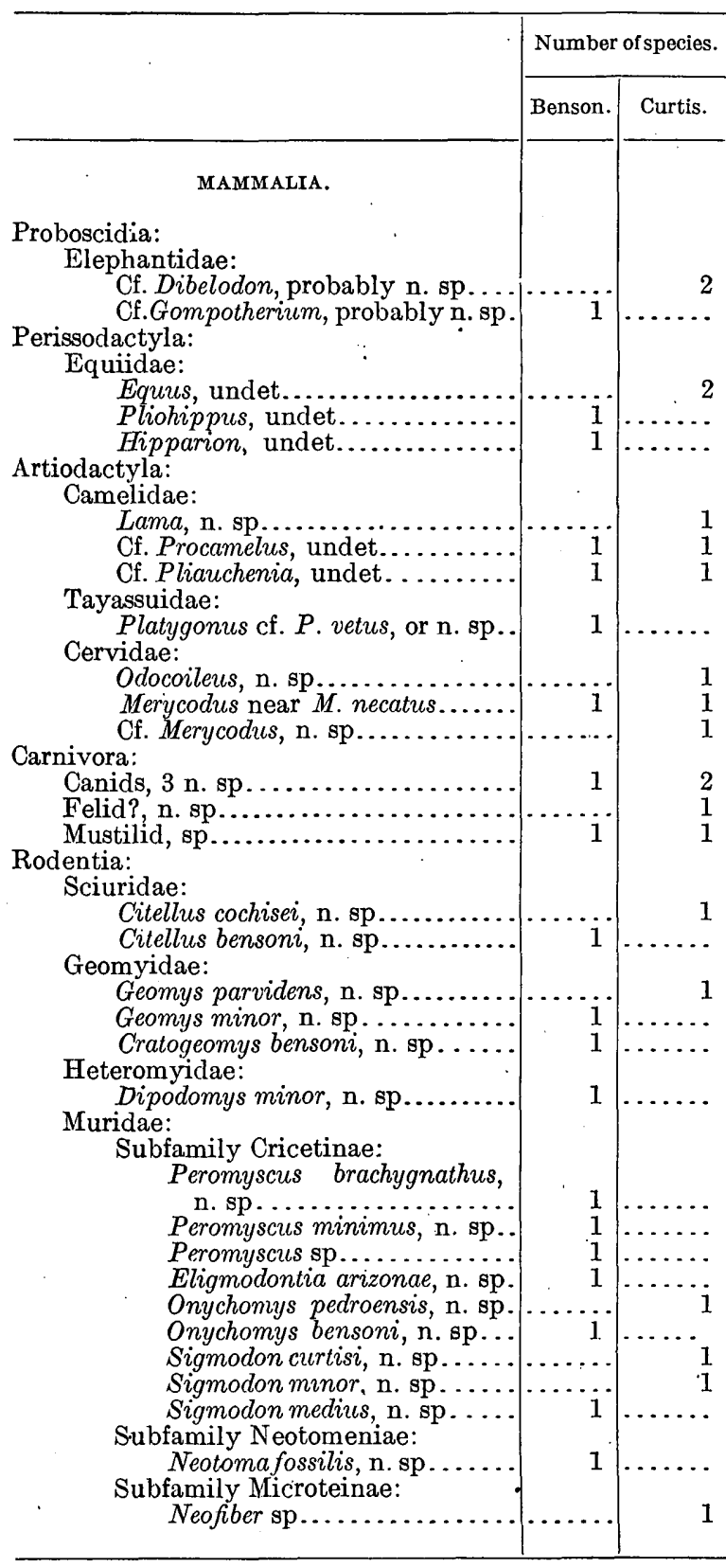

The reptilian remains, including at least two species of turtles, probably new, are being described by C. W. Gilmore, and the bird bones are being studied and will be described by Alexander Wetmore, of the Biological Survey, Department of Agriculture. The tentative lists of Reptilia and Aves given above are furnished by these gentlemen.

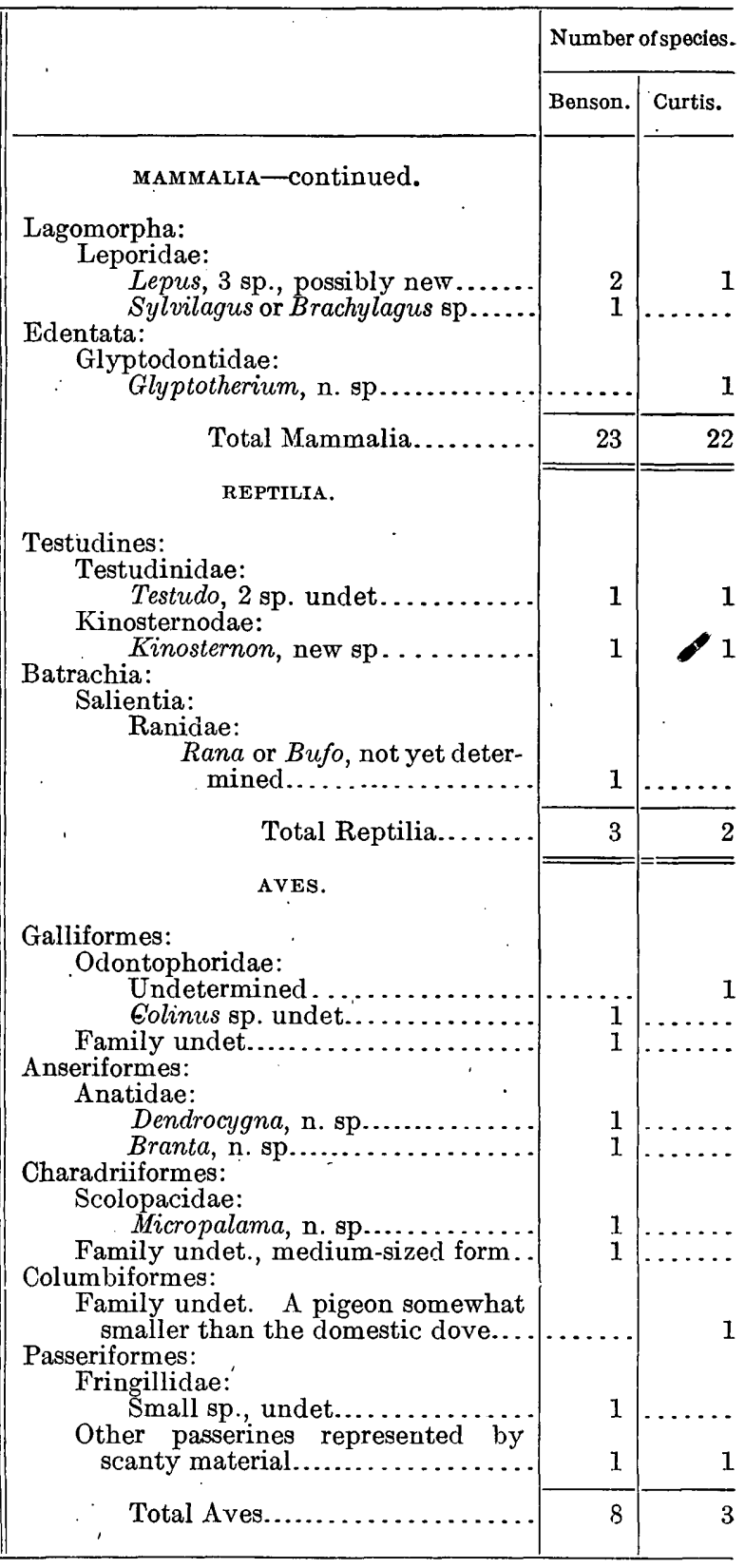

\section{GEOLOGIC HORIZON AND CLIMATIC CONDITIONS INDICATED.}

This preliminary study reveals littie positive evidence regarding the exact geologic horizon of the beds in San Pedro Valley, beyond what is stated above. They seem to be clearly Pliocene, and the peculiar mingling of modern and more ancient forms seems to point rather 
definitely to a late stage of Pliocene time. Unfortunately, the material of these collections represents for the most part new species that can not be correlated with known faunas of other localities where the age of the beds has been established. However, the species are sufficiently numerous and varied to constitute a standard for comparison,' and future field work in this region will almost certainly bring to light material that will definitely and correctly determine the proper sequence of these deposits.

The facts that there are here two or three species of true horse (Equus) and that the rodents are all referable to modern genera, some of which are found living in this general region, may suggest Pleistocene age. But to offset this evidence of a seemingly more modern fauna, the mastodons and glyptodonts are of distinctly Pliocene types, and one of the canids, though modern in skull and dental modifications, has the type of humerus belonging to the Miocene and Pliocene canids, in that the entepicondylar foramen is prominently present. This feature and the presence of Hipparion, Pliohippus, and Merycodus, together with the fact that the 15 or more species of rodents include no living species, constitute rather conclusive evidence of a faunal assemblage that is older than Pleistocene.

This general assemblage of species, including proboscidians, camels, horses, glyptodonts, and an extinct species of the ocellated turkey related to a group now living only in Central America and southern Mexico, suggests that the climate at the time the beds were laid down was rather warm and moist, probably subtropical or even tropical.

The presence of a true llama, the glyptodont, and a rodent belonging to a genus now living only in South America seems to indicate an intermingling of forms of South American origin, and the presence in these Pliocene deposits of a rodent and camel of definite South American living types suggests the derivation of their South American relatives from North America and favors the suggestion of an exchange of faunas between the two continents which took place somewhere 'near this epoch of geologic time.

\section{DESCRIPTIONS OF SPECIES.}

\section{Order RODENTIA.}

The order Rodentia is represented in the San Pedro Valley by 17 species, 11 of which occur at the Benson locality and 6 at the Curtis locality. Of these species, 15 are here described as new, and 2 are not certainly determined on the scanty material in hand. However, though all the species represented seem to be new, each is readily referable to one of ten living genera, distributed among four families-the Sciuridae, Geomyidae, Heteromyidae, and Muridae. The species belonging to the Muridae represent three subfamilies-the Cricetinae, Neotomeniae, and Microteinae.

\section{Family SCIURIDAE.}

The family Sciuridae is represented by two new species, both belonging to the genus Citellus.

Citellus cochisei Gidley, n. sp.

Plate XXXIV, figures 1, 2.

Type.-Portion of a right maxillary containing all the cheek teeth (catalog No. 10490, U. S. Nat. Mus.).

Paratype.-Portion of a left lower jaw (cata$\log$ No. 10491).

Locality.--Both are from the Curtis locality, in sec. 25 , T. 18 S., R. 21 E., and were found in exhuming a mastodon skeleton.

Description.-Length of upper cheek-tooth series 10.5 millimeters. Molars relatively wide, $\mathrm{m}^{1}$ and $\mathrm{m}^{2}$ one-third wider than long; lophs and valleys simple and narrow; both posterior transverse lophs of the molars completely united with protocone, forming a short, narrow valley opening outward and extending inward not more than one-half the width of the tooth crown, as in Cynomys. The anterior transverse lophs are more depressed and except in $\mathrm{m}^{3}$ are much longer than the other lophs, extending inward and upward to disppear in the anterior wall of the protocone. $\mathrm{P}^{4}$ differs from the anterior two molars only in being less wide and in having the anterior loph relatively and actually more extended anteriorly.

In the greater width of tooth crowns, the less extent of their median external reentrant valleys, and the relative shortness of the heel of the last molar, this species suggests Cynomys, 
but it differs from species of that genus in the much more brachyodont tooth crowns, the greater relative depth of the median external reentrant valleys, and the incipiency, amounting to almost total absence, of the posterior reentrant valleys so prominent in species of Cynomys. The first of these features might be considered as a character of degree only, indicating less advanced specialization, but the other two I consider characters that denote relationship with the living species of Citellus rather than with those of the genus Cynomys.

The lower jaw, as indicated by specimen No. 10491; which carries the incisor and the anterior two cheek teeth, is relatively short and deep, the incisor narrow and pointed, and the cheek teeth relatively wide to a degree corresponding with those of the upper series. This species compares in size with $C$. evermani, but it differs from all the living forms in one or more of the characters enumerated above.

\section{Citellus bensoni Gidley, n. sp.}

Plate XXXIV, figures 3,4 .

Type.-A first or second upper molar of the right side and a last upper molar of the left side (catalog No. 10531, U. S. Nat. Mus.).

Paratype.-The cheek-tooth series of a left lower jaw (catalog No. 10532, U. S. Nat. Mus.).

Locality.-Both from the Benson locality.

Description:-Length of cheek-tooth series (estimated from measurements of the paratype), 10.3 millimeters; upper molar of about the same proportion as the corresponding one of $C$. cochisei at the base but much narrower at the summit, owing to the greater slope of the inner wall of the protocone; the three transverse lophs about equal in length, the posterior one being broken up into two distinct but slightly joined cuspules, the inner one of which is a rounded cone entirely disconnected from the protocone.

An upper $\mathrm{m}^{3}$ which $\mathrm{I}$ associate with the type specimen, like that of $C$. cochisei, has a relatively small heel portion as compared with living species, and in addition there is a welldefined isolated cone-shaped cuspule near the center of the posterior basin.

This species seems to approach $C$. beecheyi much more closely than any other living species but differs from it in a few apparently important particulars. In $C$. beecheyi the crowns of the upper molars are relatively narrower than in the fossil species, being nearly as long as wide; the lingual wall of the protocone is less sloping, and the exterior or buccal face of this cusp is much more sloping. Other differences noted in the living species are the generally less broken up condition of the posterior transverse lophis; the somewhat shallower transverse valleys, the posterior one of which usually has a small cuspule at its external entrance; and the relatively broader and less completely inclosed posterior valley of the last upper molar.

Beyond the fact that the last lower molar, like the upper, is relatively smaller, and the valleys and cusps are somewhat more sharply defined than in $C$. beecheyi, there is little to distinguish between the lower cheek teeth of that species and $C$. bensoni.

\section{Family GEOMYIDAE.}

Three new species referable to two living genera of geomids are represented in the collection.

\author{
Geomys parvidens Gidley, n. sp. \\ Plate XXXIV, figures 5, 6.
}

Type.-The anterior portion of a skull carrying the incisors and all the cheek teeth except the first and last of the right side (catalog No. 10492, U. S. Nat. Mus.).

Paratype.-Portion of the right lower jaw carrying all the teeth except $\mathrm{m}^{3}$ (catalog No. 10493, U. S. Nat. Mus.).

Locality.-Both from the Curtis locality.

Description.-Length of upper cheek-tooth series 5.5 millimeters; width across first upper molars (measured to outer borders) 6.7 millimeters; size small, about the same as that of Geomys texensis; rostrum relatively short and heavy; incisors with two very unequal grooves, the smaller one close to the inner border of the crown, the larger one almost exactly bisecting its anterior face, making the outer of the three ridges thus formed slightly but definitely largest; the cheek teeth are relatively small and not greatly expanded laterally, $\mathrm{m}^{1}$ and $\mathrm{m}^{2}$ being almost evenly elliptical in outline but with the outer edges slightly compressed; $\mathrm{p}^{4}$ with anterior lobe decidedly smaller and less laterally expanded than the posterior one; $\mathrm{m}^{3}$ as wide as long, subtriangular, relatively small.

Besides being about equal in size to $G$. texensis, G. parvidens is almost identical with that 
species in the character of the incisors, butit differs from $G$. texensis and the other living species of the genus in general in the less lateral expansion of the cheek teeth, the shorter and deeper rostrum, and the less progressive character of $\mathrm{p}^{4}$.

The lower jaw referred to this species is relatively short, with prominent masseteric ridge and the submental foramina lying almost directly under the anterior end of the masseteric ridge. The anterior lobe of $p_{4}$ is relatively small and subcircular, with the walls very little flattened.

Geomys minor Gidley, n. sp.

Plate XXXIV, figures $7,8$.

Type-Portion of a right lower jaw lacking the last molar (catalog No. 10494, U. S. Nat. Mus.).

Paratype.-A right upper incisor (catalog No. 10534, U. S. Nat. Mus.).

Locality.-Both from the Benson locality.

Description.-Length of cheek-tooth series (estimated) 5.4 millimeters; the jaw is slightly smaller than that of $G$. parvidens and differs from it otherwise in having the anterior masseteric area more depressed, the submental foramen slightly farther back in position, the cheek teeth relatively larger, and the anterior lobe of $\mathrm{p}_{4}$ more nearly circular in outline; no anterior fossa between cheek teeth and coronoid process.

An associated upper incisor tooth is of appropriate size for the species It shows the characteristic grooving of a true Geomys, and it is this fact which has determined the generic reference of $G$. minor.

\section{Cratogeomys bensoni Gidley, n. sp.}

Plate XXXIV, figures 9-11.

Type-A portion of a left lower jaw carrying all teeth (incisors broken) (catalog No. 10495, U. S. Nat. Mus.).

Paratype-An upper incisor (catalog No. 10496, U. S. Nat. Mus.).

Locality.-Benson locality. The species is represented by four other pieces of the lower jaws from the same locality.

Description-Length of cheek-tooth series 8 millimeters (measured at summits of teeth). About the size of the living species Geomys breviceps; cheek teeth not greatly compressed; $\mathrm{p}^{4}$. with outer reentrant angle rather widely $V$-shaped, the inner one forming a distinct $U$; posterior wall of last molar in the type specimen with two distinct and two faint parallel longitudinal grooves forming three low but distinct closely grouped median longitudinal enamel ridges.

This species differs from all living species of geomids examined in having the area of the anterior portion of the masseteric ridge more depressed and in the position of the anterior submental foramen, which is nearly as in the two above-described species of Geomys. In living species this foramen is anterior to the masseteric ridge and nearly level with it. In the fossil species it is lower and more posterior in position, lying almost directly under the anterior extremity of the masseteric ridge. There is also between the cheek teeth and the anterior border of the coronoid process in $C$. bensoni a narrow but distinctly marked longitudinal fossa.

This species is referred to Cratogeomys on the evidence of an associated upper incisor of appropriate size which has the single groove characteristic of this genus.

Dipodomys minor Gidley, n. sp.

Plate XXXIV, figure 16

Type.-A nearly complete right lower jaw containing the incisor and the first cheek tooth (catalog. No. 10499, U. S. Nat. Mus.).

Locality.-Benson locality.

Description.-Length of cheek-tooth row, measured from extreme borders of the alveoli, 4.7 millimeters; size and general jaw characters about as in the living species Perodipus chapmani, differing only in its more slender proportions and in the somewhat more reduced condition of the coronoid process. The fourth lower premolar, the only one of the cheek-teeth series present, is a long crowned and anteriorly curved tooth which is double-lobed, the anterior lobe having an anterior reentrant angle as in $P$. chapmani, but this tooth differs from the tooth of that species in having the posterior lobe relatively wider. Also the alveolus of the last molar is only about one-half the width of that of the other molars, indicating that this tooth is relatively more reduced than in the living species. 
Family MURIDAE.

The family Muridae is rather abundantly represented at both localities. The 12 determinable species are distributed among three subfamilies, 10 belonging to the Cricetinae, 1 to the Microtinae, and 1 to the Neotomeniae.

\section{Genus PEROMYSCUS.}

Specimens found at the Benson locality are referable to three species of Peromyscus. Two of these are new, although one is apparently closely related to the $P$. taylori group. The other new species is more distinctive. The third, represented by a single lower jaw lacking the cheek teeth, has not been determined.

Peromyscus brachygnathus Gidley, n. sp.

Plate XXXIV, figure 12.

Type.-The greater portion of a right lower jaw carrying all the teeth (catalog No. 10501, U. S. Nat. Mus.)

Locality.-Curtis locality.

Description.-Length of cheek-tooth series, 2.8 millimeters; about the size of $P$. taylori; jaw relatively short anterior to cheek teeth; last molar very much reduced, as much as in any living species of Onychomys. The teeth are too much worn to determine accurately their normal height in unworn condition, but they appear to be of the depressed type of $P$. taylori.

The form and position of the anterior extension of the masseteric ridge, the general character of the coronoid region, and the relatively broadly expanded anterior lobe of the anterior cheek tooth seem to determine the generic reference of this species, but it differs from all living species of the genus in the relatively short jaw and the greater reduction of the last lower cheek tooth, which seems to have nearly or quite lost its hinder lobe.

\section{Peromyscus minimus Gidley, n. sp.}

Plate XXXIV, figure 13.

Type--Portion of a left lower jaw carrying all the teeth (catalog No. 10500, U. S. Nat. Mus.).

Locality.-Benson locality.

Description.-Size very small, length of cheektooth series 2.6 millimeters; cheek-tooth cusps depressed, with well-marked cingula at the entrance of the external valley, and with tendency to inclose the internal ones by an up- rising of the inner enamel wall between the cusps; anterior lobe of the first cheek tooth, $\mathrm{p}_{4}$, relatively narrow but two-cusped at the summit; posterior lobe of last cheek tooth small, almost as much reduced as in Onychomys.

This species seems more nearly related to $P$. taylori than to any other living species but differs from it in having a narrow divided anterior lobe of the first cheek tooth and a more reduced hinder molar. It further differs from that species and more nearly agrees with others of the genus in the wider angle at which the coronoid portion of the ascending ramus diverges from the alveolar portion of the jaw.

$P$. minimus is distinguished from $P$. brachygnathus in that the jaw is somewhat more slender in proportions; the masseteric ridge is less advanced forward; the cheek teeth are slightly narrower; the anterior lobe of the first cheek tooth is narrow and double cusped, while that of $P$. brachygnathus is wider and undivided, and the last cheek tooth is somewhat less reduced.

\section{Peromyscus sp.}

Plate XXXIV, figure 14.

A second and larger species, about equaling Peromyscus m. gambeli in size, is represented by a lower jaw (catalog No. 10502, U.S. Nat. Mus.) lacking all the cheek teeth. Length of cheektooth series as estimated by measurement of the alveoli, 3.8 millimeters. This jaw, in its general form and in the position of the anterior extremity of the masseteric ridge, is sufficiently characterized to make certain its generic reference, but its specific features can not be determined until the cheek teeth are known.

\section{Genus ELIGMODONTIA.}

The genus Eligmodontia, the living species of which are confined to the South America continent, is represented by a single species in the fossil collection from Arizona.

Eligmodontia arizonae Gidley, n. sp. Plate XXXIV, figure 15.

Type-Greater portion of a left lower jaw containing the complete dentition (catalog No. 10503, U. S. Nat. Mus.).

Paratype.-Single lower jaws of two other individuals (catalog Nos. 10504, 10505).

Locality.-All from Benson locality. 
Description.-Length of cheek-tooth series 3.6 millimeters; about the size of the living species $E$. morgani, but may be distinguished from it by its relatively greater depth of jaws, its decidedly shorter symphysis, and the less reduced condition of the last molar.

The anterior lobe of the first cheek tooth is distinctly notched by an anterior median reentrant angle, as is usual in Peromyscus, whereas in the living species of Eligmodontia this lobe is usually evenly convex in front. The fossil species from Arizona, however, is readily distinguished from Peromyscus by the characters which ally it to Eligmodontia, namely, by the form and position of the masseteric ridge, which extends forward to the extreme anterior border of the cheek-tooth series; by the form and situation of the capsular process for the reception of the base of the incisor, which is placed high upon the ascending ramus and is marked by a decided sulcus between it and the coronoid; and by the form of the last cheek tooth, which in species of Eligmodontia is more reduced than in Peromyscus.

Onychomys pedroensis Gidley, n. sp.

Plate XXXV, figure 1.

Type.-Portion of a left lower jaw carrying the first and last cheek teeth (catalog No. 10506, U. S. Nat. Mus.).

Paratypes.-Other lower jaw portions (catalog Nos. 10507, 10508, U. S. Nat. Mus.).

Locality.-All from Curtis locality.

Description.-Length of the cheek teeth 4.5 millimeters; size somewhat larger than $O$. leu. ruidosae, which it somewhat more nearly resembles than any other living species. It further differs from that species in its relatively greater depth of jaw, the greater degree to which the masseteric ridge is carried forward, and the somewhat less reduced condition of the last cheek tooth.

Onychomys bensoni Gidley, n. sp.

Plate XXXV, figure 3.

Type--Portion of a right lower jaw containing complete dentition (catalog No. 10509, U. S. Nat. Mus.).

Locality.-Benson locality.

Description.-Length of cheek-tooth series 3.9 millimeters; about the size of 0 . torridus but with less reduced last molar, as in the larger species 0 . leu. ruidosae. The hinder lobe $91048^{\circ}-23-9$ of the last molar is less reduced even than in the last-mentioned species. $O$. bensoni differs from all the living species of the genus in having more widely open valleys and less conspicuous lophs in the molar teeth; a more depressed heel on the last lower molar, which is distinctly lower than the anterior or triconid portion; and apparently a relatively larger and higher coronoid process.

\section{Sigmodon curtisi Gidley, n. sp.}

Plate XXXV, figure 2.

Type.-The greater parts of both lower jaws carrying complete dentition (catalog No. 10510, U. S. Nat. Mus.).

Paratype.-Portion of a right lower jaw with cheek teeth (catalog No. 10511, U. S. Nat. Mus.).

Locality.-Both from Curtis locality.

Description.-Length of cheek-tooth series 7 millimeters; about the size of $S$. hispidus arizonae, which it seems to resemble more nearly, but it differs from that as well as the other living species in the more open valleys of the reentrant angles, the more compressed lophs, the less hypsodont condition of the cheek teeth, the relatively deeper posterior inner reentrant valley of $p_{4}$ and $m_{1}$, and especially the form and proportions of the cusps of the last lower molar, which is relatively larger, with the hinder cusp relatively broader and fuller than in the living species. A feature that is characteristic of this and the species described below and is not observed in any of the living species is noted in the last molar, in which the great extension and flattening of the inner or lingual wall of the posterior lobe forms a sharp right angle with the posterior wall of the reentrant angle on that side.

I take pleasure in naming this species for Mr. Milton Curtis, in recognition of his efficient assistance in the field.

\section{Sigmodon minor Gidley, n. sp. Plate XXXV, figures 4, 5.}

Type.-Portion of a left lower jaw carrying the complete dentition (catalog No. 10512, U. S. Nat. Mus.).

Paratype.-Portion of a left maxillary carrying the anterior two cheek teeth (catalog No. 10513, U. S. Nat. Mus.).

Locality.-Curtis locality. Five other lowerjaw portions, most of them with complete 
dentition (catalog Nos. 10514 to 10518), are also referable to this species.

Description.-Length of cheek-tooth series 4.7 millimeters; smaller than S. medius and decidedly smaller than any of the living species examined. This species is distinguished from the living forms by the same characters observed in $S$. medius, except that the external reentrant valleys of the upper molars (as shown by specimen No. 10513) are of the normal modern type. S. minor differs from $S$. medius only in its smaller size, having a relatively narrower anterior lower cheek tooth, in which the anterior lobe is relatively smaller, with the adjacent reentrant. valleys nearly equal in length. The reentrant valleys of the upper cheek teeth are oblique to the same degree and of about the same proportionate depth, but the molar crowns of both the upper and lower series are less hypsodont.

\section{Sigmodon medius Gidley, n. sp.}

Plate XXXV, figures 6, 7 .

Type.-Portion of a right lower jaw containing the complete dentition and an associated fragment of a right maxillary carrying the anterior two cheek teeth, possibly of the same individual (catalog No. 10519, U. S. Nat. Mus.).

Paratypes.-Four other lower-jaw portions (catalog Nos. 10520 to 10523, U. S. Nat. Mus.).

Locality.-All from the Benson locality.

Description.-Length of cheek-tooth series 5.5 millimeters; somewhat smaller than the living species $S$. sanctae martae, with which it seems to compare more nearly than with other living forms. Its resemblances are noted in the form of the anterior lobe of the first cheek tooth, in which the anterior internal reentrant valley considerably exceeds the opposing outer one in length; in the decided angulation of the posterior portion of the inner wall of the last molar; and in the relatively heavy symphysis and considerable depth of jaw. It differs from this and other living species in having the cheek-tooth crowns slightly less hypsodont, the reentrant valleys more open, and the lophs correspondingly narrower, while there is present in the last molar a small but distinct reentrant notch on its inner side opposite the posterior reentrant valley.

The two upper cheek teeth show the same character of the more open valleys observed in the lower cheek teeth. Another difference noted is the form of the external reentrant valleys of these teeth, which clearly distinguishes them from the corresponding teeth of living species. The external reentrant valleys, instead of being straight, open directly outward, while their inner portions bend backward, forming a decided angle in their posterior enamel walls. In the living species these valleys run obliquely forward and outward in a nearly straight or but slightly curved line.

Two other lower jaws in the collection (Nos. 10521 and 10522) differ slightly in minor characters from the type but are here referred to this species. These differences, which consist wholly in a somewhat smaller size and a less proportionate depth of jaw, correspond to differences observed between males an females of the living species. S. sanctae martae. I therefore assume that the type specimen and specimen No. 10520, which agrees with it in every particular, represent males, while the smaller jaws just mentioned represent females of the species.

\section{Neotoma fossilis Gidley, n. sp.}

Plate XXXV, figures 8-10.

Type.-Portion of a right maxillary carrying the anterior cheek tooth and the alveoli for middle cheek tooth (catalog No. 10524, U. S. Nat. Mus.).

Paratypes.-Portion of a left lower jaw carrying the incisor and alveoli for the cheek teeth, and two right lower cheek teeth (catalog Nos. 10525 and 10526, U. S. Nat. Mus.).

\section{Locality.-Benson locality.}

Description.-Length of anterior cheek tooth 3.2 millimeters; width 2.2 millimeters; about the size of $N$. intermedia gilva. The following characters distinguished this from all living species: First upper cheek tooth relatively short and wide; no indication of an anterior internal reentrant valley; posterior internal reentrant valley nearly as long as the the external one; posterior notch of anterior palatial opening opposite the anterior root of the first cheek tooth.

The two lower teeth referred to this species also show distinctive characters. The anterior one $\left(p_{4}\right)$ is entirely devoid of the anterior reentrant valley so prominent in such a form as $N$. cinera, and both these teeth are like the corresponding ones of this species in having the 
posterior external reentrant valleys pitted in a way to form a nearly circular enamel lake in well-worn teeth. These lower teeth differ from those of all living species in having. the main cross lophs directed somewhat obliquely inward and backward instead of squarely across the long axis of the tooth.

The lower-jaw specimen shows nothing peculiar except that the capsular bulb at the base of the incisor is somewhat less prominent than is usual in the living species.

\section{- Neofiber sp. \\ Plate XXXV, figure 14.}

A nearly complete cheek tooth, apparently the left upper middle one; from the Curtis locality (catalog No. 10527, U. S. Nat. Mus.), seems to represent the genus Neofiber. It is slightly smaller than the corresponding tooth of Neofiber alleni, with which I compared it, but has all its characteristics. Except the slight variation in size, they differ only in that the base of the fossil tooth is closed by the formation of rootlets, whereas the specimens of the living species examined seemed to indicate growth from a persistent pulp. However, this difference may be, in part, at least, an age character, as in the closely related genus $\mathrm{On}$ datra, in which both conditions are found on examining a number of specimens of various ages.

\section{Order LAGOMORPHA.}

Four species of Lagomorpha are represented in the collection, three from the Benson locality and one from the Curtis locality. They seem not to be referable to any living species, but the material representing them is too fragmentary to warrant any attempt at diagnostic descriptions.

Species No. 1.

Plate XXXV, figure 15.

Represented by a portion of a left lower jaw carrying $\mathrm{p}_{4}, \mathrm{~m}_{1}, \mathrm{~m}_{2}$ (broken), and the alveoli for the other two cheek teeth and the incisor; from the Benson locality (catalog No. 10530, U. S. Nat. Mus.). This specimen represents a species about the size of Lepus campestris, or slightly smaller, and it agrees with that species rather closely both in jaw and tooth characters.
Species No. 2.

Plate XXXV, figure 11.

Represented by two upper incisors (broken), a first lower cheek tooth of the left side, and a median lower cheek tooth of the left side, from the Benson locality (catalog No. 10529, U. S. Nat. Mus.).

These teeth represent a small species about the size of Sylvilagus aud. arizonae or Brachylagus idahoensis. However, there are some peculiarities in one or another of all these teeth that make uncertain their definite reference to either of these living genera. The incisors are of a type to fit in with either genus, although there is not quite the difference in relative size of the two lobes formed by the anterior longitudinal groove. In the molar tooth the posterior lobe is about intermediate in relative size bebetween that of $S$. aud. arizonae and B. idahoensis, and both lobes are somewhat less laterally expanded and less sharply angulate than in either of these species. The anterior lower cheek tooth, which is of the right side, is peculiar and differs from that of any living species that has come under my observation. It is of the same general form as that of S. aud. arizonae but is proportionately a little wider, being nearly as wide as long, and is void of any reentrant angles except the normal two outer ones. Moreover, the posterior one of these extends but little more than halfway across the tooth. In all living forms examined this reentrant either extends entirely across to the inner wall of the tooth or meets an opposing reentrant from the inner side.

\section{Species No. 3.}

Plate XXXV, figure 13.

In the collection from the Curtis locality are a portion of a right lower jaw carrying the anterior two cheek teeth (catalog No. 10528, U.S.Nat.Mus.) and a lower right anterior tooth of a second individual, which represent a species about the size of Lepus californicus erennicus, or somewhat smaller. The fossil species seems to differ from the latter, however, in the proportions of all the tooth lobes which are somewhat narrower and in having the anterior lobe of the first cheek and tooth set farther inward, so that the reentrant valley faces decidedly forward and outward, instead of almost directly outward, as in the living species. 


\section{Cf. Lepus sp.}

Plate XXXV, figure 12.

A fourth species of Lagomorpha (catalog No. 10535, U. S. Nat. Mus.) is represented in the material from the Benson locality by the two incisors of the right side in a fragment of the premaxillary. It differs from the others in having an unusually high inner ridge on the large incisor. In fact, the tooth is remarkable in that the plane of its upper face is very oblique to the perpendicular plane of the skull, as in Ochotona, but the plane of its lower surfaces is nearly at right angles to the perpendicular median plane of the skull, as in the true rabbits, and its summit has the characteristic wear of a short anterior chisel point and posterior ledge or shelf observed in all species of rabbits but not found in the Pica group. The longitudinal enamel groove is filled with cement, but this feature has not even a generic significance. As this form of incisor is suggested in some degree in certain species of Lepus, as $L$. siamensis, I regard the fossil specimen as belonging to that genus. 
PLATES XXXIV-XXXV.

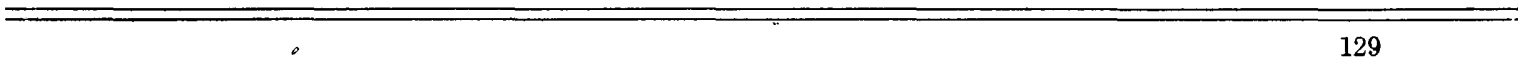




\section{PLATE XXXIV.}

[All figures about twice natural size.]

Figure 1. Citellus cochisei Gidley, n. sp. Type. Upper cheek teeth of right side, crown view. No. 10490,

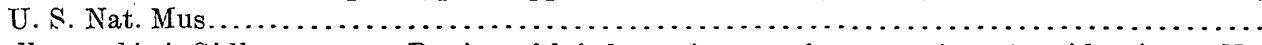

2. Citellus cochisei Gidley, n. sp. Portion of left lower jaw, tooth-crown view; 2a, side view. No. 10491, U. S. Nat. Mus.

3. Citellus bensoni Gidley, n. sp. Type. Last left upper molar, crown view; $3 \mathrm{a}, 3 \mathrm{~b}$, right upper molar

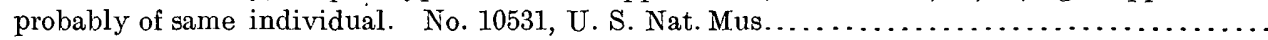

4. Citellus bensoni Gidley, n. sp. Lower cheek teeth in fragment of jaw of left side, crown view. No.

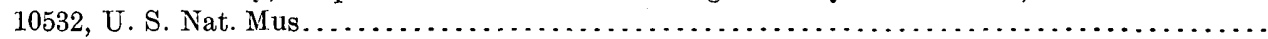

5. Geomys parvidens Gidley, n. sp. Type. Anterior portion of skull, palate view; 5a, side view.

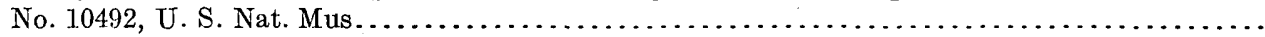

6. Geomys parvidens Gidley, n. sp. Portion of a right lower jaw, too th-crown view; 6a, side view. No.

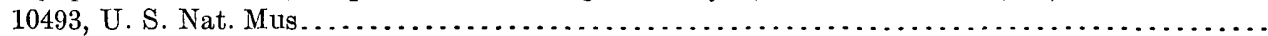

7. Geomys minor Gidley, n. sp. Type. Portion of a right lower jaw, tooth-crown view; 7a, side view.

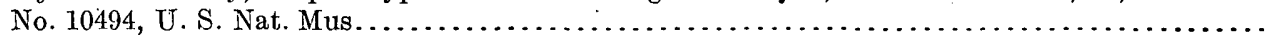

8. Geomys minor Gidley, n. sp. Upper incisor of left side, front view. No. 10534, U. S. Nat. Mus...

9. Cratogeomys bensoni Gidley, n. sp. Type. Portion of a left lower jaw, tooth-crown view; 9a, side

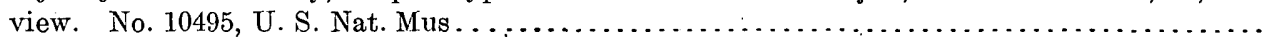

10. Cratogeomys bensoni Gidley, n. sp. Portion of a right lower jaw, tooth-crown view; 10a, side view.

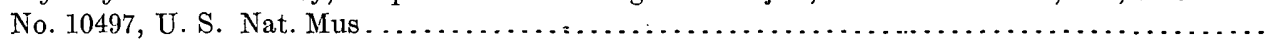

11. Cratogeomys bensoni Gidley, n. sp. Upper incisor of right side, front view. No. 10496, U. S. Nat. Mus.

12. Peromyscus brachygnathus Gidley, n. sp. Type. Portion of a right lower jaw, tooth-crown view;

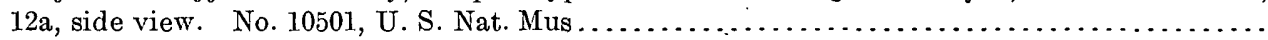

13. Peromyscus minimus Gidley, n. sp. Type. Portion of a left lower jaw, tooth-crown view; I3a,

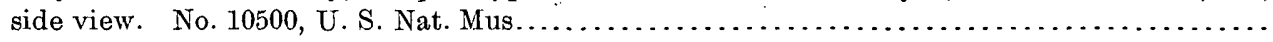

14. Peromyscus sp. Portion of a right lower jaw, side view. No. 10502, U.S. Nat. Mus.............

15. Eligmodontia arizonae Gidley, n. sp. Type. Greater portion of a right lower jaw, crown view;

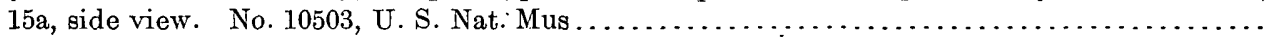

16. Dipodomys minor Gidley, n. sp. Type. Greater portion of a right lower jaw, tooth-crown view;

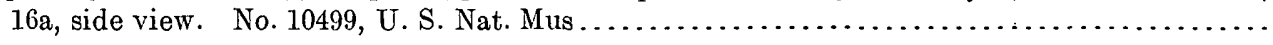


U. S. GEOLOGICAL SURVEEY

PROFESSIONAL PAPER 131 PLATE XXXIV
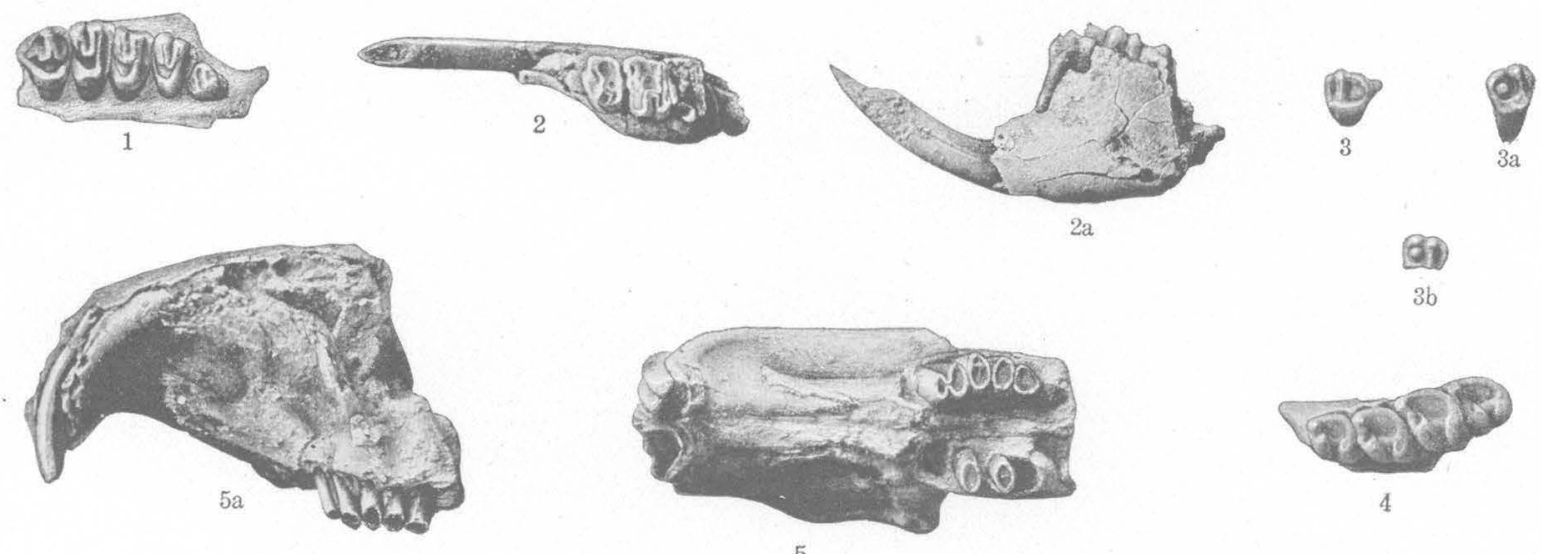

60

$3 b$
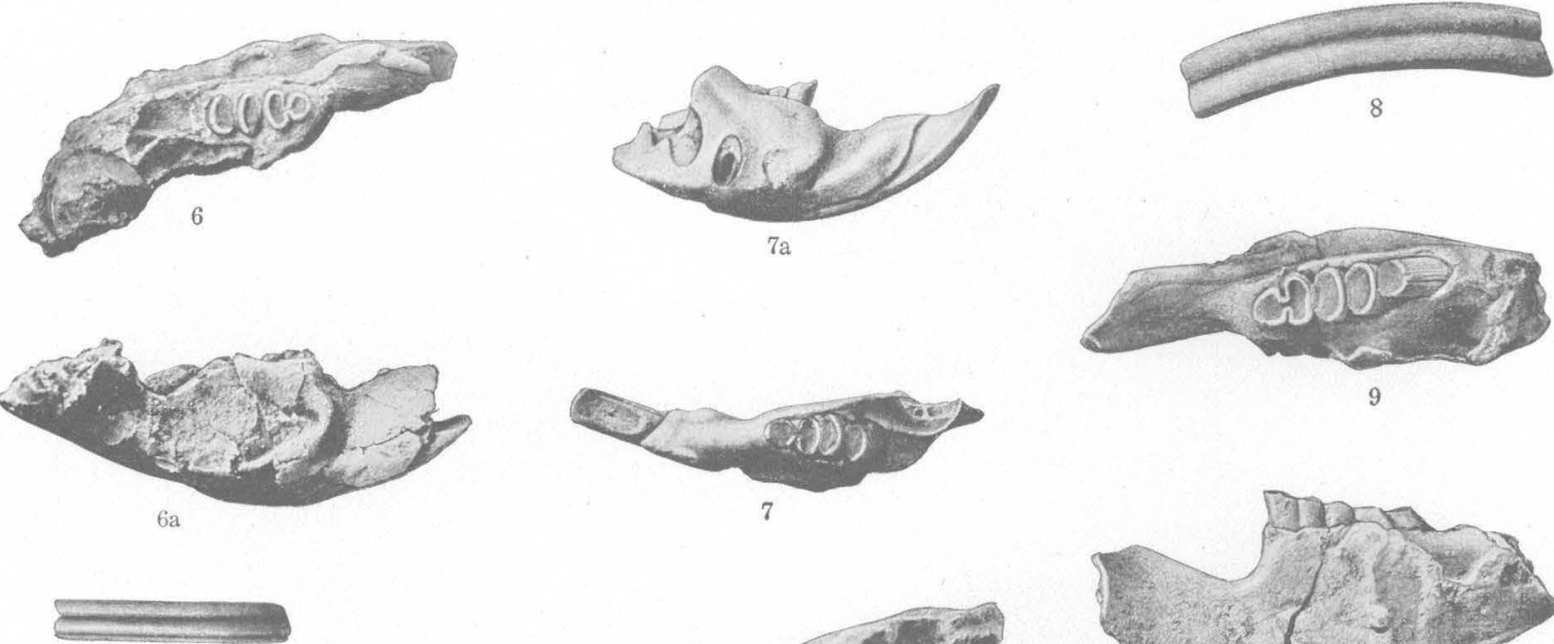

11

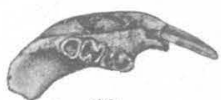

12
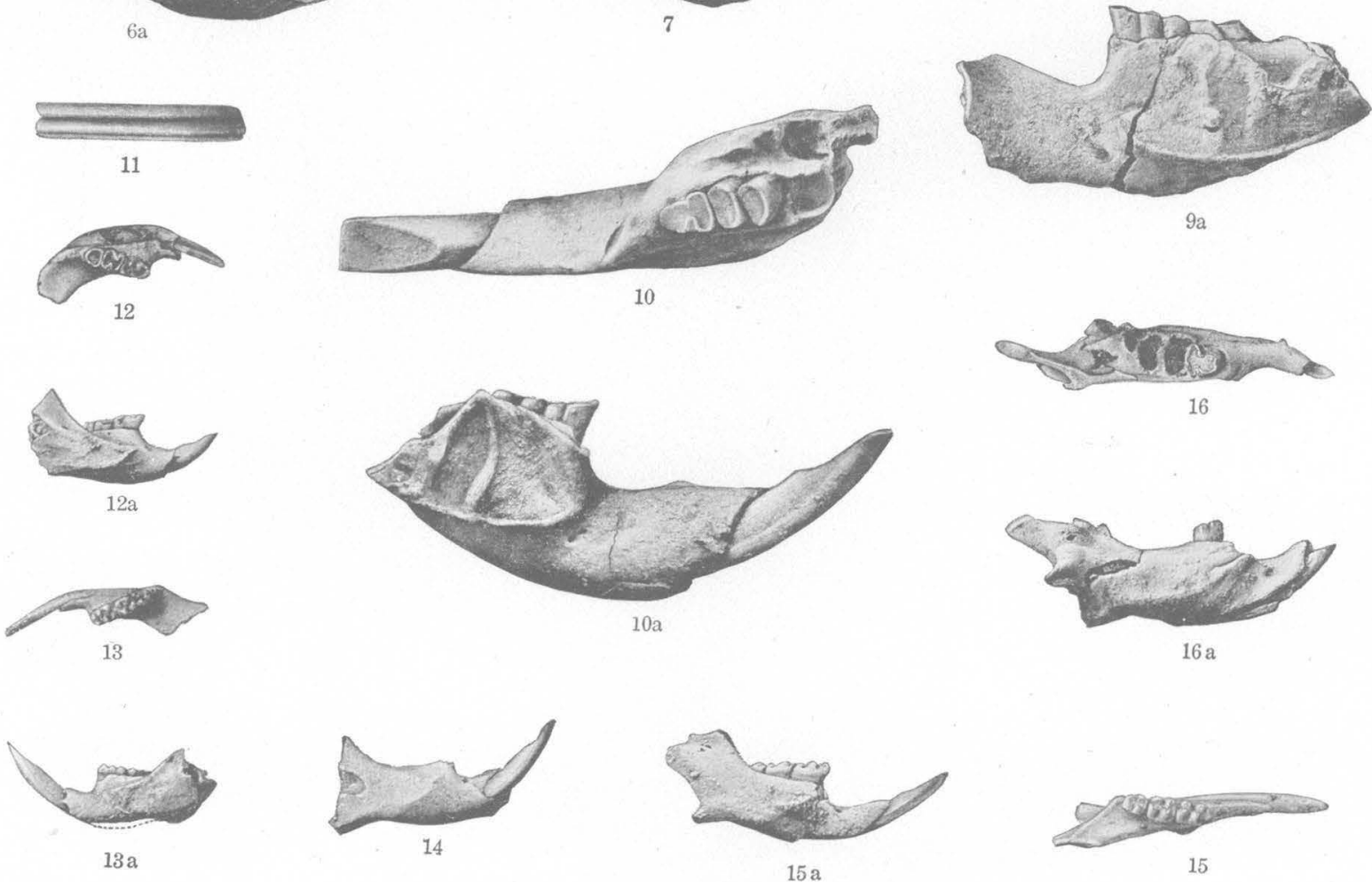

FOSSIL VERTEBRATES OF SAN PEDRO VALLEY, ARIZ. 


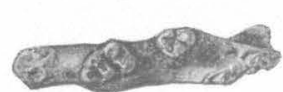

1

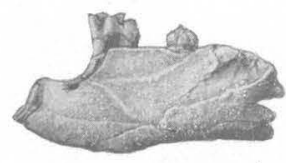

$1 a$
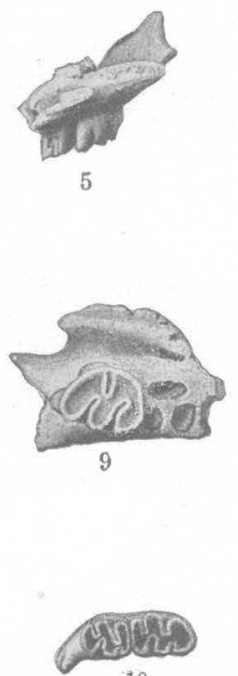

10

Wh

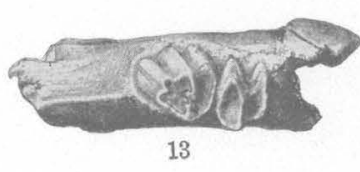

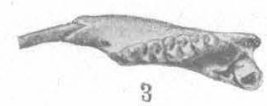

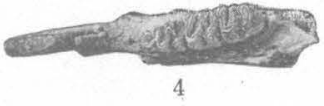

2

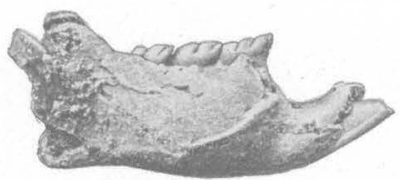

$2 a$
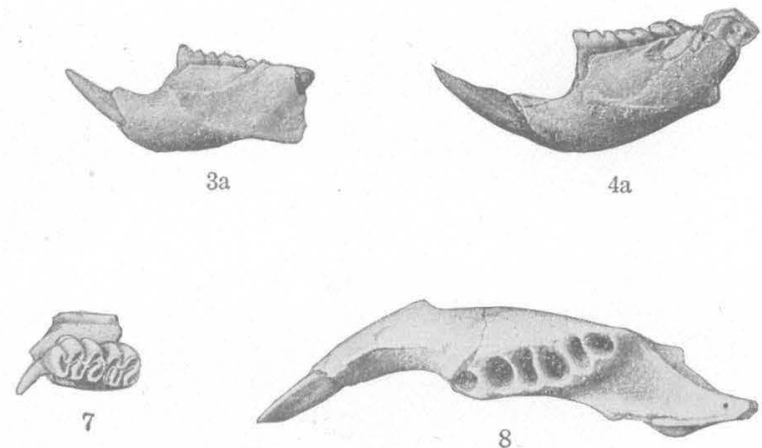

6
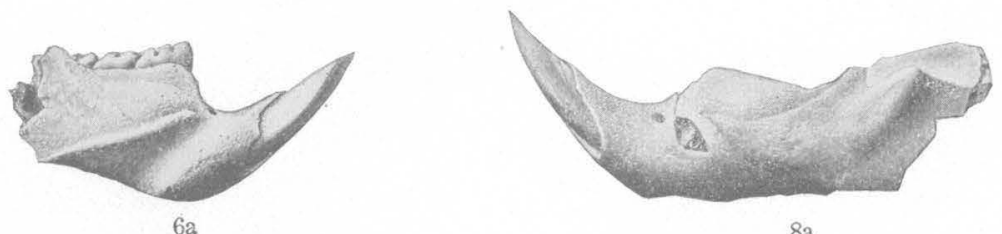

$8 \mathrm{a}$
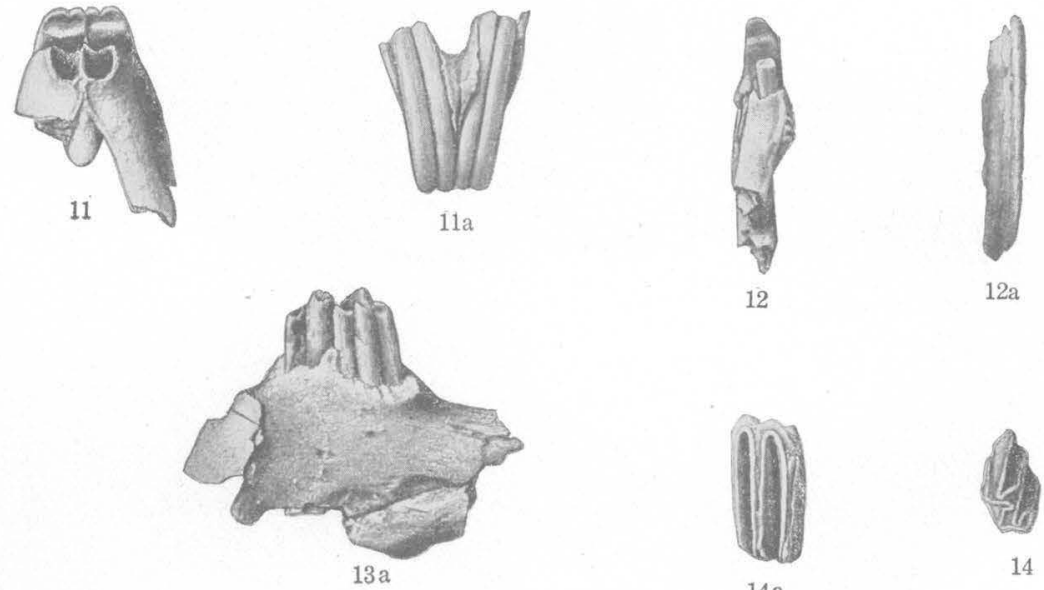

12

$12 \mathrm{a}$
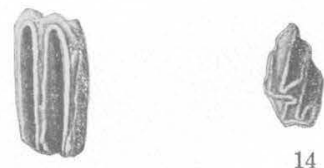

$14 \mathrm{a}$

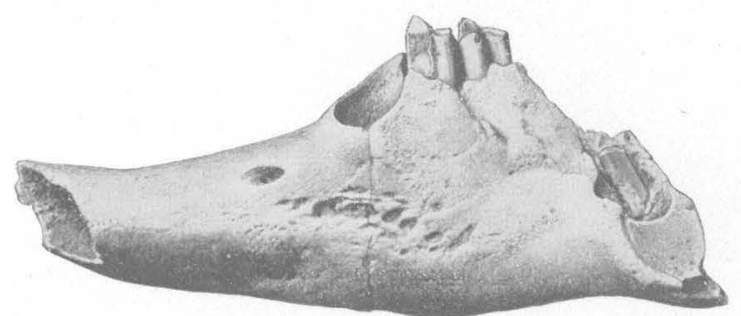

$15 \mathrm{a}$

FOSSIL VERTEBRATES OF SAN PEDRO VALLEY, ARIZ. 


\section{PLATE XXXV.}

[All figures about twice natural size.]

Fiaure 1. Onychomys pedroensis Gidley, n. sp. Type. Portion of a left lower jaw, tooth-crown view; la, side

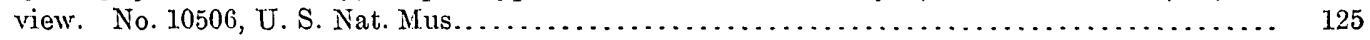

2. Sigmodon curtisi Gidley, n. sp. Type. Portion of a right lower jaw, tooth-crown view; $2 a$, side

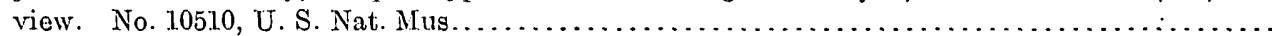

3. Onychomys bensoni Gidley, n. sp. Type. Portion of a left lower jaw, tooth-crown view; 3a, side view. No. 10509, U. S. Nat. Mus... . . . . . . . . . . . . . . . . . . . . . . . . . .

4. Sigmodon minor Gidley, n. sp. Type. Portion of a left lower jaw, tooth-crown view; 4a, side view.

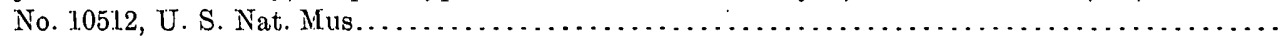

5. Sigmalon minor Gidley, n. sp. Two anterior cheek teeth in fragment of left maxillary, inner-side

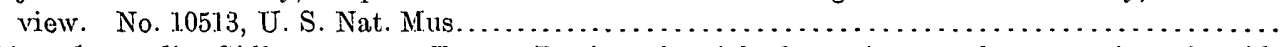

6. Sigmodon medius Gidley, n. sp. Type. Portion of a right lower jaw, tootr crown view; 6a, side

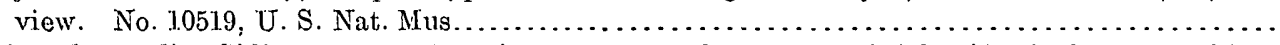

7. Sigmodon medius Gidley, n. sp. Anterior two upper cheek teeth of right si e, in fragment of jaw,

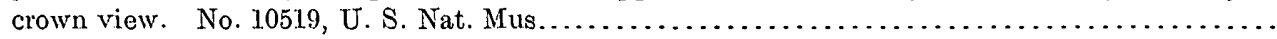

8. Neotoma fossilis Gidley, n. sp. Portion of a left lower jaw viewed from above; Sa, side view. No.

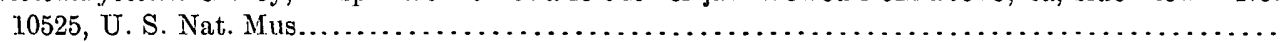

9. Neoloma fossilis Gidley, n. sp. Type. First upper cheek tooth of right side in fragment of maxillary,

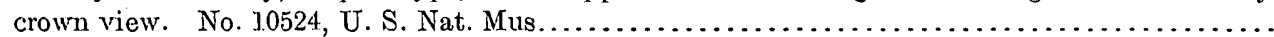

10. Neotoma fossilis Gidley, n. sp. Anterior two lower cheek teeth of right side, crown view; 10a, inner

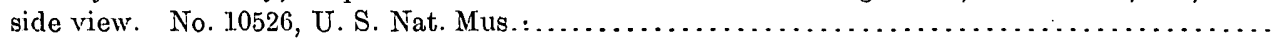

1.1. cf. Sylvilagus sp. Median incisors in fragment of premaxillary, palate view; 1la, front view. No.

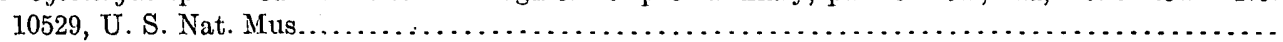

12. Lepus sp. Two upper incisors of right side in fragment of premaxillary, palate view; 12a, front view.

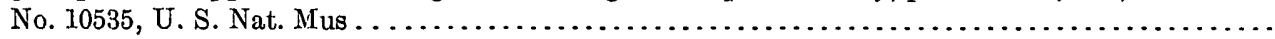

13. Lepus sp. cf. L. californicus. Anterior two cheek teeth of right side in fragment of lower jaw, crown

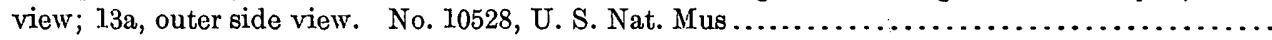

14. Neofiber sp. Portion of a left upper molar, oblique crown view; 14a, outer side view. No. 10527,

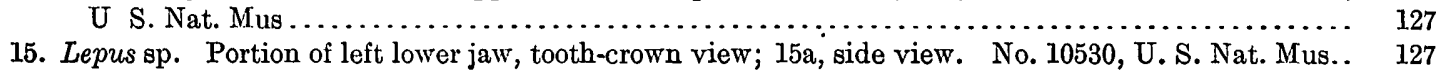




\section{REVISION OF THE FLORA OF THE GREEN RIVER FORMATION, WITH DESCRIPTIONS OF NEW SPECIES.}

By F. H. Knowleton.

\section{THE GREEN RIVER FORMATION.}

The Green River shales, later known as the Green River formation, were named and described by F. V. Hayden in $1869 .{ }^{1}$ After discussing the coal and lignite beds along the Union Pacific Railroad in western Wyoming, Hayden says:

A little east of Rock Spring station a new group commences composed of thinly laminated chalky shales, which I have called the Green River shales, because they are best displayed along Green River. They are evidently of purely fresh-water origin and of middle Tertiary age. The layers are nearly horizontal and, as shown in the valley of Green River, present a peculiarly banded appearance. When carefully studied these shales will form one of the most interesting groups in the West. The flora is already very extensive, and the fauna consists of Melanias; Corbulas, and vast quantities of fresh-water fishes. There are also numerous insects and other small undetermined fossils in the asphaltic slates. One of the marked features of this group is the great amount of combustible or petroleum shales, some portions of which burn with great readiness and have been used for fuel in stoves.

The decade that followed the naming and defining of the Green River shales as a formational unit by Hayden was one of increased geologic study in the West, with the result that these beds were recognized and more or less fully described at a number of widely separated points. Thus Peale ${ }^{2}$ recognized the Green River group, as he called it, between Grand (now Colorado) and Gunnison rivers in Colorado; Powell ${ }^{3}$ noted it along the northern foothills of the Uinta Mountains, distinguishing a "Lower" and "Upper" Green River; Emmons, ${ }^{4}$ who was connected with the Fortieth Parallcl Survey, described it very fully for the Green River Basin; Peale ${ }^{5}$ found it along the

1 U. S. Geol. Survey Terr. Third Ann. Rept. (reprint, 1873), p. 190.

2 Poalo, A. C., U. S. Geol. and Geog. Survey Terr. Ann. Rept. for 1874, pp. 147, 150-158, 1876.

3 Powell, J. W., Geology of the Uinta Mountains, pp. 40, 45, 166, 167, 1876.

4 Emmons, S. F., U. S. Expl. 40th Par. Rept., vol. 2, pp. 203, 240, 1877. - Peale, A. C., U. S. Geol. and Geog. Survey Terr. Ann. Rept. for 1876, p. 184,1878 .
Book Cliffs in western Colorado; White ${ }^{6}$ studied it in western Colorado and eastern Utah; Endlich ${ }^{7}$ described its occurrence along White River in western Colorado and south of the Wind River Mountains in Wyoming; ${ }^{8}$ and Peale ${ }^{0}$ noted it in the northern and western parts of the Green River Basin.

One of the most complete of the earlier accounts of the Green River formation is that given by Emmons ${ }^{10}$ in his description of the Green River Basin. Three Tertiary formations-or "series," as they were then calledwere recognized, the oldest of which was the Wasatch formation (nearly the same as the "Vermillion Creek group" of King and the upper part of the "Bitter Creek series" of Powell). Above this, without apparent discordance, was the Green River formation, which in turn was overlain by the Bridger formation.

The Green River beds were described by Emmons as follows:

The beds of the Green River series contrast with those of the other two groups by the relative prevalence of calcareous material and the fineness of their sediments. They were deposited in quiet, probably deeper waters and perhaps during the time that erosion was wearing away the limestones of the Upper Coal Measures. They consist of a lower series of calcareous sandstones and impure limestones, containing some lignite seams, overlain by a great thickness of remarkably fissile.calcareous shales abounding in remains of fish and insects, which reach an aggregate thickness of about 2,000 feet and are characterized throughout by their prevailing white color. The extent of the sea in which these beds were deposited was somewhat less than that of the previous period, a strip of land having been elevated above its level along the flanks of the Wasatch, and probably also a narrower strip along the shores of the Park Range; its beds, however, were deposited continuously over the ridge of Vermillion Creek Wasatch beds, between the Bitter Creek

6 White, C. A., idem, pp. 19-35.

7 Endlich, F. M., idem, p. 111.

8 Idem for 1877 , p. 130,1879 .

- Peale, A. C., idem, p. 525.

10 Emmons, S. F., U. S. Expl. 40th Par. Rept., vol. 2, pp. 203, 240, etc., 1877 . 
Cretaceous uplift and the Archean body of Red Creek, and also connected, through the low gap of the White River divide, at the eastern end of the Uinta Range, with the region to the south, in which beds corresponding to these and to the Bridger beds have been recognized, although their direct connection has not yet been traced.

It is not within the scope of the present paper to give a complete review of the literature relating to the Green River formation, but simply enough to show its areal distribution and physical characteristics that may serve as a setting for the discussion of its flora and fauna. From data obtained within the first dozen years after it was formally recognized by Hayden and abundantly confirmed by subsequent investigators, the Green River formation is known to extend from the headwater region of Green River in the Wind River Mountains, Wyo., southward to Grand Mesa, between Colorado and Gunnison rivers, Colo., a distance of approximately 300 miles. The western limit of the formation is rather sharply defined, for it abuts on the eastern foothills of the Wasatch Mountains. The eastern limits, however, are less sharp. Emmons expressed the opinion that the formation originally extended to the western slopes of the Park Range, but the evidence for this opinion is not conclusive. The Green River formation was not recognized by E. E. Smith ${ }^{11}$ in his study of the eastern part of the Great Divide coal field, though the Wasatch formation, with thicknesses ranging between 900 and 1,800 feet, is present there, nor was it definitely identified by M. W. Ball ${ }^{12}$. in his study of the western part of the Little Snake River coal field, though it may be represented in some undifferentiated beds above the Wasatch formation. The Green River formation is said by A. R. Schultz ${ }^{13}$ to extend over the north end of the Rock Springs uplift and out into the Red Desert to a point about 20 miles southeast of the Antelope Hills. It is also present at the south end of the Rock Springs. uplift, along the divide between Sage and Red creeks. It thus appears that in all probability these beds once covered a large part of the Great Divide Basin and the Red Desert but were later removed by erosion. In any event, it seems fairly well established that the maximum width of the area once covered in whole or in part by the

11 U. S. Geol. Survey Bull. 341, p. 220, 1909

12 Idem, p. 243.

18 U. S. Geol. Survey Bull. 702. p. 24, 1920.
Green River formation was little if any less than 150 miles.

As already mentioned, Powell divided the Green River formation into a "Lower Green River" and an "Upper Green River." The latest report in which these beds are discussed is that by A. R. Schultz ${ }^{14}$ on the area around the Rock Springs uplift, in Sweetwater County, Wyo. Schultz recognizes four members of the Green River formation, which in ascending order are as follows: (1) Tipton shale member, consisting of fissile shale, conglomerate, oolitic limestone, shale, clay, and sandstone; (2) Cathedral Bluffs red-beds member, composed of red or varicolored conglomeratic sandstone, shale, and clay; (3) Laney shale member, made up of white and green fissile shale, limestone, and sandstone, "similar to those so characteristic of the lower member or Tipton shale of the Green River in this part of the field and to the entire Green River formation in other parts of the Green River Basin;" (4) "Tower sandstone" and plant beds of Powell, which consist of massive, regularly bedded sandstone, sandy limestone, and shale.

Just how far these proposed subdivisions of the Green River formation can be recognized in other parts of the vast area over which it extends is not now known, though some subdivision is undoubtedly possible. The earliest known and most thoroughly exploited of the plant-bearing beds are along the Union Pacific Railroad 2 or 3 miles west of the town of Green River, where, according to Hayden, Ward, and others, they occur about 100 feet above the fish beds. This places their position some hundreds of feet below the "Tower sandstone" that is so well exposed at the town of Green River. Powell and others who have followed him seem to be in error in speaking of the plant beds as overlying the "Tower sandstone."

It seems rather remarkable, in view of the thickness and areal extent of the Green River formation, that it has been found to be fossiliferous at so few localities. Endlich remarked on this peculiarity many years ago, pointing out that it was possible to follow these beds for miles without finding a trace of animal or plant life. There is such an area north of Rock Springs, Wyo., where beds hundreds of feet in thickness are seemingly well fitted to preserve any forms of life that may have been 
present in the region, and yet so far as known they are absolutely barren of fossils. The suggestion that these beds may have been deposited in deep water far from shore does not fully explain their barrenness, for even if they were it would seem that they should contain a few specimens.

So far as now known the first fossil form from the Green River formation to be brought to sciontific attention was a small herring-like fish described by Joseph Leidy ${ }^{15}$ in 1856 , under the name Clupea humilis, later changed to Diplomystus humilis. It was collected by Dr. John Evans, who visited the Rocky Mountain region in 1849 and 1856, from the so-called fish beds near the town of Green River and was the forerunner of thousands of wonderfully preserved fish remains that have since been found.

$\Lambda$ s already stated, Hayden named the Green River formation in 1869 , and at that time he mentioned the presence of "an extensive flora," but it is not a matter of record that he brought actual specimens to Washington. However, Hayden again visited the plant and fish beds near Green River during the summer of 1870, writing as follows: ${ }^{16}$

About a mile west of the "petrified fish bed" is a cut along the railroad which passes through a moderate thickness of buff chalky limestones, filled with impressions of leaves of deciduous plants.

These plants were submitted to J. S. Newberry, and his preliminary report in the form of a letter was published by Hayden in the report cited. The collection comprised only about half a dozen forms sufficiently well preserved to be capable of identification, and of these he wrote as follows:

Among them I find two palms, both quite unlike anything before found on this continent. One is a new Phoenicites, resembling Heer's Manicaria formosa; the other but an imperfect fragment, yet altogether new and strange to me. The most abundant species contained in the collection is a Magnolia, allied to $M$. tenuinervis Lesquereux but more elongate and acute; also an oak resembling Quercus saffordi of Lesquereux. There is another oak in the collection, a laurel (probably), and fragments of two ferns, too imperfect for determination.

This account of the Green River flora, although relatively unimportant, is so far as known the first one published.

\footnotetext{
1s Philadelphin Acad. Nat. Sci. Proc., vol. 8, p. 256, 1856.

${ }^{16}$ Hayden, F. V., U. S. Gcol. Survey Wyoming Prelim. Rept., p. 143,
}

On his way back from the field in 1870 Hayden passed over the old overland stage route, which follows Bitter Creek nearly to its head, crosses the Red Desert, and thence goes through Bridger Pass to the Laramie Plains.

\section{THE OIL SHALE AND ITS MICROSCOPIC FLORA AND THE BEARING OF THE FLORA ON THE ORIGIN OF THE SHALE OIL.}

The intensive search for sources of petroleum that is now being prosecuted in many parts of the world has naturally directed renewed attention to the oil shales of the Green River formation, which are known to occur over vast areas in Wyoming, Colorado, and Utah. According to Winchester, ${ }^{17}$

Approximately 5,500 square miles in northwestern Colorado and northeastern Utah are underlain by beds of oil shale thick enough to mine and apparently rich enough to warrant the development of an industry for the manufacture of shale oil and other products.

Concerning the origin of the shale oil Winchester ${ }^{18}$. wrote as follows:

The Green River formation or that part of it including the oil shales consists of remarkably persistent and thinly bedded shales with some sandstone and at places oolite and limestone. The beds were laid down in fresh water which had an enormous expanse and was deep enough so that wave action had little effect on the sediments. The shale is in most places free from grit and contains an immense amount of vegetable matter; the richer beds show by far the greater amount of such material. Singularly enough, such low plant forms as the blue-green algae are represented in great abundance and in a state of almost perfect preservation. Pollen grains are present which came from coniferous trees which grew on land perhaps at considerable distances from the great inland lake in which the shale was deposited. There is also a vast amount of organic material which is too macerated for identification. Complete insects and excellently preserved dipterous larvae as well as fish scales and even perfect fish skeletons have been found, but in most hand specimens of the shale there is little evidence of other plant life.

The microscopic life, especially plant life, of the Green River oil shale, and its probable bearing on the origin of the oil, were under critical study by the late C. A. Davis, of the U. S. Bureau of Mines, and many valuable data have been accumulated, but his death in 1915 brought the study to a close before much had. been recorded. A great number of thin sections and other especially prepared material had been brought together, and a few months more of study would have placed the subject

17 Winchester, D. E., Oil shale in the United States: Econ. Geology, vol. 13, p. $508,1917$.

18 Idem, p. 510. 
on a firm basis. As it is, the only recorded facts resulting from this study are in the form of the following notes prepared by Davis for Winchester's paper:

Flora of the oil shale of the Green River formation.

(a) Bacteria, Crenothrix, and similar low filamentous types.

(b) Myophyceae: Blue-green algae.

(c) Algae: (1) Protococcaceae: Protococcus, Pediastrum.

(2) Conjugatae: Spirogyra.

(d) Fungi: Saprophytic molds, etc.

(e) Mosses: Spores probably from these plants.

$(f)$ Pteridophyta: Ferns; annuli from fern sporangia.

-(g) Spermatophyta:

(1) Gymnospermae: Pinaceae; pollen of Picea and Pinus.

(2) Angiospermae: Pollen and fragments of cells, tissues, etc. Bark cells and residues, small pieces poorly preserved. 'In addition there are abundant and well-preserved remains which are of good size and of frequent occurrence, which seem to be structureless so far as cellular structure are concerned. However, they have definite and pretty regular forms and, in Dictyonophora, definite areas which carry well-marked and characteristic patterns which seem like cells but which show no cell walls. These anomalous forms seem to have been the most abundant organisms in the waters in which the shales were laid down and are evidently vegetables of a low order of development. They are manifestly in place as they grew, since they do not show in pressed down masses but were buried in natural positions, very slowly.

The bearing of this microscopic flora on the origin of the shale oil is further discussed by Davis in notes quoted by Winchester but need not be mentioned here further than to state that the evidence seems to indicate that the oil was produced in place and not by migration from some other source.

\section{GREEN RIVER LAKE.}

The Green River lake was a very considerable body of water, as its length from north to south was approximately 300 miles and its width more than 150 miles. It is not known that this maximum extent was reached at any one time, but at some time during its existence its waters spread in one direction or another to these wide-flung limits. It was bordered on the north and west by what are now lofty mountain ranges, though they were then of far less elevation. Its containing barriers on the east and south are less easily recognizable but were apparently certain low-lying Cretaceous and perhaps earlier rocks that were then emergent. It may have extended as far as the western foothills of the Park Range, but this is somewhat uncertain. The lake was almost bisected by what are now the Uinta Mountains, but it is clear that there was a waterway around the east end of the Uinta Range through Brown's Park. Clarence King's conception of the physical conditions that existed in and adjacent to the Green River Basin during early Eocene time was set forth in the volume devoted to the general geology of the region traversed by the Fortieth Parallel Survey under his direction. Among the subjects discussed are the supposed Tertiary lakes in that region. ${ }^{19}$ King pointed out that at the end of Cretaceous time "the relative upheaval of the whole Rocky Mountain chain and the west shore of the Cretaceous sea, including the system of the Wahsatch and its northerly extension, resulted in walling in the system of the Colorado River, which then for the first time became an area from which the sea was quite excluded."

The Wasatch and Rocky mountains converge toward the north and join near the present headwaters of Green River, but toward the south they diverge more and more until in southern Colorado and New Mexico they are 500 miles or more apart. It was within the area inclosed by these mountain systems, but more especially in the northern part, largely in what is now the Green River Basin, that King located his succession of Tertiary lakes. The earliest of these lakes, according to his conception, was a great body of fresh water that extended 150 miles north of the 40th parallel and, from some evidence, for 200 miles to the south and was perhaps 150 miles wide. For this lake he proposed the name Ute Lake. According to King it was in the waters of this lake that the great body of sediments were deposited that later constituted the Wasatch formation.

Subsequent study has more or less discredited King's conclusion as to the lacustrine. origin of the Wasatch rocks, many observers regarding them as more probably flood-plain deposits. Be this as it may, at the end of Wasatch time there was a subsidence that.

19 King, Clarence, U. S. Geol. Expl. 40th Par. Rept., vol. 1, pp. 444448,1878 . 
permitted a wider overflow of impounded waters. It was in this body of water, named Gosiute Lake by King, that the sediments of the Green River formation were laid down. Whatever may be the origin of the Wasatch sediments, all are apparently agreed that the Green River shales are of lacustrine origin. King says:

As developed at characteristic localities in the neighborhood of Green River, this group embraces about 2,000 feet of conformable fine-grained rocks, giving general evidence of accumulation in still, rather deep water. The lower 1,200 fect are made up of finely fissile shales and calcareous clays, with some quite fine limestones. Many of the upper shales are strongly bituminous.

The position of the outlet of Green River lake is not known, though it was doubtless somewhere to the south or southwest. It seems not unlikely that it followed approximately the present Colorado River drainage system, as its surplus waters undoubtedly found their way into the Pacific Ocean.

If the deductions to be drawn from the fish fauna have been correctly interpreted the lake was at a comparatively slight elevation above sea level. Data regarding this fauna furnished by Dr. O. P. Hay, of the United States National Museum, show that about 35 fairly well authenticated species of fish are known from the Green River shales. Three families, represented in this fauna by four genera and eight species, have pronounced marine affiliations. Thus the Clupeidae, which include the very large group of herrings, are represented by three genera and six species. The herrings to-day are mainly confined to the ocean, though some ascend rivers to spawn, and a few live in rivers. The sting rays, represented by a fine, clearly defined species (Heliobatis radians) in the Green River, are mainly marine, though a few forms live in rivers. A third family is also represented by a single species, the living representatives of which are found in estuaries and rivers of Australia.

From these facts it seems certain that the sea was not far away from the Green River lake or at least was readily accessible. Cope ${ }^{20}$ who described most of the Green River fishes, says:

True herring, or those with teeth, are chiefly marine, but they run into fresh-water rivers and deposit their spawn in the spring of the year and then return to salt water. The

${ }^{20}$ Cope, IE. D., U. S. Geol. and Geog. Survey Terr. Ann. Rept. for 1870. p. 431, 1871 . young run down to the sea in autumn and remain there until old enough to spawn. The size of the fry of the Rocky Mountain herring indicates that they had not long left the spawning ground, while the abundance of adults suggests that they were not far from salt water, their native element. To believe, then, that the locality from which these specimens were taken was neither far from fresh nor far from salt waters is reasonable.

Osborn in discussing the Green River fishes in his "Age of mammals," says in part:

A large part of the teliosts are related to fishes at present confined to the Eastern Hemisphere. Thus the diplomystids ("rough-backed herrings") survive only in certain rivers and along portions of the coasts of Chile and eastern Australia.

The distance from the Green River lake to the ocean can only be approximated, though it must have been some hundreds of miles. This distance, however, would not have been a serious obstacle to the passsage of fish from one to the other, provided, of course, there were no insurmountable falls or other obstructions in the stream. Salmon are known to ascend to the upper waters of the Yukon to spawn, a distance of 2,250 miles.

About a dozen species of land and freshwater invertebrates (Helix, Physa, Viviparus, Pupa, Unio, and others) have been found in the Green River shales, but they throw little light on the ecologic conditions that prevailed at that time.

\section{FOSSIL LOCALITIES AND LISTS OF SPECIES.}

Locality unknown.-Under the heading "hard, shaly, fine-grained whitish sandstone," Lesquereux ${ }^{21}$ enumerated the species listed below and continued:

About the same consistence and color as the specimens from Carbon station. The precise locality is unknown, the labels having been lost or forgotten.

However, in Lesquereux's "Tertiary flora" 22 all these species are referred without question to the Green River formation.

Cyperus chavannesi Heer.

Populus arctica Heer.

Ficus multinervis Heer.

Ficus lanceolata Heer.

Ficus arenacea n. sp.

Ficus gaudini n. sp.

Platanus sp.

Cinnamomum sp.

These species of Ficus have been subsequently identified only in older rocks, such as

${ }^{21}$ Lesquereux, Leo, U. S. Geol. and Geog. Survey Terr. Ann. Rept. for 1871, pp. 300, 301, 1872 .

${ }_{22}$ U. S. Geol. Survey Terr. Rept., vol. 7, pp. 194, 195, 1878. 
the Mesaverde and "Laramie." There is absolutely no warrant for calling them Green River, and they are consequently dropped from this flora.

Alkali stage station, Wyo.-In 1874 Lesquereux ${ }^{23}$ described the following species from Alkali stage station, on the Sweetwater road, about 30 miles north of Green River station on the Union Pacific Railroad:

\footnotetext{
Alnites unequilateralis $\mathbf{n}$. sp.

Juglans alkalina n. sp.

Carpites viburni n. sp.
}

Lesquereux was uncertain as to the age of these species but finally concluded that they were probably of the same age as the plant beds at Black Buttes, Wyo. Although the locality has not been revisited it has usually been classed as of Green River age.

Mouth of White River and west of Green River station, Wyo.--In 1874, under the caption "New species of Tertiary fossil plants briefly described," Lesquereux ${ }^{24}$ enumerated the following Green River species:
1. Lygodium dentoni $\mathrm{n}$. sp.
2. Myrica ludwigii Schimper.
3. Quercus haidingeri Ettingshausen.
4. Ficus wyomingiana $n$. sp.
5. Cissus parrottiaefolia n. sp.
6. Phaseolites juglandinus? Heer.
7. Leguminosites alternans $\mathbf{n}$. sp.
8. Sapindus dentoni $\mathrm{n}$. sp.
9. Lomatia microphylla n. sp.

Nos. $1,2,6,7,8$, and 9 were collected by William Denton at the mouth of White River, which empties into Green River. Nos. 3, 4, and 5 were found west of Green River station.

Green River station, Wyo.-In 1872 Lesquereux ${ }^{25}$ published a paper entitled "An enumeration with descriptions of some Tertiary fossil plants from specimens procured in the explorations of Dr. F. V. Hayden, in 1870." Under the caption "Green River, above the fish beds," he enumerated the following forms:

Hemitelites torelli Heer?

Arundo göpperti Münster.

Phragmites oeningensis Al. Braun.

Juncus sp.

Salix angusta Al. Braun.

Salix media Al. Braun.

${ }^{28}$ Lesquereux, Leo, U. S. Geol. and Geog. Survey Terr. Ann. Rept. for 1874, pp. $307,308,1876$.

24 Idem, pp. 308-315; also U. S. Geol. and Geog. Survey Terr. Bull., 2d ser., No. 5, pp. 382-389, Jan. 8, 1876.

${ }_{25}$ U. S. Geol. Survey Terr. Fifth Ann. Rept., for 1871, Suppl., pp. 5-9, $22,1872$.
Salix sp.

Myrica nigricans n. sp.

Myrica salicina Unger.

- Quercus lonchitis Unger.

Ficus populina Heer.

Ficus ungeri n. sp.

Cinnamomum scheuchzeri Heer.

Eucalyptus americanus n. sp.

Ampelopsis tertiaria $\mathbf{n}$. sp.

Ilex affinis $\mathrm{n}$. $\mathrm{sp}$.

Ilex stenophylla Unger. [Excluded.]

Ceanothus cinnamomoides Lesquereux.

Rhus acuminata $\mathbf{n}$. sp.

Juglans schimperi n. sp.

Juglans acuminata Heer?

Juglans denticulata Heer?

In the same year, under the caption "Green River group, high on hills from river," Lesquereux enumerated the following species:

Ceanothus cinnamomoides Lesquereux.

Carya heerii Ettingshausen.

In the "Tertiary flora" (p. 277) Lesquereux states that Ceanothus (or Zizyphus) cinnamomoides came from "Green River station, Wyo., above the fish beds with Ampelopsis tertiaria." It was collected by F. V. Hayden and is preserved in the United States National Museum (No. 431).

Bridger Pass (?) and Washakie station, Wyo.In the "Tertiary flora" Lesquereux enumerates three species as having come from Bridger Pass, Wyo., as follows:

Laurus utahensis Lesquereux (p. 216).

Aralia? gracilis (Lesquereux) Lesquereux (p. 236).

Rhamnus intermedius Lesquereux (p. 282).

On referring to the place of original description it appears that Aralia? gracilis (or Liquidambar gracile, as it was first called) and Rhamnus intermedius are recorded by Lesquereux ${ }^{26}$ as having come from "Washakie station, near Bridger Pass." Laurus utahensis was described as new in the "Tertiary flora" and was said to have come from Bridger Pass, "in connection with Araliopsis [error for Aralia] gracilis and Populus arctica." Both these species are found at Washakie station, and with little doubt the species of Laurus was also found there.

From this evidence it seems reasonably certain that the three species above mentioned did not come from Bridger Pass, but from Washakie station, which is about 12 miles west of Bridger Pass. The improbability of their hav-

${ }^{26}$ Lesquereux, Leo, U. S. Geol. and Geog. Survey Terr. Ann. Rept. for 1871 , p. 286,1872 . 
ing come from Bridger Pass is further emphasized by the fact that, according to Ball, ${ }^{27}$ the rocks in the pass are referred to the Mesaverde. On the other hand, Washakie station is in an arca in Ball's "upper coal group," which includes "Upper Laramie," Fort Union, and basal Wasatch. As there is no indication by Lesquereux, or by Hayden, who collected these plants, as to where they came in the local section, it is absolutely impossible to place them until they are again collected from beds of known position. To refer them to the Green River formation is not warranted, and, a.t least for the present, they are excluded from this flora.

Green River, Wyo. (plants described by J.S. Newberry).-In 1883 Newberry ${ }^{28}$ named and gave preliminary descriptions of the following species:

Acrostichum hesperium.

Pecopteris (Phegopteris) sepulta.

Sabal powellii.

Manicaria haydenii.

Quercus castanoides.

Juglans dentata.

Juglans occidentalis.

Planera variabilis. .

Planera nervosa.

Zizyphus longifolia.

Aralia macrophylla.

In 1898 Newberry ${ }^{20}$ described and figured the plants enumerated in the preceding paper under the following names:

Lygodium kaulfussii.

Acrostichum hesperium.

Pecopteris (Cheilanthes) sepulta.

Equisetum wyomingense.

Sabal powellii.

Manicaria haydenii.

Juglans occidentalis.

Salix angusta?

Quercus castanoides.

Planera nervosa.

Planera variabilis.

Zizyphus longifolia.

Aralia macrophylla.

Nordenskioldia borealis.

Colorado localities (collections of D. E. Winchester).-The collections of D. E. Winchester include the species listed below.

Yellow sandstone of "Upper Green River," on Greasewood Creek, 40 miles west of Meeker, Rio Blanco County, Colo. (Winchester 7379):

Aralia wyoningensis Knowlton and Cockerell.

97 Ball, M. W., U. S. Geol. Survey Bull. 341, pl. 13, 1909 .

28 U. S. Nat. Mus. Proc., vol. 5, pp. 502-514, 1883.

20 Later extinct floras of North America: U. S. Geol. Survey Mon. 35, 1898 .
Green River oil shale, Cathedral Bluff, Little Tommies Draw, 20 miles west of Rio Blanco post office, Rio Blanco County, Colo. (Winchester 7399):

Caenomyces eucalpytae n. sp.

Myrica sp.

Pimelea spatulata $\mathrm{n} . \mathrm{sp}$.

Sedum? hesperium n. sp.

Eucalyptus? americanus Lesquereux.

Carpites inquirenda n. sp.

Green River oil shale, Greasewood Creek, 40 miles southwest of Meeker, Rio Blanco County, Colo. (Winchester 7381):

Caenomyces sp.

Danaea coloradensis $\mathrm{n}$ : $\mathrm{sp}$.

Pontederites hesperia n. sp.

Salix sp.

Myrica minuta n. sp.

Myrica praedrymeja n. sp.

Comptonia? anomala n. sp.

Oreodaphne viridiflumensis n. sp.

Sapindus winchesteri n. sp.

Rhus n. sp.

Zizyphus longifolia Newberry.

Sambucus? winchesteri n. sp.

Carpolithes caryophylloides $\mathrm{n}$. sp.

Green River oil shale, Little Duck Creek, 50 miles southwest of Meeker, Rio Blanco County, Colo. (Winchester 7381a):

Dalbergia retusa $\mathrm{n} . \mathrm{sp}$.

Sophora coloradensis n. sp.

Mimosites coloradensis n. sp.

Green River oil shale, Cathedral Bluff, 20 miles west of Rio Blanco post office, Rio Blanco County, Colo., in sec. 33, T. 4 S., R. 100 W. (Winchester 7382):

Lygodium kaulfussii Heer.

Salix linearis n. sp.

Salix longiacuminata $n$. sp.

Juglans winchesteri n. sp.

Dalbergia viridiflumensis n. sp.

Eucalyptus? americana Lesquereux.

Phyllites winchesteri $\mathrm{n}$. sp.

Green River oil shale, Camp Gulch, 25 miles northwest of De Beque, Colo. (Winchester 7384):

Achaenites cichorioides n. sp.

Green River oil shale, head of trail up ridge between Carr and Bushy creeks, 25 miles northwest of De Beque, Colo. (Winchester 7386):

- Eucalyptus? americana Lesquereux.

Green River oil shale, head of Carr Creek, 30 miles northwest of De Beque, Colo. (Winchester 7387):

Myrica sp.

SPECIES EXCLUDED FROM GREEN RIVER FLORA.

The following species have been dropped from the Green River flora for the reasons stated:

Acer sp. Lesquereux, U. S. Geol. and Geog. Survey Terr. Ann. Rept. for 1871, p. 286, 1872.

From Barrel Springs, Wyo.; not afterward recognized by Lesquereux.

Aralia gracilis (Lesquereux) Lesquereux, U. S. Geol. Survey Terr. Rept., vol. 7 (Tertiary. flora), p. 236, pl. 39, fig. $1,18,78$. 
Liquidambar gracile Lesquereux, U. S. Geol. and Geog. Survey Terr. Ann. Rept. for 1.871, p. 287, 1872.

From Bridger Pass, Wyo., hence excluded. (See p. 138.)

Arundo göpperti Münster. Lesquereux, U. S. Geol. and Geog. Survey Terr. Ann. Rept. for 1871, Suppl., p. 5, 1872; U. S. Geol. Survey Terr. Rept., vol. 7 (Tertiary flora), p. 86, pl. 8, figs. 3-5.

This species is rejected from the Green River flora and probably should not be recognized in North America. In the "Tertiary flora" Lesquereux figured three specimens that he referred to this species. Of these only one, the original of his Plate VIII, figure 3 , is now preserved in the United States National Museum (No. 95), and is before me. It is fully 8 centimeters wide, nearly three times the size of the largest specimen figured by Heer, ${ }^{30}$ and is very unlike Heer's figure in appearance. It is marked with numerous fine longitudinal veins or lines, and at fairly regular intervals, about 1 centimeter apart, are stronger lines or folds. It may be a large leaf of Cyperacites or possibly a palm leaf. It is too indefinite to be identified.

Blechnum göpperti Ettingshausen. Lesquereux, U. S. Geol. and Geog. Survey Terr. Ann. Rept. for 1871, p. 283,1872 .

From Henry's Fork, Utah; not again referred to by Lesquereux.

Carya heerii (Ettingshausen) Heer. Lesquereux, U. S. Geol. 'and Geog. Survey Terr. Ann. Rept. for 1871, p. 289,1872 .

Not afterward recognized by Lesquereux.

Cinnamomum scheuchzeri Heer. Lesquereux, U. S. Geol. and Geog. Survey Terr. Ann. Rept. for 1871, Suppl., p. 7,1872 .

Concerning this species Lesquereux said: "I refer to this species two leaves of Cinnamomum, one of which is contracted above the base, as in some forms of C. buchi Heer; the other narrower, like a variety of $C$. lanceolata Heer. Both specimens are incomplete and have the nervation of $C$. scheuchzeri, as represented in many specimens from other localities of our Ter. tiary." This species was not again alluded to as a member of the Green River flora, and the two leaves were probably transferred to some other species, but of this there is no record; they are not now known to be in existence.

Cyperites deucalionis Heer. Lesquereux, U. S. Geol. and Geog. Survey Terr. Ann. Rept. for 1871, p. 285, 1872.

From Barrel Springs, Wyo.; not afterward referred to by Lesquereux.

Cyperus braunianus? Heer. Lesquereux, U. S. Geol. and Geog. Survey Terr. Ann. Rept. for 1871, p. 285, 1872.

From Barrel Springs, Wyo.; not afterward mentioned by Lesquereux.

Cyperus chavanensis Heer. Lesquereux, U. S. Geol. and Geog. Survey Terr. Ann. Rept. for 1871, p. 300, 1872.

Not from the Green River formation. (See p. 137.)

Equisetum haydenii Lesquereux, U. S. Geol. and Geog. Survey Terr. Ann. Rept. for 1871, p. 284, 1872; U. S. Geol. Survey Terr. Rept., vol. 7 (Tertiary flora), pl. 6, figs. $2-4,1878$.

${ }^{80}$ Heer, Osw:ald, Flora tertiaria Helvetiae, vol. 1, pl. 23, fg. 1, 1854.
Ficus arenacea Lesquereux, U. S. Geol. and Geog. Survey Terr. Ann. Rept. for 1871, p. 300, 1872.

Not from the Green River formation. (See p. 137.) Ficus gaudini Lesquereux, U. S. Geol. and Géog. Survey Terr. Ann. Rept. for 1871, p. 200, 1872.

Not from the Green River formation. (See p. 137.) Ficus lanceolata Heer. Lesquereux, U. S. Geol. and Geog. Survey Terr. Ann. Rept. for 1871, p. 300, 1872. Not from the Green River formation. (See p. 137.) Ficus multinervis Heer. Lesquereux, U. S. Geol. and Geog. Survey Terr. Ann. Rept. for 1871, p. 300, 1872. Not from the Green River formation. (See p. 137.) Ficus populina Heer, Flora tertiaria Helvetiae, vol. 2, p. 66 , pl. 85 , figs. 1-7; pl. 86, figs. 1-11, 1856; Lesquereux, U. S. Geol. and Geog. Survey Terr. Ann. Rept. for 1871, Suppl., p. 6, 1872.

Ficus populina was characterized by Heer from specimens obtained in the Swiss Miocene. A number of leaves from the Green River formation were identified by Lesquereux with Heer's species, although he states that they show "some marked differences," such as being obtuse rather than long and acutely pointed, having the veins nearer the borders, and having the marginal teeth pointed rather than round. There is a great deal of variation in the size and appearance of the forms referred to Ficus populina by Heer, and as Lesquereux did not specify the particular forms he regarded as most like those he had from Green River there is no way of telling where he later referred them. This species will have to be excluded from the Green River flora.

Geonomites goldianus (Lesquereux) Lesquereux, U. S. Geol. Survey Terr. Rept., vol. 7 (Tertiary flora), p. 115, pl. 9, fig. 9, 1 S78.

Wrong identification.

Palmacites goldianus Lesquereux, U. S. Geol. and Geog. Survey Terr. Ann. Rept. for 1874, p. 311, 1875.

From Barrel Springs, Wyo.

Hemitelites torrelli Heer? Lesquereux, U. S. Geol. and Geog. Survey Terr. Ann. Rept. for 1871, Suppl., p. 5, 1872 .

Not afterward referred to by Lesquereux.

Ilex dissimilis Lesquereux, U. S. Geol. Survey Terr. Rept., vol. 7 (Tertiary flora), p. 271, pl. 50, figs. 7-9, 1878.

- This species comes from Sage Creek, Mont., in beds of doubtful age. There seems no longer any valid reason for including this in the Green River formation, even with a question, and it is excluded.

Ilex stenophylla Unger. Lesquereux, U. S. Geol. and Geog. Survey Terr. Ann. Rept. for 1871, Suppl., p. 8, 1872.

Not afterward mentioned by Lesquereux in connection with the Green River flora.

Juglans acuminata Heer? Lesquereux, U. S. Geol. and Geog. Survey Terr. Ann. Rept. for 1871, Suppl., p. \&, 1872.

Lesquereux compares his Green River leaf with $\approx$ peculiar form of Juglans acuminata from the Swiss Miocene, but as he did not afterward allude to it in this connection it was probably placed under some other form without record of such transfer.

Juglans dentata Newberry, U. S. Nat. Mus. Proc., vol. 5, p. 507,1882 [1883].

Although this species was described by Newberry it was evidently merged with some other species in the 
formal publication of the "Later extinct floras," but just which one can not be determined. Hollick, who edited this work of Newberry's, states that he could find neither specimen, figure, nor manuscript relating to it, so it would best be dropped.

Laurus utahensis Lesquereux, U. S. Geol. Survey Terr. Rept., vol. 7 (Tertiary fiora), p. 216, 1878 .

Said to have come from Bridger Pass, Wyo., but the locality is uncertain, hence it is best excluded from the Green River flora. (See p. 138.)

Leguminosites lesquereuxiana Knowlton, U. S. Geol. Survey Bull. 152 , p. 131, 1898; Mon. 32 , pt. 2, p. 730, pl. 79, fig. 4, 1899. [See below.]

Leguminosites cassioides Lesquereux, U. S. Geol. Survey T'err., Rept., vol. 7 (Tertiary flora) p. 300, pl. 59, figs. 1-4,1878. [Homonym; replaced by $L$. lesquereuxiana.] It seems probable that this species would best be excluded from the Green River flora, for although Lesquereux states that three of the figured types were obtained above the fish beds at Green River, they are not to be found with the other material from this locality that is preserved in the United States $\mathrm{Na}$ tional Museum, and their present location is unknown. The other type is from the supposed Livingston formation of the Bozeman coal field, Mont. As this species has not subsequently been found in the Green River formation, it is excluded, at least for the present.

Magnolia sp. Lesquereux, U. S. Geol. and Geog. Survey Terr. Ann. Rept. for 1871, p. 287, 1872.

This is stated to have come from Washakie station, Wyo., but as it was not afterward referred to by Lesquereux it should be dropped.

Myrica studerif Heer. Lesquereux, U. S. Nat. Mus. Proc., vol. 10, p. 38, 1887.

The locality for this specimen is supposed to be White River, Wyo., but it is so uncertain and the specimen is so obscure that it is here excluded from the Green River flora.

Phaseolites juglandinus? Heer. Lesquereux, U. S. Geol. and Geog. Survey Terr. Bull., vol. 1, p. 388, 1875 [1876].

Undoubtedly an error for Phyllites juglandinus Heer, as no record can be found in Heer of the combination given by Lesquereux. This species was described by lesquereux from material collected near the mouth of White River, Wyo., but it was not afterward referred to and was probably merged with some other form, without record of its transfer. It is consequently dropped from the Green River flora.

Poacites laevis Al. Braun. Lesquereux, U. S. Geol. and Geog. Survey Terr. Ann. Rept. for 1871, p. 285, 1872. From Barrel Springs, Wyo.

Populus arctica Heer. Lesquereux, U. S. Geol. and Geog. Survey Terr. Ainn. Rept. for 1871, p. 300, 1872.

Not from the Green River formation. (See p. 137.)

Quercus lonchitis Unger. Lesquereux, U. S. Geol. and Geog. Survey Terr. Ann. Rept. for 1871, Suppl., p. 6,1872 .

This species was identified by Lesquereux in a collection of plants from Green River but was never figured and is now lost or merged with some other form; it has not since been identified with American material. It was not mentioned by Lesquereux in the "Tertiary flora."

$$
91045^{\circ}-23-10
$$

Rhamnus washakiensis Cockerell, Am. Mus. Nat. Hist. Bull., vol. 24, p. 74, 1908. [See below.]

Rhamnus intermedius Lesquereux, U. S. Geol. and Geog. Survey Terr. Ann. Rept. for 1871, p. 286, 1872; U. S. Geol. Survey Terr. Rept., vol. 7 (Tertiary flora), p. 282, pl. 54, fig. 3, 1878. [Homonym, Steudel and Hockstetter, 1827 ; replaced by $R$. washakiensis.]

This species rests on the single type specimen as figured by Lesquereux (U. S. N. M. No. 447). It is a rather nondescript oblong-elliptical leaf, about 6 centimeters long and a little less than 2 centimeters wide, with a strong midrib and about 16 pairs of close, parallel camptodrome secondaries. This species seems to approach most closely Rhamnus obovatus Lesquereux, ${ }^{31}$ a species of somewhat doubtful age but distinguished by its obovate instead of elliptical outline. More material might bring them closer together, but for the present they are best kept apart.

From Bridger Pass, Wyo., and hence excluded from the Green River flora. (See p. 138.)

Sequoia heerii Lesquereux, U. S. Geol. and Geog. Survey Terr. Ann. Rept. for 1s71, p. 290, 1872; U. S. Geol. Survey Terr. Rept., vol. 7 (Tertiary flora), p. 77, pl. 7, figs. 11-13, 1878 .

This species was described as coming from "Sage Creek, Mont.," a locality that has not since been found; hence, of course, its age is in doubt. Sequoia heerii has been subsequently identified in the upper part of the Clarno formation of Oregon, the Kenai formation of Alaska, and the Lance formation of Montana and Wyoming. It has not been reported from any Green River locality, and the manner in which it came to be even tentatively accredited to this formation is unknown.

Zanthoxylon juglandinum? A1. Braun. Lesquereux, U.S. Geol. Survey Terr. Rept., vol. 7 (Tertiary flora), p. 294, pl. 58, fig. 10, 1878.

This species comes from Washakie, Wyo., from beds whose position is not definitely settled as in the Green River formation; hence it is excluded.

\section{SYNONYMS AND CHANGES OF NAMES.}

Acer indivisum Lesquereux $=$ Acer lesquereuxii Knowlton.

Alnites inaequilateralis Lesquereux $=$ Planera inaequilateralis.

Alnus inaequilateralis Lesquereux $=$ Planera inaequilater alis.

Ampelopsis tertiaria Lesquereux $=$ Parthenocissus tertiaria. A pocynophyllum scudderi $\cdot$ Lesquereux $=$ Eucalyptus? americana.

Aralia macrophylla Newberry = Aralia wyomingensis.

Ceanothus cinnamomoides Lesquereux $=$ Zizyphus cinnamomoides.

Juglans denticulata Heer. Lesquereux = Juglans crossii. Juglans occidentalis Newberry(part) = Carpites newberryana. Juglans schimperi Lesquereux (part) = Juglans occidentalis. Lygodium neuropteroides Lesquereux = Lygodium kaulfussii Myrica nigricans Lesquereux $=$ Rhus nigricans.

Pecopteris sepulta Newberry=Osmunda? sepulta.

Planera variabilis Newberry (part)=Planera inaequilateralis.

al Lesquereux, Leo, U. S. Geol. Survey Terr. Rept., vol. 7 (Tertiary flora), p 281, pl. 54, figs. 1, 2, 1878. 
Quercus castaneoides Newherry=Quercus castaneopsis. Rhus acuminata Lesquereux=Rhus lesquereuxii Knowlton and Cockerell.

Salix angusta Al. Braun? Newberry=Eucalyptus? americana.

Salix media Heer. Lesquereux, U. S. Geol. and Geog. Survey Terr. Ann. Rept. for 1871, Suppl., p. 6, 1872= Salix sp.

Spheria myricae Lesquereux $=$ Sphaerites myricae.

Zizyphus longifolia Newberry (part) $=Z i z y p h u s$ cinnamomoides.

\section{THE ACCEPTED GREEN RIVER FLORA.}

The Green River flora as here described comprises the following species:

Caenomyces eucalyptae Knowlton, n. sp.

Caenomyces sapindicola Knowlton, D. sp.

Sphaerites myricae (Lesquereux) Meschinelli.

Acrostichum hésperium Newberry.

Lygodium kaulfussii Heer.

Lygodium dentoni Lesquereux.

Osmunda? sepulta (Newberry) Knowlton.

Danaea coloradensis Knowlton, n. sp.

Equisetum wyomingense Lesquereux.

Arundo reperta Lesquereux.

Cyperus chavannesi Heer.

Cyperacites haydenii (Lesquereux) Knowlton.

Geonomites haydenii (Newberry) Knowlton, n. comb.

Sabal powellii Newberry.

Flabellaria florissanti Lesquereux.

Pontederites hesperia Knowlton, n. sp.

Juncus sp. Lesquereux.

Musophyllum complicatum Lesquereux.

Salix linearis Knowlton, n. sp.

Salix longiacuminata Knowlton, n. sp.

Salix sp. Knowlton.

Salix sp. Knowlton.

Myrica salicina Unger.

Myrica minuta Knowlton, n. sp.

Myrica praedrymeja Knowlton, n. sp.

Myrica ludwigii Schimper.

Myrica sp. Knowlton.

Myrica sp. Knowlton.

Comptonia? anomata Knowlton, n. sp.

Juglans occidentalis Newberry.

Juglans schimperi Lesquereux.

Juglans crossii Knowlton.

Juglans alkalina Lesquereux.

Juglans winchesteri Knowlton, n. sp.

Quercus castaneopsis Lesquereux.

Planera inaequilateralis (Lesquereux) Knowlton, n. comb.

Ficus ungeri Lesquereux.

Ficus wyomingiana Lesquereux.

Ficus tenuinervis Lesquereux.

Lomatia? microphylla Lesquereux.

Oreodaphne viridiflumensis Knowlton, n. sp.

Pimelea spatulata Knowlton, n. sp.

Brasenia? antiqua Newberry.

Sedum? hesperium Knowlton, n. sp.

Amygdalus gracilis Lesquereux.
Dalbergia viridiflumensis Knowlton, n. sp.

Dalbergia retusa Knowilton, n. sp.

Leguminosites alternans Lesquereux.

Sophora coloradensis Knowlton, n. sp.

Mimosites coloradensis Knowlton, n. sp.

Ailanthus longe-petiolata Lesquereux.

Sapindus dentoni Lesquereux.

Sapindus obtusifolius Lesquereux.

Sapindus winchesteri Knowlton, n. sp.

Rhus lesquereuxii Knowlton and Cockerell.

Rhus variabilis (Newberry) Knowlton, n. comb.

Rhus nigricans (Lesquereux) Knowlton, $\mathbf{n}$. comb.

Rhus myricoides Knowlton, n. sp.

Euonymus flexifolius Lesquereux.

Acer lesquereuxii Knowlton.

Ilex? affinis Lesquereux.

Ilex maculata Lesquereux.

Ilex vyomingiana Lesquereux.

Zizyphus longifolia Newberry.

Zizyphus cinnamomoides (Lesquereux) Lesquereux.

Cissus parrottiaefolia Lesquereux.

Parthenocissus tertiaria (Lesquereux) Knowlton, n. comb.

Eucalyptus? americanus Lesquereux.

Aralia wyomingensis Knowlton and Cockerell.

Andromeda delicatula Lesquereux.

Sambucus? winchesteri Knowlton, $\mathrm{n}$. sp.

Achaenites cichorioides Knowlton, n. sp.

Antholithes improbus Lesquereux.

Carpolithus caryophylloides Knowlton, n. sp.

Carpites viburni Lesquereux.

Carpites newberryana Knowlton, n. sp.

Carpites inquirenda Knowlton, n. sp.

Phyllites winchesteri Knowlton, n. sp.

Phyllites fremonti Unger.

Phyllites coloradensis Knowlton, n. sp.

Nordenskiöldia borealis Heer.

\section{RELATION OF GREEN RIVER FLORA TO OTHER FLORAS.}

The position of the Green River formation above the Wasatch and below the Bridger fixed its stratigraphic horizon as approximately middle Eocene. Hayden when he named the formation made no attempt to fix its position definitely within the Tertiary, though by inference it fell within the Eocene. Cope, who first studied the Green River fish, did not venture more than to place it in the Eocene, because he regarded the available data as insufficient.

Lesquereux, ${ }^{32}$ who was the first to study the flora systematically, placed these beds. in his so-called fourth group, which comprised a "Lower Green River" and an' "Upper Green River." To the first of these he referred the

${ }^{32}$ Lesquereux, Leo, U. S. Geol. Survey Terr. Rept., vol. 7 (Tertiary flora), pp. 314-326, 1878. 
localities of Barrel Springs and Green River station (above fish beds), Wyo., and Sage Creek, Mont., and to the second the localities Florissant, Colo., Elko, Ner., and White River, Wyo.

In his final consideration of the Green River flora Lesquereux ${ }^{33}$ referred all these localities to tho Green River formation. For many years thereafter the Florissant lake beds were gencrally regarded as of Green River age, but subsequent study had placed them in the upper Miocene. The plants from Elko, Nev., have not been critically studied and revised in recent years, but they are probably slightly younger than the Green River.

As pointed out in another place, the localities of Barrel Springs, Fort Bridger, and Sage Creek have been removed from the Green River formation on the ground of uncertainty as to their position.

The only described middle Eocene flora with which the Green River flora may be compared is one from the so-called Congaree clay member of the McBean formation of the Claiborne group $^{34}$ of Georgia, described by Berry. ${ }^{35}$ This is a small florn of only 17 species, belonging to the following genera:

$\begin{array}{ll}\text { Acrostichum. } & \text { Pisonia. } \\ \text { Arundo. } & \text { Pistia. } \\ \text { Castanea. } & \text { Potamogeton. } \\ \text { Conocarpus. } & \text { Rhizophora. } \\ \text { Dodonaea. } & \text { Sapindus. } \\ \text { Ficus. } & \text { Sphaerites. } \\ \text { Malapoenna. } & \text { Terminalia. } \\ \text { Mimosites. } & \text { Thrinax. } \\ \text { Momisia. } & \end{array}$

The genera common to these two floras are Acrostichum. Mimosites. Arundo. Sapindus. Ficus. - Sphaerites.

Although none of the species are held to be common to the two, there are several that are evidently rather closely related. Thus Acrostichum georgianum is regarded by Berry as closely rolated to Acrostichum hesperium, "differing from it in being somewhat more slender in habit and in having straighter mid-

\footnotetext{
B U. S. Cicol. Survey Terr. Ropt., vol. S (Cretaceous and Tertiary floras), pp. 206-21s, 1883.

84 Later moro detailed, work revealed the fact that the deposits from which this florn was collocted aro of Jackson (upper Eocene) age and belong to tho Twiggs clny member of the Barnwell formation. See U.S. Geol. Survey Prof. Paper 120, pp. 41-77, 1919.

si Berry, E. W., The Upper Cretaceous and Eocene floras of South Carolinn and Georgia: U. S. Geol. Survey Prof. Paper S4, pp. 129-163, pls. 24-29, 1914.
}

veins and less elongate, finer areolation." Arundo pseudogoepperti, although a mere fragment, is regarded as very similar to and possibly identical with Arundo reperta, from the Green River. The only species of Ficus from the Georgia locality is Ficus claibornensis. It is an oblong-lanceolate leaf in which very little of the nervation is preserved and is quite different from either of the Green River species. Mimosites georgianus is certainly very similar to Mimosites coloradensis. Sapindus georgiana, according to Berry, suggests Sapindus angustifolius and $S$. stellariaefolius, both from the Florissant lake beds, but is not particularly close to any Green River species. The Georgia species of Sphaerites is similar to Sphaerites myricae from the Green River, but all fossil leafspot fungi are so similar that without the essential organs it is almost impossible to be certain of identifications.

The ecologic conditions under which this Georgia flora grew are discussed at length by Berry, who concludes that it was distinctly a coastal flora. The only forms to which this interpretation would not apply are Castanea, which is an upland type, and Pistia and Potamogeton, both of which are aquatic but not of coastal waters. All these could have been brought down from higher land by a stream. Concerning the others Berry says:

It is interesting to note that the remaining 12 species are all plants of a coastal habitat, their modern representatives flourishing in the tidal nipa swamps of the Orient, in mangrove swamps of the Orient and Occident, on the strand in beach jungle, or on the landward side of coastal sand dunes. Nearly all are represented by forms found in the existing flora on the Florida keys or along the shores of peninsular Florida, some, like Conocarpus, flourishing equally well on either muddy or sandy shores. Every species has representatives in the American Tropics.

The actual physical conditions Berry interprets as follows:

The present winter isotherm in the latitude of Grovetown [Ga.] is approximately $48^{\circ} \mathrm{F}$. None of the closely allied modern plants flourish north of the winter isotherm of $52^{\circ} \mathrm{F}$., and most of them do not occur north of the winter isotherm of $60^{\circ} \mathrm{F}$. None of the fossil forms except possibly the Potamogeton, the modern species of which range over a great many degrees of latitude, or the Castanea, which likewise has a wide range, would be expected to occur outside the latitudes where what Schimper calls the subtropical or warm temperate rain forests are found. We would expect the Claiborne climate, at least at low elevations along the coast and in proximity to the warm Eocene ocean current or currents, to have been uniformly humid, with an annual rainfall somewhere between 150 
and 200 centimeters. The actual rainfall could become a more or less negligible factor provided the water table approached close to the surface and the humidity was high and constant. The temperature would have to be uniform rather than hot, judging by modern standards, for any degree of winter cold would have been fatal. The climate need not have been tropical, nor would it be surprising if the Claiborne marine fauna failed to show tropical forms or reef corals, for the main factors which would limit the spread. of a flora like the one described would be uniform humidity, ample rainfall, and the absence of severe cold.

As might perhaps be expected, there is comparatively little identity of species between the Green River flora and early Eocene floras. At one time it was thought that there were several "Laramie" species that persisted into the Green River, but as shown in another place this belief was due to a small collection of obviously older forms for which the locality label had been either "lost or forgotten" and which were wrongly placed in the Green River.

According to the books the following species have been found common to the Green River and Fort Union formations:

Lygodium kaulfussii.

Juglans occidentalis.

- Quercus castanopsis.

Ficus ungeri.

Zizyphus cinnamomoides.

Andromeda delicatula.

The Fort Union flora, however, is much in need of critical revision, and it is probable that when this revision is made it will be found that some of these species were misidentified.

A single Green River species (Juglans crossii) has been reported in the Hanna formation of south-central Wyoming.

So far as known no species has been found common to the Green River flora and those of the Arapahoe, Denver, Raton, or Lance formations. One Green River species (Rhus affinis) has been reported from the Wilcox flora, but as Berry seriously questions the identification it can not be considered of much importance. Another Green River species (Ficus tenuinervis) has been identified in the lower part of the Clarno formation of Oregon, and another (Sapindus obtusifolius) in the Mascall (Miocene) formation of Oregon.

Although Lesquereux referred the Florissant lake beds to the Green River formation, the present revision has shown only one species (Amygdalus gracilis) as common to the two, and even this is open to some question.

\section{BIOLOGIC AND ECOLOGIC INTERPRETATION OF THE FLORA.}

Although the known flora of the Green River formation is still rather small, it includes a number of species that are of considerable biologic interest, and it is perhaps large enough to pərmit the drawing of at least tentative conclusions regarding the climatic conditions under which it flourished. As already pointed out, the great bulk of the formation is almost if not entirely unfossiliferous, but where any fossils occur in it they are generally very abundant. Thus, the so-called fish beds near the town of Green River have yielded many thousands of fish remains, as many as a hundred occurring on a small slab. In some layers - for example, in the layers just above the fish beds that contain the remains of palms - the plant remains are so matted together as to be individually indistinguishable. In southwestern Colorado the fossiliferous beds associated with the oil shale contain a profusion of plant and insect remains. As already stated, the study of the microscopic flora of the oil shale has been only partly completed, though sufficient to show the presence of bacteria, blue-green algae, Protococcus, Spirogyra, saprophytic fungi, mosses, ferns, and various types of seed-bearing plants. Some of these-perhaps all of them-but particularly the algae appear to have contributed to the accumulation of the oil in the shale. The algae are said to occur in great abundance and in a very perfect state of preservation, which would imply warm, rather shallow water. The great mass of amorphous undifferentiated vegetable matter in the oil shale indicates the action of bacteria in its reduction, which could hardly have taken place at depths much exceeding 20 feet. There is little evidence of the presence of moss plants, and the presence of spores must have been more or less fortuitous, for the mosses are plants so small and inconsequential that their spores could hardly have been much of a factor. The moss spores, the spores and sporangia of ferns, and the pollen of conifers must have been blown from adjacent land, and hence they give no indication of the depth of water in which they fell, nor of the temperature at which they grew, for it is not possible from available data to identify the types of plants that produced them. 
Turning now to the plants described in this papcr, we have at least three distinct forms of lenf-spot fungi, occurring on three types of leares-Myrica, Sapindus, and Eucalyptus. They have the same general appearance as many present-day leaf-spot fungi, but as their spore characters can not be made out their systematic position is subject to more or less question. Their requirements as to temperature are, of course, the same as that of the leaves on which they grew.

The ferns of the Green River formation are represented by five well-marked forms, some of which are of exceptional interest. Thus Dancea, although described from a fragment, is perfectly authenticated and so far as known is the first example of the living type to be found fossil. This genus comprises more than 25 living species, all strictly American, ranging from Cuba and southern Mexico to Brazil. They are terrestrial ferns of rather coarse habit, mostly 2 or 3 feet in height, growing in the shade in moist but well-drained tropical valleys and slopes, where the humidity is high and constant. The fossil form seems to be most clearly related to a species living on the island of Trinidad. Another rather striking Grecn River fern is Acrostichum, which has only three living species living in tropical tidal marshes in both old and new worlds. Climbing ferns of the genus Lygodium are represented by two nominal species in the Green River flora. The better known of these is identified as Lygodium kaulfussii, a form first described from specimens obtained in the Miocene of Thuringia but since widely known from collections in Europe and this country. The genus is a large one distributed mainly in the Tropics of both hemispheres, especially in coastal thickets. The remaining fern of the Green River flora is referred with question to the genus Osmunda.

The Equisetacae are represented by a single species of Equisetum that is poorly preserved and can not be of much value in the present connection.

With the exception of some pollen grains found in connection with the oil shale, no remains of conifers have been reported from the Green River formation.

The monocotyledons are better represented, though there is nothing very remarkable. There are the usual nondescript forms referred to Arundo, Cyperus, and Cyperacites, with a doubtful species of Juncus. The most impressive things are the palms, of which there are three nominal forms referred to different genera, though more complete material may change certain of these references. The species. of Geonomites and Sabal are very rare-in fact, are known only from the type material-but. the form referred to Flabellaria was very abundant at one locality and of large size. The leaves are so matted together that it is. impossible to get them out whole, but from many fragments studied the conviction grows that they must have been at least 4 or 5 feet in diameter. They had a long, rather slender, unarmed petiole.

The family Palmaceae, which comprises about 150 genera and 1,000 species, is essentially tropical and about equally distributed in the Eastern and Western hemispheres. At the present time the highest northern latitude it reaches in Europe is about $43^{\circ}$ and the highest southern latitude about $45^{\circ}$ in New Zealand. A few species extend their range into temperate regions, and some can even endure a temperature below $32^{\circ}$, but they are the exception.

Palms were introduced at least as early as middle Cretaceous time and during the early part of the Tertiary period had attained a wide range, occurring, for instance, in Grinnell Land, Spitzbergen $\left(80^{\circ}\right.$ north), in Greenland $\left(70^{\circ}\right)$, and in this country in Fort Union beds near the mouth of the Yellowstone, in the Puget group of Oregon and Washington, in the Kenai formation and other Eocene beds of Alaska, in the Denver and Raton formations of eastern Colorado and northeastern New Mexico, and in the Wilcox group of the Gulf region.

The two remaining monocotyledons are Musophyllum, based on large but fragmentary Musa-like leaves that may or may not be correctly referred to the Musaceae, and Pontederites, a newly described form that seems correctly interpreted as ancestral to the genus Pontederia. The Pontederiacene are a small American family of 5 genera and about 25 species living in warm and temperate regions. Pontederia is a variable aggregation, by some regarded as a single species; others recognize two species, one confined to North America and one to South America; but the latest view inclines to the recognition of seven or eight species. The North American species (Pon- 
tederia cordata Linné), the well-known pickerel weed, ranges from Nova Scotia to Minnesota and south to Florida and Texas. It grows in shallow fresh water. The leaf of the Green River form is certainly very similar to the living form.

The Salicales are represented in this flora by four forms of Salix, two of which are so fragmentary that they have not been given. specific names. The others are small, narrow, rather nondescript leaves that it is difficult to place satisfactorily. They appear to be willow leaves, but their affinities are more or less doubtful. Hence any conclusions as to their ecologic conditions must be more or less tentative.

The Myricales are represented by six forms of Myrica and a single anomalous and more or less doubtful leaf referred to Comptonia. The five species of Juglans representing the Juglandaceae are not particularly noteworthy, nor is the single species of Quercus which represents the Fagaceae. The single species of Planera, of the family Ulmaceae, was a very abundant plant in the Green River and seems to be very well authenticated. The three species of Ficus representing the Moraceae were not apparently very numerous, but one (Ficus ungeri) had large, fine leaves. The Proteaceae are questionably represented by a single species of Lomatia. The type specimens are lost, and the generic reference is more than doubtful. They might be leaflets of some mimosaceous or Sapinduslike form. To the Lauraceae are referred two genera (Oreodaphne and Pimelea), each with a single species and each based on a single specimen. The species of Pimelea is rather closely related to a species from the Florissant lake beds. The species of Brasenia, the sole representative of the Nymphaeaceae, seems well authenticated. Brasenia is a monotypic genus of aquatic perennial plants found in North America, Cuba, eastern and tropical Asia, western tropical Africa, and Australia. The Crassulaceae are doubtfully represented by a species referred with question to Sedum, but the resemblance may be only superficial. The single species of Amygdalus is involved in so much doubt that it is hardly worth while discussing its affinities. The Papilionaceae are represented by two species of Dalbergia and one each of Sophora and Leguminosites, and the Mimosaceae by one species of Mimosites.
These are all small, narrow leaves or leaflets and if correctly identified would seem to indicate a moist lowland habitat. The living species of these genera are very numerous and are widely scattered over the warmer parts of both hemispheres, being especially abundant on all tropical seashores. In the order Geraniales the Simarubaceae are represented by a very well authenticated species of Ailanthus, though the connection between the leaf and the winged fruit may be uncertain. Ailanthus is not now a native of the Western Hemisphere, the seven living species being confined to eastern Asia and the East Indies. They are at home in warm or subtropical temperatures.

The order Sapindales is represented by several families in the Green River flora. Of these the Anacardiaceae claim four species of Rhus. This family numbers about 60 genera and 450 living species of trees and shrubs and is present in the Tropics and subtropics of both hemispheres, being specially abundant in Malaysia. Rhus is the only genus of the family found outside the Tropics. The Celastraceae are represented by a single species of Euonymus. This genus has about 60 living species, widely distributed throughout the Northern Hemisphere, but is most abundant in the Asiatic Tropics and in Japan and China. The Sapindaceae, represented in the Green River by four species of Sapindus, constitute a very large family of over 100 genera and 1,000 species. They are mostly confined to tropical or subtropical regions. The Ilicaceae comprise only five genera and less than 200 species. The principal genus is Ilex, which is found in nearly all tropical and temperate regions and is represented in the Green River flora by three species. In the order Rhamnales the family Rhamnaceae includes about 50 genera and 500 living forms, mainly of the Tropics but a few, among them Rhamnus, extending into temperate regions. The only genus of this family represented in the Green River flora is Zizyphus, with two well-marked species. There are about 40 living species of Zizyphus, mainly shrubs or small trees, of warm temperate regions, with a few in the Tropics of both hemispheres. The Vitaceae comprise about a dozen genera and nearly 500 species, mainly tropical or subtropical, though a few, such as Vitis, extend into temperate regions. Cissus is the largest genus, including 250 species, all 
or nearly all tropical. Inasmuch as the Eucalyptus in the Green River flora is questioned there is perhaps no necessity for going further into the history of this family. The final family that needs to be considered is the Araliaceae, represented in the Green River flora by a very well-defined species of Aralia. This family embraces about 50 genera and over 500 specics, mainly tropical, but a considerable number extend inte temperate regions, especially in North America and eastern Asia.

The remaining forms are referred to the genera Antholithes, Carpolithus, Carpites, Phyllites, and Achaenites and need not be further discussed. The species of Achaenites is noteworthy in that it appears to indicate with much certainty the presence of the great group of Compositae.

From the foregoing account it appears that an overwhelming preponderance of the living forms in the families represented in the Green River flora are inhabitants of tropical or subtropical regions, many of them in both hemispheres, yet a considerable number include either genera or species that extend into temperate regions. There is some evidence to show that there were at least two ecologic provinces in Green River time. Thus, there are $a$ number of the genera that are of the lowland type, such as

$\begin{array}{ll}\text { Lygodium } & \text { Lomatia } \\ \text { Acrostichum } & \text { Pimelea } \\ \text { Danaea } & \text { Oreodaphne } \\ \text { Osmunda } & \text { Dalbergia } \\ \text { Arundo } & \text { Leguminosites } \\ \text { Cyperus } & \text { Sophora } \\ \text { Geonomites } & \text { Mimosites } \\ \text { Sabal } & \text { Ailanthus } \\ \text { Flabellaria } & \text { Sapindus } \\ \text { Pontederites } & \text { Eucalyptus? } \\ \text { Musophyllum } & \text { Aralia } \\ \text { Planera } & \text { Brasenia } \\ \text { Ficus } & \end{array}$

There are other genera that seem to find a more congenial home on higher ground. These are

$\begin{array}{ll}\text { Salix } & \text { Acer } ? \\ \text { Myrica } & \text { Zizyphus } \\ \text { Comptonia? } & \text { Ilex } \\ \text { Juglans } & \text { Andromeda } \\ \text { Quercus } & \text { Sảmbucus? } \\ \text { Rhus } & \end{array}$

This division is not a very satisfactory one, and the assignments may not all be valid, but there were evidently some differences in the conditions under which the several elements were found. The physical setting can be pictured somewhat as follows: About the shores of the lake were certain flat, low-lying areas, some of them probably swampy, others sandy, whereon grew the palms, figs, Lomatia, Oreodaphne, hackberries, the several papilionaceous trees and shrubs, the ferns, grass, sedge, etc., and in the water the pickerel weed, $\mathrm{Bra}$ senia, algae, etc. On the adjacent somewhat higher land might have been the willows, waxberries, sweet fern, walnuts, oaks, sumacs, maples(?); hollies, etc.

The conditions of temperature and moisture under which the Green River flora flourished are somewhat difficult of interpretation, as there is seemingly more or less conflict between the elements of the flora. The nearest living relatives of certain of the genera that are believed to have inhabited the lowlands, such as Lygodium, Acrostichum, Danaea," Geonomites, Sabal, Flabellaria, Musophyllum, Planera, Ficus, Lomatia, Pimelea, Oreodaphne, the leguminous genera, and possibly Sapindus, Eucalyptus, and Aralia, are found mainly in subtropical or tropical areas. The palms, at least one species of which existed in abundance, could hardly have lived where the temperature fell below $42^{\circ} \mathrm{F}$. and probably not ever where it was considerably higher than this. Certain of the other genera, such as Osmunda, Arundo, Cyperus, Aralia, and Brasenia, might have withstood frost, for although the speeies of these genera are largely tropical or subtropical they include species that extend into temperate regions. All things considered it seems probable that this lowland flora must have required a temperature that was at least warm temperate and possibly bordered on subtropical.

The upland flora, including such genera as Salix, Myrica, Juglans, Quercus, Rhus, Acer, and Ilex, could well have withstood some degree of frost, but on the other hand all these genera contain species that could find a congenial habitat in a warm temperate region. It is doubtful if any of them had to withstand cutting frosts.

The inferences to be drawn regarding the climatic requirements of the insect fauna are in substantial accord with those suggested by the flora. 'I am informed by Prof. T.D. A. Cockerell that the known insect fauna. of the Green River 
shales now numbers 296 species. Concerning this fauna he says:

The really dominant and characteristic insects of the Green River shales, if any such can be specially designated, are the Fulgoridae, which have a most distinctly tropical aspect and in many cases closely resemble living tropical genera. The other groups of insects do not appear tropical, though one of the dragon-fly genera is closely related to a neotropical one. The dragon flies, caddis flies, etc., indicate that there was plenty of fresh water, but it does not follow that these breed in the lake.

Alexander, ${ }^{36}$ the well-known authority on the crane flies, has the following to say regarding the geologic history of this group:

The North American Eocene and Miocene, as represented by the White River and Green River beds and the Florissant shales, respectively, give evidence of having had a northern [tipulid] fauna, especially the Eocene. This is well shown by the great development of the Cylindrotominae, which in the White River basin almost dominated the crane-fly fauna during the Eocene. It seems probable, moreover, that the group was. forced into colder regions of the globe during the Oligocene, when the tropical element reached far north. No group of crane flies that can be considered tropical has yet been found in the Florissant beds. On the other hand, the European Oligocene, as shown by the Garnet Bay beds and the lower Oligocene Baltic amber, has a considerable tropical element apparent.

From these statements it appears that the evidence of the insects is practically the same as that of the plants, namely, they comprise a certain element that indicates tropical surroundings, and another, or others; that indicate cooler, perhaps temperate conditions.

\section{THE FLORA.}

Phylum ThaLLOPHYTA.

Class FUNGI.

Series ASCOMYCETES.

Order LABOULBILIALES.

Family LABOULBILIACEAE.

Genus CAENOMYCES Berry.

Caenomyces eucalyptae Knowlton, n. sp.

Plate XXXVI, figures $8,9$.

I follow Berry in adopting Caenomyces as the generic name of this leaf-spot fungus. Berry's description ${ }^{37}$ is as follows:

The presence of spots of different shapes on the leaves of fossil plants is exceedingly common, and a very large

${ }^{36}$ Alexander, C. P., The crane flies of New York, pt. 2: Cornell Univ. $\Lambda$ gr. Exper. Sta. Mem. 38, p. 764, 1920.

${ }_{37}$ Berry, E. W., U. S. Geol. Survey Prof. Paper 91, p. 162, 1916. number of so-called species of fossil leaf-spot fungi have been described by Ettingshausen, Heer, Saporta, and others. * * * The identification of these fossil forms obviously rests on a very insecure foundation, especially when it is recalled that scale insects and a great variety of insect galls would resemble epiphyllous fungi when preserved on impressions of fossil leaves. Nevertheless, large numbers of undoubted fungi are preserved in this manner, and it is the legitimate duty of the paleobotanist to describe and illustrate them. In order to accomplish this work without unwarranted definiteness in generic classification, I propose the term Caenomyces as a form genus for leaf-spot fungi of Cenozoic age whose precise botanic affinities can not be determined.

One of the leaves of Eucalyptus? americanus from western Colorado shows about twenty very well preserved leaf spots, apparently caused by a fungus. They are circular, are about 1.5 or 2 millimeters in diameter, and have an outer black ring perhaps 0.05 millimeter in width under which the substance of the leaf has shrunken. The center of the ring is elevated, and on the top of this in the center are several black pustules evidently where the mature spores are being or about to be discharged.

The disposition and general appearance of these leaf spots is shown in figure 8 natural size, and one of the most perfect spots in figure 9 , which is enlarged six times.

Occurrence: Green River formation, on leaf of Eucalyptus? americanus Lesquereux, Cathedral Bluff, south of Little Tommies Draw, about 20 miles west of Rio Blanco post office, Rio Blanco County, Colo., collected by D. E. Winchester, 1917.

Caenomyces sapindicola Knowlton, n. sp.

Plate XXXVI, figure 10.

The type leaflet of Sapindus winchesteri (Pl. XXXVIII, fig. 1) shows the presence of several leaf-spot fungi. The spots are circular, 1.5 to 2 millimeters in diameter, and some show an inner ring with a slightly raised central portion. It is evidently not mature and is so obscure that it is hardly worthy of mention except to call attention to the presence of fungi of this general type on Sapindus.

Occurrence: Green River formation, on type leaflet of Sapindus winchesteri Knowlton, oil shale, Smith ranch, on Greasewood Creek, about 40 miles southwest of Meeker, Colo., collected by D. E. Winchester, 1917. 


\section{Order SPHAERIALES.}

Family SPHAERIACEAE.

Sphaerites myricae (Lesquereux) Meschinelli.

Sphaerites myricae (Lesquereux) Meschinelli, Sylloge fungorum fossilium, p. 23, 1892.

Spheria myricae Lesquereux, U. S. Geol. and Geog. Survey Terr. Ann. Rept. for 1872, p. 390, 1873; U. S. Geol. Survey. Terr. Rept., vol. 7 (Tertiary flora), p. 34, pl. 1., fig. 4, 1878.

This species was first described from specimens collected at Black Buttes, Wyo., where it was found on leaves of Myrica torreyi Lesquereux. It was later found at Green River, Wyo., on leaves of Myrica nigricans (now Rhus nigricans).

It was described by Lesquereux as follows: "Perithecia punctiform, minute, either sparse or in a circle, forming round spots" about a millimeter in diameter, "the center of which is clear and of a light color." It may be the same as Caenomyces eucalyptae, described on page 148, but as it can not be certainly identified with that species it is permitted to stand as left by Lesquereux.

Occurrence: Green River formation, Green River, Wyo., on leaves of Myrica nigricans Lesquereux. "Post-Laramie" (type), Black Buttes, Wyo.

\section{Phylum PTERIDOPHYTA.}

Class FILICES.

Order FILICALES.

Family POLYPODIACEAE.

Acrostichum hesperium Newberry.

Acrostichum hesperium Newberry, U. S. Nat. Mus. Proc., vol. 5, p. 503, 1882 [1883]; U. S. Geol. Survey Mon. 35 , p. 6, pl. $6 \mathrm{l}$, figs. $2-5,189 \mathrm{~s}$.

The illustrated types of this splendid fern are all preserved in the United States National Muscum (Nos. 7013-7016).

Occurrence: Green River formation, Green River, Wyo., collected by C. A. White.

\section{Family SCHIZAEACEAE.}

Lygodium kaulfussii Heer.

Plate XXXVI, figure 7.

Lygodium kaulfussii Heer, Beiträge zur nähern Kenntniss der sachsisch-thuringischen Braunkohlenflora, $p$. 400 , pl. 8, fig. 21; pl. 9, fig. 1, 1861.

Newberry, U. S. Geol. Survey Mon. 35, p. 1, pl. 62, figs. 1-4, 1898.

Knowlton, U. S. Geol. Survey Mon. 32, pl. 2, p. 672, pl. 80, figs. 1, 2, 1898 .
Lygodium neuropteroides Lesquereux, U. S. Geol, and Geog. Survey Terr. Ann. Rept. for 1870, p. 384, 1871; U. S. Geol. Survey Terr. Rept., vol. 7 (Tertiary flora), p. 61, pl. 5, figs. 4-7; pl. 6, fig. 1, 1878 .

The genus Lygodium is so characteristic in shape and nervation that with reasonably adequate material it is easily and certainly identified. Its presence in the Green River formation was first made known by Lesquereux, who described and figured Lygodium neuropteroides. Subsequently a very large number of very well preserved examples were procured from the Green River formation by J. S. Newberry. These were identified as Lesquereux's species, and, as Newberry said, "They illustrate the growth of the plant far better than those he figured. Coming all from the same locality, indeed thickly impacted together and having the same nervation, they unquestionably represent a single species."

Before Newberry's account was published, however, Gardner ${ }^{38}$ published an account of British Eocene ferns in which he pointed out the identity of Lesquereux's Lygodium neuropteroides with Heer's Lygodium kaulfussii, and this view was accepted by both Lesquereux and Newberry. Lesquereux was shown specimens of the true Lygodium kaulfussii and pronounced them "positively identical" with his species from the Green River formation. If there is any difference it is that the American specimens are somewhat more robust and have slightly broader and less undulate lobes, but the differences are not great.

Newberry ${ }^{39}$ also reported .Lygodium leaves from Fletts Creek and Carbonado, Wash. [Puget group], which, he said,

offer no characters by which they can be distinguished from those found in the Green River group, and it seems to me probable that we have in all these specimens relics of one of those widespread and long-lived species which occur at different geological horizons among both animal and plant remains.

Newberry's conclusion has since been verified by the finding of specimens identified ${ }^{40}$ as Lygodium kaulfussii on Elk Creek, in the Yellowstone National Park, in beds believed to be of Fort Union age, and also on the bank

88 Gardner, J. S., British Eocene flora, pt. 1, Filices, p. 47, pls. 7, 1884. ${ }^{89}$ Newberry, J. S., U. S. Geol. Survey Mon. 35, p. 3, 1898 .

${ }^{40}$ Knowlton, F. H., U. S. Geol. Survey Mon. 32, pt. 2, p. 672, pl. 80, figs. $1-3,1898$. 
of Lamar River between Cache and Calfee creeks, in beds of Miocene age. The specimens from Elk Creek are as large as the largest specimens from Green River figured by Newberry, and the specimens from Lamar River are about the size of the smaller ones figured by Newberry.

The collections from the Green River shales made by $\mathrm{D}$. E. Winchester in northwestern Colorado include a number of specimens of Lygodium kaulfussii that are undoubtedly identical with certain of the smaller ones figured by Newberry. Only one of these has been figured here.

Occurrence: Green River formation, Green River, Wyo., collected by C. A. White about 1879 ?; Bàrrel Springs, Wyo., type locality for Lygodium neuropteroides, collected by $\mathrm{F}$. V. Hayden, 1870; spring on Little Duck Creek, Rio Blanco County, Colo., and sec. 33, T. 4 S., R. 100 W., Colo., collected by D. E. Winchester, 1917.

\section{Lygodium dentoni Lesquereux.}

Lygodium dentoni Lesquereux, U. S. Geol. and Geog. Survey Terr. Bull., vol. 1, p. 383, 1875 [1876]; U. S. Geol. Survey Terr. Rept., vol. 7 (Tertiary flora), p. 63 , pl. 65 , figs. $12,13,1878$.

The status of this species is unsatisfactory. The type specimens are now lost, and our knowledge of it depends on the two fragments figured by Lesquereux. It appears to be a Lygodium, but it is so fragmentary that there is little use in attempting comparison with other species.

Occurrence: Green River formation(?), mouth of White River, Wyo.

\section{Family OSMUNDACEAE?}

Osmunda? sepulta (Newberry) Knowlton, n. comb.

Pecopteris (Phegopteris) sepulta Newberry, U. S. Nat. Mus. Proc., vol. 5, p. 503, 1883.

Pecopteris (Cheilanthes) sepulta Newberry, U. S. Geol. Survey Mon. 35, p. 12, pl. 62, figs. 5, 5a, 6, 1898.

Described as follows by Newberry:

Frond small, delicate, pinnate; lower pinnae straight, broadly linear in outline, rounded above, attached to the rachis by the whole breadth of base; margins strongly lobed by the confluent pinnules, 1 centimeter wide by 5 centimeters long; upper pinnules crowded, conical in outline, gently curved upward, with waved or lobate margins; pinnules united by one-third of their length, oblong, obtuse; basal ones on lower side round, on the upper side flabellate, both attached by all their lower margin to the rachis of the frond; nervation strong and wavy, consisting of one many-branched nerve stem in each pinnule, each branch once or twice forked; fructification unknown.

The two figured types of this species are in the United States National Museum (Nos. 7042, 7043). Of course Newberry recognized the fact that this fern should properly be referred to a modern genus, and pending the determination of what that genus should be he referred it temporarily to Pecopteris. At different times in considering this species Newberry employed Phegopteris and Cheilanthes as subgenera, and in his final discussion of its possible affinities he mentioned Gleichenia, but in the absence of fructification all were dismissed as improbable.

I have ventured to transfer this form tentatively to the genus Osmunda, as it seems to agree in a number of respects with certain fossil species that have been so referred. We still lack the fruit, and in its absence any reference is more or less open to uncertainty, but it is impossible to permit this form to remain under Pecopteris.

Occurrence: Green River formation, Green River, Wyo., collected by C. A. White.

\section{Order MARATTIALES.}

Family MaRATTIACEAE.

Danaea coloradensis Knowlton, n. sp. Plate XXXVI, figure 4.

This species is based on the impression of the under side of the terminal portion of a pinnule in fruit. Its length is about 13 millimeters and its width 4 millimeters, and as it is broken squarely across the base there is strong presumptive evidence that it was considerably longer when living. It was evidently thick and fleshy and had a very strong midrib, and the synangia are closely packed on either side, though not quite reaching the margin, where there is a distinct fleshy rim. As the apical pores of the sporangia do not show it is presumed that the fruit was not quite mature.

Among living species it appears to approach most closely in size and general appearance Danaea fendleri Underwood, of the Island of Trinidad, but it differs specifically in having the synangia relatively very broad and short.

The genus Danaea is represented by about 25 species confined to tropical America from Cuba and southern Mexico to Brazil. They are terrestrial ferns of rather coarse habit and 
are dimorphous, with simply pinnate fronds (simple in one species) with linear segments bearing parallel linear synangia, each composed of two rows of closely packed sporangia opening by a terminal pore. These fruiting characters are so strongly marked that there is little difficulty in recognizing a fossil form that is adequately preserved.

The species here described is not only the first North American fossil form to be made known, but it. is apparently the only fossil species thus far described from any part of the world that is reasonably authenticated. Thus, Racyborski ${ }^{41}$ described a species from the Jurassic of Krakow, Poland, under the name Danaea microphylla, but it has the outline, size, and nervation of a Taeniopteris (cf. T. parvula Heer). The fruit as figured may entitle it to be included in the Marattiaceae, but it is so unlike the fruit of Danaea that it can hardly be placed in this genus. Several Carboniferous species were described originally under the name Danaea, but they have later and more correctly been referred to Danaeites, Danaeopsis, etc.

The Marattiacene are supposed to be of very ancient lineage - in fact, up to a decade or so ago it was commonly believed that they formed a dominant element in the forests of the coal age, but with the discovery of the "ever-widening territory of the pteridosperms" they have been brought more or less in question. Arber says:

The evidence, formerly regarded as beyond suspicion. that the eusporangiate ferns formed a dominant feature of the vegetation of the Paleozoic period has been undermined, more especially by the remarkable discovery of the male organs of Lyginodendron by Mr. Kidston. At best we can only now regard them as a subsidiary group in the epoch of the past history of the vegetable kingdom.

Even the reproductive organs are no longer decisive unless the seeds are found, for, as Seward says:

We can not in most cases be certain whether the small sporangium-like bodies on fertile pinnules are true fern sporangia or the micro-sporangia of a heterosporous pteridosperm. What is usually called exannulate fern sporangium * * * has no distinguishing features which can be used as a decisive test. The microsporophylls of the Mesozoic Bennettitales produced their spores in sporangical compartments grouped in synangia like those of recent Marattiaceae.

The Pteridospermae so far as known disappeared with the end of the Paleozoic era, and

1 Racyborski, Maryjan, Pamietnik Akad. Umiejetn., vol. 18, p. 155, pl. 6, figs. 1-6, 1894. the marattiaceous type was carried on to the present by sparsely represented forms, such as Marratiopsis, Danaeopsis, Bernouillia, and perhaps Nathorstia of the Lower Cretaceous of Greenland, and a supposed Tertiary species of Marattia ( $M$. hookeri Gardner and Ettinghausen) from the Eocene of the Isle of Wight. It is therefore of interest to be able to add another step in the recorded progress from the Paleozoic to the present in the shape of an undoubted Danaea from the middle Eocene of America.

This specimen has been submitted to Mr. Wm. R. Maxon, of the United States National Herbarium, and he pronounces it unqualifiedly as referable to Danaea.

Occurrence: Green River formation, oil shale, Rio Blanco County, about 40 miles southwest of Meeker, Colo., collected by D. E. Winchester, 1917.

\section{Order EQUISETALES}

Family EQUISETACEAE

Equisetum wyomingense Lesquereux.

Equisetum wyomingense Lesquereux, U. S. Geol. and Geog. Survey Terr. Ann. Rept. for 1873, p. 409, 1874; U. S. Geol. Survey Terr. Rept., vol. 7 (Tertiary flora), p. 69, pl. 6, figs. 8-11, 1878.

Newberry, U. S. Geol. Survey Mon. 35, p. 15, pl. 65, fig. 8,1898 .

Lesquereux's description and figures of this species are rather vague and unsatisfactory. He states that the specimens are preserved on a large slab of very hard white shale, which is "covered with a profusion of fragments of the same plants, rootlets, rhizomes, stems crushed, pressed together, and rarely separated distinctly enough to clearly show their characters." He further states that the stems and rhizomes are equally and regularly striate, and the "sheaths are dentate on the borders, and short." The stems and rhizomes are of equal size, about half a centimeter in width.

Newberry figures a single stem from Green River under Lesquereux's name but makes no comment or comparison in the text. The figured specimen is a fragment of stem about 6 centimeters long and 0.5 centimeter wide and shows three sheaths with some 10 or 12 slender, sharp-pointed teeth. It is difficult to determine whether this is really the same as Lesquereux's Equisetum wyomingense, but it perhaps is best left as at present pending additional information. 
Occurrence: Green River formation, type found 3 miles east of Green River, Wyo.; Newberry's specimen from Green River.

Phylum SPERMATOPHYTA. Class ANGIOSPERMAE. Subclass MONOCOTYLEDONES. Order GRAMINALES.

Arundo reperta Lesquereux.

Arundo reperta Lesquereux, U. S. Geol. and Geog. Survey Terr. Bull., vol. 1, p. 384, 1875 [1876]; idem, Ann. Rept. for 1874, p. 311, 1876; U. S. Geol. Survey Terr. Rept., vol. 7 (Tertiary flora), p. 87, pl. 8, figs. $6-8,1878$.

This species, it seems to me, is very unsatisfactory, and the propriety of recognizing it is doubtful. It was described by Lesquereux as follows:

Stem thick, distinctly articulate; surface striate, marked with round obtuse knots, either placed-at the articulation or here and there scattered upon the stem; fruiting panicle crushed, oval-oblong, bearing ovate-lanceolate seeds, and pallets mixed with a coating of hairs.

All the figured types of this form are in the United States National Museum (Nos. 96, 119) and are before me. The stem is striate, as described, and was apparently circular in cross section before it was entombed but is now much flattened. It may have been a hollow reedlike stem, but it also suggests a decorticated branch of a tree. The so-called articulation is only a check or crack filled with mud and thus simulating a joint. The "knots" are difficult to interpret. There are two in line with the axis of the stem, and they are about 7 millimeters in diameter and some 3 millimeters high. They seem to rest on and hardly to be a part of the organic structure of the stem-in fact, they have much the appearance of being little mud balls that happened to lodge on the specimen.

The specimen described as an underground stem is apparently correctly placed-that is to say, the scars, which occur at fairly regular intervals, are clearly the scars of roots or rootlets. The type specimen is fully 18 centimeters long and shows little diminution in size.

The cluster of seeds, although seemingly quite complete as depicted in the drawing, are really so obscure and fragmentary as to be almost impossible of accurate determination. A few of the specimens have somewhat the appearance of the palets of a large grass, but I should hesitate to say positively that this is their nature.
There is also little basis for supposing that these several organs are really parts of one species of plant. They are, indeed, associated on the same piece of matrix, but there is no positive evidence of former organic union.

With the above strictures this form is left as last revised by Lesquereux, but with the frank admission that it is seemingly of very little biologic or stratigraphic value.

Occurrence: Green River formation, Green River, Wyo., above the fish beds.

\section{Family CYPERACEAE.}

Cyperus chavannesi Heer.

Cyperus chavannesi Herr, Flora tertiaria Helvetiae, vol. 1, p. 72, pl. 22, fig. 7; pl. 28, fig. 1, 1855.

Cyperus "chavanensis"? Heer. Lesquereux, U. S. Geol. and Geog. Survey Terr. Ann. Rept. for 1871, p. 291, 1872; U. S. Geol. Survey Terr. Rept., vol. 7 (Tertiary flora), p. 92, pl. 9, figs. 1, 2, 1878.

Lesquereux first mentioned this species as coming from Evanston, Wyo., " below the coal." Later, in the "Tertiary flora," it was given as coming from Green River, Wyo., and one of the figured specimens (pl. 9, fig. 1, U. S. Nat. Mus. No. 122) is in the United States National Museum. It is a mere fragment from the middle area of a large leaf and must be considered as doubtfully the same as the European type.

Occurrence: Green River formation, Green River, Wyo.

Cyperacites haydenii (Lesquereux) Knowlton.

Cyperacites haydenii (Lesquereux) Knowlton, U. S. Geol. Survey Bull. 152, p. 83, 1898.

Cyperites haydenii Lesquereux, U. S. Geol. Survey Terr. Rept., vol. 8 (Cretaceous and Tertiary floras), p. 140, pl. 23, figs. 1-3a, 1883.

The types of this species are preserved in the United States National Museum (Nos. 1565, 1569). It has been well described and figured by Lesquereux.

Occurrence: Green River formation, Uinta (formerly incorrectly given as Randolph) County, Wyo.

\section{Order ARECALES.}

Family ARECACEAE.

Geonomites haydenii (Newberry) Knowlton, n. comb.

Mánicaria haydenii Newbierry, U. S. Nat. Mus. Proc., vol. 5, p. 504, 1883; U. S. Geol. Survey Mon. 35, p. 31, pl. 64, fig. 3, 1898 . 
The following description was given by Newberry:

Frond large, leaves pinnately plicated, folds 1.5 centimeters in width above, slightly narrowed below; flat or gently arched, smooth, springing from the midrib at an angle of $25^{\circ}, 30^{\circ}$ below; folds attached to the midrib [rachis] obliquely by the entire width, and to each other by their entire length (?); nervation fine, uniform (?), parallel.

This Green River palm is very imperfectly known-in fact, the only specimen I have seen is the type as figured by Newberry (U.S. Nat. Mus. No. 7016). It is impossible to determine the position of this fragment in relation to the whole leaf, though from its size as compared with leaves from other localities believed to be congeneric with it, it was probably from the middle or lower portion.

Newberry was frank to state in the discussion of his Manicaria haydenii that it certainly belongs to the same genus as Lesquereux's Geonomites tenuirachis, ${ }^{42}$ and with this statement I am inclined to agree. I have figure $^{43}$ a much larger and far more nearly complete specimen of Geonomites tenuirachis, from the Raton formation, than Lesquereux's type, and from this it is fairly clear that the type specimen is a small segment from the upper portion of the leaf. I can see no charncters by which this Green River palm can be excluded from Geonomites, and consequently I have transferred it to this genus. It seems closer to Geonomites tenuirachis than to Manicaria formosa Heer, ${ }^{44}$ from the Swiss Miocene, with which Newberry compared it-in fact, it would be difficult with the scant material available to separate them specifically. However, as they are so imperfectly known, and as there is so much difference in their stratigraphic position, it is perhaps best to regard Geonomites haydenii as distinct until its status can be settled with better material.

Occurrence: Green River formation, Green River, Wyo.

Sabal powellii Newberry.

Sabal powellii Newberry, U. S. Nat. Mus. Proc., vol. 5, p. 504, 1882 [1883]; U. S. Geol. Survey Mon. 35, p. 30 , pl. 63, fig. 6 ; pl. 64, figs. 1, la, 1898 .

\footnotetext{
42 Lesquereux, Leo, U. S. Geol. Survey Terr. Rept., vol. 7 (Tertiary (lon), p. 117, pl. 11, fig. 1, 1878 .

4s Knowlton, F. F., U. S. Geol. Survey Prof. Paper 101, p. 291, pl. 62, 1917.

"Hoor, Oswald, Flora tortiaria Helvetiac, vol. 1, pl. 3s, 1856.
}

The following is Newberry's description:

Leaves of medium size, 4 or 5 feet in diameter, petiole smooth, unarmed, terminating above in an angular or rounded area from which the folds diverge beneath, concavely narrowing to form a spike 3 or 4 inches in length; rays about 50 , radiating from the end of the petiole, perhaps 60 in the entire leaf, compressed to acute wedges where they issue from the petiole; strongly angled and attaining a maximum width of about 1 inch; nerves fine, about 12 stronger ones on each side of the keel, with finer intermediate ones too obscure for enumeration.

Although the remains of palms are abundant in a number of Tertiary formations they are unusually difficult of satisfactory diagnosis. Their large size, the fragmentary state in which they are usually collected, and the lack of good diagnostic characters in the leaves make their identification more or less uncertain. The allocation of Sabal powellii is a case in point. In his discussion Newberry points out that it bears considerable resemblance to Sabal? eocenica (Lesquereux) Knowlton (formerly Flabellaria eocenica) as figured by Lesquereux ${ }^{45}$ differing in having a larger number of folds and a longer point of support on the under side of the leaf. Newberry also compares his species to Sabalites grayanus (Lesquereux) Lesquereux, but this has been since divided. The type locality was the Wilcox group of the Gulf region, and the name Sabalites grayanus is retained for this form, which has also been reported from the Laramie, Lance, and Raton formations. The large leaves, which are evidently the ones Newberry had in mind, mainly from the Montana group, have been separated under the name Sabal? montana Knowlton..$^{46}$ Although this species is still imperfectly known it seems to be distinguishable by its very large size, being perhaps the largest palm in the Rocky Mountain region, and by the greater number of folds (about 90).

Sabal grandifolia Newberry ${ }^{47}$ is another large-leaved palm that may be compared with Sabal powellii. It has nearly twice the number of folds.

Occurrence: Green River formation, Green River, Wyo.

${ }^{45}$ Lesquereux, Leo, U. S. Geol: Survey Terr. Rept., vol. 7 (Tertiary flora), pl. 13, figs. 1-3, 1878.

${ }^{46}$ Knowlton, F. H., U. S. Géol. Survey Prof. Paper. 101, p. 253, pl. 32, fig. $3,1918$.

${ }^{47}$ Newberry, J. S., U. S. Geol. Survey Mon. 35, p. 28, pl. 25; pl. 63, fig. 5 (not pl. 64, figs. 2, 2a), 1898. 
Flabellaria florissanti Lesquereux.

Flabellaria florissanti Lesquereux, U. S. Geol. Survey Terr. Rept., vol. 8 (Cretaceous and Tertiary floras), p. 144, pl. 24, figs. 1-2a, 1883.

The following is Lesquereux's characterization of this species:

Fronds large; rays diverging all around from the top of the long, nearly flat, unkeeled rachis; rays large, very numerous, acutely keeled; primary nerves distinct; close intermediate veinlets three or four.

Lesquereux did not give any actual dimensions, and the two figured types are all of the original material now known to be extant. Subsequently, however, L. F. Ward collected extensively at Green River station, at a point known locally as Bell's fish cliff, and procured some very large palm leaves that in all reasonable probability are the same as Lesquereux's species. It must have been at least 5 feet in diameter and has the same rather slender petiole as the figured type. Our specimen includes the outer edge of the leaf and shows that the rays are split apart for a distance of at least 20 centimeters.

Occurence: Green River formation [types], Uinta (formerly incorrectly called Randolph) County, Wyo.; Bell's fish cliff, Green River, Wyo., collected by L. F. Ward.

\section{Order XYRIDALES}

\section{Family PONTEDERIACEAE.}

\section{Genus PONTEDERITES Knowlton; n. gen.}

Pontederites hesperia Knowlton, n. sp.

Plate XXXVI, figure 6.

Although it is perhaps more or less hazardous to base a new genus on a single fragment, the present one seems so distinct that it merits at least temporary characterization until more complete material can be procured. It is the well-preserved upper part of a leaf that was presumably broadly ovate below and rather abruptly narrowed above into a deltoidlanceolate apical portion, 1 centimeter wide at the base, 2 centimeters long, and acute at the tip. The length of the part preserved is 8 centimeters and the width about 5 centimeters. The total length was presumably not less than 12 or 15 centimeters. It is unfortunate that the shape of the base is unknown. The nervation consists of numerous close, mainly parallel veins that arise from a slightly enlarged midvein which is reduced in the apical portion to the same size as the other veins. Those that can be seen arise from the midvein at a very acute angle-about $80^{\circ}$-but in the lower portion they are closer together and apparently arise at a less acute angle. The veins spread in the broad portion of the blade, then approach again in the upper part, where some of them terminate, only about a dozen passing into the reduced apical portion. A few. intermediate veins come up from the lower portion of the blade and die out above, but so far as can be ascertained there are no fine intermediate veinlets, or at least but faint traces of them. There are, however, numerous cross veinlets, mainly at right angles to the veins.

This leaf appears to resemble most closely the leaves of Pontederia cordata Linne, the well-known pickerel weed, which grows on the borders of ponds and streams from Nova Scotia to Minnesota and south to Florida and Texas. In the living plant the thick, petioled leaves are ovate, cordate-sagittate, and 5 to 20 centimeters long, with the basal and apical lobes rounded. It has a fairly distinct midrib in the lower portion, but this disappears above. It is, of course, much to be regretted that the basal portions of these leaves can not be compared, but such a comparison must await more nearly perfect specimens. So far as the available material goes I can see no essential difference between the fossil and the living forms, and the name given to the genus brings out this point.

The fossil has some resemblance to certain forms that have been referred to Canna, such as Canna eocenica Berry, ${ }^{48}$ from the Wilcox group of the Gulf region, but this is more nearly lanceolate, with no contraction into.the reduced apical portion. The midrib is also stronger in Canna eocenica.

The only other Green River monocotyledon with which it could possibly be compared is. Musophyllum complicatum Lesquereux, ${ }^{49}$ but this is of a totally different character.

Under the name Zingiberites dubius Lesquereux ${ }^{50}$ described a fragment from the Denver formation of Colorado, but this is too much broken to give any reliable conception of its.

48 Berry, E. W., U. S. Geol. Survey Prof. Paper 91, p. 181, pl. 15, figs. $7,8,1916$.

9 Lesquereux, Leo, U. S. Geol. Survey Terr. Rept., vol. 7 (Tertiary flora), p. 96, pl. 15, figs. 1-6, 1878 .

so Idem, pl. 16, fig. 1. 
form and size, and hence it can not be compared with the present form.

Occurrence: Green River formation, Greasewood Creek, Rio Blanco County, 40 miles west of Mceker, Colo., collected by D. E. Winchester, 1917.

\section{Order LILIALES.}

Family JUNCACEAE.

Juncus sp. Lesquereux.

Juncus sp. Lesquereux, U. S. Geol. and Geog. Survey Terr. Ann. Rept. for 1871, Suppl., p. 6, 1872.

Lesquereux says:

Fragments of stems of various sizes, like Juncus retractus Heer, or Juncus scheuzeri Heer, in Flora tertiaria Helvetiae, pl. 30, figs. 2e, 3c.

These specimens are not known to be in existence, and the species should probably be discarded.

Occurrence: Green River formation, Green River, Wyo.

\section{MONOCOTYLEDONAE OF UNCERTAIN POSITION.}

Musophyllum complicatum Lesquereux.

Musophyllum complicatum Lesquereux, U. S. Geol. and Geog. Survey Terr. Ann. Rept. for 1873, p. 418, 1874; U. S. Geol. Survey Terr. Rept., vol. 7 (Tertiary flora), p. 96, pl. 15, figs. 1-6, 1878.

Most of the type material on which this species is based is preserved in the United States National Museum (Nos. 132-135). It is very obscure and difficult to interpret, and on this point Lesquereux said:

The exact character of these leaves, especially their form, their size, and their relation to the main stem, or stipe, is very obscure. I have found a bed of shale nearly 1 foot thick filled entirely with fragments of this species and have worked a whole day with a miner, trying, without avail, to get specimens more definite than those which are figured here. Large pieces of shale are covered with fragments of leaves, folded in various ways, where no trace of any middle nerve may be discovered. This proves the large size of the leaves.

As nearly as can be made out it may be described as follows: Stem or stipe very stout, at least 3 centimeters in width, longitudinally wrinkled and striate. Leaves large, with a thick irregularly veined midrib 1 centimeter or more in width. Veins of the leaf numerous, thin but distinct, mainly simple but occasionally dichotomous, especially toward the margins.

Occurrence: Green River formation, 8 miles southeast of Green River station, Wyo.
Subclass DICOTYLEDONES. Order SALICALES.

Family SALICACEAE.

Salix linearis Knowlton, n. sp.

Plate XXXVII, figure 8 .

Leaf very small, linear-lanceolate, 3.5 centimeters long, 5 millimeters broad, with a petiole 5 millimeters long; margin with a few rather remote teeth; midrib very strong; secondaries as many as the teeth, which they enter, arising at an angle about $40^{\circ}$, little curved upward; finer nervation not discernible.

This little leaf is also the only one of its kind observed in the collections. It is perhaps hazardous to characterize a new Salix on a single leaf, but it differs so clearly from any other in the collection that it is presented with the reservation that it may be shown to belong elsewhere when more material is available.

Among living species this strongly resembles a small leaf of Salix fluviatilis Nuttall, the wellknown sand-bar or river-bank willow, which ranges from Quebec to Oregon and south to Virginia, Kentucky, and New Mexico. There is no fossil species, at least from the Green River, that could be confused with this.

Occurrence: Green River formation, "Rio Blanco County, 20 miles west of Rio Blanco post office, Colo. (sec. 33, T. 4 S., R. 100 W.), collected by D. E. Winchester, 1917.

Salix longiacuminata Knowlton, n. sp.

Leaves thin but firm in texture, lanceolate, broadest a short distance above the base, whence it is gradually narrowed to a long, slenderly acuminate apex and to a wedge-shaped base; margin slightly irregular though scarcely to be called toothed; length 9 or 10 centimeters, width 1.2 centimeters; petiole slender, about 1.75 centimeters long; midrib relatively very strong, especially in the lower third; secondaries numerous, arising at various angles, in the lower part falling below a right angle, then many nearly at a right angle, and finally some at an angle of perhaps $20^{\circ}$; all secondaries curved and each joining the one next above, forming a series of loops just within the margin; intermediate secondaries numerous; finer nervation irregularly quadrangular.

The only specimen found in the collections, a nearly perfect leaf, seems well characterized by its long, slenderly acuminate apex, thick 
midrib, and very numerous secondaries, which arise at various angles and by joining form a series of bows well inside the margin.

This leaf is not greatly different in size and shape from leaves referred by Lesquereux ${ }^{51}$ to Salix angusta, though it is more slenderly acuminate, but it differs wholly in the secondary nervation. Thus, in Salix angusta the secondaries are numerous, close, parallel, and little curved upward, whereas in the present species the secondaries are more remote and by joining form a series of loops.

Among other fossil species the present one resembles in nervation Salix arcinerva Heer, ${ }^{52}$ from the Swiss Miocene, but that species differs in shape and has the margin finely toothed. It also resembles in shape and somewhat in nervation Salix longa Heer, ${ }^{53}$ from the same area, but that species is much larger and its secondaries do not form loops.

Occurrence: Green River formation, Rio Blanco County, 20 miles west of Rio Blanco post office, Colo. (sec. 33, T. 4 S.; R. 100 W.), collected by D. E. Winchester, 1917.

Salix sp.

Plate XXXVII, figures 3-5.

The collection made by Winchester includes a number of small leaves that appear to belong to Salix, though the nervation is so obscure that this assignment is not certain. They are linear-lanceolate leaves, 3.5 to about 6 centimeters long and 6 to 10 millimeters wide, and have a petiole 5 or 6 millimeters long. They are narrowed to a wedge-shaped base and are rather obtuse at the apex. The margin is perfectly entire. The nervation, with the exception of a relatively very strong midrib, is obscure but appears to consist of numerous thin secondaries at an angle of $35^{\circ}$ or $40^{\circ}$ that are camptodrome and arch just inside the margins; none of the finer nervation is observable.

Considering the uncertainty regarding these leaves it seems hardly worth while to attempt comparisons with either living or fossil species. Small, narrow, entire willow leaves are so nondescript that it is difficult to be sure of their subsequent recognition, and for this reason the present form has not been given a specific designation.

5I Lesquereux, Leo, U. S. Geol. Survey Terr. Rept., vol. 7 (Tertiary flora), pl. 22, fig. 4, 1878 .

62 Heer, Oswald, Flora tertiaria Helvetiae, vol. 2, pl. 65, figs.4, 5, 1856 68 Idem, pl. 69, figs. 12, 13.
Occurrence: Green River formation, Rio Blanco County, about 40 miles southwest of Meeker, Colo., collected by D. E. Winchester, 1917.

Salix media Heer. Lesquereux, U. S. Geol. and Geog. Survey Terr. Ann. Rept. for 1871, Suppl., p. 6, 1872; U. S. Geol. Survey Terr. Rept., vol. 7 (Tertiary flora), p. 168, pl. 22, fig. 3, 1878.

The specimen on which Lesquereux based the presence of Salix media Heer in American beds is in the United States National Museum (No. 198). It is a small leaf about 7 centimeters long and lacks most of one side and the tip. It is without a trace of nervation except a strong midrib, though secondaries have been added in the figure given in. the "Tertiary flora." The leaves from the Swiss Miocene referred by Heer ${ }^{54}$ to Salix media are all mostly without nervation except the midrib, and of course it is easy to match the American leaf with one of these, but such a comparison is obviously without value.

In the Museum collection there is another leaf not figured that was identified by Lesquereux as Salix media -in fact, it is recorded under the same number (198) as the otherbut it is a long, narrow leaf with obscurely preserved nervation in which a small portion is so preserved as to show an intramarginal vein, as in Eucalyptus? americana, and it should be referred to that species.

As the leaf figured by Lesquereux is so obscure it is here removed from Salix media and regarded as Salix sp.

Occurrence: Green River formation, Green River, Wyo.; also reported from Elko, Nev.

\section{Order MYRICALES.}

\section{Family MYRICACEAE.}

Myrica salicina Unger.

Myrica salicina Unger, Genera et species plantarum fossilium, p. 396, 1850.

.Lesquereux, U. S. Geol. and Geog. Survey Terr. Ann. Rept. for 1871, Suppl., p. 6, 1872.

The status of this species is doubtful. It was identified by Lesquereux under the above name, but the specimen on which the identification was based is lost or merged with something else without a record of such transfer. It was neither figured nor again réferred to by Lesquereux.

Occurrence: Green River formation, Green River, Wyo.

${ }_{54}$ Heer, Oswald, Flora tertiaria Helvetiae, vol. 2, pl.68, figs. 14-19, 1856. 
Myrica minuta Knowlton, n. sp.

Plate XXXVII, figure 12.

Leaves coriaceous or at least firm in texture, linear-lanceolate, prolonged above to a slender acuminate apex and scarcely less so below to the narrowly wedge-shaped base; margin entire for the lower third, thence rather strongly toothed, the teeth moderately sharp; midrib relatively strong; secondaries numerous, thin, at an angle of about $40^{\circ}$, slightly curved upward, ending in the margin in the lower untoothed portion and in the teeth in the middle and upper portion.

This little leaf, the only one observed, is about 18 millimeters long and 3 millimeters wide and has a delicate petiole 1 millimeter long. It is evidently rather thick, as the secondary nervation is faintly visible.

This species is of the same type as Myrica scottii Lesquereux, from the Florissant lake beds, but it is only one-fourth the length of that species and has rather blunt instead of very sharp teeth.

Occurrence: Green River formation, oil shale, Smith ranch, on Greasewood Creek, about 40 miles southwest of Meeker, Colo., collected by D. E. Winchester, 1917.

\section{Myrica praedrymeja Knowlton, n. sp. \\ Plate XXXVI, figures 1-3.}

Leaves small, firm in texture, lanceolate, acuminate at apex, rounded below, with the sides of the leaf at angles of about $45^{\circ}$, slightly unequal sided; margin entire for a short distance, thence with numerous rounded teeth; petiole short, stout; midrib relatively very strong, straight; secondaries numerous, 18 or 20 pairs, alternate, close, parallel, little curved upward, ending in the teeth; finer nervation obsolete.

This species is represented by a number of specimens, and three of the most nearly perfect ones are figured. They are 4 or 5.5 centimeters long and about 1.2 centimeters wide; with the petiole at least 4 millimeters long. This species is very closely similar to Myrica callicomaefolia Lesquereux ${ }^{55}$ (now Myricadrymeja (Lesquereux) Knowlton), from the Florissant lake bedsin fact, they may be identical. $M$. praedrymeja

os Lesquereux, Leo, U. S. Gool. Survey Torr. Rept., vol. 8 (Cretacoous and Tortiary floras), p. 146, pl. 26, flgs. 5-14, 1883.

$91048^{\circ}-23-11$ differs slightly, however, in having the marginal teeth obtuse or rounded instead of sharp-pointed and a stronger nervation. These differences are not marked, and a fuller series might readily show them breaking down.

Occurrence: Green River formation, oil shale, Smith ranch, on Greasewood Creek about 40 miles southwest of Meeker, Rio Blanco County, Colo., collected by D. E. Winchester, 1917.

Myrica ludwigii Schimper.

Myrica ludwigii Schimper, Paléontologie végétale, vol. 2, p. $545,1872$.

Lesquereux, U. S. Geol. and Geog. Survey Terr. Bull., vol. 1, p. 385, 1875 (1876); idem, Ann: Rept. for 1874, p. 311, 1876; U. S. Geol. Survey Terr. Rept., vol. 7 (Tertiary flora), p. 133, pl. 65, fig. 9, 1878.

The single broken leaf figured is all there is to represent this species, and this is now lost. Its status is therefore rather unsatisfactory, but it will have to stand as above until further material can be procured.

Occurrence: Green River formation, mouth of White River (emptying into Green River), Wyo.

\section{Myrica sp.}

Plate XXXVII, figure 2.

Winchester's collection contains a fragment that evidently belongs to Myrica, but it is so deficient that I have not given it a specific name. It is a fragment 2.5 centimeters long and 0.5 centimeter wide, of the upper part of a linear-lanceolate, sharply acuminate leaf. The margin in the lower part is nearly entire, with only an occasional tooth, but in the upper part it is provided with low, obtuse, irregularly. spaced teeth. The nervation consists of a relatively strong, straight midrib and very numerous secondaries that arise at a low angle and curve slightly in passing to the borders, which most of them seem to enter. These secondaries are somewhat irregularly placed; the finer nervation is not observable.

This form has the same type of nervation as Myrica nigricans Lesquereux, but it differs in the narrowly lanceolate, acuminate, irregularly toothed blade.

Occurrence: Green River formation, Cathedral Bluff, south of Little Tommies Draw, 20 miles west of Rio Blanco post office, Rio Blanco County, Colo., collected by D. E. Winchester, 1917. 
Myrica sp.

Plate XL, figure 13.

In the Winchester collection I find the single specimen here figured, which seems to be different from any other noted. It is coriaceous in texture, narrowly lanceolate, prolonged above into an acute apex (base destroyed). It was probably 9 or possibly 10 centimeters long and about 13 millimeters wide. The margin is remotely toothed, the teeth low and rather obtuse. The nervation consists of a very strong, straight midrib and numerous pairs of mainly alternate secondaries which arise nearly at right angles to the midrib, considerably curved upward and ending in the teeth or in the margin; finer nervation not well preserved.

This somewhat resembles what Lesquereux called Myrica nigricans ${ }^{56}$ (now Rhus nigricans), but it is longer and more narrowly acuminate, and has fewer secondaries. It is even closer to Myrica ludwigii Schimper, as identified by Lesquereux ${ }^{57}$ from the mouth of White

- River, Wyo., but that species is shorter and broader and has very large marginal teeth and different secondary nervation.

Occurrence: Green River formation, head of Carr Creek, Garfield County, Colo., 30 miles northwest of De Beque, collected by D. E. Winchester, 1917.

\section{Comptonia? anomala Knowlton, n. sp.}

Plate XXXVII, figure 1.

Leaf small, sessile, 2 centimeters long, 6 millimeters wide; coriaceous; lanceolate, obtuse and rounded at apex, strongly unequalsided at base; margin strongly undulatetoothed, the teeth low and rounded; midrib very strong for the size of the leaf; secondaries thin, opposite or nearly so, at a low angle, very little curved upward, ending in the marginal undulations; intermediate secondaries occasional; finer nervation obsolete.

It is with grave doubt that this little leaf is referred to the genus Comptonia. In the undulate-toothed margin and in nervation it seems identical with this genus, but the strongly unequal-sided base suggests that it is a leaflet and not a distinct leaf. However, I have not thus

${ }^{56}$ Lesquereux, Leo, U. S. Geol. Survey Terr. Rept., vol. 7 (Tertiary flora), p. 132, pl. 17, figs. 9-12, 1878.

${ }^{67}$ Idem, pl. 65, fig. 9. far been able to place it satisfactorily in any genus with compound leaves, and temporarily it is referred to Comptonia. It is so strongly marked that it can easily be recognized in future and perhaps more correctly placed when opportunity offers.

Occurrence: Green River formation, Smith ranch, on Greasewood Creek, about 40 miles southwest of Meeker, Rio Blanco County, Colo., collected by D. E. Winchester, 1917.

\section{Order JUGLANDALES.}

\section{Family JUGLANDACEAE.}

Juglans occidentalis Newberry.

Juglans occidentalis Newberry, U. S. Nat. Mus. Proc., vol. 5, p. 507, 1882 [1883]; U. S. Geol. Survey Mon. 35, p. 34 , pl. 65 , fig. 1 ; pl. 66 , figs. $2-4$ [not pl. 66 , fig. 1], 1898.

Juglans schimperi Lesquereux, U. S. Geol. Survey Terr. Rept., vol. 7 (Tertiary flora), pl. 56, figs. 7, 8, 10 [not figs. 5, 6, 9, which remain under Juglans schimperi], 1878.

Hollick, Louisiana Geol. Survey Special Rept. 5, p. 280 , pl. 33 , fig. 1 ; pl. 25 , fig. 3 [not pl. 32 , fig. 5 ?; pl. 33, fig. 2, which remain under Juglans schimperi], 1899.

Berry, U.,S. Geol. Survey Prof. Paper 91, p. 182, pl. 18, figs. 3, 5 [not pl. 18, fig. 4, which remains under Juglans schimperi], 1916.

Knowlton, U. S. Geol. Survey Prof. Paper 101, pl. 64, fig. 1, 1918.

Leaves supposedly pinnate; leaflets somewhat variable in form and size, from about8 to 18 centimeters in length, 3 to 6 centimeters wide, generally about 15 centimeters long and 4 centimeters wide, broad lanceolate, broadest near the middle, summit acute, base rounded, unsymmetrical; margin entire; midrib very strong, straight; secondaries numerous, about 20 pairs, rather slender, at a low angle of emergence, slightly curved upward, camptodrome, forming a series of bows or loops along the margin; finer nervation not well retained, but nervilles mainly oblique to the secondaries and unbroken.

Juglans occidentalis was named and described by Newberry in 1883 but was not figured until the publication of his "Later extinct floras" in 1898. He stated that there were a large number of specimens in the collection submitted to him, some of which "are found attached to the stems that bore them, but generally separated and more or less torn and broken. The tree was evidently a strong- 
growing and luxuriant one, for some of the leaves are not less than 8 inches in length."

Newberry called attention to the fact that bis specimens were from the same locality as that which furnished the leaves described by Lesquereux as Juglans schimperi but concluded that the two were not identical, because Lesquereux had described Juglans schimperi as long, narrow leaves, broadest near the base and with a camptodrome nervation, whereas Newberry stated that in Juglans occidentalis "a large part of the lateral nerves terminate in the margins, and the tertiary nervation is more open and irregular."

The figured types of both species are before me and disclose that Newberry was wrong in saying that a large part of the nerves terminate in the margins in his species; they are all camptodrome and form loops along the margin, exactly as described by Lesquereux for his Juglans schimperi. This character therefore fails, and the only way of distinguishing them is by the long, narrow, sharp-pointed leaflets with a rounded equal-sided base and slightly more acute-angled secondaries in Juglans schimperi, and the broader, less acuminate leaflets with unequal-sided base and very low-angled secondaries in Juglans occidentalis. But, as pointed out in the discussion of' Juglans schimperi below, the possibility should be considered that the leaflets now allocated to Juglans schimperi may be terminal leaflets, and if so all would naturally have to be included under Lesquereux's species. It is also pointed out in the discussion of Juglans schimperi that the disposition mentioned makes necessary certain transfers of figures from one to the other. Thus, those of Lesquereux's types of Juglans schimperi will go to Juglans occidentalis. All but two of the leaflets identified by Hollick as Juglans schimperi from the Wilcox group will go to Juglans occidentalis, as indicated in the above synonymy. These figures as reproduced by Berry in his paper on the Wilcox flora will have the same disposition, and the leaflets from the Raton flora that I identified as Juglans schimperi will also find place under Juglans occidentalis.

Occurrence: Green River formation, Green River, Wyo. Wilcox group, Louisiana and Mississippi. Raton formation, northeastern New Mexico. and southeastern Colorado.
Juglans schimperi Lesquereux.

Juglans schimperi Lesquereux, U. .S. Geol. and Geog. Survey Terr. Ann. Rept. for 1871, Suppl., p. 8, 1872; U: S. Geol. Survey Terr. Rept., vol. 7 (Tertiary flora), p. 287, pl. 56, figs, 5, 6, 9 [not figs. $7,8,10$, which=Juglans occidentalis Newberry], 1878.

Hollick, Louisiana Geol. Survey Special Rept. 5, p. 280 , pl. 32, fig. 5?; pl. 33, fig. 2 [not pl. 33, fig. 1; pl. 35 , fig. 3 , which $=$ Juglans occidentalis Newberry], 1899

Berry, U. S. Geol. Survey Prof. Paper 91, p. 182, pl. 18, fig. 4; pl. 19, fig. 4? [not pl, 18, figs. 3, 5, which $=$ Juglans occidentalis Newberry], 1916.

Leaves firm in texture, pinnately compound, leaflets lanceolate, 8 to 14 centimeters long, 2 to 3.5 centimeters wide, broadest near the abruptly rounded and equal-sided base; tapering to a long, slender point above; margin. entire, slightly undulate; petiolule very short; midrib very strong, straight; secondaries numerous, about 18 pairs, rather thin, emerging at angles of $40^{\circ}$ to $50^{\circ}$, close, parallel, slightly curved in ascending to the middle of the area, but more and gradually curved on nearing the margin, which they closely follow in simple bows; secondaries connected by close, distinct nervilles, generally at right angles to them.

Juglans schimperi was named and described by Lesquereux in 1872 but was not figured until the publication of the "Tertiary flora" in 1878. Six specimens were figured as the types, and all are in the United States National. Museum and are before me. Although several of the specimens are fragmentary, it has long: seemed to me that they show differences that might amount to specific distinctness, but they have never before been very critically examined. Three specimens (Tertiary flora, pl. 56, figs. $5,8,9$ ) are long, narrowly acuminate leaflets with an equal-sided base, whereas the others (figs. 7, 8, 10) are markedly unequal-sided at the base and have the secondaries at a much lower angle.

A few years later Newberry studied a large number of very well preserved leaves from the same locality (Green River, Wyo.) that had supplied Lesquereux's types of Juglans schimperi. These Newberry ${ }^{58}$ described and figured under the name Juglans occidentalis. It needs but a glance to show that so far as the base of the leaflets is concerned Juglans occidentalis is absolutely identical with the three figures

${ }^{68}$ Newberry, J. S., U. S. Geol. Survey Mon. 35, p. 34, pl. 65, fig. 1; 
above mentioned (figs. $7,8,10$ ) of Lesquereux's Juglans. schimperi, and the question immediately arises as to the disposition that is to be made of the various forms. If all the specimens figured by Lesquereux as types of his Juglans schimperi are considered as conspecific, then Newberry's Juglans occidentalis must be referred to it. However, it seems best to regard Juglans schimperi as a composite species and to retain the narrow, sharp-pointed leaflets with an equal-sided base and allocate them to Lesquereux's name, referring the unequal-sided specimens to Juglans occidentalis. The possibility is not to be lost sight of, however, that the narrow leaflets may be really terminal leaflets and hence would be likely to have an equalsided base, but thus far no specimens have been found that show the leaflets attached.

The proposed splitting up of Juglans schimperi makes some complications with certain subsequent identifications. Thus, Hollick ${ }^{58}$ referred a number of leaflets from the Wilcox group of Louisiana to Juglans schimperi Lesquereux. Of the four examples figured only one (pl. 33, fig. 2) appears to belong to Lesquereux's species as now restricted.

Hollick's figures above mentioned were republished by Berry ${ }^{60}$ in his paper on the Wilcox flora, but only figure 4 of Plate XVIII is to be retained under Juglans schimperi, the others going to Newberry's species.

In my report on the flora of the Raton formation $^{61} \mathrm{I}$ identified a single leaflet as Juglans schimperi on the basis of its resemblance to leaflets so identified by Hollick. This now becomes Juglans occidentalis.

Occurrence: Green River formation, Green River, Wyo. Wilcox group, Louisiana and Mississippi. Beds of Wilcox age; western Kentucky. Denver formation, Golden, Colo. Clarno formation (upper part), Bridge Creek, Oreg.

\section{Juglans crossii Knowlton.}

Juglans crossï Knowlton, U. S. Geol. Survey Bull. 152, p. 122,1898

Juglans denticulata Heer. Lesquereux, U. S. Geol. and Geog. Survey Terr. Ann. Rept. for 1871, p. 298, 1872; U. S. Geol. Survey Terr. Rept., vol. 7 (Tertiary flora); p. 289, pl. 58, fig. 1, 1878. [Homonym, Weber, 1852.]

${ }^{59}$ Hollick, Arthur, Louisiana Geol. Survey Special Rept. 5, p. 280, pl. 32, fig. 5; pl. 33, figs. 1, 2; pl. 35, flg. 3, 1899.

60 Berry, E. W., U. S. Geol. Survey Prof. Paper 91, p. 182, pl. 18, figs. 3-5; pl. 19, fig. 4, 1916.

61 Knowlton, F. H., U. S. Geol. Survey Prof. Paper 101, p. 296, pl. 64, fig. 1, 1918.
The first locality from which this species was identified by Lesquereux appears to have been the Bozeman coal field of Montana, in beds presumed to belong to the Livingston formation, but the only specimen figured in the "Tertiary flora" was obtained at Green River, Wyo., above the so-called fish beds. This specimen is in the United States National Museum (No. 482) and has been fairly well described and figured. This species has also been reported from the Hanna formation of Carbon, Wyo.

\section{Juglans alkalina Lesquereux.}

Juglans alkalina Lesquereux, U. S. Geol. and Geog. Survey Terr. Bull., vol. 1, p. 382, 1875 [1876]; idem, Ann. Rept. for 1874, p. 308, 1876; U. S. Geol. Survey Terr. Rept., vol. 7 (Tertiary flora), p. 288, pl. 62, figs. $6-9,1878$.

Leaves pinnately compound; leaflets lanceolate, tapering upward to a long acumen, either narrowed or rounded to a short petiole; borders crenulate; lateral veins distant, mostly alternate, parallel, separated by short intermediate tertiary veins, curving in passing toward the borders at an open angle of divergence and ascending high along them in festoons; nervilles in right angle to the veins, branching in the middle, and forming by subdivisions irregularly quadrate or polygonal meshes.-Lesquereux.

Three of the four types of this speciesfigures 6,7 , and 8 of Plate LXII in the "Tertiary flora" -are preserved in the United States National Museum collections (Nos. 527-529).

Occurrence: Green River formation, Alkali stage station, 30 miles north of Green River, Wyo.

Juglans winchesteri Knowlton, n. sp.

Plate XXXVIII, figure 5.

Leaflet firm in texture, elliptical or ovateelliptical, strongly unequal-sided, broadest near the middle, thence gradually narrowed to an apparently rather obtuse apex and downward to the rounded base; margin entire below, then obscurely toothed, the teeth low; petiole short, very thick and stout, curved; midrib very thick just above the petiole, very much thinner above; secondaries ten or twelve pairs, alternate, at irregular distances, arising at very low angles, much curved upward, camptodrome, sending slender branches to the marginal teeth; nervilles strong.

The specimen figured is the only one of this species noted. It is about 9 centimeters long and 4.5 centimeters wide. The petiole is 3 millimeters thick and about 8 millimeters long. 
Occurronce: Green River formation, Rio Blanco County, 20 miles west of Rio Blanco post office, Colo. (sec. 33, T. 4 S., R. 100 W.), collected by D. E. Winchester, 1917.

\section{Order FAGALES.}

Family FAGACEAE

Quercus castaneopsis Lesquereux.

Quercus castaneopsis Lesquereux, U. S. Geol. Survey Terr. Rept. vol. 8 (Cretaceous and Tertiary floras), p. $155, \mathrm{pl} .28$, fig. 10, 1883.

Quercus castanoides Newberry, U. S. Nat. Mus. Proc., vol. 5, p. 506, 1883; U. S. Geol. Survey Mon. 35, p. 70 , pl. 65, fig. 6, 1898.

Leaf firm in texture, lanceolate or narrowly ovate-lanceolate, 12 to 16 centimeters long, 2.5 to 6 centimeters wide, narrowly acuminate at the apex, rather abruptly rounded to a wedge-shaped base; margin remotely and somewhat irregularly set with coarse teeth, some of them spinous; nervation strong, the midrib especially so, straight; secondaries numerous, 18 or 20 pairs, unequally spaced, emerging nearly at right angles, slightly curved upward, all camptodrome, curving near the borders, following them and entering the short teeth by oblique nervilles; areolation of minute polygonal meshes.

This description is drawn from the type specimens of Quercus castaneopsis Lesquereux and Quercus castanoides Newberry, both of which are preserved in the United States National Museum (Nos. 1575 and 7044, respectively). Leaves obviously of the same species were described independently by Lesquereux and Newberry, but as Lesquereux's publication antedates that of Newberry by a few months his name is selected as the one the species is to bear. Both noted the resemblance to leaves of Castanea or Castanopsis, and curiously enough both selected almost identical specific names.

Occurrence: Green River formation, Uinta (formerly incorrectly called Randolph) County Wyo. (type of Quercus castaneopsis Lesquereux); Green. River, Wyo. (type of Quercus castanoides Newberry).

Order URTICALES.

Family ULMACEAE.

Planera inaequilateralis (Lesquereux) Knowlton, n. comb. Alnites inaequilateralis Lesquereux, U. S. Geol. and Geog. Survey Terr. Bull., vol. 1, p. 381, 1875 [1876]; idem, Ann. Rept. for 1874, p. 307, 1876; U. S. Geol. Sur- vey Terr. Rept., vol. 7 (Tertiary flora), p. 141, pl. 62, figs. 1-4, 1878.

Alnus inaequilateralis Lesquereux, U. S. Geol. Survey Terr. Rept., vol. 8.(Cretaceous and Tertiary floras), p. 151, 1883.

Planera variabilis Newberry, U. S. Nat. Mus. Proc., vol. 5, p. 508, 1882 [1883]; U. S. Geol. Survey Mon. 35, p. 83, pl. 66, figs. 5, 6 [not fig. 7], 1898.

Leaves evidently firm in texture, somewhat variable in size ( 4 to 8 centimeters long, 2.5 to 6 centimeters wide), broadly ovate or nearly oval, acute or rather obtusely acute at apex, strongly unequal-sided at the rounded or obtusely wedge-shaped base; margins crenulate-dentate; petiole short or absent; midrib strong, straight; secondaries mainly alternate, the lowest one on the broad side of the leaf usually with several outside branches, others considerably curved upward, ending in the low teeth or sending out minor branches that enter the teeth; nervilles at right angles to the secondaries, mainly unbroken.

This species as now accepted has had a rather complicated history. The original material was named and described, but not figured, by Lesquereux in 1875; under the name Alnites inaequilateralis. It was figured in the "Tertiary flora" (pl. 62, figs. 1-4) in 1878, but only two of the figured types (figs. 1 and 3 ) are now to be found in the collections of the United States National Museum. On the publication of the "Cretaceous and Tertiary floras," in 1883, Lesquereux changed the generic name to Alnus.

Subsequently C. A. White made a large collection of plants from the same region that had supplied Lesquereux's Alnites or Alnus inaequilateralis. This material was described by Newberry ${ }^{62}$ in 1883 and contained several leaves that he named Planera variabilis. These were not figured, however, until 1898, ${ }^{63}$ when it was at once apparent that at least two of his figured types (figs. 5, 6) were identical with Lesquereux's Alnus inaequilateralis.

Of course Lesquereux's specific name has priority, but a question arises as to the proper generic designation. It does not seem to me that these leaves can belong to Alnus, in which, so far as I know, the leaves are symmetrical at the base. I have transferred them to Planera, the genus adopted by Newberry, although it is to be admitted that they differ

${ }_{62}$ Newberry, J. S., U. S. Nat. Mus. Proc., vol. 5, p. 508, 1883. ${ }_{63}^{63}$ U. S. Geol. Survey Mon. 35, p. 83, pl. 66, 1898. 
in some particulars from leaves of the monotypic living genus. The leaves of the living species, Planera aquatica Gmelin, are 5 or 6 centimeters long, 2 to 3 centimeters wide, unequally wedge-shaped or rounded at the base, and with the margins coarsely crenulateserrate. They do not appear to have the lower secondary on the broad side of the leaf branched, but otherwise the difference is not great between these leaves and those of the fossil form under consideration.

Occurrence: Green River formation, Alkali stage station, Wyo. (type locality for Alnus inaequilateralis Lesquereux); Green River, Wyo. (type locality for Planera variabilis Newberry).

\section{Family MORACEAE.}

Ficus ungeri Lesquereux.

Ficus ungeri Lesquereux, U. S. Geol. and Geog. Survey Terr. Ann. Rept. for 1871, Suppl., p. 7, 1872; U. S. Geol. Survey Terr. Rept., vol. 7 (Tertiary flora), p. 195, pl. 30, fig. 3, 1878; idem, vol. 8 (Cretaceous and Tertiary floras), p. 163, pl. 44, figs. 1-3, 1883.

The type of this species is the specimen figured in the "Tertiary flora" (pl. 30, fig. 3) and is No. 265 in the United States National Museum; it is very well described and figured. It came from Green River, Wyo., where it was found above the so-called fish beds.

The specimens figured in the "Cretaceous and Tertiary floras" (pl. 44, figs. 1-3) are all in the Museum collection (Nos. 1598, 1599, 1600). They came from Alkali stage station, which is about 30 miles north of Green River, Wyo.

Occurrence: Green River formation, Green River, Wyo., above fish beds (type); Alkali stage station, 30 miles north of Green River, Wyo.

\section{Ficus wyomingiana Lesquereux.}

Ficus wyomingiana Lesquereux, U. S. Geol. and Geog. Survey Terr. Bull., vol. 1, p. 387, 1875 [1876]; idem, Ann. Rept. for 1874 , p. 314, 1876; U. S. Geol. Survey Terr. Rept., vol. 7 (Tertiary flora), p. 205, pl: 33, fig. $3,1878$.

The type and so far as known the only specimen of this species thus far found is in the United States National Museum collection (No. 289). It is fragmentary, lacking all of the upper portion and much of one side. As Lesquereux has said, this leaf is strikingly similar in general appearance to Ficus pseudo-populus Lesquereux, which was described from material collected at Evanston, Wyo., and which has since been found abundantly in the Raton for- mation of eastern Colorado and northeastern New Mexico and the Wilcox group of the Gulf region. It differs, however, in having the lateral ribs running nearly or quite to the apex of the blade and in the absence of any secondary branches, the space between the midrib and the lateral ribs as well as between the ribs and the margin being filled with numerous fine nervilles, which are nearly at right angles to the midrib.

Occurrence: Green River formation. Green River, Wyo.

Ficus tenuinervis Lesquereux.

Ficus tenuinervis Lesquereux, U. S. Geol. Survey Terr. Rept., vol. 8 (Cretaceous and Tertiary floras), p. 164, pl. 44, fig. 4, 1883.

This is a mere fragment of the basal part of a leaf that Lesquereux says is "oblong, or lanceolate, tripalmately nerved, rounded at base, entire." As it stands it is of comparatively little value, for it probably could not be identified again.

Occurrence: Green River formation, Alkali stage station, about 30 miles north of Green River, Wyo.

\section{Order PROTEALES.}

Family PROTEACEAE.

\section{Lomatia? microphylla Lesquereux.}

Lomatia microphylla Lesquereux, U. S. Geol. and Geog. Survey Terr. Bull., vol. 1, p. 389, 1875 [1876]; idem, Ann. Rept. for 1874, p. 346, 1876; U. S. Geol. Survey Terr. Rept., vol. 7 (Tertiary flora), p. 211, pl. 65, figs. 14, 15, 1878.

Described by Lesquereux as follows:

Leaves very small, coriaceous, entire, linear-lanceolate, gradually narrowed from the middle to a point and in the same degree to the base; secondary veins simple, abruptly curving near the borders and following them or entering a marginal band.

The two figured specimens on. which this species is based are not now known to be in existence. The smaller is about 2 centimeters long and the larger one only 3 centimeters long; the -width is 2 to 4 millimeters.

The generic reference of these little leaves is extremely uncertain. It is to be doubted if they are correctly plaoed in Lomatia, though they somewhat resemble certain forms from the Swiss Miocene so referred by Heer. They suggest leaflets of Mimosites, of Sophora, or of Sapindus, such as Sapindus angustifolius Lesquereux.

Occurrence: Green River formation, near mouth of White River (emptying into Green River), Wyo. 
Order THYMELEALES.

Family LAURACEAE.

Oreodaphne viridiflumensis Knowlton, n. sp.

Plate XXXVIII, figure 6.

Leaf coriaceous in texture, lanceolate, long wedge-shaped at the base, probably about equally narrowed above, about 12 centimeters long, 3 centimeters wide; margin perfectly entire; petiole very strong, 1 centimeter long, over 2 millimeters thick; midrib straight, very thick below and in the middle of the leaf but becoming thin above; secondaries somewhat irregular, lowest pair subopposite, thin, at an angle of about $40^{\circ}$, each running up for some distance and joining the secondary next above by a broad loop; next secondaries alternate, much stronger, each joining the one above by a loop far inside the margin, then with a series of large bows on the outer side; other secondaries similar, alternate, with a few intermediate secondaries joining the primary ones; nervilles very numerous, mostly broken, forming large rectangular areas, and filled with irregularly quadrangular areas and these again with still finer nerves.

This is a very fine species, but unfortunately it is represented by only the lower half of a leaf, though this is absolutely perfect. It may be known by its narrowly lanceolate shape, short, very thick petiole, unusually thick midrib, and the peculiar arching and branching secondaries.

In shape and size this species seeths nearest to Oreodaphne salinensis Berry, ${ }^{64}$ from the Wilcox group of Arkansas, but it differs in nervation, especially in the secondaries.

Occurrence: Green River formation, Rio Blanco County, about 40 miles southwest of Meeker, Colo., collected by D. E. Winchester, 1917.

Pimelea spatulata Knowlton, n. sp.

Plate XXXVII, figure 6

Leaf apparently firm in texture; narrowly spatulate, broadest in the upper third, whence it tapers to an acuminate apex and downward into a long, narrowly wedge-shaped base that merges with the petiole; nervation consisting of a relatively strong midrib and numerous thin, close, nearly parallel secondaries.

of Berry, E. W., U. S. Geol. Survey Prof. Paper 91, p. 303, pl. 82, flgs. $1,2,1917$.
This little leaf, which is the only one noted in the collection, is very narrowly spatulate, about 17 millimeters long including the petiole, and about 4 millimeters wide. The base is so merged into the petiole that no more than a length of 4 millimeters can be considered as petiole.

This species seems to approach most closely Pimelea delicatula Lesquereux, ${ }^{65}$ from the lake beds at Florissant, Colo., but differs in being much smaller and narrower and in the apparently somewhat thicker substance of the leaf.

Occurrence: Green River formation, oil shale, Cathedral Bluff, south of Little Tommies Draw, Rio Bíanco County, about 20 miles west of Rio Blanco post office, Colo., collected by D. E. Winchester, 1917.

\section{Order RANALES.}

Family NYMPHAEACEAE.

Brasenia? antiqua Newberry.

Brasenia antiqua Newberry, U. S. Nat. Mus. Proc., vol. 5, p. 514, 1882 [1883]; U. S. Geol. Survey Mon. 35, . p. 93, pl. 68 , fig. 7,1898 .

The type of this species is No. 7018 of the United States National Museum collections and has been well described and figured by Newberry. No additional material has been procured, and hence there is nothing to make the identification either more or less certain.

Occurrence: Green River formation, Green River, Wyo.

Order ROSALES.

Family CRASSULACEAE?

Sedum? hesperium Knowlton, n. sp.

Plate XXXVII, figure 7.

Leaf apparently thick and fleshy, broadly lanceolate, widest near the middle, thence narrowed to the obtusely wedge-shaped base, obtuse and obscurely three-lobed at the apex; margin with two or three large teeth or lobes on each side; petiole very thick and stout; nervation peculiar, consisting of a rather strong midrib and numerous thin veins that arise in the lower part of the blade and spread out, a few of them forking to occupy the area between midrib and margin.

This form is represented by the single specimen figured. It is about 2.4 centimeters long and 1 centimeter wide, with the thick petiole

${ }_{65}^{6}$ Lesquereux, Leo, U. S. Geol. Survey Terr. Rept., vol. 8 (Cretaceous and Tertiary fioras), p. 168, pl. 33, figs. 15, 16, 1883. 
2 millimeters long. It is a very peculiar leaf, well characterized by the thick, evidently fleshy substance, obtuse, three-lobed apex, several large irregular lobes or teeth, and above all by the thick petiole, strong midrib, and thin, longitudinal veins.

I am uncertain as to its affinity. I have referred it with a question to Sedum on account of its fleshy character and resemblance to the living Sedum telephïoides Michaux, but this resemblance may be only superficial. In any event it may be easily recognized in future, and more and better material may serve to place it more certainly.

Occurrence: Green River formation, Cathedral Bluff, south of Little Tommies Draw, 20 miles west of Rio Blanco post office, Rio Blanco County, Colo., collected by D. E. Winchester, 1917.

\section{Family DRUPACEAE.}

\section{Amygdalus gracilis Lesquereux.}

Amygdalus gracilis Lesquereux, U. S. Geol. Survey Terr. Rept., vol. 8 (Cretaceous and Tertiary floras), p. 199, pl. 40, figs. 12-15; pl. 44, fig. 6, 1883.

Penhallow, Report on Tertiary plants of British Columbia, p. 37,1908 .

Lesquereux characterized this species as follows:

Leaves ovate-lanceolate, gradually narrowed to the acuminate point and in the same degree to the petiole; serrulate; lateral nerves at a more or less acute angle of divergence, much curved, camptodrome and reticulate along the borders:

These fine leaves of solid membranaceous tissue average 7 centimeters long and 2 centimeters broad, with a slender petiole about 2 centimeters long. They are more or less distinctly minutely serrate; the nerves, open at base and much curved toward the borders, are joined by undulate nervilles nearly at right angles.

There appears to be much confusion regarding this species. It is based on five figured specimens, one of which (the original of pl. 40, fig. 12, of the "Cretaceous and Tertiary floras") is said to be in the Museum of Princeton University; the others should be in the United States National Museum, but only one can now be found. The original of figure 6 of Lesquereux's Plate XLIV is said to have come from Uinta County (formerly incorrectly called Randolph County), Wyo., but this specimen is missing. All the specimens shown on his Plate XL (figs. 12 to 15) are supposed to have come from Florissant, Colo., but the only specimen available (the original of fig. 13) is No. 1588 of the United States National Museum and is recorded as coming from Uinta County, Wyo., and this record is borne out by the matrix, which is clearly identical with the others from Uinta County and wholly unlike the Florissant material. This species has not been identified in any of the recently studied material from Florissant, and unless the missing specimens can ultimately be shown to have come from that locality it should be dropped from the Florissant list.

Two of the figured types of Amygdalus gracilis (pl. 40, figs. 14, 15) are poorly preserved fruits of which Lesquereux wrote as follows: "The fruits appear to belong to this genus and possibly to this species. The reference is of course hypothetical." Without access to the original specimens it is impossible to say much about them, and to judge from the figures alone there seems very little warrant for referring them to Amygdalus and absolutely none for connecting them with these leaves.

Occurrence: Green River formation. Uinta County (formerly erroneously called Randolph County), Wyo. All reference to the occurrence in the Florissant lake beds is extremely doubtful.

\section{Family PAPLIONACEAE.}

\section{Dalbergia viridiflumensis Knowlton, n. sp.}

Plate XL, figure 10.

Leaflet small, very thick in texture, obovate, strongly emarginate at the apex, wedge-shaped at the base, length 15 millimeters, width 11 millimeters; petiolule slender, 4 millimeters long; margin perfectly entire; midrib very strong, especially on the under side of the leaf, straight; secondaries thin but distinct, seven or eight pairs, at an acute angle, camptodrome, probably uniting with each other, but this point is obscure.

Unfortunately this specimen is the only one found in the collection, but it is so well marked that it can easily be recognized.

The genus Dalbergia is a large one, comprising over 80 species, mainly of the Tropics of both Old and New worlds. Many of the species have similar leaves and hence are hard to separate on this character alone. Among the 25 or more tossil species that have been described the one perhaps approached most 
closely by the present form is Dalbergia eocenica Berry, ${ }^{60}$ from the Lagrange formation of Puryear, Tenn. D. viridiflumensis differs from that species, however, in being more regularly obovate and in being petiolulate instead of sessile.

Occurrence: Green River formation, Rio Blanco County, 20 miles west of Rio Blanco post office, Colo. (sec. 33, T. 4 S., R. 100 W.), collected by, D. E. Winchester, 1917.

Dalbergia retusa Knowlton, $n$. sp.

Plate XL, flgures 5, 6 .

Leaflet thick in texture, elliptical, strongly retuse at the apex, abruptly rounded and equilateral at the base; petiolule short, very strong; midrib very strong; secondaries thin, immersed in the leaf substance, at a low angle of emergence, camptodrome, forming loops just inside the margin; fine nervation not discernible.

Unfortunately this species is represented only by a single leaflet with its counterpart, both of which have been figured, as there are certain features that can not be seen from either impression. It is regularly elliptical or slightly broader above the middle, being about 2.5 centimeters long and 2 centimeters wide. The very thick petiolule is 2 millimeters long. With the exception of the strong midrib the nervation is rather obscure but is thought to be as described above.

This little leaflet seems referable to the genus Dalbergia on the ground of being strongly retuse at the apex and slightly broader above the middle and having the type of nervation usual in the genus. It is, for instance, very similar to Dalbergia eocenica Berry, ${ }^{07}$ from the Lagrange formation (in beds of Wilcox age) of western Tennessee, except as regards size. It also resembles certain leaflets from the Swiss Miocene described by Heer. ${ }^{68}$

Dalbergia retusa is also similar to Simaruba eocenica Berry ${ }^{09}$ and Canavalia eocenica Berry, ${ }^{70}$ both from the Wilcox group.

Occurrence: Green River formation, Little Duck Creek, Rio Blanco County, about 50 miles southwest of Meeker, Colo.; collected by D. I. Winchester, 1917.

60 Borry, E. W., U. S. Geol. Survey Prof. Paper 91, p. 245, pl. 53, figs. $1,2,1010$.

07 Idem.

Heer, Oswald, Flora tertiaria Felvetiae, vol. 3, pl. 133, 1859.

os Op. cit., pl. 54, flg. 7 .

70 Op. cit., pl. 53 , fig. 3.
Leguminosites alternans Lesquereux.

Leguminosites alternans Lesquereux, U. S. Geol. and Geog. Survey Terr. Bull., vol. 1, p. 388, 1875 [1876]; idem, Ann. Rept. for 1874, p. 315, 1876; U. S. Geol. Survey Terr. Rept., vol. 8 (Cretaceous and Tertiary floras), p. 202, 1883.

Leaflet lanceolate, narrowed to the sessile base (point broken), apparently tapering and acute; secondary veins close, numerous, 15 pairs in a space of 2.5 centimeters, with indeterminate shorter tertiary veins anastomosing by crossing veinlets; areolation obsolete.

This leaf is comparable to a Dalbergia or a Podogonium by its nervation; its form, especially the narrowed base, is comparable to Cassia.

The above description by Lesquereux is all that has been written concerning this species. The type or types are not known to be in existence, and as it was never figured its status must be considered more or less unsatisfactory.

Occurrence: Green River formation, near mouth of White River (emptying into Green River), Wyo.

Sophora coloradensis Knowlton, $n$. sp.

Plate XXXVII, figures 14-16; Plate XL, figure 11.

Leaflets rather thin in texture, ovate or ovate-elliptical, obtuse and rounded at the apex, abruptly rounded or obtusely wedgeshaped at the base; petiolule short, stout; midrib moderately strong, straight; secondaries few, mainly opposite, thin, at a low angle, camptodrome, forming broad loops, especially in the upper part.

The smallest of the several leaflets referred to this species (fig. 14) is about 2.25 centimeters long and 1.8 centimeters wide, and the largest (fig. 16) about 4 centimeters long and 2 centimeters wide. In both these leaflets the base is obtusely wedge-shaped, but in another example (fig. 16) the base is much more abruptly rounded-in fact, almost truncate. It is nearly 2.5 centimeters wide and was probably not far from 5 centimeters long.

This species suggests some of the forms of Sophora wilcoxiana Berry, ${ }^{71}$ from the Wilcox group, but is more ovate or ovate-elliptical and has more arched secondaries.

Occurrence: Green River formation, Little Duck Creek, Rio Blanco County, about 50 miles southwest of Meeker, and Camp Gulch, 25 miles northwest of De Beque, Colo., collected by D. E. Winchester; 1917.

7 Berry, E. W., U. S. Geol. Survey Prof. Paper 91, p. 241, pl. 47, figs. 1-13, 1916. 
Family MIMOSACEAE.

Mimosites coloradensis Knowlton, $n$. sp.

Plate XL, figures 1-3.

Leaves pinnate; leaflets opposite, sessile or nearly so, linear or linear-lanceolate, slightly unequal-sided, rather abruptly rounded at the base, acuminate or obtuse at the apex; margin perfectly entire; nervation, except for a strong midrib, mainly obsolete.

This species is represented by one leaf that has the petiole preserved complete-2.5 centimeters long-with parts of two sessile leaflets, as well as by a considerable number of detached leaflets. The smallest is about 8 millimeters long and the longest 28 millimeters long. The width is 2 or 3 millimeters. The leaflets are evidently thick, as hardly anything but the midrib is discernible.

This species is very closely related to and perhaps identical with Mimosites linearifolius Lesquereux ${ }^{72}$ from the lake beds at Florissant, Colo., but appears to differ in being less fulcate and less sharply pointed: In one of the leaflets there is a slight indication that the midrib is excurrent.

This species is similar to certain of the smallest leaflets of Mimosites variabilis Berry, ${ }^{73}$ from beds of Wilcox age in the Lagrange formation of western Tennessee and Kentucky, and from the Wilcox group of Mississippi, but these are more nearly elliptical with obtuse base and apex.

Occurrence: Green River formation, spring on Little Duck Creek, about 50 miles southwest of Meeker, Rio Blanco County, Colo. collected by D. E. Winchester, 1917.

\section{Order GERANIALES.}

\section{Family SIMARUBACEAE.}

Ailanthus longe-petiolata Lesquereux.

Ailanthus longe-petiolata Lesquereux, U. S. Geol. Survey Terr. Rept., vol. 8 (Cretaceous and Tertiary floras), p. 197, pl. 40, figs. $6,7,1883$.

Both figured types of this species are preserved in the United States National Museum, the leaflet being No. 1586 and the fruit No. 1587. No additional examples of either leaves or fruit have been collected, and it may stand as left by Lesquereux.

${ }_{72}$ Lesquereux, Leo, U. S. Geol. Survey Terr. Rept., vol. 7 (Tertiary flora), p. 300, pl. 59, fig. 7, 1878; idem, vol. 8 (Cretaceous and Tertiary floras), p. 203, pl. 37, figs. 10-13, 1883.

${ }^{73}$ Berry,E. W., U. S. Geol. Survey Prof. Paper 91, p. 227, pl. 45, figs. 6-11, 1916.
Occurrence: Green River formation, Uinta County (formerly wrongly called Randolph County), Wyo.

Order SAPINDALES.

Family SAPINDACEAE.

Sapindus dentoni Lesquereux.

Sapindus dentoni Lesquereux, U. S. Geol. and Geog. Survey Terr. Bull., vol. 1, p. 388, 1875 [1876]; idem, Ann. Rept. for 1874, p. 315, 1876; U. S. Geol. Survey Terr. Rept., vol. 7 (Tertiary flora), p. 265, pl. 44, figs. 2-4, 1878.

Described by Lesquereux as follows:

Leaflets with entire or slightly undulate borders, lanceolate [ 6 or 7 centimeters long, 1.1 to 1.7 centimeters wide], gradually tapering to a long acumen, rounded to the [slightly unequal-sided] base and narrowed to a.short petiole [1 centimeter long]; lateral nerves close, parallel, nearly straight to the borders, where they abruptly curve.

Unfortunately the type specimens of this species are now lost; at least, they do not appear to be in the United States National Museum, and their location is not known. Lesquereux compares these "leaflets" with those of Sapindus angustifolius Lesquereux, from the Florissant lake beds, but there are sufficient differences to separate them. They can also be compared with leaves of Eucalyptus? americanus Lesquereux, as figured in the "Tertiary flora," Plate LIX, figures 11 and 12, but as we have only the drawings to go by it is perhaps best to leave them under Sapindus.

Occurrence: Green River formation, near the mouth of White River, Utah, collected by William Denton, for whom the species is named.

Sapindus obtusifolius Lesquereux.

Sapindus obtusifolius Lesquereux, U. S. Geol. and Geog. Survey Terr. Ann. Rept. for 1873, p. 419, 1874; U. S. Geol. Survey Terr. Rept., vol. 7 (Tertiary flora), p. 266 , pl. 49, figs. 8-11, 1878; idem, vol. 8 (Cretaceous and Tertiary floras), pp. 181, 235, pl. 48, figs. 5-7, 1885.

The type locality of Sapinus obtusifolius is about 8 miles southeast of Green River, Wyo., where it was found in association with Musophyllum complicatum Lesquereux and a fragment of a leaf of Carpinus grandis. The four figured types are all preserved in the United States National Museum (Nos. 392-395).

Subsequently Lesquereux ${ }^{74}$ stated that he found a single specimen with the leaflets attached in material from the lake beds at Floris-

${ }_{74}$ Lesquereux, Leo, U. S. Geol. Survey Terr. Rept., vol. 8 (Cretaceous and Tertiary foras), p. 181, 1883. 
sant, Colo. I have not seen this specimen, but Lesquereux says it is even smaller than that of figure 8 of the "Tertiary flora."

In the "Cretaceous and Tertiary floras" Lesquereux ${ }^{75}$ also reported this species from the Fort Union formation of North Dakota. The present location of the specimens so designated is not known, but they were very well figured, and from the figures it appears that, although they resemble the originals of $S$. obtusifolia, they are probably a different species. The largest lenflet is 11.5 centimeters long and 4 centimeters wide, and it seems questionable to place them with leaflets only 1 to 1.5 centimeters long. It will require a considerable series of connecting forms to show the relationship.

The recent collections from western Colorado contain a number of leaflets that are to be referred to Sapindus obtusifolius, but as they add nothing to our knowledge of the species they have not been figured.

Occurrence: Green River formation, 8 miles southeast of Green River, Wyo., collected by Leo Lesquereux, 1873; spring on Little Duck Creek, about 50 miles southwest of Meeker, Rio Blanco County, Colo., collected by D. E. Winchester, 1917.

\section{Sapindus' winchesteri Knowlton, n. sp.}

Plate XXXVIII, figure 1.

Leaflet very large, 14.5 centimeters long and 3.5 centimeters wide, lanceolate, strongly unequal-sided, broadest at about one-third of the length above the base, whence it narrows gradually to the rather obtuse apex and downward to the wedge-shaped base; nervation strong, especially the midrib, with about 16 pairs of alternate, irregularly spaced camptodrome secondaries, which arise at low angles, curve upward slightly, and arch just inside the margin, each joining the one next above; there are $a$ few intermediate secondaries and a strong secondary nervation.

This splendid species is represented by the nearly perfect leaflet figured and a number of smaller fragments. It is one of the largest, if not indeed the largest species thus far described in this country. It somewhat resembles Sapindus affinis Newberry, ${ }^{78}$ an extremely abundant form in the Fort Union, but it is more than twice the size of the ordinary

78 U. S. Geol. Survoy Torr. Rept. vol. 8, p. 235, pl. 48, figs. 5-7, 1883 70 Nowberry; J. S., U. S. Geol. Survey Mon. 35, p. 116, pl. 30, fig. 1, 1898. leaflets of that species and is much more obtuse at the apex and has a much stronger nervation. It is more like certain leaflets from the Fort Union of the Yellowstone Park identified as Sapindus affinis, ${ }^{77}$ though it is much larger and has a stronger nervation.

The only species of Sapindus heretofore noted in the Green River formation is $S$. dentoni Lesquereux; $;^{78}$ but this is a small-leaved form wholly unlike the present one:

Occurrence: Green River formation, oil shale, Smith ranch, on Greasewood Creek, about 40 miles southwest of Meeker, Rio Blanco County, Colo., collected by D. E. Winchester, 1917.

\section{Family ANACARDIACEAE.}

Rhus lesquereuxii Knowlton and Cockerell.

Rhus lesquereuxii Knowlton and Cockerell, U. S. Geol. Survey Bull. 696, p. 552, 1919.

Rhus acuminata Lesquereux, U. S. Geol. and Geog. Survey Terr. Ann. Rept. for 1871, Suppl., p. 8, 1872; U. S. Geol. Survey Terr. Rept., vol. 8 (Cretaceous and Tertiary floras), p. 194, pl. 42, figs. 14-17, 1883. [Homonym, De Candolle, 1865.]

The type locality for Rhus acuminata Lesquereux is Green River, Wyo., above the socalled fish beds, but the type specimen is not known to be in the collection of the United States National Museum and is presumably lost. It has not subsequently been found in the Green River formation, the figured specimens being from the lake beds at Florissant, Colo. (U. S. Nat. Mus. Nos. 1871-1874). Its status as a Green River species is therefore open to question.

Occurrence: Green River formation, Green River, Wyo., above the fish beds.

Rhus variabilis (Newberry) Knowlton, n. comb.

Planera variabilis Newberry, U. S. Nat. Mus. Proc., vol. 5 p. 508, 1883; U. S. Geol. Survey Mon. 35, p. 83 , pl. 66 , fig. 7 [not figs. 5 and 6 , which $=$ Planera inaequilateralis (Lesquereux) Knowlton], 1898.

Leaf firm in texture, lanceolate, about 6 centimeters long and 2 centimeters wide, acute at the apex, evenly wedge-shaped (at about $45^{\circ}$ angle) at the base; margin coarsely and somewhat irregularly toothed; petiole stout, at least 1 centimeter long; midrib strong; secondaries numerous, irregularly spaced, parallel, at a low angle, ending in the margin.

" Knowlton, F. H., U. S. Geol. Survey Mon. 32, pt. 2, pl. 102, figs. $1-3,1899$.

${ }_{78}$ Lesquereux, Leo, U. S. Geol. Survey Terr. Rept., vol. 7 (Tertiary flora), p. 265, pl. 64, figs. 2-4, 1883. 
This species is based on one of the figured types of Newberry's Planera variabilis. At the time it was made a type Newberry apparently had some misgiving, for he said:

Possibly future collections will prove that the narrower, more rigid form with the deeply cut and acute serrations and parallel, nearly straight lateral veins, shown in figure 7 , belongs to a different species; but in the very large number of Planera leaves before me it is impossible to make any division without making several. They are therefore all grouped together for the present.

He further adds that he had at his disposal a large number of specimens that seem to connect the two forms, but as these are not available it appears best to consider them as distinct.

It may also be pointed out that the leaf under discussion seems to be congeneric with Myrica (now Rhus) nigricans Lesquereux ${ }^{79}$ and for this reason has been transferred to the genus Rhus. It is more nearly lanceolate and has rather coarser marginal teeth, but otherwise does not greatly differ. It is not contained in any of the more recent collections.

Occurrence: Green River formation, Green River, Wyo. (one of the types of Planera variabilis), collected by C. A. White.

Rhus nigricans (Lesquereux) Knowlton, n. comb.

Myrica nigricans Lesquereux, U. S. Geol. and Geog. Survey Terr. Ann. Rept. for 1871, Suppl., p. 6, 1872; U. S. Geol. Survey Terr. Rept., vol. 7 (Tertiary flora), p. 132, pl. 17, figs, 9-12, 1878.

Myrica nigricans was described as follows by Lesquereux:

Leàves nearly sessile, alternate, oblong or linear-lanceolate, acuminate, round-cuneate to the base, obtusely dentate; nervation camptodrome.

He supplemented this description with the following remarks:

The leaves of this species are like those of the former [Myrica undulata? Heer], only narrower, all narrowly lanceolate or linear-lanceolate, narrowed to a long acumen, and about sessile or with a very short petiole about 1 millimeter long. They are more or less unequal at the base, distantly obtusely dentate in the middle.

Three of the figured types of this species are preserved in the United States National $\mathrm{Mu}-$ seum (figs. 9-11, Nos. 401a, 150, 151) and are seen to be fragmentary. The specimen shown in figure 9 is evidently the one on which is based the statement that the leaves are simple and

${ }^{79}$ Lesquereux, Leo, U. S. Geol. Survey Terr. Rept., vol. 7 (Tertiary flora), p. 132, pl. 17, figs. 9-12, 1878 . alternate, but a close view of the original disclosed that there was a piece of the matrix covering the point of attachment of one leaf, and when this was removed they were found to be practically opposite. They are slightly unequal-sided and in my opinion are leaflets of a pinnately compound leaf. This conclusion. of necessity removes the form from Myrica, which has simple leaves, and it seems to justify their reference to Rhus. The other types are also slightly unequal-sided and are probably conspecific. The margin is undulate-toothed in these three-figured specimens, but another figure (fig. 10a) shows the margin with sharp teeth.

Occurrence: Green River formation, Green River, Wyo., northwest of station and above the fish beds, collected by.F.. V. Hayden, 1868.

\section{Rhus myricoides Knowlton, n. sp.}

Plate XXXVII, figures 9-11.

Leaflets of firm texture, narrowly lanceolate, prolonged above into a slender acuminate tip, abruptly narrowed and unequal-sided at the base; margin entire for a short distance at the base, thence strongly toothed, the teeth deltoid, pointing upward; petiolule short, stout; midrib relatively strong, especially below; secondaries and intermediate secondaries numerous, mainly alternate, thin, emerging at a low angle, slightly curved upward, craspedodrome, the stronger ones entering the teeth, the others at intermediate points; finer nervation obscure.

This species is represented by a number of very well preserved leaflets, three of the most. nearly perfect of which have been figured. The length was apparently from about 5.5 to 6.5 centimeters and the width approximately 1 centimeter. The petiolule is very short, hardly exceeding 2 milimeters.

This species is undoubtedly most closely related to Rhus nigricans (Myrica nigricans Lesquereux ${ }^{80}$ ) - in fact, they may be identical. Rhus myricoides appears to differ in being more strongly toothed and to a minor degree in the nervation.

Occurrence: Green River formation, Smith ranch, on Greasewood Creek, about 40 miles. southwest of Meeker, Rio Blanco County, Colo., collected by D. E. Winchester, 1917.

${ }^{80}$ Lesquereux, Leo, U. S. Geol. Survey Terr. Rept., vol. 7 (Tertiary flora), p. 132, pl. 17, figs. 9-12, 1878. 


\section{Family CELASTRACEAE.}

Euonymus flexifolius Lesquereux. .

Euonymus flexifolius Lesquereux, U. S. Geol. Survey Terr. Rept., vol. 8 (Cretaceous and Tertiary floras), p. 183, pl. 38 , fig. 1.3, 1.883 .

This splendid species is described as follows by Lesquereux:

lueaves large [16.5 centimeters long, 5 centimeters wide], ovate-ncuminate from an oval base, flexures at the apex, narrowed from the middle to the petiole, sharply deeply serrate; secondary nerves alternate, equidistant and parallel, camptodrome.

The single type specimen is the only one thus far obtained. It is No. 1585 of the United States National Museum collection.

Occurrence: Green River formation, Uinta County (formerly incorrectly called Randolph county), Wyo.

\section{Family ACERACEAE.}

\section{Acer lesquereuxii Knowlton.}

Acer lesquereuxii Knowlton, U. S. Geol. Survey Bül. 152, p. $26,1898$.

Accr indivisum Lesquereux, U. S. Geol. Survey Terr. Rept., vol. 8 (Cretaceous and Tertiary floras), p. 180, pl. 36, figs. 6, 9, 1883. [Homonym, Weber, 1852.]

Lesquereux's original description reads as follows:

Leaves small, of thin texture, round-truncate in outline, five-nerved and five-lobed; lobes entire, sharply aćuminate; sinuses broad, entire or dentate in the middle; petiole comparatively long, inflated under the point of attachment.

The leaves are 5.5 centimeters broad between the points of the upper lobes and only 4 centimeters long from the top of the petiole, which is 5.5 centimeters long.

The type of the leaf on which this species is based is preserved in the United States National Museum (No. 1582), but the fruits also made cotypes are not to be found here. This species has not been found in subsequent collections.

Occurence: Green River formation, Uinta County (formerly wrongly called Randolph County), Wyo., collected by F. V. Hayden.

\section{Family ILICACEAE.}

Ilex? affinis Lesquereux.

Ilex affinis Lesquereux, U. S. Geol. and Geog. Survey Terr. Ann. Rept. for 1871, Suppl., p. 8, 1872; U. S. Geol. Survey Terr. Rept., vol. 7 (Tertiary flora), p. 270, pl. 50, figs. 2, 3, 1878.

This species is based on two examples, both of which were figured by Lesquereux, and both are in the United States National Museum collection (Nos. 400, 401). They are fragmentary, as he states, both having lost the upper portion. Lesquereux says:

These leaves, inequilateral at base, seem like pinnules of a compound leaf. The midrib is thick, the secondary veins numerous, parallel, inequidistant, and, at an open angle of divergence, either enter the point of the teeth and, by their branches, follow the borders in festoons or are truly camptodrome, with nervilles passing up from the back of the curves into the teeth.

Lesquereux questioned the generic reference of these leaves, and it is more than probable that they should be placed elsewhere, but they are so fragmentary that affinities are interpreted with difficulty, and it may be best to leave them for the present in Ilex.

Occurrence: Green River formation, Green River, Wyo., above the fish beds.

Ilex maculata Lesquereux.

Ilex maculata Lesquereux, U. S. Geol. Survey Terr. Rept., vol. 8 (Cretaceous and Tertiary floras), p. 186, pl. 44, fig. 5, 1883.

The single type specimen (No. 1603, U. S. Nat. Mus.) is the only one recorded of this species. It is poorly preserved and the generic reference is open to more or less question.

Occurrence: Green River formation, Alkali stage station, about 30 miles north of Green River, Wyo.

\section{Ilex vyomingiana Lesquereux.}

Ilex vyomingiana Lesquereux, U. S. Geol. Survey Terr. Rept., vol. 7 (Tertiary flora), p. 270, pl. 50, fig. 1, 1878.

The type of this species (No. 399, U. S. Nat. Mus.) is so fragmentary and obscure that it is difficult to interpret. Its reference to Ilex may well be questioned, but as no other relationship can reasonably be suggested it is left as placed by Lesquereux.

Occurrence: Green River formation, Green River, Wyo., above the fish beds.

\section{Order RHAMNALES.}

Family RHAMNACEAE.

\section{Zizyphus longifolia Newberry.} Plate XL, figure 7.

Zizyphus longifolia Newberry, U. S. Nat. Mus. Proc., vol. 5, p. 513, 1882 [1883]; U. S. Geol. Survey Mon. 35, p. 119, ipl. 65 , figs. 3, 4 [not fig. 5, which= Zizyphus cinnamomoides Lesquereux], 1898.

Leaves evidently very firm in texture, 7.5 to 9.5 centimeters long, about 1.5 centimeters 
wide, lanceolate, rather abruptly rounded to the obtusely wedge-shaped base, long pointed at apex; margins waved or more or less distinctly toothed; petiole slender, at least 2 centimeters long; midrib well defined from base to summit; lateral nerves or ribs arising with the petiole and nearly as strong, passing up close to the margin for nearly one-half the length of the blade, then joining the lowest pair of secondaries on the midrib; secondaries three or four pairs, alternate, curving upward, forming a festoon near the margin; nervilles finely reticulated.

Newberry figured three specimens as the types of this species, and all are preserved in the United States National Museum (Nos. 7020, 7021, 7022). Of these, two (figs. 3 and 4 of his plate) agree with the above description and are here taken as typical of Zizyphus longifolia. The other specimen is obviously different-in fact, it agrees with $Z$ izyphus cinnamomoides Lesquereux ${ }^{81}$ as Newberry himself. pointed out, and it is transferred to that species. Newberry states that Zizyphus longifolia is very abundant in the collections submitted to him and is usually associated in the beds with Lygodium and Acrostichum.

In the collections from, western Colorado I find several leaves of this species, one of which I have figured. It is a narrow leaf about 8 centimeters long and 1.6 centimeters wide. Its margin is provided with remote, low, rounded teeth. The nervation is that described and figured for the species.

Occurrence: Green River formation, Green River, Wyo.; oil shale at Smith ranch, on Greasewood Creek, about 40 rniles southwest of Meeker, Colo., collected by D. E. Winchester, 1917.

Zizyphus cinnamomoides (Lesquereux) Lesquereux.

Zizyphus cinnamomoides (Lesquereux) Lesquereux, U. S. Geol. Survey Terr. Rept., vol. 7 (Tertiary flora), p. 277, pl. 52, figs. $7,8,1878$.

Zizyphus longifolia Newberry, U. S. Geol. Survey Mon. 35 , pl. 65, fig. 5 [not figs. 3, 4], 1898.

Ceanothus cinnamomoides Lesquereux, U. S. Geol. and Geog. Survey Terr. Ann. Rept. for 1871, p. 289, 1872.

Leaves of firm texture, 5 to 9 centimeters long, 1.5 to 2.5 centimeters wide, oblong or ovate-lanceolate, broadest at or a little below the middle, woedge-shaped below, prolonged

81 Lesquereux, Leo, U. S. Geol. Survey Terr. Rept., vol. 7 (Tertiary flora), p. 277 , pl. 52 , figs. $7,8,1878$. above into a slender point; . margin more or less crenate from a point well above the base of the blade; triple-nerved from the top of the petiole, the midrib straight, with four or five pairs of thin secondaries in the upper part; lateral nerves or ribs closer to the margin than the midrib, joining the lowest pair of secondaries; finer nervation irregularly recticulate.

Lesquereux based this species on two leaves from Green River shale, both of which lack the upper portion. Later Newberry received material from the same locality and from it he characterized his Zizyphus longifolia. Of the three types figured by Newberry two are alike and are long, narrow, three-nerved leaves, but the other is clearly identical with Lesquereux's Zizyphus cinnamomoides and has been transferred to it.

Ward ${ }^{82}$ identified a single small leaf from the Fort Union formation near Glendive, Mont., with Lesquereux's Zizyphus cinnamomoides, but it has a very different nervation and mist be excluded.

Occurrence: Green River formation, Green River, Wyo.

\section{Family VITACEAE.}

\section{Cissus parrottiaefolia Lesquereux.}

Cissus parrottiaefolia Lesquereux, U. S. Geol. and Geog. Survey Terr. Bull., vol. 1, p. 388, 1875 [1876]; idem, Ann. Rept. for 1874, p. 314, 1876; U. S. Geol. Survey Terr. Rept:, vol. 7 (Tertiary flora); p. 239, pl. 40, figs. 15-17; pl. 42, fig. 1, 1878.

The three types of this species supposed to be from Green River, Wyo., are in the United States National Museum (Nos. 343, 344, 345). The matrix is rather soft yellowish sandstone, quite unlike anything from the Green River beds with which I am familiar, and there is doubt as to the propriety of continuing this as. a Green River species.

Occurrence: Green River formation, Green River, Wyo., west of station.

Parthenocissus tertiaria (Lesquereux) Knowlton, n. comb. Ampelopsis tertiaria Lesquereux, U. S. Geol. and Geog. Survey Terr. Ann. Rept. for 1871, Suppl., p. 7, 1872 ; U. S. Geol. Survey Terr. Rept., vol. 7 (Tertiary flora), p. 242, pl. 43, fig. 1, 1878.

The type and only specimen of this species found is preserved in the United States National Museum (No. 361) and has been

B2 Ward, L. F., U. S. Geol. Survey Sixth Ann. Rept., for 1884-85, p. 554 , pl. 52 , fig. 3 , 1886; idem, Bull. 37 , p. 74 , pl. 33, fig. 7, 1887. 
fairly well characterized by Lesquereux. The two leaflets on the left-hand side are represented as broken, but really they pass under one of the type specimens of Juglans schimperi and can not be excavated without destroying tho Juglans.

Occurrence: Green River formation, Green River, Wyo., above the fish beds.

\section{Order MYRTALES.}

Family MYRTACEAE?

Eucalyptus? americanus Lesquereux.

Plate XXXIX, figures 1-3.

Eucalyptus? americana Lesquereux, U. S. Geol. Survey Terr. Rept., vol. 7 (Tertiary flora), p. 296, pl. 59, figs. $11,1.2,1878$.

Eucalyptus americanus Lesquereux, U. S. Geol. and Geog. Survey Terr. Ann. Rept. for 1871, Suppl., p. 7, 1872.

Apocynophyllum scudderi Lesquereux, U. S. Geol. Survey Terr. Rept., vol. 8, (Cretaceous and Tertiary floras), p. 172, pl: 45, $A$, figs. 1-5, 1883.

Salix angusta Al. Braun? Newberry, U. S. Geol. Survey Mon. 35, p. 54, pl. 65, fig. 2, 1898.

Leaves coriaceous in texture, narrowly lanceolate, gradually tapering upward from below the middle into a long, narrow acumen and narrowed in nearly the same degree to the base, slightly unequal-sided and very slightly undulate; petiole very thick, about 1 centimeter long; midrib extremely thick, especially below, where it merges into the petiole; lateral nerves thin, immersed in the substance of the leaf, emerging at angles of $30^{\circ}$ to $45^{\circ}$, about 5 millimeters apart, irregular, many of them with intermediate nerves that join others at various distances below the margin; the main nerves all terminate in a strong, continuous intramarginal vein which is about 1 millimeter from the margin; finer nervation consisting of very thin, irregular veins oblique to the principal veins.

These are splendid leaves, clearly coriaceous or leathery in texture. There is considerable range in size, the larger ones being nearly 13 centimeters long and about 2 centimeters wide and the smaller ones 6 or 8 centimeters long and 1.5 centimeters wide. The petiole, which is enlarged at the point of attachment, does not exceed 1 centimeter in length.

The types of Eucalyptus? americana as figured by Lesquereux in the "Tertiary flora" (pl. 59, figs. 11, 12) are preserved in the United States National Museum (Nos. 489, 489a). The best preserved leaf is a nearly perfect one 12 centi- meters long and 1.5 centimeters wide. The other was a larger leaf, fully 2 centimeters wide, but lacks the upper portion. The nervation is that above described.

In 1883 Lesquereux ${ }^{83}$ described some rather fragmentary leaves from Alkali station under the name Apocynophyllum scudderi. These specimens are in the United States National Museum (Nos. 1605-1609) and are before me. Although they are somewhat smaller than the types of Eucalyptus? americanus, they clearly belong with them. They have the same coriaceous texture, very thick midrib, thin, immersed lateral veins, and continuous intramarginal vein. They seem properly to be referable to Eucalyptus? americanus.

The leaf figured by Newberry ${ }^{84}$ as Salix angusta Al. Braun? is also preserved in the United States National Museum (No. 7023) and clearly belongs to Eucalyptus? americanus. It comes from Green River and is said by Newberry to be exceedingly common, "some slabs of the rock being quite covered with the leaves." Newberry does not mention the strongly marked intramarginal vein, though it is shown in his figure and, of course, in the specimen.

The propriety of referring these leaves to the genus Eucalyptus may perhaps be open to question, as it is doubted by some that this genus ever reached America. Be that as it may, their facies-long, narrow, coriaceous leaves with exceedingly thick midrib and deeply immersed veins running into a strong intramarginal vein-is distinctly that of Eucalyptus, and I have retained them as left by Lesquereux. There are some other things that are to be considered in this connection. Thus Lesquereux in the original discussion of his Eucalyptus? americanus compares them to species of Tricera from Cuba. This is a euphorbiaceous genus with narrow leaves having a nervation similar to that of Eucalyptus. I have not seen these leaves and so can not say anything as to their probable affinity with the Green River leaves under consideration.

Berry ${ }^{85}$ has described as Ficus myrtifolius some narrow leaves from the Wilcox group

${ }_{83}$ Lesqucreux, Leo, U. S. Geol. Survey Tẹr. Rept., vol. 8 (Cretaceous and Tertiary floras), p. 172 , pl. $45, A$, figs. $1-5,18 \$ 3$.

84 Newberry, J. S., U. S. Geol. Survey Mon. 35, p. 54, pl. 65, fig. 2, 1898. 85 Berry, E. W., U. S. Geol. Survey Prof. Paper 91, p. 205, pl. 30 figs. $1-3,1916$. 
that he says are nearest to Lesquereux's Apocynophyllum scudderi. The Wilcox leaves are of about the same size and shape as Lesquereux's species and have the thick midrib and well-marked intramarginal vein, but the lateral veins are almost at right angles and are more numerous than in the Green River leaves.

Occurrence: Green River formation, Green River, Wyo., above the fish beds, types collected about 1870 by F. V. Hayden, others collected by C. A. White and still later by L. F. Ward; Alkali stage station, about 30 miles north of Green River, type locality for Apocynophyllum scudderi, collected by F. V. Hayden; Cathedral Bluff, south of Little Tommies Draw, about 20 miles west of Rio Blanco post office, Rio Blanco County, Colo., in sec. 35, T. 4 S., R. 100 W., Colo., and above oil shale, head of trail up ridge between Carr and Bushy creeks, Garfield County, Colo., collected by D. E. Winchester, 1917.

\section{Order UMBELLALES.}

\section{Family ARICACEAE.}

Aralia wyomingensis Knowlton and Cockerell.

Plate XXXIX, figure 4; Plate XL, figure 12.

Aralia wyomingensis Knowlton and Cockerell, U. S. Geol. Survey Bull: 696, p. 88, 1919.

Aralia macrophylla Newberry, U. S. Nat. Mus. Proc., vol. 5, p. 513, 1882 [1883]; U. S. Geol. Survey Mon. 35, p. 121 , pl. 67 , fig. 1 ; pl. 68 , fig. 1, 1898. [Homonym, Lindley, 1844.]

This species was described by Newberry as follows:

Leaves large, long-petioled, palmately five-parted from the middle upward, divisions conical in outline, sometimes entire, often remotely, occasionally coarsely toothed; nervation strong and regular; the midrib of the divisions strong and straight, those from the second lateral lobes springing from near the bases of the first lateral lobes; secondary nerves numerous, distinct, curved gently upward; where the margins are entire, partially camptodrome; where dentate, terminating in the teeth; tertiary nerves anastomosing to form quadrangular and very numerous areoles.

In speaking of the occurrence of these leaves, Newberry says:

In the localities where they are found the leaves of $A$. macrophylla [A. wyomingensis] are exceedingly abundant, sometimes matted together so as to obscure their outlines. These show that they vary in size, in the number of lobes, and in the character of the margins, occasionally one occurring which is only three-lobed, while almost all are five, and the margins are sometimes nearly entire, while in other leaves they are all strongly; even spinously, dentate. The leaves vary from 3 to 12 inches in length, and the lobes are sometimes long and narrow, in others much broader.

The two figured types of this species, both preserved in the United States National $\mathrm{Mu}$ seum, are large leaves, hence the name macrophylla was very appropriate, but in Newberry's discussion of the species he states that they range in length from 3 to 12 inches.

In the collections recently made in western Colorado there are a number of leaves that must be referred to Aralia wyomingensis. Two of these have been figured. One (Pl. $\mathrm{XL}$, fig. 12) is a very small leaf only 6 centimeters long and a little over 7 centimeters wide, with slender petiole 2 centimeters long. The other (Pl. XXXIX, fig. 4) is somewhat larger, probably 12 or 14 centimeters long and some 12 centimeters broad.

The leaf from Bridger Pass, W.yo., described by Lesquereux ${ }^{80}$ under the name Aralia? gracilis, may belong here, but it is so fragmentary that it can not be compared fully with Aralia wyomingensis.

Occurrence: Green River formation, Green River, Wyo. (types), collected by C. A. White; Cathedral Bluff, south of Little Tommies Draw, about 20 miles west of Rio Blanco post office, Rio Blanco County, Colo.; collected by D. E. Winchester, 1917.

\section{Order ERICALES.}

\section{Family ERICACEAE.}

Andromeda delicatula Lesquèreux.

Andromeda delicatula Lesquereux, U. S. Geol. Survey Terr. Rept., vol. 8 (Cretaceous and Tertiary floras), p. 175, pl. 34, figs. 10, 11, 1883.

The two type specimens on which this fine species is based are preserved in the United States National Museum (Nos.. 1580, 1581) and have been very well described and figured by Lesquereux. The species has not been since collected in the Green River formation, but has been reported from the supposed upper Eocene of British Columbia and the Fort Union formation of the Bull Mountains, Mont.; the latter is perhaps doubtful.

Occurrence: Green River formation, Uinta County (formerly wrongly called Randolph County), Wyo.; Eocene, Tranquille River, British Columbia; Fort Union formation, Bull Mountains, Mont.

${ }^{86}$ Lesquereux, Leo, U. S. Geol. Survey Terr. Rept., vol. 7 (Tertiary flora), p. 236, pl. 39, fig. 1, 1878. 
Order RUBLALES.

Family CAPRIFOLIACEAE.

Sambucus? winchesteri Knowlton, n. sp.

Plate XL, figures 8, 9 .

This flower is very small, having a spread of only about 4 millimeters. In the exact center is a circular mass of black carbonaceous substance that is without any observable structure. The flower is perfectly regular, with five oblong obtuse petáls, alternating with which are the five stamens. At first sight it appears that the petals are free, but as the actual insertion of both petals and stamens is obscured by the central carthonaceous mass, it is possible that the corolla is slightly gamopetalous-in fact, if the identification given is correct the petals must be slightly united. The petals are about 1.7 millimeters long and 0.8 millimeter broad, and each has three relatively strong veins which run from the base nearly to the apex. The stamens are slightly more than half the length of the petals and have large anthers.

A great many flowers have been studied in comparison with this fossil flower, and all things considered it seems to approach Sambucus most closely. This genus has the calyx tube ovoid or turbinate, adnate to the ovary, with its limb three to five toothed, and the corolla rotate $\left({ }^{\prime}\right.$ ) slightly campanulate, regular, and usually five-lobed; the five stamens are inserted on the base of the corolla.

The fossil flower under consideration seems to agree fairly well with the above diagnosis, at least so far as can be made out, but as there are some points that can not be settled with certainty, the generic reference has been questioned. This flower is named in honor of the collector.

Occurrence: Green River formation, oil shale, Rio Blanco County, about 40 miles southwest of Meeker, Colo.; collected by D. E. Winchester.

\section{Order CAMPANULALES.}

Family COMPOSITAE.

Achaenites cichorioides Knowlton, n. sp. Plate XL, figure 4.

Achene narrowly obconical, about 7 millimeters long, 2 millimeters in diameter at the top, strongly ribbed (apparently four-ribbed) with several (at least three) thinner intermediate strine; pappus simple, apparently sparse, .. not barbed, about 7 millimeters long.

$91048^{\circ}-23-12$
This little achene, the only one found in the collection, is surprisingly well preserved considering the delicate nature of some of its parts. The achene itself was evidently hard and resistant and apparently has suffered little distortion. It is strongly ribbed or ridged, especially in the lower part, and from the disposition of these ridges it seems probable that they were four in number, but this is of course somewhat uncertain. The pappus is certainly simple and without obvious barbs; it was at least as long as the achene. It appears to occupy a single ring around the outer edge of the flat-topped achene.

It is perhaps hazardous to attempt a close comparison of this fossil achene with those of any living species, though it may be pointed out that it seems to fall within the family Cichoriaceae, whence the specific name adopted for it. It is; for instance, suggestive of the achenes in certain species of Nabalus, Hieracium, etc., but more evidence will be needed before it.can be placed in any living genus. It is believed to be the first composite achene from this country to be described.

A word may be said as to the selection of the generic name for this achene. The genus Achaenites was established by Braun $^{87}$ in 1851 , with $A$. ungeri as the type species. It was not figured at that time, but in the Neues Jahrbuch for 1854 Braun described and figured it. It is an oblong, long-beaked achene with a plumose pappus:- and came from the Swiss Miocene.

In 1859 , when Heer ${ }^{88}$ came to the consideration of the numerous fruits of the Compositae found in the Miocene of Switzerland, he established the genus Cypselites, with which he merged Braun's Achaenites, notwithstanding the fact that the latter had some eight years priority. Heer described and figured no less than 19 species under his Cypselites, which he stated probably really belong to a number of different genera. None of them seem to be very close to the Green River species under discussion.

The law of priority does not sanction the substitution of one genus for another without reason, and therefore Achaenites will have to be restored for Heer's species of Cypselites. Moreover, Achaenites is more appropriate than Cypselites for these obvious acheries.

Occurrence: Green River formation, above rich oil shale, Camp Gulch, about 25 miles northwest of De Beque, Colo., collected by D. E. Winchester, 1917.

\footnotetext{
${ }^{87}$ Braun, Al., in Stizenberger, Ernst, Uebersicht der Versteinerungen des Grossherzogthums Baden, p. 83, 1851.
}

${ }_{88}$ Heer, Oswald, Flora tertiaria Helvetiae, vol. 3, p. 2,1859 
PLANTS OF UNCERTAIN POSITION. Antholithes improbus Lesquereux.

Antholithes improbus Lesquereux, U. S. Geol. Survey Terr. Rept., vol. 8 (Cretaceous and Tertiary floras), p. 204, pl. 40, figs. 20, 21, 1883.

Both the figured types of this peculiar organism are preserved in the United States National Museum (No. 1666). I am not able to interpret them any more satisfactorily than Lesquereux did.

Occurrence: Green River formation, Uinta County (formerly wrongly called Randolph County), Wyo.

Carpolithus caryophylloides Knowlton, n. sp. Plate XXXVII, figure 13.

The collections from western Colorado made by Winchester include the little specimen here figured. It is apparently a dry capsule, ovoid in shape, about 5 millimeters long and 4 millimeters in diameter at the base, and with a slender pedicel 2 millimeters long. It appears to be made on the plan of five, and is split down about half its length, each segment being apparently bifid at the apex and with a strong central rib or ridge.

This specimen is so small and indifferently preserved that it is difficuls of interpretation. From the fact that it is not much crushed or distorted the inference is drawn that it was a dry capsule that had discharged its seeds when entombed. It may be split down for more than half its length, but it does not seem to be.

It is of course more or less hazardous to attempt to refer this capsule to a living genus or even family, and consequently. it has been placed in the form genus and convenient catchall Carpolithus, until it can be more definitely assigned. However, it may be pointed out that this specimen undoubtedly has a strong albeit superficial likeness to the capsule of certain Caryophyllaceae, as, for example, the genus Lychnis. The several species of Lychnis have a globular or ovoid one-celled capsule that opens by the splitting apart of the ten or five segments, which are often two-cleft at the apex. The capsule of Lychnis dioica Linné is especially suggested by this Green River capsule.

Occurrence: Green River formation, Smith ranch, on Greasewood Creek, about 40 miles southwest of Meeker, Rio Blanco County, Colo,. collected by D. E. Winchester, 1917.

\section{Carpites viburni Lesquereux.}

Carpites viburni Lesquereux, U. S. Geol. and Geog. Survey Terr. Bull., vol. 1, p. 382,1875 [1876]; U. S. Geol. Survey Terr. Rept., vol: 7 (Tertiary flora), p. 305, pl. 60 , figs. $26,26 \mathrm{a}, 1878$.
The original description by Lesquereux reads as follows:

Seeds or nutlets cordate, obtuse, 5 to 7 millimeters long, 3 or 4 millimeters broad, convex, grooved in the middle from the point to the base, surrounded by a membranaceous pellicle, the remains of an apparently fleshy outer envelope.

They resemble seeds of a similar kind which I have found in great quantity at Golden [Colo.] and referred to the genus Viburnum.

A complication has arisen concerning the locality from which this species came. At the time it was named and described it was distinctly stated by Lesquereux to have come from Alkali stage station, 30 miles north of Green River, Wyo., but three years later, when it was described and figured in the "Tertiary flora," the locality was given as Black Buttes, Wyo. The type specimen is fortunately preserved in the United States National Museum (No. 494), and it is there recorded in Lesquereux's handwriting as coming from Black Buttes. There is reason to believe, however, that the original assignment is correct, and that it really came from Alkali station and hence from the Green River formation, and not from Black Buttes. The matrix is a fine-grained yellowish sandstone, similar in character to that of other specimens from Alkali station, and, moreover, the temporary label affixed to the specimen by Lesquereux is an oval, blue-bordered "sticker" identical with those used on other specimens from Alkali station, whereas those on the specimens from Black Buttes are of a different shape and bordered with red. No specimens from Black Buttes were described by Lesquereux in the report in which the specimens from Alkali station were described, and, further, it seems inherently improbable that a mixture would occur when a collection from a given locality was first considered. It is believed that this species actually came from Alkali station, and it will be so regarded hereafter.

Occurrence: Green River formation, Alkali stage station, 30 miles north of Green River, Wyo. [incorrectly accredited to Black Buttes, Wyo.].

Carpites newberryana Knowlton, $n$. sp.

Juglansoccidentalis Newberry, U. S. Geol. Survey Mon. 35, p. 34, pl. 66, figs. 4a -4c, 1898 [not figs. 1-4].

This species was characterized by Newberry as follows:

Fruit small, elongated, somewhat prismatic; divisions of the envelope lenticular in outline, narrow, thin.

The fruit, of which fortunately one specimen was found in immediate contact with the leaves, is small, marked with raised lines, elongate in form, and resembles more the fruit of 
Carya olivaeformis [Hicoria pecan Britten?] than any other of our living species. ' It might be inferred from the size of the nut and its elongated form that it was immature, but near it lies a segment of the envelope which has apparently exfoliated at maturity. As only one specimen of the fruit has been discovered, it is possible that it does not represent the average size and form.

Newberry placed this form under Juglans, although he expressly states that it clearly belongs to Hicoria, but justified this disposition on the ground of the wider limit of the old genus Juglans. He also stated that the fruit is in "immediate contact". with the leaves, but a study of the types, which are preserved in the United States National Museum, shows that they are merely associated with leaves of Juglans occidentalis on the same piece of matrix but are not in organic comnection with them or in $\boldsymbol{B}$ position that suggests such union: It therefore seems necessary to transfer it to the genus to which it apparently belongs. if it has been correctly interpreted, and to give it a new name.

The three type specimens have been very carefully studied. The original of figure $4 \mathrm{a}$ is about 16 millimeters long and 7 millimeters brond near the middle. It stands on a short, stout pedicel, which is somewhat expanded and probably cup-shaped and in which rests the fruit. It has a deep longitudinal median furrow and on either side a slender ridge that nearly or quite disappears before reaching the apex. There is very little other structure or marking between the ribs or ridges.

On the same piece of matrix as the specimen just described, about 1 centimeter from it, is the specimen shown in Newberry's figure $4 \mathrm{~b}$. It is about 15 millimeters long and about 4 millimeters wide. When viewed in the position in which it was drawn for Newberry's figure it appears to be concave, much as one of the segments of the exocarp of Hicoria would appear, but when the orientation is reversed it is found to be convex.

The third specimen (Newberry's fig. 4c) is : 19 millimeters long and about 7 millimeters wide. It appears to sit in the excavated apex of the pedicel as described for the first specimen mentioned. It has a single furrow a little to one side of the middle, and there is some evidence of the presence of a thin exocarp or something of the kind on one side.

It seems to me very unlikely that these -specimens can belong to Hicoria, and they -certainly can not belong to Juglans. Under the circumstances it appears best to refer. them to the noncommittal Carpites until additional material may help to place them more definitely.

Occurrence: Green River formation, Green River, Wyo. (described and figured as fruit of Juglans occidentalis Newberry; types, U.S. Nat. Mus., Nos. 7031, 7032).

Carpites inquirenda Knowlton, n. sp. Plate XXXVIII, figure 4.

The collection from western Colorado includes a small fruit that I am not able to place biologically. It is elliptical in outline, about 6 millimeters long and 5 millimeters broad, and has an inner dark nucleus, also elliptical, about 3 millimeters long and 2 millimeters broad. This inner part has a slight projection at one end, but whether this is the apex or the point of attachment has not been determined. Similarly it is impossible with present knowledge to determine whether the outer portion is to be interpreted as a wing, or whether the whole thing is a monospermous capsule.

This organism is so little understood that it might perhaps better be omitted altogether, yet it is a very definite entity that someone may be able to interpret correctly.

Occurrence: Green River formation, oil shale, Cathedral Bluff, south of Little Tommies Draw, Rio Blanco County, Colo., collected by D. E. Winchester, 1917.

Phyllites winchesteri Knowlton, n. sp. Plate XXXVIII, figure 2.

The collections from the oil shales of western Colorado include the present nearly perfect little leaf. It seems unfortunate to be compelled to describe so fine a specimen under the name Phyllites, but I am wholly unable to suggest a generic name with any degree of assurance. It is a linear-lanceolate leaf about 3 centimeters long and 6 millimeters wide. The upper part is narrowed for fully a third the length of the blade into a sharp-pointed apex; below it is more abruptly narrowed to the rather thick petiole, which is nearly 1 centimeter in length. The margin is perfectly entire. The nervation is peculiar. In the middle and upper portions there is some indication of a thin midrib, but in the basal portion the midrib can not be differentiated. Five or six nerves of equal strength arise below the base of the blade and spread out to divide equally the area of the lower third of the leaf, with little indication that the middle one is 
the stronger. In the middle and upper portions even these nerves appear to be immersed in the leaf substance.

Occurrence: Green River formation, Rio Blanco County, 20 miles west of Rio Blanco post office, Colo., in sec. 33, T. 4 S., R. 100 W., collected by D. E. Winchester, 1917.

Phyllites fremonti Unger.

Phyllites fremonti Unger, Genera et species plantarum fossilium, p. 503, 1850

Knowlton, U. S. Geol. Survey Prof. Paper 108, p. 94, 1917.

Leaf of a dicotyledonous plant (?) Hall, in Frémont, Report of the exploring expedition to the Rocky Mountains in 1842, etc., Appendix B, p. 306, pl. 11, fig. 4, 1845.

This species has had an interesting history. It was collected by Frémont in 1843 on his celebrated exploring expedition to the Rocky Mountains and beyond and was included in a collection of plants from the vicinity of what is now Cumberland, Wyo. The plants from this locality were long supposed to be of Jurassic age but are now known to belong to the Colorado group (Frontier formation). ${ }^{80}$ The plant under consideration was placed by Hall, who described the collection, at the end of his paper with the following remarks:

Locality in the neighborhood of the specimens containing the preceding fossils and regarded by Capt. Frémont as belonging to the same formation. The rock containing them is a soft or very partially indurated clay, very unlike the hard and brittle mass containing the other species.

The probability that it did not come from the vicinity of the Cumberland locality is further strengthened by the chance statement "Fr. Aug. 17, and No. 201 of collection," which appears to mean that it was collected on Friday, August 17, whereas the others are recorded under the date August 19. Frémont's itinerary for the earlier date indicates that on that day the expedition encamped on Blacks Fork of Green River, some 40 miles east of the locality reached on August 19. In the low hills bordering the stream he found "strata containing handsome and very distinct vegetable fossils." This locality is presumably in the Green River formation, and if the above reasoning is correct it appears to dispose of the reference of this species to the Colorado flora. The type specimen is now lost, and hence a study of the matrix in which it was preserved is impossible.

${ }^{89}$ Knowlton, F. H., U. S. Geol. Survey Prof. Paper 108, pp. 73-107, 1917.
This species was named and described as Phyllites fremonti from Hall's figure. Unger fell into the usual error of ascribing it to Oregon, as the expedition went to "Oregon and north California." The above history has been given at some length for the purpose of setting forth the somewhat unsatisfactory status of this species and thus preventing future misunderstanding.

Occurrence: Green River formation(?), Blacks Fork of Green River, Wyo.

Nordenskiöldia borealis Heer.

Nordenskiöldia borealis Heer, Flora fossilis arctica, vol. 2, Abt. 3, p. 65, pl. 7, figs. 1-13, 1870.

Newberry, U. S. Geol. Survey Mon. 35, p. 137, pl. 68, figs. 4-6, 1898.

Whatever the nature of this organism may be there seems no doubt that it is identical with that described and figured by Heer.

Occurrence: Green River formation, Green River, Wyo.

Phyllites coloradensis Knowlton, n. sp. Plate XXXVIII, figure 3.

Leaf compound; rachis strong, straight; leaflets opposite, lanceolate, unequal-sided, sharply acuminate at the apex, narrowed to the base and decurrent in a narrow wing that reaches the leaflets next below; margin perfectly entire; nervation obscure, consisting of a fairly strong midrib and apparently with thin secondaries at an angle of about $40^{\circ}$, but this is uncertain.

This species is represented by the single specimen figured, which shows three pairs of opposite leaflets. The lower pairs are about 3 centimeters long and 8 or 9 millimeters wide; the next pairs are about 2 centimeters long and 5 or 6 millimeters wide, and the terminal (or uppermost pair preserved) leaflets are only 5 millimeters wide.

I am uncertain as to the generic reference of this specimen. The shape and nervation of the leaflets strongly suggest Sapindus, and it may be recalled that in certain of the living species, such as Sapindus saponaria Linné, the rachis is winged between the leaflets, as indeed it is in some living species of Rhus, but in the present specimen it is the basal portion of the leaflet that is prolonged as a narrow wing down the rachis.

Occurrence: Green River formation, spring on Little Duck Creek, about 50 miles southwest of Meeker, Rio Blanco County, Colo., collected by D. E. Winchester, 1917. 
PLATES XXXVI-XL. 


\section{PLATE XXX̄i.}

Figures 1-3. Myrica praedrymeja Knowlton. From Greasewood Creek, about 40 miles southwest of Meeker, Colo. U. S. Nat. Mus. Nos. $36557,36558,36559$. (See p. 157.)

4. Danaea coloradensis Knowlton. From Rio Blanco County, Colo., about 40 miles southwest of Meeker. Pinnule, $\times 2$. U. S. Nat. Mus. No. 36560 . (See p. 150.)

5. Danaea fendleri Underwood. Living species from Trinidad, introduced for comparison. Segment of fruiting pinnule, $\times 6$.

6. Pontederites hesperia Knowlton. From Greasewood Creek, about 40 miles southwest of Meeker, Colo. U. S. Nat. Mus. No. 36561. (See p. 154.)

7. Lygodium kaulfussii Heer. From Little Duck Creek, Rio Blanco County, Colo: U. S. Nat. Mus. No. 36582. (See p. 149.)

8. Caenomyces eucalyptae Knowlton, on leaves of Eucalyptus? americanus Lesquereux. From Little Duck Creek, about 50 miles southwest of Meeker, Colo. $\times 2$. For natural size, see Plate XXXIX, figure 2. U. S. Nat. Mus. No. 36589. (See p. 148.)

9. Same as figure $8, \times 6$. Figure retouched.

10. Caenomyces sapindicola Knowlton, on leaflet of Sapindus winchesteri Knowlton. From Greasewood Creek, about 40 miles southwest of Meeker, Colo. $\times 4$. For natural size, see Plate XXXVIII, figure 1. Figure retouched. U. S. Nat. Mus. No. 36590. (See p. 148.) 


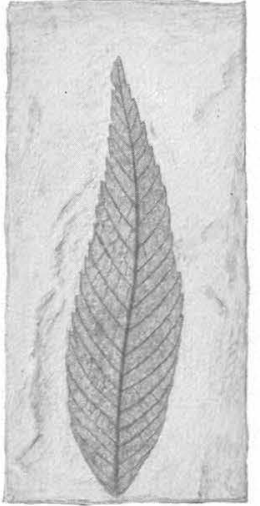

1
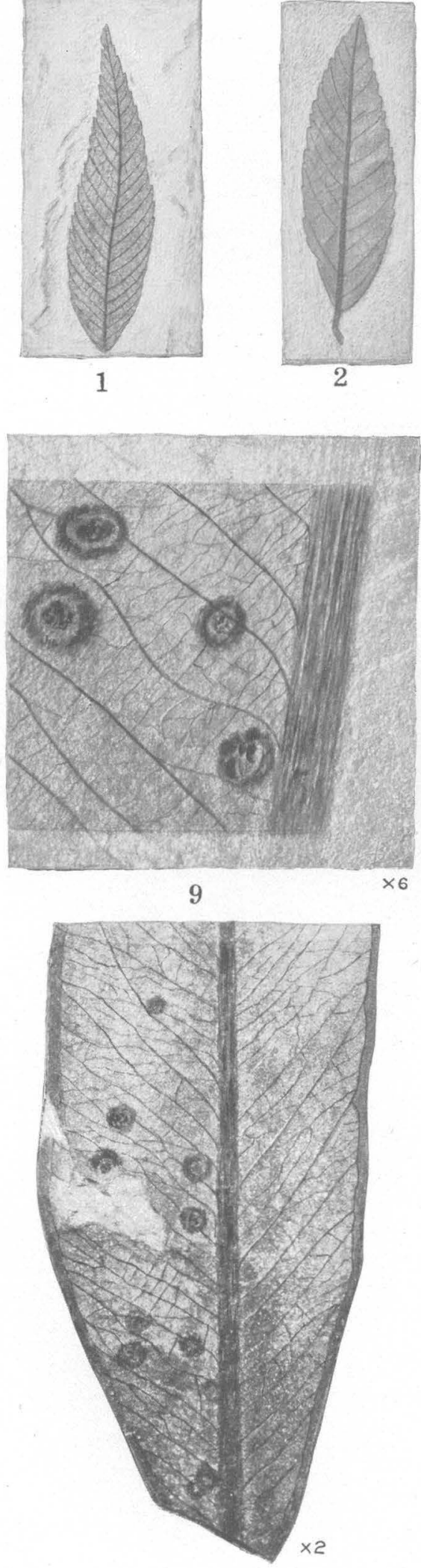

8
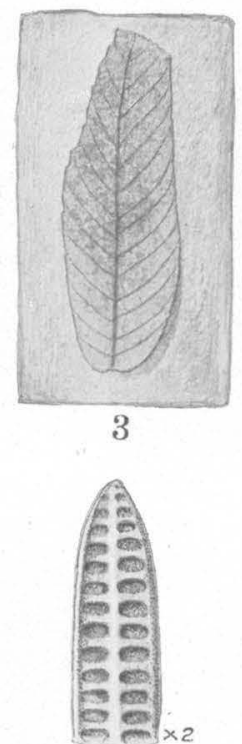

4

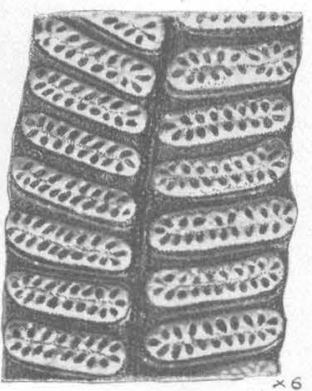

5

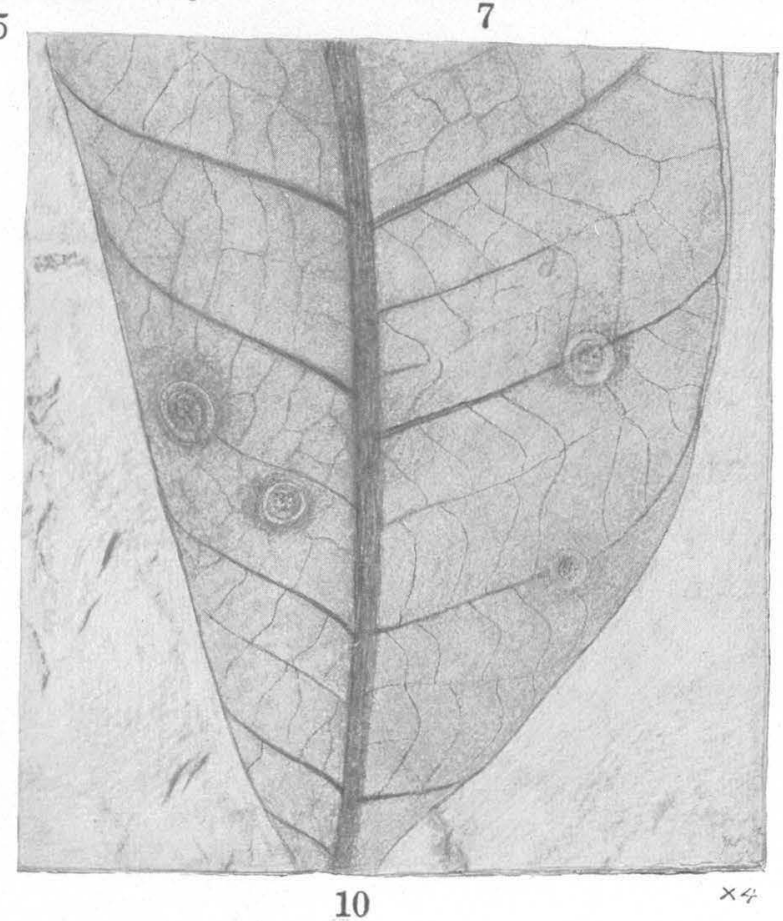

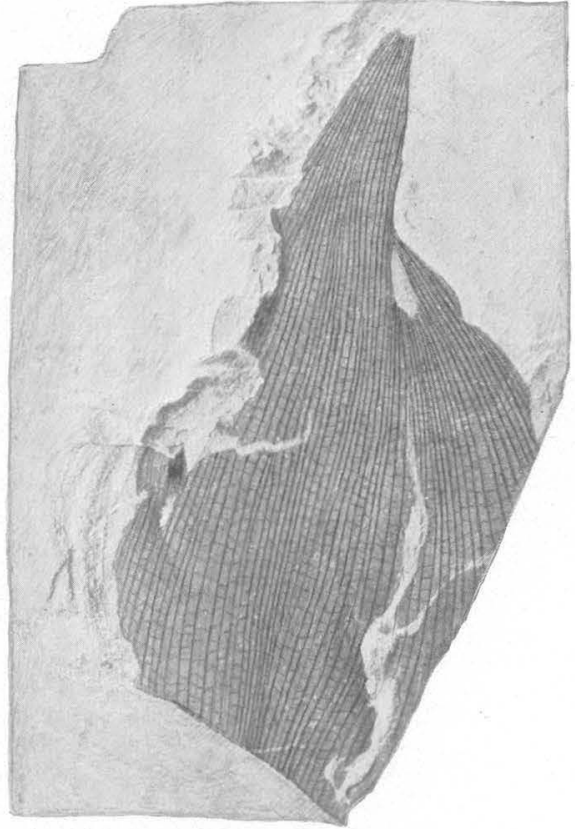

6

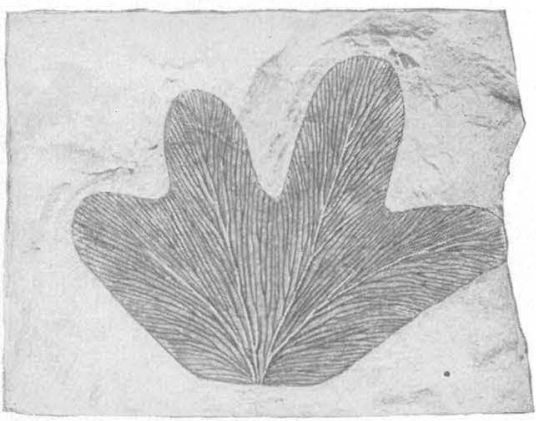


U, S, GEOLOGICAL SURVEY

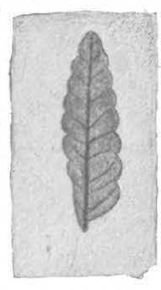

1
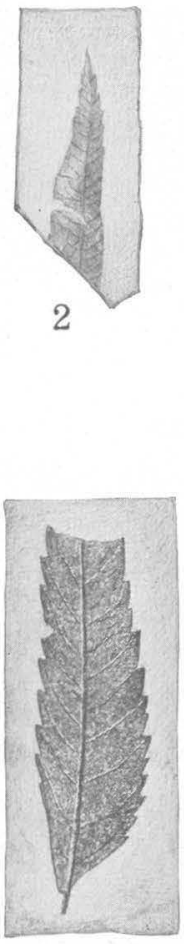

9

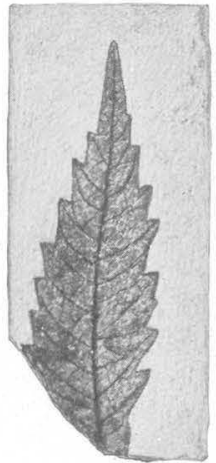

10

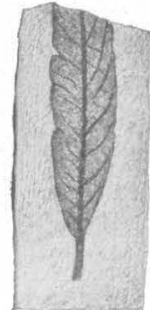

3

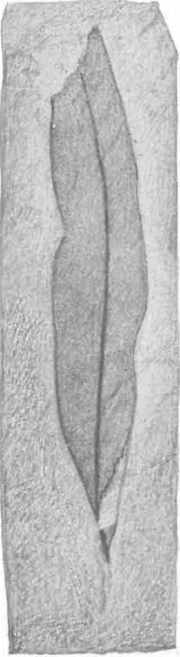

4

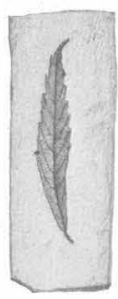

12

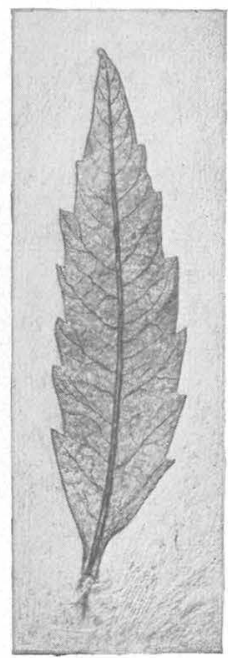

11

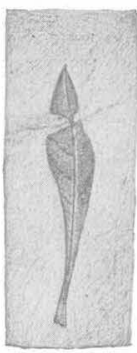

6

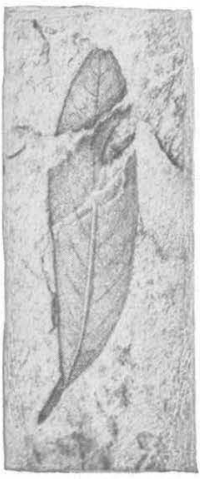

5
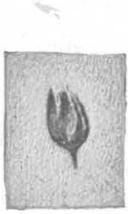

13

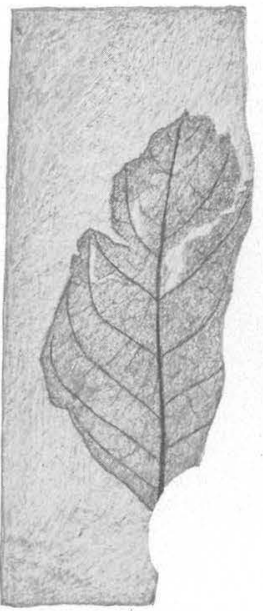

15

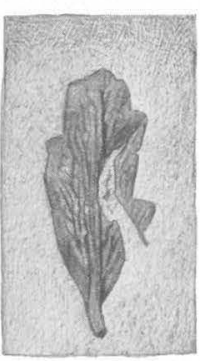

7

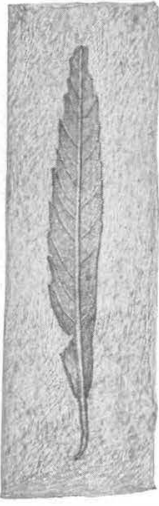

8

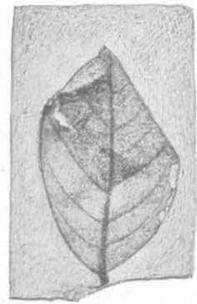

14

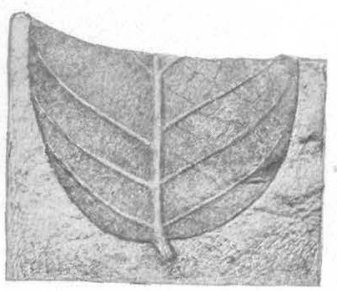

16

FLORA OF THE GREEN RIVER FORMATION. 


\section{PLATE XXXVII.}

Fiqure 1. Comptonia? anomala Knowlton. From Greasewood Creek, about 40 miles southwest of Meeker, Colo. U. S. Nat. Mus. No. 36563 . (See p. 158.)

2. Myrica sp. From Cathedral Bluff, 20 miles west of Rio Blanco post office, Colo. U. S. Nat. Mus. No. 36564. (See p. 157.)

3-5. Salix sp. From Rio Blanco County, about 40 miles southwest of Meeker, Colo. U. S. Nat. Mus. Nos. $36565,36566,36567$. (See. p. 156.)

6. Pimelea spatulata Knowlton. From Cathedral Bluff, about 20 miles west of Rio Blanco post office, Colo. U. S. Nat. Mus. No. 36568 . (See p. 163.)

7. Sedum? hesperium Knowlton. From Cathedral Bluff, about 20 miles west of Rio Blanco post office, Colo. U. S. Nat. Mus. No. 36569. (See p. 163.)

8. Salix linearis Knowlton. From Rio Blanco County, Colo., about 20 miles west of Rio Blanco post office. U. S. Nat. Mus. No. 36570 . (See p. 155.)

9-11. Rhus myricoides Knowlton. From Greasewood Creek, about 40 miles southwest of Meeker, Colo. U. S. Nat. Mus. Nos. $36571,36572,36573$. (See p. 168.)

12. Myrica minuta Knowlton. From Greasewood Creek, about 40 miles southwest of Meeker, Colo. U. S. Nat. Mus. No. 36574. (See p. 157.)

13. Carpolithus caryophylloides Knowlton. From Greasewood Creek, 40 miles southwest of Meeker, Colo. U.S. Nat. Mus. No. $36575 . \quad$ (See p. 174.)

14-16. Sophora coloradensis Knowlton. Figures 14 and 16 from Little Duck Creek, Rio Blanco County, Colo., about 50 miles southwest of Meeker; figure 15 from Camp Gulch, 25 miles northwest of De Beque, Colo. U. S. Nat. Mus. Nos. $36576,36577,36578$. (See p. 165.) 


\section{PLATE XXXVIII.}

Figure 1. Sapindus winchesteri Knowlton. From Greasewood Creek, about 40 miles southwest of Meeker, Colo. U. S. Nat. Mus. No. 36579. (See p. 167.)

2. Phyllites winchesteri Knowlton. From Cathedral Bluff, about 20 miles west of Rio Blanco post office, Cool. U. S. Nat. Mus. No. 36580. (See p. 175.)

3. Phyllites coloradensis Knowlton. From Little Duck Creek, about 50 miles southwest of Meeker, Colo. U. S. Nat. Mus. No. 36581. (See p. 176.)

4. Carpites inquirenda Knowlton. From Cathedral Bluff, about 20 miles west of Rio Blanco post office, Colo. U. S. Nat. Mus. No. 36582 . (See p. 175.)

5. Juglans winchesteri Knowlton. From Cathedral Bluff, about 20 miles west of Rio Blanco post office, Colo. U. S. Nat. Mus. No. 36583. (See p. 160.)

6. Oreodaphne viridiflumensis Knowlton. From Rio Blanco County, Colo., about 40 miles southwest of Meeker. U. S. Nat. Mus. No. 36584. (See p. 163.) 


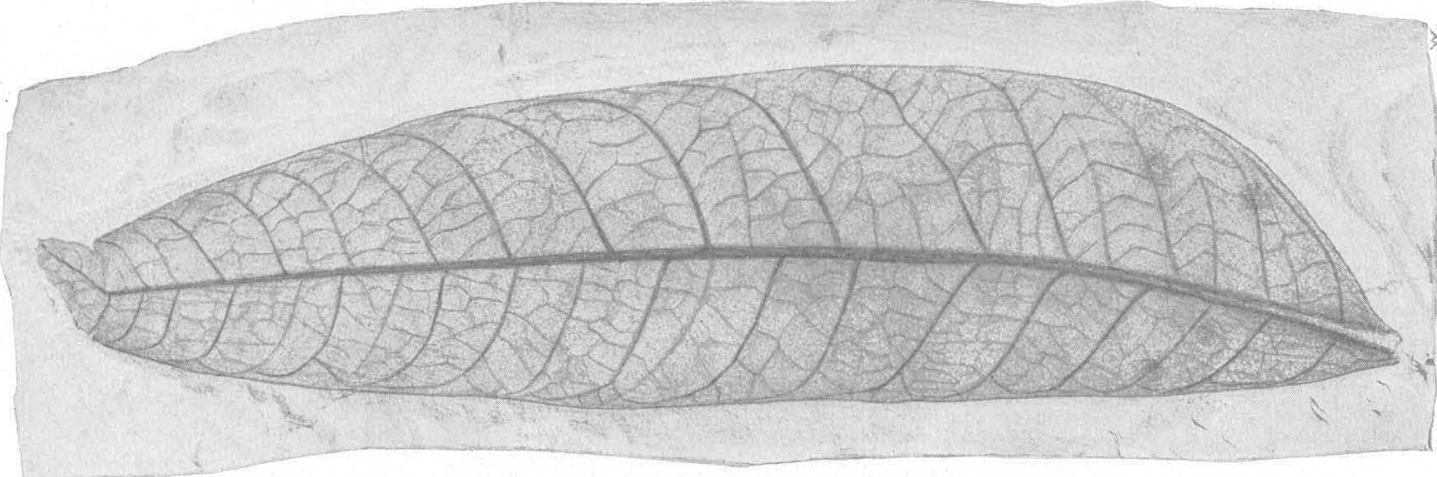

1

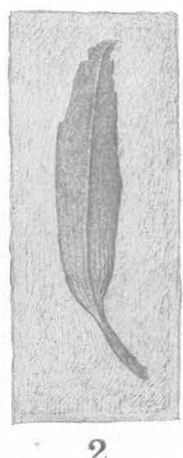

2

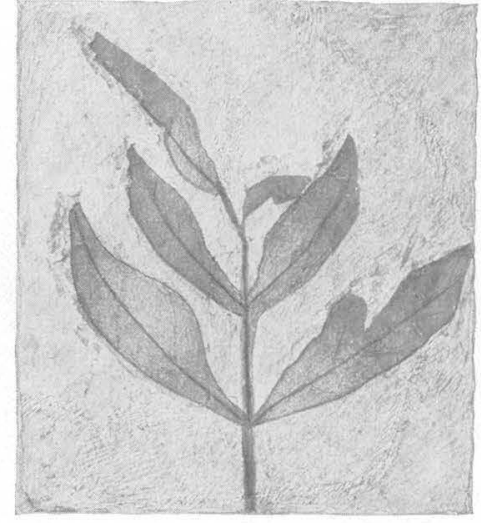

3

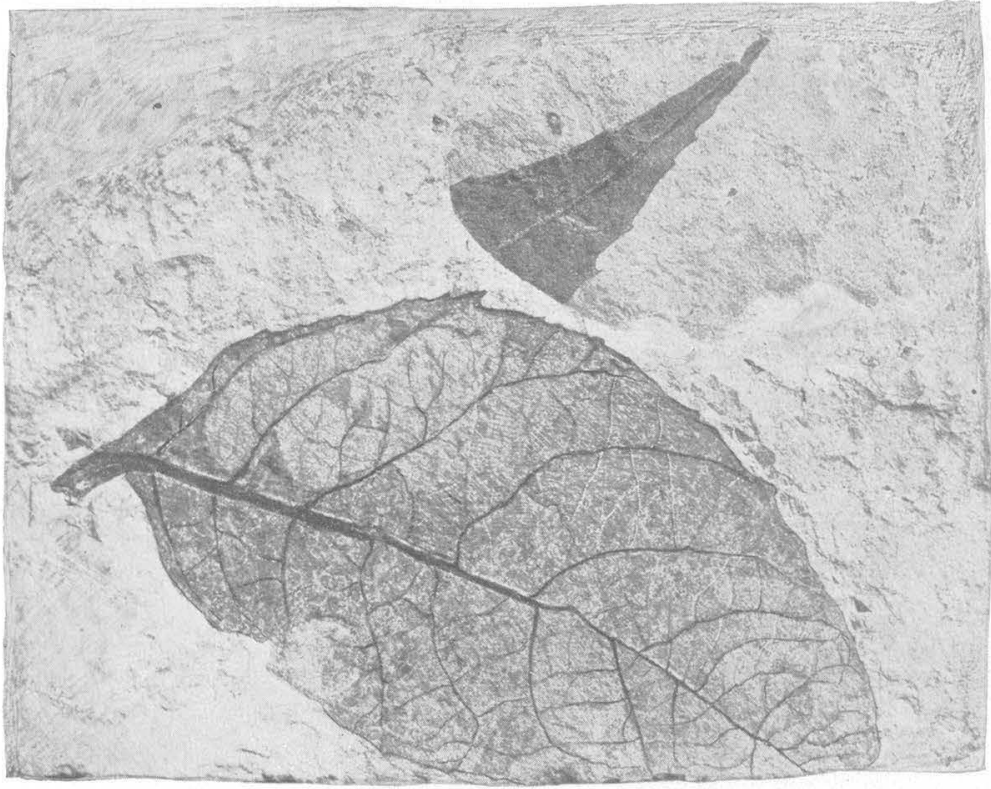

5

FLORA OF THE GREEN RIVER FORMATION.

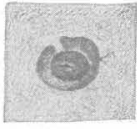

4

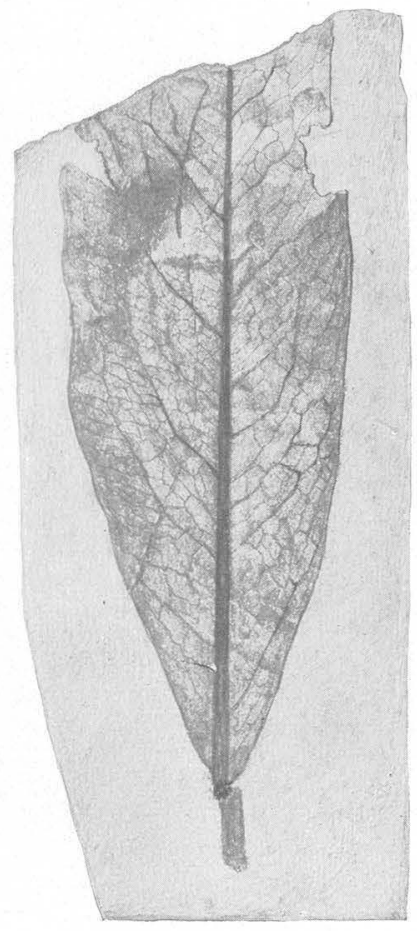

6 


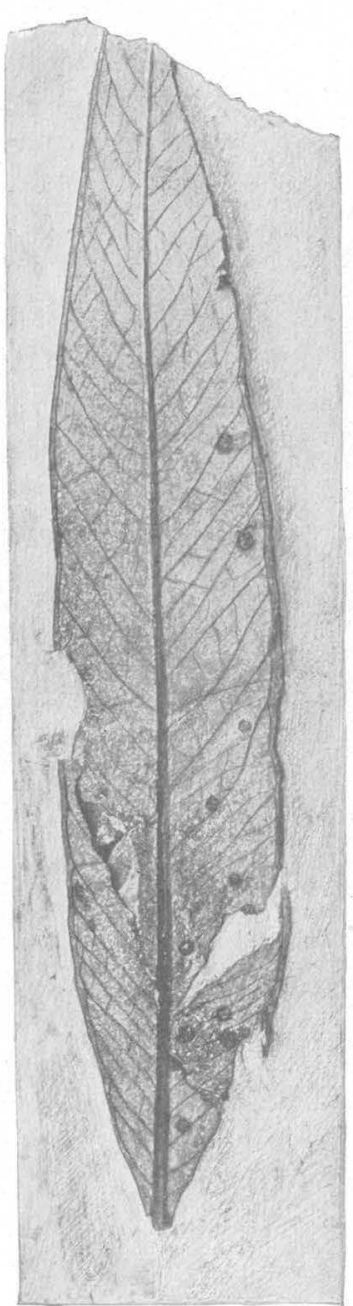

1

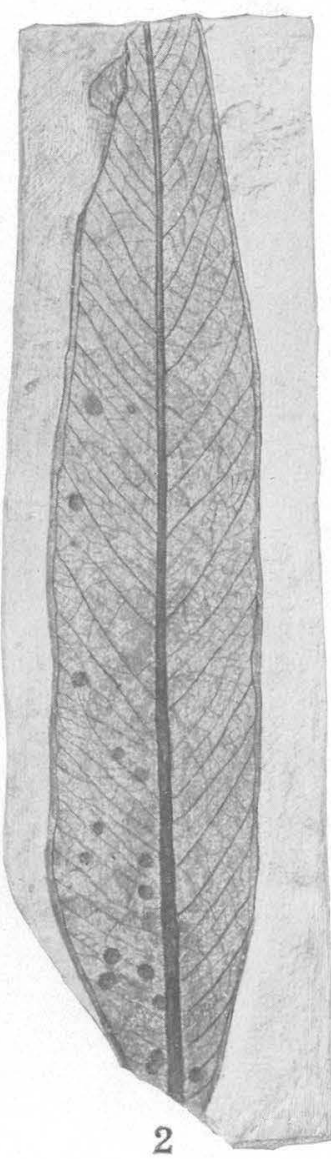

2

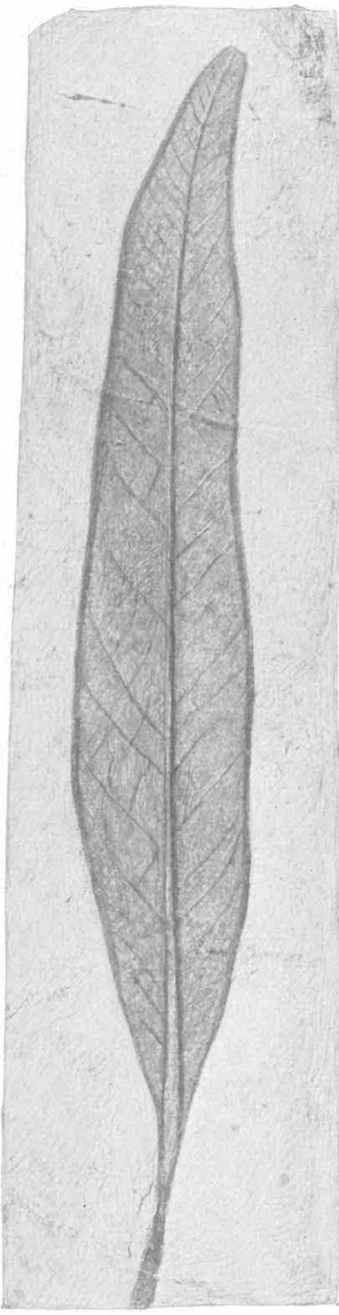

3

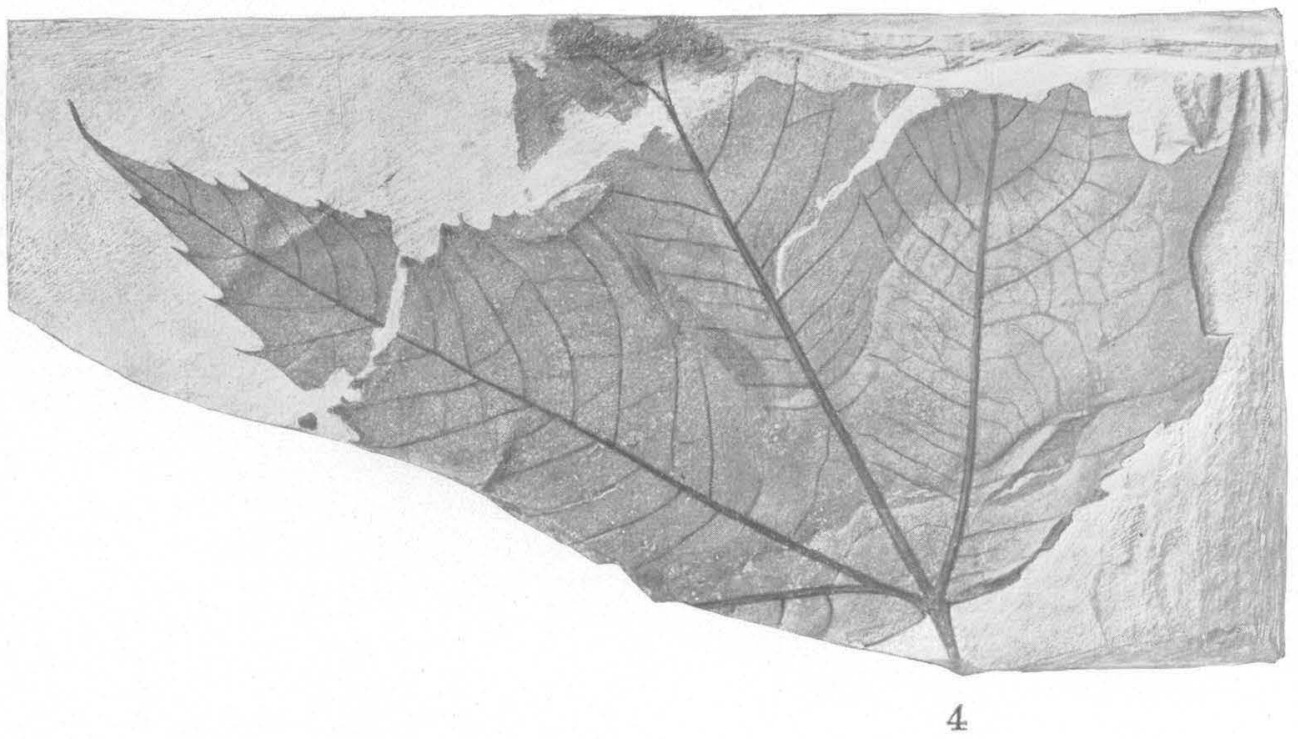

FLORA OF THE GREEN RIVER FORMATION. 


\section{PLATE XXXIX.}

Figures 1-3. Eucalyptus? americanus Lesquereux. Figures 1 and 2 from Little Duck Creek, 50 miles southwest of Meeker, Colo.; figure 3 from ridge between Carr and Bushy creeks, Garfield County, Colo. U. S. Nat. Mus. Nos. $36585,36586,36587$. (See p. 171.)

4. Aralia wyomingensis Knowlton and Cockerell. From Cathedral Bluff, about 20 miles west of Rio Blanco post office, Colo. U. S. Nat. Mus. No. 36588: (See p. 172.) 


\section{PLATE XL.}

Figures 1-3. Mimosites coloradensis Knowlton. From Little Duck Creek, about 50 miles southwest of Meeker, Colo. U..S. Nat. Mus. Nos. 36591, 36592, 36593. (See p. 166.)

4. Achaenites cichorioides Knowlton. From Camp Gulch, about 25 miles northwest of De Beque, Colo. U. S. Nat. Mus. No. 36594. (See p. 173.)

5, 6. Dalbergia retusa Knowlton. From Little Duck Creek, about 50 miles southwest of Meeker, Colo. U.S. Nat. Mus. Nos. 36595, 36596. (See p. 165.)

7. Zizyphus longifolia Newberry. From Greasewood Creek, about 40 miles southwest of Meeker, Colo. U. S. Nat. Mus. No. 36597. (See p. 169.)

8, 9. Sambucus? winchesteri Knowlton. Figure 8 , natural appearance, $\times 6$; figure 9 , restoration of figure $8, \times 9$ From Rio Blanco County, Colo., about 40 miles southwest of Meeker. U. S. Nat. Mus. No. 36598. (See p. 173.)

10. Dalbergia viridifumensis Knowlton. From Rio Blanco County, Colo., about 20 miles west of Rio Blanco post office. U. S. Nat. Mus. No. 36599. (See p. 164.)

11. Sophora coloradensis Kṇowlton. From Little Duck Creek, about 50 miles southwest.of Meeker, Colo. U. S. Nat. Mus. No. 36600 . (See p. 165.)

12. Aralia wyomingensis Knowlton and Cockerell. From Cathedral Bluff, about 20 miles west of Rio Blanco post office, Colo. U. S. Nat. Mus. No. 36601. (See p. 172.)

13. Myrica sp. From head of Carr Creek, about 30 miles northwest of De Beque, Coio. U. S. Nat. Mus. No. 36602. (See p. 158.) 
U. S. GEOLOGICAI SURVEY

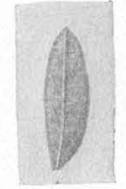

1

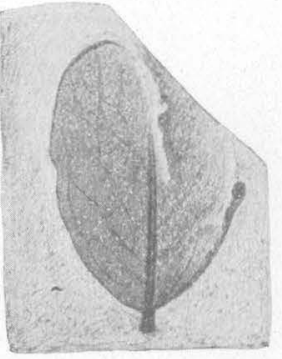

6

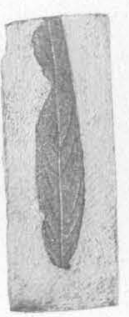

3

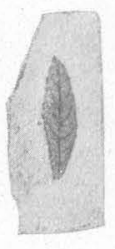

2

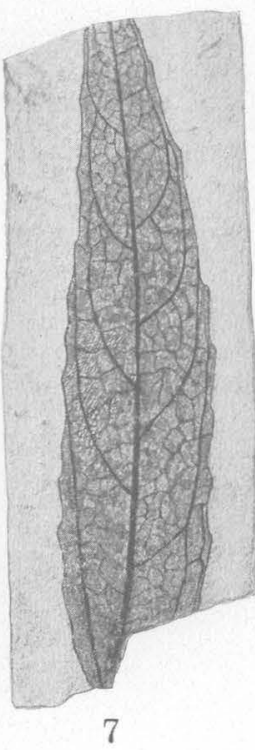

7
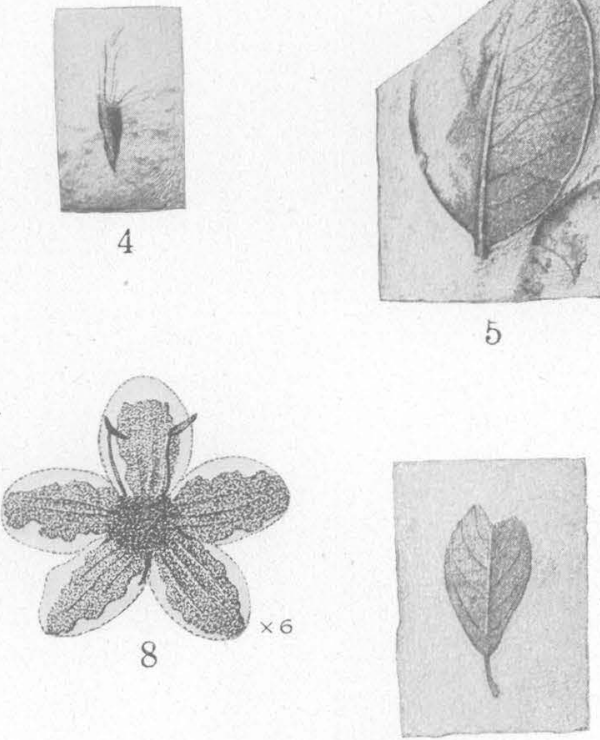

10
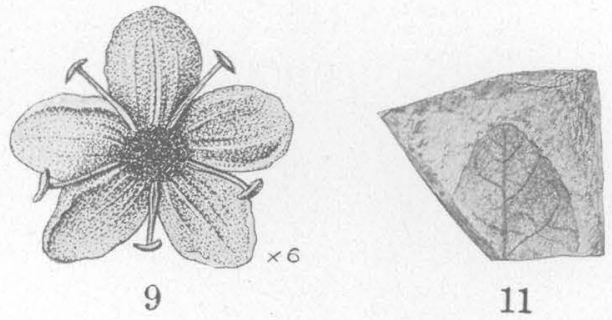

11
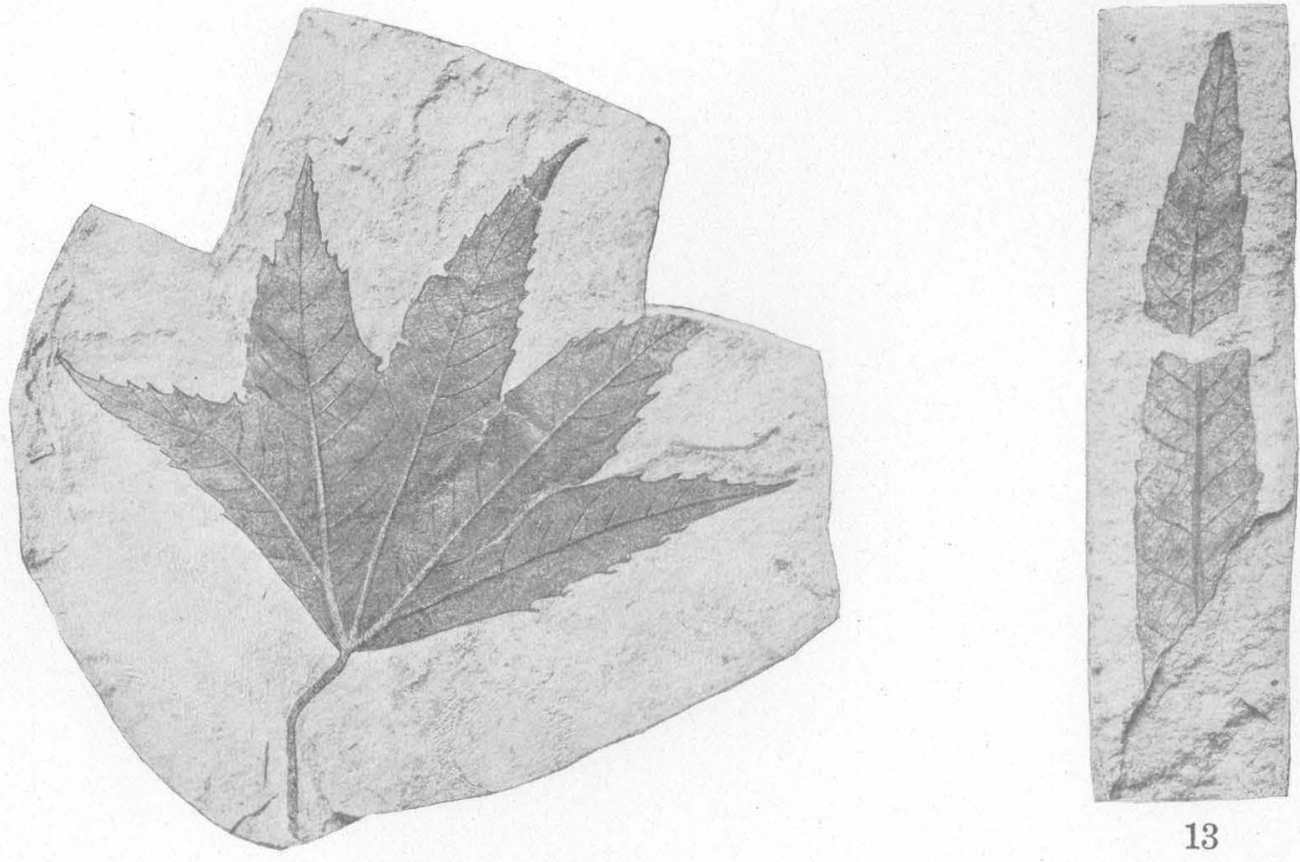


\section{FOSSIL PLANTS FROM THE TERTIARY LAKE BEDS OF SOUTH-CENTRAL COLORADO.:}

By F. H. Knowlton.

The first of the Tertiary lake beds of Colorado to be brought to scientific attention were those at Florissant, discovered in 1873 by Dr. A. C. Peale, of the Hayden Geological Survey. Lake Florissant was a small lake, approximately 5 miles in length and not much if any exceeding a mile in width, occupying a mountain valley with its laterals eroded in granite by stream action. The present altitude of the lake beds is a little more than 5,000 feet above sea level. The composition of these beds is described by Henderison ${ }^{1}$ as follows:

The beds are composed chiefly of volcanic ashes, mud, and sand, the component particles of which are generally somewhat though not very much worn by the action of water. The conclusion reached in both field and laboratory is that the deposits were formed largely by volcanic ashes from repeated eruptions falling upon the surface of the water and settling to the bottom, assorted by the sluggish lake currents; also by mud and ashes falling or flowing into position where they were rapidly washed into the lake by rains, streams, and waves without much grinding.

The Florissant lake beds have proved to be highly fossiliferous, perhaps more abundantly so than any other deposits in the world. They are especially rich in remains of plants and insects. During the period of nearly 50 years since their discovery these fossil riches have been abundantly exploited, and they are now known to include more than 1,000 species of insects and nearly 250 species of plants.

The Florissant lake beds were long supposed to be unique, but the more and more intensive geologic work prosecuted in the Rocky Mountain region, especially within the last 20 years, has disclosed a number of other lake-bed deposits in the San Juan Mountain region of south-central Colorado. The object. of the present paper is to bring to scientific attention

\footnotetext{
1 Henderson, Junius; Colorado Univ. Studies, vol. 3, pp. 145-15i, 1906.
}

the location, present known extent, and flora of these scattered lake beds. The description of the flora is purely preliminary and will undoubtedly be greatly increased with more thorough exploration.

The plants described in the following pages were all collected from rocks deposited during the volcanic period of the San Juan Mountain region, though from several different formations. The lake beds aggregate some thousands of feet in thickness, and there is evidence to show that several of the formational units were separated by periods of extensive erosion, during which canyons were cut to the depth of several thousand feet. The position in the geologic column can be understood from the accompanying generalized section, which has been supplied by E. S. Larsen, of the United States Geological Survey.

Mr. Larsen makes the following statement:

The periods of erosion separating these formations were all of sufficient length to develop canyons several thousand feet deep and a youthful topography comparable to that of the present San Juan Mountains. This no doubt represents a very great number of years but only a small fraction of the time required to develop a mature topography.

The most abundant and best-preserved plant remains were collected from the Creede formation. This formation is made up chiefly of thin-bedded rhyolite tuff in its lower part, but it carries much gravel, and some lava flows in its upper part. Some travertine is present. The formation was deposited in a deep, steep-walled basin that was cut in rocks of the Potosi volcanic series and that coincides approximately with the present valley of the Rio Grande from Wagon Wheel Gap westward to the mouth of Trout Creek, a distance of about 25 miles, but was considerably narrower. The maximum thickness is over 2,000 feet. The best plant remains were collected from the thinly laminated tuffs in the lower part of the formation. The cliffs exposed above Sevenmile Bridge are about 100 feet high and are almost continuous on the northwest bank of the river for over a mile. 
The localities and the species found at each are listed below.

Cross. No. La G. 2 [5951]. Crude formation, La Garita quadrangle, Colo. Ridge north of stream which passes Hot Spring Hotel at altitude of 9,000 feet:

Minute fragments of bark, coniferous leaves, etc., but nothing determinable.

Cross. No. La G. 24 [5952]: Creede formation, south bank of Rio Grande 150 yards above wagon bridge, $3 \frac{1}{2}$ miles below Creede, Colo.:

Feather of bird.

Planera myricaefolia (Lesquereux) Cockerell.

Fragments.

Cross. No. La G. 93 [5953]. Creede formation, west side of Rio Grande one-fourth mile north of Sevenmile Bridge, below Creede, Colo., near boundary of San Cristobal quadrangle:

Pinus crossii Knowlton, n. sp.

Abies rigida Knowlton, $\mathrm{n}$. sp.

Myrica myricaefolia (Lesquereux) Cockerell.

Feather of bird.

Cross. No. S. C. 1566 [5954]. Huerto formation, in a lens 100 yards long, N. $37 \frac{1}{2}^{\circ} \mathrm{E}$. of houses at north end of Lake Santa Maria, San Cristobal quadrangle, Colo., altitude 10,350 feet:

Pinus similis Knowlton, n. sp.

Ribes protomelaenum Cockerell.

Planera myricaefolia (Lesquereux) Cockerell?

Phyllites potentilloides Knowlton, n. sp.

Cross. 1911. No. La G. 536 [6198]. Creede formation, west side of Rio Grande near Sevenmile Bridge, near Creede, Colo., altitude 8,800-9,000 feet:

Pinus crossii Knowlton, n. sp.

Abies rigida Knowlton, n. sp.

Planera myricaefolia (Lesquereux) Cockerell.

Odostemon marginata (Lesquereux) Knowlton, n. comb.

Vitis florissantella Cockerell.

Populus lesquereuxi Cockerell.

Insect (beetle?).

Feathers.

Cross. 1914. No. 516 [6889]. Conejos (?) formation, Saguache quadrangle, Colo., gulch west of Henderson Mountain, about $1 \frac{1}{4}$ miles north of Saguache River: Coniferous wood, not further studied.

Cross. 1914. No. 437 [6858]. Saguache quadrangle, Colo., rhyolite tuff in railroad cut below (west $c^{\circ}$ ) Marshall Pass, where railroad crosses gulch at Shavano siding; geologic position uncertain but probably considerably below Conejos formation:

Pinus crossii Knowlton, n. sp.? Fragments not determinable.

Larsen. 1916. [7242]. Creede formation, north bank of Rio Grande near Sevenmile Bridge, above Creede, Colo. Pinus crossii Knowlton, n. sp. Pinus similis Knowlton, $\mathrm{n}$. sp. Pinus coloradensis Knowlton, n. sp. Pinus florissanti? Lesquereux. Abies rigida Knowlton, $\mathrm{n}$. sp. Sabina linguaefolia (Lesquereux) Cockerell. Alnus? larseni Knowlton, n. sp. Populus lesquereuxi Cockerell.
Planera myricaefolia (Lesquereux) Cockerell.

Ribes protomelaenum Cockerell.

Rubus? inquirendus Knowlton, n. sp.

Vitis florissantella Cockerell.

Odostemon marginata (Lesquereux) Knowlton, n. comb.

Odostemon hakeaefolia (Lesquereux) Knowlton, $\mathrm{n}$. comb.

Sterculia aceroides Knowlton, n. sp.

Phyllites, two sp.

From the foregoing lists it appears that 5 of the 8 collections and no less than 18 of the 19 forms enumerated come from the Creede formation. From beds believed to belong to the Huerto formation the single collection yielded three named species, all of which occur also in the Creede formation.

A complete list of forms described in this paper is as follows:

Pinus crossii Knowlton, $\mathrm{n}$, sp.

Pinus similis Knowlton, n. sp.

Pinus florissanti? Lesquereux.

Pinus coloradensis Knowlton, n. sp.

Abies rigida Knowlton, n. sp.

Abies longirostris Knowlton, n. sp.

Sabina linguaefolia (Lesquereux) Cockerell.

Populus lesquereuxi Cockerell.

Alnus? larseni Knowlton, n. sp.

Planera myricaefolia (Lesquereux) Cockerell.

Ribes protomelaenum Cockerell.

Rubus? inquirendus Knowlton $\mathrm{n}$. sp.

Vitis florissantella Cockerell.

Odostemon marginata (Lesquereux) Knowlton, $\mathbf{n}$. comb.

Odostemon hakeaefolia (Lesquereux) Knowlton, $\mathbf{n}$. comb.

Sterculia aceroides Knowlton, n. sp.

Phyllites potentilloides Knowlton, n. sp.

Phyllites, two sp.

On eliminating the forms not named there remain 8 species described as new and 8 . previously known species. As all these previously known species are found in the lake beds at Florissant, Colo., it seems reasonable to conclude that the age of the lake beds of the Creede formation is the same as that of the Florissant beds, namely, upper Miocene. From the Huerto formation were obtained three named species (Pinus similis, Planera myricaefolia, and Ribes protomelaenum) and an unamed Phyllites. All three of the named species are found in the Creede formation, and two of them are well-known Florissant. species. The only other collection-that from Marshall Pass-contains a single doubtfully identified form (Pinus crossii?) and detached 
Geologic formations in a part of southwestern Colorado.

[Supplicd by E. S. Larsen. The waved lines indicate erosion intervals.

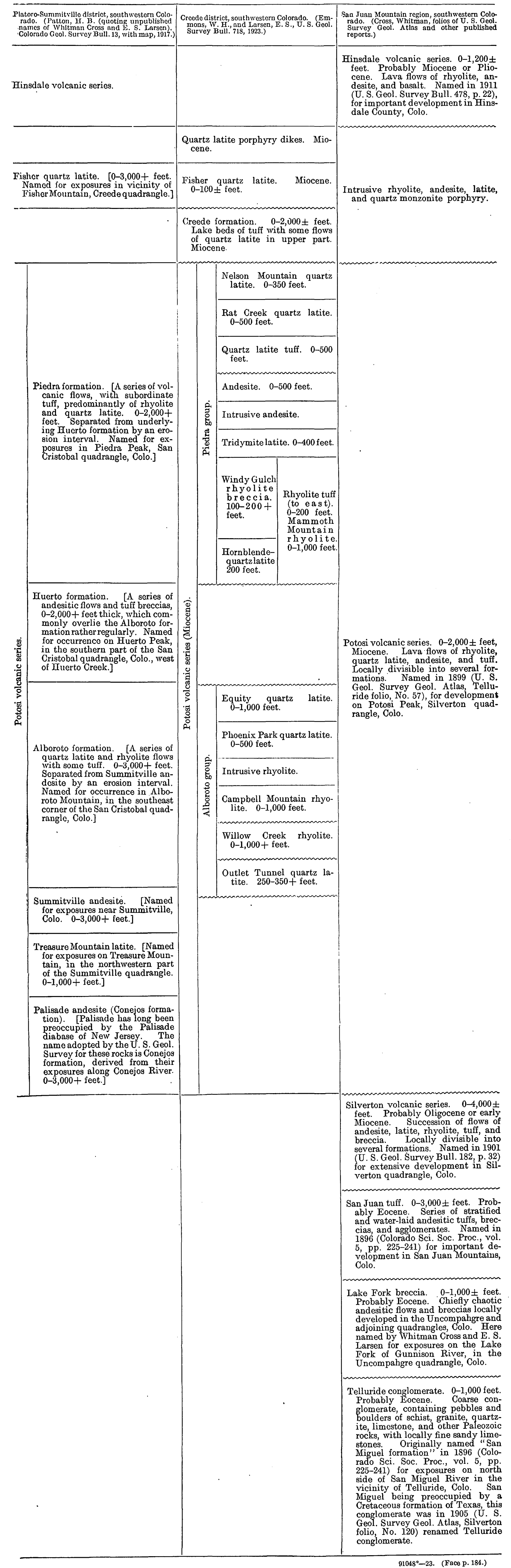


leaves of Pinus and probably Abies. This collection is supposed to be much older than the others, but its position is somewhat uncertain.

So far as present known facts go it appears that the same flora ranges through the entire thickness of these lake deposits. Although the formational units involved are hundreds of feet thick, and although many of these units are separated by unconformities representing periods of erosion during which thousands of feet of beds were cut out, the deposition of the whole series occupied relatively so short a time that the changes in conditions do not appear to be reflected in the flora. Of course subsequent studies and collections may modify this conclusion, but it is all that can be said at present.

The flora of these lake beds as described in this paper is so small that it is perhaps hardly worth while to attempt any extensive discussion of the affinity, probable origin, and climatic requirements of the species included, yet they show a number of biologic features of considerable interest. The most abundant element in the flora consists of the Coniferae, which comprise over a third of the species and nearly half of the individual specimens. Although nine forms of conifers have been reported from the Florissant lake beds, all but one or two are very rare as individuals. It is probable that the increased elevation of the Creede deposits may account for the abundance of conifers, though more extended exploration will doubtless reduce this apparent preponderance. The most interesting of these conifers are the species of Abies, of which the specimens collected represent leafy branches and cone scales. It is possible that the branches and scales may belong to a single species, but as they are wholly unconnected it has been necessary to give them separate names. The cone scales indicate the group of Abies in which the bracts adhere firmly to the scale and are prolonged above into a long, slender tip, which may be as much as 4 centimeters in length. This group seems to be most closely related to Abies venusta Koch, the so-called silver fir of California. This is the first time, at least in this country, that cone scales of this type have been observed. The pines represent both the soft or white pines and the hard pines, the former known by their cluster of leaves in fives or fours.

The next in abundance and interest are the two species of Odostemon, the genus to which the well-known Oregon grape belongs. Both species-if they are really distinct-occur also in the Florissant beds, and it is believed that they are correctly placed generically, as they agree in all essential particulars with the living species. Four living species of Odostemon are now found in the Rocky Mountain area, and it would seem that they are the direct descendants of the Miocene forms.

None of the other genera (Populus, Alnus, Ribes, Vitis) offer features of particular biologic interest. The species referred with some question to Rubus is a small spray of flowers and immature fruit that if not actually a member of this genus is certainly very strongly suggestive of it.

The climatic requirements of this little flora would seem to be temperate, perhaps cool temperate, but it is still too small to warrant a very positive conclusion.

\section{Pinus crossii Knowlton, n. sp.}

Plate XLI, figures 3, 8-10.

Leaves in clusters of five, stout, rigid, slightly incurved, sharp pointed, 2.5 to about 4 centimeters long; sheaths of the leaf clusters deciduous.

This species is represented by a number of specimens, several of the best of which are figured. It is assumed that the normal number of leaves is five in each cluster, but there are a few examples in which only three can be made out. Thus, in the fragment of a branch shown in figure 3 , there are two clusters, each with three leaves that otherwise agree with the fiveleaved clusters. Although it is not impossible for the leaves to vary in number from three to five in the same species, it seems improbable in the present case, and, as stated above, the normal number is presumed to be five.

This species seems clearly to belong to the group of soft or white pines, not only as shown by the leaves being in clusters of five but more particularly by the complete absence of the sheath to the leaf bases. It seems to be most closely related to Pinus albicaulis Engelmann, a species of alpine slopes and exposed ridges 
throughout the Rocky Mountain region, at altitudes ranging from 5,000 to 12,000 -feet.

Two species based on leaves have been described from the lake beds at Florissant-Pinus hambachi Kirchner, ${ }^{2}$ supposed to have the leaves in clusters of three, and Pinus wheeleri Cockerell, ${ }^{3}$ with the leaves in fives. In the original description of $P$. wheeleri the leaves are said to be 12 centimeters or more in length, but in descriptions of later specimens the length has been given as somewhat less. Nothing is said as to the sheath in this species, so this feature can not be compared with $P$. crossii.

Occurrence: Creede formation, north bank of Rio Grande near Sevenmile Bridge, Creede, Colo.; rhyolite tuff of unknown age but probably considerably older than Conejos formation, below (west of) Marshall Pass, Saguache quadrangle, Colo.

Pinus similis Knowlton, n. sp.

Plate XII, figures 11, 12 .

Leaves in clusters of four, stout, straight 4.5 to 5.5 centimeters long; sheath of the leaf clusters absent.

It is with considerable hesitation that this form is described as a new species, as it may be - only a slightly larger form of Pinus crossii. The base of the leaves is indistinguishable in - appearance in the two forms, and the presence of only four leaves in the cluster of $P$. similis may be due to accident, though there is no evidence of it in the best preserved example. A single detached leaf on the same piece of matrix is the largest one observed: (5.5 centimeters).

Individual leaves of this form are indistinguishable from leaves of Pinus hambachi Kirchner, ${ }^{4}$ from the Florissant lake beds, but that species is said to have the leaves in clusters of three, and the resemblance may be only superficial.

Occurrence: Creede formation, north bank of Rio Grande, near Sevenmile Bridge, Creede, Colo.; Huerto formation, north end of Lake Santa Maria, San Cristobal quadrangle, Colo.

2 Kirchner, W. C. G., St. Louis Acad. Sci. 'Trans., vol. 9, p. 179, pl. 13, fig. 3,1898 .

${ }^{3}$ Cockerell, T. D. A., Am. Mus. Nat. Hist. Bull., vol. 24 , p. 78, pl. 6, figs. 5, 11, 1908.

4 Kirchner, W. C. G., St. Louis Acad. Sci. Trans., vol. 9, p. 174, pl. 13, fig. $3,1898$.

\section{Pinus florissanti? Lesquereux.}

Plate X̨LI, figure 7.

Pinus florissanti Lesquereux, U. S. Geol.: Survey Tern. Rept., vol. 8 (Cretaceous and Tertiary floras), p. 138, pl. 21, fig. 13, 1883 .

The collection contains a single large frag-. mentary cone that seems to be the same as Pinus florissanti Lesquereux.

Occurrence: Creede formation, north bank of Rio Grande, near Sevenmile Bridge, Creede, Colo.

Pinus coloradensis Knowlton, n. sp.

Plate XLI, figure 6.

Cone with a very short, thick stalk, ovoid, very obtuse at apex, 3 centimeters long, 2.3 centimeters in diameter; scales much thickened at the end; apparently with a short spine.

The example figured is the only one of this type observed in the collections. It is fairly perfect except for a few scales at the base. By making an impression in clay the original appearance is restored, as shown in figure 6 . At first it was presumed that this specimen was probably the cone of Pinus crossii, with :which it was associated, but whereas the absence of persistent sheaths to the leaf clusters proves that form to belong to the soft pines, the thickened tips of the scales in the present form show it clearly to belong to the hard pines. This form is, for instance, not greatly unlike the cone of Pinus arizonica Engelmann, but this resemblance is doubtfully to be interpreted as a real relationship.

The only fossil species of the region and age with which this may be compared is Pinus florissanti Lesquereux, ${ }^{5}$ from the Florissant lake beds, but this is a cone 10 centimeters or more in length and 6 centimeters in diameter, and, moreover, the thickened tips. of the cone scales appear to be different.

Occurrence: Creede formation, north bank of Rio Grande, near Sevenmile Bridge, Creede, Colo.

\section{Abies rigida Knowlton, n. sp.}

Plate XLI, figures 1, 2, 4, 5.

The collection from Creede contains a number of leafy branches that appear to belong to the genus Abies, but whether they represent.

5 Lesquereux, Leo, U. S. Geol. Survey Terr. Rept., vol. 8 (Cretaceous and Tertiary floras), pl. 21, fig. 13, 1883. 
more than one species is difficult to decide. The one shown in figure 5 is a segment from a branch and is about 6 centimeters long, 6 millimeters in diameter at the base, and 5 millimeters at the rexex. It shows the scars of leaves disposed in oblique rows. On one side the leaves are attached, these being apparently rather rigid, slightly arched upward, and obtusely pointed at the tips; they are about 12 millimeters long. The branch shown in figure 2 is the tip of a branch about 4 millimeters in diameter and has the leaves preserved on all sides. The leaves are much the same as in figure 5. Leaf scars are present at several points on the branch. Figure 4 is also the tip of a branch that retains most of the leaves. The leaves seem narrower and less rigid than in the other specimens mentioned; they are 2 centimeters or more in length. The specimen given in figure 1 is a shoot segment from which most of the leaves have fallen and is figured mainly because it shows the leaf scars so plainly. The leaves appear to agree most closely with those of figure 2.

It is possible that the specimens shown in figures 1 and 2 are specifically distinct from those of figures 4 and 5, but as only one type of Abies cone has been found it seems best to keep them together for the present. It is of course not at all certain that the cone scales belong to either of the branches, though it is perhaps a fair inference that they do.

Occurrence: Creede formation, north bank of Rio Grande, near Sevenmile Bridge, Creede, Colo.

Abies longirostris Knowlton, n. sp.

$$
\text { Plate XLiI, figures } 1,2 .
$$

Cone scales thin, flat, much broader than long (16 to 18 millimeters wide, 8 to 10 millimeters long exclusive of the basal attached point); bracts of cone scales oblong, firmly attached to the scales and deciduous with them, prolonged above into a slender, rigid tip 2 to 4 centimeters long.

The collection contains a number of detached cone scales that appear certainly to belong to Abies. They are excellently preserved, the two selected for figuring being practically perfect. They show both sides of the scale. The one in figure 1 shows the back of the scale with the narrowly oblong bract firmly adhering to it and prolonged above into a rigid tip or spine fully 4 centimeters long. The other (fig. 2) exhibits the upper side of the cone scale with the bract prolonged above it for more than 4 centimeters.

This species appears to be most closely related to Abies venusta Koch, the so-called silver fir of the Santa Lucia Mountains in Monterey County, Calif.; at least it agrees with that species in some important particulars, such as the firm consolidation of the bract with the cone scale and its prolongation into the long, slender tip.

Occurrence: Creede formation, north bank of Rio Grande near Sevenmile Bridge, Creede, Colo.

Sabina linguaefolia (Lesquereux) Cockerell.

Sabina linguaefolia (Lesquereux) Cockerell, Colorado Univ. Studies, vol. 3, p. 175, 1906; Am. Mus. Nat. Hist. Bull., vol. 24, p. 79, 1908.

Knowlton, U. S. Nat. Mus. Proc., vol. 51, p. 249, 1916. Widdringtonia linguaefolia Lesquereux, U. S. Geol. Survey Terr. Rept., vol. 8 (Cretaceous and Tertiary floras), p. 139, pl. 21, figs. 14, 14a, 1883.

This characteristic species is represented by a single branch with two or three short branchlets.

Occurrence: Creede formation, north bank of Rio Grande near Sevenmile Bridge, Creede, Colo.

Populus lesquereuxi Cockerell.

Plate XLIV.

Populus lesquereuxi Cockerell, Torrey Bot. Club Bull., vol. 33, p. 307, 1906.

Populus heerii Saporta. Lesquereux, U. S. Geol. Survey Terr. Rept., vol. 8 (Cretaceous and Tertiary floras), p. 157, pl. 30, figs. 1-8; pl. 31, fig. 11, 1883.

The basal portion with its petiole complete of a very large leaf is all that was found of this species. The petiole is nearly 3 millimeters thick and 7.5 centimeters long. The width of the blade is slightly more than 6 centimeters.

This leaf is similar in size to the largest one figured by Lesquereux (op. cit., pl. 30, fig. 5), which lacks the basal portion and the petiole, which the present leaf supplies. Lesquereux's leaf must have been nearly or quite 24 centimeters in length.

Occurrence: Creede formation, west bank of Rio Grande near Sevenmile Bridge, Creede, Colo. 
Alnus? larseni Knoẉlton, n. sp.

Plate XLII, figure 3.

Leaf small, evidently firm in texture, elliptical, about equally narrowed to both base and apex; margin sharply serrate; petiole long, slender; nervation faintly preserved, consisting of a relatively strong midrib and seven or eight pairs of thin secondaries at an angle of about $40^{\circ}$; finer nervation not retained.

Only a single specimen of this form with its counterpart was found in the collection. It is regularly elliptical, 6 centimeters long and 2.8 centimeters wide, with the petiolt preserved for a length of 1.5 centimeters.

I am a little in doubt as to the generic reference of this leaf. In living species of Alnus the margin is often doubly serrate, sometimes crenate-dentate, and only rarely-as, for instance, in Alnus maritima Nuttall-simply serrate. The present leaf is similar to Alnus corrallina Lesquereux, ${ }^{6}$. from the Miocene of California, but it has fewer, more irregular secondaries. The finer nervation can not be compared.

The species is named in honor of Esper S. Larsen, of the United States Geological Survey, who collected it.

Occurrence: Creede formation, north bank of Rio Grande near Sevenmile Bridge, Creede, Colo.

Planera myricaefolia (Lesquereux) Cockerell.

Plate XLIII, figures $16,17$.

Planera myricaefolia (Lesquereux) Cockerell, Am. Mus. Nat. Hist. Bull., vol. 24, p. 88, 1908.

Knowlton, U. S. Nat. Mus. Proc., vol. 51, p. 266, pl. 21, fig. 2, 1916.

Planera longifolia myricaefolia Lesquereux, U. .S. Geol. Survey Terr. Rept., vol. 8 (Cretaceous and Tertiary floras), p. 161, pl. 19, figs. 14-27, 1883.

The collection from Creede contains about a dozen leaves that are undoubtedly identical with this species. They are smaller than the average leaves figured by Lesquereux, though not smaller than the smallest one.

Occurrence: Creede formation, north bank of Rio Grande near Sevenmile Bridge, Creede, Colo. Huerto formation, north end of Lake Santa Maria, San Cristobal quadrangle, Colo.

${ }^{6}$ Lesquereux, Leo, U. S. Geol. Survey Terr. Rept., vol. 8 (Cretaceous and Tertiary floras), pl. 51, figs. $1-3,1883$.
Rubus? inquirendus Knowlton, n. sp.

Plate XLIII, figure 11.

Inflorescence racemose, main axis zigzag, about 14 millimeters long, flowers scattered, pediceled, the pedicels slender, 2 or 3 millimeters long; calyx inferior, five-parted; fruit (?) obscure.

It is with some hesitation that this little inflorescence is referred to Rubus. It is very small and delicate, and the preservation is not all that could be desired. Neither the main axis nor the pedicels are provided with prickles or glands, nor is each pedicel subtended by a bract, as in many living species; but, on the other hand, there are a number of recent species without all or some of these features. The calyx is very obscure. It appears certainly to be inferior and five-parted, though only three lobes are preserved in any one flower. The central part of the "flower" is so poorly preserved that its exact nature can not be made out with certainty. It may consist of a definite number or possibly a mass of carpels.

It is possibly unwise to attempt even a tentative placing of this fragment, but fossil flowers and fruits are so rare that even poorly preserved specimens may have some value. This form is perhaps definite enough to permit its recognition if again found.

Occurrence: Creede formation, north bank of Rio Grande near Sevenmile Bridge, Creede, Colo.

\section{Ribes protomelaenum Cockerell.}

Plate XLII, figures 5-9.

Ribes protomelaenum Cockerell, Am. Mus. Nat. Hist. Bull., vol. 24, p. 93, pl. 7, fig. 15, 1908.

This species was founded on a single example from the Florissant lake beds and is described "as being about 4.6 centimeters long and fully 6 centimeters broad. It is described as having the base deeply cordate, "the sides of the basal portion rounded, without lobes." The figure shows that the basal portion is entirely absent on one side, and the other appears rather indefinite.

The collection from Creede contains about a dozen leaves referred to this species, of various sizes and very perfectly preserved. They are all distinctly five-lobed, and the 
basal lobes are smaller than the upper lobes and in some specimens nearly entire. The largest leaf (fig. 8) is 5.3 centimeters long to the top of the petiole and 5.7 centimeters broad. It has the petiole preserved for a length of 1 centicleter. The next in size (fig. 9) is absolutely perfect and is 3 centimeters long and 4 centimeters broad between the upper lobes. The petiole complete is 1.8 centimeters long. Still smaller leaves are shown in figures 5-7. Figure 7 represents an almost perfect leaf 1.7 centimeters long and 2.3 centimeters wide, with the petiole 1.2 centimeters long.

Ribes protomelaenum resembles closely a number of liring species. Cockerell compared it to Ribes nigrum Linné and $R$. hudsonianum Richards, but even more clearly it seems to me to resemble $R$. rubrum Linné and $R$. prostratum L'Héritier.

Occurrence: Creede formation, north bank of Rio Grande near Sevenmile Bridge, Creede, Colo.; Huerto formation, north end of Lake Santa Maria, San Cristobal quadrangle, Colo.

Vitis florissantella Cockerell.

Plate XLII, figure 4.

Vitis florissantella Cockerell, Am. Mus. Nat. Hist. Bull., vol. 24, p. 102, pl. 7, fig. 18, 1908.

A single leaf with its counterpart clearly belongs to this species. It is even smaller than the type, being only about 22 millimeters long and 23 millimeters broad. It lacks the basal portion but otherwise agrees with the type.

Occurrence: Creede formation, west bank of Rio Grande near Sevenmile Bridge, Creede, shlo.

Odostemon marginata(?) (Lesquereux) Knowlton, n. comb.

Plate XIIII, figures 7-10.

Hedera marginata Iesquereux, U. S. Geol. Survey Terr. Rept., vol. 8 (Cretaceous and Tertiary floras), p. 1.77, pl. 40 , fig. 8, 1883.

Leaves pinnate (?), at least trifoliolate, petiole short, stout; leaflets coriaceous in texture, closely sessile at the top of the petiole, nearly circular or broadly ovate, very obtusely wedge-shaped, truncate or even slightly heartshaped at base, the margin with usually three strong teeth or lobes on each side, the lobes: sharp-pointed and apparently spine-tipped.; nervation palmate from the base, the middle rib slightly stronger, other nervation much joined or sometimes running to the lateral. lobes.

The specimens from Creede that are here figured have been the basis of a good deal of study and not a little speculation. It was early recognized that they were certainly identical with the Hedera marginata of Lesquereux, but the question of their relationship was much in doubt. It seemed improbable that they were correctly referred to Hedera; in fact, Lesquereux expressed the opinion when the species was first described that he knew "nothing to which this leaf may be related," and others have expressed the same uncertainty. It was not until the specimen with the leaflets attached was discovered that the affinity of this form was suspected. This specimen (fig. 7) has one leaflet complete and the bases of the other two, together with the perfect petiole. The best leaflet is 10 millimeters long and 7 or 8 millimeters broad. The spread of the whole leaf should be about 22 millimeters; the length of the petiole is 8 millimeters. The best preserved leaflet has three teeth on the lower side and two on the upper side. The terminal leaflet has only the obtusely wedge-shaped basal portion preserved. Another well-preserved leaflet is the one shown in figure 9 . It is slightly larger than the one just described, being about 18 millimeters long and 17 millimeters wide. It has large spine-tipped teeth and in size, teeth, and nervation closely resembles the type of Hedera marginata. Still larger, but so fragmentary that it can not be accurately measured, is the one seen in figure 10. This has the nervation well preserved and also the spine on one of the teeth. The largest specimen-figure 8-is nearly perfect. It is oblique and slightly heart-shaped at the base and has the usual strong teeth and the characteristic nervation. Its length is about 28 millimeters and its width about 30 millimeters.

The genus Odostemon Rafinesque (Mahonia of Nuttall; Berberis section Mahonia of authors) comprises about 20 species in central Asia, China, North America, and adjacent Mexico. They are unarmed shrubs with pin$91048^{\circ}-23-13$ 
nately compound spinose-toothed evergreen leaves.

Occurrence: Creede formation, north bank of Rio Grande, near Sevenmile Bridge, Creede, Colo.

Odostemon hakeaefolia (Lesquereux) Knowlton, n. comb.

Plate XLIII, figures 1-6.

Lomatia hakeaefolia Lesquereux, U. S. Geol. Survey Terr. Rept., vol. 8 (Cretaceous and Tertiary floras), p. 166, pl. 32, fig. 19, 1883.

Lomatites haekaefolia (Lesquereux) Cockerell, Am. Mus. Nat. Hist. Bull., vol. 24, p. 89, 1908.

Knowlton, U. S. Nat. Mus. Proc., vol. 51, p. 267, pl. 26, figs. 1, 2, 1916 .

Carduus florissantensis Cockerell, Torrey Bot. Club Bull. vol. 33, p. 311, text fig. 6, 1906.

?Odostemon florissantensis Cockerell, Am. Mus. Nat. Hist. Bull., vol. 24, p. 91, 1908.

The leaves of Odostemon are pinnate, and it is assumed that the leaves of the present fossil species were similarly arranged, but as none have thus far been found attached it is impossible to be certain. The leaflets, if this has been correctly interpreted, were closely sessile, with an obtusely wedge-shaped or nearly truncate base and slender, sharp-pointed apex. They are lanceolate in general outline, with usually three teeth on each side; these teeth are separated by rounded sinuses and are spinous tipped, as is the apical lobe. The nervation consists of a relatively strong midrib and a rather loose network of veins that supply the several lobes. The leaflets are evidently thick and coriaceous in texture and have the margin all around thickened as if bound with a cord, precisely as in the living species. The length varies between 2 and 4 centimeters and the width between 1 and 2 centimeters. Some of the specimens, perhaps the majority, are broadest at the base, and others are broadest between the points of the upper lobes.

If my assumption is correct, as it is now believed to be, this species was first described under the name Lomatia hakeaefolia Lesquereux ${ }^{7}$ from material collected in the Florissant lake beds. It was based on a single specimen about 5 centimeters long and 2.5 centimeters wide. It has four teeth or lobes on each side and no trace of nervation except a strong midrib.

7 Lesquereux, Leo, U. S. Geol. Survey Terr. Rept., vol. 8 (Cretaceous and Tertiary floras), p. 166, pl. 32, fig. 19, 1883.
Lesquereux states that his Lomatia hakeaefolia he regards as closely related to his Lomatia spinosa, which was described ${ }^{8}$ at the same time. L. spinosa was also based on a single specimen about 8 centimeters long and 2.5 centimeters wide and differs from L. hakeaefolia in being deeply cut into very large, sharppointed lobes. The apical portion especially is drawn out into a long, slender point. There is no nervation preserved except a short basal portion of the midrib.

These two species are certainly congeneric and probably conspecific. Additional examples of Lesquereux's Lomatia hakeaefolia have been procured at Florissant by Cockerell, Knowlton, and others. The leaves figured in my recent paper ${ }^{0}$ on the Florissant plants are undoubtedly identical with $L$. hakeaefolia; and $L$. spinosa of Lesquereux is only an elongated, narrow, stronger-toothed form. It is comparable, for instance, to the specimen shown in figure 1 except as regards size, the latter being only about half as long.

The leaf described by Cockerell ${ }^{10}$ as Carduus florissantensis undoubtedly belongs here, being indistinguishable from figure 1 . The thickened margin and peculiar arched veins more or less parallel to the midrib he describes are characters of Odostemon.

Cockerell ${ }^{11}$ also described as Odostemon florissantensis a leaflet from Florissant that probably belongs with Odostemon hakeaefolia. It was not figured but is said to be similar to Odostemon simplex (Newberry) Cockerell (Berberis simplex Newberry), from the upper Eocene of Bridge Creek, Oreg., except that the "inferior basal angle is produced into a tooth, so that the truncate base of the leaf is greatly broadened." It is about 4.2 centimeters long and 4.8 centimeters wide and has three teeth on each side, "not counting the base." This, seems to fit the description of Odostemon hakeaefolia, and therefore Cockerell's form has been referred to that species.

Occurrence: Creede formation, north bank of Rio Grande near Sevenmile Bridge, Creede, Colo.

8 Lesquereux, Leo, op. cit., p. 166, pl. 43, fig. 1.

9 Knowlton, F. H., U. S. Nat. Mus. Proc., vol. 51, p. 267, pl. 26, figs. 1, 2, 1916.

10 Cockerell, T. D. A., Torrey Bot. Club Bull., vol. 33, p. 311, text fig. 6, 1906.

il Cockerell, T. D. A., Am. Mus. Nat. Hist. Bull., vol. 24, p. 91, 1908. 
Sterculia aceroides Knowlton, n. sp.

Plate XLIII, figure 12.

Leaf small, semicoriaceous in texture, rounded and truncate at the base, three-lobed, the central lobe apparently much the longest and strongest (broken), lateral lobes short, acute, at an angle of about $45^{\circ}$; nervation obscure, except for the very strong midrib and the much lighter lateral ribs. which arise near the base of the blade.

This little leaf, the only one seen in the collection, has the basal portion well preserved, but the evidently large central lobe is broken. The distance between the tips of the lateral lobes is about 3.5 centimeters.

Two species of Sterculia have been described from material found in the Florissant lake beds-Sterculia rigida Lesquereux ${ }^{12}$ and $S$. engleri Kirchner. ${ }^{13}$ These species are of the same type, about the only difference being in size; they should probably be combined.

The present form differs from the Florissant forms in being rounded and full instead of wedge-shaped at the base and in having relatively shorter lateral lobes. The central lobe, to judge from the very strong midrib, was probably very long and slender. The nervation, except for the three ribs, is practically obsolete.

Occurrence: Creede formation, north bank of Rio, Grande. near Sevenmile Bridge, Creede, Colo.

\section{Phyllites sp.}

Plate XLIII, figure 15.

Leaf minute, delicate in texture, obovate, rounded at the apex, long ridge-shaped at the base; apparently short petioled; margin entire; nervation very delicate, consisting of a straight midrib and about three pairs of thin secondaries that pass up for a considerable distance; finer nervation obsolete.

This little leaf or leaflet, the only one observed in the collection, is about 7 millimeters long and 5 millimeters broad. It was spparently sessile, or nearly so.

I have hesitated to assign this leaf to a definite genus, as it is so nondescript that it is

${ }_{12}$ Lesquercux, Lco, U. S. Geol. Survey Terr. Rept., vol. 8 (Cretaceous and Tertiary floras), p. 179, pl. 34, fig. 12, 1883 .

18 Kirchner, W. C. G., St. Louis Acad. Sci. Trans., vol. 8, p. 180, pl. 14, fig. $3,1898$. hard to place with any degree of reasonableness. It resembles a number of described forms, such as Celastrus murchisoni $\mathrm{Heer},{ }^{14}$ from the Swiss Miocene, though it is much smaller. It is also similar to certain leaflets that have been 'called Leguminosites, but conjectures as to its affinity would hardly serve any useful end.

Occurrence: Creede formation, north bank of Rio Grande near Sevenmile Bridge, Creede Colo.

\section{Phyllites sp.}

Plate XLIII, figure 13.

In the collections from Creede I find the little leaf here figured, which with its counterpart is the only one noted. It is small, about 18 millimeters long and 9 millimeters broad, ovate, somewhat decurrent at the base, and moderately pointed at the apex. The margin has about four relatively large, sharp-pointed teeth on each side. The nervation is very light, consisting of a straight midrib and four pairs of thin, opposite secondaries, which end in the teeth.

It is so difficult, not to say impossible, to place this. little leaf in the correct genus that it has been referred without specific name to the nondescript genus Phyllites.

Occurrence: Creede formation, north bank of Rio Grande near Sevenmile Bridge, Creede, Colo.

\section{Phyllites potentilloides Knowlton, n. sp.}

Plate XLIII, figure 14.

The material from Lake Santa Maria includes the single example figured, which appears to be a small compound leaf with at least seren leaflets. The terminal leaflet is deeply cut into three lanceolate segments, the margins of which are provided with rather remote, sharp teeth. The lower leaflets are sessile or nearly so, lanceolate-acuminate, with sharply toothed margins. The nervation consists of a very strong midrib and a few secondaries that seem to enter the teeth. The whole leaf is about 5 centimeters long, and the lower leaflets are 1.5 to 2 centimeters long and 0.5 centimeter wide.

14 Heer, Oswald, Flora tertiaria Helvetiae, vol. 3, pl. 121, fig. 6, 1859. 
This specimen is so well preserved that seemingly it should not be difficult to place generically, but nevertheless its generic reference is uncertain. It resembles a number of things, particularly certain pinnate-leaved species of Potentilla, such as $P$. hippiana I Jehmann, but there are features that do not agree, and rather Colo. than make a wrong genëric reference I think best to place it; at leastitemporarily, in Phyllites. It has been given a specific name that suggests its resemblance to Potentilla.

Occurrence: Huerto formation, north end of Lake Santa Maria, San Cristobal quadrangle, 
PLATES XLI-XLIV.

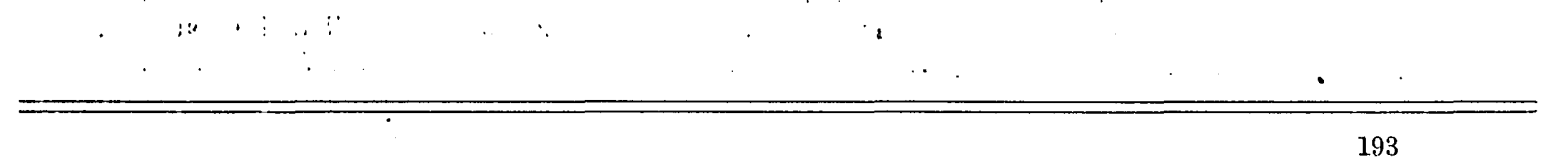




\section{PLATE XLI.}

Figures 1, 2, 4, 5. Abies rigida Knowlton, from Creede formation, near Creede, Colo. U. S. Nat. Mus: catalog

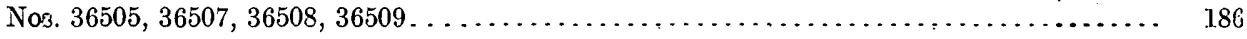

6. Filus coloradensis Knowlton, from Creede formation, near Creede, Colo. U. S. Nat Mus.

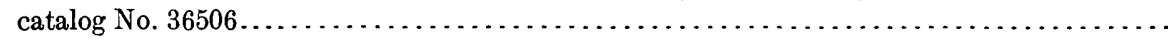

7. Pinus florissanti? Lesquereux, from Creede formation, near Creede, Colo. U. S. Nat. Mus.

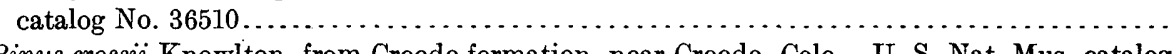
3, 8-10. Pinus crossii Knowlton, from Creede formation, near Creede, Colo. U. S. Nat. Mus. catalog

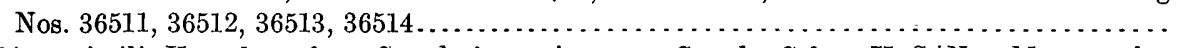

11, 12. Pinus similis Knowlton, from Creede formation, near Creede, Colo. U. S. Nat. Mus. catalog. 


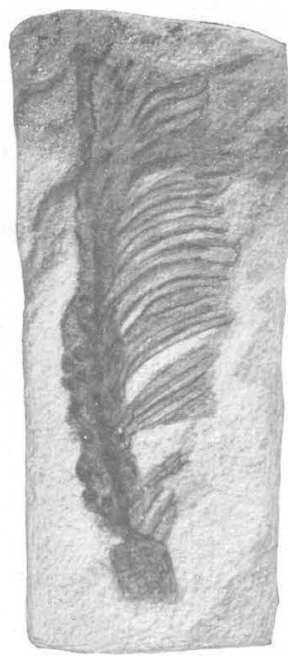

1
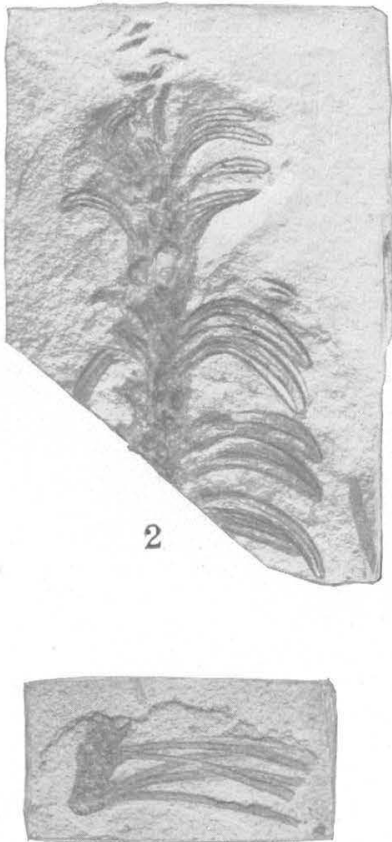

3

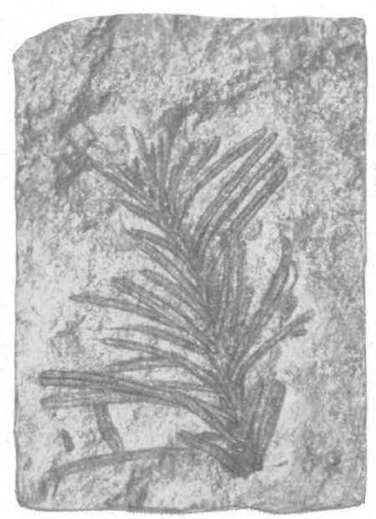

4

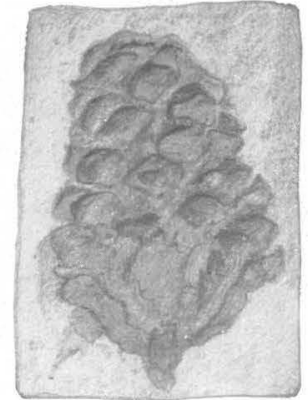

6
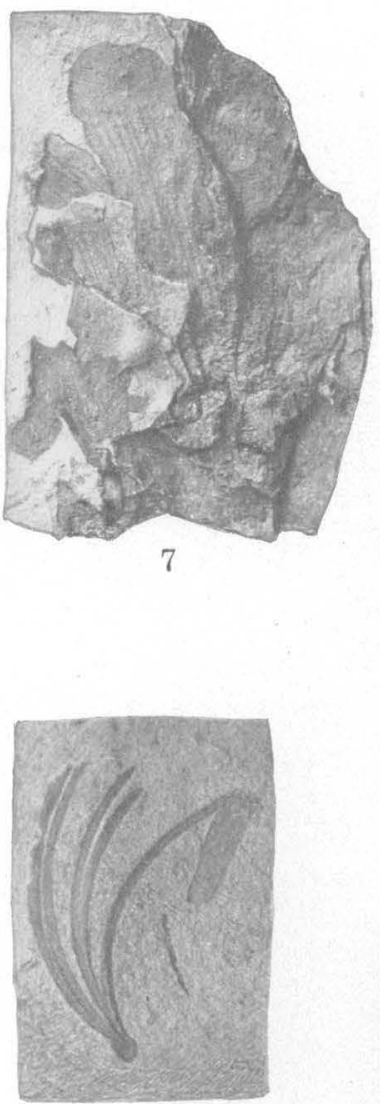

10

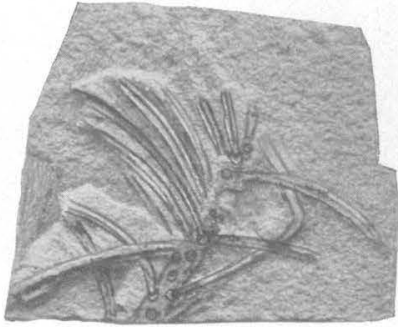

5

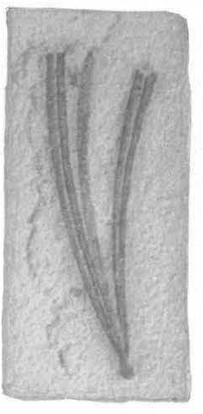

8

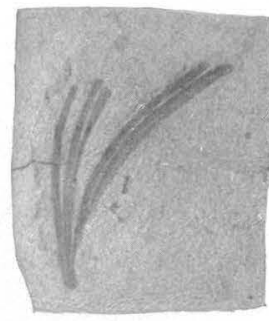

9

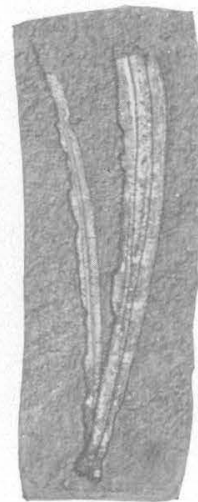

11

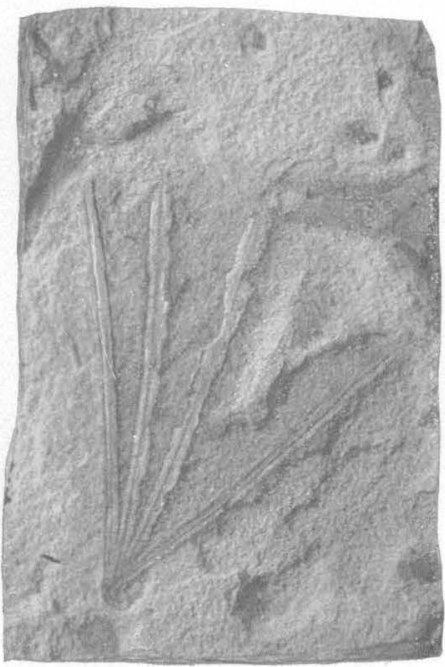

12

FOSSIL PLANTS FROM THE TERTIARY LAKE BEDS OF SOUTH-CENTRAL COLORADO. 
U. S. GEOLOGICAL SURVEY
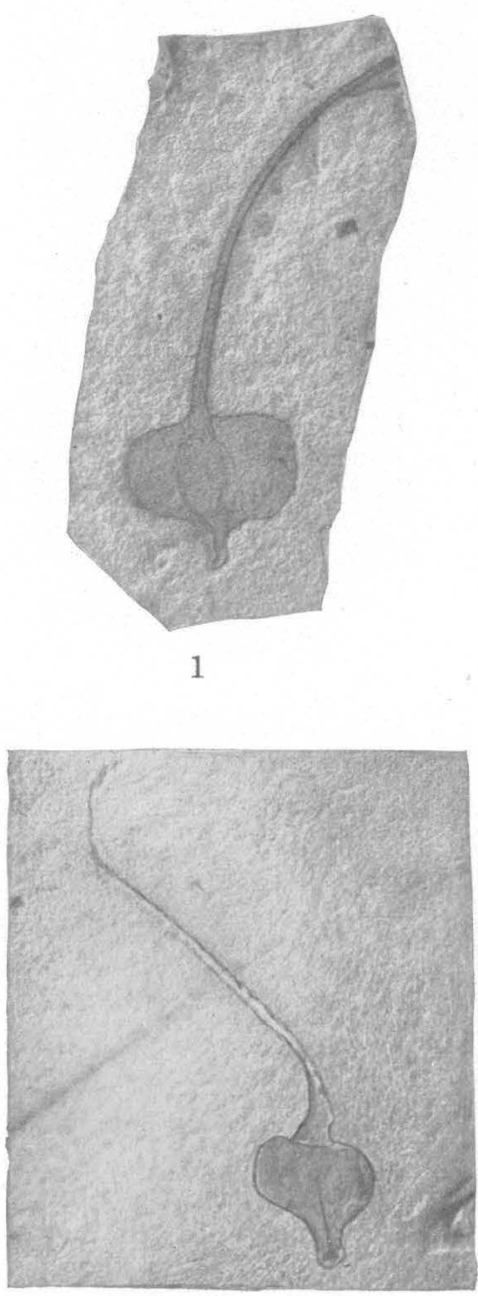

2

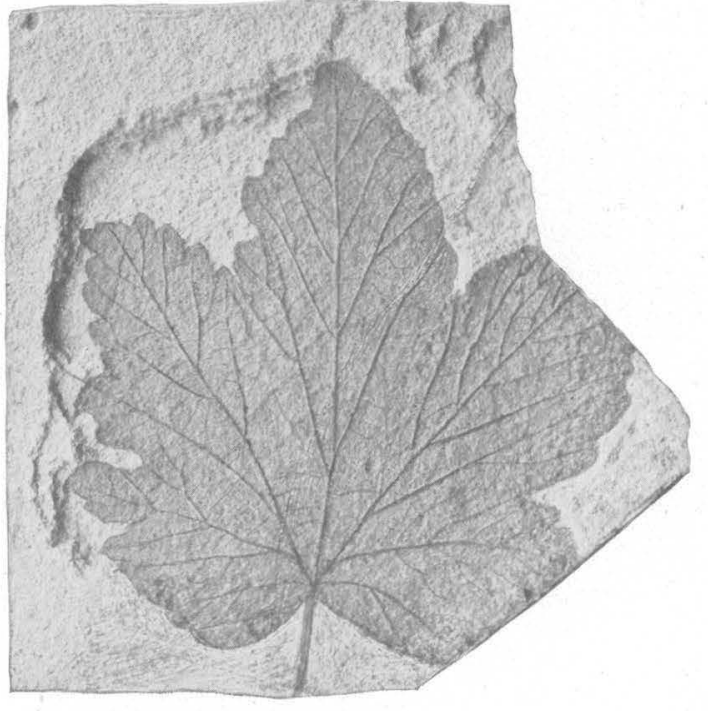

8

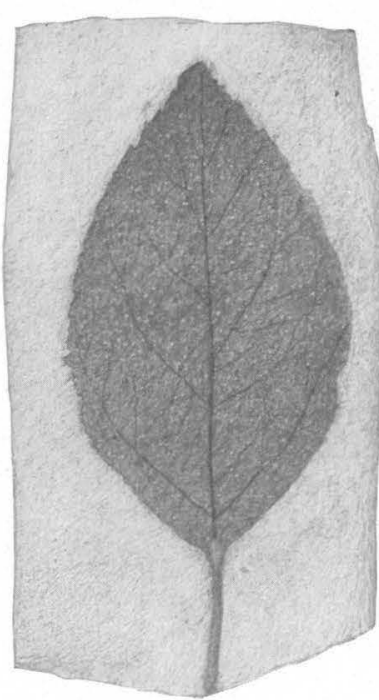

3

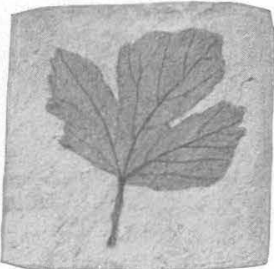

6

ROFESSIONAL PAPER 131 PLATE XLII

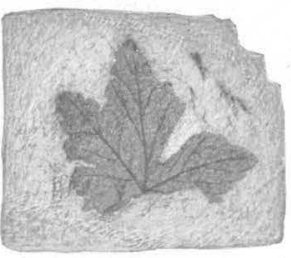

4

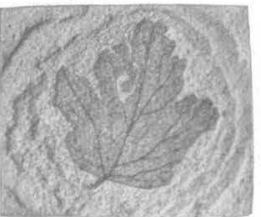

5

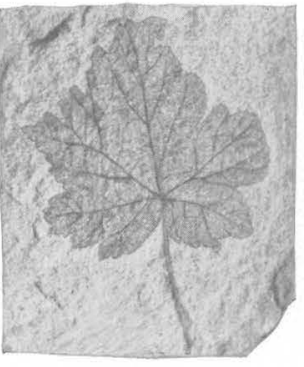

7

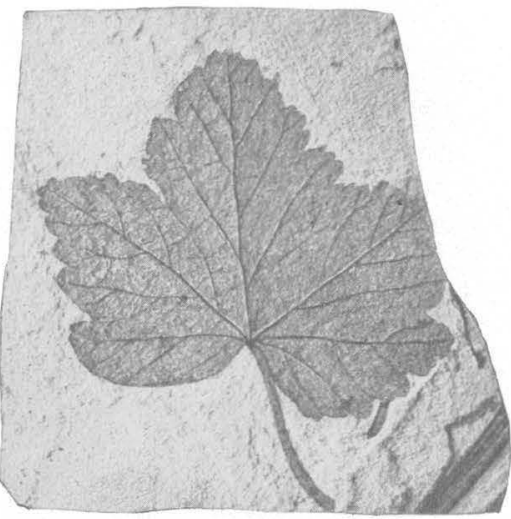

9

FOSSIL PLANTS FROM THE TERTIARY LAKE BEDS OF SOUTH-CENTRAL COLORADO. 


\section{PIATE XLII.}

Page.

Figures 1, 2. Abies longirostris Knowlton, from Creede formation, near Creede, Colo. U. S. Nat. Mus. catalog

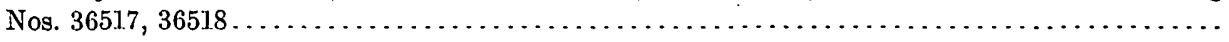

3. Alnus \& larseni Knowlton, from Creede formation, near Creede, Colo. U. S. Nat. Mus. catalog No.

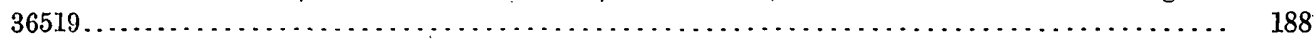

4. Vitis florissantella Cockerell, from Creede formation, near Creede, Colo. U. S. Nat. Mus. catalog

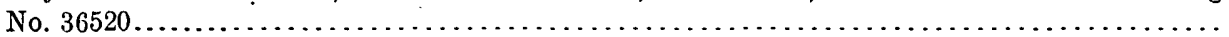

5-9. Ribes protomelaenum Cockerell, from Creede formation, near Creede, Colo. U. S. Nat. Mus.

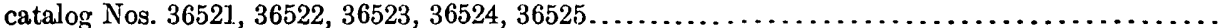




\section{PLATE XLIII.}

Figures 1-6. Odostemon hakeaefolia (Lesquereux) Knowlton, from Creede formation, near Creede, Colo. U. S. Nat. Mus. catalog Nos. 36526, 36527, 36528, 36529, 36530, 36531....................... 7-10. Odostemon marginata (Lesquereux) Knowlton, from Creede formation, near Creede, Colo. U. S.

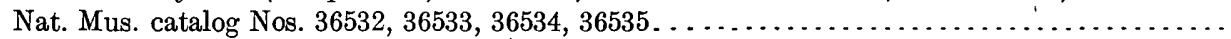

11. Rubus? inquirendus Knowlton, from Creede formation, near Creede, Colo. U. S. Nat. Mus. catalog

No. $36536 \ldots \ldots \ldots \ldots \ldots \ldots \ldots \ldots \ldots \ldots \ldots \ldots \ldots \ldots \ldots \ldots \ldots \ldots \ldots \ldots \ldots \ldots \ldots \ldots \ldots \ldots \ldots \ldots \ldots \ldots \ldots \ldots \ldots \ldots \ldots \ldots \ldots \ldots$
12. Sterculia aceroides Knowlton, from Creede formation, near Creede, Colo. U. S. Nat. Mus. catalog

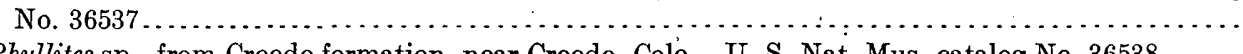

13. Phyllites sp., from Creede formation, near Creede, Colo. U. S. Nat. Mus. catalog No. 36538 ......

14. Phyllites potentilloides Knowlton, from Huerto formation, north end of Lake Santa Maria, San

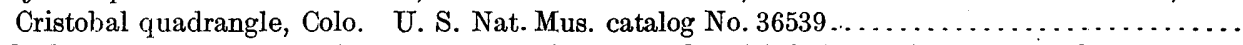

15. P. Pyllites sp., from Creede formation, near Creede, Colo. U. S. Nat. Mus. catalog No. $36540 \ldots$ 16,17. Planera myricaefolia (Lesquereux) Cockerell, from Creede formation, near Creede, Colo. U. S.

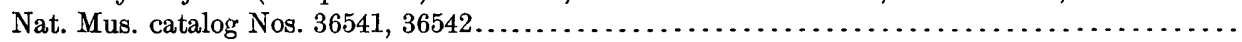


U. S. GEOLOGICAL SURVEY

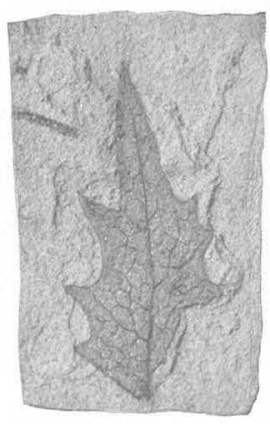

1

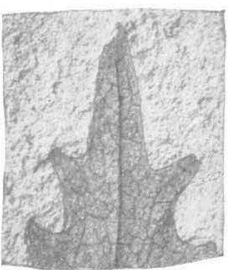

4

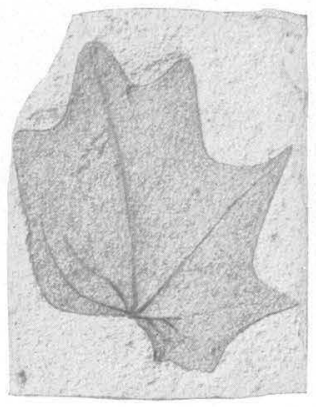

8

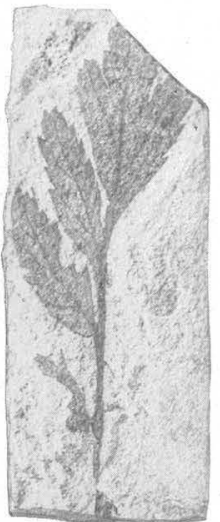

14

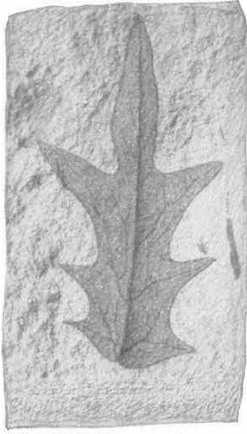

2

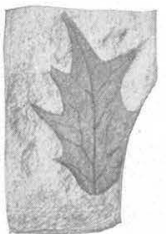

5
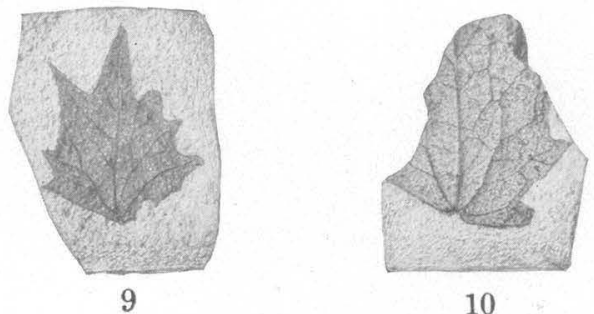

10

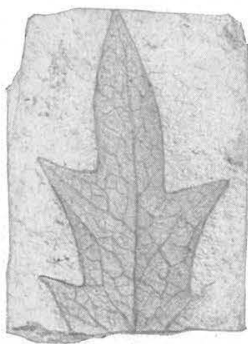

6

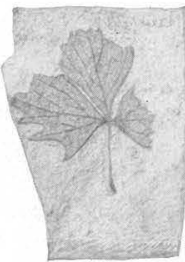

7

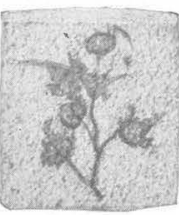

11

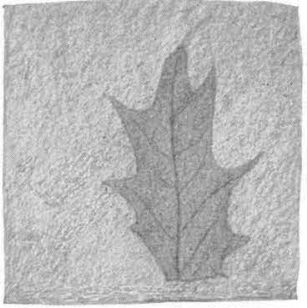

3

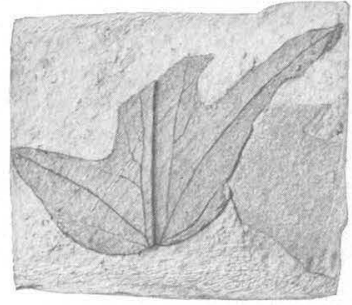

12

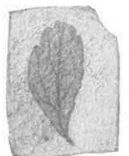

15

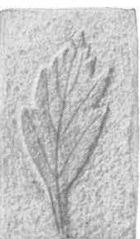

13

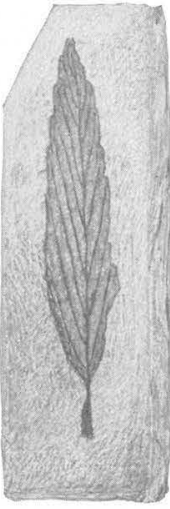

17

FOSSI, PLANTS FROM THE TERTIARY LAKE BEDS OF SOUTH-CENTRAL COLORADO. 


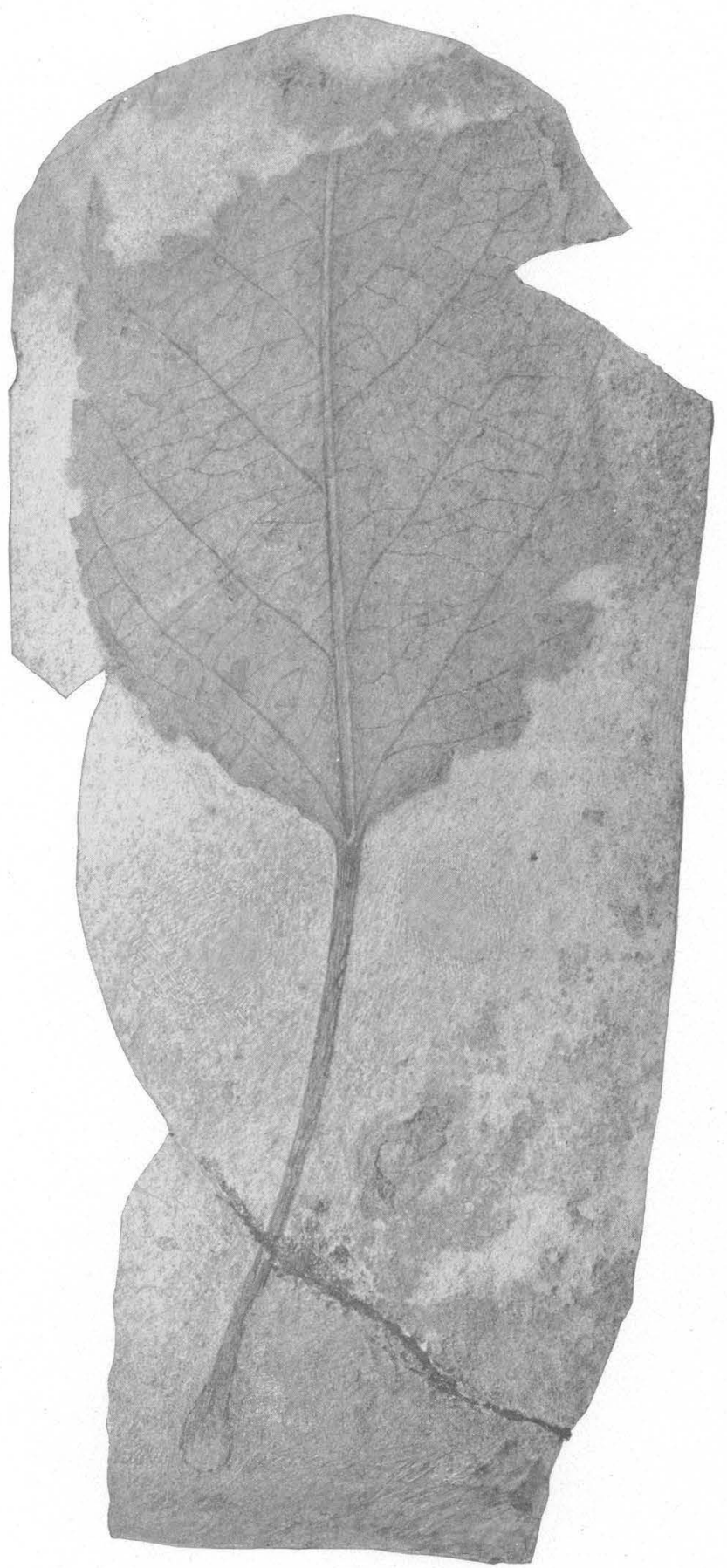

FOSSIL PLANT FROM THE TERTIARY LAKE BEDS OF SOUTH-CENTRAL COLORADO. 


\section{PLATE XLIV.}

Populus lesquereuxi Cockerell, from Creede formation, near Creede, Colo. U. S. Nat. Mus. catalog No. 36543 .... 187 
$\therefore$

i

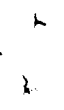

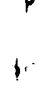




\title{
THE FAUNA OF THE SO-CALLED DAKOTA FORMATION OF NORTHERN CENTRAL COLORADO AND ITS EQUIVALENT IN SOUTHEASTERN WYOMING.
}

\author{
By John B. Reeside, Jr.
}

\section{INTRODUCTION.}

This paper describes a small fauna from beds in northern central Colorado that have long been designated the Dakota formation, often with doubt that all the beds so named were really equivalent to the typical Dakota sandstone of eastern Nebraska. The upper part of the equivalent beds in southeastern Wyoming was referred by some writers to the Benton shale and the lower part to the Cloverly formation. This so-called Dakota formation of northern central Colorado and its equivalent in southeastern Wyoming consist of cherty conglomerate, brown quartzose sandstone, and dark shale. The conglomerate is usually at the base of the series and at many localities is overlain by a single shale unit and that in turn by a sandstone. At other localities, however, there are several alternations of sandstone and shale above the basal conglomeratic layer. The fossils described in this paper, except one specimen, were obtained from the shales of the middle part of the formation. The single specimen, an ammonite, came from the uppermost sandstone.

Fossils from the "Dakota formation" of northern Colorado were first recorded by Prof. Junius Henderson, ${ }^{1}$ of the University of Colorado. Henderson states that fossils were found by T. W. Stanton and himself at almost every good exposure of the "medial shales" from a locality 5 miles north of Boulder, Colo., to Owl Canyon, in northern Larimer County, though they were not determinative. Ho suggests that the presence of Comanche fossils at Canon City and the persistence of a tripartite division in the "Dakota formation" indicate "that at least part of the medial

1 Fenderson, Junius, The foothills formations of north-central Colorado: Colorado Gisol. Survey First Ann. Ropt., pp. 172-176, 1908; The Cretaceous formations of northeastern Colorado and the foothills formations of north-central Colarado: Colorado Geol. Survey Bull. 19, pp. 83-85, 1920. shales and lower sandstone member in the Boulder district and northward may be the time equivalent of the Comanche." The fossils of the northern area are mostly in poor condition and are said to include one or more species of Ostrea, an Inoceramus indistinguishable from $I$. labiatus Schlotheim, and an Avicula closely related to $A$. linguaeformis Evans and Shumard, though probably not identical.

Mr. Stanton made six collections from as many localities in 1906 and others in 1909 and 1920. In 1907 Prof. Henderson made a collection of which a part was presented by him to the Geological Survey. In 1921 larger collections were made at six localities by W. T. Lee. These later collections have supplied more adequate specimens of most of the species than were contained in the earlier collections and have shown more definitely the relationships of the fossils. All the material in these collections has, through Mr. Stanton's kindness, been in the writer's hands, as well as specimens for comparison from the Washita fauna of southern Colorado, New Mexico, Kansas, and Texas contained in the collections of the Geological Survey.

\section{THE FAUNA AND ITS RELATIONS.}

The fauna of the "middle Dakota shale" of northern Colorado and southern Wyoming includes seven species, of which one is not definitely determinable, three are assigned to new species, and three are assigned to species previously described. The list of species is as follows:

Inoceramus comancheanus Cragin.

Inoceramus bellvuensis Reeside, n. $\mathrm{sp}$.

Pteria salinensis White.

Ostrea larimerensis Reeside, n. sp.

Ostrea noctuensis Reeside, $\mathrm{n}$. sp.

Anchura kiowana Cragin?

. Ammonite, undetermined. 
To this list may be added the scales and bones of undetermined fish and also teeth collected near Loveland, Colo., by Prof. Henderson and identifiéd by J. W; Gidley as probably plesiosaurian. ${ }^{2}$ Inoceramus comancheanus, Pteria salinensis, and Anchura kiowana occur in rocks of Washita age in Kansas and other States, and their occurrence in the beds here considered therefore supports a correlation of the "middle Dakota" with the Washita group, although such a correlation, based on a single species each of Inoceramus and Pteria and a somewhat doubtfully identified species of Anchura, has a rather frail foundation. The other species are not very close to any described forms from the Washita group or the Benton shale and have little value in correlation. The absence of such widespread and abundant species as Ostrea quadriplicata Shumard, Gryphaea corrugata Say, Trigonia emoryi Conrad, Pholadomya sanctisabae Roemer, Cardium kansasense Meek, Protocardia multilineata Shumard, Turritella seriatim-granulata Roemer, and Pachydiscus brazoensis (Shumard), which occur in many collections from the Purgatoire formation and its equivalents, ${ }^{3}$ is surprising. There is no feature of the sediments that indicates conditions of deposition in northern Colorado very different from those in southern Colorado-in fact, on the contrary, the sediments of the two areas are so much alike that tentative correlations between them have been based on the similarity. It is difficult to explain why conditions that would permit the existence of Inoceramus comancheanus, Pteria salinensis, and an Anchura very like $A$. Kiowana would completely shut out any trace of their usual associates, which are present in southern Colorado, scarcely 200 miles away.. Whether these three species were hardier and could endure conditions that completely precluded the existence of the other species can not be determined. The Washita fauna, as shown by Stanton, ${ }^{4}$ suffers a progressive change northwestward from the Tucumcari region of New Mexico and the Cimarron River region of Oklahoma by the disappearance of

\footnotetext{
2 Henderson, Junius, The Cretaceous formations of northeastern Colorado and the foothills formations of north-central Colorado: Colorado Geol. Survey Bull. 19, p. 85, 1920.

${ }^{3}$ Stanton, T. W., The Morrison formation and its relations with the Comanche series and the Dakota formation: Jour. Geology, vol. 13, pp. $657-669,1905$.

4 Stanton, T. W., idem.
}

one species after another from the faunal assemblage. In the Purgatoire River region of Colorado the fauna lacks a number of Washita species that are prominent at the localities farther southeast. In the Apishapa River region still more species have dropped out of the fauna, and at Canon City only two or three are known. Such a change as this may well account for the paucity of recognized Washita species in northern central Colorado and southeastern Wyoming, though the causes of the change are entirely conjectural. It has been suggested by Stanton ${ }^{5}$ that the difference between the fauna of the Purgatoire formation and that of the so-called Dakota formation of northeastern Colorado is due to a differencè in age, the sea in which the Purgatoire formation was deposited not having reached northern Colorado until Dakota time, when many of the characteristic Washita species had ceased to exist. The relationship of the beds of Washita age in Kansas to the overlying Dakota formation is so intimate as to preclude any great difference in age, and the difference in interpretation of the fauna is therefore not very great. However, it seems to the writer that it is better to regard the fossils of the so-called Dakota formation as of the same age as those of the Purgatoire formation and attribute the. differences between them to some now unknown difference in the conditions under which the sediments were deposited. The fauna from northern Colorado, in spite of its paucity, is more like that of the Washita group than that of the succeeding Benton shale or that of any known Dakota beds, and a correlation based on the fauna must be a correlation with the Washita rather than with the Benton. The fauna is apparently an extension of the known range of the late Comanche fauna as far north as southern Wyoming.

The single ammonite, Pachydiscus? sp., from the uppermost sandstone of the "Dakota formation," is sufficient only to show that this sandstone is in at least one locality of marine origin. The specimen might belong to the Washita fauna or to a later one. The marine origin of the sandstone at two other localities is indicated by the presence of Halymenites. These localities are at the mouth of Little

${ }^{5}$ Stanton, T. W., Some prob'ems connected with the Dakota sandstonc: Geol. Soc. America Bull., vol. 33, pp. 265-272, 1922. 
Thompson Canyon and 10 miles north of Boulder, Boulder County, Colo. ${ }^{\circ}$

- Henderson, Junius, The Cretaceous formations of northeaste:n Colo rado and the foothills formations of north-central Colorado: Colorado Geol. Survoy Bull. 19, p. 85, 1920 .

\section{DISTRIBUTION OF SPECIES.}

The following table and list show the geographic distribution of the species described in this paper:

Distribution of species from the so-called Dakota formation of northern central Colorado and southern Wyoming by localities.

\begin{tabular}{|c|c|c|c|c|c|c|c|c|c|c|c|c|c|c|c|c|}
\hline & $c 1$ & 2 & 3 & 4 & 5 & 6 & 7 & 8 & 9 & 10 & 11 & 12 & 13 & 14 & 15 & 10 \\
\hline Inoceramus comanchcanus Cragin. & X & & & $x$ & $x$ & & & X & $x$ & $x$ & $x$ & $x$ & & X & $x$ & X \\
\hline Pteria salinensis White. & $x$ & $x$ & $x$ & $x$ & & $x$ & & $x$ & & $x$ & $x$ & $x$ & & & $x$ & $x$ \\
\hline Ostrea larimerensis Reeside. & $\cdots$ & $\ldots$ & & $\ldots$ & & $x$ & & $x$ & $x$ & $x$ & $x$ & & & $x$ & $\cdots$ & $x$ \\
\hline Ostrea noctuensis Reeside. & & $\ldots$ & & X & - & $x$ & $x$ & $x$ & $x$ & $x$ & $x$ & & & $\cdots$ & & $\cdots$ \\
\hline Anchura kiowana Cragin?. & & $\cdots$ & & $\ldots$ & & $\ldots$ & ... & $x$ & .. & $x$ & $x$ & & & $\ldots$ & & $\cdots$ \\
\hline Fish scales and bones. & $\ldots$ & $x$ & $\cdots$ & - & $x$ & $x$ & $x$ & x & $x$ & $x$ & . & & $\cdots$ & $x$ & $x$ & $x$ \\
\hline
\end{tabular}

a Numbers rofer to the lozalities given in the following list.

1. U. S. G. S. locality 3689 . Sixmile Canyon, 4 miles north of Boulder, Boulder County, Colo.; sandy shale. between the "Dakota" sandstones; T. W. Stanton, collector, 1906:

Inoceramus comancheanus Cragin.

Pteria salinensis White.

Ostrea sp. undetermined.

2. U. S. G. S. locality 3690 . Lykins Gulch, 9 miles north of Boulder, Boulder County, Colo.; sandy shale between the "Dakota" sandstones; T. W. Stanton, collector, 1906:

Pteria salinensis White.

Ostrea sp. undetermined.

Fish remains.

3. U. S. G. S. locality 3685 . South end of Rabbit Mountain, 7 miles northwest of Longmont, Boulder County, Colo.; shales between the "Dakota" sandstones; T. W. Stanton, collector; 1906:

Inoceramus sp. undetermined.

Pteria salinensis White.

Ostrea sp. undetermined.

4. U. S. G. S. locality 3686 . Lykins ranch, at mouth of canyon of Little Thompson Creek, Boulder County, Colo.; sandy shale between the "Dakota" sandstones; T. W. Stanton, collector, 1906:

Inoceramus comancheanus Cragin.

Inoceramus bellvuensis Reeside.

Pteria salinensis White.

Ostrea noctuensis Reeside.

5. U. S. G. S. locality 10631. Handy ditch, canyon west of Loveland, Larimer County, Colo.; sandy shale beneath the "upper Dakota" sandstone; W. T. Lee, collector, 1921:

Inoceramus comancheanus Cragin.

Fish remains.

6. U. S. G. S. locality 10657. Handy ditch, canyon west of Loveland, Larimer County, Colo.; middle of shale between the "Dakota" sandstones; W. T. Lee, collector, 1921.

Inoceramus sp. undetermined.

Pteria salinensis White.

Ostrea larimerensis Reeside.

Ostrea noctuensis Reeside

Fish remains.
7. U. S. G. S. locality 3688 . Eight miles northivest of Loveland and 2 miles north of the junction of Big Thompson and Buckhorn creeks, Larimer County, Colo.; sandy shale between the "Dakota" sandstones; T. W. Stanton, collector, 1906:

Ostrea noctuensis Reeside.

Fish remains.

8. U. S. G. S. locality 10659. Soldier Canyon, west of Fort Collins, Larimer County, Colo.; middle of shale of "middle Dakota"; W. T. Lee, collector, 1921:

Inoceramus comancheanus Cragin.

Pteria salinensis White.

Ostrea larimerensis Reeside.

Ostrea noctuensis Reeside.

Anchura kiowana Cragin?

Fish remains.

9. U. S. G. S. locality 3687 . Ditch bank on north side of Cache la Poudre River, 9 miles northwest of Fort Collins and 2 miles above Laporte, Larimer. County, Colo.; shale between the "Dakota"' hogbacks; T. W. Stanton, collector, 1906.

Inoceramus comancheanus Cragin.

Inoceramus bellvuensis Reeside.

Ostrea larimerensis Reeside.

Ostrea noctuensis Reeside.

Fish remains.

10. U. S. G. S. locality 10660. Ditch on "Dakota" ridge in sec. 12 , T. 8 N., R. $70 \mathrm{~W} .$, north of Bellvue, Larimer County, Colo.; upper part of "middle Dakota"; W. T. Lee, collector, 1921:

Inoceramus comancheanus Cragin.

Inoceramus bellvuensis Reeside.

Pteria salinensis White.

Ostrea larimerensis Reeside.

Ostrea noctuensis Reeside.

Anchura kiowana Cragin?

Fish remains.

11. U. S. G. S. locality 5401. Owl Canyon; 12 miles north of Fort Collins, Larimer County, Colo.; "middle Dakota' '; Junius Henderson, collector, 1907.

Inoceramus comancheanus Cragin.

Inoceramus bellvuensis Reeside.

Pteria salinensis White.

Ostrea larimerensis Reeside. 
Ostrea noctuensis Reeside.

Anchura kiowana Cragin?

12. U. S. G. S. locality 10375 . Two miles southeast of Greenacre ranch, 20 miles north of Fort Collins, Larimer County, Colo.; dark shale beneath the "upper Dakota" hogback; T. W. Stanton, collector, 1920:

Inoceramus comancheanus Cragin.

Pteria salinensis White.

13. U. S. G. S. locality 10375a. Same locality as 10375 ; upper sandstone of the "Dakota" hogback, above the dark shales; T. W. Stanton, collector, 1920:

Pachydiscus? sp.

14. U. S. G. S. locality 10662. Schoolhouse near Box Elder Creek, southeast of Greenacre ranch, Larimer County, Colo.; upper part of "middle Dakota"; W. T. Lee, collector, 1921:

Inoceramus comancheanus Cragin.

Ostrea larimerensis Reeside.

Fish bone.

15. U. S. G. S. locality 5863. Horse Creek, 30 miles northwest of Cheyenne, Laramie County, Wyo.; shale beneath the upper ledge of the "Dakota"; T. W. Stanton, collector, 1909:

Inoceramus comancheanus Cragin.

Pteria salinensis White.

Gastropod, undetermined.

Fish remains.

16. U. S. G. S. locality 10670. Gap of Chugwater Creek at Iron Mountain, Laramie County, Wyo.; "middle Dakota" shale; W. T: Lee, collector, 1921:

Inoceramus comancheanus Cragin.

Pteria salinensis White.

Ostrea larimerensis Reeside.

Ammonite, undetermined.

Fish remains.

\section{DESCRIPTIONS OF SPECIES.}

Genus INOCERAMUs Sowerby.

Inoceramus comancheanus Cragin.

Plate XLV, figures 1-7

1895. Inoceramus comancheana Cragin, Colorado Coll. Studies, 5th year, pp. 53-55.

1901. Inoceramus comancheanus Cragin. Hill, U. S. Geol. Survey Twenty-first Ann. Rept., pt. 7, pl. 35, fig. 4.

1920. Inoceramus comancheanus Cragin. Adkins and Winton, Texas Univ. Bull. 1945, p. 73 , pl. 17, fig. 1-3.

Cragin's original description is as follows:

Shell equivalve, broadly and obliquely rhombic-ovate, more gibbous than that of $I$. labiatus Schlotheim, the axis of greatest dimension diverging from the hinge line much more widely than in the latter species; alar outline rounded; anterior margin descending steeply in a nearly straight line for a considerable distance on front of the beaks, then curving rather suddenly away toward the somewhat prominently convex distal part of the basal outline, anterior and posterior margins making nearly a right angle with each other; beaks placed opposite the anterior extremity of the hinge, moderately inflated and moderately elevated above the hinge line, anteriorly flattened but not abruptly so; hinge plate rather short, broad, the ligamental grooves crowded, more numerous and longer than in I. labiatus, though ample and shallow; valves thin, ornamented with numerous concentric riblike folds, which on the distal and ventral parts are quite strongly elevated and much narrower than the intervals between them.

Height 82 , length 95 , breadth 54 , axis of greatest dimension 107 milimeters. In some examples the species attains considerably larger dimensions.

The writer has in hand a number of fairly good specimens of an Inoceramus indistinguishable from specimens of $I$. comancheanus. This species is characterized by its elongate form, the axis of elongation making an angle of $50^{\circ}$ to $70^{\circ}$ with the hinge line; moderately coarse, rounded, concentric ribs without finer sculpture between; ribs somewhat irregular; umbo rather slender; anterior margin straight or slightly concave, making an angle of $70^{\circ}$ to $100^{\circ}$ with the hinge line. It differs from the later I. labiatus, as pointed out by Cragin, in the greater angle between the axis of elongation and the hinge line. It is also less elongated, has stronger sculpture and less smoothly ovate concentric ribs, and lacks the fine striae between the concentric ribs. It somewhat resembles an undescribed species associated with $I$. labiatus and related to $I$. lamarcki var. cuvieri Sowerby, though it differs in having a more elongate form and much finer sculpture. Inoceramus anglicus Woods, of the Gault; $I$. crippsi Mantell, of the Cenomanian; and $I$. pictus Sowerby, of the Cenomanian, are related species. I. anglicus has more regular concentric ribs and a broader curvature and is a wider shell. I. crippsi has a greater angle between the anterior margin and the hinge line $\left(140^{\circ}\right)$, a thicker umbo, and fine striae between the concentric ribs. I. pictus differs chiefly in possessing finer sculpture. These comparisons are based largely on figures by Woods ${ }^{7}$ and might not hold in an actual comparison of specimens, but so far as the writer is able to determine, I. comancheanus is closer to I. crippsi and I. pictus than to the other species mentioned.

Occurrence: Many localities in Texas, Kansas, Oklahoma, and southern Colorado. In northern Colorado: Sixmile Canyon, Lykins ranch, canyon west of Loveland, Soldier Canyon, Cache la Poudre River, north of

7 Woods, Henry, A monograph of the Cretaceous Lamellibranchia of England, vol. 2, pt. 7, pp. 264, 273, 279, text figs. 29, 33-36; pl. 45, figs. 8-10; pl. 48, figs. 2, 3: pl. 49, figs. 5, 6, 1911. 
Bellvue, Owl Canyon, 2 miles southeast of Greenacre ranch, Boxelder Creek. In Wyoming: Horse Creek and Iron Mountain. ${ }^{8}$

Inoceramus bellvuensis Reeside, $n$. sp.

Plate XLVI, figures 1-3.

Shell apparently equivalve, very inequilateral. Outline of valve subquadrate; anterior part moderately convex; posterior part flattened, forming an ill-defined wing dorsally. Anterior margin nearly straight; ventral margin broadly convex; posterior margin nearly straight. Anterior margin makes an angle of $120^{\circ}$ with the hinge line. Small part of hinge line preserved shows ligament pits small and shallow. Umbones nearly terminal. Ornamentation of somewhat irregular narrow concentric ribs with. unsymmetrical curvature; interspaces wider than ribs, concave.

This species is marked by its broad subquadrate valves, small convexity, and sculpture. It is perhaps closer to Inoceramus crippsi Mantell than to any other species but shows no trace of the fine striae between the ribs that are present on that species.

The specific name is derived from Bellvue, Colo., near which the type was collected.

Occurrence: Lykins ranch, Cache la Poudre River, north of Bellvue, and Owl Canyon, Colo.

\section{Genus PTERIA Scopoli.}

Pteria salinensis White.

Plate XLVII, figures 1-5.

1880. Pteria (Oxytoma) salinensis White, U. S. Nat. Mus. Proc., vol. 2, pt. 2, pp. 296, 297, pl. 5, figs. 1, 2.

1883. Pteria (Oxyloma) salinensis White, U. S. Geol. and Geog. Survey Terr. Twelfth Ann. Rept., pt. 1, pp. 15, 16, pl. 16, figs. 2a, b.

11893. Pteria salinensis White. Cragin, Texas Geol. Survey Fourth Ann. Rept., p. 211.

White's original description is as follows:

Shell rather large for a Cretaceous Pteria; the body, exclusive of the wings, obliquely subovate, broad at the base, moderately gibbous, distinctly but not very greatly inequivalve; the left valve, as usual, more convex than the right and its beak more prominent; the convexity of the valves somewhat uniform but increasing toward the umbonal region in each, where it is greatest; anterior wing moderately large, defined from the body of the shell by being laterally compressed but not by any distinct auricular furrow, the byssal sinus under the anterior wing of the right valve having the usual size and shape common

8 Tho full desiription of all these localitios is given on pages - to Oxytoma; posterior wing not proportionately large and not distinctly defined from the body of the shell except by a somewhat gradual lateral compression; its posterior angle not greatly produced; hinge line less than the axial length of the shell; posterior adductor scars not distinct; anterior adductor scars distinct and deep for a shell of this genus, placed immediately in front of the beaks, that of the left valve being more distinct than the other. ***

It is known to have reached an axial length of more than 60 millimeters, a transverse width near its base of at least 50 millimeters, and a thickness of about 25 millimeters when both valves were in natural position.

The character of the surface is not known, but it was evidently nearly smooth, as is usual with Oxytoma.

The writer has in hand a number of specimens that include both valves of a smoothshelled Pteria. Such simple shells are somewhat unsatisfactory material for comparisons, as very similar species occur at a number of very distinct horizons, from the Paleozoic on. However, in comparison with species from the Washita, Colorado, and Montana groups the specimens in hand are so close to $P$. salinensis that it is difficult to pick out an essential difference. $P$. gastrodes (Meek) of the Benton is a large, stout, nearly equivalve shell with the outline of the valves well rounded, the anterior ear short proportionately, and the axis of the shell only moderately oblique. $P$. linguaeformis (Evans and Shumard) is a proportionately small, inequivalve shell, with valves rather elongated and oblique, and the anterior ear small. $P$. salinensis has a less elongated form than $P$.linguaeformis and is much larger, but it is not nearly so stout and rounded as $P$. gastrodes. It has also a relatively long and narrow anterior ear and is nearly equivalve.

Occurrence: Washita group of Texas and rocks of same age in Kansas and southern Colorado. In northern Colorado: Sixmile Canyon, Lykins Gulch, Lykins ranch, south end of Rabbit Mountain, canyon west of Loveland, Soldier Canyon, north of Bellvue, Owl Canyon, and 2 miles southeast of Greenacre ranch. In Wyoming: Horse Creek and Iron Mountain.

Genus OSTREA Linnaeus.

Ostrea larimerensis Reeside, n. sp.

Plate XLVII, figures 6-12.

Shell very thin, flattened, acutely triangular in outline; small, an average specimen attaining a length of 60 millimeters. Beak narrowly tapered; base of valve smoothly rounded. 
Margins of the valves smooth. Surface irregularly and finely wrinkled, especially near the beak. Internal cast reflects the larger wrinkles, but otherwise smooth. Hinge not seen; probably small and weakly developed.

The writer has hesitated to apply names to this and the following species of Ostrea. Both belong to a type of simple oyster that appears in many faunas from Jurassic to Recent time, and although differences may be pointed out the variability of the shells is so great that no differences seem to hold good, and separation into species is more or less arbitrary. However, there appear to be no described forms in the equivalent or adjacent faunas of the region that may be compared with these, and as a matter of convenience names are here applied.

The specific name of $O$. larimerensis is derived from Larimer County, Colo.

Occurrence: Canyon west of Loveland, Soldier Canyon, Cache la Poudre River, north of Bellvue, Owl Canyon, and Box Elder Creek, Colo.; Iron Mountain, Wyo.

\section{Ostrea noctuensis Reeside, n. sp.}

\section{Plate XLVIII, figures 1-5.}

Shell very thin, gently arched, subquadrate, of medium size, an average individual attaining a length of 80 or 90 millimeters. Beak bluntly rounded, basal part of shell broadly rounded. Margins of valves smooth. 'Surface of most of the specimens marked by fine, rather regular concentric lines and a few broad, obscure folds. Surface of other specimens irregularly wrinkled, much as in 0 . larimerensis. Internal cast smooth except for the reflection of the broad folds. Hinge small and weak.

This species may possibly be cilly a variant of $O$. larimerensis, as it is of the same general type, but its broad outline is distinct, and so is its sculpture in most of the specimens.

The specific name is derived from the locality of the type, Owl Canyon (noctuus $=$ owl).

Occurrence: Lykins ranch, canyon west of Loveland, northwest of Loveland, Soldier Canyon, Cache la Poudre River, north of Bellvue, and Owl Canyon, Colo.
Genus ANCHURA Conrad.

\section{Anchura kiowana Cragin?}

Plate XLVIII, figures 6-8.

1895. Anchura kiowana Cragin, Colorado Coll. Studies, 5th year, pp. 66, 67 .

Cragin's original description is as follows:

Shell small, consisting of six convex whorls; spire elevated; suture impressed; wing of moderate size, consisting of a proximal flangelike part, continued posteriorly across half or more of the first spire whorl, and a carinated falciform process; carina gradually arising at the base of the falciform process and traversing the latter to the extremity; falciform process much shorter and less upturned distally than that of the somewhat similar species $A$. ruida White, not rising to the lowest level of the suture between the body whorl and the first spire whorl but having its point directed outward and somewhat upward so as to make a large angle with the axis of the spire, extero-inferior outline of wing rounded and the border between this and the canal sinuous, margin of upper (flange) part of wing. describing a slightly concave to sigmoid outline and more or less thickened and reflexed;inner lip provided with a. moderately broad and prominent callous; canal short and obliquely truncated; spire whorls and posterior half to two-thirds of body whorl ornamented with narrow curved, subvertical ribs or folds, of which there are about 24 on the first spire whorl, and with numerous revolving striae, the latter ornamentation gradually becoming prominent and superseding the ribs on the lowest third to half of the body whorl.

Height 19, breadth of body whorl, including excursion of the wing, 15 millimeters; angle of spire slopes about as in $A$. ruida White. * * * This species is distinguished from Anchura ruida White by the vertically costate body whorl, by the shorter, . differently directed falciform process, and by having the alar carina confined directly to the wing and nearly to the falciform process instead of kcing common to the wing and part of the body whorl.

The writer has six specimens of a small species of Anchura, all poorly preserved but showing enough of the details to indicate a close relationship to $A$. Kiowana, as defined by Cragin's description and by good specimens. One specimen preserves a mold of the exterior of the wing, and although fine details are lacking it is clear that the wing has the form of that of $A$. kiowana and that the carina is confined practically to the wing. The presence of vertical ribs is also indicated on the body whorl of this specimen. Another specimen preserving a mold of the spire and perhaps part of the body whorl shows a strong sculpture like that 
on A. kiowana. The material available is inadequate for certain identification, but the differences from $A$. ruida White and other species of equivalent and adjacent formations and the resemblances to A. kiowana make a tentative assignment to that species justifiable

Occurrence: Kiowa shale of Kansas. Soldier Canyon, north of Bellvue, and Owl Canyon, Colo.

\section{Genus PACHYDISCUS Zittel.}

Pachydiscus? sp.

Plate XLIX, figure 1.

A single specimen of an ammonite, much weathered and preserving few details but suggesting strongly the genus Pachydiscus, is contained in the collections. It might well be a weathered specimen of $P$. brazoensis (Shumard), but it might equally well belong to some later species, and even a certain generic assignment must await better material.

The stratigraphic position of this specimen is a little higher than that of the remainder of the fossils described in this paper. It came from the upper sandstone of the "Dakota" hogback, above the dark shales, and not from the shales themselves, as did the other fossils.

Occurrence: Two miles southeast of Greenacro ranch, Colo.

Ammonite, genus and species undetermined. Plate XLIX, figure 2.

A singlo small specimen of an ammonite preserving few distinctive features is contained in $91048^{\circ}-23-14$ the collections. The shell is clearly that of a much compressed species with very small umbilicus and truncated but unchanneled venter. The earlier part of the shell preserved shows: coarse, apparently rounded ribs, but the later part is practically smooth. The greatest diameter of the shell is 30 millimeters, and the width. of the truncated venter a little more than 1 millimeter. The shell might be a species of Engonoceras, Knemiceras, Metoicoceras, or some. other genus.

Occurrence: Iron Mountain, Wyo.

Fish scales and bones, undetermined.

Plate L, figures 1-11.

Fish scales and bones occur at several of the localities from which fossils are described in this paper. Some of them resemble Leuchichthyops vagans Cockerell, ${ }^{9}$ and others resemble Ichthyodectes sp. Cockerell. ${ }^{10}$ A few specimens are figured for the sake of more completely illustrating the known fauna.

Occurrence: Lykins Gulch, canyon west of Loveland, northwest of Loveland, Soldier Canyon, Cache la Poudre River, north of Bellvue, and Box Elder Creek, Colo.; Horse Creek and Iron Mountain, Wyo.

${ }^{9}$ Cockerell, T. D. A., Some American Cretaceous fish scales: U. S. Geol. Survey Prof. Paper 120, p. 1S0, pl. 35, figs. 1-15, 1919.

${ }^{10}$ Idcm, p. 179, pl. 34, figs, $3,4$. 
4

$+$

$\bullet$

4 


\section{PLATES XLV-L.}


U. S. GEOLOGICAL SURVEY

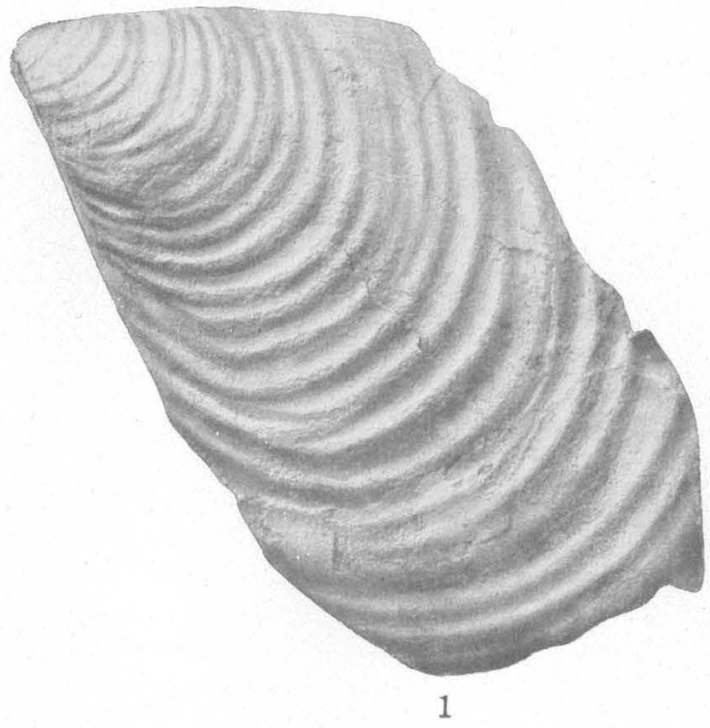

PROFESSIONAL PAPER 131 PLATE XLV
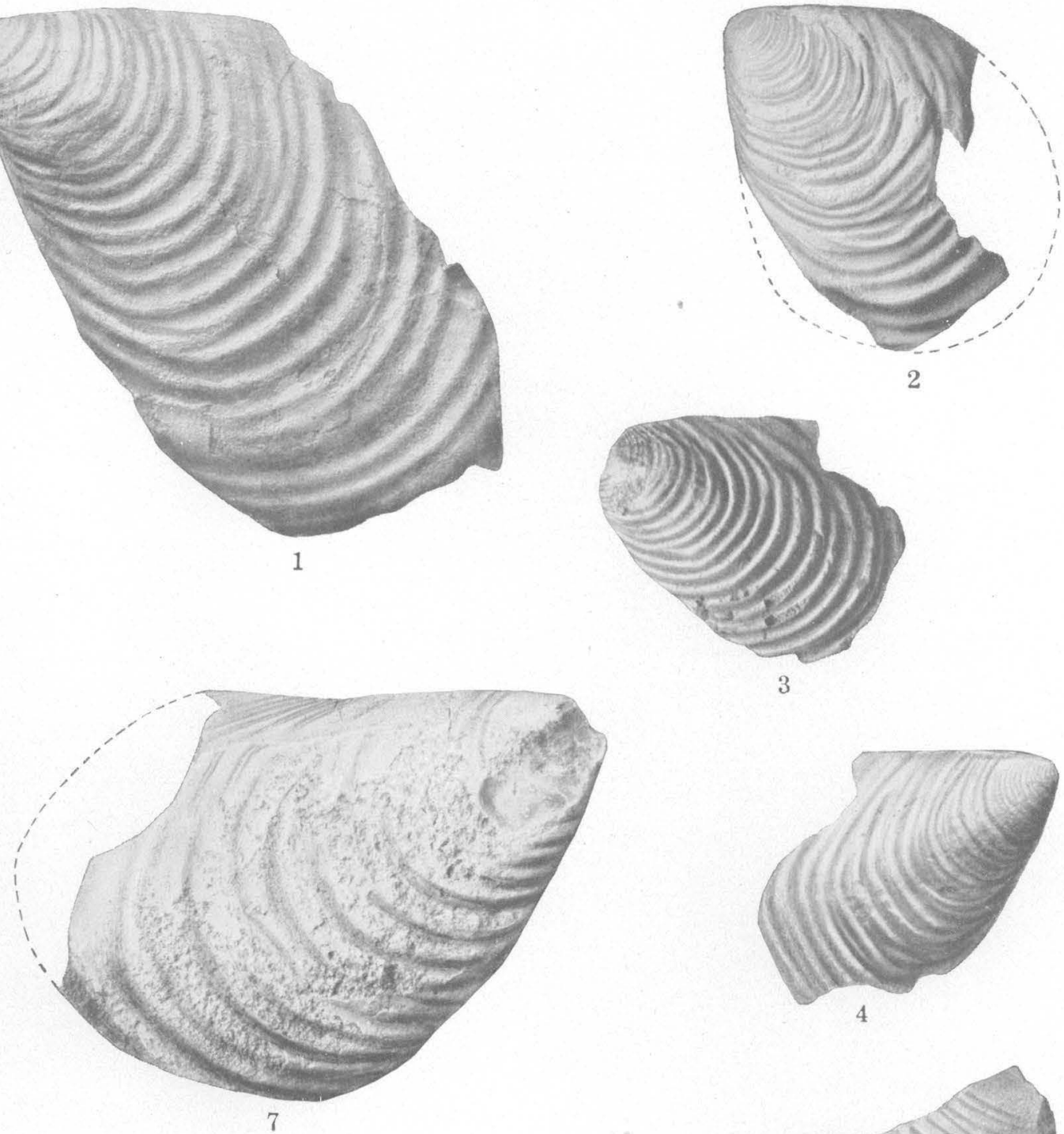

4

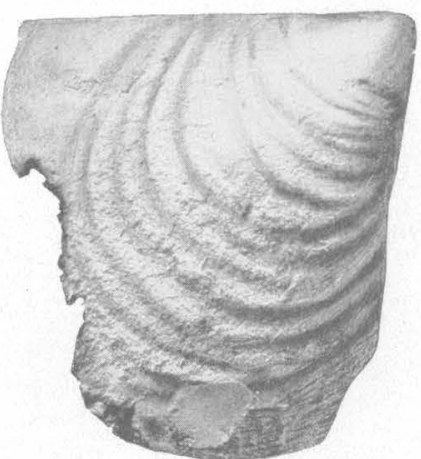

5

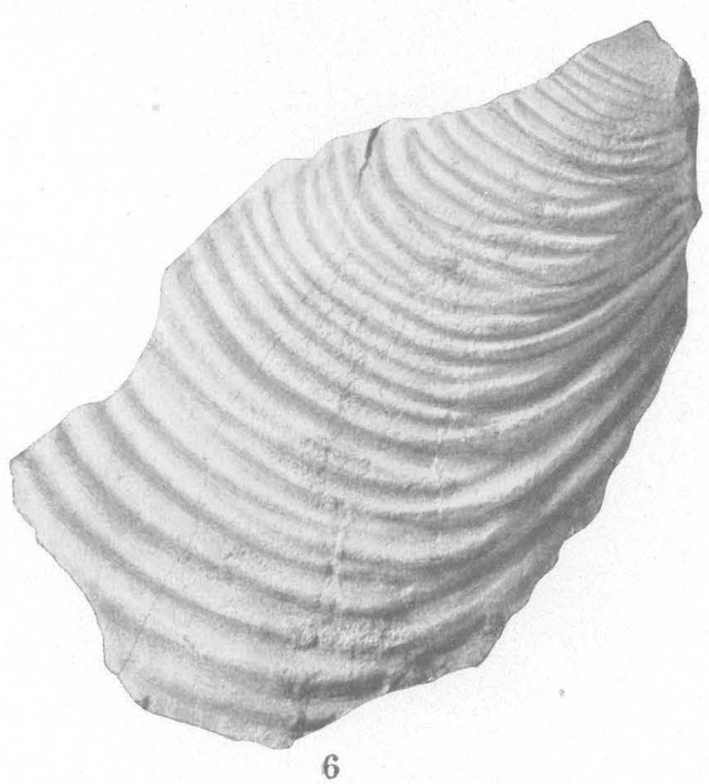

FOSSIIS OF THE SO-CALLED DAKOTA FORMATION OF NORTHERN CENTRAL COLORADO AND SOUTHEASTERN WYOMING.

Inoceramus comancheanus Cragin, north of Bellvue, Colo. 1-3, Left valves of three specimens (U. S. Nat. Mus. catalog No. 32513 ); 4-7. right valves of four specimens (U. S. Nat. Mus. catalog No. 32513). 
U. S. GEOLOGICAL SURVEY

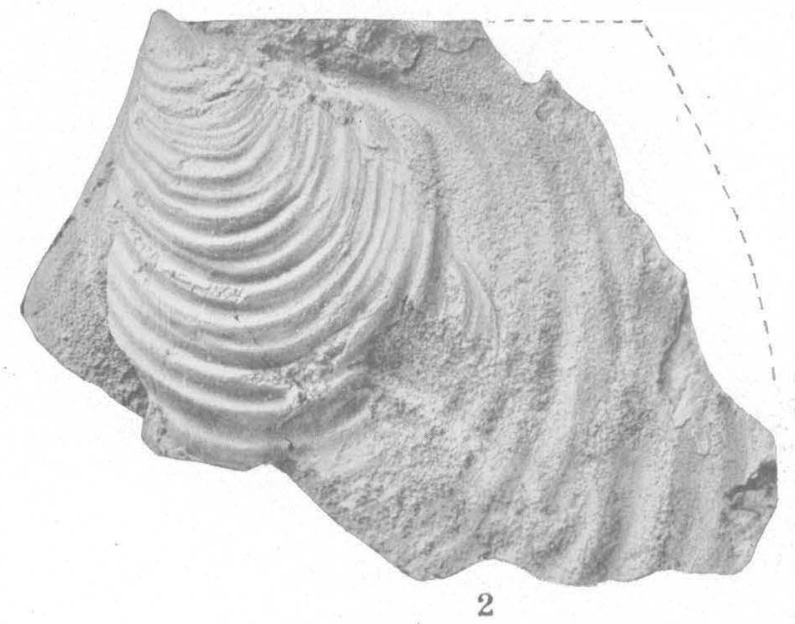

PROFESSIONAL PAPER 131 PLATE XLVI

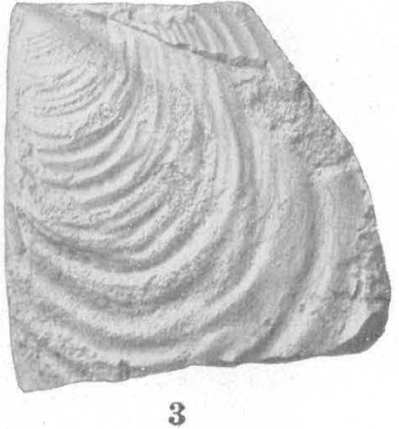

3

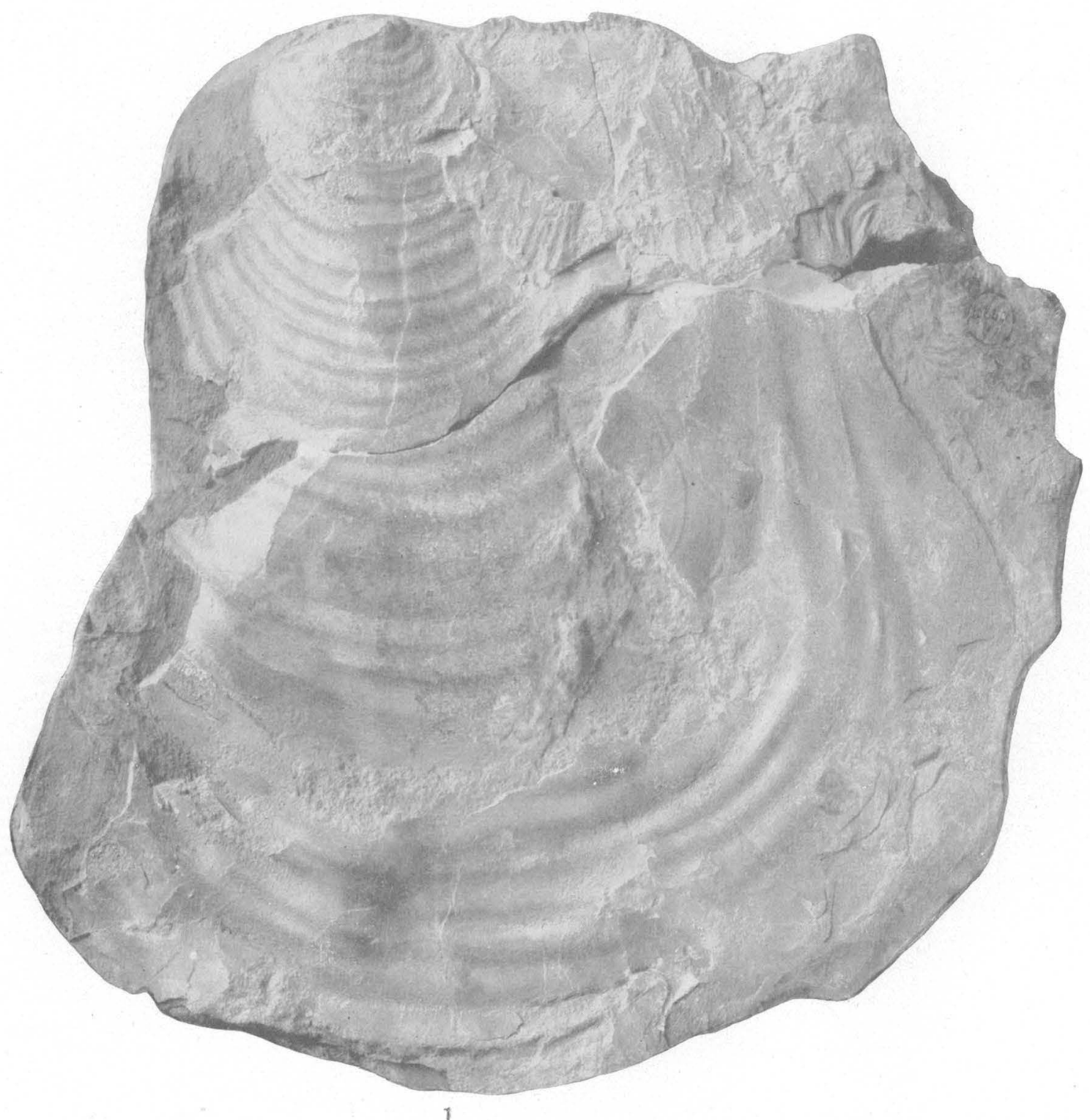

1

FOSSHS OF THE SO-CALLED DAKOTA FORMATION OF NORTHERN CENTRAL COLORADO AND SOUTHEASTERN WYOMING.

Inoceramus bellvuensis Reeside, n. sp, north of Bellvue, Colo, 1, Type specimen $\left(\times \frac{4}{5}\right)$, left valve (U. S. Nat. Mus. catalog No, 32514); 2, 3, left valves of two specimens (U. S. Nat. Mus. catalog No. 32515). 


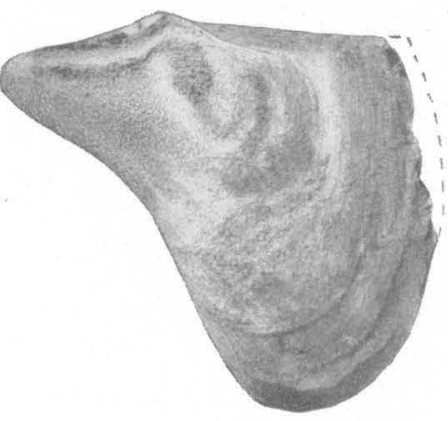

1

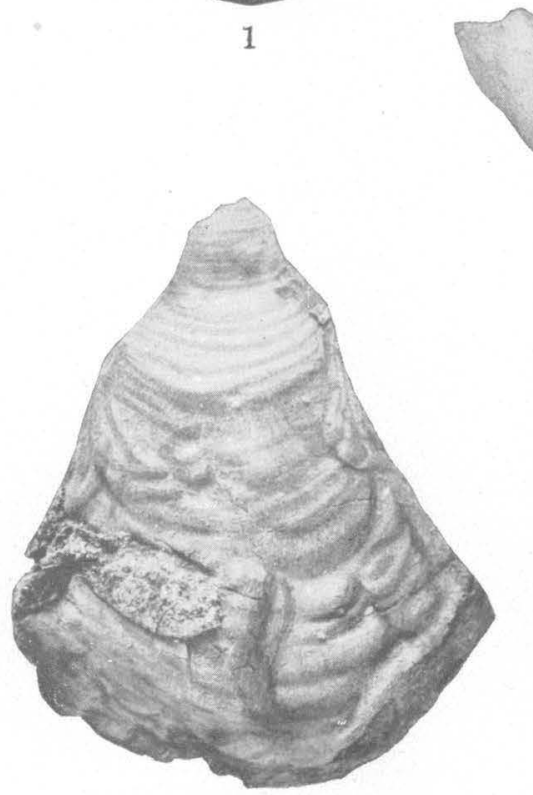

6

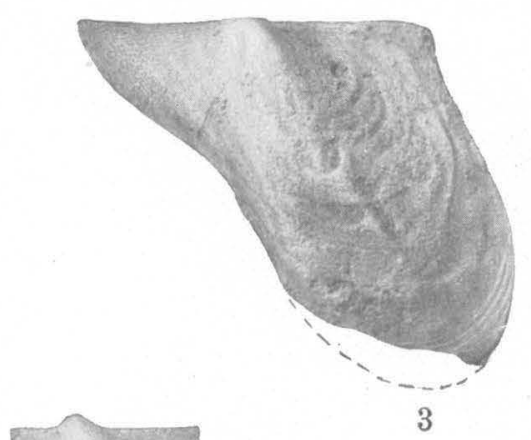

3

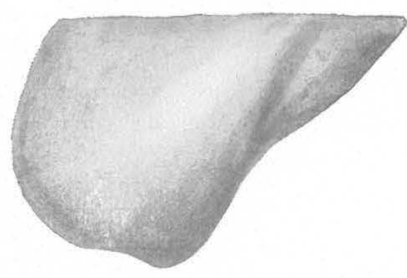

4

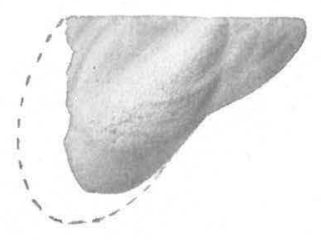

5
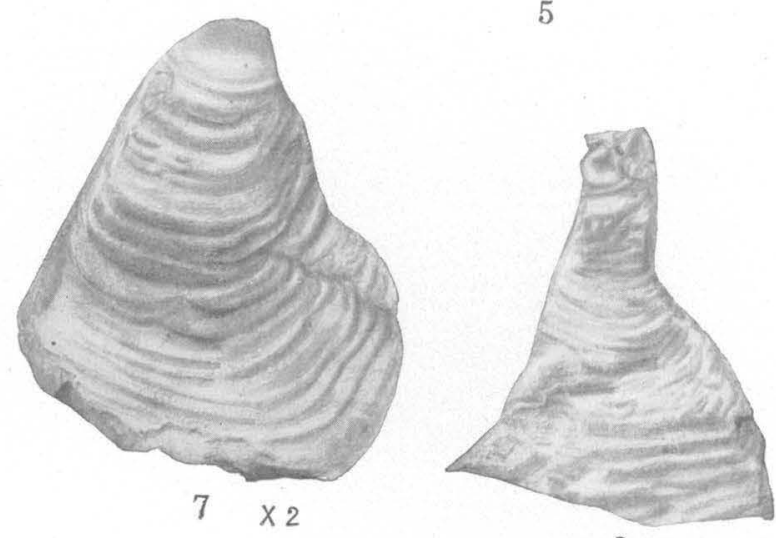

8

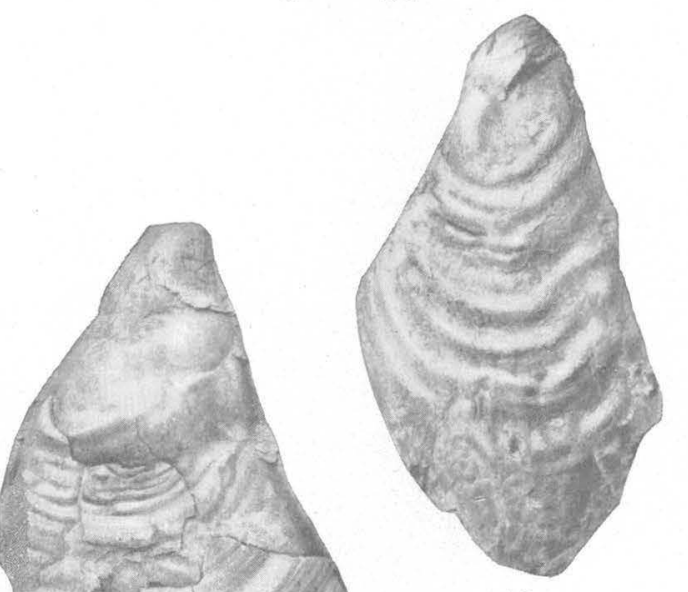

10

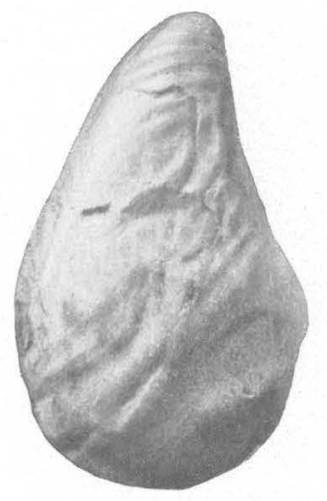

11

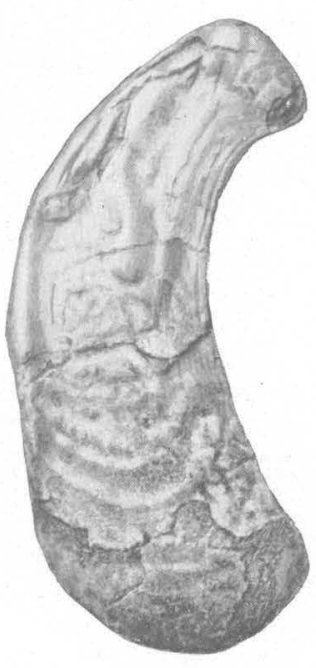

12

FOSSILS OF THE SO-CALLED DAKOTA FORMATION OF NORTHERN CENTRAL COLORADO AND SOUTHEASTERN WYOMING.

1-5. Pteria salinensis White, north of Bellvue, Colo. 1-3, Left valves of three specimens (U. S. Nat. Mus. catalog No. 32516); 4, 5, right valves of two specimens (U. S. Nat. Mus. catalog No. 32516).

6-10. Ostrea 7arimerensis Reeside, n. sn., Soldier Canyon, Colo, 6, Small complete valve, selected as the type (U. S. Nat. Mus, catalog No. 32517): 7,8, apical part of two valves, showing the sculpture (U. S. Nat. Mus. catalog No. 32518): 9, 10, two larger specimens, partly exfoliated (U. S. Nat. Mus. catalog No. 32518 ).

11, 12. Ostrea larimerensis Reeside, n. sp., north of Bellvue, Colo. 11, Internal cast of an unusually convex specimen (U. S. Nat. Mus, catalog No. 32519); 12, a nearly complete valve retaining the shell (U. S. Nat. Mus. catalog No. 32519). 


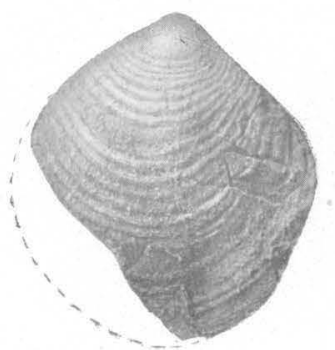

2

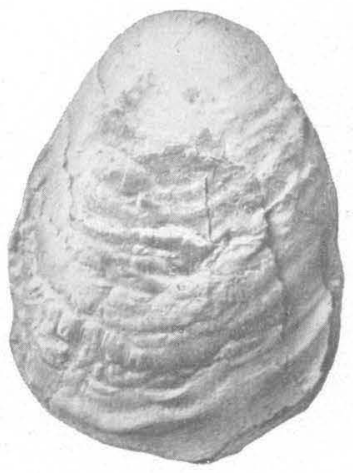

3

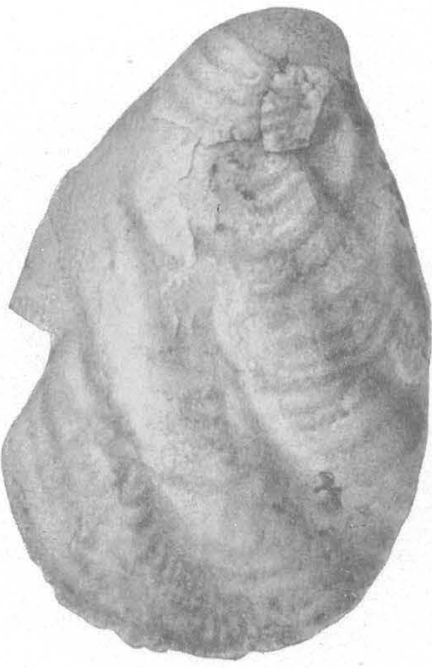

4

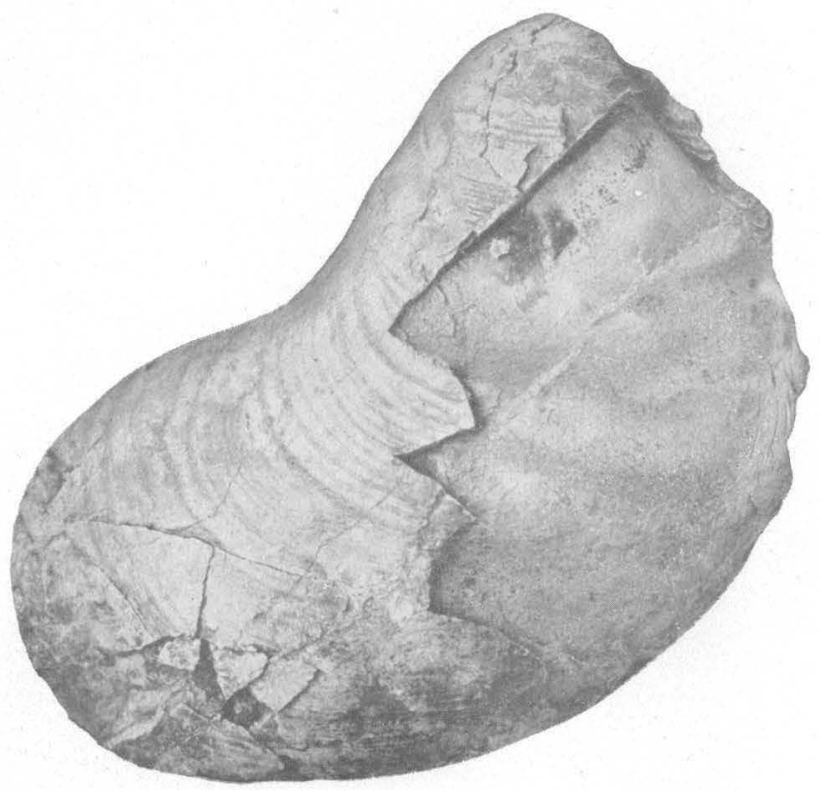

1
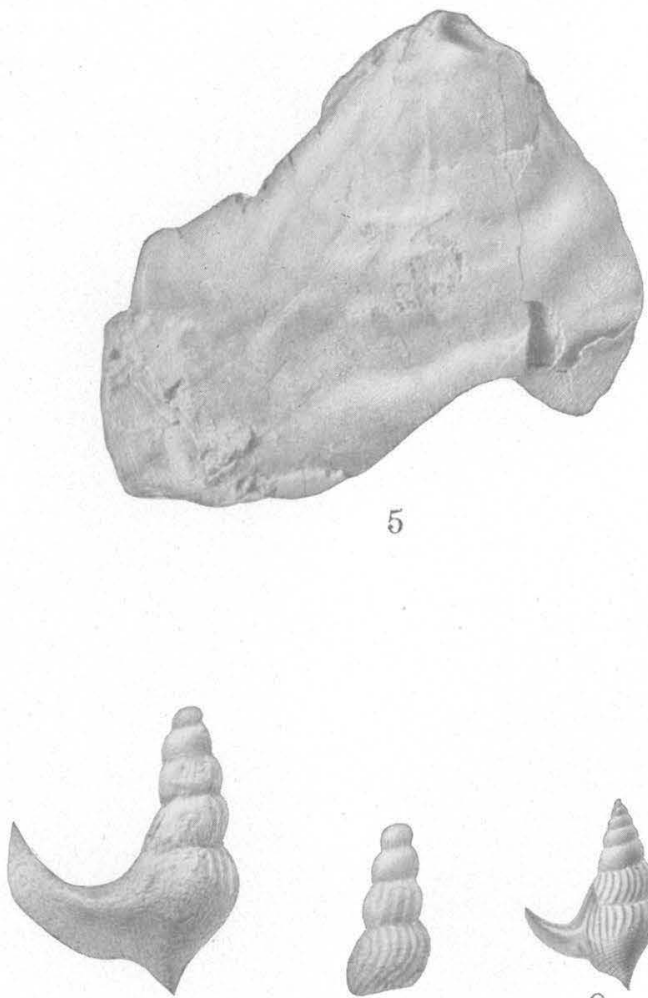

6

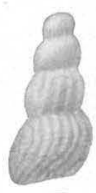

7

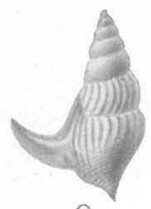

8

FOSSILS OF THE SO-CALLED DAKOTA FORMATION OF NORTHERN CENTRAL COLORADO AND SOUTHEASTERN WYOMING.

1,2. Ostrea noctuensis Reeside, n. sp., Owl Canyon, Colo. 1, Type specimen (U. S. Nat. Mus. catalog No. 32520); 2, Apical part of another specimen (U. S. Nat. Mus. catalog No. 32521).

3,4. Ostrea noctuensis Reeside, n. sp., north of Bellvue, Colo. 3, Specimen retaining most of the shell (U. S. Nat. Mus. catalog No. 32522); 4, specimen retaining only the apical part of the shell (U. S. Nat. Mus. catalog No. 32522).

5. Ostrea noctuensis Reeside, n. sp., Soldier Canyon, Colo. Internal cast. (U. S. Nat. Mus, catalog No. 32523.)

6, 7. Anchura kiowana Cragin?, Soldier Canyon, Colo. Two specimens (X 2). (U. S. Nat. Mus. catalog No. 32524.)

8. A nchura kiowana Cragin; typical example from Kansas for comparison. 


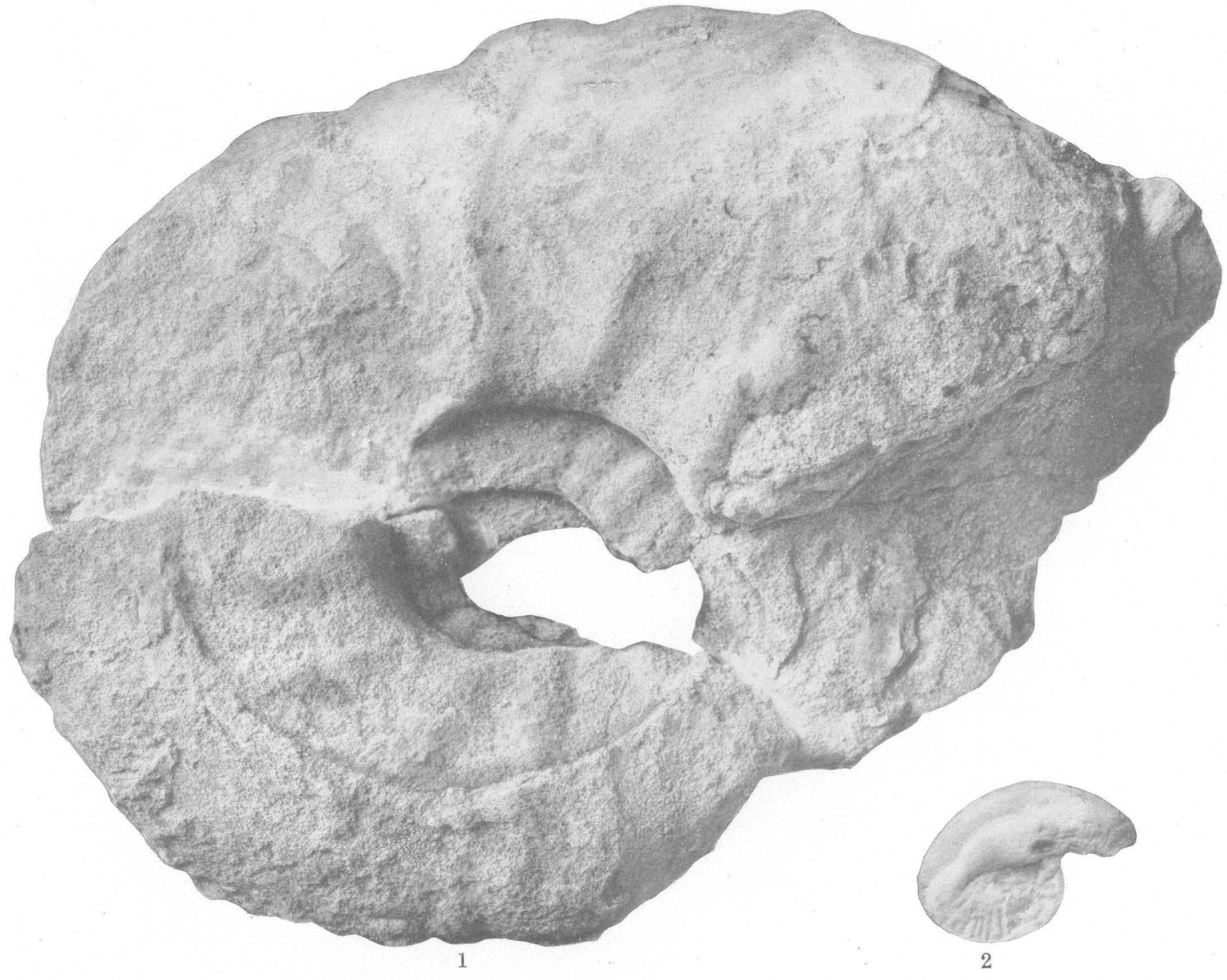

FOSSILS OF THE SO-CALLED DAKOTA SANDSTONE OF NORTHERN CENTRAL COLORADO AND SOUTHEASTERN WYOMING.

1. Pachydiscus? sp., 2 miles southeast of Greenacre ranch, Colo. (U. S. Nat. Mus. catalog No. 32525).

2. Ammonite, undetermined, Iron Mountain, Wyo. (U. S. Nat. Mus. catalog No. 32526). 


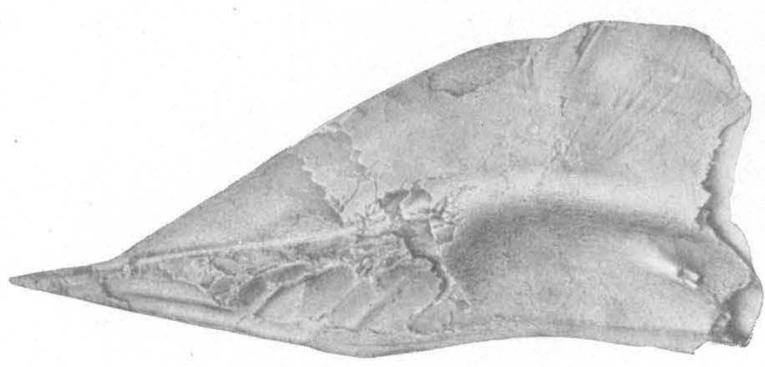

1
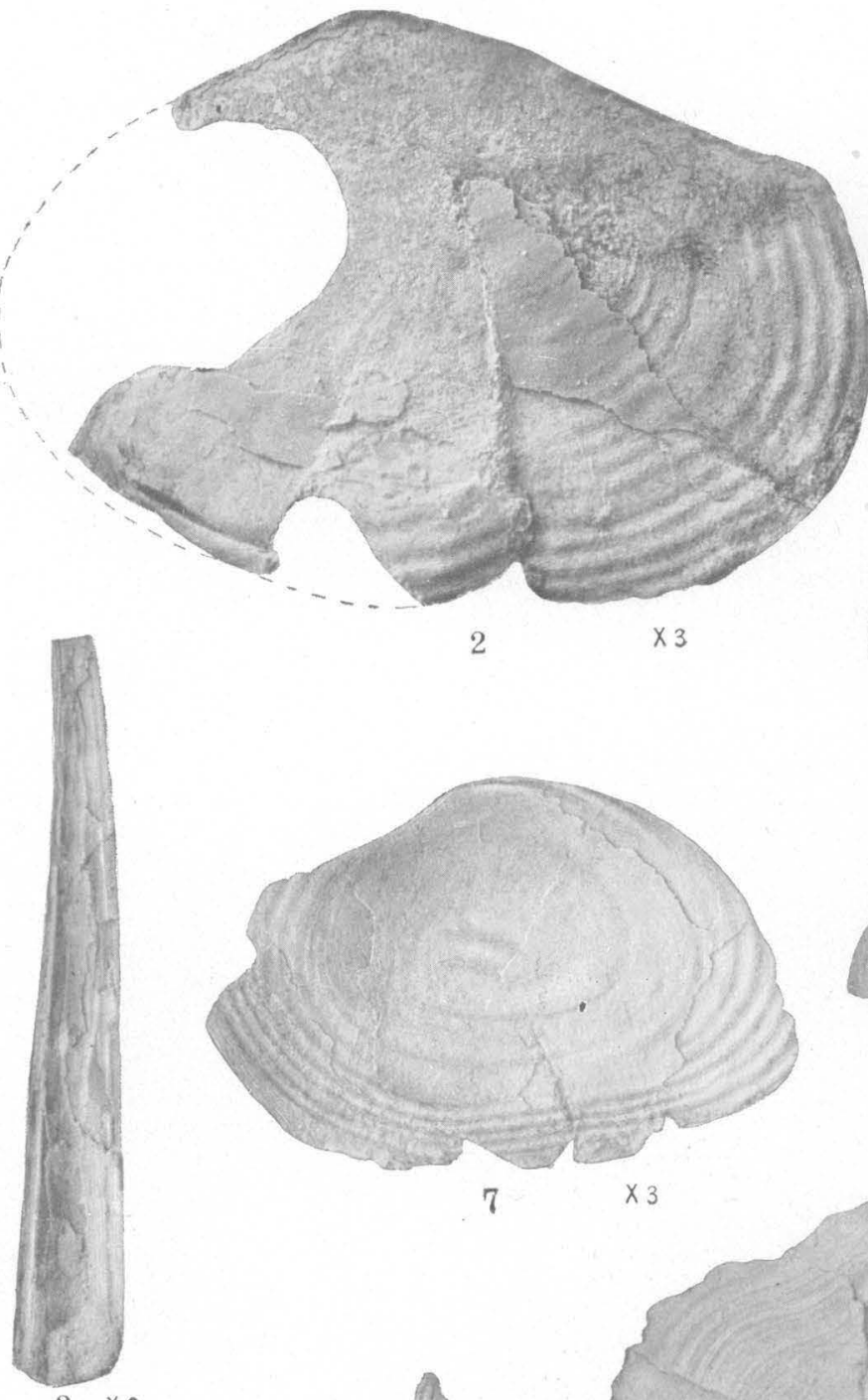

2

$\times 3$
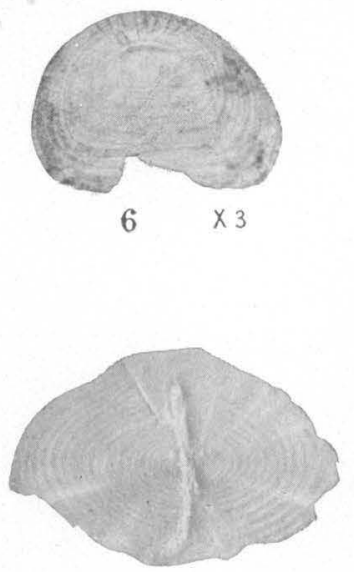

$\times 3$
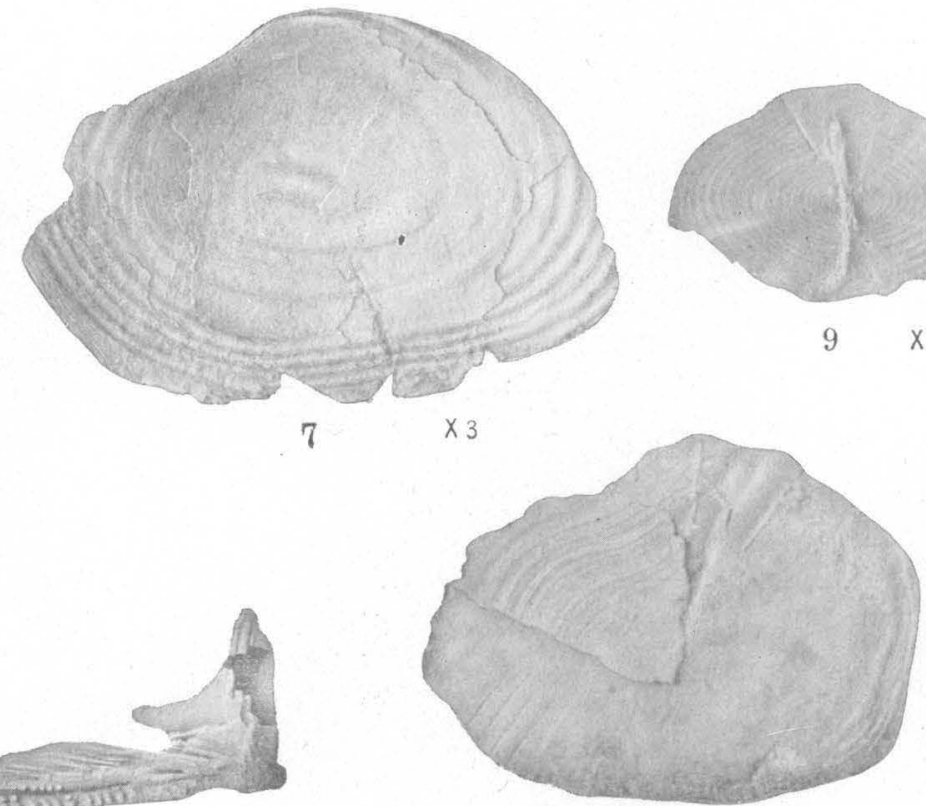

7

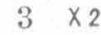

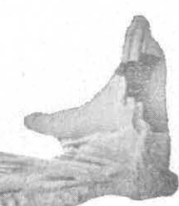

$\times 2$

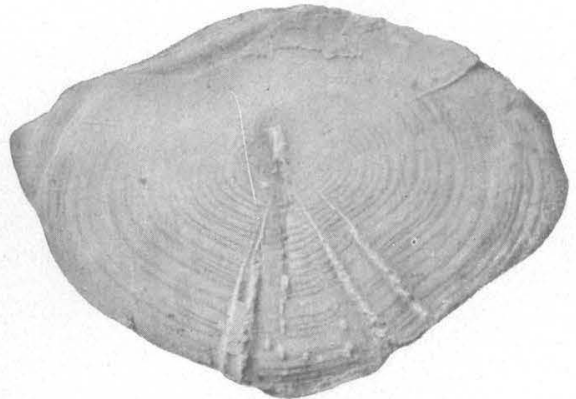

5

$\times 3$

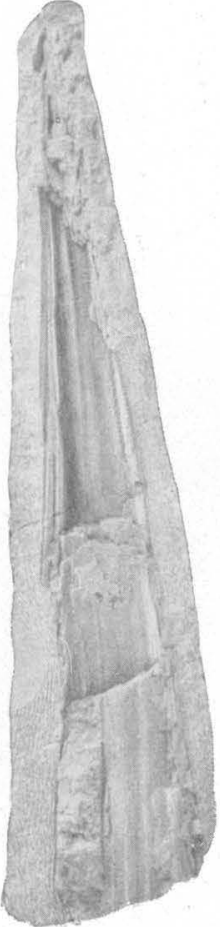

10

FOSSILS OF THE SO-CALLED DAKOTA SANDSTONE OF NORTHERN CENTRAL COLORADO AND SOUTHEASTERN WYOMING.

1-7. Fish seales and bones, north of Bellvue, Colo. (U. S. Nat. Mus. catalog No, 10771).

8-10. Fish scales and bone, Iron Mountain, Wyo. (U. S. Nat. Mus. catalog No. 10772).

11. Fish bone, Horse Creek, Wyo. (U. S. Nat. Mus. catalog No. 10773). 


\section{INDEX.}

$A$.

Abies longirostris Knowlton, $\mathrm{n}$. $\mathrm{sp}$ rigida Knowlton, n. sp

Acer Indivisum Lesquereux.

(a)

$\Lambda$ cknowledgments for aid ................................ $1,83,85$

Acrostichum hesperium Newberry sp .

Ailanthus longe-petiolata lesquereux.

Alexander, C. P., cited

Alnites inaequilateralis.

Alnus inacquilateralis. .............................

Alnus? larseni Fnowlton, n. sp....

Ammonite, undetermined.

Ampelopsis tertiaria Lesquereux

Amygdalus gracilis Lesquereux.

Anacardiaceac.

167-16s

Anchura kiowana Cragin?.............................. 204-205

Andromeda delicatula Lesquereux....................... 172

Angiospermae................................. \&-20, 152-176

Antholithes improbus Lesquereux........................ 174

A pocynophyllum constrictum Berry . ..................... 20 mississippiensis Berry..$\ldots \ldots \ldots \ldots \ldots \ldots \ldots \ldots \ldots \ldots \ldots .20$ scudderi Lesquereux...

Aralia macrophylla Newberry.

wyomingensis Knowlton and Cockerell

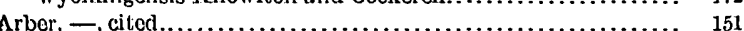

Arecacene.......................................... 8, 152-154

Aricacene. ......................................... 172

Artocarpoides balli Barry, n. sp........................ 8

Arundo reperta Lesquereux............................... $\quad 152$

Ascomycotos.................................... 148-149

B.

Ball, O. M., acknowledgment to $\ldots \ldots \ldots \ldots \ldots \ldots \ldots \ldots \ldots \ldots \ldots \ldots$
Baker, C. L., acknowledgment to..............................

Bass trail, Ariz., Cambrian formations exposed at................ 85 Carboniferous formations present near.................... 54-71 columnar section of Paleozoic strata at ................... 26 detailed section of Paleozoic strata at................... 27-36 general section of Paleozoic strata at..................... 26-27

Berry, Edward Wilber, acknowledgment to.................... 85 Additions to the flora of the Wilcox group................. 1-21 cited ........................................... 143, 148

Blossé ranch, Mexico, section of Midway formation near........ 88-89

Bordas scarp, features of .............................. 85

Boydsville, Ark., Wilcox fossils from locality near.............. 2

Brasenia? antiqua Newberry $. . \ldots \ldots \ldots \ldots \ldots \ldots \ldots \ldots \ldots \ldots . .163$

Brenks of the Rio Grande, features of .................. 85

Bridger Pass, W yo., Green River fossils from ............... 138-139

Bright Angel shale, analysis of limestone from................... 40 fossils in, near the Bass trail, Ariz ........................ 42 nature of................................... 26, 34-35, 39-41 thickness of ..................................... 41-42 typical oxposure of, opposite mouth of Garnet Canyon, Ariz., plate showing

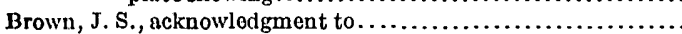

Bryophyta.

40
83

\section{C.}

Cacnomycos eucalyptae Knowlton, n. sp.................. 148 sapindicols Knowlton, $n$. sp........................... 148 Caesalpiniacere........................................ 14

Calatoloides eocenicum Berry, n. sp.................... 14-15

Callocardia astartoides Gardner, n. sp ................ 113, Pl. XXXII Campanulales.
Page:-

Caprifoliaceae.......................................

Cardita alticosta ta Conrad............................... 112

Carditidae.................................................. 112-113

Carduus florissantensis Cockerell.......................... $190^{\circ}$

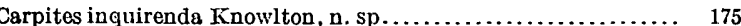

newberryana Knowlton, n. sp..................... 174-175

viburni Lesquereux ................................ 174

Carpolithus caryophylloides Knowlton, $\mathrm{n} . \mathrm{sp} \ldots \ldots \ldots \ldots \ldots \ldots . . \ldots 174$

Carrizo Springs, Tex., Wilcox fossils from ................... 4

Cassia emarginata Berry .......................................

Ceanothus cinnamomoides Lesquereux........................ 170

Cedar Mountain, Ariz., beds overlying the Kaibab limestone in . $71-73$ view of from Desert View Camp, Ariz, plite showing .... 65

Celastraceae....................................... 169

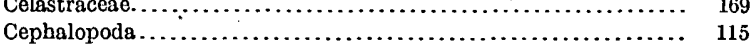

Cerithium? sp. A............................... 115

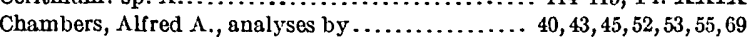

Changes of names in Green River flora................... 141-142

Cinnamomum mississippiensis Lesquereux.................... 9

Cissus parrottiaefolia Lesquereux............................ 170

Citellus bensoni Gidley, $\mathrm{n} . \mathrm{sp} \ldots \ldots \ldots \ldots \ldots \ldots \ldots \ldots \ldots \ldots \ldots, 122$

cochisei Gidley, n. sp ................................ 121-122

Claiborne group of Georgia, flora common to Green River formation and..................................... 143

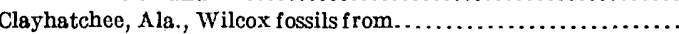

Cobbles, roller-shaped, in two stages of formation, plate showing.. $\quad 72$

Cockerell, T. D. A., cited............................ 147-149

Coconino sandstone, fossils in, on the Hermit trail, $A$ riz ......... 68 nature of, in the Grand Canyon, Ariz................ 26, 28,66-67 thickness of . . ........................................ $67-68$

Colorado localities, Green River fossils from.................

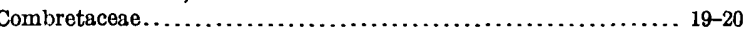

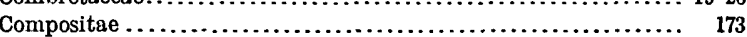

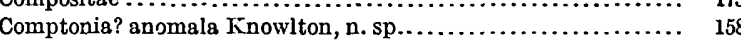

Concillas Creek, Tex., Wilcox fossils from...................

Coniferophytae.........................................

Cope, E. D., cited.........................................

Cope Butte, near Hermit Creek, Ariz., analysis of limestonefrom. section of strata in ................................... 53

Cornus studeri Lesquereux.............................. 16

Cragin, F. W., cited................................. 202, 204

Crassulaceae?.............................................. 163-164

Cratogeomys bensoni Gidley, n. sp ........................ 123

Cucullaea Lamarck.................................... (macrodonta subsp.?) texana Gardner, n. subsp.111-112, Pl. XXIX saffordi Harris. ........ Cupressinoxylon Goeppert.......................................... wilcoxense Berry, n. sp . ............................. $66_{6-8}$

Cyperacites haydenii (Lesquereux) Knowlton............... 152

Cyperites haydenii Lesquereux $\ldots \ldots \ldots \ldots \ldots \ldots \ldots \ldots \ldots \ldots \ldots, 152$

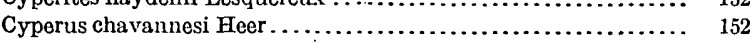

"chavanensis"? Heer ....................................... 152

D.

"Dakota formation" of northern Colorado, fauna of.......... 201-202 Dalbergia eocenica Berry ............................. 14 puryearensis Berry, new name...................... 14

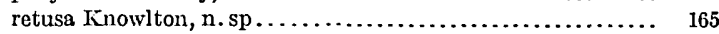

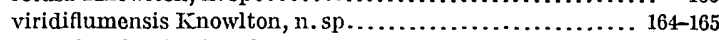

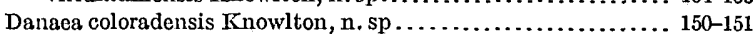
Davis, C. A., study of Green River oil shale by.............. 135-136

Deussen, Alexander, acknowledgment to.................... 85 Dicotyledones................................... 8-20, 155-176 Dipodomys minor Gidley, n. sp ......................... 123 Dombeyopsis occidentalis Lesquereux........................ Drupaceae ........................................ 164

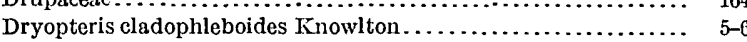
Dumble, E. T., acknowledgment to . 
$\mathbf{E}$

Eligmoāontia

azizonae Gialey, n. sp............................. 124-125

Emmons, S. F., cited.............................. 133-134

Enclimatoceras vaughani Gardner, n. sp.............. 115, Pl. XXXIII

Equisetaceae.................................... 151-152

Equisetum wyomingense Lesquereux .................. 151-152

Ericaceae. . ...................................... 172

Eucalyptus? americanus Lesquereux................... 171-172

Euonymus flexifolius Lesquereux.

\section{F.}

Fagaceae.

Ficus, reexamination of species of

Ficus clintoni Lesquereux.

latifolia Knowlton.

mississippiensis (Lesquere

neoplanicostata Knowlton.

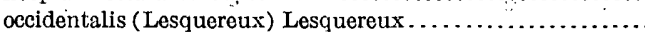

planicostata Lesquereux...

clintoni Knowlton.....

goldiana Lesquereux

latifolia Lesquereux.

maxima Berry .

pseudopopulus Lesquereux.

richardsoni Knowlton...

tenuinervis Lesquereux

ungeri Lesquereux.

wyomingiana Lesquereux

Filicales.

Flabellaria florissanti Lesquereux

Florissant, Colo., lake beds, features of

Fort Hale, Conn., beach at, plate showing.

cliff of jointed trap at, plate showing.

conditions of abrasion near.

sizes and sources of beach gravel near.

(Deen River formation and

s on Coconino sandstone, Bright Angel quadrangle

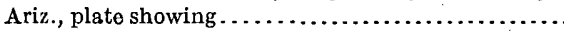

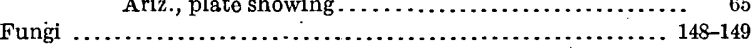

$$
\text { G. }
$$

Gardner, Julia, New species of Mollusca from the Eocene deposits of southwestern Texas.

109-117

Gastropoda...................................... 114-115

Gentianales.......................................... 20

Geomys minor Gidley, n. sp............................ 123

parvidens Gidley, n. sp........................ 122-123

Geonomites haydenii (Newberry) Knowlton, n. comb......... 152-153

Geraniales....

Gidley, James W., fossils determined by.....................

Preliminary report on fossil vertebrates of the San Pedro Valley, Ariz.

Girty, G. H., fossils determined by ................... 56, 57, 70-71

Graminales................................................. $\quad 152$

Carboniferous formations in.

$54-71$

Devonian formation in.......

possible unconformity between the Devonian and Carboniferous systems in .

unconformity between the Cambrian and Devonian systems in . $49-51$

Grand Junction, Tenn., Wilcox fossils from.

Gravel, in pocket beach south of Nantasket, Mass., plate showing.

of promontory south of Nantasket, Mass., plate showing......

Green River formation, biologic interpretation of ........... 144-148

climate during deposition of ...................... 144-147

early descriptions of............................. 133-135

eclogic interpretation of . . . . . . . . . . . . . . .

flora of, accepted names of ............................ 142

age of ........................................ 142-144

ferns in ........................................... 145

highland genera of ............................. 147

lowland genera of .............................. 147

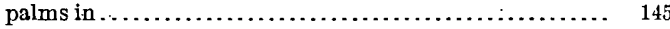

relation of, to other floras........................ 142

species excluded from. . ........................ 139-141

synonyms and changes of names in ................. 141-142 $\begin{aligned} & \text { Page. }\end{aligned}$ reen River formation, insect fauna of, climate required by .... 147-148: organic remains in ............................... 135-136 Green River lake, fishes of ............................. 137

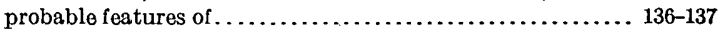
Green River station, fossils from . . . . . . . . fossils from locality west of .......................... 138 Gulf Coastal Plain of Texas, geologic map of ................. 104

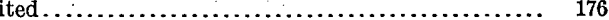

Hayden, F. V., cited ............................................ 133,135

Hedera marginata Lesquereux.............................. 189

Helictoxylon wilcoxianum Berry, n. sp.................... 18

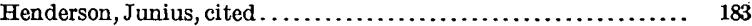

Hepaticae.........................

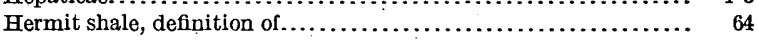

fossils in, near Red Top, Ariz .......................... 65-66

nature and thickness of ......................26, 28-29, 64-65

typical exposure of, in Tapeats Amphitheater, Ariz., plate showing..................................

unconformities between the Supai formation and, Bright Angel quadrangle, Ariz . . . . . . . .

plates showing $\ldots \ldots \ldots \ldots \ldots \ldots \ldots \ldots \ldots \ldots \ldots \ldots \ldots \ldots \ldots \ldots \ldots \ldots \ldots, 64$

I.

Icacinaceae.

Ilex maculata Lesquereux.................................... 169

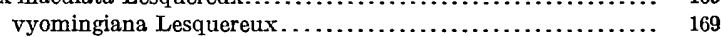

Mex? affinis Lesquereux................................... 169

Inoceramus bellvuensis Reeside, n. sp..................... 203

comancheana Cragin ............................... 202

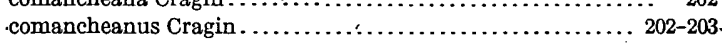

$\mathrm{J}$.

Jacksonville, Ark., Wilcox fossils near...................... 2

Juglans alkalina Lesquereux . . . . . . . . . . . . . . . . . . . . . . . . .

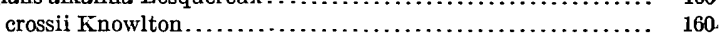

denticulata Heer................................. 160

occidentalis Newberry . . . . . . . . . . . .

schimperi Lesquereux.......................... 158, 159-160.

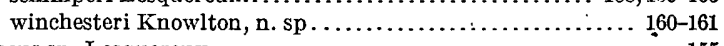

Juncus sp. Lesquereux................................

\section{K.}

Kaibab limestone, analyses of limestone from............... 69

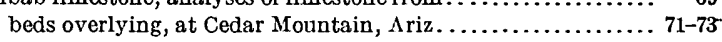
fossils in, at Bass Canyon, $\Lambda$ riz. . . . . . . . . . . . . . . $70-71$ nature of .................................... 26, 27-28,68-70 subdivisions of ................................. 70

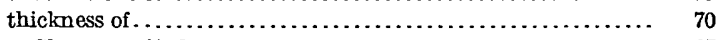

King, Clarence, cited..................................... 137

Kirk, Edwin, cited.

Knowlton, F. H., Fossil plants from the Tertiary lake beds of south-central Colorado....................... 183-197 Revision of the flora of the Green River formation........ 133-182 L.

Laboulbiliales.

(148

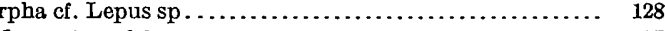

sp. Nos. 1,2 , and $3 \ldots \ldots \ldots \ldots \ldots \ldots \ldots \ldots \ldots \ldots \ldots \ldots \ldots \ldots$
ke beds of south-central Colorado, fossil plants from......... $184-197$

nature and stratigraphic places of . ................... 183-184

La Pryor crossing on Nueces River, Tex., Wilcox fossils from locality near................................. 304

Larsen, E. S., cited . ................................. 183-184

Lauraceae............................................ 163

Laurinoxylon branneri Knowlton....................... 19

wilcoxianum Berry, n. sp .......................... 19

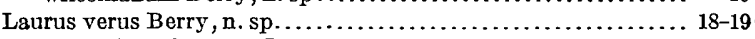

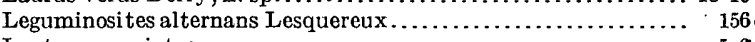

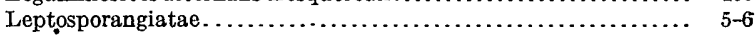

Lesquereux, Leo, cited............................ 137,

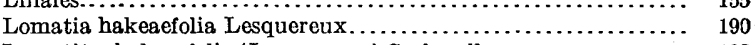

Lomatites hakeaefolia (Lesquereux) Cockerell .................... 190

Lomatia? microphylla Lesquereux........................ 162

Lull, R. S., f ossils determined by $\ldots \ldots \ldots \ldots \ldots \ldots \ldots \ldots \ldots \ldots \ldots \ldots \ldots \ldots, 68$

Lygodium dentoni Lesquereux........................... 150

kaulfussii Heer................................................

neuropteroides Lesquereux............................... 
Magnolia angustifolia Newberry attenuata Wober.

lanceolata Losquercux.

losleyana Lesquereux. loel Knowlton.

Magnoliacoae.

Malvales.

Manicaria haydenii Newberry.

Marattiaceno.............. 150-151

Marchantites stephensoni Berry, n. sp.................... 4-5

Marchantiales............................................

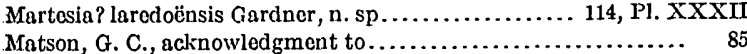

Matson, G. C., acknowledgment to ........................ 85

Menispermacenc........................................ 12-14

Mimosites coloradensis Knowlton, n. sp.................. 166

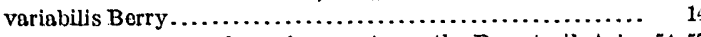

Miss'ssippian series, members of, present near the Bass trail, Ariz. 54-57 probable unconformity between Pennsylvanian series and, near Bright Angel trail, Ariz.................. 57-59

Monocarpellitos perkinsi Berry, n. sp..................... 16-17

Monocotyledones................................... 8, 152-155

Moraccao....................................... 8-12,162

Mua 7 limestono, analyses of limestones from................ 43, 45

fossilsin, near Bass Canyon, Ariz..................... 48-49

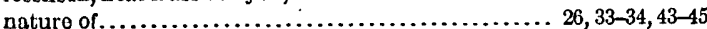
subdivisions of ......................................... $43-45$ thicknoss and correlation of . ........................ 45-48 typical exposure of, opposite mouth of Garnet Canyon, Ariz., plate showing

unconformities between Temple Butte limestone and, in Shinumo quadrangle, Ariz., plates showing........... 50 ,

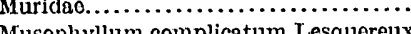

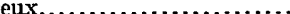

Myrica ludwigii Schimper.

minuta Knowlton, n. $\mathrm{sp}$

nigricans Lesqueroux..

pracdrymeja Knowiton, n. sp

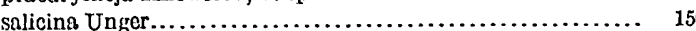

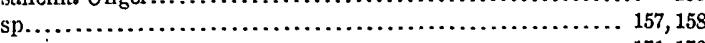

Myrtacene?...................................... 171-172

Myrtales............................................. 19-20

$\mathrm{N}$.

Nantasket Boach, Mass., south end of, conditions of abrasion on. . 75-76 south end of, gravel and cobbles on, plates showing.......... 76

sizos and sources of pebbles on .........................

Necdmoro, Tax., Wilcox fossils from locality near................

Nogrect, La., Wilcox fossils from.............................

Nooflbor $\mathrm{sp}$..

Neotoma fossilis Gidley, n. sp....................... 126-127

Nowberry, J. S. cited............ 135, 139, 149, 150, 153, 168, 172, 174-17

Noble, I. F., A section of the Palcozoic formations of the Grand Canyon at the Bass trail....................... 23-73

Nordenskiöldia borealis Heer........................... 176

Nuculn sp...................................... 109, Pl. XXIX

Nymphacacere.

0.

Oakville, Tex., Wilcox fossils from lorality northeast of.........

Odostamon hakeaefolia (Lesquereux) Knowlton, n. comb....... 190 marginata? (Losquereux) Knowlton, n. comb............. 189-190

?Odostemon florissantonsis Cockerell.

Oil shales of the Green River formation, extent of source of oil in...

............................. 144

n. sp........................... 125

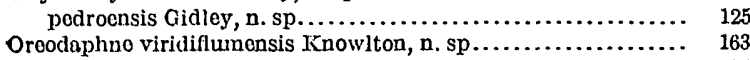

Osborn, H. F., , cited.

Osmunda? sepulta (Newberry) Knowlton, n. comb. ......... 150

Ostroa alabamiensis subsp. georgians Conrad................ 110-111,

PIs. XXIX, XXX

contracta Conrad

$\mathrm{XXX}$
110

latimerensis Reeside, n. sp........................... 203-204

noctuensis Reoside, $n$. sp............................. 204

tasex Gardner, n. sp........................ 109-110, Pl. XXXI

titon Conred.

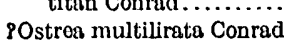

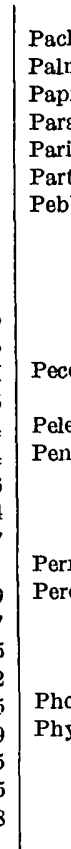

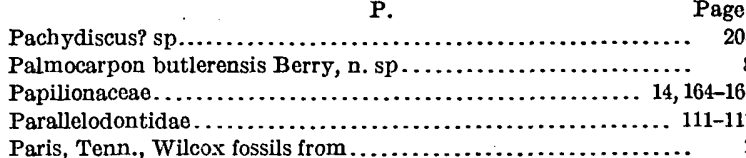

Parthenocissus tertiaria (Lesquereux) Knowlton, n. comb ...... 170-171

Pebbles, beach, conditions that determino shapes of........... 75, 82-83

beach, laboratory determinations on .................. 76

methods of measuring............................. 76

purpose of the study of......................... 75

roundness and flatness ratios of, methods of computing... . 76 results of computations of ...................... $76-\$ 2$

Pecopteris (Cheilanthes) sepulta Newberry................ 150

(Phegopteris) sepulta Newberry ..................... 150

Pelecypoda....................................... 109-114

Pennsylvanian series, formations of, present near the Bass trail,

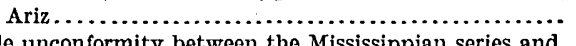

probable unconformity between the Mississippian series and,

in the Grand Canyon, Ariz ......................
Permian series, formation of, in the Grand Canyon, Ariz.......

Peromyscus...................................... 124

brachygnathus Gidley, n. sp........................ 124

minimus Gidley, n. sp............................. 124

sp ........................................... 124

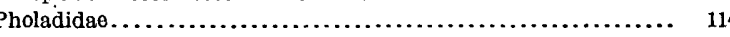

Phyllites coloradensis Knowlton, n. sp ....................... 176

fremonti Unger.................................... 176

potentilloides Knowlton, $n$. sp.................... 191-192

sp.......................................... 191

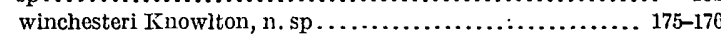

Pimelea spatula Innowlton, n. sp........................ 163

Pinales............................................ $6-8$

Pinus coloradensis Knowlton, $n . \mathrm{sp} \ldots \ldots \ldots \ldots \ldots \ldots \ldots \ldots . . \ldots 186$ crossii Knowlton, n. sp.............................. 185-186 florissanti? Lesquereux................................. 180 similis Knowiton, n. sp............................. 180

Planera inaequilateralis (Lesquereux) Knowlton, n. comb..... 161-162 Iongifolia myricaefolia Lesquereux ...................... $18 s$ myricaefolia (Lesquereux) Cockerell ..................... 188 variabilis Newberry ................................. 161, 167-168

Polypodiaceae ................................... 5-6,149

Pontederites hesperia, Knowlton, 1. sp ................. 154-155

Populus heerii Saporta................................... 187

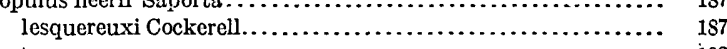

Proteaceae ........................................... 162

Pteria (Oxytoma) salinensis White....................... 203

salinensis white..................................... 203

Pteridophyta...................................... $5-6,149-152$

Pterobalanus Berry, n. gen ............................. 20

texanus Berry, n. sp............................. 20

Pulliam ranch, Zavalla County, Tex., Wilcox fossils from locality near.................................... Q.

Quercus castaneopsis Lesquereux....................... 161 161

R.

Ranales....................................... 12-14, 163

Ransome, F. L., cited ................................... 65

Redwall limestone, analyses of limestone from .................. definition of ........................................ 5 fossils in, near Bass trail, Ariz........................ 56-57 nature of............................................... $26,31-32,54-55$

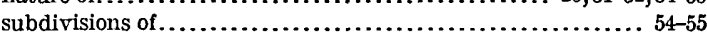
thickness of ..................................... 56

typical exposure of, opposite mouth of Garnet Canyon, Ariz., plate showing.

Reeside, John B.,jr., The fauna of the so-called Dakota formation of northern central Colorado and its equivalent in southeastern Wyoming........................ 199-207

Rhamnaceae . $15-16,169-170$

Rhamnites knowltoni Berry, new name...................... 16

Rhamnus cleburni Lesquereux........................... 15

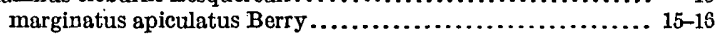

Rhus acuminata Lesquereux........................... 167 lesquereuxii Knowlton and Cockerell................... 167 myricoides Knowlton, n. sp.......................... 168 nigricans (Lesquereux) Knowlton, n. comb................ 168 variabilis (Newberry) Knowlton, n. comb................. 167-168 Ribes protomelaenum Cockerell.......................... 188-189 Rio Colorado, Tex., water carried by .......................... 102 
Page.

Rodentia

Rosales....

Rubus? inquirendus Knowlton, n. sp ..................... 188

Sabal powellii Newberry

$\mathrm{S}$.

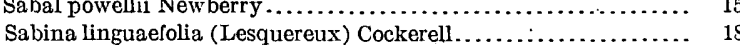

Salix angusta Al. Braun? Newberry.................... 171

linearis Knowlton, $\mathrm{n} . \mathrm{sp} \ldots \ldots \ldots .155$

iongiacuminata Knowlton, $n . s p \ldots \ldots \ldots \ldots \ldots \ldots \ldots \ldots . \ldots \ldots$ 155-156

media Heer . . ......................................... 156 sp......

Salt, occurrence of, in the Tapeats sandstone

San Pedro Valley, Ariz., collection of fossils in............... geologic horizon indicated for....................... 120-121 list of fossil vertebrates from $\ldots 120$ past climatic conditions indicated in .................. 120-121

Sapindales.................................... 14-15, 166-169

Sapindus dentoni Lesquereux............................ 166

obtusifolius Lesquereux............................ 166-167

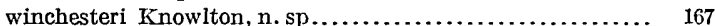

Schizaeaceae....................................... 149-150

Schuchert, Charles, cited......................... 42, 43, 57, 59,65-66

Sciuridae........................................ 121-122

Sedum? hesperium Knowlton, n. sp .......... 163-164

Seward, - cited.

Simarubaceae.......................................... 166

Sigmodon curtisi Gidley, n. sp......................... 125

medius Gidley, n. sp.............................. $\quad{ }_{126}$

minor Gidley, n. sp................................... 125-126

Sophora coloradensis Knowlton, n. sp.................... 165

Species, principles that should govern founding of ............. 10

spermatophyta................................ 8-20,152-176

Sphaerites myricae (Lesquereux) Meschinelli................. 149

Spheria myricae Lesquereux ............................. 149

Sterculia aceroides Knowlton, $n$. sp ...................... 191 puryearensis Berry.

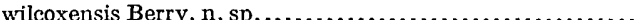

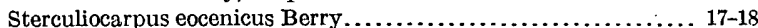

Supaị formation, definition of . ............................. $59-60$ fossils in, near Bass Canyon, Ariz.....................62-63

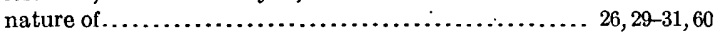

subdivisions of..

typical exposure of, opposite mouth of Garnet Canyon, Ariz.,

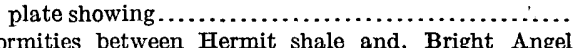
unconformities between Hermit shale and, Bright Angel quadrangle, Ariz., plate showing.

unconformity between Hermit formation and, on the Hermit trail, Ariz.

T.

Tapeats sandstone, fossils in, at Nunkoweap Valley, Ariz ....... 38-39 nature of, at Bass trail, Ariz................ 27, 35-36, 37-38 stratigraphic relations of ............................. 38 subdivisions of.

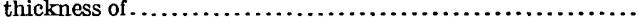

typical exposure of, opposite mouth of Elves chasm, Ariz. plate showing

Taxodiaceae.

Tellina sp. A...............................113-114, Pl. XXXII

Temple Butte limestone, analyses of limestone from, near Bass trail, Ariz

fossils in.

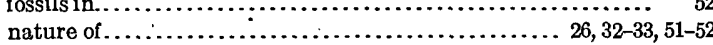
typical exposure of, opposite mouth of Garnet Canyon, Ariz., plate showing unconformities between Muav limestone and, in Shinumo quadrangle, Ariz., plates showing ................ 50,51

Teredo maverickensis Gardner, n. sp. .............. 114, Pl. XXXII

Terminalia lesleyana (Lesquereux) Berry ................... 19-20 radobojensis Heer

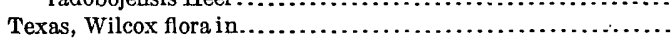
extreme southern, Beaumont clay in.................. 100-101 extreme southern brick clays in .

Carrizo sandstone in ................................ 91

Claiborne group in............................ 93-97

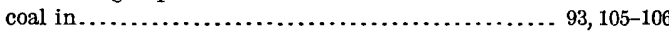
coastal deposits in............................. 103

Cook Mountain formation in. ................... 94-96

Cretaceous-Eocene line in . ....................... 87

delta deposits in ............................. 102

economic geology of ................................. 104-107

Eocene formations in........................... 87-98

Fayette sandstone in........................... 97

fossils collected in .. 89, 90, 91, 92, 94, 95, 96, 97, 100, 101, 102, 109, 117

Frio clay in.................................. 97-92

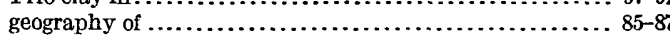

gravel, sand, and road material in ................ 106-107

Indio formation in . . .

Leona formation in .............................. 101-102

Lissie gravel in.................................... 100

Midway formation in.............................. $88-89$

Miocene formations in $\ldots \ldots \ldots \ldots \ldots \ldots \ldots \ldots \ldots \ldots, \quad 98$

Mount Selman formation........................... 93-94

Oakville sandstone in .............................. 98

oil and gas in .......................................... 104-105

Pleistocene formations in...................... 100-102

Pliocene (?) formation in . . . . . . . . . . . .

Recent deposits in .......................... 102-103

Reynosa formation in .............................. 98-100

stratigraphy of ................................. 87-103

structure of ................................ 103-104

terraces on rivers in $\ldots \ldots \ldots \ldots \ldots \ldots \ldots \ldots \ldots \ldots \ldots, 101$

Wilcox group in ............................. 89-93

wind-blown sand in ............................ 102-103

Yegua formation in . . . . . . . . . . . . . .

Thallophyta. ............... 148-149 Thymeleales................................... 18-19, 163 Tonto group, columnar sections of, in the Grand Canyon, Ariz ... 36 divisions and general features of, at Bass trail, Ariz... 26-27, 36-37 Tonto shelves, shelter for camps afforded by ............... Trowbridge, A. C., A geologic reconnaissance in the Gulf Coastal plain of Texas near the Rio Grande.............. 85-117 $\mathrm{U}$.

Udden, J. A., acknowledgment to........................ 85 Ulmaceae......................................... 161-162 Umbellales .......................................... 172 Urticales . ..................................... 8, 12, 161-162: $\mathrm{v}$

Vaughan, T. W., acknowledgment to..................... Venericardia alticostata subsp. Gardner, n. subsp............112-113 (alticostata subsp.) whitei Gardner, n. subsp...... 112, Pl. XXXI n. subsp. hesperia........................ 112, Pl. XXXII perantiqua Conrad $. . \ldots \ldots \ldots \ldots \ldots \ldots \ldots \ldots \ldots \ldots \ldots, 112$ Veneridae. .......................................... 113 vitaceae . . . . . . . . . . Vitis florissantella Cockerell............................. 189 W.

Walcott, C. D., acknowledgment to...................... 23

cited . Washakie station, Wyo., Green River fossils from .............. 138-139 Wentworth, Chester $\mathrm{K}$., The shapes of beach pebbles.......... $75-83$ White, C. A., cited..................................... 203 White, David, fossils determined by ....................... 66 White River, Wyo., Green River fossils from mouth of ........... 138 Widdringtonia linguaefolia Lesquereux $\ldots \ldots \ldots \ldots \ldots \ldots \ldots \ldots \ldots, \quad 187$ Wilcox flora, new species added to. .......................

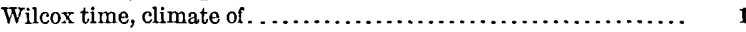
Winchester, D. E., cited.......................... 135, 139 Woodworth, J. B., acknowledgment to...................... 83 $\mathrm{X}$.

Xyridales. $\mathrm{Z}$

Zizyphus cinnamomoides (Lesquereux) Lesquereux.......... 170 longifolia Newberry $. . \ldots \ldots \ldots \ldots \ldots \ldots \ldots \ldots \ldots \ldots \ldots \ldots \ldots, 169-170$ 